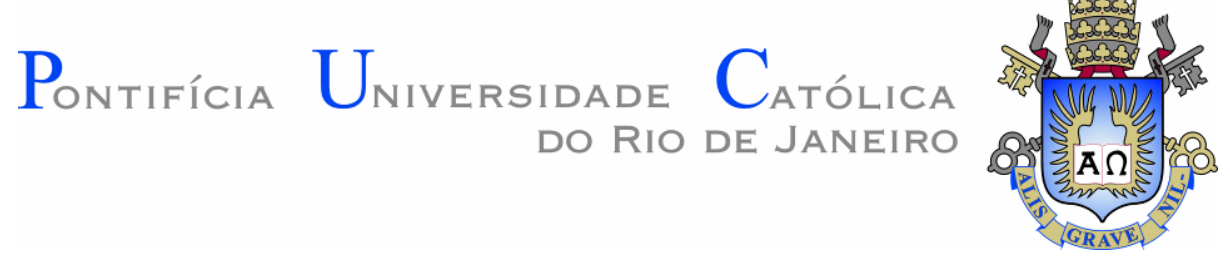

Acyr de Gerone Junior

\title{
Uma história da difusão das \\ Escrituras Sagradas \\ A atuação das Sociedades Bíblicas no Brasil
}

Tese de Doutorado

Tese de Doutorado apresentada ao Curso de Pós-Graduação em Teologia da Pontifícia Universidade Católica do Rio de Janeiro, como requisito parcial para obtenção do grau de Doutor em Teologia.

Orientador: Prof. Luís Corrêa Lima

Volume I

Rio de Janeiro

Fevereiro de 2018 


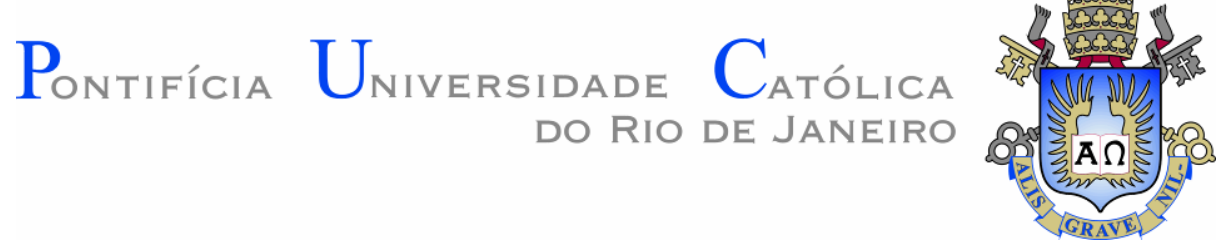

Acyr de Gerone Junior

\title{
Uma história da difusão das Escrituras Sagradas: a atuação das Sociedade Bíblicas no Brasil
}

Tese apresentada como requisito parcial para obtenção do grau de Doutor pelo Programa de Pós-Graduação em Teologia do Departamento de Teologia do Centro de Teologia e Ciências Humanas da PUC-Rio. Aprovada pela Comissão Examinadora abaixo assinada.

\author{
Prof. Luís Corrêa Lima \\ Orientador \\ Departamento de Teologia - PUC-Rio \\ Prof. Joel Portella Amado \\ Departamento de Teologia - PUC-Rio \\ Prof. Waldecir Gonzaga \\ Departamento de Teologia - PUC-Rio
}

Prof. Antonio Renato Gusso

Faculdades Batista do Paraná

Prof. Erni Walter Seibert

Profa. Monah Winograd Coordenadora Setorial de Pós-Graduação e Pesquisa do Centro de Teologia e Ciências Humanas - PUC-Rio

Rio de Janeiro, 28 de fevereiro de 2018. 
Todos os direitos reservados. É proibida a reprodução total ou parcial do trabalho sem autorização da universidade, do autor e do orientador.

\section{Acyr de Gerone Junior}

Graduou-se em Teologia pelo Seminário Teológico Betânia de Curitiba e pela Pontifícia Universidade Católica do Paraná (PUC/PR). Possui MBA em Gestão Empresarial pela Fundação Getúlio Vargas (FGV) e MBA em Propaganda, Marketing e Comunicação Integrada pela Universidade Estácio de Sá (UNIESA). É pós-graduado em Projetos Sociais no Terceiro Setor pela Faculdade Teológica Batista do Paraná (FTBP) e em Ciências da Religião pela Faculdade Entre Rios (FAERPI). É mestre em Educação pela Universidade Federal do Pará (UFPA) e doutor em Teologia pela Pontifícia Universidade Católica do Rio de Janeiro (PUC-Rio). É pastor evangélico, palestrante e autor de livros e artigos sobre Teologia, Missão, Terceiro Setor, Gestão e Educação.

Ficha Catalográfica

Gerone Junior, Acyr de

Uma história da difusão das Escrituras Sagradas: a atuação das Sociedades Bíblicas no Brasil / Acyr de Gerone Junior; orientador: Luís Corrêa Lima. - 2018.

2 v.: il. color.; $30 \mathrm{~cm}$

Tese (doutorado)-Pontifícia Universidade Católica do Rio de Janeiro, Departamento de Teologia, 2018.

Inclui bibliografia

1. Teologia - Teses. 2. Sociedade Bíblica do Brasil. 3. Bíblia. 4. Difusão da Bíblia. 5. Teologia. 6. História. 7. Escrituras Sagradas. I. Lima, Luís Corrêa. II. Pontifícia Universidade Católica do Rio de Janeiro. Departamento de Teologia. III. Título.

CDD: 200 
A Deus, autor das Escrituras, razão primeira e última da minha existência. À minha família, onde tenho o aconchego mais seguro para amar e ser amado. 


\section{Agradecimentos}

A gratidão é um dos sentimentos mais nobres que existem nas relações humanas. A decisão de agradecer alguém é sempre uma atitude espontânea, que expressa os mais sinceros sentimentos que passam pelo coração. A gratidão também é o reconhecimento de que ninguém faz nada sozinho. Até é possível andar rápido quando se está sozinho, mas é bem mais provável chegar mais longe quando se caminha com alguém. A gratidão, nessa perspectiva, é um verdadeiro reconhecimento. Sendo assim, é impossível concluir uma caminhada acadêmica sem agradecer e reconhecer algumas pessoas e organizações que durante os anos de curso contribuíram significativamente para que se alcançasse êxito.

Em primeiro lugar, a gratidão é dada a Deus. Como bem lembra o apóstolo João, ninguém pode receber coisa alguma se do céu não lhe for dado (João 3,27). Portanto, a Deus reitero meu reconhecimento de que tudo que tenho e sou veio de Suas mãos. Ele tem me sustentado em cada etapa da vida. Sempre que momentos difíceis e angustiantes se achegaram, Ele, por meio de Sua Palavra e Sua Graça, me mostrou um caminho de esperança. Nesta caminhada de estudo, não foi diferente. Agradeço a Deus por tudo e dedico a Ele todas as coisas: "Porque dele, e por meio dele, e para ele são todas as coisas. A ele seja a glória para sempre. Amém!" (Rm 11,36).

Em segundo lugar, a gratidão se expressa numa trama de sentimentos e emoções. À minha família, expresso minha eterna gratidão. Estou casado há 19 anos com uma mulher especial, que faz toda a diferença em minha vida: Tânia. Juntos, construímos um lar com dois filhos maravilhosos: Acyr Neto e Isabella. Minha família é meu refúgio, meu abrigo, meu amparo. Em meu lar tenho pessoas que me amam e me apoiam. São pessoas que sabem das minhas falhas e conhecem minhas limitações; ainda assim, expressam seu amor, carinho e cuidado - dos quais eu não sou merecedor. Agradeço a vocês, Tânia, Neto e Bella, por sempre, sempre mesmo, estarem ao meu lado. A conclusão de mais esta etapa é fruto do apoio de vocês, que abriram mão do tempo em família para que eu pudesse seguir firme nos estudos. Muito obrigado. Amo vocês!

Da mesma forma, agradeço aos meus pais, Acyr e Sandra, que sempre me ensinaram no caminho que eu deveria andar. Eles me ensinaram o "bê-á-bá" da fé cristã; eles me apresentaram Jesus. Muito obrigado por tudo. Se hoje concluo mais essa etapa é porque vocês lançaram uma semente que germinou e deu frutos.

Também, como fruto histórico de uma caminhada, agradeço à igreja de Cristo. Nasci, cresci e vivi boa parte da minha vida dentro de uma igreja. Por meio das muitas relações fraternas construídas entre irmãos de fé, pude cultivar verdadeiras amizades e desfrutar de momentos especiais. Em inúmeras mudanças realizadas de uma cidade para outra, encontrei uma aconchegante família de fé na igreja de Cristo. Em especial, agradeço à Igreja Redenção, de Curitiba. Nesta igreja eu conheci a Jesus e dei meus primeiros passos de fé e ministério pastoral. Agradeço também à Igreja Missionária Evangélica Maranata, onde, quando cheguei ao Rio de Janeiro, em 2013, fui recebido, junto com a minha família, com muito carinho e hospitalidade. 
Agradeço também à Sociedade Bíblica do Brasil, uma instituição que admiro e respeito cada dia mais. Tenho acompanhado há quase vinte anos o trabalho bíblico realizado pela SBB. A escolha pela temática se deu justamente pela admiração e respeito que tenho por essa instituição. Agradeço ao Rev. Dr. Rudi Zimmer, ao Rev. Dr. Erni Seibert, ao Rev. Marcos G. F. Silva, ao Rev. Paulo Teixeira e ao Rev. Dr. Vilson Scholz. Todos eles colaboraram em minha caminhada e todos, da mesma forma, contribuíram com apoio, incentivo, sugestões e diálogos sobre esta pesquisa. Paralelamente, agradeço aos colaboradores da SBB que cooperaram com informações para que esta pesquisa alcançasse êxito. São eles: Bettina Flor, Vera Siqueira, Stella Souza, Márcia Carneiro, Luiz Forlim, Emilene Araujo, Alessandro Souza, Janete Leonel, Denis Timm, Camila Vilvock, Hebert Nobre, Marta Assunção, Walter Eidam, Daniele Santos e Naiara Brandão.

Agradeço, ainda, de forma especial, aos colaboradores da Sociedade Bíblica do Brasil no Rio de Janeiro, que me deram um grande apoio na realização deste trabalho. Destaco Patrícia Cabral, Marcos Batista e Vinicius Lacerda, os quais, por diversos momentos, ajudaram em etapas decisivas desta pesquisa. Sem o apoio e a ajuda de vocês esta caminhada teria se tornado mais difícil.

Quero também agradecer ao Programa de Pós-graduação em Teologia da Pontifícia Universidade Católica do Rio de Janeiro e a todos os professores do Departamento de Teologia que me ajudaram nessa caminhada. As contribuições dos membros da banca de qualificação, Prof. Dr. D. Joel Amado Portela, Prof. Dr. Isidoro Mazzarolo e Prof. Dr. Waldecir Gonzaga, foram muito úteis na reflexão das ideias aqui apresentadas. Em especial, agradeço ao meu orientador, Prof. Dr. Luis Corrêa Lima, que me aceitou como seu orientando e durante todo esse tempo, fez contribuições significativas que resultaram nessa pesquisa. Muito obrigado pela paciência, pelo incentivo e pelos ensinamentos. Estendo também minha gratidão aos muitos colegas, católicos e protestantes, que compartilharam comigo momentos preciosos enquanto cursávamos algumas disciplinas. Agradeço, igualmente, ao CNPq e à PUC-Rio, pelos auxílios concedidos, sem os quais este trabalho não poderia ter sido realizado.

Agradeço a Quéfren Moura, que desde meu curso de mestrado sempre ofereceu apoio e incentivo para que esta pesquisa fosse concluída. Ela foi a responsável pela revisão do texto, mas, para além disso, sempre contribuiu com análises e sugestões que enriqueceram o trabalho final. Mesmo estando em férias, quase sem disponibilidade, ela conseguiu separar um tempo para se dedicar à revisão do último capítulo. Muito obrigado, Quéfren. Agradeço, também, pelo apoio de Sueli Rocha, Lucas Gerone e Aislan Coulter, que, da mesma forma, contribuíram com revisões e sugestões em algumas partes do texto.

Ao agradecer citando nomes, há sempre o risco, pela nossa limitação, de esquecer pessoas que contribuíram para esta caminhada. Por isso, agradeço a todos que de forma direta ou indireta me ajudaram nesta trajetória. Não tenho dúvidas de que todas as pessoas que encontro, com quem trabalho, converso e compartilho ideias, entre outras possibilidades, têm participação nesta jornada.

A todos, muito obrigado! 


\section{Resumo}

Gerone, Acyr de Gerone Junior; Lima, Luís Corrêa. Uma história da difusão das Escrituras Sagradas: a atuação das Sociedades Bíblicas no Brasil. Rio de Janeiro, 2017. 400p. Tese de Doutorado - Departamento de Teologia, Pontifícia Universidade Católica do Rio de Janeiro.

Esta tese foi desenvolvida com o objetivo de analisar a caminhada histórica da atuação das Sociedades Bíblicas no Brasil, sob a ótica da difusão das Escrituras Sagradas. Para melhor contextualizar a temática, a análise teve início no tempo da transmissão oral da Palavra de Deus, antes de qualquer registro por escrito, e se desenvolveu pelos diversos contextos em que as Escrituras acompanharam o povo de Deus na história, tanto na realidade do povo de Israel quanto na perspectiva da igreja cristã. O trabalho de difusão das Escrituras, realizado pelas Sociedades Bíblicas no Brasil, constituiu o objeto principal do estudo. Analisou-se como se deu o processo de chegada e o desenvolvimento do trabalho das Sociedades Bíblicas em quase duzentos anos de atividades no país. De forma especifica, discorreu-se sobre o trabalho realizado pela Sociedade Bíblica do Brasil (SBB) desde a sua fundação, em 1948. Esse trabalho foi analisado a partir do ciclo de vida da Bíblia, método utilizado para a SBB tornar a Bíblia disponível, acessível e relevante na sociedade e na igreja. $\mathrm{O}$ trabalho foi desenvolvido sob as bases de uma pesquisa histórica. Sua área de concentração foi estabelecida na teologia sistemáticapastoral. Metodologicamente, a pesquisa foi realizada por meio de uma revisão bibliográfica, contemplada por historiadores e biblistas que são referenciais em relação a temática proposta. Foram também utilizadas pesquisas em documentos oficiais disponibilizados pela SBB. No último capítulo foram utilizados além da descrição histórica, uma análise de conteúdo com base nas atividades desenvolvidas pela SBB por meio do ciclo de vida da Bíblia. Os resultados evidenciaram que o trabalho de difusão das Escrituras, desenvolvido pelas Sociedades Bíblicas no Brasil, em especial a SBB, tem contribuído de forma significativa com a igreja e a realidade da sociedade brasileira em diversos aspectos sociais e espirituais.

\section{Palavras-chave}

Sociedade Bíblica do Brasil; Bíblia; Difusão da Bíblia; Teologia; História; Escrituras Sagradas. 


\section{Abstract}

Gerone, Acyr de Gerone Junior; Lima, Luís Corrêa (Advisor). A narrative of the history of the Holy Scriptures diffusion: the action of Bible Societies in Brazil. Rio de Janeiro, 2017. 400p. Tese de Doutorado - Departamento de Teologia, Pontifícia Universidade Católica do Rio de Janeiro.

This thesis has been developed with aim of analyzing the the historical journey of the Biblical Societies in Brazil, from the point of view of the diffusion of the Holy Scriptures. In order to better contextualize the theme, the analyze had its beginning during the time of the oral transmission of the Word of God, before any written record, and it developed through several contexts in which the Scriptures followed God's people in history, both in the reality of the people of Israel and in the perspective of the Christian church. The work of spreading the Scriptures, held by the Bible Societies in Brazil, was established as the main object of study. It was analyzed how the process of arrival and development of the Bible Societies work in almost two hundred years of activities in the country. In a specific way, it was analyzed the work held by the Brazilian Bible Society (SBB) since its foundation in 1948. This work was analyzed starting from the life cycle of the Bible, a method used by the BBS to make the Bible available, accessible, and relevant in the society and in the church. The study was conducted on the basis of a historical research. Its area of concentration was established in the pastoral systematic theology. Methodologically, the research was made through a bibliographical review, overseen by historians and bible scholars, who are referential in relation to the proposed theme. Researches were also made in official documents provided by the BBS. In the last chapter, besides the historical description, it was used an analysis of content based on the activities developed by the BBS through the life cycle of the Bible. The results showed that the work of spreading the Scriptures, developed by the Bible Society in Brazil, especially the BBS, has contributed in a meaningful way to the church and to the Brazilian society in several social and spiritual aspects.

\section{Keywords} Scriptures

Brazil Bible Society; Bible; diffusion of the Bible; Teology; History; Holy 


\section{Sumário}

1 Introdução 17

1.1 Questões metodológicas da pesquisa 24

1.2 A estrutura da tese: o conteúdo e a sua distribuição 27

2 Perspectivas históricas na difusão das Escrituras Sagradas: da transmissão oral à Idade Média 30

2.1 A difusão da Palavra de Deus antes dos escritos 32

2.2 A difusão da Palavra de Deus em transição: da oralidade aos primeiros registros

2.3 Traduzir para difundir: a primeira tradução das Escrituras

Sagradas

43

2.4 Jesus e os apóstolos na difusão das Escrituras Sagradas 48

2.5 A difusão das Escrituras Sagradas no tempo dos Pais da Igreja 56

2.5.1 A difusão das Escrituras Sagradas do rolo ao livro 62

2.5.2 A contribuição de Orígenes na difusão das Escrituras

Sagradas

64

2.5.3 A contribuição de Jerônimo na difusão das Escrituras

Sagradas

68

2.6 A contribuição do monasticismo na difusão das Escrituras

Sagradas

73

2.7 A difusão das Escrituras Sagradas na Idade Média 76

2.7.1 A difusão das Escrituras Sagradas no período da Teologia

Escolástica

78

2.8 A difusão das Escrituras Sagradas como paradigma de vida pessoal e eclesial

82

2.9 A difusão das Escrituras Sagradas por meio da arte e da literatura 87

3 A difusão das Escrituras Sagradas a partir da Reforma

Protestante e da Contrarreforma Católica até a contemporaneidade

3.1 A difusão das Escrituras Sagradas e a Reforma Protestante $\quad 97$

3.1.1 Os pré-reformadores e a questão da Bíblia 99

3.1.2 Causas e fatos que contribuíram com a Reforma e a difusão das Escrituras Sagradas

3.1.3 Os reformadores em sua relação com as Escrituras

Sagradas e a sua difusão

3.1.4 A difusão das Escrituras Sagradas pós-reforma 
3.1.5 A difusão das Escrituras Sagradas a partir do princípio reformado Sola Scriptura

3.2 A difusão das Escrituras Sagradas e a Contrarreforma Católica

3.3 A difusão das Escrituras Sagradas da modernidade à contemporaneidade

3.3.1 O lugar das Escrituras Sagradas no período das Confissões de Fé

3.3.2 O lugar das Escrituras Sagradas em tempos de Puritanismo, Pietismo lluminismo e Liberalismo teológico

3.3.3 Uma tentativa de síntese: a difusão das Escrituras Sagradas nessas relações contemporâneas

3.3.4 Questões contemporâneas sobre a difusão das Escrituras Sagradas nas igrejas cristãs

3.3.4.1 Contemporaneidade católica e as Escrituras Sagradas

3.3.4.1.1 O Concílio Vaticano II, a Dei Verbum e o lugar das Escrituras Sagradas na Igreja Católica

3.3.4.1.2 O Sínodo dos bispos: continuidade e avanços sobre a importância da Palavra de Deus na vida da Igreja Católica

3.3.4.2 Contemporaneidade protestante e as Escrituras Sagradas

3.4 A difusão das Escrituras Sagradas no Brasil Colônia e início do Império

172

\section{A história e a atuação das Sociedades Bíblicas na difusão das Escrituras Sagradas}

4.1 A história de Mary Jones como relato fundante das Sociedades Bíblicas e a necessidade das Escrituras Sagradas no mundo

4.2 A fundação da primeira Sociedade Bíblica, seus objetivos no trabalho de difusão das Escrituras Sagradas e alguns aspectos importantes de sua história

4.2.1 Desafios e dificuldades no trabalho das Sociedades Bíblicas no relacionamento com a Igreja Católica

4.2.2 Desafios e dificuldades no trabalho das Sociedades Bíblicas no serviço às igrejas protestantes

4.3 A atuação das Sociedades Bíblicas na difusão das Escrituras Sagradas no Brasil

4.3.1 Os primeiros registros e os primeiros documentos sobre o trabalho das Sociedades Bíblicas no Brasil Império

4.3.2 A atuação das Sociedades Bíblicas na difusão das Escrituras Sagradas durante o Brasil Império

4.3.2.1 A atuação dos primeiros representantes da Sociedade

Bíblica Americana no Brasil e a instalação de sua primeira agência 
4.3.2.2 A atuação dos primeiros representantes da Sociedade Bíblica Britânica e Estrangeira no Brasil e a instalação de sua primeira agência

4.3.3 A atuação das Sociedades Bíblicas na difusão das Escrituras Sagradas durante o Brasil República

4.3.3.1 Desafios na difusão das Escrituras Sagradas: as primeiras décadas da causa da Bíblia no Brasil República

4.3.3.2 Meio século de história no trabalho de difusão das Escrituras Sagradas realizado pelo Reverendo Tucker

4.3.3.3 Entre crises e conquistas: a atuação conjunta das Sociedades Bíblicas na difusão das Escrituras Sagradas no Brasil no início do século XX

4.4 A atuação dos colportores das Sociedades Bíblicas na difusão das Escrituras Sagradas no Brasil

\section{A história e a atuação da Sociedade Bíblica do Brasil} na difusão das Escrituras Sagradas

5.1 A história de fundação da Sociedade Bíblica do Brasil 271

5.1.1 Constituição, finalidade e missão da SBB 274

5.2 A atuação da SBB na difusão das Escrituras Sagradas 275

5.2.1 O aspecto da disponibilidade no trabalho bíblico: tradução, publicação e produção das Escrituras Sagradas no Brasil

277

5.2.1.1 Disponibilidade por meio de traduções da Bíblia 278

5.2.1.1.1 A clássica tradução de Almeida 280

5.2.1.1.1.1 João Ferreira Annes d'Almeida, o tradutor 281

5.2.1.1.1.2 Almeida Revista e Corrigida (ARC) 286

5.2.1.1.1.3 Almeida Revista e Atualizada (ARA) 287

5.2.1.1.1.4 Nova Almeida Atualizada (NAA) 290

5.2.1.1.2 A histórica Tradução Brasileira (TB) 293

5.2.1.1.3 A dinâmica Nova Tradução na Linguagem de Hoje (NTLH) 295

5.2.1.1.4 O desafio de tradução para as línguas indígenas e minoritárias do Brasil $\quad 302$

5.2.1.2 Disponibilidade por meio de publicações da Bíblia 308

5.2.1.3 Disponibilidade por meio da produção das Escrituras Sagradas: a Gráfica da Bíblia

5.2.2 $O$ aspecto da acessibilidade no trabalho bíblico: distribuição e incentivo à leitura das Escrituras Sagradas no Brasil

5.2.2.1 Acessibilidade às Escrituras Sagradas por meio da presença 320

5.2.2.1.1 A adaptação histórica da colportagem bíblica para 
5.2.2.1.2 A criação de unidades regionais para se dar acesso às Escrituras Sagradas

5.2.2.1.3 A acessibilidade das Escrituras Sagradas por meio de programas e projetos especiais de propagação da Bíblia

5.2.2.2 A acessibilidade das Escrituras Sagradas por meio dos Programas Bíblicos de Impacto Social

5.2.2.2.1 Pressuposto histórico no trabalho holístico das Sociedades Bíblicas

5.2.2.2.2 Pressupostos bíblico, teológico, social e estatutário no trabalho bíblico holístico da SBB

5.2.2.2.3 História e atualidade dos programas bíblicos de impacto social desenvolvido pela SBB

5.2.2.3 O incentivo à leitura bíblica nos Programas de Difusão das Escrituras Sagradas

5.2.3 $\mathrm{O}$ aspecto da relevância no trabalho bíblico: envolvimento e defesa das Escrituras Sagradas no Brasil

5.2.3.1 O trabalho de difusão das Escrituras Sagradas por meio do envolvimento das pessoas na Causa da Bíblia

5.2.3.2 O trabalho de difusão das Escrituras Sagradas por meio da defesa da Bíblia e a sua causa

6 Conclusão

7 Referências bibliográficas

369

7.1 Bíblia Sagrada

369

7.2 Bibliografia fundamental

370

7.3 Acesso exclusivo em meio eletrônico

394 


\section{Abreviaturas e siglas}

ABNB

ABS

ALEM

ARA

ARC

AT

BLH

BFBS

BJ

CBB

CCB

CEBI

CGADB

CNBB

CONPLEI

CPAD

GB

IBB

IBGE

JOCUM

$\mathrm{MACi}$

MEIB

MEVA

MUBI

NAA

NT

NTLH

OMS

SBA

SBB

SBBE

SBN
A Bíblia no Brasil

American Bible Society

Associação Linguística Evangélica Missionária

Almeida Revista e Atualizada

Almeida Revista e Corrigida

Antigo Testamento

Bíblia na Linguagem de Hoje

Britsch Foreign Bible Society

Bíblia de Jerusalém

Convenção Batista Brasileira

Centro Cultural da Bíblia

Centro de Estudos Bíblicos

Convenção Geral das Assembleias de Deus no Brasil

Conferência Nacional dos Bispos do Brasil

Conselho Nacional de Pastores e Líderes Indígenas

Casa Publicadora das Assembleias de Deus

Gráfica da Bíblia

Imprensa Bíblica Brasileira

Instituto Brasileiro de Geografia e Estatística

Jovens com uma missão

Missão Amigos dos Ciganos

Missão Evangélica aos Índios do Brasil

Missão Evangélica da Amazônia

Museu da Bíblia

Nova Almeida Atualizada

Novo Testamento

Nova Tradução na Linguagem de Hoje

Organização Mundial da Saúde

Sociedade Bíblica Americana

Sociedade Bíblica do Brasil

Sociedade Bíblica Britânica e Estrangeira

Sociedade Bíblica da Nigéria 
SBU

SCB

SIL

SLR

SPCK

TB

TLH

UBS
Sociedades Bíblicas Unidas

Seminário de Ciências Bíblicas

Sociedade Internacional de Linguística

Scriptures Languages Report

Society for Promotion Christian Knowledge

Tradução Brasileira

Tradução na Linguagem de Hoje

United Bible Societies 


\section{llustração}

Figura 1 - Ciclo de vida da Bíblia 276 
"Porém a palavra de Deus era anunciada em toda parte e ia se espalhando".

[At 12,24 - NTLH] 


\title{
1 \\ Introdução
}

A Bíblia, Palavra de Deus. Esse é um pressuposto básico pelo qual esta pesquisa se estabelece. Tal afirmativa, característica entre os cristãos, está baseada no pressuposto de que "Deus é o autor da Bíblia e, consequentemente, a palavra contida neste livro é a Palavra de Deus. [...] é a inspiração divina que justifica e fundamenta a autoridade desse livro que se impõe a nós com a sua exigência de obediência e submissão"1. Entretanto, antes de discorrer sobre essa questão própria ao cristianismo, importa entender esse tema sob uma perspectiva mais ampla.

Um fato comum na maioria das grandes religiões existentes no mundo é a existência de textos sagrados. Tal expressão caracteriza um tipo de literatura exclusiva ao mundo das religiões. Estes textos, normalmente, estão catalogados em coleções de livros ou escritos e servem como fundamento e expressão das práticas religiosas vivenciadas através dos povos. É muito comum que as religiões afirmem que esses textos têm origem divina, transcendental, portanto, são consideradas como palavras divinas. Por assim ser,

\begin{abstract}
As tradições religiosas preservam seus ensinamentos e normas através de textos que são considerados sagrados. Atribui-se a eles uma origem divina através de um mensageiro, um iluminado ou um discípulo. Os textos são expressões da relação do humano com o divino. Neles há um forte apelo do Criador e das forças sobrenaturais para que o ser humano torne-se mais justo, compassivo, bom e santo. O leitor sabe que, ao acolher os ensinamentos dos textos sagrados, pode tornar-se perfeito ou aproximar-se da divindade, dando maior sentido à sua existência. Os livros sagrados revelam o desejo de transcendência presente nas culturas e povos das mais diferentes regiões do planeta nos diversos períodos da história ${ }^{2}$.
\end{abstract}

Nessa perspectiva, os textos sagrados são considerados por muitas religiões como inspirados e inalteráveis, pois têm sua origem na própria divindade. Os textos ensinam, advertem e indicam o caminho que os fiéis devem seguir, permitindo

\footnotetext{
${ }^{1}$ MESTERS, Carlos. Por trás das palavras: um estudo sobre a porta de entrada no mundo da Bíblia. Petrópolis: Vozes, 2012, p. 207

${ }^{2}$ BRUSTOLIN, Leomar Antônio. Textos Sagrados nas grandes religiões. Revista Renovação da CNBB Sul 3. Porto Alegre, julho/agosto de 2004, n. 357, p. 1
} 
um estreito vínculo do ser humano ao ser divino através da revelação sagrada contida nestes textos.

Entre os textos sagrados mais conhecidos está a Bíblia Sagrada, também reconhecida como "Escrituras" ou "Escrituras Sagradas" para os seguidores do cristianismo. A terminologia Bíblia deriva do grego, $\beta i \beta \lambda \iota \alpha$, plural de $\beta i \beta \lambda \imath \iota v$, que transliterado resulta em bíblion, rolo ou livro ${ }^{3}$. Para os cristãos, a Bíblia é o livro por excelência, o fundamento da fé e a manifestação verbal do próprio Deus. Isto é, a Bíblia foi inspirada por Deus e é normalmente por meio dela que o ser humano pode se desenvolver espiritualmente e conhecer mais sobre o plano e a vontade de Deus para a sua vida.

Ainda que a utilizem e a interpretem de forma diferente, a Bíblia também é utilizada pelos adeptos do judaísmo e do islamismo, visto que, concomitante ao cristianismo, essas religiões acreditam que o plano divino foi iniciado por Deus por meio de uma aliança com Abraão. Sob esse aspecto de fé, portanto, as religiões nascidas da Bíblia (judaísmo, cristianismo e islamismo), foram mormente denominadas "religiões do livro" . Isto porque, a história das Escrituras Sagradas se confunde com a história da fé judaico-cristã e das civilizações que essa crença ajudou a fundar. Em relação ao cristianismo, entretanto, uma ressalva se faz necessária. Por meio da encarnação de Cristo, o Verbo que se fez carne (Jo 1,14), o cristianismo está para além da designação de religião do livro. O cristianismo é a religião da Palavra de Deus.

A Bíblia está dividida em duas partes, isto é: Antigo e Novo Testamento. A palavra testamento significa aliança, acordo, pacto entre Deus e o povo. O Antigo Testamento (AT) é a mesma Tanakh judaica ${ }^{5}$. Na história do AT, o pacto foi estabelecido com os judeus ${ }^{6}$; já no Novo Testamento (NT), a aliança se estendeu a

\footnotetext{
${ }^{3}$ SCHOLZ, Vilson. A Bíblia: sua natureza, funções e finalidade. In: ZIMMER, Rudi (org.). Manual de Ciências Bíblicas. Barueri: Sociedade Bíblica do Brasil, 2008, p. 8;

${ }^{4}$ BARRERA, Júlio Trebolle. A Bíblia judaica e a Bíblia cristã. Petrópolis: Vozes, 1995, p. 156

${ }^{5} \mathrm{O}$ termo $\mathrm{TaNaKh}$ é utilizado no Judaísmo para designar os vinte e quatro livros sagrados que compõem o cânon judaico. Trata-se de um acrônimo, formado pelas primeiras sílabas das três partes que compõem a Escritura Sagrada dos judeus, tais quais: Torá (5 livros, conhecidos pelos cristãos como Pentateuco), Neviim (8 livros, presentes no cânon cristão das Escrituras nas categorias de livros proféticos e livros históricos) e Khetuvim (11 livros, presentes no cânon cristão das Escrituras nas categorias de livros proféticos, livros históricos e livros poéticos). Cf. TEIXEIRA, Paulo; ZIMMER, Rudi. A formação do cânon. In: ZIMMER, Rudi (org.). Manual do Seminário de Ciências Bíblicas. Barueri: Sociedade Bíblica do Brasil, 2008, p. 19.

${ }^{6}$ Pessoas que pertencem ao grupo étnico-religioso que teve origem nos patriarcas Abraão, Isaque e Jacó e, também, nas tribos de Israel. Eles também podem ser reconhecidos como hebreus ou israelitas. São originários da região do Antigo Oriente, na atual Palestina.
} 
todos os povos da Terra. Conceitualmente, portanto, o Antigo Testamento "foi escrito pela comunidade judaica, e por ela preservado um milênio ou mais antes da era de Jesus"7. Por outro lado, o Novo Testamento, escrito pelos apóstolos, discípulos e seguidores de Cristo, caracterizou-se em dois aspectos, pelo menos, isto é, na "necessidade de ensinar os novos convertidos e no desejo de relatar o testemunho dos primeiros discípulos em relação à vida e aos ensinamentos de Cristo"8. Dessa forma, enquanto essencialmente o AT relata situações vivenciadas pelo povo judeu — desde a promessa a Abraão até as profecias que apontavam para a vinda do Messias - o NT descreve o cumprimento dessa promessa por meio do nascimento e do ministério de Jesus, culminando no início da igreja cristã 9

Como na maioria dos textos sagrados, na Bíblia também existe um cânone estabelecido, isto é, uma definição dos textos que são considerados sagrados e inspirados. Isso não quer dizer que esta definição seja unânime. Na história da igreja, as diferenças canônicas prevaleceram e estão, atualmente, presentes nos diversos segmentos do cristianismo - católicos, ortodoxos e protestantes. Cada segmento tem o seu cânon de forma divergente ao outro. No contexto brasileiro, as diferenças são facilmente percebidas nas Bíblias utilizadas por católicos e protestantes ${ }^{10}$.

\footnotetext{
${ }^{7}$ GEISLER, Norman; NIX, William. Introdução bíblica: como a Bíblia chegou até nós. São Paulo: Editora Vida, 2003, p. 6

${ }^{8}$ BRUSTOLIN, Leomar Antônio. Textos Sagrados nas grandes religiões, p. 4.

${ }^{9} \mathrm{O}$ termo igreja será utilizado para se referir ao "povo de Deus, a comunidade e o corpo de Cristo e a comunhão do Espírito Santo". In: FERGUNSON, Sinclair B. Novo Dicionário de Teologia. São Paulo: Hagnos, 2009, pp. 529-531. Trata-se, portanto, de uma definição que contempla as principais confissões cristãs existentes (católicos, protestantes e ortodoxos), considerando-as como igreja ou, também, igreja cristã. No decorrer do texto, quando surgir a necessidade de se ressaltar alguma das tradições existentes, serão utilizados os termos Igreja Católica (ou Igreja, com letra maiúscula) para se referir à Igreja Católica Apostólica Romana e igreja protestante (no singular ou no plural) para se referir às igrejas oriundas da Reforma Protestante ou, como também são atualmente reconhecidas, igrejas evangélicas. Outros termos, tais quais, igrejas reformadas, igrejas pentecostais, igrejas neopentecostais etc. poderão surgir quando, dentro do contexto, houver a necessidade de seu uso. Vale ressaltar, ainda, que, considerando o lócus da pesquisa, isto é, a difusão das Escrituras no Brasil, a Igreja Católica e a igreja protestante (evangélicas, em geral) recebem a primazia na análise.

${ }^{10}$ Nesse sentido, é importante salientar que este trabalho não pretende apresentar o status quaestiones em relação aos estudos do cânon bíblico. Quando surgir no texto uma abordagem do cânon do AT ou do NT, o que importa, de fato, são os aspectos introdutórios ao tema que podem constituir elementos basilares para que se tenha uma melhor compreensão do objeto de estudo nesta pesquisa, isto é, a difusão das Escrituras Sagradas. Para aqueles que têm interesse na temática do cânon bíblico recomeda-se, entre outros, as seguintes obras: MACDONALD, Lee Martin. A origem da Bíblia: um guia para os perplexos. São Paulo: Paulus, 2013; MILLER, John. As origens da Bíblia: repensando a história canônica. São Paulo: Loyola, 2004.
} 
De fato, independentemente das posições divergentes, a Bíblia é o livro mais importante da história da humanidade. É o livro "mais traduzido, distribuído, vendido e mais lido em todo o mundo" "11. Trata-se, portanto, de um livro que venceu o tempo e prevaleceu por meio de seu persistente influxo no curso da história humana e das religiões judaico-cristã. A influência das Escrituras Sagradas, nos dias atuais, se estende, entre outros, pela ciência, pela arqueologia, pela cultura, pela história, etc. Não há, portanto, como negar a forte influência que a Bíblia exerceu e exerce, sobre o mundo ocidental. Nesse sentido, “estudar a Bíblia é, necessariamente, estudar a história"12. Embora não tenha o propósito de ser um livro de história, diante da longa história que tem para contar, "a Bíblia é uma fonte ímpar. Não existe nenhum outro registro antigo da maioria das coisas que a Bíblia narra sobre o passado"13. Nesse sentido, "a Bíblia é também um livro histórico; [pois] nasceu no meio da vida dos homens" ${ }^{\text {"14. }}$.

É justamente sob uma perspectiva da história que se encontra um relato significativo de como as Escrituras Sagradas foram difundidas. Na história bíblica, essa difusão teve início por meio da oralidade. Com o passar do tempo, essas histórias foram escritas - o que resultou nas Escrituras Sagradas - e passaram a ser difundidas. Para o povo hebreu, esse foi um princípio de fé e de vida, afinal, cada família tinha por missão ensinar aos seus filhos os escritos sagrados (Dt 6). Já no contexto do NT, após a ascensão de Cristo, foi a palavra pregada pelo apóstolo Pedro (At 2,14-36), fundamentada nas Escrituras e reinterpretadas a partir dos ensinos de Jesus, que deram início à difusão das Escrituras. Era assim que a palavra de Deus crescia e os discípulos se multiplicavam (At 6,7; 12,24; 19,20).

$\mathrm{Na}$ história da igreja, a Escritura continuou a ser difundida. Os primeiros cristãos estudavam e compartilhavam as Escrituras. Os Pais da Igreja, por sua vez, estabeleceram as bases e os ensinos da fé cristã fundamentados nos Escritos Sagrados. Eles liam o Antigo Testamento e viam as promessas se cumprirem em Cristo. Com isso, junto com os líderes e a igreja dos primeiros séculos, eles ajudaram a definir o cânon neotestamentário. As Escrituras Sagradas, formada pelo AT e pelo NT, constituíram, assim, a diretriz necessária para que a igreja de Cristo se desenvolvesse e se espalhasse pelos confins do mundo.

\footnotetext{
${ }^{11}$ SCHOLZ, Vilson. A Bíblia: sua natureza, funções e finalidade, p. 8

${ }^{12}$ GABEL, John; WHEELER, Charles. A Bíblia como literatura. São Paulo: Loyola, 2003, p. 49

${ }^{13}$ Ibid., p. 56

${ }^{14}$ BARTH, Karl. A proclamação do Evangelho. São Paulo: Fonte Editorial, 2009, p. 47
} 
No contexto da Reforma do século XVI, as Escrituras Sagradas estabeleceram o cerne das principais diferenças suscitadas entre católicos e protestantes. $\mathrm{E}$ foi justamente a partir desse contexto histórico que a Bíblia passou a ser ainda mais difundida. Inicialmente os protestantes levaram à frente tal missão; afinal, a propagação e a leitura da Bíblia constituíam a base do arcabouço doutrinário dos reformadores. Posteriormente, os católicos também passaram a difundir as Escrituras de forma significativa em suas atividades pastorais. Como se percebe, a difusão das Escrituras sempre fez parte da história, seja sob uma perspectiva bíblica, ou sob uma perspectiva eclesial. De fato, a história da difusão das Escrituras ocorre de forma concomitante à história da igreja. Por vezes, se torna até interdependente. Em alguns momentos atua de forma oposta aos rumos da igreja; em outros, é a própria difusão das Escrituras que impulsiona a igreja para a missão. Deste modo, de forma intensa ou amena em cada contexto, a igreja cristã sempre foi a portadora e a difusora das Escrituras.

Sem desconsiderar esse aspecto norteador, já entre o final do século XVIII e início do século XIX, começaram a surgir organizações missionárias que tinham como objetivo principal servir a igreja em sua missão por meio da difusão das Escrituras. E até hoje, no mundo todo, existem diversas organizações que desenvolvem um trabalho no intuito de disponibilizar a Bíblia para todas as pessoas. Uma dessas organizações, mundialmente reconhecida, é a UBS (United Bible Societies), Sociedades Bíblicas Unidas, cuja missão é promover a mais ampla distribuição possível da Bíblia no mundo. Desde a sua criação, as Sociedades Bíblicas atuam de forma conjunta com igrejas e organizações cristãs das mais diferentes denominações sob a missão de levar a Bíblia a todas as pessoas em todos os lugares possíveis. No Brasil, o trabalho histórico realizado pelas Sociedades Bíblicas se desenvolveu de forma significativa, a ponto de o país se tornar uma referência no trabalho bíblico no mundo. Parte desse êxito, sem dúvida, pode ser conferido devido ao trabalho realizado pelas Sociedades Bíblicas no país.

É justamente nesta perspectiva que esse trabalho se desenvolveu, ou seja, se descreveu, por meio de uma pesquisa histórica, como foi realizado o trabalho de difusão das Escrituras Sagradas. Para além disso, procurou-se apreender como essa difusão foi realizada por meio da atuação das Sociedades Bíblicas no Brasil. A temática, portanto, foi estabelecida sob um viés histórico, a fim de analisar como as Sociedades Bíblicas chegaram ao país para realizarem a difusão das Escri- 
turas Sagradas no Brasil. Esse trabalho tem se desenvolvido por quase duzentos anos e tem contribuído significativamente com o trabalho realizado pelas igrejas cristãs no Brasil, tanto no aspecto evangelístico, como no aspecto teológico e pastoral. Trata-se, portanto, de uma pesquisa relevante e pertinente.

A Sociedade Bíblica do Brasil é fonte de pesquisa em alguns trabalhos acadêmicos. Alguns, desconhecendo sua missão, limitam-se a uma análise pura e simplesmente baseada no aspecto comercial, destacando os números gerados a partir das vendas e da quantidade de Bíblias distribuídas, como é o caso da pesquisa realizada por Campos ${ }^{15}$, por exemplo. No aspecto teológico, as pesquisas se pautam mormente nas questões de tradução, devido ao fato de que a SBB tem um trabalho significativo na área da tradução bíblica. Um exemplo é o trabalho de Queiróz ${ }^{16}$.

Diante de tais fatos, o presente trabalho tem pertinência ao ser descrito sob as bases de uma pesquisa histórico-teológica, afinal, como bem afirmou Mies, a teologia, "se remete à Bíblia, e a toda a Bíblia"17. Portanto, "a história da teologia é, nesse sentido, a história das leituras e das releituras, dos usos e das reutilizações das Escrituras" $"$. Sob esses pressupostos, constata-se que toda pesquisa teológica está, direta ou indiretamente, permeada pelas Escrituras. Compreender como as Escrituras se difundiram na história constitui, portanto, uma relevante contribuição com a teologia e a história da Igreja. Nesse sentido, como advertiu Lortz, "a história da Igreja é teologia"19. Por isso, quando se discorre sobre a história da difusão das Escrituras propriamente dita, se discorre, também, sobre a teologia imbricada nela. Da mesma forma há significativa importância para a igreja cristã no Brasil, afinal,

Em meio a toda a agitação que cerca a vivência da fé cristã neste mundo plural e secularizado em que vivemos, encontramos talvez muito poucas unanimidades.

\footnotetext{
15 CAMPOS, Leonildo Silveira. Bíblias no Mercado: o poder dos consumidores e a competição entre os editores - o caso da Sociedade Bíblica do Brasil. Rever, ano 12, n. 2, jul/dez, 2012, pp. 35-61.

${ }^{16}$ QUEIROZ, Martha Maria Romeiro de. Do plurilingüismo em Babel ao ecumenismo na tradução bíblica: o caso da versão católica da Bíblia Sagrada - Nova Tradução na Linguagem de Hoje. Dissertação de Mestrado. Pontificia Universidade Católica do Rio de Janeiro: Rio de Janeiro, 2007, 265p.

${ }^{17}$ MIES, Françoise. Bíblia e teologia: a inteligência da fé. São Paulo: Loyola, 2011, p. 11

18 DORIVAL, Gilles. Antiguidade Cristã Grega e Bíblia. In: LONGTON, Joseph; POSWICK, Réginald-Ferdinand [et al.] (orgs.). Dicionário Enciclopédico da Bíblia. São Paulo: Loyola, Paulinas, Paulus; Santo André: Academia Cristã, 2013, p. 100

${ }^{19}$ LORTZ, Joseph. Historia de La Iglesia: en la perspectiva de la historia del pensamiento. Antiguedad y edad media. Vol. I. Madrid: Ediciones Cristandad, 1965, p. 5 (tradução nossa).
} 
Não existem muitos pontos de convergência onde todos os cristãos coincidam em termos do que lhes ajuda a viver sua fé [...]. No entanto, podemos afirmar que a Bíblia é sem dúvida uma delas, senão a maior, a mais importante e muitas vezes a única ${ }^{20}$.

Nessa perspectiva, desde a sua fundação, em 1948, a Sociedade Bíblica do Brasil procura servir as igrejas, visto que por elas foi criada. Mesmo que historicamente a fundação da SBB tenha sido realizada pelas igrejas evangélicas daquele contexto histórico, atualmente a SBB procura servir todas as igrejas cristãs com as Escrituras Sagradas. As inúmeras publicações existentes, tanto para servir às igrejas protestantes quanto para servir a Igreja Católica corroboram essa afirmação. Tal realidade se evidenciará na apresentação dos fatos nesta pesquisa. Há, portanto, significativa importância da pesquisa para a igreja brasileira, afinal, a Bíblia é o livro do povo cristão, é o livro da igreja.

Como afirma Mesters, a Bíblia tem implicância direta na forma do povo viver, afinal "grande parte das coisas que estão na Bíblia nasceu assim da vida do povo simples"21. Nessa perspectiva, a Bíblia é relevante para todos os tempos e todos os povos, pois ela emerge da realidade cotidiana das pessoas. A história da difusão das Escrituras é, também, nesse sentido, a história das pessoas, da igreja e da sociedade. Dessa forma, essa pesquisa também se caracteriza pela relevância à sociedade. Afinal, as ações desenvolvidas por meio dos diferentes programas bíblicos desenvolvidos pela Sociedade Bíblica do Brasil, nos mais diferentes contextos sociais do país, têm contribuído significativamente com a forma de viver do povo brasileiro.

Torna-se necessário ressaltar, igualmente, a experiência pessoal do autor na realização desse trabalho. Trata-se de um grande privilégio estudar e escrever esta pesquisa, principalmente pelo interesse existente pela temática. Durante todo o processo de escrita desta tese, a sensação era de como se estivesse realizando uma viagem pela história das Escrituras. Foi possível imergir nela, tornando, assim, o processo emocionante, estimulador e desafiador para a caminhada que ainda precisa ser trilhada, tanto na vida quanto no ministério pastoral.

\footnotetext{
${ }^{20}$ FERNANDES, Leonardo Agostini. A Bíblia e sua mensagem: introdução à leitura e ao estudo da Bíblia. Rio de Janeiro: PUC-Rio; São Paulo: Reflexão, 2010, p. 9.

${ }^{21}$ MESTERS, Carlos. Palavra de Deus na história dos homens. $2^{\circ}$ volume. Petropólis: Vozes, 1971, p. 23.
} 


\title{
1.1 Questões metodológicas da pesquisa
}

O presente trabalho se desenvolve sob as bases de uma pesquisa histórica e se concentra na área da teologia sistemática-pastoral. A questão investigativa que emerge se dá na apreensão sobre como se desenvolveu a missão de difundir as Escrituras. Nessa perspectiva, essa tese pretende analisar a caminhada histórica da atuação das Sociedades Bíblicas no Brasil, sob a ótica da difusão das Escrituras Sagradas. O objeto material se estabelece na difusão das Escrituras Sagradas no Brasil e o objeto formal se dá por meio da atuação das Sociedades Bíblicas nessa difusão. Espera-se que, com esse trabalho, se possa evidenciar, tanto no aspecto pessoal quanto no aspecto comunitário eclesial, a importância de uma missão voltada para a difusão das Escrituras.

A pesquisa bibliográfica foi escolhida para a realização desta investigação. Para tanto, realizou-se uma revisão de literatura por meio de teóricos que contribuem para a análise das questões anteriormente soerguidas e com os objetivos propostos pela pesquisa. Nesse sentido, Gressler ${ }^{22}$ destaca a importância de uma revisão bibliográfica ou de literatura quando diz que:

\begin{abstract}
A revisão bibliográfica possibilita uma melhor posição para se interpretar os resultados de um novo estudo, permitindo a realização de implicações teóricas e comparações úteis, bem como a localização dos resultados do estudo no corpo de conhecimentos existente.
\end{abstract}

Portanto, no caminho que foi trilhado nesta investigação, foram utilizadas as produções teóricas que focalizam, descrevem e analisam a temática proposta. Nesse sentido, biblistas e historiadores da igreja contribuíram significativamente nessa perspectiva; isso se evidencia em cada capítulo. Há de se considerar, entretanto, que a difusão das Escrituras é pouco discutida. Há pouco referencial teórico-bibliográfico sobre a difusão das Escrituras Sagradas. Se fez necessário, portanto, "garimpar" nos teóricos relacionados - historiadores da igreja e biblistas os elementos que evidenciam o assunto.

Considerando a temática, as contribuições de Giraldi e Steer foram de significativa importância. A escolha de Giraldi se justifica devido a produção literária de várias obras do autor que descrevem a História da Bíblia no Brasil. Steer, por

${ }^{22}$ GRESSLER, Lori Alice. Introdução à pesquisa: projetos e relatórios. São Paulo: Loyola, 2004, p. 132. 
sua vez, contribuiu significativamente ao narrar a história e o trabalho das Sociedades Bíblicas no mundo, desde a sua fundação. Para além destes referenciais teóricos, fez-se necessário contemplar, também, a pesquisa documental, incorporando alguns documentos internos da organização, tais como a Revista A Bíblia no Brasil, estatuto, relatórios, entre outros - úteis para a análise. Carvalho ${ }^{23}$ ressalta que este tipo de análise:

É aquela realizada a partir de documentos considerados autênticos (não fraudados); e tem sido largamente utilizada na investigação, a fim de descrever/comparar fatos sociais, estabelecendo suas características ou tendências. Além das fontes primárias, os documentos propriamente ditos, utilizam-se das fontes chamadas secundárias, como dados estatísticos, elaborados por institutos especializados e considerados confiáveis para a realização da pesquisa.

Foi sob esses pressupostos que os Plano Nacional de Trabalho e Relatório Nacional de Trabalho, editados anualmente pela SBB, também serviram como base de análise das ações realizadas pela organização em seu trabalho de difusão das Escrituras. De forma concomitante, alguns documentos de acesso exclusivo por meio eletrônico, tais quais, sites e e-mails, por exemplo, foram igualmente utilizados ${ }^{24}$. Excepcionalmente no último capítulo, em que se descreveu o trabalho de difusão das Escrituras realizado pela Sociedade Bíblica do Brasil, se fez necessário utilizar uma metodologia diferente e especifica. Tal necessidade decorre do próprio método utilizado pela SBB para realizar e comunicar a forma pela qual desenvolve seu trabalho, isto é, o ciclo de vida da Bíblia. Como este instrumento foi elaborado a partir de algumas categorias específicas (disponibilidade, acessibilidade e relevância), optou-se em realizar a descrição dos fatos a partir da análise de conteúdo. De acordo com Janis,

A análise de conteúdo fornece meios precisos para descrever o conteúdo de qualquer tipo de comunicação: jornais, programas de rádio, filmes, conversações quotidianas, associações livres, verbalizadas, etc. As operações da análise de conteúdo consistem em classificar os sinais que ocorrem em uma comunicação segundo um conjunto de categorias apropriadas ${ }^{25}$.

\footnotetext{
${ }^{23}$ CARVALHO, Maria Cecília Maringoni. Construindo o saber - Metodologia científica: fundamentos e técnicas. Campinas: Papirus, 1997, p. 154.

${ }^{24}$ FERREIRA, Sueli Mara Soares Pinto; KROEFF, Márcia Silveira. Referências bibliográficas de documentos eletrônicos. v. 1, Ensaios APB, n.35. São Paulo: APB, 1996, p. 6.

${ }^{25}$ JANIS, Irving Lester. O problema da validação da análise de conteúdo. In: LASSWELL, Harold; KAPLAN, Abraham. A linguagem da política. Brasília: Editora da Universidade de Brasília, 1982, p. 53.
} 
A tradução bíblica escolhida para a citação das Escrituras Sagradas, utilizada na pesquisa, foi, preferencialmente, a Nova Tradução na Linguagem de Hoje $(\mathrm{NTLH})^{26}$. A escolha da referida tradução se dá por dois motivos. O primeiro é o fato de que a linguagem utilizada pela NTLH facilita a fluência do texto e a compreensão do leitor e, em segundo lugar, pelo fato de que a NTLH é uma tradução bíblica aceita e utilizada tanto por católicos como por protestantes. Em raras exceções, obviamente destacadas nas notas de rodapé, as traduções Almeida Revista e Atualizada (ARA) ${ }^{27}$ e a Bíblia de Jerusalém (BJ) ${ }^{28}$ também foram utilizadas. Tais usos acontecem quando as palavras ou versículos utilizados nestas respectivas traduções contemplam com melhor acuidade a intenção e o contexto em que o texto está inserido.

Para além destas questões, vale ressaltar que essa tese não se propôs a analisar toda a história da difusão das Escrituras. Tal tarefa seria praticamente impossível. Também não se propôs a desenvolver uma análise sobre a leitura da Bíblia no meio católico ou protestante. Nem mesmo foi desenvolvida para analisar a teologia bíblica de ambos os segmentos e os seus respectivos desdobramentos. Pelo contrário, todos os relatos foram descritos a partir da temática proposta, ou seja, a atuação das Sociedades Bíblicas no Brasil no trabalho de difusão das Escrituras. No entanto, isso não quer dizer que não se fez necessário introduzir o tema sob uma perspectiva histórica bem anterior ao início do trabalho das Sociedades Bíblicas. Essas questões são percebidas nos dois primeiros capítulos, pois a maioria dos assuntos se entrelaçam em algum momento histórico posterior.

Se faz necessário observar, ainda, que o presente trabalho também não pretende ser uma análise introdutória à Bíblia ou ao seu cânon. Igualmente, não é uma análise literária, textual, hermenêutica, exegética ou crítica da Bíblia. Também não está firmado na análise das fontes, das tradições e das redações. Não é uma história do texto em si. Tudo isso pode até aparecer em um momento ou outro no decorrer da pesquisa, mas não constitui seu objeto de estudo. Aliás, existe muito material produzido sobre essas temáticas.

\footnotetext{
${ }^{26}$ Cf. BÍBLIA Sagrada. Português. Bíblia de Estudo NTLH. Nova Tradução da Linguagem de Hoje. Barueri: Sociedade Bíblica do Brasil, 2005.

${ }^{27}$ Cf. BÍBLIA Sagrada. Português. Bíblia de Estudo Almeida. Trad. de João Ferreira de Almeida, versão Revista e Atualizada. Barueri: Sociedade Bíblica do Brasil, 2006.

${ }^{28}$ Cf. BÍBLIA Sagrada. Português. Bíblia de Jerusalém. São Paulo: Paulus, 2002
} 
Essa pesquisa, portanto, se propõe a descrever como as Escrituras Sagradas se difundiram a partir de um viés da história. Por isso, essa investigação não se caracteriza como um texto generalista ou exclusivista. Ela tem seu objeto, seu foco na descrição histórica de como as Escrituras Sagradas foram difundidas a partir da atuação das Sociedades Bíblicas no Brasil.

\section{2 \\ A estrutura da tese: o conteúdo e a sua distribuição}

Na seção introdutória constam informações que procuram contextualizar o assunto e delimitar o tema, estabelecendo o objeto de estudo pelo qual a pesquisa foi desenvolvida. O segundo capítulo se desenvolve sob uma análise histórica, tanto numa perspectiva bíblica quanto numa perspectiva eclesial. Tal relato teve início a partir do conceito da oralidade, a primeira forma pela qual a Palavra de Deus começou a ser transmitida e apreendida pelos seres humanos. Na caminhada, procurou-se descrever como ocorreram, por conseguinte, os primeiros registros para que, atualmente, se pudesse se conceber a ideia de uma Escritura Sagrada. Em seguida, foram analisados o contexto histórico da primeira tradução da Bíblia, a Septuaginta, para, posteriormente, apreender a forma como Jesus e os apóstolos difundiram as Escrituras. A análise bíblica da história da difusão das Escrituras se limitou até aqui.

Posteriormente, a descrição se estabeleceu na forma que os Pais da Igreja difundiram as Escrituras, incluindo, entre eles, Orígenes e Jerônimo. O trabalho bíblico realizado no período do monasticismo também foi considerado. Após esse período, a análise se voltou para a maneira pela qual as Escrituras foram difundidas no contexto histórico da Idade Média. Na parte final do capítulo, sob uma perspectiva mais ampla, foram analisadas como as Escrituras foram difundidas por meio da arte e da literatura.

O terceiro capítulo foi desenvolvido por meio da análise histórica do início do período das Reformas da igreja, tanto no viés da Reforma Protestante quanto na Contrarreforma Católica e, se estendeu até uma análise mais contemporânea sobre como as Escrituras foram difundidas. Na caminhada foram analisadas questões que instigaram o movimento e a participação de alguns precurssores da Reforma em suas relações com as Escrituras. Foram também desenvolvidas análises 
sobre como os reformadores protestantes utilizaram as Escrituras como um meio para propagar as suas respectivas mensagens. Por conseguinte, foram analisadas como a Contrarreforma Católica se desenvolveu, limitando todas estas análises ao objeto da pesquisa, isto é, as questões em torno das Escrituras e a sua difusão.

Em seguida, foram analisadas como se desenvolveu a difusão das Escrituras a partir do contexto pós-reforma até a contemporaneidade. Nesse ínterim, foram analisados os contextos das confissões de fé, pietismo puritanismo, iluminismo e liberalismo teológico. Procurando contextualizar a temática sobre a difusão das Escrituras na atualidade, desenvolveu-se uma reflexão sobre as questões contemporâneas da difusão das Escrituras nas igrejas católica e protestante. Sob uma perspectiva mais ampla, introduziu-se também como as Escrituras Sagradas difundiram-se no Brasil nos tempos da Colônia e início do Império.

Depois de discorrer numa análise mais ampla da história da difusão das Escrituras, o quarto capítulo foi desenvolvido sob uma análise mais voltada ao objeto de estudo, ou seja, procurou-se aprofundar a análise histórica do trabalho de difusão das Escrituras realizado pelas Sociedades Bíblicas. Para tanto, descreveuse como se deu o surgimento das Sociedades Bíblicas, tanto numa perspectiva do relato fundante de Mary Jones como no movimento criado pelas igrejas no intuito de criar uma organização bíblica. Evidenciaram-se, assim, algumas dificuldades surgidas nos primeiros anos de existência das Sociedades Bíblicas, tanto no campo católico como no protestante.

Posteriormente, a análise se voltou novamente para o Brasil, a partir dos relatos de como as Sociedades Bíblicas começaram a realizar o trabalho de difusão das Escrituras no país. Nessa análise, foram contemplados os aspectos históricos do trabalho durante os períodos do Império e início da República. Em seguida, foi desenvolvido um relato histórico de como o trabalho dos colportores bíblicos, em missão pelas Sociedades Bíblicas, contribuiu com a difusão das Escrituras Sagradas no Brasil.

No quinto capítulo, realizou-se uma análise histórica de como se desenvolveu o trabalho de difusão das Escrituras realizado pela Sociedade Bíblica do Brasil, a partir de 1948. No início do capítulo foram descritos o contexto histórico que possibilitou a criação da SBB, bem como sua constituição, finalidade e missão. Por conseguinte, foram analisados como a SBB procura realizar seu trabalho a partir do ciclo de vida da Bíblia. Nessa perspectiva, procurando contemplar aspec- 
tos históricos atrelados às questões contemporâneas do trabalho realizado pela $\mathrm{SBB}$, a pesquisa se desenvolveu sob a análise das três categorias especificas do ciclo de vida da Bíblia: disponibilidade, acessibilidade e relevância.

$\mathrm{Na}$ categoria da disponibilidade se discorreu como a SBB procura difundir as Escrituras no Brasil por meio da tradução da Bíblia. Para tanto, foram analisadas a história e os princípios que permeiam as traduções da SBB. Em seguida analisou-se como a SBB realiza o trabalho de publicações das Escrituras e constatouse como a Gráfica da Bíblia tem contribuído com a difusão da Bíblia no Brasil e no mundo.

$\mathrm{Na}$ categoria da acessibilidade se discorreu sobre como a SBB procura facilitar o encontro das pessoas com as Escrituras Sagradas. Constatou-se inúmeras formas que a SBB utiliza para tornar a Bíblia mais acessível no contexto diversificado do país. Essas formas contemplam a implantação de unidades regionais, o trabalho de colportores e a realização de alguns programas especiais de propagação bíblica. Foram igualmente analisados os programas bíblicos de impacto social que, ao serem desenvolvidos pela SBB, evidenciam uma missão holística na realização do trabalho bíblico. Em seguida, constatou-se como a SBB desenvolve ações que incentivam a leitura bíblica pelo povo brasileiro. Todas estas ações são realizadas a fim de tornar a difusão das Escrituras mais significativa por meio do acesso das pessoas à Bíblia.

Na categoria relevância, se discorreu sobre como a SBB procura realizar o trabalho que enfoca a importância das Escrituras Sagradas na vida do povo brasileiro e da igreja cristã do país. Analisou-se alguns programas de difusão bíblica que a SBB realiza no intuito de envolver as pessoas, das mais diferentes igrejas e nos mais variados contextos, com a causa da Bíblia. Essas pessoas propagam as Escrituras, oram e contribuem pela causa da Bíblia. Por último, relatou-se como a SBB procura ressaltar a credibilidade das Escrituras Sagradas por meio da valorização da história da Bíblia e, também, por meio da realização de encontros temáticos que envolvem as Ciências Bíblicas. 


\section{2 \\ Perspectivas históricas na difusão das Escrituras Sagradas: da transmissão oral à Idade Média}

A Bíblia, Palavra de Deus na história dos seres humanos; esse é um dos pressupostos basilares para a compreensão deste capítulo, afinal, a Bíblia é o livro "que mais influência tem exercido em toda a história da humanidade" ${ }^{29}$. As Escrituras Sagradas estabelecem, em sua gênese, a história da revelação e do favor de Deus em sua relação com o ser humano; concomitantemente, são o relato de como o ser humano fez parte dessa mesma história. Assim,

Perceber o nível de envolvimento entre a Bíblia e a história é tomar conhecimento da convicção central daqueles que escreveram o AT e o NT: que a sua divindade - o Deus do Israel antigo e do judaísmo e do cristianismo - era um ser divino que penetrou na história humana e organizou as coisas nos termos do seu próprio plano para a humanidade. Ao fazê-lo, ele tanto realizou os seus propósitos como se revelou ao povo ${ }^{30}$.

Dessa forma, Deus, em sua iniciativa, falou ao seu povo, e esse povo, considerando a importância da fala divina em sua própria existência, com o passar do tempo, registrou, transmitiu e difundiu essa mensagem às gerações futuras.

Este povo, pela sua história religiosa, percebeu-se escolhido, isto é, vocacionado por Deus para servir e ser mediador entre os homens e sua Palavra. Pode-se dizer que Deus, de algum modo, encarnou o seu pensamento e a sua vontade salvífica na sensibilidade, na mentalidade e na história do povo que Ele escolheu para ser o depositário e o protagonista-guardião da sua Revelação ${ }^{31}$.

Eis, portanto, a Palavra de Deus adentrando a história e mudando-a. Por isso, é possível afirmar que a Bíblia é um livro com muita história. A própria "história da Bíblia é a história da Palavra de Deus aos homens" ${ }^{32}$. Existem histórias nela, histórias sobre ela, mas existem, também, histórias a partir dela ${ }^{33}$. Aquelas

\footnotetext{
${ }^{29}$ GEISLER, Norman; NIX, William. Introdução bíblica: como a Bíblia chegou até nós, p. 5.

${ }^{30}$ GABEL, John; WHEELER, Charles. A Bíblia como literatura, p. 49.

${ }^{31}$ FERNANDES, Leonardo Agostini. A Bíblia e sua mensagem: introdução à leitura e ao estudo da Bíblia, p. 15.

${ }^{32}$ MANNUCCI, Valério. Bíblia, Palavra de Deus: curso de introdução à Sagrada Escritura. São Paulo: Paulus, 1985, p. 15.

${ }^{33}$ Ressalta-se que as Escrituras fazem referência à sua própria existência e importância quando utilizam expressões como "Escritura" (2Tm 3,16), "Palavra" (Hb 4,12), "Lei” (Js 1,8) etc.
} 
podem ser lidas na própria Bíblia. Estas, em especial, constituem "as memórias dos fatos vividos por um povo na história da humanidade"34. São, por assim dizer, histórias de como o povo de Deus recebeu, leu e transmitiu os Escritos Sagrados desde os tempos mais remotos até o presente. Afinal,

Um povo não começa sua história escrevendo livros. Primeiro se vive e depois se escreve para recordar o que se viveu e oferecê-lo como lição de vida às futuras gerações. Os livros são a "memória" privilegiada dos povos. Também o povo de Deus, o antigo e o novo Israel, fixaram a sua história e a sua experiência numa memória escrita: a Bíblia ${ }^{35}$.

Nessa perspectiva, a afirmação de Mesters tem muita propriedade pois, de fato, a Bíblia é um "livro feito em mutirão" 36 , não reduzindo em nada, porém, sua legítima e divina procedência. A Bíblia é a Palavra de Deus na história dos seres humanos. Obviamente, além de improvável, seria muito pretensioso descrever com exatidão e completude o caminho percorrido na difusão da Palavra de Deus desde o início. Além de ser praticamente impossível determinar esse começo, uma investigação cuidadosa constatará uma história ampla, e mesmo que fosse possível acessar todo o material existente para essa tarefa, seguramente, o objeto desta pesquisa seria alterado ou, pelo menos, prejudicado.

Há de se considerar ainda que, por tal amplitude, seria difícil descrevê-la com total neutralidade. Em cada história, em cada obra escrita sobre a Bíblia, há sempre um ponto de partida, uma teologia que permeia a narrativa. Neutralidade, portanto, mesmo sob o rigor acadêmico que se espera, se torna algo muito difícil, desde a leitura até a interpretação e a descrição dos fatos históricos ocorridos. Isso não limita, obviamente, a necessidade ou até mesmo o desejo de se descrever um pouco dessa caminhada histórica das Escrituras Sagradas. Aliás, muitos já o fizeram, cada um, como já afirmado, a partir de suas ênfases e de suas intenções. As referências ao final desta pesquisa podem contribuir significativamente com o leitor interessado na temática.

Sendo assim, o objetivo deste capítulo é descrever, ainda que com as devidas limitações, como as Escrituras Sagradas foram difundidas na história: na sua própria história e na história do povo de Deus. O recorte temporal, neste capítulo, se dá entre o início das primeiras compreensões da revelação da Palavra de Deus

\footnotetext{
${ }^{34}$ KONINGS, Johan. A Bíblia, sua origem e sua leitura: introdução ao estudo da Bíblia. Petrópolis: Vozes, 2014, p. 43.

${ }^{35}$ MANNUCCI, Valério. Bíblia, Palavra de Deus: curso de introdução à Sagrada Escritura, p. 74.

${ }^{36}$ MESTERS, Carlos. Bíblia: livro feito em mutirão. São Paulo: Paulus, 1993, p. 3.
} 
na vida do povo escolhido, quando ela foi recebida e transmitida de forma oral, até o fim da Idade Média. Acrescenta-se, ainda, uma seção especial onde se analisa como a arte, a literatura, a música e outras expressões artísticas contribuíram nessa difusão por um período que se estende da Antiguidade à contemporaneidade. Espera-se que seja possível perceber como, nessa caminhada, o povo de Deus, no antigo Israel ou na atual igreja de Cristo, realizou a difusão das Escrituras e que implicações teológicas advieram, por vezes imbricadas, nessa caminhada histórica.

\section{1}

\section{A difusão da Palavra de Deus antes dos escritos}

A Bíblia não caiu do céu, não foi entregue por um anjo e não foi escrita em um momento psicográfico. Como bem afirma Scholz, ela "foi escrita por pessoas, que usaram linguagem de gente" ${ }^{37}$. No início, entretanto, a palavra escrita não existia $^{38}$. Era a palavra falada que se difundia. Por isso, "a história de Deus com o seu povo é uma história que fala" 39 . Ainda que a história de como a mensagem foi revelada seja diversificada, e, por vezes, segundo os relatos bíblicos, experiências místicas tenham ocorrido em sua composição, a Palavra de Deus, por ser falada, esteve bastante atrelada ao cotidiano das pessoas. Ela "surgiu da terra, da vida do povo de Deus. Surgiu como fruto da inspiração divina e do esforço humano" 40 . Por assim ser, "nada impede que, sendo escrita por homens, tenha sua origem em Deus" $"$.

Por ser fruto de uma revelação, obviamente, a iniciativa é toda divina. É o próprio Deus que decide se revelar ao ser humano, culminando "na plenitude dos tempos" (Gl 4,4), o ápice de sua revelação com a encarnação do "verbo de Deus", do próprio Cristo (Jo 1,1-14). Mesmo que situações sobrenaturais tenham ocorrido

${ }^{37}$ SCHOLZ, Vilson. Princípios de interpretação bíblica: introdução à hermenêutica com ênfase em gêneros literários. Canoas: ULBRA, 2006, p. 13.

${ }^{38}$ Os primeiros sistemas de escrita do mundo surgiram na Mesopotâmia (atual Iraque). Era um tipo de escrita denominada "cuneiforme". A palavra "cuneiforme tem origem na palavra latina cuneus que significa 'cunha', referindo-se à forma dos sinais usados na escrita cuneiforme [...]. No Egito, onde os descendentes de Jacó trabalhavam como escravos, estavam em uso os hieróglifos" (MILLER, Stephen; HUBER, Robert. A Bíblia e sua história: o surgimento e o impacto da Bíblia. Barueri: Sociedade Bíblica do Brasil, 2006, p. 14).

${ }^{39}$ MANNUCCI, Valério. Bíblia, Palavra de Deus: curso de introdução à Sagrada Escritura, p. 43.

${ }^{40}$ MESTERS, Carlos. Bíblia: livro feito em mutirão, p. 9.

${ }^{41}$ SCHOLZ, Vilson. A Bíblia: sua natureza, funções e finalidade. In: ZIMMER, Rudi (Org.). Manual do Seminário de Ciências Bíblicas, pp. 7-8. 
nesse processo revelacional, normalmente, quando se manifesta, Deus o faz no cotidiano da vida humana; afinal, sua revelação é uma forma de apresentar seu plano para a humanidade. Esse plano, por certo, envolve toda uma vida. Envolve o presente e o futuro.

As pessoas que viviam nos tempos bíblicos não imaginavam que um dia essas experiências, escritas naqueles momentos ou até mesmo posteriormente, constituiriam o que atualmente se concebe como a Bíblia Sagrada. Essas pessoas simplesmente viviam. Assim, elas foram formando um povo, uma comunidade, e a fé em Deus era a essência de sua existência. Essa fé não era vazia; ela levava a obedecer a Deus e a viver de forma justa. Esse era o eixo da vida. Elas construíram sua história e, assim, com o passar do tempo, pessoas de fé reconheceram a Palavra de Deus nessas histórias. Humanamente falando, assim nasceu a Bíblia: a partir da revelação de Deus ao seu povo e da "vontade do povo de ser fiel a Deus [...]; nasceu da preocupação de transmitir aos outros e a nós esta mesma vontade de ser fiel" ${ }^{42}$.

E assim, a Escritura ajudou a construir "a história do povo de Israel, desde Abraão até a destruição do Templo de Jerusalém" ${ }^{43}$. Essa história transmitida, história de Deus e do povo de Deus, narrava os relatos da criação, do dilúvio, da chamada de Abrão ${ }^{44}$ e de como ele obedeceu a Deus, formando sua família e se estabelecendo no que hoje é conhecido como "terra santa" ou "terra bíblica". Era também a história de como o povo foi para o Egito e, depois, de lá, saiu por meio de um libertador, Moisés. Era uma história de sofrimento, mas também da fé de um povo - um povo escolhido por Deus, que recebeu sua revelação e a transmitiu. Assim, “os hebreus contavam e recontavam suas histórias, muitas das quais foram registradas na Bíblia" ${ }^{45}$. Era, portanto, uma história transmitida de boca em boca; era a transmissão oral. Era uma forma de contar a história, valorizar a cultura e transmitir a fé.

Trebolle Barrera ${ }^{46}$ destaca que essa forma de se contar a história, de transmiti-la oralmente, não era exclusiva dos hebreus ou restrita a eles. Outros povos,

\footnotetext{
${ }^{42}$ MESTERS, Carlos. Bíblia: livro feito em mutirão, p. 10.

${ }^{43}$ MIRANDA, Evaristo Eduardo de. Bíblia: história, curiosidades e contradições. Petrópolis: Vozes, 2015, p. 11.

${ }^{44}$ Depois chamado de Abraão.

${ }^{45}$ MILLER, Stephen; HUBER, Robert. A Bíblia e sua história: o surgimento e o impacto da Bíblia, p. 12.

${ }^{46}$ Cf. BARRERA, Júlio Trebolle. A Bíblia judaica e a Bíblia cristã, p. 126.
} 
tais quais os babilônios, também possuíam suas histórias, algumas semelhantes às histórias do povo de Deus e, da mesma forma, transmitidas oralmente. Era algo comum, era algo da vida. E foi dessa forma que o povo escolhido difundiu a Palavra revelada de Deus no início da história.

Portanto, "antes de ser escrita, a Bíblia foi narrada e contada nas rodas de conversa e nas celebrações" 47 . Independentemente da forma, a Palavra de Deus era continuamente transmitida, e mesmo depois de os registros por escrito iniciarem, o povo de Deus continuou transmitindo a Palavra de Deus por meio da oralidade. Pode-se dizer que a oralidade nunca deixou de acompanhar a história do povo escolhido, da igreja de Cristo e das Escrituras Sagradas. Era "a Bíblia antes da Bíblia"48. Assim se difundia a Palavra de Deus, muito antes de o Livro Sagrado ser compilado nos diversos formatos que o compuseram na história - e assim "a Palavra de Deus foi preservada no coração do seu povo"49.

\section{2 \\ A difusão da Palavra de Deus em transição: da oralidade aos primeiros registros}

Ainda que seja "praticamente impossível determinar o tempo que durou a transmissão oral" ${ }^{\prime 50}$ das Escrituras Sagradas, é evidente que, por meio da oralidade, os relatos eram mantidos bem vividos no cotidiano do povo de Deus durante toda a sua existência. É por isso que, considerando a importância dessas histórias, acatadas pelo próprio povo como Palavra de Deus, percebeu-se que era importante escrevê-las.

Há, na Bíblia, muitos imperativos ligados à oralidade: "dize" (Is 40,9), "proclama" (Jr 7,2), "anuncia" (Ez 40,4), "prega" (2Tm 4,2), "fala" (Tt 2,1). Fica a impressão de que muito se fala sobre a palavra oral, e pouco ou quase nada sobre a palavra escrita. [...] O verbo escrever aparece 453 vezes na Bíblia (242 vezes no Antigo Testamento; 193 vezes no Novo Testamento) ${ }^{51}$.

Como se percebe, mesmo que um fato não exclua o outro, há uma clara transição da oralidade à escrituração. Na história, a escrita do povo de Deus, por

\footnotetext{
${ }^{47}$ MESTERS, Carlos. Bíblia: livro feito em mutirão, p. 15.

${ }^{48}$ KONINGS, Johan. A Bíblia, sua origem e sua leitura: introdução ao estudo da Bíblia, p. 61.

${ }^{49}$ SCHOLZ, Vilson. A transmissão do texto bíblico. In: ZIMMER, Rudi (Org.). Manual do Seminário de Ciências Bíblicas. Barueri: Sociedade Bíblica do Brasil, 2008, p. 27.

${ }^{50}$ SOCIEDADE BÍBLICA COLOMBIANA. Introducción a La Bíblia. Bogotá: Sociedade Bíblica Colombiana, 2010, p. 47 (tradução nossa).

${ }^{51}$ SCHOLZ, Vilson. Op. cit., p. 27.
} 
meio do alfabeto hebraico ${ }^{52}$, surgiu com o definitivo estabelecimento do povo de Deus em sua terra, em Canaã. Por isso, a maioria dos livros denominados pelos cristãos como o Antigo Testamento ou pelos judeus como o TaNaKh foram escritos em hebraico.

Inicialmente, essa era a língua com a qual o povo de Deus recebeu, transmitiu e difundiu as Escrituras Sagradas na história. Foram esses escritos que marcaram este povo, definindo-o mais tarde como uma nação religiosa, que recebeu as leis de Deus, as registrou e as difundiu nas diversas gerações. O povo de Deus se tornou o povo da Lei de Deus. E a Lei de Deus constituiu a identidade daquele povo como nação. Aliás, “o primeiro caso de 'canonização de facto' de um escrito bíblico talvez tenha sido a recepção dos Dez Mandamentos gravados na pedra ${ }^{53}$ por Moisés" $" 54$. Por isso, a difusão, nesse momento da história, era algo vital para esse povo. A Palavra de Deus deveria ser difundida. Era algo para muito além de um rito religioso; era algo da vida e da família.

\begin{abstract}
São esses os mandamentos e as leis que o SENHOR, nosso Deus, mandou que eu ensinasse a vocês. Portanto, obedeçam a esses mandamentos na terra em que vão entrar e que vão possuir. Temam o SENHOR, nosso Deus, vocês, os seus filhos e os seus netos, e cumpram sempre todos os mandamentos e leis que eu lhes estou dando e assim vocês viverão muitos anos. Povo de Israel, tenha o cuidado de cumprir a lei de Deus. Então, conforme disse o SENHOR, o Deus dos nossos antepassados, tudo correrá bem para vocês, e vocês se tornarão numerosos naquela terra boa e rica onde vão viver. - Escute, povo de Israel! O SENHOR, e somente o SENHOR, é o nosso Deus. Portanto, amem o SENHOR, nosso Deus, com todo o coração, com toda a alma e com todas as forças. Guardem sempre no coração as leis que eu lhes estou dando hoje e não deixem de ensiná-las aos seus filhos. Repitam essas leis em casa e fora de casa, quando se deitarem e quando se levantarem. Amarrem essas leis nos braços e na testa, para não as esquecerem; e as escrevam nos batentes das portas das suas casas e nos seus portões ${ }^{55}$ (Dt 6,1-9).
\end{abstract}

\footnotetext{
${ }^{52}$ A língua hebraica pertence à família das línguas semíticas, surgidas no segundo milênio a.C., na região do atual Oriente Médio. Esta designação tem sua raiz em um dos filhos de Noé, o personagem bíblico Sem (Gn 10,21-31) que, conforme consta, foi o ancestral dos povos de origem semita. A língua hebraica é, também, reconhecida na própria Escritura como "a língua de Canaã" (Is 19,18) ou "judaico" (2Rs 18,26-30; Is 36,11-13; Ne 13,24). Cf. BARRERA, Júlio Trebolle. A Bíblia judaica e a Bíblia cristã, pp. 68-69.

${ }^{53}$ Antes dos famosos papiros ou pergaminhos, diversos materiais serviram como superfície para a escrituração bíblica, tais quais: pedras, óstracos (pequenas peças de cerâmica), tábuas de argila, ferro, bronze, metais, pedaços de madeira. Cf. SEMBLANO, Martinho Lutero. Materiais, formatos e instrumentos utilizados no processo de escrituração da Bíblia. Rio de Janeiro: Scriptura, 2013, p. 31.

${ }^{54}$ KONINGS, Johan. A Bíblia, sua origem e sua leitura: introdução ao estudo da Bíblia, p. 156.

${ }^{55}$ BÍBLIA Sagrada. Português. Bíblia de Estudo NTLH. Dt 6,1-9 (grifo nosso).
} 
A Palavra de Deus era algo que deveria permear toda a vida do povo e, por isso, era importante "expressar e transmitir aos outros" 56 . Eles deveriam ler, obedecer, guardar no coração, repetir no convívio familiar e fora dele, ensinar aos filhos e aos netos e transmitir às gerações futuras. Era assim que a Palavra de Deus era difundida e, sem dúvida, essa forma de propagação influenciou a difusão das Escrituras em todos os momentos.

Com o passar do tempo, todavia, entre outros aspectos, foi a ausência de um paradigma firmado no cumprimento da Palavra de Deus que fez o povo de Deus enfrentar momentos difíceis. Enquanto na liderança de Josué, sucessor de Moisés, a Lei era uma referência (Js 1,8), nas gerações futuras, no tempo dos Juízes, o povo, segundo os relatos bíblicos, se afastou da Palavra do Senhor (Jz 2,20-23), passando a experimentar momentos complicados de sua história.

No tempo dos primeiros reis de Israel, a diligência em relação às leis de Deus volta a ter sua proeminência. Miller e Huber ${ }^{57}$ destacam que uma grande contribuição de Davi foi a de registrar as histórias de seu tempo que, posteriormente, se tornariam Escritos Sagrados. Davi fez isso "ao pedir que se escrevesse a história da nação emergente que ele governava" ${ }^{" 58}$. A própria narrativa bíblica pode ter registrado a importância que o rei deu a esse fato ao apresentar entre os oficiais nomeados por Davi dois escritores: “Josafá, filho de Ailude, era o cronista. Seva, o escrivão" (2Sm 20,24-25) ${ }^{59}$. Não se sabe o que eles escreveram. Mas é bem possível que aquilo que escreveram tenha se difundido, favorecendo e compondo as histórias relatadas nos tempos de Davi.

O registro tinha a intenção de preservar e divulgar a história do povo, dos reis, das conquistas etc. Na própria Bíblia é possível constatar que essas histórias dos reis foram registradas (1Rs 14,29) e, boa parte delas, preservadas com muito zelo e cuidado. Nesse processo, tão natural quanto possível, Deus usou a história do povo, dos seus governantes para firmar a sua ação na história. Essas histórias foram amplamente contadas entre o povo; depois foram escritas e difundidas, compondo o que hoje se concebe como as Escrituras Sagradas para judeus e cristãos.

\footnotetext{
${ }^{56}$ MESTERS, Carlos. Bíblia: livro feito em mutirão, p. 15.

${ }^{57}$ Cf. MILLER, Stephen; HUBER, Robert. A Bíblia e sua história: o surgimento e o impacto da Bíblia, p. 22.

${ }^{58}$ Ibid.

${ }^{59}$ BÍBLIA Sagrada. Português. Bíblia de Estudo Almeida, 2Sm 20,24-25.
} 
Além das histórias, o povo registrava também as suas poesias, os seus provérbios, a sua sabedoria. Como bem lembra Mesters, os "provérbios são a expressão da sabedoria"60 daquele povo. Não se sabe exatamente quando e por quanto tempo esses escritos foram compilados. Miller e Huber, por exemplo, afirmam que não se tem conhecimento sobre quando exatamente a maioria das canções que compunham os Salmos foram escritas, mas que esse período pode compreender aproximadamente um milênio, do êxodo ao exílio. Segundo alguns biblistas, é bem possível, portanto, que os cânticos bíblicos se configurem como os textos mais antigos da Bíblia. De fato, para eles, "o início da literatura bíblica estaria representado pelo Cântico de Débora, no livro dos Juízes (Jz 5). Esse cântico, com certeza, surgiu logo depois do acontecimento que ele celebra" ${ }^{\prime \prime}$.

Contudo, o que mais importa nesse caso é o fato de que estes escritos constituíram um tipo de literatura diferente. Não era para ser lido como os outros; antes, era para ser cantado, refletido ou declamado. A poesia servia para ilustrar verdades importantes do cotidiano e, ao mesmo tempo, incutir a Palavra de Deus. Era uma forma de difundir as Escrituras por meios diferentes, mais pedagógicos, utilizados nos diversos momentos: liturgia, peregrinação, cerimônias etc. Assim, "por mais de 2.000 anos os Salmos foram copiados, cuidadosamente preservados e estimados por judeus e cristãos"62. Como os Salmos representam orações, cânticos e expressões de sentimentos diante dos desafios da vida, Mesters destaca que este foi "o livro mais divulgado e mais conhecido" 63 por muitos.

Além dos cantos, a literatura hebraica está cheia de poesia. De fato, "mais ou menos uma terça parte do Antigo Testamento (AT) foi escrita em forma de poesia" ${ }^{64}$. Praticamente cada livro do Antigo Testamento tem, no mínimo, uma poesia. Outros, aliás, formam livros inteiros com esse tipo de literatura. A importância da difusão das Escrituras é tão significativa na poesia bíblica a ponto de não importar tanto a rima - como na língua portuguesa - mas a repetição da ideia. Trata-se do paralelismo. Há uma afirmação na primeira sentença, repetida de outra forma, com outras palavras, na segunda linha. A difusão desse tipo de literatura

\footnotetext{
${ }^{60}$ MESTERS, Carlos. Palavra de Deus na história dos homens. Petrópolis: Vozes, 1970, p. 79.

${ }^{61}$ ARENHOEVEL, Diego. Assim se formou a Bíblia. São Paulo: Paulinas, 1978, p. 57

${ }^{62}$ MILLER, Stephen; HUBER, Robert. A Bíblia e sua história: o surgimento e o impacto da Bíblia, p. 25.

${ }^{63}$ MESTERS, Carlos. Deus, onde estás? Uma introdução prática à Bíblia. Petropólis: Vozes, 1989, p. 112.

${ }^{64}$ SCHOLZ, Vilson. Princípios de interpretação bíblica: introdução à hermenêutica com ênfase em gêneros literários, p. 183.
} 
nas Escrituras foi tão importante na história que até hoje os textos poéticos são cantados ou lidos nas diferentes igrejas cristãs, de todas as tradições. Os judeus, da mesma forma, ainda o difundem como partes dos escritos sagrados da TaNaKh.

Uma das formas mais significativas de difundir a Palavra de Deus antes da chegada do Messias era por meio das profecias. De forma especial Deus falava, e essa fala, sendo palavra de Deus, "surpreende um homem histórico - o profeta — num lugar preciso num tempo determinado"65. Não são poucas as sentenças bíblicas que iniciam dizendo: “Assim diz o SENHOR”. O profeta era o porta-voz da Palavra de Deus. Os profetas falaram a juízes, a reis, a sacerdotes e ao povo. A difusão da Palavra de Deus por meio dos profetas tinha um caráter de correção, de juízo, de consolo e de alerta ${ }^{66}$. Além disso, era uma palavra que trazia esperança, pois muitos deles anunciavam a chegada do Messias. Miller e Huber destacam que

Os profetas anunciavam suas profecias espontaneamente. [...] suas palavras foram, mais tarde, escritas de forma poética muito bem estruturada, e ninguém sabe quem as escreveu. Talvez os próprios profetas tenham escrito e retocado as mensagens que haviam pregado, mas existe a possibilidade de que, em muitos casos, os discípulos dos profetas tenham registrado as palavras dos seus mestres para que pudessem ser estudadas e ensinadas mais adiante. ${ }^{67}$

Para dar a sua palavra aos profetas, Deus se comunicava com eles de duas formas, isto é, por "visões e palavras, que não se excluem mutuamente" ${ }^{68}$. Recebidas estas revelações proféticas, consideradas como Palavra de Deus, se fazia necessário transmiti-las aos diversos públicos que compunham a nação de Israel. A Palavra de Deus, na boca dos profetas, devia ser difundida. Para difundi-la, as palavras podiam ser faladas ou escritas. Algumas vezes a Bíblia relata que o próprio Deus pediu que os profetas registrassem e difundissem o que recebiam. $\mathrm{O}$ capítulo 36 do livro do profeta Jeremias é um exemplo. Depois de receber uma ordem de Deus, Jeremias ditou suas palavras proféticas ao seu escriba-secretário Baruque, que as copiou em um rolo. Depois de copiá-las, Baruque foi ao Templo para, publicamente, ler e difundir a Palavra de Deus. O relato bíblico descreve o fato da seguinte forma:

\footnotetext{
${ }^{65}$ MANNUCCI, Valério. Bíblia, Palavra de Deus: curso de introdução à Sagrada Escritura, p. 45.

${ }^{66}$ Cf. SICRE, José Luis. Profetismo em Israel: o profeta, os profetas, a mensagem. Petropólis: Vozes, 2008, pp. 126-136, 337-338.

${ }^{67}$ MILLER, Stephen; HUBER, Robert. A Bíblia e sua história: o surgimento e o impacto da Bíblia, pp. 32-33.

${ }^{68}$ SICRE, José Luis. Op.cit., p. 105.
} 
No quarto ano em que Jeoaquim, filho de Josias, reinou em Judá, o SENHOR Deus me disse: - Jeremias, pegue um rolo - um livro - e escreva nele tudo o que Ihe falei a respeito do povo de Israel e de Judá e a respeito de todas as nações. Escreva tudo o que eu disse desde a primeira vez em que falei com você, quando Josias era rei, até hoje. O povo de Judá vai ficar sabendo de toda a destruição que estou pensando fazer cair sobre eles. Aí talvez todos abandonem os seus maus caminhos, e eu perdoarei a maldade e os pecados deles. Depois, eu chamei Baruque, filho de Nerias, e ditei tudo o que o SENHOR me tinha dito, e ele escreveu num rolo. Então the dei as seguintes instruções: - Eu estou proibido de ir ao Templo. Mas quero que você vá até lá quando o povo estiver jejuando. Leia o rolo em voz alta, de modo que eles escutem tudo o que o SENHOR Deus me disse e que eu ditei a você. Faça isso de maneira que o povo e também os que vierem das cidades de Judá possam ouvir. Pode ser que assim eles orem a Deus e abandonem os seus maus caminhos, pois o SENHOR está furioso e muito irado com este povo. Então Baruque leu no pátio do Templo as palavras do SENHOR, exatamente como eu havia mandado ${ }^{69}$ (Jr 36,1-9).

Esse relato demonstra um pouco desse processo para que a Palavra de Deus, por meio do profeta, chegasse ao povo. Nesse caso específico, Deus se revelou ao profeta e pediu que ele escrevesse o que recebeu desde as primeiras revelações. Depois ele transmitiu a Baruque, que também escreveu e, sob a ordem de Jeremias, foi ao Templo para ler a Palavra de Deus que tinha sido revelada ao profeta. A mensagem difundida era uma advertência para que o povo de Deus obedecesse e, assim, evitasse as consequências do exílio. A história bíblica relata que a Palavra de Deus, recebida, escrita e lida em voz alta, não foi obedecida e, assim, as consequências sobrevieram.

O exílio babilônico foi um dos piores momentos da vida do povo de Israel $^{70}$, constituindo "a mais grave crise de sua história"71. Com a destruição de Jerusalém, a cidade sagrada, e do Templo, o lugar sagrado de adoração, restou ao povo somente a Palavra de Deus. Alguns profetas, como Ezequiel, por exemplo, desenvolveram um papel importante nesse período. Diante de tanto sofrimento, o povo passou a reavaliar a sua fé e procurar respostas. E a conclusão a que chegaram foi de que eles não tinham valorizado a Palavra de Deus como deviam. Foi durante essa época do exílio que "os judeus copiaram e editaram boa parte das histórias e

\footnotetext{
${ }^{69}$ BÍBLIA Sagrada. Português. Bíblia de Estudo NTLH. Jr 36,1-9 (grifo nosso).

${ }^{70}$ É importante esclarecer que, após a divisão do Reino, o primeiro cativeiro ocorreu em 722 a.C., com a invasão do Império Assírio ao Reino do Norte, também conhecido por Israel. A outra invasão que gerou a destruição do Reino do Sul, ou seja, Judá, ocorreu, segundo alguns historiadores, em momentos distintos, tendo seu último ato por volta de 586 a.C. A partir desse momento, considerando que o Reino do Norte deixou de existir como tal, o Reino do Sul (Judá) passou a ser designado pelo nome de Israel. Cf. BATISTA, Marcos da Silva. História de Israel. v. 1. Rio de Janeiro: [s.n], 2015, pp. 121-122, 147, 214.

${ }^{71}$ MANNUCCI, Valério. Bíblia, Palavra de Deus: curso de introdução à Sagrada Escritura, p. 80.
} 
ensinamentos do Antigo Testamento, formando o texto escrito que temos hoje"72. Da mesma forma, segundo a tradição judaica, "reuniram-se os escritos proféticos em três grupos"73: a Torá, os Profetas e os Escritos.

O período do exílio constituiu, portanto, um marco na história do povo de Israel em sua relação com as Escrituras. Enquanto a nação tinha sido formada com a libertação dos escravos hebreus do Egito, agora a religião judaica era estabelecida e a identidade nacional era restaurada sob o alicerce da Escritura Sagrada ${ }^{74}$. Foi um período de profunda reflexão e de ampla valorização das Escrituras. As histórias mais antigas do povo de Israel, agora atreladas às histórias mais recentes do exílio, ganharam maior significado na vida daquele povo. Por assim ser, essas histórias precisavam ser difundidas e, a partir desse momento, as Escrituras se consolidaram com relevada importância na história, na fé e na teologia judaica.

O judaísmo, portanto, "não se constituiu sobre a vida histórica de Moisés, nem de seus sucessores. Ele se constituiu sobre a Torá" ${ }^{\text {"75 }}$. Lazare reitera a importância dos escritos, quando destaca que "a leitura pública da Torá é tão antiga quanto a própria Torá" ${ }^{, 76}$. Eis, portanto, o significado das Escrituras na vida do povo escolhido. O clímax dessa realidade se evidencia claramente no foco estabelecido quando do retorno dos judeus a Jerusalém. Enquanto Neemias se concentra na reconstrução social, Esdras realiza uma cerimônia litúrgica e paradigmática para o povo, dando ênfase à importância que as Escrituras Sagradas deveriam ter:

Já no sétimo mês, todo o povo de Israel estava morando nas suas cidades. No dia primeiro desse mês, todos se reuniram em Jerusalém, na praça em frente ao Portão das Águas. Então pediram a Esdras, o sacerdote e mestre da Lei, que trouxesse o Livro da Lei que o SENHOR Deus tinha dado ao povo de Israel por meio de Moisés. Esdras levou o livro para o lugar onde o povo estava reunido: os homens, as mulheres e as crianças que já tinham idade para entender. E ali, na praça em frente ao portão, Esdras leu a Lei para o povo, desde o nascer do sol até o meiodia. E todos ouviram com atenção. Esdras estava de pé num estrado de madeira que havia sido feito para aquela ocasião. [...] Esdras ficou ali no estrado acima do povo, e todos olhavam para ele. Quando abriu o livro, todos se levantaram, e Esdras disse: - Louvem o SENHOR, o grande Deus! Todo o povo levantou os braços e respondeu: - Amém! Amém! Aí se ajoelharam e, com o rosto encostado na terra, adoraram a Deus, o SENHOR. Depois se levantaram e ficaram nos seus luga-

${ }^{72}$ MILLER, Stephen; HUBER, Robert. A Bíblia e sua história: o surgimento e o impacto da Bíblia, p. 34.

${ }^{73}$ LAZARE, Lucien. Judaísmo e Bíblia. In: LONGTON, Joseph; POSWICK, Réginald-Ferdinand [et al.] (orgs.). Dicionário Enciclopédico da Bíblia, p. 770.

${ }^{74}$ Cf. GOLDBERG, David; RAYNER, John Desmond. Os judeus e o judaísmo. Rio de Janeiro: Xenon, 1989, p. 64; BRIGHT, John. História de Israel. São Paulo: Paulinas, 1978, p. 473

${ }^{75}$ MIRANDA, Evaristo Eduardo de. Bíblia: história, curiosidades e contradições, p. 579.

${ }^{76}$ LAZARE, Lucien. Judaísmo e Bíblia. Op. cit., p. 772. 
res. Então os levitas explicaram a Lei para o povo. [...] Eles iam lendo o Livro da Lei e traduzindo; e davam explicações para que o povo entendesse o que era lido. Quando ouviram a leitura da Lei, eles ficaram tão comovidos, que começaram a chorar. Então Neemias, o governador, e Esdras, o sacerdote e mestre da Lei, e os levitas que estavam ali explicando a Lei disseram a todo o povo: - Este dia é sagrado para o SENHOR, nosso Deus, e por isso vocês não devem se lamentar nem chorar. Vão agora para casa e façam uma festa. Repartam a sua comida e o seu vinho com quem não tiver nada preparado. Este dia é sagrado para o nosso Deus; portanto, não fiquem tristes. A alegria que o SENHOR dá fará com que vocês fiquem fortes. Os levitas foram pelo meio do povo, acalmando-os e dizendo que não ficassem tristes num dia tão santo. Então todos foram para casa, e comeram, e beberam alegremente. E o que eles tinham repartiram com os outros porque entenderam o que havia sido lido para eles. ${ }^{77}(\mathrm{Ne} 8,1-12)$

Ao comentar sobre o fato de Esdras ter trazido o Livro da Lei perante o povo, Boselli sustenta que, naquele momento, "o livro da lei devia ser visto antes de ser escutado"78. Para o autor, trata-se de uma visibilidade necessária para aquele povo, pois a percepção da presença do Livro estava associada à percepção da presença de Deus. O Senhor falou por meio da sua Palavra no Livro. Elevar o livro à vista de todo o povo é tanto um sinal de respeito como um ato que manifesta a presença de Deus entre o povo. Para Boselli, tal rito é um gesto litúrgico de extrema importância e significado. A Palavra de Deus, nessa perspectiva, ganha notório significado, porque "é uma realidade que deve ser vista, antes de tudo, como livro apresentado à assembleia e, em seguida, ouvida como texto lido à assembleia"79. Assim, a difusão se dá na contemplação, na leitura e na audição da Palavra de Deus!

Destaca-se, igualmente, o fato de que esta é a primeira experiência de tradução de uma parte (um pequeno texto em forma de mensagem) das Escrituras. O povo que retornou do exilio já não compreendia o hebraico ${ }^{80}$. Para que as Escrituras estivessem, de fato, acessível, eles precisavam ler e, nesse caso, ouvir na língua aramaica que passaram a falar. A narrativa bíblica ressalta, nesse sentido, que junto à leitura do texto hebraico estavam atrelados dois aspectos: a tradução para o aramaico e a explicação sobre o texto, aplicado à realidade que vivenciavam. $\mathrm{O}$

\footnotetext{
${ }^{77}$ BÍBLIA Sagrada. Português. Bíblia de Estudo NTLH. Ne 8,1-12 (grifo nosso)

${ }^{78}$ BOSELLI, Goffredo. O sentido espiritual da liturgia. Brasília: CNBB, 2014, p. 62.

${ }^{79}$ Ibid., p. 63.

${ }^{80}$ Existem poucos relatos bíblicos e históricos sobre os remanescentes de Judá (aqueles que não foram deportados para o exílio babilônico). Por tais razões, não há como saber se, de fato, aqueles que ficaram na terra mantiveram a familiaridade com o hebraico das Escrituras. Lawrence, por exemplo, lembra que permaneceram em Judá, "apenas o povo mais pobre da terra para cuidar das vinhas e dos campos”. In: LAWRENCE, Paul. Atlas Histórico e Geográfico da Bíblia. Barueri: Sociedade Bíblica do Brasil, 2008, p. 102
} 
resultado dessa ação foi uma reação de aceitação espontânea do povo frente ao que era lido.

Essa experiência, como se percebe, foi marcante. $\mathrm{Na}$ atualidade, o rito do hagbahá (elevação) ainda é realizado em certas sinagogas judaicas. Entretanto, essa não é a primeira vez que o Livro da Lei servia de fundamento para restaurar a vida do povo de Deus. Isso já tinha ocorrido em outro momento da história de Israel, por meio do rei Josias, considerado um reformador no momento de caos em que o povo se encontrava, provocado pela displicência religiosa e social dos reis que o antecederam e do povo que não se atentava às Escrituras. A Bíblia descreve que essa reforma de Josias ocorreu porque ele tinha encontrado o Livro da Lei escondido no Templo. Esse livro, considerado por alguns biblistas uma versão preliminar, "é considerado o núcleo do atual livro de Deuteronômio, o 'Deuteronômio primitivo" ",81. A difusão dos escritos sagrados no tempo do rei Josias provocou uma ampla reforma social, política e religiosa em seu tempo.

Como é possível perceber, a história do povo de Deus é uma história da Palavra de Deus no meio do seu povo. Essa história começa na oralidade e, progressivamente, se solidifica por meio das Escrituras:

Os livros das leis de Moisés (Dt 31,24-26) e Esdras (Ne 8), os rolos de Isaías (Is 8,16-17) e Jeremias (36) e o livro das revelações secretas de Daniel (Dn 7,1, 12,4) são claros indícios de que a palavra de Deus sempre esteve associada com um livro que devia ser lido na e para uma comunidade de fé e $^{82}$.

Essas experiências na história relatam a relevância das Escrituras Sagradas na vida do povo de Deus no antigo Israel, a ponto de se constatar que o judaísmo, como religião de uma nação, nasce como expressão genuína de fé por meio da valorização das Escrituras no momento pós-exílico, isto é, nasce da leitura, compreensão e difusão das Escrituras Sagradas, formada por "uma coleção de escritos sagrados da religião de Israel" 83 . Essa experiência marcará a vida e a fé do povo judeu, pois "o povo que voltou do exílio se reconhece a si mesmo nesta história" ${ }^{" 4}$. A Escritura passou a constituir a razão da existência e a essência da própria vida deles, pois nela "encontravam um espelho de si mesmos; encontravam lá

\footnotetext{
${ }^{81}$ KONINGS, Johan. A Palavra se fez, livro. São Paulo: Loyola, 2014, p. 28.

${ }^{82}$ BEUKEN, Win; FREYNE, Sean; WEILER, Anton (orgs.). A Bíblia e seus leitores. Revista Concilium. Petropólis: Vozes, 1991, p. 13.

${ }^{83}$ BARRERA, Júlio Trebolle. A Bíblia judaica e a Bíblia cristã, p. 26.

${ }^{84}$ KONINGS, Johan. Op. cit., p. 29.
} 
dentro os critérios de todo o seu viver, pensar e agir" ${ }^{\prime 85}$. De forma pedagógica, a Escritura era também

Uma advertência acerca do que acontecera para levar esse povo à beira da extinção e do que poderia acontecer caso se persistisse no antigo curso de ação. Esperavam esse povo um futuro e uma esperança, mas somente se ele fosse obediente à Torá ${ }^{86}$ de Moisés - essa era a mensagem enraizada na biblioteca de "a Lei e os Profe$\operatorname{tas}{ }^{87}$.

Séculos depois, no relato do evangelista Lucas, no capítulo 4, é possível perceber que a cerimônia litúrgica da qual Jesus participou na Sinagoga de Nazaré é justamente caracterizada pela leitura das Escrituras. Ler e difundir as Escrituras passou a ser "aquilo que dava sentido" à vida. Trebolle Barrera, por exemplo, destaca que o costume de se ler as Escrituras "na manhã de sábado, no primeiro século, era comum tanto em Israel (At 15,21) como na diáspora" ${ }^{\prime 8}$. Na Sinagoga de Nazaré, o próprio Jesus realiza a leitura a partir do rolo do profeta Isaías, texto do lecionário sinagogal para aquele dia. De fato, as Escrituras Sagradas influenciaram de forma significativa a vida, a fé, os valores e a liturgia judaica e, de certa forma, também influenciarão a fé cristã em todas as suas dimensões. Nessa perspectiva, tanto para judeus como para cristãos, “a Bíblia é a voz de Deus que continua ecoando em nossos ouvidos, graças à sua fixação por escrito" ${ }^{\text {"89. }}$.

\section{3}

\section{Traduzir para difundir: a primeira tradução das Escrituras Sagradas}

O exílio ${ }^{90}$ e os eventos que o sucederam provocaram significativas transformações no povo de Israel. Entre outras, três merecem destaque especial a partir

\footnotetext{
${ }^{85}$ MESTERS, Carlos. Por trás das palavras: um estudo sobre a porta de entrada no mundo da Bíblia, p. 135.

${ }^{86}$ Lazare reitera que no judaísmo é preciso afastar de imediato o termo "Bíblia", pois, para os judeus, a importância preponderante está no livro da Torá, e não na Bíblia Sagrada, que se caracteriza de forma especial como um livro distinto para os cristãos (LAZARE, Lucien. Judaísmo e Bíblia. In: LONGTON, Joseph; POSWICK, Réginald-Ferdinand [et al.] (orgs.). Dicionário Enciclopédico da Bíblia, p. 769).

${ }^{87}$ MILLER, John. As origens da Bíblia: repensando a história canônica, p. 124.

${ }^{88}$ BARRERA, Júlio Trebolle. A Bíblia judaica e a Bíblia cristã, p. 140.

${ }^{89}$ FERNANDES, Leonardo Agostini. A Bíblia e sua mensagem: introdução à leitura e ao estudo da Bíblia, p. 43.

${ }^{90} \mathrm{O}$ início do exílio para o Reino do Sul (Judá), o único reino ainda existente, ocorreu com a invasão do Império Babilônico, sob o governo de Nabucodonosor. Posteriormente, o Império MedoPersa conquistou a Babilônia e dominou o povo de Israel por cerca de 200 anos. A diferença de um império para o outro é que este último concedeu um pouco mais de liberdade ao povo de Israel. Foi no período de dominação persa que as deportações conduziram o retorno do povo a Jerusalém (Cf. BRIGHT, John. História de Israel, pp. 463-487). Hale destaca que o ano de 535 a.C., período
} 
da temática proposta nessa pesquisa. A primeira já foi apresentada na seção anterior, que, como visto, pode ser resumida no fato de os judeus passarem a dar maior importância às Escrituras Sagradas. Resta óbvio que, posteriormente, essa importância resultou em perseguições violentas, como, por exemplo, a experiência ocorrida no período de dominação do Império Grego ${ }^{91}$. Em parte deste período, os judeus foram proibidos de ler, difundir ou até mesmo carregar uma simples cópia dos Escritos Sagrados. Naquele tempo, "cópias da lei foram confiscadas e destruídas" ${ }^{92}$. A punição para quem tivesse uma cópia era de pena de morte, conforme se evidencia no relato do primeiro livro dos Macabeus ao descerever a luta religiosa vivenciada pelos judeus no tempo da dominação grega dos selêucidas: "Quanto aos livros da Lei, os que lhes caíam nas mãos eram rasgados e lançados ao fogo. Onde quer que se encontrasse, em casa de alguém, um livro da Aliança ou se alguém se conformasse à Lei, o decreto real o condenava à morte"93.

As mudanças ocorridas também provocaram a diáspora ${ }^{94}$. Alguns judeus preferiram não voltar do exílio, construindo sua vida fora de Israel. Outros, no entanto, foram profundamente influenciados pelo novo momento político pelo qual o mundo civilizado da época passava. Estes fizeram parte da diáspora por opção, se assim se pode afirmar. Eles passaram a viver sob a influência grega que prevalecia naquele momento.

O Império Grego tinha conquistado o Império Persa em 332 a.C. por meio de seu maior conquistador, Alexandre, o Grande. Depois da morte de Alexandre, o mundo que estava sob o controle dos gregos foi dividido entre seus generais. A região onde se localizava Israel, junto com o Egito, ficou sob o domínio de um dos principais generais de Alexandre, Ptolomeu I, que foi sucedido por seu filho, Ptolomeu II em 285 a. $C^{95}$. Diferentemente de outros que o sucederam e que perseguiram os judeus, este governante marcou a história do mundo daquele período

de governo de Ciro II (iniciado em 538 a.C.), é a data mais provável que marca o ínicio do retorno dos judeus à Judá, por meio de Zorobabel. Em 485 a.C. Esdras conduziu mais uma deportação de retorno e, em 445 a.C. ocorreu a última deportação liderada por Neemias. Cf. HALE, Broadus David. Introdução ao Estudo do Novo Testamento. São Paulo: Hagnos, 2001, p. 9.

${ }^{91}$ Antíoco IV (Epifânio) exerceu muita perseguição aos judeus durante seu governo no período de dominação grega.

${ }^{92}$ HALE, Broadus David. Introdução ao Estudo do Novo Testamento, p. 13.

${ }^{93}$ BÍBLIA Sagrada. Português. Bíblia de Jerusalém, 1Mc 1,56-57.

${ }^{94}$ Cf. DAVIS, John. Novo Dicionário da Bíblia. São Paulo: Hagnos, 2006, p. 345. O termo, em grego, "diáspora" significa dispersão. Na história, a dispersão judaica pelo mundo se deu algumas vezes por iniciativa do próprio povo ou, em outros casos, por motivo de perseguição.

${ }^{95}$ HALE, Broadus David. Op. cit., p. 12. 
promovendo e incentivando o ensino. Em sua época, a cidade de Alexandria se tornou o principal centro de ensino no mundo mediterrâneo. Sua biblioteca - a Biblioteca de Alexandria - ficou amplamente conhecida e foi um marco na história, inclusive na história do cristianismo. E assim, “um grande número de judeus havia deixado a sua terra para trabalhar e estudar em terras estrangeiras, incluindo o Egito" $"$.

Um aspecto que também influenciou o mundo da época e até mesmo os próprios judeus foi o contato com as línguas de outros povos. Após retornarem do exílio, boa parte do povo de Israel já não falava mais o hebraico. Eles voltaram falando uma segunda língua, que, inclusive, faz parte de alguns textos bíblicos do Antigo Testamento: o aramaico. Por isso, na leitura que Esdras fez da Lei em hebraico, como se costumava ler as Escrituras no rito judaico, se fez necessário que alguém traduzisse (explicasse) o que estava sendo lido (cf. Ne 8,8). Por outro lado, a dominação grega foi muito além da militarização e da conquista. Os gregos conquistaram o mundo por meio da cultura e da língua. $\mathrm{O}$ mundo daquela época foi profundamente influenciado pela cultura helenista e pela língua grega, que passou a ser a língua universal. Miller e Huber resumem esses fatos da seguinte forma: "Eles falavam a língua grega, recebiam uma educação grega e adotavam muitos costumes gregos. Com o tempo, esses judeus dispersos [...] não conseguiam mais ler as suas próprias Escrituras, escritas em hebraico"97.

A língua comumente falada era o aramaico; a língua religiosa era o hebraico e a língua universal que influenciava o comércio e a política era o grego. Assim, por muito tempo "os judeus viveram em um contexto bilíngue ou trilíngue" 98 . Por outro lado, muitos judeus tinham se dispersado pelo mundo e, imersos em outras culturas, o hebraico 'sagrado' ficava cada dia mais distante. Considerando a importância das Escrituras para o povo judeu, que não deveria se limitar à leitura realizada pelos escribas que conseguiam ler o hebraico, se fez necessária uma tradução das Escrituras para o grego, a língua que o povo no mundo conhecia e fala$\mathrm{va}^{99}$.

\footnotetext{
${ }^{96}$ MILLER, Stephen; HUBER, Robert. A Bíblia e sua história: o surgimento e o impacto da Bíblia, p. 48.

${ }^{97}$ Ibid.

${ }^{98}$ BARRERA, Julio Trebolle. A Bíblia judaica e a Bíblia cristã, p. 87.

${ }^{99}$ Vale ressaltar que, para aqueles que falavam a língua aramaica, existiam os "targuns". Os targuns eram uma tradução das Escrituras Sagradas para os judeus que já não falavam hebraico. Essa tradução poderia ser em forma de paráfrase (tradução livre) ou poderia se constituir de comentá-
} 
De fato, "para que pudessem continuar a se alimentar da palavra de Deus, foi necessário que a Bíblia fosse traduzida"100. Era uma necessidade e, por que não dizer, um pedido da comunidade judaica que vivia imersa na cultura helenista. Assim, com o objetivo de difundir as Escrituras Sagradas para todos, principalmente para os judeus dispersos ou para os que falavam grego, surgia a primeira tradução das Escrituras do hebraico para o grego: a Septuaginta ${ }^{101}$. De acordo com alguns historiadores, a ideia de se realizar essa tradução surgiu quando Ptolomeu, o general grego, desejou que existisse uma cópia de todos os livros existentes no mundo em sua biblioteca. Assim,

Ansioso por possuir uma tradução dos livros judaicos, Ptolomeu ordenou que uma carta fosse escrita a Eleasar, o sumo sacerdote judeu em Jerusalém, pedindo que ele enviasse 72 dos seus melhores estudiosos para Alexandria, para que fosse feita uma tradução acurada da lei judaica ${ }^{102}$.

A história dessa tradução é sempre acompanhada de muitas lendas. Sendo verdade ou não, a importância está no fato em si. Começando pelos cinco primeiros livros da Lei até completar a tradução com os Profetas e os Escritos, a tradução, tão necessária, foi desenvolvida, tornando-se a versão grega das Escrituras Sagradas. A Septuaginta contribuiu significativamente com a difusão das Escrituras Sagradas, tanto para judeus de língua grega como para os povos do mundo inteiro. Até hoje essa tradução é uma referência e continua a ser publicada pelas Sociedades Bíblicas.

Essa ampla difusão das Escrituras por meio dessa tradução grega ganhou maior notoriedade por estar atrelada a um fato relevante para o cristianismo. A Septuaginta foi o texto das Escrituras Sagradas utilizado pelos cristãos primitivos, ou seja, "com esta tradução, o Antigo Testamento tornou-se a Escritura Sagrada do cristianismo antigo. Não era um em tantos outros livros cristãos; para eles, era o livro sagrado"103. Na maioria das vezes que os autores do Novo Testamento

rios feitos em aramaico a partir da leitura e da interpretação do texto hebraico (uma tradução interpretativa). Cf. DOUGLAS, James Dixon (org.). O Novo Dicionário da Bíblia. São Paulo: Vida Nova, 2006, pp. 1297-1298.

100 TEIXEIRA, Paulo. Traduções da Bíblia: história, princípios e influência. In: ZIMMER, Rudi (Org.). Manual do Seminário de Ciências Bíblicas, p. 42.

${ }^{101}$ Cf. BÍBLIA. Septuaginta. Editio Altera. Revised Edition. Stuttgart: Deutsche Bibelgesellschaft. Barueri: Sociedade Bíblica do Brasil, 2011.

${ }^{102}$ MILLER, Stephen; HUBER, Robert. A Bíblia e sua história: o surgimento e o impacto da Bíblia, p. 49.

${ }^{103}$ LORTZ, Joseph. Historia de La Iglesia: en la perspectiva de la historia del pensamiento. Antiguedad y edad media. Vol. I, p. 35 (tradução nossa). 
citaram as Escrituras, na verdade, era a Septuaginta que eles citavam. Lopes, com muita propriedade, ressalta que de 350 citações do AT presentes em versículos do NT, “300 concordam perfeitamente com a versão da LXX"104.

Pouco se sabe, portanto, sobre o uso do texto hebraico, a não ser nas leituras lirtugicas no Templo e, talvez, nas Sinagogas. Contudo, Lortz faz uma ressalva que nas sinagogas, mesmo as situadas em Jerusalém, "a Bíblia não era lida em hebraico, mas em grego"105. É por isso que, com o passar do tempo, devido ao uso dos apóstolos e dos Pais da Igreja, "os cristãos incorporaram e conservaram a Bíblia grega dos LXX"106. Era o texto utilizado; era o texto respeitado; era o texto difundido como "Escrituras Sagradas". O cristianismo, em sua gênese, usou tanto essa versão que ela chegou a ser definida como uma versão cristã das Escrituras.

Para reduzir tal força, os judeus, insatisfeitos com a Septuaginta, traduziram três novas traduções do hebraico para o grego. Elas "foram atribuídas aos estudiosos judeus Áquila, Símaco e Teodocião" "107. Áquila e Teodocião, em sua tradução, optaram pela literalidade, ou melhor, principalmente no caso de Áquila, foi uma opção pela hiperliteralidade. O mais importante era o sentido "hebraico". Assim, ambas as traduções se tornaram de difícil leitura. Símaco, em sentido oposto, se preocupou mais com uma tradução inteligível, sendo, portanto, uma tradução de leitura facilitada e com melhor elegância literária ${ }^{108}$.

Os próprios judeus, em menos de cem anos, reuniram-se e retornaram ao texto hebraico "mesmo que o povo simples já não dominasse essa língua"109, reduzindo, assim, a importância da Septuaginta, visto que, progressivamente estabeleceu-se que "para o judaísmo, a Torá é hebraica, e qualquer tentativa de lê-la, de escutá-la ou de estudá-la em outra língua está fadada ao fracasso" "110. Deste modo, eles criaram uma versão oficial, também utilizada até os dias atuais. Quando comparadas, em alguns casos, é possível constatar algumas diferenças entre os dois textos, isto é, entre a Septuaginta e a Bíblia Hebraica. Essas diferenças contem-

\footnotetext{
${ }^{104}$ LOPES, Geraldo. Dei verbum: texto e comentário. São Paulo: Paulinas, 2012, p. 36.

${ }^{105}$ LORTZ, Joseph. Historia de La Iglesia: en la perspectiva de la historia del pensamiento. Antiguedad y edad media. Vol. I, p. 61 (tradução nossa).

${ }^{106}$ BARRERA, Júlio Trebolle. A Bíblia judaica e a Bíblia cristã, p. 22.

${ }^{107}$ MILLER, Stephen; HUBER, Robert. A Bíblia e sua história: o surgimento e o impacto da Bíblia, p. 49.

108 Ibid., pp. 49-51

109 TEIXEIRA, Paulo. Traduções da Bíblia: história, princípios e influência. In: ZIMMER, Rudi (Org.). Manual do Seminário de Ciências Bíblicas, p. 43.

${ }^{110}$ LAZARE, Lucien. Judaísmo e Bíblia. In: LONGTON, Joseph; POSWICK, Réginald-Ferdinand [et al.] (orgs.). Dicionário Enciclopédico da Bíblia, p. 771.
} 
plam alguns trechos do próprio texto, mas, também, o cânon ${ }^{111}$. Essa diferença impactará o cristianismo, como se perceberá mais adiante.

Em nada, porém, se reduz a sua importância, pois "a Septuaginta sempre terá o mérito de ter sido a primeira tradução das Escrituras para outra língua"112. Seu texto "permanece importante até hoje para nos ajudar a compreender melhor a Palavra de Deus"113. Como bem resume Lopes, "a LXX tornou-se a mãe das diversas traduções" $" 114$.

\section{4}

\section{Jesus e os apóstolos na difusão das Escrituras Sagradas}

Se no aspecto secular a história é dividida entre antes e depois de Cristo, não há dúvidas de que essa mesma distinção é ainda mais relevante quando se está em análise a própria história judaico-cristã. Da mesma forma, a difusão das Escrituras, a partir de Jesus Cristo e, posteriormente, dos apóstolos é marcada de forma peculiar e distinta. Jesus e os apóstolos são amplos difusores das Escrituras Sagradas.

Para uma análise mais correta se faz necessário fazer uma distinção. A difusão das Escrituras realizada por Jesus, e principalmente, depois da ascensão de Cristo, pelos apóstolos, precisa ser separada em duas categorias. A primeira é a difusão das Escrituras do Antigo Testamento ${ }^{115}$ e a outra é a difusão dos escritos dos apóstolos e dos evangelistas, que mais tarde viriam a ser o que se denominou "Novo Testamento".

$\mathrm{Na}$ história, “as Escrituras hebraicas foram não apenas a primeira Bíblia cristã, mas também [foram] deliberadamente conservadas e defendidas como

\footnotetext{
111 "Alguns estudiosos afirmam que o cânon da Bíblia hebraica foi definido no final do primeiro século d.C. pelos líderes judeus reunidos no Concílio de Jâmnia (ou Jbane)" (MILLER, Stephen; HUBER, Robert. A Bíblia e sua história: o surgimento e o impacto da Bíblia, p. 56).

112 TEIXEIRA, Paulo. Traduções da Bíblia: história, princípios e influência. In: ZIMMER, Rudi (Org.). Manual do Seminário de Ciências Bíblicas, p. 44.

${ }^{113}$ MILLER, Stephen; HUBER, Robert. Op. cit., p. 51.

${ }^{114}$ LOPES, Geraldo. Dei verbum: texto e comentário, p. 26.

${ }^{115}$ Vale ressaltar que os primeiros cristãos não faziam essa distinção entre Antigo e Novo Testamento. Para Jesus e os apóstolos, o que hoje se denomina no seio cristão de Antigo Testamento eram, na verdade, as Escrituras Sagradas. Essa distinção se deu no decorrer dos tempos sob a influência dos cristãos. Já no período subapostólico ( 70 - 135 d.C.), a Escritura hebraica era reconhecida sob a expressão "Lei e Profetas", e a Escritura cristã que surgia na época poderia ser designada "Profetas e Apóstolos". Cf. BARRERA, Júlio Trebolle. A Bíblia judaica e a Bíblia cristã, p. 276.
} 
tal"116. Jesus lia o Antigo Testamento e afirmava que nele se cumpriam a Escrituras Sagradas. De certa forma, pode-se "dizer que o próprio Jesus foi quem deu início à acolhida das Escrituras judaicas na comunidade que surgia dele, a comunidade cristã" ${ }^{\prime 17}$. Posteriormente, os apóstolos liam o Antigo Testamento, rememoravam as palavras de Jesus e confirmavam ser ele o Messias. Eles pregavam sobre isso, mas, também, passaram a escrever sobre isso, culminando em escritos posteriormente considerados sagrados, constituindo parte fundamental das Escrituras Sagradas para os cristãos ${ }^{118}$. Não é de se admirar que neste processo, "determinados textos do Antigo Testamento tenham influenciado inclusive a redação do Novo Testamento"119 e, em certo sentido, "o Novo Testamento é uma releitura global do Antigo"120.

A difusão das Escrituras nesse período singular da história se dá, portanto, nestas duas vertentes. Os autores do NT olhavam para o Antigo Testamento (sobretudo a Septuaginta) e, conforme liam e interpretavam os escritos — os profetas e a Lei -, escreviam em harmonia com os ensinos de Cristo, sem saber, obviamente, que estes escritos se tornariam parte integrante da Bíblia Sagrada. Entre outros aspectos, a escrita do Novo Testamento surge também da intenção de se divulgar as Escrituras Sagradas do Antigo Testamento, apontando que em Cristo esses textos se cumpriam. A leitura e a difusão do Antigo Testamento legitimavam Cristo como o Messias e, para confirmar tal fato, eles escreviam novos textos. Deste modo, "alguns desses textos começaram a ser lidos em conjunto com as Escrituras em hebraico nos cultos cristãos. Nos séculos seguintes, um certo número desses livros foi reunido e passou a ser considerado o Novo Testamento"121.

De acordo com Nicole ${ }^{122}$, existem, no mínimo, 295 citações diretas do Antigo Testamento no Novo Testamento. Essas citações estão presentes em cerca de 350 versículos neotestamentários, mencionados com base em 278 versículos do

\footnotetext{
${ }^{116}$ MILLER, John. As origens da Bíblia: repensando a história canônica, p. 13.

${ }^{117}$ KONINGS, Johan. A Bíblia, sua origem e sua leitura: introdução ao estudo da Bíblia, p. 158.

${ }^{118}$ Cf. MANNUCCI, Valério. Bíblia, Palavra de Deus: curso de introdução à Sagrada Escritura, pp. 229-236.

${ }_{119}$ DREHER, Martin Norberto. Bíblia: suas leituras e interpretações na História do Cristianismo. São Leopoldo: CEBI e Sinodal, 2006, p. 9.

${ }^{120}$ MESTERS, Carlos. Por trás das palavras: um estudo sobre a porta de entrada no mundo da Bíblia, p. 91.

${ }^{121}$ MILLER, Stephen; HUBER, Robert. A Bíblia e sua história: o surgimento e o impacto da Bíblia, p. 64.

${ }^{122}$ Cf. NICOLE, Roger. New Testament Use of the Old Testament. In: HENRY, Carl F. H. Revelation and the Biblie: Contemporary Evangelical Trought. Grand Rapids: Backer, 1958; London: The Tindayle Press, 1959, p. 137.
} 
AT (alguns versículos são citados mais de uma vez). As citações ocorrem da seguinte forma: 94 versículos do Pentateuco, 99 versículos dos Profetas e 85 versículos dos Escritos. Vale ressaltar que a análise de Nicole contempla apenas citações diretas. Por outro lado, se forem consideradas as alusões (citações indiretas) de textos do Antigo no Novo Testamento, esse número pode variar significativamente, passando de mil alusões. Diante da complexidade da análise, não há consenso entre os diversos autores ou comentaristas bíblicos ${ }^{123}$. Ainda assim, esses dados evidenciam o quanto as Escrituras Sagradas eram importantes para os escritores neotestamentários, assim como foi para o próprio Jesus.

Segundo a narrativa do evangelista Lucas, o início do ministério público de Jesus se deu em Nazaré, depois de ser batizado e tentado no deserto. É interessante notar que na perspectiva lucana, Jesus inicia seu ministério lendo, interpretando e ensinando as Escrituras (Lc 4,14-18). Na Sinagoga, ele lê o texto de Isaías e assume que naquele dia, "se cumpriu a Escritura" que eles tinham acabado de ouvir (Lc 4,21). Como se percebe, as sinagogas constituíram um importante ambiente para a divulgação das Escrituras pelos cristãos primitivos desde Jesus até a pregação apostólica, principalmente por Paulo. Isso fica claro na narrativa dos Evangelhos e no livro de Atos dos Apóstolos.

Após cumprir a missão em seu ministério terreno, logo depois da ressurreição, o mesmo evangelista descreve Jesus caminhando ao lado de dois discípulos que se dirigiam a Emaús. Procurando animá-los diante de tudo o que havia sucedido (a morte de Jesus), o mestre faz uma alusão direta às Escrituras: "E, começando por Moisés, discorrendo por todos os Profetas, expunha-lhes o que a seu respeito constava em todas as Escrituras" (Lc 24,27). Como se percebe, as Escrituras Sagradas mereciam uma atenção especial do mestre em todo o seu ministério. $\mathrm{Na}$ verdade, "radicalmente nova é a interpretação da Escritura dada por Jesus" ${ }^{24}$. De fato, em Cristo as Escrituras têm novo sentido, visto que "Jesus trouxe a chave para o povo poder entender o sentido verdadeiro da longa caminhada do Antigo Testamento"125. Em Jo 5,39-40, por exemplo, Jesus deixa claro aos seus seguidores que é impossível ler as Escrituras, nesse caso o Antigo Testamento,

123 Cf. BRUCE, Frederick. Fyvie. The New Testament development of some Old Testament themes. Exeter: The Paternoster Press, 1970, pp. 122; ROBERTSON, A. W. El Antiguo Testamento en el Nuevo. Buenos Aires: Nueva Creación, 1996, pp. 262.

${ }^{124}$ MANNUCCI, Valério. Bíblia, Palavra de Deus: curso de introdução à Sagrada Escritura, p. 70.

${ }^{125}$ MESTERS, Carlos. Bíblia: livro feito em mutirão, p. 27. 
sem perceber que elas testificam dele. Para o mestre não há dúvidas. Terminantemente, "a testemunha definitiva culminante e comprobatória são as Escrituras"126.

O início da pregação apostólica também ocorre por meio da explicação das Escrituras. Em At 2,14-36, o apóstolo Pedro realiza o primeiro sermão amplamente alicerçado e citado a partir das Escrituras. Ele cita os profetas Joel e Davi. Ele demonstra que as Escrituras se cumpriram em Jesus, o Messias. De fato, "as primeiras coordenadas da narração a respeito de Jesus foram estabelecidas, na pregação oral, por aqueles que, depois de sua morte, o anunciaram ao mundo como Cristo/Messias e Salvador" ${ }^{\prime 27}$. Da mesma forma, o apóstolo Paulo contempla em suas cartas várias citações, alusões e interpretações do Antigo Testamento. As Escrituras Sagradas, tendo Cristo como chave hermenêutica, por meio de sua morte e ressurreição, constituíram a essência da pregação apostólica.

Essa forma de compreender o Antigo Testamento era como também os primeiros autores das Escrituras cristãs (o Novo Testamento) entendiam seus escritos. Eles falavam sobre o Antigo Testamento da mesma maneira que Jesus: para eles, o livro não conta apenas a história pré-cristã; ele narra essa história com um significado presente e futuro para os cristãos ${ }^{128}$.

Teologicamente fundamentada, a história da salvação faz todo sentido na junção dos escritos vetero e neotestamentários, sempre consolidados, obviamente, no Novo Testamento por meio de afirmações que dizem: "está escrito", "dizem as Escrituras", "para que se cumprissem as Escrituras" etc. Nessa perspectiva, "história e querigma estão intimamente relacionados porque ambos juntos exprimem a única e idêntica Palavra de Deus"129.

Até onde se sabe, "Cristo não deixou textos sagrados para a Igreja"130. Também não pediu que escrevessem. Ele simplesmente pregava e provava que suas palavras eram importantes. Segundo a narrativa de Mateus, o próprio Cristo dizia: "Passará o céu e a terra, porém as minhas palavras não passarão"131 (Mt 24,35). Essas palavras constituíam uma pregação simples e direta. A mensagem do Reino

\footnotetext{
${ }^{126}$ CARSON, Donald Arthur. As Escrituras dão testemunho de mim: Jesus e o evangelho no Antigo testamento. São Paulo: Vida Nova, 2015, p. 18.

${ }^{127}$ KONINGS, Johan. A Bíblia, sua origem e sua leitura: introdução ao estudo da Bíblia, p. 123.

128 GRUDEM, Wayne; COLLINS, John; SCHREINER, Thomas (orgs.). Origem, confiabilidade e significado da Bíblia. São Paulo: Vida Nova, 2013, p. 19.

${ }^{129}$ MANNUCCI, Valério. Bíblia, Palavra de Deus: curso de introdução à Sagrada Escritura, p. 54.

${ }^{130}$ CAIRNS, Earle Edwin. O cristianismo através dos séculos: uma história da igreja cristã. São Paulo: Vida Nova, 2008, p. 37.

${ }^{131}$ BÍBLIA Sagrada. Português. Bíblia de Estudo Almeida, Mt 24,35.
} 
de Deus era a sua ênfase, como bem afirma Schillebeeckx ${ }^{132}$, ao pontuar que no ministério de Jesus o conceito do Reino teve proeminência.

Deste modo, a diferença na pregação de Jesus está justamente na sua forma de interpretar as Escrituras e, concomitantemente, acrescentar sentenças que o diferenciam como a "Palavra que se fez carne". Ele era (e é) a Palavra de Deus encarnada, contextualizada à realidade humana. A sua hermenêutica, inclusive, é mais importante do que a sua leitura. Ele lê a Escritura, mas, por vezes, acrescenta, a sua própria interpretação ("Eu, porém, vos digo"). Mais importante era, portanto, o novo sentido que Cristo deu às Escrituras do que a própria leitura realizada. Assim, o mestre "demonstra que a sua missão de Revelador se fundamenta

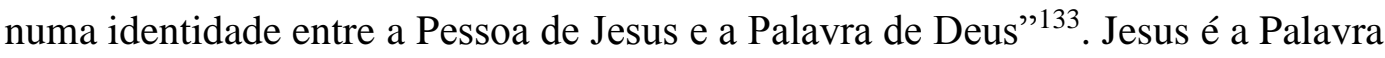
que lê, interpreta e anuncia as Escrituras, pois "a Palavra encarnou-se também na Bíblia. [...] A palavra continua viva [...], a Palavra se fez texto" ${ }^{\prime 34}$.

Os apóstolos, após a ascensão de Jesus, continuaram a pregar sob esta mesma percepção, isto é, sobre o Cristo que as Escrituras advertiam que chegaria. Cristo era o paradigma da pregação. Paulo, por exemplo, ao escrever à igreja de Corinto revela o caráter de sua pregação, quando afirma: "Eu, irmãos, quando fui ter convosco, anunciando-vos o testemunho de Deus, não o fiz com ostentação de linguagem ou de sabedoria. Porque decidi nada saber entre vós, senão a Jesus Cristo e este crucificado"135 (1Cor 2,1-2).

Portanto, assim como ocorreu com o Antigo Testamento, o Novo Testamento, antes de qualquer estrutura ou cânon pré-estabelecido, começou a tomar forma por meio da oralidade, da pregação, do testemunho. Afinal, "os textos bíblicos surgiram em comunidades de fé, como expressão da fé"136. De forma especial, as pregações apostólicas difundiram as Escrituras Sagradas e contribuíram para elaborar e, posteriormente, definir o cânon neotestamentário. Esse processo, obviamente, foi natural e gradativo, não intencional. Os evangelistas não pretendiam escrever uma biografia, muito menos uma história precisa; eles escreveram "obras

${ }^{132}$ SCHILLEBEECKX, Edward. História humana: revelação de Deus. São Paulo: Paulus, 1994, pp.150-151.

${ }_{133}$ MANNUCCI, Valério. Bíblia, Palavra de Deus: curso de introdução à Sagrada Escritura, p. 136.

${ }^{134}$ KONINGS, Johan. A Bíblia, sua origem e sua leitura: introdução ao estudo da Bíblia, p. 13.

${ }^{135}$ BÍBLIA Sagrada. Português. Bíblia de Estudo Almeida, 1Cor 2,1-2 (grifo nosso).

${ }^{136}$ LIMA, Maria de Lourdes Corrêa. História e Teologia. Reflexões na perspectiva da exegese bíblica. Atualidade Teológica. Ano XVII, n. 43, jan.-abr., 2013, p. 107. 
teológicas" que evidenciavam quem Jesus era ${ }^{137}$. Paulo também não esperava ser o grande teólogo escritor que se tornou ${ }^{138}$. "Os primeiros seguidores de Jesus não se consideravam parte de uma nova religião que precisava de suas próprias Escrituras. Eles eram, na sua maioria, bons judeus que aceitavam as Escrituras em hebraico e criam que Jesus eram o cumprimento delas" ${ }^{\text {"139. }}$.

Como eles esperavam a volta iminente de Cristo, a ênfase estava na pregação, na oralidade. As tradições a respeito do Messias estavam vivas na mente, na vida e nas pregações deles. Era o evangelho oral, era o "evangelho antes dos evangelhos" ${ }^{140}$. Foi depois de algum tempo, entre duas e três décadas, que os primeiros escritos dos apóstolos e dos evangelistas começaram a surgir. Assim, progressivamente,

A Igreja se difunde amplamente no mundo e se distancia sempre mais dos dias do Jesus de Nazaré e do Pentecostes; a única memória oral e vital dilui-se no tempo e corre o risco de se desfigurar a figura, a mensagem e o ministério de Jesus Cristo; torna-se necessário um ponto de referência escrito ${ }^{141}$.

A difusão de tudo o que Jesus tinha feito, por meio da oralidade e da pregação apostólica, era tão importante que, para não se correr o risco de esquecer, se fazia necessário escrever. Por isso, "tudo o que Jesus fez e ensinou, desde o começo do seu trabalho até o dia em que ele foi levado para o céu" foi se tornando texto. Surgiam, assim, as "coleções das palavras de Jesus (logia)"142, isto é, "uma coletânea de sentenças e milagres de Jesus, para servir de subsídio aos novos evangelizadores que não participaram pessoalmente dos acontecimentos"143. Trebolle Barrera ${ }^{144}$ reitera que esses textos foram difundidos naquele período em folhas soltas de papiro como uma forma de propagar a fé cristã. Um pouco mais tarde esses escritos ajudaram a compor o que se tornou Escritura Sagrada para os cristãos $^{145}$. De fato, "Não era intenção dos evangelistas narrar acontecimentos como fariam os jornalistas ou os historiadores. Eles relataram uma história real,

\footnotetext{
${ }^{137}$ Cf. HALE, Broadus David. Introdução ao Estudo do Novo Testamento, pp. 29-30.

${ }^{138}$ Cf. KUMMEL, Werner Georg. Sintese Teológica do NT de acordo com as testemunhas principais: Jesus, Paulo e João. São Paulo: Editora Teológica, 2003, p. 396; KONINGS, Johan. A Bíblia, sua origem e sua leitura: introdução ao estudo da Bíblia, p. 129

${ }^{139}$ MILLER, Stephen; HUBER, Robert. A Bíblia e sua história: o surgimento e o impacto da Bíblia, p. 67.

${ }^{140}$ KONINGS, Johan. A Bíblia, sua origem e sua leitura: introdução ao estudo da Bíblia, p. 124.

${ }^{141}$ MANNUCCI, Valério. Bíblia, Palavra de Deus: curso de introdução à Sagrada Escritura, p. 86.

${ }^{142}$ BARRERA, Júlio Trebolle. A Bíblia judaica e a Bíblia cristã, p. 118.

${ }^{143}$ KONINGS, Johan. Op. cit., p. 124.

${ }^{144}$ Cf. BARRERA, Júlio Trebolle. Op. cit., p. 106.

${ }^{145}$ Cf. BíBLIA Sagrada. Português. Bíblia de Estudo NTLH. Lc 1,1-2.
} 
realmente acontecida, mas o fizeram à luz da Palavra de Deus, interpretada e compreendia com base na Palavra de Deus" ${ }^{\text {"146. }}$

Alguns acreditam que, por exemplo, o primeiro Evangelho escrito, o Evangelho de Marcos, foi elaborado a partir das pregações e dos ensinos do apóstolo Pedro enquanto ambos estavam em Roma ${ }^{147}$. Essa afirmativa encontra fundamento na obra do historiador Eusébio de Cesareia, em sua História eclesiástica, citando Papias (140 d.C., bispo em Hierápolis, discípulo de João). Outros, como Justino Mártir (159 d.C.) e Irineu de Lyon (130 - 202 d.C.) reforçaram tal argumento na história. Eusébio afirma que aqueles que ouviam a pregação de Pedro

[...]. Não ficavam satisfeitos apenas ouvindo-o uma vez, nem com o ensinamento não escrito da pregação divina, mas com todo tipo de pedidos importunavam Marcos - de quem se diz que é o Evangelho e que era companheiro de Pedro - para que lhes deixasse também um memorial escrito da doutrina que de viva voz lhes era transmitida, e não o deixaram em paz até que o homem o tivesse terminado, e desta forma tornaram-se a causa do texto chamado Evangelho de Marcos. E dizem que o apóstolo, quando por revelação do Espírito soube o que tinha sido feito, alegrou-se pela boa vontade daquela gente e aprovou o escrito para ser lido nas igrejas $^{148}$.

Como se sabe, o Evangelho de Marcos influenciou e serviu de base para os demais evangelistas sinópticos (Mateus e Lucas) ${ }^{149}$. Considerando como verdade tais relatos, pode-se presumir o quanto a pregação do apóstolo Pedro sobre Cristo era importante e, por tal importância, se fazia necessária a preservação e a difusão desses escritos. Assim, fica claro que "Deus não só pronunciou em Cristo a sua Palavra última e definitiva. Ele a manifesta também quando Cristo é anunciado na pregação apostólica" ${ }^{150}$.

Mais tarde, essa mesma pregação sobre Cristo, realizada agora por Paulo nas diversas igrejas às quais dedicou parte de seu ministério como apóstolo aos gentios, precisava de mais explicações. As igrejas que receberam tais pregações e foram, em sua maioria, por ele estabelecidas, precisavam esclarecer certos pro-

\footnotetext{
${ }^{146}$ MIRANDA, Evaristo Eduardo de. Bíblia: história, curiosidades e contradições, p. 581.

${ }^{147}$ Cf. HALE, Broadus David. Introdução ao estudo do Novo Testamento, p. 74.; HORSTER, Gerhard. Introdução e síntese do Novo Testamento.Curitiba: Esperança, 1996, p. 28; KONINGS, Johan. A Bíblia, sua origem e sua leitura: introdução ao estudo da Bíblia, p. 138.

${ }^{148}$ CESAREIA, Eusébio de. História eclesiástica. São Paulo: Novo Século, 2002, p. 41 (Livro II, $\mathrm{XV}, 1-2)$ (grifo nosso).

149 "Cerca de noventa por cento de Marcos é reproduzido em Mateus e Lucas. Apenas cerca de trinta por cento dos 661 versículos de Marcos não aparece em Mateus ou Lucas. Alguns destes versículos são idênticos quanto ao vocabulário e ordem das palavras" (HALE, Broadus David. Introdução ao estudo do Novo Testamento, p. 73).

${ }^{150}$ MANNUCCI, Valério. Bíblia, Palavra de Deus: curso de introdução à Sagrada Escritura, p. 137.
} 
blemas que surgiram, além de entender certos aspectos da fé, do evangelho, de Cristo etc. Paulo tinha passado pouco tempo com eles. Eles sabiam o básico da fé. Precisavam de mais. Assim, surgiram os escritos paulinos às igrejas ${ }^{151}$, que são os "mais antigos documentos escritos da missão cristã"152. Pode-se dizer que foram estes os primeiros escritos que vieram a compor as Escrituras Sagradas para os cristãos. Cada carta escrita era fruto "relevante da preocupação pastoral e teológica de Paulo"153.

Como se sabe, muitos livros do Novo Testamento foram escritos por Paulo ou, pelo menos, foram a ele atribuídos, formando, asim, o corpus paulinum. Essas cartas se tornaram, em sua maioria, cartas circulares, ou seja, eram enviadas a várias igrejas. Cada igreja lia e passava à frente para que outras igrejas também pudessem ler $(\mathrm{Cl} 4,16)$. Essa circulação das cartas contribuiu significativamente, exercendo grande influência nos primeiros cristãos. Em uma dessas cartas já se tem, por exemplo, uma alusão de que os escritos dos Evangelhos, nesse caso o Evangelho de Lucas, também era Escritura, conforme consta na narrativa de 1Tm 5,18 .

Tal realidade contribuiu para que esses escritos fossem percebidos de forma especial, pois, "lidas nos cultos, essas cartas passaram a fazer parte da base doutrinal da comunidade" 154 . Eles eram tão relevantes, tinham tanta consistência e estavam tão firmados no evangelho de Cristo que, com o tempo, passaram a ser considerados escritos sagrados tanto quanto eram as Escrituras Sagradas do Antigo Testamento. Paulo destaca essa realidade ao afirmar que sua pregação e seus escritos estão tão firmados na Palavra de Deus que devem ser lidos em assembleia e obedecidos pelos cristãos (1Ts 5,27; 2Ts 2,15; 1Tm 1,18; 4,11). A Segunda Carta de Pedro, obviamente não escrita por Paulo, segue o mesmo raciocínio, considerando os escritos paulinos como Escrituras:

Lembrem que a paciência do nosso Senhor é uma oportunidade para vocês serem salvos. Pois o nosso querido irmão Paulo, com a sabedoria que Deus lhe deu, escreveu a vocês sobre esse assunto. $\mathrm{E}$ foi isso mesmo que ele disse em todas as suas cartas quando escreveu a respeito disso. Nas cartas dele há algumas coisas difíceis de entender, que os ignorantes e os fracos na fé explicam de maneira errada, como

${ }^{151}$ Cf. KONINGS, Johan. A Bíblia, sua origem e sua leitura: introdução ao estudo da Bíblia, pp. 129-134.

${ }^{152}$ Ibid., p 124.

${ }^{153}$ MAZZAROLO, Isidoro. Florilégios da Bíblia 2. Rio de Janeiro: Mazzarolo, 2009, p. 26.

${ }^{154}$ DREHER, Martin Norberto. Bíblia: suas leituras e interpretações na História do Cristianismo, p. 11. 
fazem também com outras partes das Escrituras Sagradas. E assim eles causam a sua própria destruição ${ }^{155}(2 \mathrm{Pd} 3,15-16)$.

As cartas de Paulo ganham status de Escritura junto com a Lei, os Escritos e os Profetas. Como se sabe, essas cartas, assim como os Evangelhos e os demais livros do Novo Testamento, foram escritas em grego. Essa era a língua universal e acessível a todos do império e foi dessa forma que esses escritos se difundiram. A citação do Antigo Testamento era realizada por meio dos textos da Septuaginta, em grego, e os novos escritos, também escritos em grego, na língua comum do povo, foram sendo considerados, paulatinamente, como Escrituras Sagradas ${ }^{156}$. Assim, tiveram ampla difusão. A escolha do grego evidencia um propósito específico, pois, para os cristãos, a Palavra de Deus precisava ser difundida da forma mais ampla possível, afinal essa Palavra era a Palavra de Deus (At 4,29.31; 1Ts 2,13); era a Palavra do Senhor (At 8,25). E isso passou a acontecer, conforme se constata nas declarações de Lucas - pelo menos três - ao escrever no livro de Atos, que a Palavra de Deus crescia, prevalecia, multiplicava e se espalhava (At 6,$7 ; 12,24$ e 19,20).

\section{5}

\section{A difusão das Escrituras Sagradas no tempo dos Pais da Igreja}

Considerando a estima dos primeiros líderes cristãos — sucessores dos apóstolos nos primeiros séculos —, alguns foram reconhecidos e, posteriormente, chamados de "Pais" ou "Padres" da Igreja ${ }^{157}$, dada a sua importância na história da fé cristã. Com propriedade, Hall resume essa designação, ao afirmar que

O termo adquiriu sentido mais técnico a partir do quarto século, especialmente no contexto das controvérsias teológicas que povoaram o quarto e o quinto séculos. Enquanto os bispos - os professores da igreja - foram chamados pais do segundo século em diante, bispos que preservaram e protegeram fielmente as decisões do Concílio de Niceia (325 d.C.), Constantinopla (381) e Calcedônia (451) receberam

\footnotetext{
${ }^{155}$ BÍBLIA Sagrada. Português. Bíblia de Estudo NTLH, 2Pd 3,15-16 (grifo nosso).

$156 \mathrm{O}$ processo que levou à canonização dos livros do Novo Testamento foi gradual. As igrejas receberam esses textos e foram, aos poucos, reconhecendo neles alguns critérios que os distinguiam das demais literaturas. O cânon oficial, estabelecido séculos mais tarde nos concílios, foi a formalização de algo que já havia sido aceito pela maioria dos cristãos da época. Cf. CULLMANN, Oscar. A formação do Novo Testamento. São Leopoldo: Sinodal, 2001, pp. 89-92.

${ }^{157}$ A designação "pai/padre da Igreja" foi utilizada "originalmente para denominar os bispos que foram os sucessores das testemunhas diretas de Jesus Cristo, isto é, dos apóstolos e dos varões apostólicos (Marcos, Lucas, Tito, Timóteo, Silas etc.). Os padres da Igreja ensinaram, preservaram e zelaram pela doutrina da fé e pelos costumes" (FERNANDES, Leonardo Agostini. A Bíblia e sua mensagem: introdução à leitura e ao estudo da Bíblia, p. 17).
} 
esta designação como pessoas dignas de especial consideração por terem preservado o ensino ortodoxo durante o tempo da grande prova ${ }^{158}$.

Diante dessa presença relativamente prolongada nos primeiros séculos da história eclesiástica, os Pais da Igreja podem ser divididos em três categorias, a saber: "Pais Apostólicos", "Apologistas" e "Polemistas"159. Essa divisão não impede que um ou outro esteja incluído em mais de uma categoria. Historicamente, logo após o fim da era apostólica, surgiram os primeiros pais, reconhecidos como "Pais Apostólicos". Trata-se de "alguém que conhecia alguém que conhecia Jesus", como bem simplificam Miller e Hubber ${ }^{160}$ ao lembrar a relação mais próxima que estes tinham com os apóstolos. A responsabilidade pela Igreja cristã, recém-nascida, estava agora sob eles. Por assim ser, escreveram, entre o primeiro e o segundo séculos, textos que edificaram a Igreja. Entre eles, destacam-se Clemente de Roma, Inácio de Antioquia e Policarpo.

Os apologistas formam um segundo grupo. Por meio de seus escritos e de suas reconhecidas habilidades, eles escreveram consistentes defesas da fé cristã, principalmente no período de significativa perseguição do Estado. Escrevendo contra os hereges ou a líderes do Estado, eles se esforçavam "para convencê-los da verdade da Bíblia através do argumento literário" ${ }^{161}$. Nesse argumento resta óbvio que "a Escritura ocupa um papel central nas controvérsias teológicas"162 nos escritos dos Pais da Igreja, na Antiguidade. Situados a partir do segundo século, destacam-se Justino Mártir e Tertuliano.

Por conseguinte, os polemistas, situados a partir do terceiro século, são caracterizados por escritos que combatiam falsos ensinos surgidos dentro ou fora da igreja. Destacam-se entre os polemistas Irineu, Orígenes, entre outros. Vale ressaltar que os Pais da Igreja também podem ser categorizados em latinos/ocidentais (entre eles, Ambrósio, Agostinho, Jerônimo e Gregório, o Grande) e gregos/orientais (entre eles Atanásio, Basílio, Gregório de Nazianzo e João Crisóstomo) ${ }^{163}$.

\footnotetext{
${ }^{158}$ HALL, Christopher. Lendo as Escrituras com os pais da Igreja. Viçosa: Ultimato, 2007, p. 60. ${ }^{159}$ CAIRNS, Earle Edwin. O cristianismo através dos séculos: uma história da igreja cristã, p. 120.

${ }^{160}$ MILLER, Stephen; HUBER, Robert. A Bíblia e sua história: o surgimento e o impacto da Bíblia, p. 80

${ }^{161}$ CAIRNS, Earle Edwin. Op. cit., p. 90.

${ }^{162}$ DORIVAL, Gilles. Antiguidade Cristã Grega e Bíblia. In: LONGTON, Joseph; POSWICK, Réginald-Ferdinand [et al.] (orgs.). Dicionário Enciclopédico da Bíblia, p. 99.

${ }^{163}$ Cf. HALL, Christopher. Op. cit., p. 66.
} 
Como se percebe, esse período foi marcado por intensa atividade apologéti$\mathrm{ca} /$ polemista por meio da escrita ${ }^{164}$. Esses escritos constituíram, por assim dizer, as primeiras literaturas cristãs, sendo designados, então, pela alcunha Pais Apostólicos. Não se trata de qualquer escrito, antes, pelo contrário, “as fontes dos pais da Igreja era a Bíblia" ${ }^{165}$. Por isso, muitos desses escritos eram uma reescrita parafraseada das Escrituras. Eles repetiam "o que afirmava um versículo ao reescrevê-lo a seu modo, na língua de seu século" ${ }^{166}$. Era o cristianismo se desenvolvendo e se fortalecendo sob o fundamento das Escrituras.

Ainda que em certos momentos algum escrito ou até mesmo algum dos "Pais" tenham sidos questionados, a teologia que eles construíram fortaleceu a igreja, servindo como base doutrinária até os dias atuais para os cristãos. Eles defendiam a fé cristã com ousadia diante do paganismo e das heresias (o gnosticismo com seus "evangelhos gnósticos", por exemplo) que surgiam. Por meio de seus escritos, algumas doutrinas cristãs, alicerces para a igreja em toda a história, foram por eles desenvolvidas. Nas palavras de Hall, esses escritos formam "um amplo conjunto de proposições teológicas, que tem permanecido básico para a ortodoxia cristã para quase todas linhas denominacionais"167.

Contudo, o que largamente se ressalta nessa realidade patrística ${ }^{168}$ é a relação com as Escrituras Sagradas. De fato, o primeiro "e mais fundamental pressuposto, que regula a exegese patrística, é considerar a Escritura como divina"169. Por isso, os Pais da Igreja, constantemente, "citam e usam a linguagem das Escrituras"170. Deus confiou a Escritura Sagrada à igreja; cabia a eles proclamá-la. Sob esse alicerce, as Escrituras, reconhecidas por eles como inspiradas por Deus, constituem o alicerce do trabalho patrístico por meio dos escritos, da oração, da liturgia, da homilia. Não se trata de uma simples relação teórica, apesar de eles terem desenvolvido, em paralelo aos outros escritos, muitos “comentários sobre a Sa-

${ }^{164}$ Cf. PADOVESI, Luigi. Introdução à Teologia Patrística. São Paulo: Loyola, 1999, pp. 17-34. ${ }^{165}$ LORTZ, Joseph. Historia de La Iglesia: en la perspectiva de la historia del pensamiento. Antiguedad y edad media. Vol. I, p. 411 (tradução nossa).

166 DORIVAL, Gilles. Antiguidade Cristã Grega e Bíblia. In: LONGTON, Joseph; POSWICK, Réginald-Ferdinand [et al.] (orgs.). Dicionário Enciclopédico da Bíblia, p. 97.

${ }^{167}$ HALL, Christopher. Lendo as Escrituras com os pais da Igreja, p. 64.

168 Patrística é nome que designa o arcabouço de doutrinas desenvolvidos pelos pais da igreja. Compreende boa parte da literatura cristã desenvolvida entre o segundo e o quinto século. Cf. PADOVESI, Luigi. Op. cit., pp. 21-24.

169 KANNENGIESSER, Charles. A leitura da Bíblia na Igreja Primitiva. In: BEUKEN, Win; FREYNE, Sean; WEILER, Anton (orgs.). A Bíblia e seus leitores. Revista Concilium. Petropólis: Vozes, 1991, p. 41. (grifo do autor).

${ }^{170}$ CAIRNS, Earle Edwin. O cristianismo através dos séculos: uma história da igreja cristã, p. 60. 
grada Escritura" ${ }^{" 171}$. Eles tinham as Escrituras Sagradas como o fundamento de fé e de prática nas diversas situações que enfrentavam. As Escrituras Sagradas constituíam a resposta mais segura que eles tinham para as situações da vida, da sociedade e da igreja no tempo em que viveram. Mesters, ao analisar contextos específicos contemporâneos à João Crisóstomo e Agostinho, aponta que:

Fatos, acontecimentos, problemas, preocupações, experiências e vivencias do século IV e V trouxeram uma contribuição substancial para a compreensão dos velhos textos da Bíblia [...]. Ao abrirem a Bíblia, [Agostinho e João Crisóstomo] eram motivados por perguntas bem concretas, levantadas pela vida e pela história, para os quais buscavam uma resposta ${ }^{172}$.

Dessa forma,

Vista como dotada de autoridade divina e portadora de uma doutrina salutar, a Sagrada Escritura gozava de uma autoridade maior que outra qualquer na Igreja. Quando se tratava da edificação da Igreja, da definição de sua identidade em meios aos debates e inevitáveis confusões nos primeiros dias daquilo que era o movimento de Jesus, a Escritura divina era a única garantia de uma autêntica fé em Cristo ${ }^{173}$.

Nessa perspectiva, os Pais Apostólicos, além de aplicá-las ao cotidiano e citá-las com certa frequência, contribuíram com a definição do cânon. Inicialmente, ainda sob influência do tempo apostólico, eles usavam e citavam muito mais o AT do que o NT. Progressivamente, entretanto, eles passaram a inverter essa ordem, dando mais importância às palavras de Cristo e dos apóstolos devido às disputas teológicas que surgiram ${ }^{174}$. Deste modo, eles testificaram

[...] em termos insofismáveis que os quatro evangelhos e os escritos dos apóstolos estavam começando a ser reconhecidos como Escritura Sagrada com a mesma autoridade do Antigo Testamento, mesmo que o Novo Testamento ainda não tivesse alcançado sua forma final em sua época. Quase todos os livros que chegaram a ser incluídos no Novo testamento são citados ou referidos nos Pais Apostólicos ${ }^{175}$.

Nos Pais da Igreja, portanto, o cânon, que viria a formar o que atualmente concebe-se como Novo Testamento, é reconhecido. Entre outros, um dos critérios necessários para que se chegasse à conclusão da canonicidade dos livros do Novo Testamento era exatamente o seu uso pela igreja e pelos Pais. Como se percebe,

\footnotetext{
${ }^{171}$ LORTZ, Joseph. Historia de La Iglesia: en la perspectiva de la historia del pensamiento. Antiguedad y edad media. Vol. I, p. 420 (tradução nossa).

${ }_{172}$ MESTERS, Carlos. Palavra de Deus na história dos homens, p. 198.

${ }^{173}$ KANNENGIESSER, Charles. A leitura da Bíblia na Igreja Primitiva. In: BEUKEN, Win; FREYNE, Sean; WEILER, Anton (orgs.). A Bíblia e seus leitores. Revista Concilium, p. 42.

${ }^{174}$ Cf. DORIVAL, Gilles. Antiguidade Cristã Grega e Bíblia. In: LONGTON, Joseph; POSWICK, Réginald-Ferdinand [et al.] (orgs.). Dicionário Enciclopédico da Bíblia, p. 99.

${ }^{175}$ HÄGGLUND, Bengt. História da teologia. Porto Alegre: Concórdia, 2003, p. 17.
} 
os Pais falavam e difundiam as Escrituras. A Segunda Carta de Clemente de Roma, por exemplo, iguala o Antigo Testamento (chamado de Bíblia) com o Novo Testamento (chamado de Apóstolos). Além disso, ao se referir a um texto encontrado no em Mt 9,13, Clemente define-o como "outro texto da Escritura"176. Nesta mesma carta constam ainda cerca de trinta citações explícitas do $\mathrm{NT}^{177}$. A Epístola de Barnabé e a Carta de Inácio de Antioquia seguem esse mesmo padrão ${ }^{178}$. Tratam-se, portanto, de afirmações pós-apostólicas ainda do primeiro século que consideram os textos do Novo Testamento como Escritura Sagrada, assim como eram os textos do Antigo Testamento. Deste modo, a difusão do texto sagrado e o estabelecimento do seu respectivo cânon ocorrem de forma indissociável.

Obviamente, como bem lembra Hall, essa relação com as Escrituras poderia se dar, também, "em pontos de acordo e de desacordo acerca de como se deve interpretar a Bíblia. [Ainda assim] Todos concordavam que a Bíblia é um texto inspirado"179. Historicamente, essas discordâncias foram e são comuns. O que mais importa, entretanto, é que, constituindo um alicerce necessário para a igreja cristã que crescia frente aos desafios que lhe eram impostos,

Não foi tanto através das alianças políticas nem tampouco graças ao tipo de administração herdada do Império Romano tardio, que se garantiu a unidade formal entre os patriarcados cristãos, mas pela sua comum submissão à mesma revelação divina recebida da Escritura. Em um período que se estende do século II até ao século VII da era cristã, a irradiação criativa da Escritura impregnou todos os valores tradicionais da Antiguidade tardia ${ }^{180}$.

Por meio de seus escritos, enquanto difundiam as Escrituras, os Pais constituíram as bases do desenvolvimento da Igreja em seu aspecto coletivo e comunitário, sem deixar, entretanto, de ressaltar a necessidade da disposição pessoal e espiritual para que se pudesse ler adequadamente a Palavra de Deus.

Para os cristãos dos primeiros séculos, a atualidade da Bíblia é tal que quase não existem espaços da vida que não sejam organizados a partir de um referencial à Es-

\footnotetext{
${ }^{176}$ MILLER, Stephen; HUBER, Robert. A Bíblia e sua história: o surgimento e o impacto da Bíblia, p. 81. Miller e Hubber ressaltam que o texto citado por Clemente está em 2Clemente 14.2.

177 DORIVAL, Gilles. Antiguidade Cristã Grega e Bíblia. In: LONGTON, Joseph; POSWICK, Réginald-Ferdinand [et al.] (orgs.). Dicionário Enciclopédico da Bíblia, p. 98.

${ }^{178}$ Cf. DREHER, Martin Norberto. Bíblia: suas leituras e interpretações na História do Cristianismo, p. 11.

${ }^{179}$ HALL, Christopher. Lendo as Escrituras com os pais da Igreja, p. 151.

${ }^{180}$ KANNENGIESSER, Charles. A leitura da Bíblia na Igreja Primitiva. In: BEUKEN, Win; FREYNE, Sean; WEILER, Anton (orgs.). A Bíblia e seus leitores, p. 46.
} 
critura. Pode-se dizer que há uma cristianização, em termos bíblicos, quase completa do tempo e do espaço ${ }^{181}$.

Para a igreja que crescia aos poucos, principalmente nos primeiros séculos, esse é um momento de vital importância. É no período patrístico, por exemplo, que o culto cristão começa a tomar forma. Semelhante ao culto judaico de uma sinagoga, as Escrituras também obtiveram significativa importância na recémcriada liturgia cristã. Obviamente, a grande diferença se deu pelo acréscimo da leitura do Novo Testamento. Como cerne da liturgia, "aquilo que a Igreja tinha que proclamar era a Escritura"182 e, assim, "ao lado da liturgia eucarística havia liturgias da Palavra" "183. Lortz resume com propriedade esses fatos ao lembrar que

Uma vez que os cristãos se separaram da comunidade judaica e se abstiveram do serviço do templo, eles organizaram seu culto seguindo o modelo judaico: leitura das Sagradas Escrituras e a pregação (como Paulo em Atos 20,7ss); a isso foi adicionado o "partir do pão", isto é, a celebração eucarística da Ceia do Senhor ${ }^{184}$

Nesse sentido, as "Escrituras são, sem dúvida, norma da liturgia. Nesta estreita vinculação entre Escrituras e liturgia, está todo o entendimento espiritual que os Padres da Igreja intuíram e concretizaram" ${ }^{85}$. De acordo com os Pais da Igreja, portanto, o culto é um lugar onde a Escritura se torna indispensável, pois, por meio da liturgia, eles "descortinavam as Sagradas Escrituras para toda a comunidade". Até mesmo as orações eram algumas vezes retiradas dos Evangelhos ou das Cartas Paulinas. Já no terceiro século as cerimônias foram atreladas aos dias festivos, estabelecendo leituras que estavam relacionadas ao que se celebrava. O fato preponderante nesse processo é que "muitas informações da Bíblia formaram a liturgia cristã e seu calendário litúrgico" ${ }^{186}$.

Constata-se, então que, tanto no aspecto litúrgico, como no aspecto doutrinário da fé cristã, a influência dos pais da igreja, sob o fundamento das Escrituras, foi um marco na história, principalmente naquela época em que havia um "alto

\footnotetext{
${ }^{181}$ DORIVAL, Gilles. Antiguidade Cristã Grega e Bíblia. In: LONGTON, Joseph; POSWICK, Réginald-Ferdinand [et al.] (orgs.). Dicionário Enciclopédico da Bíblia, p. 100.

${ }^{182}$ KANNENGIESSER, Charles. A leitura da Bíblia na Igreja Primitiva. In: BEUKEN, Win; FREYNE, Sean; WEILER, Anton (orgs.). A Bíblia e seus leitores, p. 43.

${ }^{183}$ MARKSCHIES, Christoph. De meados do século II até o final do século III. In: KAUFMANN, Thomas [et al.] (orgs.). História Ecumênica da Igreja 1: dos primórdios até a Idade Média. São Paulo: Loyola; Paulus; São Leopoldo: Sinodal, 2012, p. 76.

${ }^{184}$ LORTZ, Joseph. Historia de La Iglesia: en la perspectiva de la historia del pensamiento. Antiguedad y edad media. Vol. I, p. 125 (tradução nossa).

${ }^{185}$ BOSELLI, Goffredo. O sentido espiritual da liturgia, p. 16.

${ }^{186}$ FITZMYER, Joseph. Augustine. A Bíblia na Igreja. São Paulo: Loyola, 1997, p. 104.
} 
índice de analfabetismo" ${ }^{187}$. Quando liam, eles explicavam, pregavam e inseriam as Escrituras na vida da igreja e, ao mesmo tempo, evidenciavam a sua importância. Tal evidência foi tão significativa que contribuiu com o fechamento do cânon. Assim, na realidade patrística, "formação do Novo Testamento, leitura da Bíblia e liturgia estão muito próximas" $" 188$.

Para além da presença marcante das Escrituras nesses aspectos, "na catequese, a Bíblia tem uma importância central" ${ }^{\text {"189 }}$. O ensinamento para o neófito ou para o leigo é de tamanha importância que as Escrituras são colocadas como foco nessa formação. Nesse período, constata-se, então, uma difusão das Escrituras que estimula a fé, edifica a igreja, estabelece o cânon neotestamentário, combate heresias, fundamenta a liturgia, constitui a doutrina e constrói a teologia. Não é de se admirar, portanto, que até hoje os Pais da Igreja sejam referências para a igreja cristã.

\subsection{1}

\section{A difusão das Escrituras Sagradas do rolo ao livro}

Nesse estudo da patrística se faz necessário intercalar um assunto importante que favoreceu significativamente a difusão das Escrituras Sagradas a ponto de até nos dias de hoje se perceber tal importância do fato. Os manuscritos bíblicos, por muito tempo, foram escritos a mão em materiais não muito duráveis, razão esta que reduziu a vida destes materiais. Além de outros materiais utilizados desde os primeiros registros das Escrituras, um amplamente utilizado, principalmente na escrita do Antigo Testamento, era o papiro, formado a partir de uma espécie de planta do mesmo nome, importada do Egito. O "papiro foi usado desde aproximadamente 1400 a.C. até 600 d.C." ${ }^{190}$, pois era barato, mais facilmente encontrado e tinha folhas grandes que facilitavam a escrita. Com o passar do tempo, outro material também usado em abundância foi o pergaminho, formado a partir da pele retirada de animais. Apesar de ser mais durável que o papiro, seu uso não substituiu inicialmente o papiro.

\footnotetext{
${ }^{187}$ MARKSCHIES, Christoph. De meados do século II até o final do século III. In: KAUFMANN, Thomas [et al.] (orgs.). História Ecumênica da Igreja 1: dos primórdios até a Idade Média., p. 75. ${ }^{188}$ DREHER, Martin Norberto. Bíblia, p. 12.

189 DORIVAL, Gilles. Antiguidade Cristã Grega e Bíblia. In: LONGTON, Joseph; POSWICK, Réginald-Ferdinand [et al.] (orgs.). Dicionário Enciclopédico da Bíblia, p. 102.

${ }^{190}$ SCHOLZ, Vilson. A transmissão do texto bíblico. In: ZIMMER, Rudi (Org.). Manual do Seminário de Ciências Bíblicas, p. 28.
} 
Dessa forma, os manuscritos mais antigos de que se tem conhecimento eram agrupados, um ao lado do outro, formando assim rolos. Inclusive, alguns "livri-

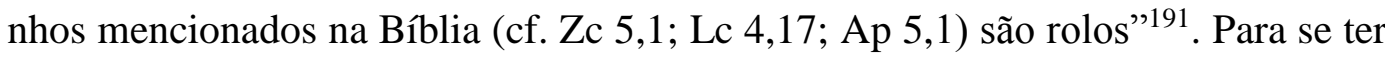
uma ideia de quão complexo era transcrever as Escrituras nesse tipo de formato, Hale $^{192}$ relata que todo o Novo Testamento escrito no papiro poderia perfazer um rolo de aproximadamente 65 metros. Realmente, ler as Escrituras era um desafio e tanto.

Porém, foi justamente no período dos pais da igreja que se iniciou o uso do códice, que era uma espécie de encadernação atual. Já aproximadamente no quarto século, o códice começou a substituir os rolos, assim como o pergaminho ao papiro. $\mathrm{O}$ fato que se destaca nesse processo é que "levando em conta o número de códices que permaneceram desde o segundo século, os cristãos rapidamente adotaram essa nova forma de livro. Dos 870 códices sobreviventes dessa época, apenas 14 não são textos cristãos"193.

Constata-se, portanto, que os códices constituíram uma mudança de paradigma interessante nesse período. Os cristãos perceberam nos códices uma tendência que se confirmaria com o tempo ${ }^{194}$, mas que, também, se tornou um diferencial que os distinguiram dos judeus com seus rolos sagrados. Ao mesmo tempo, essa mudança favoreceu a difusão e a leitura das Escrituras pelos cristãos. "A imediata adoção do códice pelos cristãos representou uma ruptura com a tradição judaica que não autorizava a cópia dos textos sagrados em outro formato a não ser o do volume ou do rolo"195.

Deste modo, já a partir do segundo século, o códice foi utilizado para a Escritura Sagrada pelos cristãos, tanto no Antigo como no Novo Testamento. Esses fatos, apesar de técnicos, se enquadram nesta pesquisa pelo fato de que, a partir dessas transformações, a difusão das Escrituras foi fortalecida e facilitada; afinal, cada detalhe podia beneficiar ou prejudicar o acesso e a difusão da Palavra de Deus. A próxima transformação significativa dos materiais utilizados na escritura-

\footnotetext{
${ }^{191}$ SCHOLZ, Vilson. A transmissão do texto bíblico. In: ZIMMER, Rudi (Org.). Manual do Seminário de Ciências Bíblicas, p. 29.

192 Cf. HALE, Broadus David. Introdução ao Estudo do Novo Testamento, p. 38.

${ }^{193}$ MILLER, Stephen; HUBER, Robert. A Bíblia e sua história: o surgimento e o impacto da Bíblia., p. 88 .

194 "Sabe-se com certeza que este novo formato do livro foi adotado e difundido pelos cristãos" (SCHOLZ, Vilson. Op. cit., p. 29).

${ }^{195}$ BARRERA, Julio Trebolle. A Bíblia judaica e a Bíblia cristã, p. 118.
} 
ção bíblica ocorrerá bem mais tarde, na Idade Média, quando o papel é introduzido como opção para se copiar as Escrituras.

\title{
2.5 .2
}

\section{A contribuição de Orígenes na difusão das Escrituras Sagradas}

É no período da patrística, por meio de um dos Pais da Igreja ${ }^{196}$, que se tem o que atualmente poderia ser concebido como uma Bíblia de Estudo, isto é, uma Bíblia que além de seu texto escriturístico fornece concomitantemente auxílios que facilitam a leitura e a interpretação das Escrituras. Trata-se da Bíblia Héxapla de Orígenes, um dos mais profícuos escritores, brilhante professor, exímio pregador e erudito teólogo da igreja. Lortz, ao comentar tal feito, destaca que

\begin{abstract}
A erudição de Orígenes, bem como sua aplicação, supera todo o imaginável. Uma fecundidade literária igualmente grande correspondia à sua enorme capacidade de trabalho. Ele não só comentou quase todas as Sagradas Escrituras de diferentes pontos de vista; como também foi pioneiro na reconstrução filológica exata do texto dos Livros Sagrados (do Antigo Testamento), colocando o texto hebraico (na língua hebraica e em sua transcrição grega), além de quatro traduções gregas existentes, em seis colunas (=Hexapla) um ao lado de outro ${ }^{197}$.
\end{abstract}

De fato, o projeto é muito amplo. Por sua extensão, poderia até ser considerado um conjunto enciclopédico da Bíblia, pois além de levar 15 anos para ficar pronta, calcula-se que a obra tinha “cerca de 6.500 páginas, num total de mais ou menos 15 volumes" ${ }^{198}$, limitados, porém, ao Antigo Testamento. A Héxapla de Orígenes tinha seis versões diferentes das Escrituras judaicas colocadas em colunas paralelas. A ideia de Orígenes era permitir que o leitor pudesse comparar as versões disponíveis e, ao mesmo tempo, encontrar meios mais fáceis para encontrar textos bíblicos, comparando-os com versões distintas a fim de usá-las como argumentação teológica em seus debates. Trata-se de um trabalho que contribuiu muito com a difusão e o estudo das Escrituras, pois naquela época

\footnotetext{
${ }^{196}$ Hall afirma que Orígenes não é reconhecido por alguns como um dos Pais da Igreja devido a alguns desvios doutrinários. Alguns de seus ensinos, inclusive, foram condenados pelo II Concílio em Constantinopla no ano 553 (Cf. HALL, Christopher. Lendo as Escrituras com os pais da Igreja, p. 62).

${ }^{197}$ LORTZ, Joseph. Historia de La Iglesia: en la perspectiva de la historia del pensamiento. Antiguedad y edad media. Vol. I, p. 97 (tradução nossa)

${ }^{198}$ MILLER, Stephen; HUBER, Robert. A Bíblia e sua história: o surgimento e o impacto da Bíblia., p. 90 .
} 
Havia muitas versões do Antigo Testamento, várias em hebraico e algumas contendo trechos que outras não continham. Havia também muitas traduções gregas da Bíblia Hebraica, incluindo muitas variações da Septuaginta, a primeira tradução em grego. Então, ele decidiu colocar as melhores versões em colunas paralelas para melhor poder estudá-las. [...] Orígenes dedicou a maior parte do seu tempo à quinta coluna, isto é, à revisão da Septuaginta. Algumas passagens da Septuaginta não aparecem no texto hebraico, e outras partes que apareciam no texto em hebraico estavam faltando na Septuaginta. Orígenes incluiu tudo na sua versão revisada (com notas indicando quais passagens estavam faltando no hebraico e quais foram adicionadas) $)^{199}$.

Como se percebe, foi um trabalho intenso. Essa obra de Orígenes foi tão significativa para a história da difusão das Escrituras que foi, inclusive, base para a tradução que mais tarde seria desenvolvida por Jerônimo em sua Vulgata. Orígenes, por meio da Bíblia Héxapla, contribuiu significativamente para que a difusão das Escrituras chegasse a um patamar ainda pouco ou quase nunca alcançado na leitura bíblica por meios dos auxílios ao estudo bíblico pelo leitor.

Vale ressaltar ainda que Orígenes contribuiu significativamente com a definição do cânon neotestamentário. Conforme afirmado anteriormente, esse período foi marcado pela definição do cânon, e os Pais da Igreja foram fundamentais nessa composição. A contribuição de Orígenes se deu por meio de uma pesquisa realizada por ele entre igrejas cristãs da época. Ele queria saber quais livros as igrejas estavam usando regularmente, visto que o uso pelas igrejas locais constituiria um dos critérios mais relevantes para o fechamento do cânon. É importante lembrar que, naquele tempo,

Sob condições da Igreja imperial, de longe nem todas as comunidades possuíam uma Bíblia completa; partes da Bíblia - o Novo testamento completo foi transmitido em quatro volumes: evangelhos, epístolas paulinas, Atos do Apóstolos e epístolas católicas com o Apocalipse - parecem ter assumido esse papel ${ }^{200}$.

Cada igreja utilizava certos livros com regularidade. Esse uso era fundamental, pois conferia legitimidade aos livros considerados inspirados. Assim como ocorreu com o Antigo Testamento, pode-se perceber que o cânon neotestamentário se desenvolveu de forma progressiva e histórica. Essa é uma razão pela qual se constata que a "maior parte do Cânon é formada por livros que referem acontecimentos na história"201.

\footnotetext{
${ }^{199}$ MILLER, Stephen; HUBER, Robert. A Bíblia e sua história: o surgimento e o impacto da Bíblia., p. 91.

${ }^{200}$ MARKSCHIES, Christoph. De meados do século II até o final do século III. In: KAUFMANN, Thomas [et al.] (orgs.). História Ecumênica da Igreja 1: dos primórdios até a Idade Média., p. 88.

${ }^{201}$ LIMA, Maria de Lourdes Corrêa. História e Teologia. Atualidade Teológica, p. 103.
} 
O resultado obtido na pesquisa de Orígenes permitiu que se estabelecessem três categorias de livros que poderiam compor o Novo Testamento. Essa pesquisa certamente influenciou Atanásio de Alexandria, que, em 367 d.C., elaborou uma "lista que contém todos (e apenas) os 27 livros do NT"202. Os resultados da pesquisa sobre os livros utilizados nas igrejas foram assim categorizados por Eusébio: os aceitos (homologoumena), os questionados (antilegomena) e os rejeitados (pseudepígrafos).

Vale ressaltar que, contra algumas teorias de conspiração que existem, a definição do cânon não ocorreu a partir do nada. Ela surgiu num processo histórico que contou com a contribuição de Orígenes, Eusébio, Constantino, entre tantos outros $^{203}$. Historicamente, portanto, os 27 livros do Novo Testamento “já eram quase universalmente aceitos como a segunda parte da Bíblia. Isso se confirmou quando os líderes da Igreja adotaram o cânon em várias conferências no Norte da África: em Hipona, em 393; Cartago, em 397 e em 419"204. Konings reitera essa percepção ao dizer que

Comumente se imagina que a canonização tenha acontecido de um dia para outro, pela vontade de alguns rabinos ou bispos reunidos. Na realidade, os livros sagrados foram, gradativamente, "canonizados de facto", pelo uso da comunidade que neles encontrava um referencial adequado de sua fé. A canonização oficial foi, em geral, uma consagração ulterior do uso que nascera da intuição da fé da comunidade ${ }^{205}$.

Como se percebe, as Escrituras criam a igreja e a igreja reconhece as Escrituras. Por conseguinte, os livros bíblicos, antes queimados pela perseguição sofrida nos primeiros séculos ${ }^{206}$, por meio de sua difusão e uso, eram agora aceitos e agrupados num cânon que criou, junto com os escritos do Antigo Testamento, a Bíblia Sagrada. Como fruto de um desenvolvimento prolongado e progressivo, "assim surgiu uma lista de livros ou de escritos, reconhecidos por todos como

\footnotetext{
${ }^{202}$ SCHOLZ, Vilson. Princípios de interpretação bíblica: introdução à hermenêutica com ênfase em gêneros literários, p. 26.

203 "O primeiro elenco dos livros do Novo Testamento é um texto do século II, o "cânon de Muratori"” (KONINGS, Johan. A Palavra se fez livro, p. 71). Trata-se de um fragmento antigo onde consta uma lista dos livros utilizados na igreja de Roma e que coincidem com quase todos os livros do Novo Testamento, escrito por volta de 170 d.C.

${ }^{204}$ MILLER, Stephen; HUBER, Robert. A Bíblia e sua história: o surgimento e o impacto da Bíblia, p. 97.

${ }^{205}$ KONINGS, Johan. A Bíblia, sua origem e sua leitura: introdução ao estudo da Bíblia, p. 154.

${ }^{206}$ CESAREIA, Eusébio de. História eclesiástica, p. 177 (Livro VIII, II, 4.5).
} 
sendo a expressão da sua fé, das suas convicções, da sua história, das suas leis, do seu culto, dos seus cantos, da sua missão"207.

Outra participação de Orígenes em relação à difusão das Sagradas Escrituras se deu pelo incentivo da leitura bíblica fundamentada em um tipo de interpretação: a alegoria ${ }^{208}$. De certa forma, a alegoria sempre esteve presente na história da leitura das Escrituras. Os escritos paulinos, por exemplo, por vezes se baseiam em alegorização. A questão que deve ser percebida, entretanto, é a intensidade e a profundidade de seu uso. A tipologia é um tipo de alegoria. Quando se lê o Antigo Testamento, encontrando Cristo presente nele, como fizeram muitos dos primeiros cristãos e dos Pais da Igreja, se está lendo sob a ótica de uma leitura alegórica.

A questão é que a alegoria constituía uma leitura muito popular naquela época. E, em Alexandria, cidade de Orígenes, a alegoria tinha encontrado boa aceitação por meio de outros personagens que se destacaram na história, como Fílon de Alexandria, por exemplo. Por isso, Orígenes se tornou um grande defensor e propagador desse tipo de leitura Bíblia, constituindo, assim, a Escola de Alexandria, reconhecida pela leitura e interpretação alegórica da Bíblia ${ }^{209}$. Para Orígenes, havia três níveis básicos de significado. Os menos importantes eram o sentido literal e o sentido histórico; o terceiro, o significado simbólico, era alcançado por meio do uso da alegoria" ${ }^{210}$.

Em contraposição a este tipo de leitura, surgiu na Síria a Escola de Antioquia, pela qual a leitura bíblica era incentivada por um método diferente que, mesmo assim, aceitava com certos limites a possibilidade da interpretação alegórica por meio de tipologias.

A escola de Antioquia ficou conhecida por sua abordagem histórica e literal na interpretação das Escrituras. Seus líderes incentivavam o estudo das línguas bíblicas originais (hebraico e grego) e foram autores produtivos que escreveram vários comentários sobre as Escrituras. Para eles, o que ligava o Antigo e o Novo Testamento eram a tipologia e as profecias, em lugar da alegorização alexandrina ${ }^{211}$

\footnotetext{
${ }^{207}$ MESTERS, Carlos. Bíblia: livro feito em mutirão, p. 11.

${ }^{208}$ Alegoria "é um tipo de metáfora expandida na qual um acontecimento ganha um significado que vai além daquele que é evidente" MILLER, Stephen; HUBER, Robert. A Bíblia e sua história: o surgimento e o impacto da Bíblia, p. 102).

${ }^{209}$ Cf. KLEIN, William; HUBBARD JR, Robert; CRAIG, Blomberg. Introdução à intepretação bíblica: Rio de Janeiro: Thomas Nelson Brasil, 2017, p. 102.

${ }^{210}$ MILLER, Stephen; HUBER, Robert. Op. cit., 102.

${ }^{211}$ BASTOS, Márcio Vinicius. Breve história da Escola de Antioquia e sua influência na hermenêutica da Reforma Protestante. Revista Ensaios Teológicos. Vol. 1, nº 01, Jun 2015, p. 134.
} 
Por tais razões, o método alegórico "foi criticado por uma série de autores que escreviam em Antioquia" "212. Teodoro de Mopsuéstia (que estudou a Bíblia por dez anos) e João Crisóstomo (que era um exímio orador das Escrituras) são as grandes referências desta escola ${ }^{213}$. A Escola de Alexandria exerceu grande influência por longos períodos da história da Igreja. Já a Escola de Antioquia não continuou por muito tempo, mas, ainda assim, exerceu certa influência em dois grandes expoentes da fé cristã: Agostinho e Jerônimo ${ }^{214}$.

Nesta trajetória, vale lembrar mais uma possível contribuição de Orígenes na sua relação com as Escrituras. Scholz pontua que ele foi, "aparentemente, o primeiro a aplicar o termo 'Bíblia' aos livros inspirados do Novo Testamento",215, sendo que, com o passar do tempo, esse termo foi utilizado para todos os livros da atual Bíblia Sagrada.

\subsection{3}

\section{A contribuição de Jerônimo na difusão das Escrituras Sagradas}

Os primeiros séculos da era cristã foram distintos na história da igreja, bem como na história da difusão das Escrituras. O período pós-apostólico, até cerca do século quarto, ficou, em vários momentos, marcado por perseguições e sofrimentos. O cristianismo chegou a ser "proibido por uma lei específica no ano 303 d.C. num dos quatro éditos (o texto exato se perdeu) do imperador Diocleciano" ${ }^{216}$. Nesse período, além da destruição de igrejas, os livros cristãos que formavam as Escrituras eram, por vezes, queimados, conforme pode se constatar no relato do historiador Eusébio de Cesaréia:

Era este o ano dezenove do império de Diocleciano e o mês de Distro - entre os romanos se diria o de março - quando, estando próxima a festa da Paixão do Salvador, por todas as partes estenderam-se editos imperiais mandando arrasar até o solo as igrejas e fazer desaparecer pelo fogo as Escrituras, e proclamando privados de honras a aqueles que delas desfrutavam e de liberdade aos particulares se

\footnotetext{
212 DORIVAL, Gilles. Antiguidade Cristã Grega e Bíblia. In: LONGTON, Joseph; POSWICK, Réginald-Ferdinand [et al.] (orgs.). Dicionário Enciclopédico da Bíblia, p. 92.

${ }^{213}$ Cf. ZUCK, Roy. A interpretação bíblica: meios de descobrir a verdade da Bíblia. São Paulo: Vida Nova, 1994. p. 43.

${ }^{214}$ Cf. KAISER JUNIOR, Walter Christian; SILVA, Moises. Introdução à Hermenêutica Bíblica. São Paulo. Editora Cultura Cristã, 2002, p. 214.

215 SCHOLZ, Vilson. A Bíblia: sua natureza, funções e finalidade. In: ZIMMER, Rudi (Org.). Manual do Seminário de Ciências Bíblicas, p. 8.

${ }^{216}$ MARKSCHIES, Christoph. De meados do século II até o final do século III. In: KAUFMANN, Thomas [et al.] (orgs.). História Ecumênica da Igreja 1: dos primórdios até a Idade Média., p. 58.
} 
permanecessem fiéis em sua profissão de cristianismo. Assim foi o primeiro edito contra nós, mas não muito depois vieram-nos outros editos nos quais se ordenava: primeiro, lançar nas prisões todos os presidentes das igrejas em todo lugar, e depois, forçá-los por todos os meios a sacrificar ${ }^{217}$.

Contudo, a partir do século quarto, com a conversão do imperador, a fé cristã se espalhou por várias regiões e, obviamente, as Escrituras acompanharam a igreja em sua expansão pelo mundo. A difusão da fé cristã, portanto, se entrelaça à difusão das Escrituras. Entre outros, Agostinho ${ }^{218}$ e Jerônimo contribuíram significativamente para que a Palavra de Deus se espalhasse e se solidificasse na vida da Igreja.

Jerônimo é um doutor da Igreja. Ele, entre outros, recebe esta designação dada pela Igreja Católica por se distinguir pelo saber e pela contribuição profundamente teológica que fez à igreja cristã. Um doutor da Igreja nem sempre é um Pai da Igreja. Mas, para Jerônimo, ambas as designações são salutares. Nesse sentido, Miller e Hubber destacam que "como estudioso da Bíblia Jerônimo não tinha quem chegasse perto dele; foi o melhor de sua época" ${ }^{\text {219 }}$. É por isso que, como bem lembra Lortz, ao falar sobre Jerônimo, há sempre a necessidade de se "aludir ao seu trabalho bíblico"220.

Conhecedor dos clássicos gregos e romanos, Jerônimo se tornou também um hábil estudioso das Escrituras Sagradas, inclusive das línguas originais. Seu interesse "pela Bíblia foi o resultado de uma verdadeira conversão"221. Para ele, o conhecimento das Escrituras era fundamental, pois se aproximando das Escrituras seria possível conhecer o próprio Jesus. Em suas palavras, “ignorar as Escrituras é

\footnotetext{
${ }^{217}$ CESAREIA, Eusébio de. História eclesiástica, p. 177 (Livro VIII, II, 4.5) (grifo nosso).

${ }^{218}$ Sobre o lugar das Escrituras na vida de Agostinho, Lortz lembra que antes de sua conversão, "as histórias da Sagrada Escritura pareciam "contos de viejas [histórias antigas contadas por pessoas idosas não dignas de crédito]", mas agora, sob a influência das homílias de São Ambrósio, a leitura da Bíblia se transformou em um costume regozijante" In: LORTZ, Joseph. Historia de La Iglesia: en la perspectiva de la historia del pensamiento. Antiguedad y edad media. Vol. I, p. 179 (tradução nossa).

${ }^{219}$ MILLER, Stephen; HUBER, Robert. A Bíblia e sua história: o surgimento e o impacto da Bíblia, p. 106.

${ }^{220}$ LORTZ, Joseph. Historia de La Iglesia: en la perspectiva de la historia del pensamiento. Antiguedad y edad media. Vol. I, p. 184 (tradução nossa).

${ }^{221}$ AUWERS, Jean-Marie. Antiguidade Cristã Latina e Bíblia. In: LONGTON, Joseph; POSWICK, Réginald-Ferdinand [et al.] (orgs.). Dicionário Enciclopédico da Bíblia. São Paulo: Loyola, Paulinas, Paulus; Santo André: Academia Cristã, 2013, p. 105.
} 
ignorar a Cristo"222. Como consequência de tal apreço "ele também comentou muitos dos livros da Escritura"223.

Em sua trajetória, foi monge, sacerdote e secretário do papa Dâmaso, que fez a ele um pedido especial: revisar as tradições latinas da Bíblia Sagrada ${ }^{224}$. Mesmo após a morte do papa, Jerônimo, já residindo em Belém, concluiu sua tradução da Bíblia, a Vulgata. Além dessa tradução, Jerônimo também se distinguiu como um grande biblista. Ele escreveu diversas obras a partir da Bíblia (comentários, dicionários, mapas etc.) e, apesar de se basear no estilo alegórico de interpretação da Bíblia, devido ao seu conhecimento, ele conseguiu alcançar o equilíbrio, evitando quaisquer excessos ${ }^{225}$. Nem tanto para alegoria, nem tanto para a literalidade. Hall destaca que, em certo momento, inclusive, Jerônimo teceu sérias críticas ao método alegórico ${ }^{226}$. Nesse sentido, Lortz acrescenta que Jerônimo,

Com base na verdade histórica e, conseqüentemente, no sentido literal, queria enfatizar seu conteúdo espiritual. É por isso que ele lutou tanto contra o modelo proposto por Orígenes, por causa de seu alegorismo. A única coisa que realmente importava para Jerônimo era o texto correto ${ }^{227}$.

A Vulgata de Jerônimo é, mais uma vez, um consistente exemplo da necessidade de se traduzir a Bíblia para a língua do povo. Na época de Jesus era o grego que o povo falava e, assim, os livros do Novo Testamento foram escritos em grego. Na época de Jerônimo, entretanto, a língua litúrgica utilizada pelos cristãos ocidentais era o latim. Aliás, mais do que isso. Como bem lembra Lortz, "o latim, a partir da segunda metade do século IV, tornou-se uma espécie de paládio da

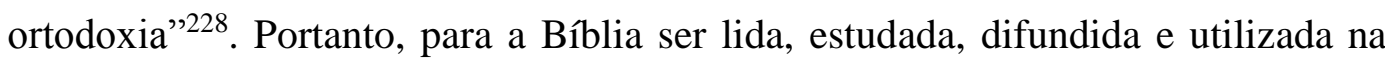
liturgia, ela precisava ser traduzida mais uma vez. Ainda que houvesse traduções latinas da Bíblia, elas não eram tão boas. Assim, Jerônimo foi o resposavel por essa diligente missão da tradução bíblica. Há certa divergência histórica sobre o

\footnotetext{
222 JERONIMO apud FERNANDES, Leonardo Agostini. A Bíblia e sua mensagem: introdução à leitura e ao estudo da Bíblia, p. 11.

${ }^{223}$ LORTZ, Joseph. Historia de La Iglesia: en la perspectiva de la historia del pensamiento. Antiguedad y edad media. Vol. I, p. 184 (tradução nossa)

${ }^{224}$ Cf. TEIXEIRA, Paulo. Traduções da Bíblia. In: ZIMMER, Rudi (Org.). Manual do Seminário de Ciências Bíblicas, p. 47

${ }^{225}$ Cf. MILLER, Stephen; HUBER, Robert. A Bíblia e sua história: o surgimento e o impacto da Bíblia, p. 107.

${ }^{226}$ Cf. HALL, Christopher. Lendo as Escrituras com os pais da Igreja, p. 117.

${ }^{227}$ LORTZ, Joseph. Loc. cit.

${ }^{228}$ Ibid., p. 155 (tradução nossa)
} 
fato de Jerônimo ter concluído sua tradução. Alguns ${ }^{229}$ argumentam que seu trabalho se limitou ao Antigo Testamento e alguns livros do Novo Testamento; outros afirmam que ele concluiu completamente sua tarefa.

É interessante notar que, inicialmente, como ocorre até os dias atuais com muitas traduções, o trabalho de Jerônimo foi em parte rejeitado e por alguns criticados. Para estes, o "texto soava demasiado popular" ${ }^{230}$. Em resposta a estas críticas, ele, sarcasticamente, argumenta que "se alguém preferir a edição dos Setenta (a Septuaginta), ela está aí disponível, pois foi corrigida por mim"231.

Jerônimo rejeitou alguns dos livros que constavam na Septuaginta ${ }^{232}$. Entre outras hipóteses, este é um motivo que levou os críticos a se revoltarem contra ele e sua tradução. Jerônimo pela primeira vez chamou alguns desses livros deuterocanônicos de apócrifos. Fernandes justifica tal discurso ao afirmar que ele foi "muito influenciado pelos rabinos de sua época"233. Entretanto, mesmo considerando esses livros de tal forma, ele os traduziu e os incluiu em sua tradução da Bíblia. Com o passar do tempo, as objeções caíram, e essa tradução ficou reconhecida como a Bíblia Vulgata, que permaneceu por mais de 1.500 anos como a Bíblia oficial da Igreja Católica Apostólica Romana. Sem dúvida, um grande legado para a fé cristã e para a difusão das Escrituras Sagradas.

Após o Concílio Vaticano II a Vulgata foi revisada, sendo substituída pela Neovulgata que, no lugar de sua antecessora, é a tradução oficial utilizada pela Igreja Católica. Contudo, também como consequência das mudanças ocorridas após o Concílio e conforme preconiza a instrução Liturgiam Authenticam ${ }^{234}$, de João Paulo II, a Igreja Católica, por meio das Igrejas locais de cada país, pode seguir a língua vernácula na liturgia. A Neovulgata permanece como um texto de referência e consulta, caso haja alguma dúvida na tradução utilizada. Entretanto, essas traduções vernáculas devem ser aprovadas pela Conferência dos Bispos lo-

${ }^{229}$ Cf. MILLER, Stephen; HUBER, Robert. A Bíblia e sua história: o surgimento e o impacto da Bíblia, p. 108; TEIXEIRA, Paulo. Traduções da Bíblia. In: ZIMMER, Rudi (Org.). Manual do Seminário de Ciências Bíblicas, p. 48.

${ }^{230}$ TEIXEIRA, Paulo. Op. cit., p. 48.

231 JERONIMO apud MILLER, Stephen; HUBER, Robert. Op. cit., p. 108.

${ }^{232}$ Cf. MANNUCCI, Valério. Bíblia, Palavra de Deus: curso de introdução à Sagrada Escritura, p. 255.

${ }^{233}$ FERNANDES, Leonardo Agostini. A Bíblia e sua mensagem: introdução à leitura e ao estudo da Bíblia, p. 19.

${ }^{234}$ Cf. PAPA JOÃO PAULO II. Liturgiam authenticam. Nova instrução para a reta aplicação da constituição sobre a Sagrada Liturgia do Concílio Vaticano II, 2001. Disponível em: http://www.vatican.va/roman_curia/congregations/ccdds/documents/rc_con_ccdds_doc_20010507 _comunicato-stampa_po.html. Acesso em 13 jul. 2017. 
cal, em sintonia com a Santa Sé, e devem ser elaboradas com base nos textos das línguas originais.

Vale ressaltar que a Bíblia Vulgata não foi a única tradução desse tempo, entre o quarto e o quinto século. "O cristianismo propagou-se nas margens ou limites do Império Romano-Bizantino, graças a um esforço ingente na tradução da Bíblia (AT e NT) para as línguas destes povos. O cristianismo foi classificado por isto como 'fenômeno de tradução', „235. Nesse sentido, difusão e tradução das Escrituras são aspectos indissociáveis.

Teixeira, Miller e Hubber ${ }^{236}$ destacam que, entre outras, a história registra o surgimento da tradução da Bíblia Gótica ${ }^{237}$ realizada por Úlfilas para as tribos germânicas dos godos. Na Armênia, um monge chamado Mesrop (ou Mesrópio) também traduziu a Bíblia para a língua armênia. Na Geórgia e na Albânia também surgiram traduções da Bíblia. Na Morávia (atual Eslováquia), a Bíblia e algumas cerimônias foram traduzidas para a língua nativa. $\mathrm{O}$ ponto comum nessas traduções é que esses povos não tinham um alfabeto desenvolvido. Úlfilas primeiro criou o alfabeto gótico e depois traduziu a Bíblia. Tal feito é de enorme importância, uma vez que não se tratou "apenas de uma tradução do texto, mas de uma transposição de conceitos e ideias bíblicas para a mentalidade germânica" ${ }^{238}$. Mesrop também criou o alfabeto para os povos da Armênia, Geórgia e Albânia. Para o povo armênio, além do alfabeto ele realizou a tradução. Para o povo da Geórgia e da Albânia ele contribuiu desenvolvendo o alfabeto, facilitando, assim, o surgimento posterior das traduções da Bíblia. Cirilo desenvolveu o alfabeto e iniciou uma tradução da Bíblia para os eslavos.

Essas traduções cristãs das Escrituras Sagradas foram, de certo modo, o "pontapé inicial”, porque estabeleceram a marca distintiva da Bíblia em detrimento aos demais livros sagrados de outras religiões. O cristianismo se propagou pelo mundo, sempre que possível, junto a uma tradução das Escrituras para as mais

\footnotetext{
${ }^{235}$ BARRERA, Júlio Trebolle. A Bíblia judaica e a Bíblia cristã, p. 150 (grifos do autor).

${ }^{236}$ Cf. MILLER, Stephen; HUBER, Robert. A Bíblia e sua história: o surgimento e o impacto da Bíblia, pp. 118-119; TEIXEIRA, Paulo. Traduções da Bíblia: história, princípios e influência. In: ZIMMER, Rudi (Org.). Manual do Seminário de Ciências Bíblicas, p. 47.

${ }^{237}$ Lortz lembra, entretanto, da heresia ariana que influenciou a igreja surgida nas tribos germânicas. Nesse sentido, o autor ressalta que, "o veículo da difusão deste arianismo dos alemães era, em qualquer caso, a tradução da Bíblia para o gótico, feita por Úlfila". In: LORTZ, Joseph. Historia de La Iglesia: en la perspectiva de la historia del pensamiento. Antiguedad y edad media. Vol. I, p. 160 (tradução nossa).

${ }^{238}$ KOTJE, Raymund. A Idade Média. In: KAUFMANN, Thomas et al (orgs.). História Ecumênica da Igreja 1: dos primórdios até a Idade Média, pp. 184-185.
} 
diferentes línguas do mundo; afinal, "nenhuma outra religião é tão orientada pela palavra do que a religião cristã" 239 . Nesse sentido, Dorival e Longton destacam que até o ano 1000, aproximadamente,

Versões da Bíblia foram realizadas em todas as línguas de grande cultura da Europa e do Oriente Médio antigos, quer se trate de línguas semitas (hebraico, samaritano, aramaico, siríaco, árabe, etiópico), indo-europeias (grego, latim, armênio, gótico, sogdiano, pelevi, eslavo antigo), camito-semitas (copta), cuchitas (núbio) ou caucásicas (georgiano) ${ }^{240}$.

Tais fatos evidenciam a importância da difusão das Escrituras no primeiro milênio da história da Igreja. Além do aspecto da fé e do desenvolvimento da igreja ao redor do mundo, a necessidade de uma tradução instigou a criação de alfabetos, unificou a língua, fortaleceu a igreja cristã e, como aconteceu na Armênia, uniu a nação. Em muitos casos, a tradução da Bíblia "foi o primeiro monumento da literatura nacional" ${ }^{241}$, firmando-se como "fonte de primeira ordem para o estudo das línguas antigas" 242 .

\section{6}

\section{A contribuição do monasticismo na difusão das Escrituras Sagradas}

A história da igreja cristã na Antiguidade apresenta ainda outro fato que merece destaque sob a ótica de sua relação com as Escrituras Sagradas. Trata-se do estilo de vida monástico ${ }^{243}$. Jerônimo e Agostinho constituem exemplos deste paradigma de pessoas que procuraram viver uma vida mais singela e, ao mesmo tempo, mais consagrada a Deus. Para conseguir tal êxito, muitos deles deixaram as cidades para conviver em monastérios, sob um estilo de vida caracterizado por

\footnotetext{
239 TEIXEIRA, Paulo. Traduções da Bíblia: história, princípios e influência. In: ZIMMER, Rudi (Org.). Manual do Seminário de Ciências Bíblicas, p. 41.

${ }^{240}$ DORIVAL, Gilles; LONGTON, Joseph. Versões antigas da Bíblia. In: LONGTON, Joseph; POSWICK, Réginald-Ferdinand [et al.] (orgs.). Dicionário Enciclopédico da Bíblia, p. 1352.

${ }^{241}$ BARRERA, Júlio Trebolle. A Bíblia judaica e a Bíblia cristã, p. 151.

${ }^{242}$ DORIVAL, Gilles; LONGTON, Joseph. Op. cit., p. 1354.

${ }^{243}$ Cairns destaca que o monasticismo teve sua origem no século IV e aprofundou suas raízes na história da Igreja por muito tempo. Nos séculos X e XI há um segundo momento importante do monasticismo. Cf. CAIRNS, Earle Edwin. O cristianismo através dos séculos: uma história da igreja cristã, p. 129.
} 
orações, regras, jejuns, devoção e leitura ${ }^{244}$. Já no aspecto histórico-teológico, esse período se caracterizou pela influência e "continuação da teologia patrística"

Obviamente, as Escrituras Sagradas constituíram parte importante do cotidiano dos monges; afinal, "a vida do monge está marcada pela Bíblia" ${ }^{246}$. Aliás, este era um critério para todo aquele que desejasse aderir ao estilo de vida monástico, isto é, era necessário ser "um cristão que segue os mandamentos claros e simples da Bíblia" ${ }^{247}$. Schindler, nessa perspectiva, ressalta que a prática ascética dos monges tinha por objetivo o resgate da obediência bíblica. $\mathrm{O}$ alvo da vida constituía-se, portanto, em "ser cristão com fundamento na Escritura"248. Mesmo que alguns não soubessem ler e que ainda não fosse comum que cada um tivesse a sua "Escritura", eles memorizavam os textos sagrados para poder recitá-las nos cânticos e nas orações. Dessa forma, "os salmos eram cantados e nos refeitórios, onde as refeições eram tomadas em silêncio, livros bíblicos eram lidos ao lado da biografia dos santos" $" 249$.

A contribuição dos monges para a difusão das Escrituras Sagradas é singular. Todos os cristãos, em todas as épocas, devem a eles gratidão, pois durante dois terços do tempo que contempla a história da igreja cristã muitos manuscritos bíblicos foram copiados, em sua maior parte, pelos monges. Se atualmente existem milhares de cópias antigas das Escrituras — considerando que não temos os autógrafos, isto é, os textos originais —, é aos monges que deve ser atribuído tal trabalho. Como bem afirma Shedd, "os monges nos mosteiros mantiveram a luz acesa pelas cópias das Escrituras que guardavam e copiavam" 250 . De fato,

Apesar de pessoas leigas também copiarem manuscritos no período medieval posterior, a maior parte desse trabalho foi feito por monges. Como os escribas judeus de antigamente, os monges realizavam o seu trabalho com a maior seriedade. Por causa do seu cuidado, a exatidão das Escrituras Sagradas foi preservada através dos

\footnotetext{
${ }^{244}$ CAIRNS, Earle Edwin. O cristianismo através dos séculos: uma história da igreja cristã, p. 129.

${ }^{245}$ VALKENBERG, Pim. Leitores da Escritura e ouvintes da Palavra na Igreja da Idade Média. In: BEUKEN, Win; FREYNE, Sean; WEILER, Anton (orgs.). A Bíblia e seus leitores. Revista Concilium. Petropólis: Vozes, 1991, p. 61.

246 DORIVAL, Gilles. Antiguidade cristã grega e Bíblia. In: LONGTON, Joseph; POSWICK, Réginald-Ferdinand [et al.] (orgs.). Dicionário Enciclopédico da Bíblia, p. 103.

247 SCHINDLER, Alfred. Os primórdios do monasticismo. In: KAUFMANN, Thomas et al (orgs.). História ecumênica da Igreja 1: dos primórdios até a Idade Média, p. 158.

248 Ibid., p. 172.

${ }^{249}$ DREHER, Martin Norberto. Bíblia: suas leituras e interpretações na História do Cristianismo, p. 39.

${ }^{250}$ SHEDD, Russel Philip. A Bíblia e os livros. São Paulo: Shedd Publicações, 2013, p. 10.
} 
séculos e, hoje, podemos estar confiantes de que a palavra de Deus chegou até nós na sua forma real ${ }^{251}$.

Como há de se imaginar, copiar um manuscrito bíblico era algo difícil e, ao mesmo tempo, desafiador. As condições não eram adequadas. A luminosidade, o tipo de material utilizado, a forma de escrita, a posição do corpo, o cansaço físico, o clima (muito frio, algumas vezes), entre outros aspectos, constituíam um grande desafio a esse trabalho. Ainda assim eles exerceram tal missão, deixando várias porções manuscritas das Escrituras (Evangelhos, Salmos etc.) e, em alguns casos, Bíblias inteiras. Pela seriedade do trabalho e pelas condições existentes, as cópias eram realizadas de forma lenta e com apurada precisão ${ }^{252}$.

Além de copiar as Escrituras, os monges também a tinham em grande estima. Eles queriam viver uma vida que agradasse a Deus e viam na Bíblia um caminho seguro para isso. Por conseguinte, na "teologia monástica a Escritura, juntamente com a interpretação dos textos sagrados pelos Padres da Igreja, forma o ponto de partida natural" ${ }^{253}$. Eles liam, interpretavam e comentavam as Escrituras.

É nesse período também que surge um estilo de leitura e difusão das Escrituras que até hoje faz parte de algumas igrejas cristãs: a Lectio Divina. A Lectio Divina surgiu como um método sob a influência da vida monástica. Dessa forma, ao separar várias horas de oração e leitura bíblica por dia, se estabelecia, concomitantemente, uma leitura bíblica que se realiza enquanto se ora. Trata-se de uma leitura contemplativa e reflexiva. A leitura das Escrituras estava atrelada à meditação e à oração. Enquanto ora, o monge lê as Escrituras e medita nelas, procurando se concentrar no significado daquela leitura em sua vida e em sua espiritualidade.

O estilo de vida monástico foi um período importante na história da igreja e na história da difusão das Escrituras. Mesmo na Idade Média e em outras épocas, a vida dos monges constituiu um referencial em muitos aspectos. Sem dúvida, a preservação dos manuscritos bíblicos, realizados em sua maior parte pelos monges, é um grande legado na história e na teologia da difusão das Escrituras Sagra-

\footnotetext{
${ }^{251}$ MILLER, Stephen; HUBER, Robert. A Bíblia e sua história: o surgimento e o impacto da Bíblia, p. 123.

${ }^{252}$ Ibid.

${ }^{253}$ VALKENBERG, Pim. Leitores da Escritura e ouvintes da Palavra na Igreja da Idade Média, p. 61.
} 
das. Mais do que uma obrigação, copiar as Escrituras Sagradas era um ato de devoção, uma missão de vida e uma forma de difundir as Escrituras.

\section{7}

\section{A difusão das Escrituras Sagradas na Idade Média}

Um grande desafio que emerge na História da Igreja é chegar a um consenso em relação à periodização da história eclesiástica. De forma geral, “divide-se a história em patrística, escolástica, moderna e contemporânea. Trata-se de uma divisão calcada na história civil, tendo várias boas razões a seu favor" ${ }^{254}$. Ainda assim, os debates são muitos e as opções escolhidas pelos diferentes autores também são divergentes. Essas discordâncias (ou perspectivas) estão presentes dentro de cada respectiva tradição cristã, tais quais catolicismo e protestantismo, ou seja, em ambos os grupos os autores divergem entre si; por outro lado, as divergências também se estendem com significativa relevância entre católicos e protestantes. Cada segmento tem o seu olhar da história.

Nessa perspectiva, tanto em relação ao início quanto ao término do que se denomina "Idade Média", o que se pode constatar são constantes debates e divergências, muitas vezes inconciliáveis. Kottje, na obra História Ecumênica da Igreja, reitera esse fato ao afirmar que "acerca do início da Idade Média, apesar das vivas discussões, as opiniões continuam acentualmente divergentes" ${ }^{255}$. Cairns, na obra $O$ cristianismo através dos séculos ${ }^{256}$, Hägglund, na obra História da Teologia $^{257}$ e Walker na obra História da Igreja Crist $\tilde{a}^{258}$ reiteram tal dificuldade. Entretanto, esses mesmos autores, Kottje, Cairns, Hägglund e Walker, em suas respectivas obras, têm em comum um marco divisório entre a História da Igreja Antiga e a História da Igreja na Idade Média. Unanimemente, eles situam Gregório I como um limite entre antes (Antiguidade) e depois (período medieval) na história. Nessa pesquisa, opta-se pelo mesmo critério.

Outra divergência se caracteriza pela interpretação de como a igreja percorreu esse período na história. Católicos e protestantes divergem entre si. Para aque-

\footnotetext{
${ }^{254}$ MONDIN, Battista. Os grandes teólogos do século vinte. São Paulo: Teológica, 2003, p. 398.

${ }^{255}$ KOTJE, Raymund. A Idade Média. In: KAUFMANN, Thomas et al (orgs.). História Ecumênica da Igreja 1: dos primórdios até a Idade Média, p. 182.

${ }^{256}$ Cf. CAIRNS, Earle Edwin. O cristianismo através dos séculos: uma história da igreja cristã, p. 143.

${ }^{257}$ Cf. HÄGGLUND, Bengt. História da teologia, p. 123.

${ }^{258}$ Cf. WALKER, Williston. História da Igreja Cristã. Vol I e II, p. 255.
} 
les, foi um período de florescimento; para estes, um período de trevas. Sem pormenorizar tais fatos, a ressalva dessa pesquisa se dá pelo fato de que o que mais importa nessa análise é a história imbricada na difusão das Escrituras nesse período. A periodização ou a interpretação de cada tradição, portanto, ficam num segundo plano de importância, pois, de fato, independentemente de cada interpretação, a história é contínua e progressiva. Ela se estabelece em um "vai e vem" de relações. E é nessas relações que a Palavra de Deus foi difundida nesse período.

A Idade Média, numa perspectiva da história secular, iniciou sob um legado conflituoso do período anterior. A queda do Império Romano, provocada, entre outros, pelas invasões bárbaras, pela crise econômica e pelas disputas militares em busca do poder, resultou num período complicado para o mundo. Tal realidade influenciou a teologia da época, que, aos poucos, parecia perder sua importância. Essa realidade será alterada somente no período da teologia escolástica.

Marcado, posteriormente, é claro, como um divisor entre os períodos antigo e medieval, Gregório entrou para a história da teologia dessa época e solidificou com bastante firmeza o seu papado ${ }^{259}$. Sob influência de Agostinho, aceitou a doutrina da graça. Expôs, de forma consistente, a doutrina da expiação, que influenciou posteriormente alguns teólogos medievais, tais quais Anselmo e Abelardo. No aspecto escriturístico, "entre os escritos mais importantes de Gregório encontra-se sua interpretação do livro de Jó"260. Kottje descreve esse escrito como "a mais extensa e provavelmente a mais divulgada obra de Gregório na Idade Média" ${ }^{261}$. Gregório, portanto, contribuiu lançando fundamentos para a teologia e a cultura medieval.

Antes da escolástica, há uma era denominada de carolíngia. Com pouco desenvolvimento teológico no período, a distinção se dá pela intensa atividade missionária, caracterizada pela influência do expansionismo imperial que prevaleceu na época. Em relação à difusão das Escrituras, principalmente quando comparado ao período anterior da Antiguidade cristã, há pouco que se falar. Hartmann resume esse tempo atrelando a ênfase missionária expansionista que restou à Igreja da época carolíngia como "a tentativa de mover todos os habitantes do reino dos

${ }^{259}$ Cf. CAIRNS, Earle Edwin. O cristianismo através dos séculos: uma história da igreja cristã, p. 144.

${ }^{260}$ HÄGGLUND, Bengt. História da teologia, p. 125.

${ }^{261}$ KOTJE, Raymund. A Igreja ocidental rumo a uma nova unidade exterior e interior. In: KAUFMANN, Thomas et al (orgs.). História ecumênica da Igreja 1: dos primórdios até a Idade Média, p. 196. 
francos a uma vida segundo as orientações da Bíblia e do direito eclesiástico"262. Hägglund acrescenta ainda que a leitura e a difusão das Escrituras se limitaram a alguns poucos comentários bíblicos (chamados de catenae, isto é, "comentários em cadeia") que surgiram na época, onde eram comparadas "as interpretações patrísticas de várias passagens da Bíblia"263.

\subsection{1 \\ A difusão das Escrituras Sagradas no período da Teologia Escolástica}

A escassez teológica e escriturística evidenciada no período anterior teve uma mudança significativa a partir do período escolástico. Hägglund introduz a teologia escolástica sob a seguinte definição:

Dentro do contexto da história do dogma, o termo escolástica refere-se à teologia que tomou forma nas universidades ocidentais, principiando em meados do século XI, alcançando seu apogeu no século XIII, e deteriorando na Baixa Idade Média, sendo finalmente destruída pelo humanismo e pela Reforma ${ }^{264}$.

Em concordância com Hägglund, Cairns ressalta o reflorescimento teológico no período, pois "os escolásticos substituíram os Pais da Igreja como os principais guardiães da verdade"265. Entretanto, esse desenvolvimento ganhou um aspecto teológico diferente. Trata-se de uma teologia influenciada pela filosofia aristotélica. Obviamente, não há nenhum demérito nisso. A constatação se dá simplesmente pela ênfase pretendida nessa pesquisa. A teologia de outrora tinha suas raízes mais próximas das Escrituras; a teologia escolástica, por ora, se aproxima mais da razão. Foi uma transição significativa, de um oposto a outro. Assim, “a leitura contemplativa da Escritura, que dá mais ênfase ao sentido espiritual da Escritura, aos poucos abre espaço para uma leitura da Escritura mais racional, que

\footnotetext{
262 HARTMANN, Wilfried. A Igreja no período carolíngio. In: KAUFMANN, Thomas et al (orgs.). História ecumênica da Igreja 1: dos primórdios até a Idade Média, p. 223

${ }^{263}$ HÄGGLUND, Bengt. História da teologia, p. 127.

${ }^{264}$ Ibid., p. 139. Contudo, vale ressaltar que a escolástica teve um importante renascimento nos séculos XVI e XVII, período este que ficou reconhecido como a segunda escolástica, sobretudo na Peninsula Ibérica.

265 CAIRNS, Earle Edwin. O cristianismo através dos séculos: uma história da igreja cristã, p. 207.
} 
toma como ponto de partida apenas o sentido literal dos questionamentos científi$\cos ^{2} 266$.

Nessa perspectiva, a escolástica é caracterizada sob a finalidade de racionalizar a teologia para que se sustente a fé com a razão. Pela razão, se espera estabelecer um arcabouço racional das verdades essenciais da fé amplamente aceitas pela igreja. "A teologia seria, então, tratada de uma perspectiva mais filosófica do que bíblica"267, sem deixar, no entanto, de ser "fiel à maneira como os Padres da Igreja liam a Escritura"268. Para resumir esse momento, Hägglund ainda acrescenta que "além da Escritura e da tradição, as posições adotadas pelos vários mestres (doutores) também chegaram a desempenhar papel de destaque"269. Esse período ficou marcado, então, pelo fato de que, na busca da verdade, “fé e Escrituras eram importantes, mas não as únicas fontes" ${ }^{270}$. A Bíblia, como um livro em si, "tornase gradualmente o objeto de um verdadeiro estudo científico que perscruta muitos ângulos: cronologia, topografia, genealogias, doutrinas e diversos temas teológi$\cos ^{2,271}$.

Entre os principais personagens desse período destacam-se Anselmo de Cantuária e Tomás de Aquino. A contribuição de Anselmo se caracteriza pela famosa declaração Credo ut intelligam, isto é, "crer para entender"272. Com tal afirmação, Anselmo ressalta que não é necessário primeiro entender para depois crer. Antes, ao passo que se crê é possível compreender. Já Tomás de Aquino se tornou o grande teólogo, responsável pelo desenvolvimento de boa parte da teologia católica. Cairns destaca que "a prodigiosa sabedoria de Tomás foi dedicada ao ideal da integração (naquele tempo) da filosofia natural de Aristóteles com a teologia revelada na Bíblia como interpretada pela Igreja" e complementa que junto a outros aspectos doutrinários fundamentais, o "homem pode alcançar a verdade pela fé na Bíblia, conforme interpretação dos Pais e concílios"273.

\footnotetext{
266 VALKENBERG, Pim. Leitores da Escritura e ouvintes da Palavra na Igreja da Idade Média, p. 63.

267 CAIRNS, Earle Edwin. O cristianismo através dos séculos: uma história da igreja cristã, p. 207.

268 VALKENBERG, Pim. Loc. cit.

${ }^{269}$ HÄGGLUND, Bengt. História da teologia, p. 139.

${ }^{270}$ MILLER, Stephen; HUBER, Robert. A Bíblia e sua história: o surgimento e o impacto da Bíblia, p. 142 .

${ }^{271}$ LAPLANTE, Alcide. Idade Média Ocidental e Bíblia. Dicionário Enciclopédico da Bíblia. São Paulo: Loyola, Paulinas, Paulus; Santo André: Academia Cristã, 2013, p. 656.

${ }^{272}$ Cf. HÄGGLUND, Bengt. Op.cit., p. 139.

${ }^{273}$ CAIRNS, Earle Edwin. Op.cit., p. 212.
} 
Como resultado desse período, a Summa Theologica, obra mais importante de Tomás de Aquino, se distinguiu em proporcionar "uma base racional para os mistérios da Bíblia, mostrando que fé e razão são maneiras complementares de se compreender o mundo" ${ }^{274}$. Ao destacar a importância da Escritura em Tomás de Aquino, Valkenberg acrescenta:

Tomás faz uso do termo "doutrinação cristã" (sacra doutrina) à qual pertencem tanto a Escritura como a teologia: a teologia faz parte de um processo de doutrinação cristã, que o teólogo recebe de Deus pela Escritura, e que ele, por sua vez, transmite para os seus alunos da doutrinação teológica. Isto significa que a Escritura não é apenas a fonte mais importante da qual se faz uso na argumentação teológica, mas que ela também é a fonte e o quadro da própria argumentação. [...] [Dessa forma] cada quaestio teológica deveria ser um questionamento sobre a Escritu$\mathrm{ra}^{275}$.

Trata-se, portanto, de uma teologia bíblica "com os pés no chão" e com o intelecto firmado na razão. A Escritura é a base da teologia de Aquino e, direta ou indiretamente, ela sempre está presente nas questões, seja no início como uma provocação que exige investigação, seja no final como conclusão de seu raciocínio. Portanto, é possível afirmar que "a Escolástica construiu seu sistema nas afirmações da Escritura" ${ }^{276}$.

Ressalta-se, ainda, que as universidades, recém-criadas no período, contribuíram significativamente com a teologia escolástica e com a difusão das Escrituras. A teologia, por meio da lógica, retórica e razão, passou a ser estudada nos currículos universitários da época. E, nestas faculdades de teologia, "ler e estudar a Sagrada Escritura foi a base para todo o resto"277. A teologia se tornou, naquele tempo, "a rainha das ciências".

Com essa atitude de abertura em relação ao aprendizado, os estudiosos começaram a cavar cada vez mais fundo procurando respostas para as suas questões. Trabalhar somente com as traduções latinas da Bíblia era, agora, considerado algo inadequado. Os melhores estudiosos queriam ler a Bíblia nos originais hebraico e grego. Por volta do ano 1300, todas as grandes universidades tinham departamentos que ofereciam disciplinas sobre hebraico e grego ${ }^{278}$.

Por conseguinte,

\footnotetext{
${ }^{274}$ MILLER, Stephen; HUBER, Robert. A Bíblia e sua história: o surgimento e o impacto da Bíblia, p. 143.

${ }^{275}$ VALKENBERG, Pim. Leitores da Escritura e ouvintes da Palavra na Igreja da Idade Média, p. 65.

${ }^{276}$ LORTZ, Joseph. Historia de La Iglesia, vol I, p. 478 (tradução nossa)

${ }^{277}$ Ibid., p. 479 (tradução nossa)

${ }^{278}$ MILLER, Stephen; HUBER, Robert. Loc. cit.
} 
Com o florescimento das universidades europeias no século XIII, os métodos de ensino superior passaram a exigir livros completos, apresentando não somente comentários bíblicos, mas também introduções técnicas aos livros sagrados e longas respostas teológicas para solucionar as numerosas quaestiones levantadas durante a lectio da Escritura ${ }^{279}$.

Diante de tais aprofundamentos, a difusão das Escrituras Sagradas nesse período se caracterizou por uma ampla produção de obras relacionadas à Bíblia, tais quais livros, dicionários, atlas, comentários, concordâncias etc. ${ }^{280}$ Essas obras foram importantes para a difusão da Bíblia naquela época, visto que forneceram “novos auxílios para o estudo das Escrituras"281. Entretanto, esta realidade não se estendeu por muito tempo. Como bem lembra Lortz, quase no final da Idade Média, "a importância de estudar a Bíblia nas universidades caiu tragicamente"282.

Nesse interím, uma novidade surgida no período causou grande impacto em toda a história da difusão e da leitura das Escrituras. Stephen Langton, um estudioso da Universidade de Paris (instituição muito importante no período escolástico), mais tarde escolhido como arcebispo de Cantuária, procurou facilitar o estudo e o uso das Escrituras por meio de técnicas de leitura diferenciadas. Até aquela época, o texto bíblico não possuía divisões, nem de capítulos, nem de versículos, o que, certamente, dificultava uma leitura acadêmica. Langton, então, introduziu a divisão por capítulos, novidade que passou a ser aceita e utilizada pelos cristãos com o passar do tempo. A divisão em versículos ocorreria um pouco mais tarde, mas, sem dúvida, a novidade apresentada pelo Cardeal Langton se tornou uma ferramenta importante para todas as pessoas que leem e estudam a Bíblia ${ }^{283}$.

Obviamente, há muito mais que se falar sobre esse período, sobre Tomás e Anselmo e sobre as demais contribuições da escolástica. Mas, considerando a temática, a descrição acima se limitou às relações estabelecidas entre a escolástica, seus expoentes referenciais e as Escrituras Sagradas. Pode-se dizer que no período

\footnotetext{
${ }^{279}$ LAPLANTE, Alcide. Idade Média Ocidental e Bíblia. In: LONGTON, Joseph; POSWICK, Réginald-Ferdinand [et al.] (orgs.). Dicionário Enciclopédico da Bíblia, p. 652.

${ }^{280}$ Cf. KORNTGEN, Ludger. A Igreja no século XII: vida religiosa, educação e ciência. In: KAUFMANN, Thomas et al (orgs.). História ecumênica da Igreja 2: da alta Idade Média até o início da Idade Moderna. São Paulo: Loyola; Paulus; São Leopoldo: Sinodal, 2014, pp. 5-52.

${ }^{281}$ VALKENBERG, Pim. Leitores da Escritura e ouvintes da Palavra na Igreja da Idade Média, p. 64.

${ }^{282}$ LORTZ, Joseph. Historia de La Iglesia: en la perspectiva de la historia del pensamiento. Antiguedad y edad media. Vol. I, p. 534 (tradução nossa)

${ }^{283}$ Cf. MILLER, Stephen; HUBER, Robert. A Bíblia e sua história: o surgimento e o impacto da Bíblia, p. 143; VALKENBERG, Pim. Op. cit., p. 64.
} 
escolástico “o conteúdo de seu estudo era a Bíblia, os credos dos concílios ecumênicos e os escritos dos Pais da Igreja" ${ }^{284}$, sempre em harmonia com a filosofia.

\section{8 \\ A difusão das Escrituras Sagradas como paradigma de vida pessoal e eclesial}

Enquanto, por um lado, a igreja não passou pelos melhores momentos de sua história durante um bom tempo na Idade Média, por outro, em momentos anteriores, contemporâneos e posteriores ao período escolástico, emergiram certas reações que buscavam o resgate de uma vivência simples, baseada nos valores do evangelho. Alguns desses movimentos são caracterizados como movimentos de reforma. Não se trata da Reforma Protestante, que ocorrerá mais tarde. Antes, são iniciativas, em sua maior parte realizadas por leigos e religiosos, que procuravam resgatar, a partir do próprio exemplo do monasticismo medieval, um maior zelo espiritual para a sociedade daquela época. Era, por assim dizer, um monasticismo reformador, levado a cabo por indivíduos, movimentos ou ordens mendicantes.

Dessa forma, "como pregadores, pastores de almas e teólogos, membros das ordens mendicantes promoveram em grande medida a característica intensificação da piedade e da eclesialidade" 285 . Entretanto, em vez de uma vida reclusa, como a dos monges, eles optaram pela pregação entre o povo. Francisco de Assis, um frade, entre outros, foi um dos personagens de maior destaque desse período.

Em vários momentos da história, alguns indivíduos buscaram certas mudanças na igreja. A maioria não alcançava êxito, seja pela postura, seja pela forma como conduziam essa busca. Diferentemente da maioria, Francisco de Assis "conseguiu mudar algumas coisas na igreja apenas pelo seu exemplo de vida"286. Depois de viver uma juventude rica e relativamente rebelde, Francisco passou por uma experiência transformadora em um momento em que orava. $\mathrm{Na}$ Capela de São Damião, ouviu uma voz que o chamou a restaurar a casa do Senhor. Depois

\footnotetext{
${ }^{284}$ CAIRNS, Earle Edwin. $O$ cristianismo através dos séculos: uma história da igreja cristã, p. 209.

${ }^{285}$ OHST, Martin. A Igreja no Século XIII: as ordens mendicantes. In: KAUFMANN, Thomas et al (orgs.). História ecumênica da Igreja 2: da alta Idade Média até o início da Idade Moderna, p. 63.

${ }^{286}$ MILLER, Stephen; HUBER, Robert. A Bíblia e sua história: o surgimento e o impacto da Bíblia, p. 144.
} 
de não compreender muito bem o significado dessa voz e de se frustrar com seu pai, Francisco decidiu viver uma vida de extrema pobreza e serviço a Deus ${ }^{287}$.

Tal opção se fortaleceu quando "em 1209, Francisco ouviu a leitura de Mateus $10,7-10 " 288$ e, sob a força das Escrituras, sua grande inspiração passou a ser a vida de Jesus. Os Evangelhos, portanto, tinham um lugar especial em sua vida. Era pela leitura dos Evangelhos que Francisco conseguiria imitar a Cristo. Nessa perspectiva, "a palavra da Escritura que caracteriza São Francisco e os primórdios de sua irmandade é novo e renovar" ${ }^{289}$. Para ele, era importante renovar a vida da igreja, a fé e a pobreza, a simplicidade e a humildade. Seu estilo de vida, aos poucos, conquistou a simpatia do povo, atraiu seguidores e, mesmo que sob algumas dificuldades, a aprovação do papa. "Sempre mantendo os Evangelhos como seu foco, Francisco viajou para longe, pregando alegremente o amor de Deus e o amor de um ao outro. [...] Francisco de tal forma imitou Jesus, assim como ele é retratado nos Evangelhos, que ficou conhecido como 'o outro Cristo" ${ }^{290}$.

Em Francisco, a difusão se deu mais com a sua vida do que com a exposição das Escrituras, pois ele encarnou os valores do evangelho. Outros movimentos ocorreram antes, durante e depois desse período. Eles eram semelhantes em propósito, mas distintos em forma e em êxito. Dois deles podem ser identificados como vita apostólica ${ }^{291}$, pois tinham como ênfase o desejo de que a igreja retornasse a viver os valores do evangelho como nos primórdios da igreja primitiva relatados no livro de Atos dos Apóstolos. Um deles, Arnaldo (ou Arnoldo) de Bréscia, abade em Lombardia (Itália) reagiu contra o clero da época (por volta de 1138) e convocou a igreja a uma reforma. Sua ação não era pacífica, mas era de afronta, marcada, inclusive "com exigências radicais"292. Essa é uma boa razão

\footnotetext{
${ }^{287}$ Cf. OHST, Martin. A Igreja no Século XIII: as ordens mendicantes. In: KAUFMANN, Thomas et al (orgs.). História ecumênica da Igreja 2: da alta Idade Média até o início da Idade Moderna, p. 64.

${ }^{288}$ DREHER, Martin Norberto. Bíblia: suas leituras e interpretações na História do Cristianismo, p. 36.

${ }^{289}$ LORTZ, Joseph. Historia de La Iglesia: en la perspectiva de la historia del pensamiento. Antiguedad y edad media. Vol. I, p. 468 (tradução nossa, grifo do autor).

${ }^{290}$ MILLER, Stephen; HUBER, Robert. A Bíblia e sua história: o surgimento e o impacto da Bíblia, p. 144.

${ }^{291}$ Ohst diz que este movimento tem por característica "a realização radical do projeto de vida apostólico, na total renúncia dos bens sem proteção legal e sem privilégios" (OHST, Martin. Op. cit., p. 66).

${ }^{292}$ KORNTGEN, Ludger. Mudança e continuidade, unidade e diversidade. In: KAUFMANN, Thomas et al (orgs.). História ecumênica da Igreja 2: da alta Idade Média até o início da Idade Moderna, p. 39.
} 
que justifica o fato de não ter encontrado êxito, sendo preso, enforcado e queima$\mathrm{do}^{293}$.

Pedro Valdo é outro exemplo (anterior a Francisco) desse anseio por reforma na região da França. O "movimento de Valdo se enraíza, como o de Francisco de Assis, na tradição evangélica do radicalismo itinerante da pregação do Evange1ho" ${ }^{294}$. Nessa perspectiva, "leitura da Bíblia e prática da vida" o levaram a "profundas críticas a uma Igreja que esquecera o Cristo pobre"295. Assim como Francisco, Valdo também era rico. Ao se converter, "abandonou todos os seus bens, exceto o necessário para o sustento de sua família" ${ }^{296}$, e passou a viver de acordo com os valores do evangelho. Era "uma imitação do Evangelho ao pé da letra"297, isto é, "Evangelho era para ele lei que exigia obediência"298.

Como ele não lia latim, não podia ler a Bíblia. Assim, solicitou que se fizessem traduções de porções das Escrituras para o francês ${ }^{299}$, passando a memorizar longas passagens bíblicas ou até mesmo livros inteiros das Escrituras. Além de procurar viver imitando a Cristo, como Francisco, Pedro Valdo passou a pregar sobre essa necessidade em contraposição às riquezas. Sua mensagem encontrou aceitação, e muitos também passaram a segui-lo. Esses seguidores foram posteriormente enviados de dois em dois a pregar as Escrituras. De acordo com Lortz, "eles começaram o grande movimento bíblico medieval" 300 . Eles percorriam "as redondezas para anunciar o Evangelho, difundindo-o na linguagem do povo" ${ }^{\text {301. }}$ Aliás, para Dreher, o grande mérito de Pedro Valdo e seus seguidores foi ter "tra-

\footnotetext{
${ }^{293}$ KORNTGEN, Ludger. Mudança e continuidade, unidade e diversidade. In: KAUFMANN, Thomas et al (orgs.). História ecumênica da Igreja 2: da alta Idade Média até o início da Idade Moderna, p. 40.

${ }^{294}$ VOUGA, François. Protestantismo e Bíblia. Dicionário Enciclopédico da Bíblia. São Paulo: Loyola, Paulinas, Paulus; Santo André: Academia Cristã, 2013, p. 1102.

${ }^{295}$ DREHER, Martin Norberto. Bíblia: suas leituras e interpretações na História do Cristianismo, p. 28.

${ }^{296}$ CAIRNS, Earle Edwin. O cristianismo através dos séculos: uma história da igreja cristã, p. 204.

${ }^{297}$ VALKENBERG, Pim. Leitores da Escritura e ouvintes da Palavra na Igreja da Idade Média, p. 67.

${ }^{298}$ DREHER, Martin Norberto. Op. cit., p. 29.

299 "Valdo tinha dois clérigos traduzindo a Sagrada Escritura em Provençal". In: LORTZ, Joseph. Historia de La Iglesia, vol I, p. 458 (tradução nossa). O provençal é uma das variedades da língua occitana falada na Provença e na metade oriental do Gard, no sudeste francês.

${ }^{300}$ Ibid., p. 458 (tradução nossa)

${ }^{301}$ VALKENBERG, Pim. Loc. cit.
} 
zido a Bíblia ao povo" ${ }^{302}$, ainda que tenham caído "no erro de querer seguir a Escritura ao pé da letra" ${ }^{\prime 303}$.

O papa chegou a "aprovar o estilo de vida valdense, mas não a tradução da Bíblia nem a pregação feita por leigos ${ }^{304 ”}$. Uma das crenças fundamentais dos valdenses era que "todos os homens deviam possuir a Bíblia em sua própria língua, devendo ser ela autoridade final para a fé e para a vida" ${ }^{305}$. Como consequência, o foco do conflito com a igreja se firmou no fato de considerarem o clero hierárquico da igreja desnecessário ${ }^{306}$. Nessa lógica, os valdenses, mesmo com a proibição do papa, continuaram a pregar e, por isso, foram excomungados. Esse movimento, considerado cismático na história católica, continuou por muito tempo. Após a Reforma Protestante, os valdenses abraçaram alguns dos ideais protestantes e constituíram sua própria igreja. Cairns ressalta, por exemplo, que ainda existe um grupo de valdenses no Norte da Itália.

Valkenberg acrescenta que esse mesmo ideal "conduz à origem das ordens mendicantes, as quais, ao menos em parte, constituíam uma tentativa para fazer frutificar dentro da Igreja uma nova experiência bíblica"307. A Escritura Sagrada, no estilo de vida das ordens mendicantes, tinha por objetivo principal imitar Jesus (como descrito nos Evangelhos), viver uma vida de pobreza (como viviam os apóstolos) e pregar (como fizeram os primeiros seguidores de Cristo). Francisco e seus seguidores evidenciam essa realidade. Como a maioria das pessoas era analfabeta ou pobre, o trabalho desses cristãos da Idade Média em torno do evangelho é significativo. A pregação ou a arte poderiam ser as únicas formas de acesso às Escrituras pelo povo. Porém, por causa dessa ênfase na pregação realizada por leigos, esse período ficou marcado pelos “conflitos dos valdenses, mas também das ordens mendicantes, com a autoridade eclesiástica" ${ }^{308}$. Assim, progressiva-

\footnotetext{
${ }^{302}$ DREHER, Martin Norberto. Bíblia: suas leituras e interpretações na História do Cristianismo, p. 31.

${ }^{303}$ LAPLANTE, Alcide. Idade Média Ocidental e Bíblia. In: LONGTON, Joseph; POSWICK, Réginald-Ferdinand [et al.] (orgs.). Dicionário Enciclopédico da Bíblia, p. 659.

${ }^{304}$ MILLER, Stephen; HUBER, Robert. A Bíblia e sua história: o surgimento e o impacto da Bíblia, p. 157.

${ }^{305}$ CAIRNS, Earle Edwin. $O$ cristianismo através dos séculos: uma história da igreja cristã, p. 206.

${ }^{306}$ Cf. LORTZ, Joseph. Historia de La Iglesia: en la perspectiva de la historia del pensamiento. Antiguedad y edad media. Vol. I, pp. 458-459.

${ }^{307}$ VALKENBERG, Pim. Leitores da Escritura e ouvintes da Palavra na Igreja da Idade Média, p. 67.

${ }^{308}$ Ibid., p. 69.
} 
mente, já no século XIV o clero não vivia o melhor de seus dias, nem para a igreja, nem para eles mesmos. De fato,

A alta Idade Média faz sentir uma necessidade intensa de contato com Deus. A piedade daquele tempo é marcada por esta precisão. Porém, a resposta da Igreja e da teologia a esta precisão decepciona. Faltam-lhe impulsos renovadores e apenas insiste em intensificar o uso dos meios costumeiros ${ }^{309}$.

Por isso, movimentos continuaram surgindo, sempre sob um mesmo anseio de reforma. Entre eles se destacam os "místicos" e os "concílios reformadores". Esses movimentos "não acentuaram o valor da Bíblia"310 como outros movimentos tinham feito, nem pela pregação nem pelo estilo de vida. De qualquer forma, eles representaram, igualmente, uma tentativa de resgatar um estilo de vida diferente para a igreja da época, a qual, já no final da Idade Média, encontrava suas dissidências e suas resistências, visto que desde "o século XI os impulsos de reforma da vida eclesiástica haviam também atingido a vida religiosa comunitária"311. Uma evidência dessa necessidade de reforma se percebe no discurso abaixo, conforme segue:

Nós sabemos que na Sé Apostólica, há anos, tem acontecido abusos em assuntos espirituais, violação dos mandamentos e muitas outras coisas erradas. Não é, pois, de se admirar que a doença vai da cabeça para os membros, do papa para os prelados que lhe são sujeitos. Nós todos [...] nos desviamos, seguindo cada um o seu caminho e já há muito tempo não existe sequer um só que pratique o bem. Por isso, é necessário que todos nós demos glória a Deus, nos humilhemos perante ele, e que cada um de nós examine o motivo pelo qual pecou, e cada qual julgue a si mesmo com maior rigor do que será castigado pelo Senhor com a vara da ira. No que se refere a nós, isso significa que haveremos de empregar todo o nosso esforço para que a cúria seja renovada, pois dela originou-se todo mal. E, como dela fluiu a perdição para todos os que abaixo dela se encontram, também dela devem provir a cura e a reforma de todos. E nós nos sentimos tanto mais obrigados quanto vemos que todo o mundo está ansioso por uma reforma desta espécie [...]. Ninguém se admire se não vir todos os erros e abusos serem ao mesmo tempo supressos, pois trata-se de uma doença muito antiga, que não é simples, mas com muitas causas e muito complexa $^{312}$.

\footnotetext{
309 AUGUSTIJN, Cornelis. Os reformadores do século XVI e a Bíblia. In: BEUKEN, Win; FREYNE, Sean; WEILER, Anton (orgs.). A Bíblia e seus leitores. Revista Concilium. Petropólis: Vozes, 1991, p. 72.

${ }^{310}$ CAIRNS, Earle Edwin. O cristianismo através dos séculos: uma história da igreja cristã, p. 228.

311 KORNTGEN, Ludger. A Igreja no século XII: vida religiosa, educação e ciência. In: KAUFMANN, Thomas et al, (orgs.). História ecumênica da Igreja 2: da alta Idade Média até o início da Idade Moderna., p. 27.

${ }^{312}$ DE BONI, Luis Alberto. O reformador Lutero e as causas que levaram à Reforma do século XVI. In: HEIMANN, Leopoldo (org.). Fórum ULBRA de Teologia. Canoas: ULBRA, 2008, pp.13-14.
} 
Pela seriedade do assunto e pela ênfase da crítica, alguém poderia pensar que se trata da fala de um reformador protestante. Pelo contrário, trata-se do discurso do papa Adriano VI (1522-1523), lido pelo Núncio pontifício Francisco Chieregati e destinado a alguns príncipes alemães que estavam reunidos em dieta na cidade de Nuremberg, em 3 de janeiro de 1523. Como se percebe, a Reforma batia às portas da Igreja.

\title{
2.9
}

\section{A difusão das Escrituras Sagradas por meio da arte e da literatura}

\begin{abstract}
A Bíblia, principalmente o Antigo Testamento, mas também muitas cenas do Novo Testamento (anunciação, nascimento de Cristo, milagres, paixão, etc.) foi em todos os tempos a principal fonte de inspiração da arte (pintura, escultura, música) no Ocidente. Para as pessoas simples e iletradas a arte, sobretudo a pintura, torna-se o principal meio de comunicação ${ }^{313}$.
\end{abstract}

A Bíblia sempre foi percebida com o Livro dos livros e, em "seu caráter sapiencial, é um livro metafísico, meta-histórico e metatemporal” ${ }^{\text {314 }}$. Por isso, como percebido acima, em toda a sua história, "desde o final do século I d.C. (nas catacumbas de Roma)"315, mas, principalmente, a partir do quarto século, a Bíblia foi fonte de inspiração para pintores, poetas, dramaturgos, escritores e outros artistas. Isto não quer dizer, porém, que tensões não tenham surgido na história. Desde o surgimento do movimento protestante, por exemplo, o que, muitas vezes, prevaleceu foi uma interpretação coibitiva à representação figurativa do sagrado ${ }^{316}$. No ano de 1522, em Wittemberg, protestantes se reuniram para retirar imagens com histórias bíblicas das paredes das igrejas, reforçando uma postura iconoclasta, isto é, o repúdio ao uso de qualquer imagem religiosa entre as igrejas oriundas da Reforma ${ }^{317}$.

\footnotetext{
313 TERRA, João Evangelista Martins. A Bíblia na evangelização do Brasil. São Paulo: Loyola, 1988 , p. 60.

${ }^{314}$ MAZZAROLO, Isidoro. Florilégios da Bíblia, p. 13. Vale ressaltar que o autor utiliza a preposição grega 'meta' como sentido de 'para além de'.

${ }^{315}$ CANNUYER, Christian. Artes plásticas e Bíblia. In: LONGTON, Joseph; POSWICK, Réginald-Ferdinand [et al.] (orgs.). Dicionário Enciclopédico da Bíblia, p. 175.

316 É obvio que não são todos os protestantes que pregam o iconoclasmo, mas há uma parcela significativa de igrejas, principalmente no movimento pentecostal, que é contra o uso de qualquer tipo de imagem que possa representar o sagrado.

${ }^{317}$ Cf. DREHER, Martin Norberto. Bíblia: suas leituras e interpretações na História do Cristianismo, pp. 49-54.
} 
Entretanto, mesmo na história da igreja primitiva se tem poucas informações sobre o uso das artes. O que se constata é um uso restrito de alguns símbolos como a cruz, a pomba, o peixe, entre outros. A música, a dança, o teatro, entre outras expressões artísticas, foram, aparentemente, rejeitadas pelos Pais Apostólicos devido suas associações com a cultura pagã da época. De forma geral, constata-se que somente depois do quarto século é que as artes, de fato, se introduziram à vida da igreja.

Obviamente, devido à extensão da temática proposta sobre a difusão das Escrituras por meio da arte e da literatura, essa sessão abordará, com as devidas limitações de tempo e espaço, a questão a partir da Idade Antiga até a Idade Contemporânea. Abordar essa temática neste capítulo, nesta seção, trata-se de uma exceção necessária, visto que o assunto percorre quase todo o período da História da Igreja e, por conseguinte, da história da difusão das Escrituras. Considerando que tal início ocorre ainda na Antiguidade, optou-se por inserir essa seção no final deste capítulo, constituindo, portanto, uma exceção que se distancia da linearidade histórica estabelecida até aqui.

Como já se constatou, escrever ou copiar um manuscrito era uma tarefa manual que envolvia muito zelo e diligência. Considerando a importância das Escrituras e procurando atrair o leitor, "os escribas começaram a adicionar elementos visuais" ${ }^{318}$ nos manuscritos bíblicos. O trabalho era bem artesanal. O destaque se dava para as folhas de ouro ou de prata que eram colocadas nas cópias. Sob a luz, as páginas das Escrituras ficavam iluminadas, criando, assim, uma "iluminura". Imagens com desenhos ou cenas de passagens bíblicas também foram aos poucos sendo inseridas. Como há de se imaginar, o trabalho final, concluído pelo monge especializado nesse tipo de atividade, tornava o manuscrito bíblico uma verdadeira obra de arte.

No período medieval e na Renascença, essa arte não se limitou às páginas das Escrituras. As capas, igualmente, começaram a ser trabalhadas manualmente com imagens e acabamento luxuoso. Madeira entalhada, mármore esculpido, tecido bordado, ouro, prata e bronze foram alguns dos materiais utilizados nesse tipo de detalhe inserido nas Escrituras ${ }^{319}$. Como é possível perceber na atualidade, as

\footnotetext{
${ }^{318}$ MILLER, Stephen; HUBER, Robert. A Bíblia e sua história: o surgimento e o impacto da Bíblia, p. 126.

${ }^{319}$ Cf. Ibid, pp. 126-131.
} 
capas ainda constituem um critério importante na escolha das pessoas. Em relação às Bíblias, as variedades existentes evidenciam que as pessoas que leem a Bíblia também gostam de ver nelas uma capa e um acabamento que as agrade.

A pintura também foi marcada na história por seu apego às Escrituras. No inicio da Idade Média, o Papa Gregório enfatizou a importância das pinturas com temas voltados para as Escrituras e, numa realidade de pouca instrução e muito analfabetismo, caracterizou tal arte como a Bíblia dos iletrados. Deste modo, se tornou comum os artistas produzirem artes de acordo com as interpretações teológicas e bíblicas da igreja ${ }^{320}$. Já no final da Idade Média, Leonardo da Vinci e Michelangelo se destacaram por sua influência nesse tipo de trabalho, onde "o desenvolvimento da pintura sobre o painel veio trazer um novo campo artístico à ilustração bíblica"321. Na Idade Moderna, a pintura barroca seguiu o mesmo caminho de interação e divulgação das Escrituras por meio da arte. Dreher ressalta a importância desse tipo de difusão das Escrituras quando diz que

As muitas imagens nas igrejas medievais tinham função didático-pedagógica. Eram a Bíblia dos analfabetos. Caminhando com o filho ao longo das paredes e dos altares dos templos medievais, o pai ia contando a história bíblica ao filho, apontando para as imagens. Imagens são a Bíblia de pobres analfabetos ${ }^{322}$.

Historicamente, porém, uma ala radical da Reforma, sob uma leitura literal dos Dez Mandamentos, fez com que esse tipo de recurso, em que se divulgavam as histórias bíblicas por meio da pintura, fosse abolido e condenado em muitas igrejas. Mesmo que Lutero, por exemplo, tenha sido contra essa iconoclastia bíblica, a onda se espalhou entre os protestantes ${ }^{323}$. Até hoje, em algumas igrejas evangélicas, existe certa resistência, mesmo que sejam pinturas que relatem personagens e histórias especificamente bíblicas.

Retornando à história, as Escrituras Sagradas também inspiraram a arte teatral. Enquanto no começo da igreja o teatro não era recomendado aos cristãos, já a partir do quarto século, gradualmente, cenas de histórias bíblicas foram inseridas como uma forma de difundir as Escrituras e evangelizar.

\footnotetext{
${ }^{320}$ MILLER, Stephen; HUBER, Robert. A Bíblia e sua história: o surgimento e o impacto da Bíblia, pp. 126-131.

321 TERRA, João Evangelista Martins. A Bíblia na evangelização do Brasil, p. 62.

${ }^{322}$ DREHER, Martin Norberto. Bíblia: suas leituras e interpretações na História do Cristianismo, p. 49.

${ }^{323}$ Cf. Ibid., p. 53.
} 
Essas cenas se desenvolveram em pequenas peças teatrais. A peça mais antiga conhecida é sobre a ressurreição e foi preservada por monges beneditinos. [...] A peça estava em latim, o que significava que os congregados continuavam sem compreender o que era dito. Mas eles conheciam a história que estavam sendo contada e eram capazes de acompanhar as peças ${ }^{324}$.

As encenações bíblicas difundidas nas peças teatrais agradaram as pessoas. Com o passar do tempo, mais e mais peças eram introduzidas; mais e mais históricas bíblicas eram encenadas. Assim, o calendário cristão, com seus diversos eventos, era marcado por peças teatrais baseadas nas Escrituras por toda a Europa. Considerando o sucesso dessa forma de difusão bíblica, as peças deixaram as igrejas e passaram a ser realizadas na rua. Já a partir do século XIV as peças passaram a ser realizadas na língua do povo, e não mais em latim. Dessa forma, “o público participava emocionalmente do espetáculo, juntando muitas vezes a sua voz à dos atores, e comovendo-se com eles nas situações mais dramáticas”325. Em certos períodos do ano,

Uma série de peças era apresentada sobre plataformas elevadas e providas de rodas, o que permitia que fossem levadas de um lugar da cidade para outro. Muitas vezes eram apresentadas de 25 a 50 peças que falavam de histórias bíblicas [...] apresentadas na ordem que as histórias aparecem na Bíblia ${ }^{326}$.

Essa foi uma forma importante que a igreja conseguiu utilizar para difundir as Escrituras entre o povo. Como bem afirma Dreher, era uma arte "a serviço da pregação do Evangelho" 327 . Entretanto, a profissionalização que surgiu naturalmente pela envergadura que o projeto alcançou acarretou alguns prejuízos. Com o passar do tempo, já no século XVI, as peças passaram a ser percebidas como diversão, e não mais como evangelização por meio das histórias bíblicas encenadas. Os “autores já não eram exclusivamente eclesiásticos, mas profissionais seculares" ${ }^{\prime 28}$, começando a surgir zombaria, deboche e elementos alheios às Escrituras, tornando, assim, cada vez mais escasso esse tipo de arte como uma ação cristã para divulgar a Palavra de Deus.

Contudo, o conceito tinha sido lançado e tinha sido um sucesso. Por isso, dramaturgos seculares captaram a ideia e passaram a utilizar o teatro para entreter

\footnotetext{
${ }^{324}$ MILLER, Stephen; HUBER, Robert. A Bíblia e sua história: o surgimento e o impacto da Bíblia, p. 140.

325 TERRA, João Evangelista Martins. A Bíblia na evangelização do Brasil, p. 55.

${ }^{326}$ MILLER, Stephen; HUBER, Robert. Op. cit., p. 141.

${ }^{327}$ DREHER, Martin Norberto. Bíblia: suas leituras e interpretações na História do Cristianismo, p. 91.

${ }^{328}$ TERRA, João Evangelista Martins. Op. cit., p. 55.
} 
o povo. Algumas dessas peças, mesmo que mais distantes das histórias bíblicas, tinham, por vezes, um pano de fundo cristão. Shakespeare, por exemplo, começou a escrever nesse tempo, e muitas de suas peças ficaram caracterizadas pelo uso do linguajar bíblico ${ }^{329}$.

As Escrituras também foram difundidas e refletidas na poesia. Por meio das Escrituras Sagradas, poetas e prosadores "procuraram descobrir, ao longo dos séculos, no quadro de uma história, a riqueza de um imaginário, a profundeza de uma psicologia, os mistérios de um destino, a trama do desígnio de Deus e o modo de um estilo"330. Assim como os teatros, as primeiras poesias estavam em latim, mas já a partir do sétimo século as poesias foram escritas na língua do povo. Algumas poesias eram baseadas em textos bíblicos, outras eram as próprias histórias bíblicas. Mas também surgiram poesias que criticavam pessoas ou fatos relacionados à Bíblia ou à igreja. Historicamente, "o mais antigo poema foi, provavelmente, um hino exaltando a criação," ${ }^{331}$ escrito no sétimo século. Todavia, o grande destaque se dá um pouco mais tarde:

A primeira grande obra-prima da Renascença foi do poeta italiano Dante Alighieri, A Divina Comédia, que foi concluída em 1321. Nesse grande épico de três volumes, o poeta fez um passeio pelo inferno, purgatório e céu. A obra está cheia de alusões à Bíblia, e personagens da Bíblia aparecem nos três volumes ${ }^{332}$.

Essa obra foi um marco na história da arte e tem a Bíblia como inspiração. Em épocas mais recentes, principalmente pela influência da Renascença e, posteriormente, do Iluminismo, a Bíblia também passou a ser percebida por alguns apenas pelo seu mérito literário, e não mais como Escrituras Sagradas ou como base para a teologia. Esse tipo de análise se limitou aos aspectos mais técnicos, por meio das ferramentas da crítica literária secular. Não importava a mensagem em si, mas o gênero, o estilo, a linguagem, a unidade dos livros, a estrutura das narrativas, das frases, do vocabulário etc. ${ }^{333}$ Para além do aspecto técnico literário, a Bíblia também inspirou alguns escritos e escritores.

\footnotetext{
${ }^{329}$ Cf. MILLER, Stephen; HUBER, Robert. A Bíblia e sua história: o surgimento e o impacto da Bíblia, p. 141.

${ }^{330}$ CANNUYER, Christian. Literatura e Bíblia. In: LONGTON, Joseph; POSWICK, RéginaldFerdinand [et al.] (orgs.). Dicionário Enciclopédico da Bíblia, p. 810.

${ }^{331}$ MILLER, Stephen; HUBER, Robert. A Bíblia e sua história: o surgimento e o impacto da Bíblia, p. 182.

${ }^{332}$ Ibid.

${ }^{333}$ Ibid.
} 
Livro dos livros, a Bíblia exerceu uma influência considerável no desenvolvimento das literaturas do mundo inteiro, sobretudo onde o cristianismo e o judaísmo foram implantados de uma forma sólida. [...] Não existe, ou quase, uma literatura que tenha escapado desse impacto bíblico ${ }^{334}$.

Um significativo exemplo dessa abrangência bíblica na literatura está na obra Moby Dick (1851), que em sua composição apresentou algumas narrativas bíblicas abreviadas. No Brasil, Moacyr Scliar, um grande escritor brasileiro de contos, romances, ensaios e literatura infanto-juvenil, afirmou algumas vezes que a Bíblia venceu o tempo e era sua fonte de inspiração, visto também ser ele um leitor assíduo das Escrituras ${ }^{335}$. A literatura é uma importante forma de se difundir as Escrituras, pois "bons livros de ficção podem comunicar a mensagem bíblica, muitas vezes, com maior força do que os tratados pedantes, carentes de poder imaginativo",336.

Não menos importante, as Escrituras foram a fonte de belas canções musicais por toda a história. Além das próprias músicas que fazem parte de muitas narrativas bíblicas, é bom lembrar que

Desde sempre, em seu ritual sagrado e profano, a Bíblia interessou aos músicos. Ligada desde as origens às maneiras de expressão é às formas musicais das grandes civilizações da Antiguidade (Mesopotâmia, Egito), ela legou a seus herdeiros o rico patrimônio da cantilação bíblica e da salmodia ${ }^{337}$.

A música, como um elemento cultural significativo nas diversas sociedades, sempre esteve presente na história da difusão das Escrituras. Seja dentro das igrejas ou fora delas, a Bíblia inspirou compositores e cantores que cantarolaram músicas que descrevem histórias da Bíblia ou, até mesmo, doutrinas bíblicas. A música inspirada na Bíblia foi, sem dúvida, um marco na identidade nacional de muitas culturas e países. Aliás, "a Bíblia é a fonte de onde nasceu toda a música ocidental" 338 . Por assim ser, a influência das Escrituras também se estendeu por grandes óperas, que dramatizaram algumas histórias bíblicas tanto do Antigo como do Novo Testamento.

\footnotetext{
${ }^{334}$ CANNUYER, Christian. Literatura e Bíblia. In: LONGTON, Joseph; POSWICK, RéginaldFerdinand [et al.] (orgs.). Dicionário Enciclopédico da Bíblia, p. 810.

${ }^{335}$ Cf. SCHOLZ, Vilson. A Bíblia: sua natureza, funções e finalidade. In: ZIMMER, Rudi (Org.). Manual do Seminário de Ciências Bíblicas, pp. 8-9.

${ }^{336}$ SHEDD, Russel Philip. A Bíblia e os livros, p. 40.

${ }^{337}$ LIPINSKI, Édouard. Música e Bíblia. In: LONGTON, Joseph; POSWICK, Réginald-Ferdinand [et al.] (orgs.). Dicionário Enciclopédico da Bíblia, p. 936.

338 TERRA, João Evangelista Martins. A Bíblia na evangelização do Brasil, p. 72.
} 
Nessa mesma perspectiva, vale advertir que "a indústria cinematográfica dos Estados Unidos da América, centralizada em Hollywood, praticamente desde o seu início viu a Bíblia como fonte de inspiração ${ }^{339 "}$ ". Agel estabelece esse início entre 1897 e $1907^{340}$. De fato, são inúmeros os filmes que de forma direta ou indireta apresentam na tela histórias da Bíblia, histórias de personagens da Bíblia, histórias marcadas pela ética bíblica etc.

Como consequência, a televisão seguiu o mesmo caminho em diversos países como também no Brasil. Histórias bíblicas, tais quais os Dez mandamentos, Noé, Davi, Jesus Cristo, Maria, Pedro, Paulo entre outros, têm servido de inspiração para a produção de filmes, séries e telenovelas. Recentemente, no Brasil, a Rede Record de Televisão, por exemplo, explorou significativamente esse nicho, chegando a igualar ou até a superar, em alguns momentos, os níveis de audiência da Rede Globo de Televisão, que é a grande líder de audiência no Brasil, principalmente por suas tramas ${ }^{341}$. Tais fatos evidenciam que as Escrituras Sagradas têm um lugar especial na vida das pessoas. As pessoas gostam das histórias bíblicas, e muitas vezes as preferem em detrimento de outras opções de entretenimento. Entretanto, percebe-se que alguns se limitam a somente esse tipo de contato com a Bíblia. Assim, tendo a possibilidade de apreciar certos "ensinos bíblicos no cinema e na televisão", muitas vezes abandonam a igreja.

Há de se considerar, ainda, que, por mais que as produções televisas, cinematográficas, poéticas etc. tenham inspiração bíblica, elas, por sua vez, estão repletas de ficção que são inseridas nas histórias bíblicas. Junto às verdadeiras histórias, pode-se construir, paralelamente, uma ilusão, pois o conhecimento bíblico na sociedade é escasso.

Resguardadas essas questões, como se percebe, as Escrituras Sagradas, por meios de suas histórias e seus textos, se difundiram por meios diferentes. Para além do próprio livro, a Bíblia foi narrada, contada, encenada, cantada, tocada e proclamada em diversas línguas — no português também —, e se espalhou por

\footnotetext{
${ }^{339}$ MILLER, Stephen; HUBER, Robert. A Bíblia e sua história: o surgimento e o impacto da Bíblia, p. 234.

${ }^{340}$ Cf. AGEL, Henri. Cinema e Bíblia. In: LONGTON, Joseph; POSWICK, Réginald-Ferdinand [et al.] (orgs.). Dicionário Enciclopédico da Bíblia, p. 305.

${ }^{341}$ Cf. GUARALDO, Luciano. Tramas bíblicas da Record quebram hegemonia da Globo. GUARALDO, Luciano. Tramas bíblicas da Record quebram hegemonia da Globo. Notícias da TV. Publicado em 21 jun. 2017. Disponível em: http://noticiasdatv.uol.com.br/noticia/televisao/tramasbiblicas-da-record-quebram-hegemonia-da-globo-nos-estados-unidos-15586? cpid=txt. Acesso em 21 ago. 2017.
} 
vários lugares. Entre outros, era uma forma de difusão das Escrituras também entre os analfabetos, afinal, era um meio de reforçar a "instrução sobre o conteúdo da pregação cristã para aqueles que não sabem ler. Eles narram a história sagrada, reforçam a memória, elevam a piedade" ${ }^{342}$. A difusão das Escrituras, nesses formatos específicos, contribuiu para que principalmente a civilização ocidental se estabelecesse sob os valores da Bíblia Sagrada. De fato, "para todos no Ocidente, crentes ou não, a Bíblia foi o texto fundador de suas culturas, através do Cristianismo"343. Como se constata, portanto, o pensamento filosófico ocidental está imbricado nas Escrituras.

${ }^{342}$ LORTZ, Joseph. Historia de La Iglesia: en la perspectiva de la historia del pensamiento. Antiguedad y edad media. Vol. I, p. 235 (tradução nossa)

${ }^{343}$ MIRANDA, Evaristo Eduardo de. Bíblia: história, curiosidades e contradições, p. 11. 


\section{3 \\ A difusão das Escrituras Sagradas a partir da Reforma Protestante e da Contrarreforma Católica até a contemporaneidade}

A Bíblia, Palavra de Deus na História da Igreja; esse é um dos pressupostos fundamentais para se compreender este capítulo, afinal, as Escrituras Sagradas sempre acompanharam a igreja em sua existência por toda a história. Essa presença das Escrituras na história eclesiástica, por vezes, se deu com maior intensidade; em outros momentos, se deu de forma mais sutil. Seja da forma que for, por revelar o plano de Deus e a história da salvação, que tem seu ápice na encarnação vida, morte e ressurreição - de Jesus, a Bíblia é o livro da igreja. Para qualquer religião não cristã, não há dúvidas: a Bíblia Sagrada é o livro dos cristãos ${ }^{344}$, sejam eles católicos, protestantes ou ortodoxos. Portanto, "unindo ou dividindo, a Bíblia é a nossa herança" 345 .

Para além desta percepção, dentro do próprio cristianismo ou da História da Igreja, outro aspecto ganha maior relevância. A Bíblia Sagrada é o livro da Reforma - e, como tal, exerce significativa influência em todos os acontecimentos do período.

A reforma trouxe coisas novas, mas não foi uma creatio ex nihilo ${ }^{346}$.Ela teve origem numa larga corrente que, entre outras causas, é marcada por um novo entusiasmo pela Bíblia, uma curiosidade veemente pelo conteúdo da Bíblia, pelas línguas em que foi escrita e pela sua mensagem ${ }^{347}$.

Vale ressaltar que esse aprofundamento na relação com as Escrituras não se deu de forma unilateral. Na Contrarreforma Católica, a Bíblia também esteve em debate e em evidência. Sob uma análise histórica mais cuidadosa, se perceberá que existem alguns mitos que ainda hoje estão presentes em ambas as correntes cristãs. Por vezes, os protestantes afirmam certos fatos (nem sempre verdadeiros)

\footnotetext{
${ }^{344}$ Sem esquecer, obviamente, que o AT - parte da Bíblia Sagrada dos cristãos -, constitui, primeiramente, a Escritura Sagrada do Judaísmo.

${ }^{345}$ MIRANDA, Evaristo Eduardo de. Bíblia: história, curiosidades e contradições, p. 11.

${ }^{346}$ Creatio ex nihilo é uma expressão latina quem em português significa "criação a partir do nada".

${ }^{347}$ AUGUSTIJN, Cornelis. Os reformadores do século XVI e a Bíblia, p. 71.
} 
sobre como a Igreja Católica lidou com a Bíblia a partir da Reforma. Por outro lado, os católicos fazem certas afirmações (tampouco verdadeiras) sobre o papel da Bíblia na igreja protestante a partir da Reforma. Nessa relação, muitas vezes de troca de acusações, surgem afirmações que são propagadas por pessoas que desconhecem a história ou que estão mal-intencionadas. Espera-se, com as devidas limitações e baseando-se na interpretação do autor desta pesquisa, reduzir essas possíveis incompreensões, procurando mostrar como a Bíblia esteve presente neste momento crítico, mas importante, da História da Igreja.

Obviamente, mais uma vez se faz necessário pontuar que seria muito difícil apresentar com rigor todo o curso da difusão da Palavra de Deus desde a Reforma até os dias atuais. Essa história é ampla demais; seria difícil descrevê-la em sua totalidade. Por isso, essa análise se limitará ao objeto de estudo da pesquisa. Vale salientar mais uma vez que, por mais que a neutralidade seja o anseio do autor, é possível que, em algum momento, o viés protestante na descrição dos fatos possa sobressair; afinal, como bem afirmou $\mathrm{Weber}^{348}$, a neutralidade é praticamente impossível nas ações humanas. Contudo, tais fatos não podem (e não devem) limitar a diligência e a seriedade que se espera e se pretende na descrição e na análise histórica da difusão das Escrituras Sagradas a partir da Reforma.

Além da relevância da Bíblia Sagrada no debate ocorrido durante o período da Reforma, importa, também, perceber qual o impacto desses fatos na história subsequente. É importante apreender como os momentos históricos que surgiram na história da teologia (confessionalismo, pietismo, puritanismo, liberalismo etc.) influenciaram ou até mudaram significativamente a forma como se leu e se difundiu as Escrituras. É fundamental analisar, da mesma forma, como a Bíblia passou a ser percebida e, por conseguinte, difundida por ambas as tradições cristãs nos tempos mais atuais. Se procurará, igualmente, perceber como a Bíblia foi difundida no Brasil, descoberto no mesmo período em que a Reforma acontecia na Europa. Ainda que pareça deslocada do todo até aqui, essa análise sobre a difusão da Bíblia no Brasil é significativa porque abre as portas para os próximos capítulos, os quais aprofundarão o objeto da investigação.

Sendo assim, pretende-se neste capítulo descrever, ainda que guardadas as devidas limitações, como as Escrituras Sagradas foram difundidas na Reforma

${ }^{348}$ Cf. WEBER, Max. A "objetividade" do conhecimento nas ciências sociais. São Paulo: Ática, 2006, pp. 43-44, 58-59. 
Protestante e na Contrarreforma Católica, e como, a partir disso, ela esteve presente na caminhada da igreja cristã. Importa também apreender como ela foi difundida de diversas formas, em diversos momentos da história, a partir do século XVI até a contemporaneidade.

\section{1}

\section{A difusão das Escrituras Sagradas e a Reforma Protestante}

Considerando que cada lado tem a sua percepção da história, resta óbvio constatar que existe divergência de opiniões quanto à interpretação do que, exatamente, foi a Reforma. Aliás, encontrar esse "exatamente" é um grande desafio. Nessa perspectiva, Lortz, com muita propriedade, destaca que "um processo histórico de tal complexidade e importância nunca pode ser totalmente decifrado em todas as suas causas principais e secundárias com sua influência e significado recíprocos" ${ }^{\text {349. }}$. Nesse sentido, complementa que, é possível estabelecer “apenas um escasso esqueleto ou estrutura para responder ao problema das causas da Reforma, mas nunca será sua solução real e completa" ${ }^{350}$.

Popularmente, por exemplo, se espalharam informações de que a Reforma foi uma heresia inspirada por Martinho Lutero por várias razões, entre as quais a vontade de casar. É óbvio que, ainda que ele quisesse se casar, esse não foi o motor principal. A Reforma, como já constatado no capítulo anterior, não se deu a partir do nada. Não foi um movimento abrupto ou inesperado. Não se pode subestimar que clamores por reforma na igreja já estavam acontecendo há alguns séculos, desde, pelo menos, a grande cisão ocorrida em 1054, quando a Igreja do Oriente se separou da Igreja Ocidental. Entre outras, esta última, constitui uma entre algumas razões históricas destacadas por Lortz em sua análise sobre quais seriam os pressupostos fundamentais que instigaram "a necessidade de uma reforma da igreja" ${ }^{351}$. Como já se constatou, esses clamores emergiram em vários momentos, tanto por leigos quanto por religiosos, instigando reformas em nível ético e, por vezes, doutrinário ${ }^{352}$.

\footnotetext{
${ }^{349}$ LORTZ, Joseph. Historia de La Iglesia: en la perspectiva de la historia del pensamiento. Edad moderna y contemporanea. Vol. II. Madrid: Ediciones Cristandad, 1965, p. 91 (tradução nossa).

${ }^{350}$ Ibid.

${ }^{351}$ Ibid, p. 92

${ }^{352}$ Cf. SMOLINSKY, Heribert. Os pressupostos da Reforma. In: KAUFMANN, Thomas et al (orgs.). História Ecumênica da Igreja 2, pp. 239-244.
} 
$\mathrm{Na}$ mesma tentativa de entender a Reforma, alguns autores costumam dar atenção a fatores secundários, ou seja, valorizam aspectos políticos, econômicos, sociais e tendem a esquecer-se de que a Reforma foi um movimento eminentemente religioso. Por sua vez, alguns autores protestantes interpretam a Reforma como um movimento única e puramente religioso, que procurou redescobrir a pureza do Cristianismo primitivo, como descrito no Novo Testamento. Essa interpretação muitas vezes tende a não levar em consideração os outros fatores (econômicos, políticos e sociais) que, atrelados aos aspectos religiosos, são importantes para uma compreensão mais minuciosa do que, de fato, foi o movimento da Reforma.

A partir dessas percepções, uma conclusão possível por onde se pode compreender o que, de fato, foi a Reforma Protestante se dá sob a percepção de que ela foi um movimento eminentemente religioso, que não exclui de seu bojo certas implicações políticas, econômicas, sociais e intelectuais, e que teve a Bíblia em seu cerne, definindo-a como autoridade final para a igreja ${ }^{353}$. Tanto no aspecto religioso, quanto no aspecto politico-social, "a Reforma foi um reflexo fiel do final do século XV"354.

Portanto, para além de todos estes aspectos, obviamente importantes numa análise ampla, é possível afirmar que, indubitavelmente, "uma das ênfases centrais da Reforma protestante do século XVI foi a centralidade da Escritura” ${ }^{355}$. Essa centralidade é destacada por Augustijn ${ }^{356}$ de três maneiras, pelo menos: o crescimento de novas traduções da Bíblia (em língua vernácula, sendo, algumas delas, numa linguagem menos formal, portanto mais acessível e popular), a ênfase na pregação bíblica e uma nova interpretação bíblica a partir da doutrina da justificação.

\footnotetext{
${ }^{353}$ Cf. CAIRNS, Earle Edwin. O cristianismo através dos séculos: uma história da igreja cristã, pp.247-257.

${ }^{354}$ LORTZ, Joseph. Historia de La Iglesia: en la perspectiva de la historia del pensamiento. Edad moderna y contemporanea. Vol. II, p. 90 (tradução nossa).

${ }^{355}$ FERREIRA, Franklin. Pilares da fé: a atualidade da mensagem da Reforma. São Paulo: Vida Nova, 2017, p. 43.

${ }^{356}$ Cf. AUGUSTIJN, Cornelis. Os reformadores do século XVI e a Bíblia, pp. 73, 75 e 77.
} 


\title{
3.1.1
}

\section{Os pré-reformadores e a questão da Bíblia}

Como já se constatou, o fim da Idade Média estava tumultuado, e a difusão da Bíblia estava comprometida. Por outro lado, a corrupção atingira alguns níveis altos da igreja da época. Cargos eclesiásticos eram comprados e vendidos livremente. A venda exacerbada de indulgências, os estímulos às coleções de relíquias, entre outras diversas superstições, haviam se tornado prática comum durante o período medieval ${ }^{357}$. Há de se considerar, ainda, que, na história, o surgimento de dissidências ou expressões alternativas da fé cristã, eventualmente consideradas heréticas - a maioria das quais apelavam para as Escrituras —, levava alguns líderes da igreja a temerem e, por assim ser, desaconselharem a leitura da Bíblia pelos leigos. Dessa forma, a igreja fortalecia seu posicionamento de que somente a ela pertencia o direito de interpretar as Escrituras. Por isso,

\begin{abstract}
A leitura bíblica tornou-se problemática e problematizadora, sempre mais reclusa no estreito círculo dos clérigos. Perdeu-se o conhecimento das línguas originais e o sentido literal do texto. Lia-se na Bíblia o que já se tinha na cabeça, fruto de discussões escolásticas e de moralismo casuísta. Forçava-se o texto a dizer o que se desejava que dissesse... e isso nem sempre para iluminar a vida, mas para acender a fogueira para algum adversário ${ }^{358}$.
\end{abstract}

Obviamente, em vários momentos, alguns movimentos ou até mesmo indivíduos isolados se opuseram a esses conceitos, antes, durante e depois da Reforma. Konings ${ }^{359}$ cita Domingos e Francisco (que buscavam a piedade por meio do evangelho), Tomás de Kempis (que buscava a "imitação de Cristo"), Erasmo (que, firmando no humanismo, buscava as fontes originais dos textos bíblicos) e iniciativas reformadoras de Savonarola, Huss e Lutero (que buscavam a reforma da Igreja). Alguns já foram comentados anteriormente e outros (não todos) passarão a ser percebidos a partir de agora.

Entre aqueles que se opuseram estão alguns indivíduos que ficaram conhecidos, somente a partir do século XVII, sob a alcunha de pré-reformadores. Eles foram chamados assim porque antecederam, em alguns anos, os mesmos desejos e

\footnotetext{
${ }^{357}$ Cf. CAIRNS, Earle Edwin. O cristianismo através dos séculos: uma história da igreja cristã, pp. 254-255; SMOLINSKY, Heribert. Os pressupostos da Reforma. In: KAUFMANN, Thomas et al (orgs.). História Ecumênica da Igreja 2, pp. 239-244; WALKER, Williston. História da igreja cristã. Vol I e II, p. 8 (vol. II).

${ }^{358}$ KONINGS, Johan. A Palavra se fez livro, p. 78.

${ }^{359}$ Ibid.
} 
a mesma pregação que os reformadores protestantes expuseram um tempo depois. John Wycliffe e John Huss, entre outros, foram personagens muito importantes nesta análise entre aqueles que clamavam por mudanças na igreja a partir das Escrituras.

Wycliffe (1330 - 1384) foi um professor de Filosofia em Oxford, considerando um importante teólogo da Inglaterra ${ }^{360}$. Ele é considerado como um préreformador justamente porque "sua teologia pode ser caracterizada, em sentido eminente, como teologia da Escritura" ${ }^{" 361}$. Lortz argumenta que, a partir do contexto anticlerical e anti-romano que rondava a Inglaterra daquela época, Wycliffe afirmava que "a Bíblia era a única fonte da fé"362. Foi sob essa perspectiva que, lendo a Palavra de Deus, ele percebeu certas diferenças em relação ao ensino que alguns líderes da época faziam e o que as Escrituras diziam. Criando uma certa agitação, ele começou a pregar, ensinar e escrever sobre isso.

Em suas pregações e escritos, não poucas vezes, Wycliffe teceu críticas ao papado. Em certa ocasião, por exemplo, ele censurou duramente a disputa existente entre dois papas da época, Urbano e Clemente. Em outro argumentou enfaticamente que "o papa não era a voz de Deus na terra, essa voz era a Bíblia"363 e, por assim ser, a Bíblia "deveria normatizar todos os âmbitos de vida na Igreja e no mundo" 364 . Seus escritos normalmente destacam tal pressuposto. Entre outras, tais fatos podem ser percebidos nas obras De sufficientia legis Christi (prelúdio para a obra Opus Evangelicum) e De veritate Sacre Scripturae. Na primeira, Wycliffe defendia que as Escrituras eram suficientes para governar o mundo, sem a intervenção da igreja. Na segunda, ao defender a Bíblia como a Palavra revelada, Wycliffe defendeu que ela deveria ser soberana e superior a qualquer interpretação realizada pelos clérigos ${ }^{365}$. Sua pregação, “encontrou um grande eco em todos

\footnotetext{
${ }^{360}$ Cf. TEIXEIRA, Paulo. Traduções da Bíblia: história, princípios e influência. In: ZIMMER, Rudi (Org.). Manual do Seminário de Ciências Bíblicas, p. 49.

${ }^{361}$ LEPPIN, Volker. Teologia da Idade Mérdia tardia. In: KAUFMANN, Thomas et al (orgs.). História ecumênica da Igreja 2: da alta Idade Média até o início da Idade Moderna., p. 189.

${ }^{362}$ LORTZ, Joseph. Historia de La Iglesia: en la perspectiva de la historia del pensamiento. Antiguedad y edad media. Vol. I, p. 527 (tradução nossa)

${ }^{363}$ WYCLIFFE apud MILLER, Stephen; HUBER, Robert. A Bíblia e sua história: o surgimento e o impacto da Bíblia, p. 154. A citação na refirada obra não faz menção sobre a a fonte primária onde constam as palavras de Wycliffe.

${ }^{364}$ LEPPIN, Volker. Loc. cit.

${ }^{365}$ Cf. WYCLIF'S, John. De veritate Scrae Scripturae. Londres: The Wiclif Society by Trubner \& Co, 1905, passim; WYCLIF'S, John. Opus Evangelicum. Londres: The Wiclif Society by Trubner \& Co, 1895, cap. XXVII-XXIX.
} 
os estratos da população, mesmo entre a nobreza e no tribunal"366. Diante de tais fatos, alguns consideram que ele preparou o caminho da Reforma um século antes.

A relação de Wycliffe com as Escrituras não se limitou às leituras, pregações ou críticas. Ele agiu com insistência para que se desenvolvesse uma tradução da Palavra de Deus em sua própria língua, a fim de substituir a versão latina que somente os cultos e o clero podiam ler. Para ele, "como as doutrinas da fé estão nas Escrituras, os cristãos deveriam ter as Escrituras em uma língua que pudessem compreender completamente"367. Assim, Wycliffe difundiu a primeira tradução da Bíblia na língua inglesa.

Acredita-se que ele não tenha concluído a tradução, tendo traduzido pelo menos o Novo Testamento, terminado-o em $1382^{368}$. Por ser uma tradução literal do latim, não resultou em fácil leitura e compreensão. Por isso, alguns anos depois da sua morte, foi realizada uma revisão que ficou mais fácil de ser lida. Assim como já tinha acontecido em séculos anteriores em outras nações, a Bíblia de Wycliffe ajudou a unir a língua inglesa, pois até aquele momento existiam três dialetos na Inglaterra.

Wycliffe também inspirou e depois comissionou alguns de seus seguidores, chamados de lolardos, a se tornarem ministros viajantes que tinham a missão de "ler a Bíblia e ensiná-la ao povo por toda a Inglaterra"369. O papa promulgou cinco bulas ordenando sua prisão. Ele chegou a ser convocado em Roma. A Igreja da Inglaterra o julgou três vezes, mas ele nunca foi condenado em vida. Entretanto, 43 anos depois de sua morte (em 1428), a Igreja ordenou que seus ossos fossem retirados do túmulo, queimados até virar cinza e jogados num rio $^{370}$. O legado de John Wycliffe para a difusão das Escrituras foi tão significativo que até hoje existe uma organização chamada Tradutores de Wycliffe. Eles realizam inúmeros projetos de tradução da Bíblia pelo mundo inteiro.

\footnotetext{
${ }^{366}$ LORTZ, Joseph. Historia de La Iglesia: en la perspectiva de la historia del pensamiento. Antiguedad y edad media. Vol. I, p. 528 (tradução nossa)

${ }^{367}$ MILLER, Stephen; HUBER, Robert. A Bíblia e sua história: o surgimento e o impacto da Bíblia, p. 154.

${ }^{368}$ Cf. CAIRNS, Earle Edwin. O cristianismo através dos séculos: uma história da igreja cristã, p. 226.

${ }^{369}$ Ibid., p. 227.

${ }^{370}$ Cf. TEIXEIRA, Paulo. Traduções da Bíblia: história, princípios e influência. In: ZIMMER, Rudi (Org.). Manual do Seminário de Ciências Bíblicas, p. 49.
} 
Logo após Wycliffe, e também por ele influenciado, surgiu outro préreformador: John Huss (1372-1415). Huss era um camponês da Boêmia que se tornou sacerdote e exímio pregador na Capela de Belém, em Praga (atual República Tcheca). Inspirado por Wycliffe, ele pregava que a Bíblia, e não o clero, deveria ser autoridade suprema para os cristãos. Além disso, "atacou a moralidade dos sacerdotes e o culto às relíquias" ${ }^{\text {"371 }}$. Por tais posicionamentos, foi proibido de pregar; mas sob a proteção do Imperador (que era favorável a Wycliffe), conseguiu ser nomeado Reitor da Universidade de Praga. Em 1410, o papa Alexandre V ordenou que se queimasse os livros de Wycliffe e que Huss fosse excomungado.

No Concílio de Constança Huss foi julgado, mas ainda assim obteve um salvo-conduto do Imperador. Posteriormente, entretanto, com o salvo-conduto anulado, "em razão da semelhança de suas doutrinas com as de Wycliffe"372, "ele foi condenado como herege e imediatamente queimado; suas cinzas foram espalhadas no [Rio] Reno"373. Huss inspirou um movimento por meio de seus seguidores que ficou conhecido como hussitas; eles também vieram a constituir uma igre$\mathrm{ja}^{374}$. Cairns destaca que os ensinos e os exemplos de Huss foram uma inspiração para Lutero, que, em pouco tempo, continuou a realizar esse tipo de pregação ${ }^{375}$.

\subsection{2 \\ Causas e fatos que contribuíram com a Reforma e a difusão das Escrituras Sagradas}

Para além da própria ação dos reformadores, existem algumas causas históricas que contribuíram com a Reforma e, por conseguinte, com a difusão das Escrituras Sagradas. São elas: o Renascimento e o surgimento da imprensa. Arru$\mathrm{da}^{376}$, entre outros historiadores, afirma que a Idade Média, um dos mais longos períodos da história, chegou ao fim por volta do século XV, dando início a um

\footnotetext{
${ }^{371}$ DREHER, Martin Norberto. Bíblia: suas leituras e interpretações na História do Cristianismo, p. 40.

${ }^{372}$ LEPPIN, Volker. Teologia da Idade Mérdia tardia. In: KAUFMANN, Thomas et al (orgs.). História ecumênica da Igreja 2: da alta Idade Média até o início da Idade Moderna., p. 191.

${ }^{373}$ LORTZ, Joseph. Historia de La Iglesia: en la perspectiva de la historia del pensamiento. Antiguedad y edad media. Vol. I, p. 529 (tradução nossa)

${ }^{374}$ Cf. MILLER, Stephen; HUBER, Robert. A Bíblia e sua história: o surgimento e o impacto da Bíblia, p. 157.

375 CAIRNS, Earle Edwin. O cristianismo através dos séculos: uma história da igreja cristã, p. 227.

${ }^{376}$ Cf. ARRUDA, José Jobson de A. História moderna e contemporânea. São Paulo: Ática, 1980, pp. 21-53.
} 
novo período, marcado por profundas transformações sociais, políticas e religiosas. Para eles, o Renascimento é, justamente, o marco divisor entre o fim da Idade Medieval e o início definitivo da Idade Moderna ${ }^{377}$. O Renascimento provocou transformações intelectuais significativas que favoreceram o desenvolvimento da Reforma e, consequentemente, da difusão das Escrituras. A revolução científica e literária que se deu durante o Renascimento é chamada de "humanismo, cuja influência sobre a Reforma é indiscutível e fundamental"378.

Como um movimento de crítica ao seu tempo, "seu interesse maior estava centrado no ser humano, em sua individualidade, em sua autonomia, em sua liberdade" 379 . Como admiradores da cultura antiga, os humanistas aprendiam as línguas antigas a fim de decifrar documentos antigos. Por sua vez, o humanismo cristão deu ênfase ao estudo das Escrituras nas línguas originais (hebraico e grego) e valorizou o indivíduo, seus valores e direitos, procurando desprendê-los de quaisquer pesos que sobre eles estavam impostos ${ }^{380}$. Obviamente, o humanismo instigou certos temores na igreja da época; afinal, "os humanistas cristãos insistiam em usar a sabedoria humana e o estudo para reavaliarem e reformarem o Cristianismo"381. Eles, então, começaram a advertir que não existia base bíblica para certas práticas que permeavam a realidade eclesial e que uma incorreta compreensão da Bíblia (ou a ausência dela) tinha proporcionado alguns equívocos que se caracterizavam por preceitos distorcidos, rituais desnecessários e comportamentos inadequados $^{382}$.

\footnotetext{
377 O Renascimento ou Renascença foi um movimento cultural iniciado no século XIV na Itália, e que alcançou seu apogeu nos séculos XV, XVI e XVII e espalhou-se por toda a Europa. Este movimento está relacionado à redescoberta de antigos escritos gregos e romanos. O Renascimento foi um período de descobertas em muitos campos; novas leis científicas, novas formas de arte e literatura, descoberta de novas terras, novas ideias religiosas e políticas. A Renascença fomentou também um reavivamento da vida urbana com suas indústrias e interesses. Cf. ARRUDA, José Jobson de A. História moderna e contemporânea, pp. 30-43.

${ }^{378}$ SMOLINSKY, Heribert. Os pressupostos da Reforma. In: KAUFMANN, Thomas et al (orgs.). História Ecumênica da Igreja 2, p. 239.

379 DREHER, Martin Norberto. Bíblia: suas leituras e interpretações na História do Cristianismo, p. 41.

${ }^{380}$ Um exemplo da implicação dessa nova forma de pensar foi o chamado "sacerdócio universal de todos os crentes", defendido pelos reformadores. Cf. GEORGE, Timothy. Teologia dos reformadores. São Paulo: Vida Nova, 1993, p. 96.

${ }^{381}$ MILLER, Stephen; HUBER, Robert. A Bíblia e sua história: o surgimento e o impacto da Bíblia, p. 158.

${ }^{382}$ Cf. CAIRNS, Earle Edwin. O cristianismo através dos séculos: uma história da igreja cristã, pp. 254-257.
} 
Enquanto secularmente "os humanistas inauguraram um modo novo de abordar os textos antigos" ${ }^{\prime 383}$, se firmando no princípio ad fontes (de volta às fontes), isto é, nas obras da Antiguidade clássica greco-romana, os humanistas cristãos, e mais tarde os reformadores, fizeram o mesmo com a Bíblia. Eles retornaram aos textos originais hebraico e grego em detrimento da versão latina. Lorenzzo Valla, um humanista cristão italiano, já tinha escrito uma obra em que procurava corrigir erros da tradução latina; era a obra Anotações sobre o Novo Testamento, publicada em $1455^{384}$. Mas vale ressaltar que tal retorno não contribuiu somente com a Reforma Protestante. De acordo com Lortz, o lema do retorno às fontes, que "provou de forma convincente sua eficácia na recuperação da Sagrada Escritura e dos Padres da Igreja, foi um movimento de incalculável importância para a reforma católica do século XVI"385.

Contudo, a obra mais importante foi a do sacerdote Desidério Erasmo (1466-1536), ou como é mais conhecido, Erasmo de Roterdã, considerado o príncipe dos humanistas $^{386}$. Em 1516, procurando restaurar o cristianismo a partir das antigas fontes, ele publicou o primeiro Novum Instrumentum que foi, de fato, a primeira edição grega do NT impressa. Essa obra tem significativa importância na difusão das Escrituras, pois, como se sabe, cópias do NT eram manuscritas de forma isoladas até o século XV. Erasmo, de forma revolucionária, agrupa "seis

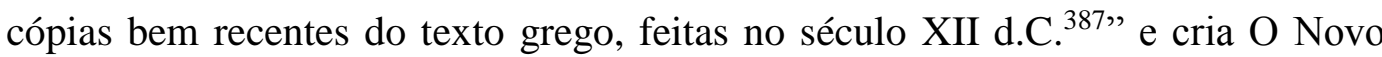
Testamento Grego ${ }^{388}$, conhecido na história como Textus Receptus (texto recebido). No prefácio do seu NT, que "ele dedicou ao papa" ${ }^{389}$, Erasmo afirmou que assumiu o projeto para que todos, um dia, pudessem ler a Bíblia. Até hoje, obviamente, com as devidas atualizações e com melhores edições críticas, a obra de Erasmo serve de base para traduções bíblicas realizadas em várias regiões. Trata-

${ }^{383}$ MANNUCCI, Valério. Bíblia, Palavra de Deus: curso de introdução à Sagrada Escritura, p. 317.

${ }^{384}$ Cf. MILLER, Stephen; HUBER, Robert. A Bíblia e sua história: o surgimento e o impacto da Bíblia, p. 159.

${ }^{385}$ LORTZ, Joseph. Historia de La Iglesia: en la perspectiva de la historia del pensamiento. Edad moderna y contemporanea. Vol. II, p. 54 (tradução nossa).

${ }^{386}$ Em seus estudos, Erasmo "se orientava nos grandes modelos da Antiguidade Cristã: Bíblia, Pais da Igreja, Orígenes e Jerônimo". In: DREHER, Martin Norberto. Bíblia: suas leituras e interpretações na História do Cristianismo, pp. 41-42.

${ }^{387}$ SCHOLZ, Vilson. A transmissão do texto bíblico. In: ZIMMER, Rudi (Org.). Manual do Seminário de Ciências Bíblicas, p. 33.

388 Cf. NESTLE-ALAND. Novum Testamentum Graece. $28^{\mathrm{a}}$ edição revisada. Deutsche Bibelgesellschaft. Barueri: Sociedade Bíblica do Brasil, 2018

${ }^{389}$ LEPPIN, Volker. Humanismo. In: KAUFMANN, Thomas et al (orgs.). História ecumênica da Igreja 2: da alta Idade Média até o início da Idade Moderna., p. 234. 
se de uma ferramenta que é muito útil nas traduções da Bíblia realizadas pelas Sociedades Bíblicas, por exemplo.

Além disso, os escritos de Erasmo influenciaram significativamente a cristandade e a teologia daquela época, conforme destaca Lortz.

A influência de Erasmo foi universal. Sem ele, a vida espiritual dos séculos XVI, XVII e XVIII seria inconcebível. Devido ao traço individualista de sua atitude e religiosidade espiritual, a edição do Novo Testamento grego, sua crítica textual da Bíblia e sua crítica muitas vezes destrutiva contra a Igreja, Erasmo também foi uma das causas mais imediatas da Reforma ${ }^{390}$.

De fato, os escritos de Erasmo exerceram grande influência nos reformadores. Entre eles, o próprio Lutero; pois foi o NT grego de Erasmo que o reformador utilizou para desenvolver sua tradução da Bíblia para o alemão. De certa forma, ele preparou o terreno para a Reforma, apesar de resistir e não a querer como tal. Como bem lembra Cairns, inicialmente Erasmo até "simpatizou com Lutero, mas depois se opôs a ele"391.

Além do aspecto intelectual, há outro aspecto material que também contribuiu com a Reforma. Como já se constatou, durante muitos anos as cópias da Bíblia eram escritas à mão, dificultando, seguramente, uma difusão mais ampla das Escrituras Sagradas, visto que eram produzidos um exemplar de cada vez. Antes, porém, da revolução criada pela prensa de Gutenberg, surgiu um outro tipo de impressão. Era um tipo de impressão em que o "texto e as figuras eram gravados em blocos de madeira resistente do tamanho de uma folha de papel" ${ }^{\text {"392 }}$. Esse tipo de impressão exigia, portanto, um trabalho manual, em que alguém precisava escrever e desenhar as figuras de forma bem artesanal para depois serem assentadas no papel. É obvio que esse modelo de impressão já era melhor que o anterior, mas ainda não era o ideal.

Em pouco tempo, com o progresso do conhecimento e o avanço da tecnologia da época a técnica da prensa surgiu e proporcionou uma grande transformação na história. Essas mudanças ocorreram em diversas áreas da sociedade, e como não poderia deixar de ser, o movimento da Reforma, que nasceria alguns anos

\footnotetext{
${ }^{390}$ LORTZ, Joseph. Historia de La Iglesia: en la perspectiva de la historia del pensamiento. Edad moderna y contemporanea. Vol. II, p. 73 (tradução nossa).

${ }^{391}$ CAIRNS, Earle Edwin. O cristianismo através dos séculos: uma história da igreja cristã, p. 237.

${ }^{392}$ MILLER, Stephen; HUBER, Robert. A Bíblia e sua história: o surgimento e o impacto da Bíblia, p. 150 .
} 
depois, também se favoreceu. Deste modo, atrelado ao inconformismo religioso por parte de alguns, junto à onda humanista que permeava a sociedade, o surgimento da prensa com tipos móveis emergiu contribuindo significativamente com a Reforma Protestante. É interessante notar que as tentativas anteriores de espalhar o conhecimento bíblico ou ainda os escritos que argumentavam sobre a necessidade da realização de reformas na igreja não tinham alcançado tanto êxito. De fato,

Um século antes de Lutero, John Wycliffe e John Huss haviam lançado as centelhas de reforma. Mas o fogo não se espalhou. A mensagem de reforma de Lutero, entretanto, rapidamente tomou conta da Alemanha, se alastrou para outras nações da Europa e continuou crescendo. A grande diferença entre Lutero e os reformadores anteriores é que Lutero teve acesso à recém-inventada tecnologia de impressão de Gutemberg. Lutero podia publicar sua mensagem de forma barata em livros e panfletos e, então, distribuí-la a centenas de milhares de pessoas. Mais importante ainda: ele pôde publicar a Bíblia na língua do povo ${ }^{393}$.

Segundo Scholz, entre outros historiadores, a Bíblia "foi o primeiro livro a ser impresso" 394 . Entretanto, não foi a primeira publicação a ser realizada nessa nova tecnologia da época. Miller e Hubber afirmam que as primeiras publicações realizadas na prensa foram poemas sobre o Dia do Juízo, calendários de 1448 e indulgências para a Igreja ${ }^{395}$. Antes mesmo da Reforma, Gutemberg já havia iniciado (mesmo sem ele mesmo chegar a concluir devido a certos desentendimentos com seu sócio) a publicação da sua famosa Bíblia de Gutenberg, iniciada em 1450 e concluída, provavelmente, em 1455 por João Fust. Aliás, segundo Walker ${ }^{396}$, por volta de 1500, 92 edições da Bíblia Latina Vulgata já haviam sido impressas.

O aparecimento dessa tecnologia de impressão facilitou e contribuiu com a Reforma ${ }^{397}$, mas, mais do que isso, contribuiu para que as Escrituras Sagradas passassem a ser publicadas cada vez mais, visto que a tecnologia de impressão se difundiu de forma acelerada. Na ocasião do conflito de Lutero com a igreja, existiam lojas de impressão em aproximadamente todas as principais cidades do con-

\footnotetext{
${ }^{393}$ MILLER, Stephen; HUBER, Robert. A Bíblia e sua história: o surgimento e o impacto da Bíblia, p. 160.

${ }^{394}$ SCHOLZ, Vilson. A Bíblia: sua natureza, funções e finalidade. In: ZIMMER, Rudi (Org.). Manual do Seminário de Ciências Bíblicas, p. 8.

${ }^{395}$ Cf. MILLER, Stephen; HUBER, Robert. loc. cit.

${ }^{396}$ Cf. WALKER, Williston. História da Igreja Cristã. Vol I e II, p. 409 (vol. I)

${ }^{397}$ Sob uma análise mais secular e literária do que religiosa, alguns creditam o sucesso da Reforma ao surgimento da prensa. Cf. EISENSTEIN, Elisabeth L. A revolução da cultura impressa: os primórdios da Europa Moderna. São Paulo: Ática, 1998, pp. 167-206. Para outros, há uma relação de contribuição recíproca, mas não de dependência. Cf. FEBVRE, Lucien. MARTIN, Henri-Jean. O aparecimento do livro. Lisboa: Fund. Calouste Gulbenkian, 2000, pp. 376-405.
} 
tinente europeu ${ }^{398}$. Como resultado desta nova realidade, Walker acrescenta que "a segunda metade do século décimo quinto presenciou grande distribuição de Bíblias Vulgata e de traduções" ${ }^{\text {399 }}$ realizadas a partir dela.

\subsection{3 \\ Os reformadores em sua relação com as Escrituras Sagradas e a sua difusão}

Há muito que se falar sobre os movimentos da Reforma e seus respectivos reformadores. Por isso, nessa pesquisa, o objeto deve se limitar essencialmente sob a perspectiva de como tais fatos contribuíram para que as Escrituras Sagradas se difundissem de forma contínua e crescente. Isto porque, como destacou Lortz, “esses movimentos extraíram a força religiosa da Bíblia. Ao contrário do que aconteceu até então, a leitura da Bíblia foi muito difundida"400.

Lutero, por motivos óbvios, receberá a primeira e mais significativa análise. Raramente se discorda que Lutero marcou decisivamente a história, principalmente a história da igreja e a história da difusão das Escrituras. Visto com certas reservas por alguns, e com certa admiração por outros, Lutero foi um marco divisor para que a Reforma ocorresse como tal, mesmo que ele e os demais reformadores, pelo menos inicialmente, não quisessem tal ruptura. Historicamente, "nem para uns nem para outros era questão de dividir a cristandade ou de fundar uma nova confissão"401. Para além das divergências doutrinárias, Lutero marcou significativamente a forma como a igreja deveria ler, interpretar e valorizar as Escrituras. Essa marca se evidenciou como algo bem característico na fé protestante.

Depois de se tornar mestre em artes e ter iniciado o estudo de Direito, Lutero decidiu se tornar um monge agostiniano. Essa decisão surgiu de um voto feito a Deus, caso ele conseguisse sair vivo de uma tempestade. Contudo, o fato de Lutero fazer-se monge não foi suficiente para aplacar o seu medo da morte e aquietar a sua consciência pesada pelos erros cometidos. Assim, segundo suas palavras, ele procurava por todos os meios possíveis fazer-se aceito por Deus; mas não conse-

\footnotetext{
${ }^{398}$ Cf. BRIGGS, Asa; BURKE, Peter. Uma história social da mídiaI: de Gutember à Internet. Rio de Janeiro: Jorge Zahar Ed., 2006, p. 24

${ }^{399}$ WALKER, Williston. História da Igreja Cristã. Vol I e II, p. 409 (vol. I).

${ }^{400}$ LORTZ, Joseph. Historia de La Iglesia: en la perspectiva de la historia del pensamiento. Edad moderna y contemporanea. Vol. II, p. 75 (tradução nossa).

401 VOUGA, François. Protestantismo e Bíblia. In: LONGTON, Joseph; POSWICK, RéginaldFerdinand [et al.] (orgs.). Dicionário Enciclopédico da Bíblia, p. 1102.
} 
guia. Por não ter certeza da salvação de sua alma, Lutero procurava mortificar o seu corpo, jejuando por vários dias seguidos, se dedicando a muitas orações e vigílias. Fazia sempre muito além daquilo que era requerido pela ordem. Ele se confessava diariamente e, às vezes, de hora em hora ${ }^{402}$.

Nesse ínterim, Johann von Staupitz, seu confessor e deão da Faculdade Teológica da Universidade de Wittemberg, conhecendo profundamente seus problemas interiores tentou tranquilizá-lo sobre o amor e a misericórdia divina. Não alcançando êxito, o orientou a buscar a paz ajudando a outros e estudando as Escrituras, o que o tornou, posteriormente, professor de Bíblia ${ }^{403}$. Assim, Lutero se tornou professor da Universidade de Wittemberg, onde recebeu o doutorado em Teologia. Nessa trajetória, ao ler Rm 1,17, ele encontrou a paz que tanto anelava para sua alma. Nessa descoberta, Lutero chegou à conclusão de que a salvação vem através da fé e não por obras humanas. Ali Lutero firmou decisivamente que, a partir daquele momento, em sua teologia, o "tema central é o da justiça de Deus" ${ }^{\text {"404 }}$. Esse foi, por assim dizer, o estopim que fez Lutero mudar radicalmente sua vida, transmitir essa mensagem ${ }^{405}$ a outros e se voltar completamente para as Escrituras.

Em 31 de outubro de 1517, Lutero afixou as suas 95 teses à porta da Igreja de Wittemberg ${ }^{406}$. Esta medida provocou um turbilhão de reações que em pouco tempo o conduziram a um completo rompimento com a igreja de sua época. E, assim, a teologia de Lutero se tornou a Teologia da Palavra. Esse contato de Lutero com as Escrituras o fez repensar o lugar da Palavra de Deus na vida da igreja.

${ }^{402}$ Cf. CÉSAR, Elben Magalhães Lenz. Conversas com Lutero: história e pensamento. Viçosa: Ultimato, 2006, p. 27-32.

${ }^{403}$ CÉSAR, Elben Magalhães Lenz. Conversas com Lutero: história e pensamento, p. 25; KUNZ, Claiton André. Martinho Lutero: vida, doutrina e contribuições. Revista Via Teológica. Vol. 17, n. 34, dez. 2016, pp.4-5.

${ }^{404}$ VOUGA, François. Protestantismo e Bíblia. In: LONGTON, Joseph; POSWICK, RéginaldFerdinand [et al.] (orgs.). Dicionário Enciclopédico da Bíblia, p. 1102.

${ }^{405}$ Lutero "pregava mais ou menos duas a três vezes por semana na igreja de Wittenberg" (AUGUSTIJN, Cornelis. Os reformadores do século XVI e a Bíblia, p. 77).

${ }^{406}$ Esse ato representava uma atitude comum de se apregoar uma disputa teológica. Era uma instituição regular da vida universitária e não existia nada de dramático nem desrespeitador no ato. $\mathrm{O}$ texto estava em latim, porque seu alvo era o clero, não o povo em si. Lutero confiava receber o apoio do papa pelo fato de revelar os males do tráfico das indulgências. Assim, as 95 teses tinham por intenção discutir com os teólogos sobre penitência, indulgências e a salvação pela fé. O evento marcou o início da Reforma Protestante. Cf. KUNZ, Claiton André. Op. cit., p. 7. Vale ressaltar, ainda, que nas 95 teses, "Lutero não formulou uma negação absoluta da indulgência", evidenciando, pelo menos inicialmente, que não se tratava de um "documento estritamente reformador". Cf. SMOLINSKY, Heribert. Os inícios da Reforma. In: KAUFMANN, Thomas et al (orgs.). História ecumênica da Igreja 2: da alta Idade Média até o início da Idade Moderna., p. 256. 
Ele concluiu que nada poderia substituí-la, pois, para ele, "a Palavra de Deus é a primeira de tudo" $" 407$.

Para o reformador, que até os 20 anos não tinha visto um exemplar das Escrituras, ${ }^{408}$ a Bíblia se tornou sinônimo de um "livro que o próprio Deus transformou em sua voz entre os seres humanos" ${ }^{\$ 09}$. Por isso, ela cria a fé, é o fundamento da teologia, tem preeminência sobre a tradição e tem Cristo por seu centro ${ }^{410}$. Na teologia bíblica de Lutero, portanto, o Evangelho constitui o núcleo fundamental das Escrituras. Nessa perspectiva, "o Evangelho é a causa da revelação escriturística e o evangelho é um efeito da revelação escriturística. Em outras palavras, o grande propósito eterno de Deus de redenção (que é expresso no evangelho) dá surgimento à Bíblia, e a Bíblia serve para realizar o propósito de Deus no Evangelho",411.

Diante destes pressupostos, evidencia-se que, para Lutero, a Scriptura sui interpres $^{412}$, isto é, a Escritura "deve servir de critério de interpretação da Escritura" ${ }^{413}$. Essa não é uma ideia nova de Lutero. Trata-se de uma aproximação muito significativa à compreensão dos Pais da Igreja, que, ao combater os erros teológicos dos primeiros séculos, estabeleceram "o método que consiste em explicar a Escritura pela Escritura”, como bem lembra Dorival ${ }^{414}$. Nova é a consequência dessa interpretação. A igreja, antes considerada a única fiel intérprete dos textos sagrados, a partir de Lutero, passa a ser percebida como "criação das Escrituras". Para ele a igreja só existia por causa da Palavra de Deus. Essa é uma posição completamente oposta ao que preconiza a doutrina católica sobre o lugar das Escrituras na igreja. Para os católicos, as Escrituras surgem por causa da igreja.

Sobre a relação Tradição e Escrituras, um mito deve ser desconstruído. É importante ressaltar que Lutero "não se opõe à tradição patrística e medieval en-

\footnotetext{
${ }^{407}$ LUTERO, Martinho. Martinho Lutero: uma coletânea de escritos. São Paulo: Vida Nova, 2017, p. 118.

${ }^{408}$ Cf. GEORGE, Timothy. Teologia dos reformadores, p. 80.

409 MOELLER, Bernd. A era de ampliação e consolidação da Reforma - 1525-1555. In: KAUFMANN, Thomas et al (orgs.). História ecumênica da Igreja 2: da alta Idade Média até o início da Idade Moderna., p. 320.

${ }^{410}$ Cf. HÄGGLUND, Bengt. História da teologia, p. 187-189.

${ }^{411}$ CARSON, Donald Arthur; KELLER, Timothy. O Evangelho no centro: renovando nossa fé e reformando nossa prática. São José dos Campos: Fiel, 2013, p. 51.

${ }^{412}$ Cf. LUTERO, Martinho. Martinho Lutero: uma coletânea de escritos, pp. 97-99; GEORGE, Timothy. Teologia dos reformadores, p. 85.

413 VOUGA, François. Protestantismo e Bíblia. In: LONGTON, Joseph; POSWICK, RéginaldFerdinand [et al.] (orgs.). Dicionário Enciclopédico da Bíblia, p. 1102.

${ }^{414}$ DORIVAL, Gilles. Antiguidade Cristã Grega e Bíblia. In: LONGTON, Joseph; POSWICK, Réginald-Ferdinand [et al.] (orgs.). Dicionário Enciclopédico da Bíblia, p. 100.
} 
quanto tal ${ }^{\prime 415}$. Para Lutero, assim como para principalmente os protestantes históricos, existe a importância da "tradição". Aliás, Lutero se refere à tradição em vários momentos. É preciso afirmar, portanto, que "não houve um rompimento entre a leitura da Bíblia feita na Reforma, e a tradição teológica acumulada ao longo da história cristã" ${ }^{\prime 16}$. A diferença enfatizada por Lutero está no fato de que a tradição está sujeita à própria Escritura. Nesse ínterim, é simples perceber que ele realmente fez "da Palavra de Deus o ponto de partida e a autoridade final de sua teologia" 417 e, caso haja controvérsia doutrinária, a Escritura é a autoridade capaz em detrimento do ensino dos Pais, que podem $\operatorname{errar}^{418}$.

Para os reformadores, portanto, as Escrituras atuam como norma normans non normata, isto é, "a norma que regula, mas não é regulada", enquanto a Tradição, mesmo que tenha significativa importância, será norma normata, isto é, "a norma que está sujeita a outra norma superior", ou seja, será sempre regulada pelas Escrituras ${ }^{419}$. Sob essa ótica, a tradição fica submissa e, até mesmo, sob crítica das Escrituras. Como se percebe, tal tema proporciona uma interminável discussão. Konings procura equilibrar essa questão ao contrapor as posições católicas e protestantes da seguinte forma: "Embora Lutero considerasse a Escritura "norma normans, non normata", observamos que ela é uma norma relativa, originada da (tradição da) fé que a assume. Todavia, a fé transmitida pela tradição Eclesial não pode estar em contradição com sua referência escrita, que é a Bíblia"420.

Essa ênfase sobre a preeminência das Escrituras é acentuada por Lutero porque, para ele, é da autoridade de Cristo que depende a autoridade das Escrituras. Para Lutero, “a Bíblia é a Palavra de Deus porque nela chega Jesus Cristo até nós. Quem lê a Bíblia e não encontra nela Jesus Cristo, não tem lido a Palavra de Deus" ${ }^{\prime 21}$. Nessa perspectiva, em suas 95 teses ele questiona algumas vezes o valor que a igreja estava dando à Palavra em detrimento de outros aspectos secundários.

\footnotetext{
415 VOUGA, François. Protestantismo e Bíblia. In: LONGTON, Joseph; POSWICK, RéginaldFerdinand [et al.] (orgs.). Dicionário Enciclopédico da Bíblia, p. 1102.

${ }^{416}$ ROCHA, Alessandro Rodrigues. Entre a solidão, a solitude e a solidariedade. Leituras no contexto brasileiro. In: Proença, Eduardo (org.). Bíblias e outros ensaios. Theologando Revista Teológica. Ano V, n. 5. São Paulo: Fonte Editorial, 2011, p. 32.

${ }^{417}$ KUNZ, Claiton André. Martinho Lutero: vida, doutrina e contribuições. Revista Via Teológica, p. 14.

${ }^{418}$ FERREIRA, Franklin. Pilares da fé: atualidade da mensagem da Reforma, p. 53.

${ }^{419}$ Ibid.

${ }^{420}$ KONINGS, Johan. A Bíblia, sua origem e sua leitura: introdução ao estudo da Bíblia, p 154.

${ }^{421}$ GONZALEZ, Justo. Uma história ilustrada do cristianismo: a era dos reformadores. Vol 6. São Paulo: Vida Nova, 1995, p. 66.
} 
Na quinquagésima quarta tese, ele afirma, por exemplo, que "ofende-se a Palavra de Deus quando, em um sermão, é dedicado tanto tempo ou mais às indulgências do que a ela" ${ }^{" 422}$. Como decorrência dessa centralidade dada às Escrituras, todos os outros pilares da Reforma (cinco solas) são fundamentados a partir de sua teologia bíblica.

Os cinco solas $^{423}$ (Sola Fide, Sola Gratia, Solus Christus, Soli Deo Gloria e Sola Scriptura) representam os princípios básicos e essenciais da Reforma Protestante. A expressão latina sola significa "somente" em português. Eles resumem, por assim dizer, os credos teológicos fundamentais na teologia reformada. Entretanto, vale ressaltar que mesmo que os reformadores tenham escrito e pregado a partir desses referenciais, essas cinco afirmações "só foram articuladas sistematicamente em meados do século $20 " 424$.

É por isso que, então, para Lutero e, posteriormente, para todos os protestantes, a Bíblia precisa ser traduzida e difundida entre todos. Logo, a difusão das Escrituras Sagradas ganha importância singular na missão cristã sob o viés protestante. Nesse sentido, um importante legado de Lutero é a sua tradução da Bíblia para a língua alemã. Após sua condenação em Worms, refugiado como cavaleiro George no castelo de Wartburg, e usando como base a Vulgata e o texto grego de Erasmo, Lutero iniciou a tradução do Novo Testamento ${ }^{425}$. A tradução do NT levou apenas algumas poucas semanas ${ }^{426}$. Posterioremente, Lutero traduziu também o Antigo Testamento, que levou cerca de 12 anos, justamente porque, reconhecendo suas dificuldades com a língua e a cultura hebraica, procurou conhecer melhor essas questões ${ }^{427}$.

Assim como em outros momentos, essa tradução ajudou a unir a língua alemã, que na época tinha vários dialetos, e se tornou um referencial para a evolução da moderna língua alemã. Nesse interím, o princípio de tradução utilizado por

\footnotetext{
${ }^{422}$ LUTERO, Martinho. Martinho Lutero: uma coletânea de escritos, p. 45.

${ }^{423}$ É importante lembrar que na Teologia Luterana a ênfase se concentra em somente três solas, a saber: Sola Fide, Sola Gratia e Sola Scriptura. Os outros dois são ressaltados principalmente na Teologia Reformada Calvinista.

${ }^{424}$ FERREIRA, Franklin. Pilares da fé: atualidade da mensagem da Reforma, p. 32.

${ }^{425}$ SMOLINSKY, Heribert. Os pressupostos da Reforma. In: KAUFMANN, Thomas et al (orgs.). História ecumênica da Igreja 2: da alta Idade Média até o início da Idade Moderna, pp. 265-266. ${ }^{426}$ STADELMANN, Luís. Lutero, tradutor da Bíblia. Persp. Teol., v. 17, n. 41 (1985), p. 89. Disponível em: http://www.faje.edu.br/periodicos/index.php/perspectiva/article/view/1938/2241. Acesso em 17 fev. 2018.

${ }^{427}$ Lutherbibel se tornou a tradução alemã da Bíblia produzida por Martinho Lutero, impressa pela primeira vez em 1534.
} 
Lutero em sua tradução da Bíblia merece destaque, afinal, como era comum naquela época, ele optou em não fazer uma tradução literal do texto sagrado. Para Lutero, as Escrituras deveriam soar do jeito que os alemães falavam ${ }^{428}$. Em certo momento, declarou que "traduzir adequadamente é exprimir o sentido de uma língua estrangeira em seu próprio idioma. Eu procuro traduzir como as pessoas falam no mercado. Ao traduzir Moisés, eu o torno tão alemão que ninguém suspeitaria que ele era um judeu" 429 .

Após sua publicação, a Bíblia de Lutero começou a se difundir. Vale ressaltar que a Bíblia de Lutero não era a primeira a ser publicada na língua alemã. Ela não é "inovadora" nesse sentido. Contudo, ela adquire um significado especial justamente porque a sua publicação em língua vernácula, sob uma tradução menos formal, representa um estímulo à leitura da Bíblia pelos cristãos leigos, sem a participação direta da igreja. Esse é o resultado substancial que a Bíblia de Lutero provoca. E assim a Bíblia caiu na mão do povo. O Novo Testamento, primeira parte concluída e publicada da Bíblia de Lutero, "custava o equivalente ao salário pago a uma pessoa simples por uma semana de trabalho [e] [...] vendeu cerca de 5.000 cópias nos primeiros dois meses e mais de 100 mil durante a vida de Lutero" ${ }^{430}$. Como se constata, um dos objetivos da Reforma começava a se cumprir: a ampla difusão da Palavra de Deus.

A grande força propulsora da Reforma Protestante, portanto, foi a Bíblia. Lutero mesmo dizia: "Não fiz nada. A Palavra fez tudo"431. Para os reformadores, se a Bíblia é a Palavra de Deus, escrita para a instrução e o encorajamento do povo de Deus, todo cristão tem o direito e o dever de lê-la e estudá-la. Certa vez, deixando em segundo plano tudo o que fez e escreveu, Lutero concluiu que a sua tradução da Bíblia foi a sua mais importante contribuição para o mundo. Para a difusão das Escrituras, não restam dúvidas de que essa afirmação tem todo o sentido.

Para além de Lutero e da própria Alemanha (ou melhor, dos territórios alemães que formavam a parte central do Sacro Império Romano-Germânico na época), onde tais fatos aconteceram, o movimento da Reforma se espalhou por outros

\footnotetext{
${ }^{428}$ Cf. TEIXEIRA, Paulo. Traduções da Bíblia: história, princípios e influência. In: ZIMMER, Rudi (Org.). Manual do Seminário de Ciências Bíblicas, p. 50.

${ }^{429}$ LUTERO apud MILLER, Stephen; HUBER, Robert. A Bíblia e sua história: o surgimento e o impacto da Bíblia, p. 165.

430 Ibid., p. 166.

${ }^{431}$ GEORGE, Timothy. Teologia dos reformadores, p. 55.
} 
lugares da Europa. De acordo com Lindberg ${ }^{432}$, a Suíça, por ser um território europeu com grande liberdade naquele tempo, se tornou uma terra fértil para a Reforma. Os cantões suíços tinham plena liberdade para escolher que religião abraçar. Por isso, três movimentos reformadores afloraram na Suíça. Nos cantões do Norte, de fala alemã, preponderou a Reforma de Zuínglio. No Sul, de fala francesa, Calvino prevaleceu e, espalhados por toda a Suíça, os anabatistas, considerados como reformadores radicais, se estabeleceram.

Zuínglio era contemporâneo de Lutero e, como ele, também era sacerdote. Em seus estudos, foi profundamente influenciado pelos escritos de Erasmo e pelo humanismo que estava em evidência naquela época. Por isso, aprendeu latim e grego, distinguindo-o dentre outros, inclusive de alguns sacerdotes que pouco conheciam as Escrituras. Para amenizar essa escassez de conhecimento bíblico ${ }^{433}$, Zuínglio criou um instituto para se estudar as Escrituras.

O programa deste instituto determinava que algumas vezes por semana uma parte da Bíblia devia ser tratada na língua de origem e comentada em conjunto, primeiramente para os clérigos da cidade, e em seguida esta parte da Bíblia era explicada, na forma de uma prática, ao povo. Interessante é o fato que também os leigos eram convidados a tomar parte ${ }^{434}$.

Como bem afirma George, "a Bíblia teve seu lugar no centro da reforma zuingliana" ${ }^{435}$. Entretanto, em sua ênfase bíblica, Zuínglio foi mais radical do que Lutero $^{436}$, forjando uma teologia bem anticatólica. Partindo do princípio de "que tudo o que não fosse encontrado explicitamente nas Escrituras devia ser rechaçado"437, ele condenou os votos monásticos, o celibato clerical, o caráter sacrificial da missa, a salvação pelas obras em defesa da justificação pela fé. Em 1525, eliminou imagens, relíquias e até mesmo órgãos nas igrejas.

Rejeitando a missa, Zuínglio desenvolveu um tipo de culto em alemão, onde a pregação das Escrituras tinha preeminência. De forma diferente para a época, ele deu início a um novo estilo de pregação. Deixando de lado a escolha de textos

\footnotetext{
${ }^{432}$ LINDBERG, Carter. As reformas na Europa. São Leopoldo: Sinodal, 2001, pp. 203-237.

${ }^{433}$ Smolinsky afirma que "um aspecto importante que se deplorava era a falta de conhecimento dos párocos, que não estava mais à altura das exigências dos leigos" (SMOLINSKY, Heribert. Os pressupostos da Reforma. In: KAUFMANN, Thomas et al (orgs.). História ecumênica da Igreja 2: da alta Idade Média até o início da Idade Moderna., p. 240).

${ }^{434}$ AUGUSTIJN, Cornelis. Os reformadores do século XVI e a Bíblia, p. 76.

${ }^{435}$ GEORGE, Timothy. Teologia dos reformadores, p. 126.

${ }^{436}$ Lutero e Zuínglio não concordaram um com o outro em alguns poucos aspectos doutrinários, como, por exemplo, sobre a Eucaristia.

${ }^{437}$ GONZALEZ, Justo. Uma história ilustrada do cristianismo: a era dos reformadores, p. 93.
} 
bíblicos das perícopes pré-selecionadas, o reformador suíço começou a pregar expositivamente toda a Escritura, a ponto de "nos primeiros doze anos de sua atividade em Zurique, ele expor todos os livros da Bíblia"438. Esse método será utilizado por Calvino e influenciará o estilo de pregação protestante até os dias de hoje. Ainda que pouco comentado, vale ressaltar que Zuínglio, junto a outras pessoas, também fez uma tradução da Bíblia. Trata-se da Bíblia de Zurique, que "é uma das traduções mais fiéis para o alemão"439.

Outro suíço de importância no período é Calvino, "um reformador da segunda geração" 440 . Calvino é estimado como um dos mais importantes sistematizadores da teologia reformada e "o mais prolífico expositor das Escrituras. [Ele] Dava mais ênfase à Escritura que à teologia e considerava esta fruto da interpretação correta daquela"441. Mesmo sendo um teólogo na prática, Calvino jamais estudou teologia nos moldes tradicionais. Deste modo, "seu encontro com a Bíblia, com a Patrística e com os textos de teologia do protestantismo emergente, não estava condicionado pela escolástica" ${ }^{442}$. No aspecto acadêmico, estudou jurisprudência e, como Zuínglio, conheceu o Humanismo e as doutrinas de Wycliffe, Huss e Lutero. Calvino, na verdade, sentia-se convocado para ser um estudioso e não tinha intenção de chegar a ser um dos líderes da Reforma. E foi justamente escrevendo que ele desenvolveu sua principal obra: As Institutas da Religião Cristã (1536), considerada a obra-prima da teologia sistemática do século XVI. Nessa obra,

A Bíblia é crucial, e Calvino enfatiza isso no primeiro livro das Institutas. Ele compara a Bíblia a óculos, alegando que precisamos usá-los porque somos míopes e temos uma consciência muito vaga e difusa de Deus. [...] [Diz também que] somos ignorantes, mas que a Bíblia vem a nós como nosso professor, para ser a regra do nosso pensar e falar acerca de Deus ${ }^{443}$.

Enquanto para Lutero a autoridade das Escrituras está firmada em Cristo, para Calvino, a Bíblia tem autoridade por causa de sua essência. Como um docu-

\footnotetext{
${ }^{438}$ AUGUSTIJN, Cornelis. Os reformadores do século XVI e a Bíblia, p. 78.

${ }^{439}$ DREHER, Martin Norberto. Bíblia: suas leituras e interpretações na História do Cristianismo, p. 56.

${ }^{440}$ SMOLINSKY, Heribert. Os pressupostos da Reforma. In: KAUFMANN, Thomas et al (orgs.). História ecumênica da Igreja 2: da alta Idade Média até o início da Idade Moderna., p. 339.

${ }^{441}$ GRUDEM, Wayne; COLLINS, John; SCHREINER, Thomas (orgs.). Origem, confiabilidade $e$ significado da Bíblia, p. 24.

442 DREHER, Martin Norberto. Op. cit., p. 68.

${ }^{443}$ FLUHRER, Gabriel. Firme fundamento: a inerrante Palavra de Deus em um mundo errante. Rio de Janeiro: Anno Domini, 2013, p. 30.
} 
mento fiel, a "Escritura é o meio que Deus, em sua Providência, escolheu para se fazer conhecer aos homens. Ele lhes revelou, por meio dela, todas as coisas necessárias para a sua salvação"444. Dessa forma, sem negar a importância da tradição — também citada constantemente por ele —, para Calvino, a preeminência das Escrituras está na causa de sua origem, isto é, no próprio Deus. Por isso, ela possui autoridade intrínseca em sua totalidade, e não somente a partir do evangelho ou de Cristo, como expressa Lutero. Antigo e Novo Testamentos constituem a vontade normativa de Deus para o ser humano e, por isso, ambos os testamentos constituem a ética e a hermenêutica calvinista ${ }^{445}$. Em Calvino, o "Sola Scriptura se torna o equivalente a tota Scriptura ${ }^{446 " . ~ T a l ~ a p e g o ~ a ̀ s ~ E s c r i t u r a s ~ o ~ l e v o u ~ a ~ e s-~}$ crever "comentários de todos os livros da Bíblia, com a exceção de 2 e 3João e Apocalipse" 447 , e resultou na pregação expositiva das Escrituras, fato que se destaca até os dias atuais.

Ainda há que se considerar a Reforma radical, realizada pelos anabatistas, que eram "mais críticos do que Lutero e Zuínglio" 448 . É difícil descrever as características e os personagens desse movimento, pois ele apresenta uma multiplicidade de costumes e práticas, sem uma organização unicamente estabelecida, como ocorreram nos outros movimentos. Como origem desse grupo, Cairns destaca que a "insistência de Zuínglio na Bíblia como fundamento da ação dos pregadores encorajou a formação de conceitos anabatistas baseados na Bíblia"449.

Sob essa ótica e entre vários representantes e pensamentos, os anabatistas, firmados na autoridade da Bíblia, se caracterizaram principalmente pela rejeição ao batismo infantil, pela adesão ao batismo de adultos crentes e pela exigência da separação entre igreja e Estado. Tal pensamento se fundamenta na compreensão de que "a igreja é uma comunidade voluntária e não uma sociedade dentro da qual nascemos" $" 450$.

\footnotetext{
${ }^{444}$ VOUGA, François. Protestantismo e Bíblia. In: LONGTON, Joseph; POSWICK, RéginaldFerdinand [et al.] (orgs.). Dicionário Enciclopédico da Bíblia, p. 1103.

${ }^{445}$ Cf. FERREIRA, Franklin. Pilares da fé: a atualidade da mensagem da Reforma, p. 49.

${ }^{446}$ VOUGA, François. Protestantismo e Bíblia. Loc. cit.

${ }^{447}$ CAIRNS, Earle Edwin. O cristianismo através dos séculos: uma história da igreja cristã, p. 283.

${ }^{448}$ MOELLER, Bernd. A grande divisão do movimento de Reforma. In: KAUFMANN, Thomas et al (orgs.). História ecumênica da Igreja 2: da alta Idade Média até o início da Idade Moderna., p. 293.

${ }^{449}$ CAIRNS, Earle Edwin. Op. cit., p. 274.

${ }^{450}$ GONZALEZ, Justo. Uma história ilustrada do cristianismo: a era dos reformadores, p. 98.
} 
Deste modo, eles também eram contra a Reforma de Zuínglio, Calvino e Lutero, pois achavam que em muitos aspectos representavam uma continuação da Igreja Católica. Alguns até os distinguem pela busca de uma "reforma da Reforma" ${ }^{" 451}$, tornando-os, assim, uma "alternativa a católicos e protestantes" ${ }^{\text {" }} 42$. Nessa perspectiva, como bem afirma Ferreira, vale atentar para o fato de que "a Reforma não dividiu apenas a antiga fé cristã na Europa Ocidental. Ela cedo também se dividiu" ${ }^{453}$.

A justaposição entre os reformadores radicais e os estatais se deu precisamente na proeminência que todos esses movimentos conferiram às Escrituras. Assim, "mesmo quando a fonte, a Sagrada Escritura, foi interpretada de forma diferente e até mesmo contraditória, ainda havia uma conexão forte com ela" ${ }^{\$ 454}$. Para eles, portanto, a Bíblia era a única fonte de autoridade para o cristão. Ressalva-se, somente, o fato de que entre os reformadores radicais havia uma "tendência natural à interpretação literal da Bíblia" ${ }^{\text {455 }}$.

Em certos momentos, essa concepção provocou sérios problemas na relação entre eles, na relação com os demais reformadores, com os católicos e com as autoridades civis. Como consequência, os anabatistas foram perseguidos e considerados como revolucionários ou "reformadores anárquicos" ${ }^{456}$, tanto por protestantes quanto por católicos. Apesar disso, se espalharam pela Europa, em países como Suíça, Alemanha, Áustria, Holanda etc. Um legado desse movimento foi o surgimento dos irmãos morávios, que, bem mais tarde, foram responsáveis por enviar muitos missionários pelo mundo. Walker destaca esse aspecto ao afirmar que

As intenções moravianas de irem a qualquer lugar servindo a Cristo logo deram nobre impulso missionário ao movimento e o qual ele jamais perdeu. Até hoje organização alguma protestante tem estado tão alerta à obra missionária, e nenhuma é tão consagrada a ela em proporção ao seu número ${ }^{457}$.

\footnotetext{
${ }^{451}$ GEORGE, Timothy. Teologia dos reformadores, p. 254.

452 DREHER, Martin Norberto. Bíblia: suas leituras e interpretações na História do Cristianismo, p. 59.

${ }^{453}$ FERREIRA, Franklin. Pilares da fé: a atualidade da mensagem da Reforma, p. 25.

${ }^{454}$ LORTZ, Joseph. Historia de La Iglesia: en la perspectiva de la historia del pensamiento. Edad moderna y contemporanea. Vol. II, p. 129 (tradução nossa).

455 CAIRNS, Earle Edwin. O cristianismo através dos séculos: uma história da igreja cristã, p. 277.

${ }^{456}$ DREHER, Martin Norberto. Op. cit., p. 60.

${ }^{457}$ WALKER, Williston. História da Igreja Cristã. Vol I e II, p. 199 (Vol. II).
} 
Entre os anabatistas, um grupo que resistiu foram os menonitas, que derivam seu nome de Menno Simons (1496-1561) seu líder e fundador. Aliás, para George, Menno Simons foi o líder mais importante e o mais bíblico do ramo anabatista, marcado "pela quantidade absoluta de citações, referências e alusões à Bíblia" ${ }^{458}$. Mais tarde eles deram origem a dois movimentos dissidentes: os amitas (ou amish), de Jacob Amman, e os huteristas, de Jacob Hutter.

No contexto inglês, dois fatos marcaram esse período. Em primeiro lugar, não há como falar da difusão das Escrituras no período da Reforma sem fazer referência a William Tyndale, um sacerdote inglês que tinha anseio de traduzir as Escrituras para a sua língua. Para cumprir esse desejo, Tyndale enfrentou muitas dificuldades. Mesmo pedindo autorização ao bispo para realizar sua tradução, teve seu pedido negado, visto que o momento não era propício: a Reforma estava em plena ascensão pela Europa.

Usando o texto de Erasmo e fora dos domínios da Inglaterra, por medo de ser morto, Tyndale concluiu a sua tradução do Novo Testamento. Mesmo sob muitas dificuldades e perseguições, fez com que "6.000 cópias fossem contrabandeadas para a Inglaterra em barris de farinha e em peças de tecido"459. Porém, quando descobertas, as Escrituras foram queimadas. Tyndale morreu com idade próxima aos 40 anos, condenado como herege por ter traduzido a Bíblia e pensar como Lutero. Após a sua morte, Bíblias que tinham sido traduzidas, por sua influência ou até mesmo com sua participação, foram distribuídas por toda a Inglaterra, tanto para o povo como para as paróquias, com a aprovação do rei.

Ainda no contexto da Inglaterra, historicamente, se sabe que a Reforma Inglesa ocorreu por motivos diferentes dos outros movimentos reformadores, tendo como moto principal um aspecto específico. O Rei Henrique VIII não estava satisfeito no seu casamento com Catarina de Aragão, visto que ela, já em idade avançada, não havia dado a ele herdeiros varões. Como consequência de tal fato, o rei Henrique VIII, quis divorciar-se para se casar com Ana Bolena, sua amante. O papa, contudo, não quis conceder ao rei a satisfação de seu desejo. O casamento, portanto, não seria legitimado pela igreja. Por causa deste incidente (entre outros), Henrique VIII reduziu o clero da Inglaterra à sua submissão e rompeu com Ro-

\footnotetext{
${ }^{458}$ GEORGE, Timothy. Teologia dos reformadores, p. 254.

${ }^{459}$ MILLER, Stephen; HUBER, Robert. A Bíblia e sua história: o surgimento e o impacto da Bíblia, p. 170.
} 
$\mathrm{ma}^{460}$. O assunto do divórcio foi discutido e, devido à pressão do rei, o divórcio foi permitido pela igreja inglesa. Doutrinariamente, portanto, a Igreja Anglicana permaneceu bem próxima à Igreja Católica e, por isso, as divergências em relação às doutrinas bíblicas não tiveram proeminência neste contexto reformador.

Contudo, uma ressalva se faz necessária. Por meio da expansão dos povos de língua inglesa pelo mundo, atrelada à visão missionária de alguns movimentos oriundos da igreja inglesa, como o puritanismo, por exemplo, mesmo que indiretamente, a Reforma inglesa exercerá certa influência em vários lugares. Também será a partir da Inglaterra que algumas sociedades missionárias surgirão com o objetivo de difundir as Escrituras em várias regiões.

\subsection{4}

\section{A difusão das Escrituras Sagradas pós-reforma}

Nos primeiros anos subsequentes à afixação das 95 teses de Lutero na Catedral de Wittemberg, ato que marcou a origem propriamente dita da Reforma Protestante, tanto a mensagem e a teologia da Reforma como novas traduções da Bíblia se difundiram significativamente, desencadeando novas publicações das Escrituras tanto no original quanto nas línguas vernáculas. É importante destacar que essa realidade não tem sua origem única e exclusivamente na Reforma. Já “durante o século XV, a Bíblia desfrutava de uma grande difusão"461. A invenção da imprensa, e a sua consequente propagação, já haviam contribuido com o surgimento de muitas edições da Bíblia, tanto em latim quanto em línguas vernáculas. Por outro lado, é claro que a Reforma contribuiu dando um impulso também significativo. Smolinsky ressalta, por exemplo, que "a tradução da Bíblia constituiu um elemento importante na venda de livros" naquela época. O autor ainda destaca que, entre outros, tal realidade "transformou a Bíblia no eminente livro da Reforma"462.

George, acrescenta, nessa mesma perspectiva, que a partir da Reforma houve uma "ampla distribuição da Bíblia na Europa" ${ }^{463}$. Miller e Hubber ${ }^{464}$ apresen-

\footnotetext{
${ }^{460}$ Cf. GONZALEZ, Justo. Uma história ilustrada do cristianismo: a era dos reformadores, pp. $124-128$

${ }^{461}$ LORTZ, Joseph. Historia de La Iglesia: en la perspectiva de la historia del pensamiento. Edad moderna y contemporanea. Vol. II, p. 42 (tradução nossa).

${ }^{462}$ Ibid., p. 279

${ }^{463}$ GEORGE, Timothy. Teologia dos reformadores, p. 81.
} 
tam algumas dessas edições em suas respectivas línguas: holandês (1526), inglês (Coverdale, 1535; Matthew, 1537; Grande Bíblia, 1539; a Bíblia dos bispos, 1568), dinamarquês (1550), sueco (1541), islandês (1584), polonês (1563), sérvio/croata (1562), esloveno (1584), húngaro (1541), português (1681/1748), italiano (1607), francês (1523), antuérpio (1530), espanhol (1569), dentre outras. No período, Bíblias poliglotas também foram produzidas, tais quais: Poliglota de Antuérpia (1572), Paris (1629) e Londres (1654).

Como se percebe, a difusão das Escrituras cresceu e se desenvolveu expressivamente. Entre outros, esse é um legado significativo da Reforma para a igreja cristã, pois muitas dessas Bíblias também foram produzidas no ambiente católico. Mais um mito cai. A Igreja Católica não era contrária a Bíblia, como pensam alguns protestantes. Historicamente, não existem dúvidas que ela também contribuiu com a difusão das Escrituras Sagradas. De fato, naquele contexto específico, o que a Igreja Católica expressou foi uma recomedação sobre o cuidado que se deveria ter em relação a leitura e a tradução das Escrrituras, como se pode perceber em um dos trechos do decreto tridentino confirmado pelo papa Pio IV na Constiutição Domici gregis custodis (1564):

Já que a experiência mostra que, se se permite a sagrada Bíblia em língua vulgar em todo lugar indiscriminadamente, dái surge mais dano que utilidade, por causa da temeridade dos homens, compete, neste ponto, ao juízo do bispo ou do inquisidor, com o conselho do pároco, conceder a leitura dos livros bíblicos traduzidos em língua vernácula por autores católicos àqueles que, segundo sua percepção, possam de tal leitura receber não dano, mas aumento de fé e de piedade. ${ }^{465}$

Trata-se de um cuidado pertinente, afinal, como se tem constatado, muitas heresias e distorções doutrinárias tem sua origem (principalmente no seio protestante) justamente na leitura equivocada da Bíblia, realizada por homens "temerários" que não conseguem desenvolver um exame adequado das Escrituras, firmado nos critérios corretos da interpretação bíblica. Como bem se afirma na citação acima, a difusão das Escrituras deve gerar, entre outros, o aumento de fé e piedade naquele que a lê; não a sua perdição.

Para além destes aspectos, entretanto, o anseio pelas Escrituras, imbricado pela propagação instigada na Reforma, fez com que novas técnicas de produção

${ }^{464}$ Cf. MILLER, Stephen; HUBER, Robert. A Bíblia e sua história: o surgimento e o impacto da Bíblia, pp. 168-173.

${ }^{465}$ DENZIGER, Heinrich; HÜNERMANN, Peter. Compêndio dos símbolos, definições e declarações de fé e moral. São Paulo: Loyola/Paulinas, 2007, n. 1854 (grifo nosso) 
surgissem e fortalecessem a difusão da Palavra de Deus. Por um tempo, as Bíblias não eram de fácil leitura por causa da monotonia dos blocos de textos impressos, sem divisão, com sequência ininterrupta (estilo scriptio continua), sob uma escrita gótica carregada. Com a intensa propagação das Escrituras, isso mudou. Depois de, na Idade Média, terem sido introduzidos capítulos pelo Cardeal Stephen Langton, como já visto, Sante Pagnini di Luca e Robert d'Estienne, respectivamente, introduziram versículos no Antigo e no Novo Testamento ${ }^{466}$. Com o passar do tempo foram introduzidos, também, cabeçalhos em cada página, indicação do livro bíblico, divisão entre AT e NT e também entre os livros ${ }^{467}$. As letras escuras e pesadas foram substituídas por um estilo mais leve e legível; a letra romana se tornou o padrão ${ }^{468}$. A Bíblia, portanto, com o passar do tempo se tornou agradável e fácil para ler. Como consequência, se difundiu pelo mundo.

É também nesse período que surgiram duas Bíblias que marcaram a história do protestantismo em sua ênfase na difusão das Escrituras: a Bíblia de Genebra, publicada de forma completa em 1576 (com os deuterocanônicos), e a Bíblia King James, publicada em $1611^{469}$. Até hoje essas Bíblias são utilizadas no mundo inteiro por muitas igrejas protestantes; a Bíblia de Genebra por seus comentários e notas teológicas, e a King James por ser a clássica Bíblia da língua inglesa.

\subsection{5 \\ A difusão das Escrituras Sagradas a partir do princípio reformado Sola Scriptura}

Como já se constatou, o Sola Scriptura constitui um dos princípios fundamentais da Reforma Protestante ${ }^{470}$. Como tal, este pressuposto “está associado intimamente a uma estratégia para a difusão da Reforma em toda a Europa"471. Segundo esse princípio, as Sagradas Escrituras não necessitam de elementos interpretativos alheios que estejam nivelados às Escrituras. De fato, "o princípio da

\footnotetext{
${ }^{466}$ Cf. FERNANDES, Leonardo Agostini. A Bíblia e sua mensagem: introdução à leitura e ao estudo da Bíblia, p. 47.

${ }^{467}$ Cf. GEISLER, Norman; NIX, William. Introdução bíblica: como a Bíblia chegou até nós, p. 9.

${ }^{468}$ Cf. MILLER, Stephen; HUBER, Robert. A Bíblia e sua história: o surgimento e o impacto da Bíblia, pp. 172-173.

${ }^{469}$ Cf. TEIXEIRA, Paulo. Traduções da Bíblia: história, princípios e influência. In: ZIMMER, Rudi (Org.). Manual do Seminário de Ciências Bíblicas, pp. 51-54.

${ }^{470}$ Cf. FERREIRA, Franklin. Pilares da fé: a atualidade da mensagem da Reforma, p. 43.

${ }^{471}$ FLUHRER, Gabriel. Firme fundamento: a inerrante Palavra de Deus em um mundo errante, p. 121.
} 
Sola Scriptura não significava apenas a rejeição de toda regra de fé e de interpretação exterior à Escritura. Implicava a possibilidade para a Escritura revelar por si mesma o seu significado" 472 .

Assim, Martinho Lutero, Ulrico Zuínglio, João Calvino, entre outros, afirmaram o princípio da autoridade suprema das Escrituras em matéria de fé, prática e doutrina. Tal princípio, entretanto, não deve ser compreendido como nuda Scriptura (Escritura desacompanhada). Esse princípio, com certa influência no meio protestante fundamentalista, descarta os credos, as confissões etc. Como há de se imaginar, não é o melhor caminho, pois sob esse pressuposto abre-se uma brecha perigosa em que "cada pessoa ou comunidade passa a ser livre para interpretar a Bíblia sem referência ao passado cristão"473. Daí surgem muitas vezes "o individualismo, o subjetivismo e o caos teológico" 474 .

A compreensão do princípio do Sola Scriptura intencionada pelos reformadores, em maior ou menor intensidade, pode ser apreendida pela forma como esse tema influenciou a fé cristã protestante. Além do desenvolvimento de uma "atividade altamente desenvolvida no campo da teologia bíblica" ${ }^{\natural 75}$, com o passar do tempo, a vida das comunidades passou a girar em torno das Escrituras, da sua mensagem e da sua difusão. A própria arquitetura dos templos passou a refletir as novas convicções, como, por exemplo, a decoração, o destaque dado ao púlpito e à mesa da comunhão. $\mathrm{O}$ foco central do culto passou a ser a pregação expositiva da Bíblia, e os pastores começaram a ser reconhecidos como "ministros da palavra". Assim, na igreja reformada, "no centro ótico encontra-se o púlpito e em cima a Bíblia aberta, usada pelo "pregador" ou "servo da palavra" — em todas as línguas a denominação do clérigo - que distribui a Palavra de Deus, portanto, lê e explica" ${ }^{476}$.

A Bíblia estava no centro da identidade e da autocompreensão da Reforma Protestante. Enquanto muitos outros fatores se combinaram para tornar a Reforma possível, acima de tudo era a crença dos reformadores em voltar à autoridade da Bíblia que definiu o movimento ${ }^{477}$. As Escrituras influenciaram significativamente

\footnotetext{
${ }^{472}$ MANNUCCI, Valério. Bíblia, Palavra de Deus: curso de introdução à Sagrada Escritura, p. 316.

${ }^{473}$ FERREIRA, Franklin. Pilares da fé: a atualidade da mensagem da Reforma, p. 67.

${ }^{474}$ Ibid.

${ }^{475}$ HÄGGLUND, Bengt. História da teologia, p. 232.

${ }^{476}$ AUGUSTIJN, Cornelis. Os reformadores do século XVI e a Bíblia, p. 74.

${ }^{477}$ Cf. GEORGE, Timothy. Teologia dos reformadores, p. 312.
} 
todos os aspectos do universo protestante: a teologia, a liturgia, os paramentos, a pregação, a hinódia, a devoção pessoal e familiar, a vida intelectual, a literatura e a arte, bem como as concepções éticas, políticas e sociais ${ }^{478}$. Tudo deveria estar em harmonia com as Escrituras.

Nos países marcados pela Reforma, o próprio idioma absorveu um grande número de palavras e expressões bíblicas. Nesse ínterim, "a reforma ajudou a criar um interesse pela educação elementar porque, já que se podia interpretar a Bíblia livremente, era necessário algum conhecimento" ${ }^{479}$. Desde então, o princípio reformado de que ao lado de uma igreja deveria ter uma escola se tornou conhecido e se firmou como um pressuposto básico para as missões protestantes. O Brasil é um exemplo dessa realidade. Os primeiros missionários protestantes que vieram ao país realizaram trabalhos de pregação, distribuição de Bíblias e, concomitantemente, abriam escolas.

Como já se afirmou, mas vale ressaltar, tal ênfase protestante não deve desconsiderar que os católicos também contribuíram significativamente, preservando manuscritos, realizando traduções etc. Como bem afirma Gonzalez, nesse período conturbado do séxulo XVI, "tanto entre os protestantes como entre os católicos houve gigantes" ${ }^{480}$ que sustentaram a fé cristã. Outra área da vida das igrejas protestantes que teve profunda conexão com as Escrituras foi o esforço missionário. Desde os primeiros contatos com os povos não cristãos, os protestantes se preocuparam em traduzir a Bíblia para as línguas nativas, fator este que culminou, mais tarde, no surgimento de Sociedades Bíblicas.

\section{2}

\section{A difusão das Escrituras Sagradas e a Contrarreforma Católica}

Engana-se quem pensa que a Reforma se limitou aos protestantes. Por parte da Igreja Católica, também surgiram significativas reações que fortaleceram a Igreja e renovaram o ardor da fé. Passadas as circunstâncias que inflamaram a Europa por meio das ações dos reformadores, a fé reformada começou a se espalhar por muitos lugares. Os reformados, por meio de sua pregação, avançaram por

\footnotetext{
${ }^{478}$ Cf. AUGUSTIJN, Cornelis. Os reformadores do século XVI e a Bíblia, pp. 78, 81.

479 CAIRNS, Earle Edwin. O cristianismo através dos séculos: uma história da igreja cristã, p. 327.

${ }^{480}$ GONZALEZ, Justo. Uma história ilustrada do cristianismo: a era dos reformadores, p. 217.
} 
boa parte do continente. Sob a ótica católica, algo precisava ser feito. E esse algo aconteceu por um movimento de reação desenvolvido pela Igreja: foi a Contrarreforma Católica.

Como já se constatou, há algum tempo, setores da Igreja já se manifestavam pedindo reformas. Jedin ${ }^{481}$ contribui com uma distinção importante sobre esse aspecto. $\mathrm{O}$ autor lembra que ocorreram mudanças renovadoras na Igreja Católica no século XVI que, em si, não tem relação direta com a Reforma Protestante. Elas surgiram como resultado de uma reflexão anterior, independente do protestantismo. Entre elas, pode-se destacar o surgimento da Bíblia Complutense, em 1517, e a fundação de ordens religiosas que, por meio de seus respectivos trabalhos, ajudaram a renovar a Igreja. Algumas serão melhor analisadas mais à frente. Por outro lado, Jedin não desconsidera que outras mudanças são uma reação ao protestantismo, como se percebe em alguns decretos tridentinos e no Índice de Livros Proibidos. Portanto, como fruto de um desenrolar histórico, o tempo de avaliação, reflexão e renovação se aprofundou, fazendo com que Paulo III convocasse mais um Concílio da Igreja.

A importância desse Concílio não tem precedentes, tanto para a vida da Igreja quanto para sua doutrina: para a vida, porque salvou a Igreja da ruína completa que a ameaçava, tanto interna quanto externamente; para a doutrina, porque recolheu, esmiuçou e avaliou o imenso material que fora acumulado através dos séculos, desencadeando assim o renascimento pós-tridentino ${ }^{482}$

O Concílio foi realizado em Trento, na Itália, tendo como início de trabalho o mês de dezembro de 1545 e como término o mesmo mês do ano de 1563 . Por meio de 25 sessões, foram 18 anos de intensa atividade e reflexão teológica, os quais contribuíram significativamente para que a Igreja Católica retomasse o rumo após a ruptura provocada pela Reforma Protestante. Há de se considerar, inicialmente, que "o Concílio de Trento, em sua ideia original, deveria ter sido mais um concílio para superar a divisão da Cristandade ocidental. [Porém] O mais tardar após 1555 ele havia se tornado definitivamente uma instância separada de resposta apologética à reforma"483.

\footnotetext{
${ }^{481}$ Cf. JEDIN, Hubert. A History of the Council of Trent. Vol. 1. St. Louis: B. Herder book co., 1957, passim.

${ }^{482}$ MONDIN, Battista. Os grandes teólogos do século vinte, p. 400.

${ }^{483}$ HOLZEM, Andreas. Bases européias para uma confessionalização católica. In: KAUFMANN, Thomas et al (orgs.). História ecumênica da Igreja 2: da alta Idade Média até o início da Idade Moderna, p. 375.
} 
Nessa perspectiva, o Concílio "confirmou muitas das antigas crenças e práticas da Igreja Católica e condenou as doutrinas protestantes que se opunham à visão católica" ${ }^{484}$. O Credo Niceno foi reafirmado. Os sete sacramentos foram confirmados, em contraposição à afirmação protestante de que somente o Batismo e a Ceia constituíam os sacramentos. A presença real de Cristo na Eucaristia foi ressaltada ${ }^{485}$ e outros ensinos da doutrina católica foram discutidos e confirmados. As indulgências, por exemplo, que tinham sido a causa da fixação das teses de Lutero em Wittemberg, foram validadas, com a ressalva de que fossem praticadas com moderação e sem a necessidade de pagamento para obtê-las.

A Contrarreforma Católica, portanto, se caracterizou de duas formas. Primeiramente, buscou a renovação interna na vida eclesial e, por outro lado, estabeleceu uma reação externa, a fim de segurar o avanço do protestantismo. Gonzalez, nesse sentido, resume que a Contrarreforma tinha por objetivo "reformar a vida e os costumes eclesiásticos, utilizar a melhor erudição possível para purificar a fé e fomentar a piedade pessoal" 486 .

O trabalho missionário realizado pelas ordens religiosas, que ajudaram a desacelerar o crescimento do protestantismo, também contribuiu com a renovação da fé católica. A pregação, o ensino e o trabalho social desenvolvido por aqueles que pertenciam a essas ordens resultou em um novo respeito da sociedade pela Igreja Católica. O surgimento destas novas ordens religiosas remonta até uma iniciativa reformista anterior que teve foco na Espanha, onde, inclusive, "a Bíblia recebeu papel de destaque" ${ }^{487}$. Além das Escrituras, essa iniciativa católica, também valorizou a teologia, a mística e a devoção. Assim, harmonizando a iniciativa espanhola anterior com o momento incitado na Reforma Protestante, foi instigado o trabalho missionário da Companhia de Jesus, fundada por Inácio de Loyola. Entre outros, este é um efeito que pode ser percebido como uma das importantes contribuições do Concílio para o renovo da fé católica.

As ordens religiosas exerceram grande influência na evangelização e na expansão da fé católica pelo mundo. Devido ao trabalho missionário realizado por

${ }^{484}$ MILLER, Stephen; HUBER, Robert. A Bíblia e sua história: o surgimento e o impacto da Bíblia, p. 174.

485 Cf. HOLZEM, Andreas. Bases européias para uma confessionalização católica. In: KAUFMANN, Thomas et al (orgs.). História ecumênica da Igreja 2: da alta Idade Média até o início da Idade Moderna, pp. 375-389.

${ }^{486}$ GONZALEZ, Justo. Uma história ilustrada do cristianismo: a era dos reformadores, p. 183.

${ }^{487}$ DREHER, Martin Norberto. Bíblia: suas leituras e interpretações na História do Cristianismo, p. 72. 
elas no Oriente e nas Américas, o século XVI ficou reconhecido como "o século das missões católico-romanas" ${ }^{488}$. Os jesuítas levaram a fé católica à América Latina (inclusive ao Brasil, como se constatará mais a frente), ao Quebec, ao Sudeste da Ásia, e, por outro lado, reconquistaram regiões que já haviam sido conquistadas pelos protestantes, como, por exemplo, o sul da Holanda e a Polônia.

A Espanha, que já tinha iniciado uma reforma interna na Igreja, foi uma grande referência para a Contrarreforma. Procurando solidificar o Estado espanhol e, ao mesmo tempo, banir muçulmanos, judeus ou falsos convertidos, a reforma em terras espanholas se caracterizou por uma reação incisiva em repressão aos hereges, entre os quais os protestantes, chamados no país de "luteranos, título que davam a toda pessoa que tomasse posições remotamente parecidas com as de Lutero" 489 .

A ação ocorria por meio de dois instrumentos: a Inquisição e o Index Librorum Prohibitorum (Índice dos Livros Proibidos). Esta última é a que mais interessa nesta pesquisa. A imprensa tinha se firmado e espalhado por muitas cidades e, assim, Bíblias e livros com a mensagem da Reforma Protestante estavam se propagando. Com isso, o Índex serviu como tática para refrear essa difusão, com base em "uma lista de livros que os fiéis não poderiam ler"490. Na Espanha, "a Inquisição perseguiu os possuidores, impressores ou importadores de Bíblias não aprovadas pela Igreja Católica"491. Quem ousasse desobedecer a restrição era condenado à morte ou tinha seus bens confiscados ${ }^{492}$. O Índex foi abolido somente em 1966.

Assim como a Reforma Protestante evidenciou alguns personagens, a Contrarreforma Católica também foi marcada por seus nomes de referência. Inácio de Loyola dedicou-se intensamente ao serviço da Igreja e sua missão; Roberto de Nobili (1577-1656) depois de estudar e imergir na cultura indiana, ajudou a difundir a Igreja Católica naquele país; Roberto Bellarmino (1542-1621) foi o principal teólogo que desenvolveu os argumentos contra o protestantismo; Fran-

\footnotetext{
${ }^{488}$ CAIRNS, Earle Edwin. $O$ cristianismo através dos séculos: uma história da igreja cristã, p. 282.

${ }^{489}$ GONZALEZ, Justo. Uma história ilustrada do cristianismo: a era dos reformadores, p. 203.

${ }^{490}$ CAIRNS, Earle Edwin. Op. cit., p. 319.

${ }^{491}$ GIRALDI, Luiz Antonio. A Bíblia no Brasil Império: como um livro proibido durante o Brasil colônia tronou-se uma das obras mais lidas nos tempos do Império. Barueri: Sociedade Bíblica do Brasil, 2012, p. 45.

${ }^{492}$ ALVES, Herculano. A Bíblia de João Ferreira Annes d'Almeida. Coimbra: Sociedade Bíblica de Portugal; Barueri: Sociedade Bíblica do Brasil, 2006, p. 238.
} 
cisco Xavier (1506-1552) foi um dos mais importantes missionários jesuítas, alcançando o extremo Oriente (principalmente a Índia e o Japão) com seu trabalho missionário; e Matteo Ricci (1552-1610), que devido ao seu amplo conhecimento científico (geografia, matemática e astronomia), conquistou o respeito de vários sábios e oficiais chineses e, assim, conseguiu pregar sua mensagem ${ }^{493}$.

Entretanto, importa, de fato, perceber qual foi a resposta católica em relação às Escrituras e a sua difusão; afinal, não se deve esquecer que a Bíblia foi o cerne que fundamentou o movimento protestante. A Bíblia constituía, por assim dizer, o princípio formal que suscitou e fortaleceu a Reforma. Sobre o lugar da Bíblia no Concílio, Miller e Huber destacam que "decretos a respeito das Escrituras foram emitidos durante a quarta sessão, que ocorreu em 1546. Contrariando a doutrina de Lutero de que a fonte da verdade cristã só podia ser encontrada nas Escrituras, o Concílio reafirmou a validade da tradição no mesmo patamar"494.

O Concílio Tridentino foi, então, significativo para firmar a posição doutrinária da Igreja referente às Escrituras. Os Pais da Igreja foram lembrados e a tradição recebida desde os apóstolos foi reafirmada. Foi confirmado, também, o cânon bíblico da Vulgata ${ }^{495}$. Esse momento é significativo, visto que os debates que se estenderão nos próximos séculos sobre quais livros devem ser aceitos ou rejeitados no cânon constituirão um dos aspectos que afastarão ainda mais protestantes e católicos. Acrescenta-se, ainda, a essas divergências alguns elementos doutrinários "quanto à interpretação de determinadas passagens bíblicas"496.

Na relação entre Tradição e Escrituras, "concluiu-se que as tradições, como definidas por Trento [iniciadas com Cristo, passando pelos apóstolos e preservadas na história da Igreja], foram ditadas pelo Espírito Santo tal como o foram as Escrituras canônicas" ${ }^{497}$. Assim como a definição do cânon, esse tema também servirá de debate entre protestantes e católicos.

\footnotetext{
${ }^{493}$ Cf. CAIRNS, Earle Edwin. O cristianismo através dos séculos: uma história da igreja cristã, p. 315.

${ }^{494}$ MILLER, Stephen; HUBER, Robert. A Bíblia e sua história: o surgimento e o impacto da Bíblia, p. 174.

${ }^{495}$ CANNUYER, Christian; POSWICK, Réginald-Ferdinand. Catolicismo e Bíblia. In: LONGTON, Joseph; POSWICK, Réginald-Ferdinand [et al.] (orgs.). Dicionário Enciclopédico da Bíblia, p. 283.

${ }^{496}$ DREHER, Martin Norberto. Bíblia: suas leituras e interpretações na História do Cristianismo, p. 74.

${ }^{497}$ HÄGGLUND, Bengt. História da teologia, p. 246.
} 
Diante do surgimento de várias traduções bíblicas nas línguas vernáculas, em outro decreto, "a Vulgata latina foi declarada versão autêntica, isto é, dogmaticamente correta da doutrina da Igreja" 498 . Destarte, "sem proibir formalmente o recurso dos textos originais" 499 , a Vulgata ficou confirmada como o texto oficial da Igreja Católica para uso litúrgico, labor teológico, catequese e pregação. Contudo, o Concílio sugeriu que a tradução latina fosse revisada e reimpressa na versão mais exata possível. Essa revisão foi publicada no papado de Clemente VIII, em 1592, permanecendo como a versão oficial da Igreja até o Concílio Vaticano II $^{500}$.

Um problema que havia se constatado já há algum tempo, mas que durante a Reforma se ressaltou, era o despreparo de alguns clérigos em relação à Bíblia. É claro que não é possível generalizar tais afirmações, afinal, foi no próprio ambiente da Igreja que os reformadores (alguns deles, anteriormente sacerdotes católi$\cos$ ), receberam tal formação bíblica. Lutero, por exemplo, era professor de Bíblia no contexto da Igreja Católica. Contudo, alguns clérigos, de fato, não tinham o conhecimento necessário das Escrituras. Lortz, nesse sentido, faz uma análise sobre a conjuntura que levou, por exemplo, o humanismo a criticar o clero do período anterior à Reforma. Entre outros aspectos, ele ressalta que a formação bíblica e teológica do clero era muito rasa. Era quase que uma simples instrução ${ }^{501}$. Dessa forma, enquanto os principais personagens da Reforma estavam capacitados a discutir humanismo, teologia e Escrituras Sagradas, muitos clérigos não tinham respostas bíblicas aos questionamentos suscitados por Zuínglio, Lutero etc.

Nesse sentido, em 1546, na quinta sessão do Concílio, o papa "estabeleceu uma relação indissolúvel entre o estudo da teologia e o da Bíblia" ${ }^{\text {502 }}$. Os resultados dessa decisão refletiram, sem dúvida, na história. De fato, conforme acrescen-

\footnotetext{
${ }^{498}$ LORTZ, Joseph. Historia de La Iglesia: en la perspectiva de la historia del pensamiento. Edad moderna y contemporanea. Vol. II, p. 207

${ }^{499}$ CANNUYER, Christian; POSWICK, Réginald-Ferdinand. Catolicismo e Bíblia. In: LONGTON, Joseph; POSWICK, Réginald-Ferdinand [et al.] (orgs.). Dicionário Enciclopédico da Bíblia, p. 283.

${ }^{500}$ Após o Concílio Vaticano II, o papa Paulo VI instituiu uma comissão que se encarregou de revisar a Vulgata a fim de preparar uma edição que deveria ser utilizada pelos católicos, principalmente na liturgia. A revisão foi concluída em 1975. Assim surgiu a Nova Vulgata (Neovulgata), que foi promulgada pelo papa João Paulo II em 25 de abril de 1979, tornado-se, desta forma, a Bíblia oficial da Igreja Católica Apóstolica Romana. Cf. GARCÍA-MORENO, Antonio. Recensiones. Scripta Theologica. Vol. 19, no 1-2, 1987, pp. 457-459.

${ }^{501}$ Cf. LORTZ, Joseph. Historia de La Iglesia: en la perspectiva de la historia del pensamiento. Edad moderna y contemporanea. Vol. II, pp. 41-42.

${ }^{502}$ CANNUYER, Christian; POSWICK, Réginald-Ferdinand. Op. cit., p. 284.
} 
ta Lortz, "a nova formação, baseada em um cultivo intensivo da Bíblia e uma teologia extraída dela, trouxe para o povo e para os soberanos as teses dos reformadores sobre a fé, e mostrou-se que essa fraqueza era mortal"503.

Considerando a liberdade que a Reforma procurava dar em relação à interpretação da Bíblia, o Concílio reafirmou que a Igreja Católica Apostólica Romana era a única e legítima intérprete das Escrituras Sagradas, visto que, preservando a interpretação, a Igreja Católica poderia limitar interpretações equivocadas que poderiam ocorrer, prejudicando a fé dos leigos.

Sob uma ótica comparativa das duas posições em relação à temática, é possível perceber alguns aspectos. A liberdade interpretativa oriunda da Reforma Protestante é, por um lado, positiva, pois estimula o estudo e o aprofundamento da mensagem bíblica, mas, por outro, abriu negativamente uma porta muito grande para interpretações errôneas, carregadas de heresias e individualismos. A pluralidade de igrejas oriundas da Reforma é um exemplo desse perigo assumido pela igreja protestante.

A restrição interpretativa reafirmada em Trento pelos católicos é, por um lado, negativa, pois restringe o acesso e a leitura das Escrituras por parte do leigo. Por tal fato, o catolicismo ficou marcado por um certo distanciamento das Escrituras por um tempo. Por outro lado, de forma positiva, o catolicismo, bem diferente do protestantismo, conseguiu se manter mais unido tanto em comunhão quanto em doutrina. Essa restrição interpretativa das Escrituras pode ter contribuído para tal fato. Como se percebe, parece que cada lado tem suas justificativas e, por conseguinte, suas consequências.

\section{3 \\ A difusão das Escrituras Sagradas da modernidade à contemporaneidade}

Mesmo que com divergências e críticas entre os historiadores, por vezes surge a necessidade de se periodizar a história, para que, por meio de dados cronológicos, se torne mais fácil a apreensão dos fatos. Contudo, o que mais importa são os fatos em si, e não tanto a cronologia. Nesta seção, portanto, importa mais os fatos do que as datas. Isso não impede, porém, que esses fatos estejam situados

${ }^{503}$ LORTZ, Joseph. Historia de La Iglesia: en la perspectiva de la historia del pensamiento. Edad moderna y contemporanea. Vol. II, p. 42 (tradução nossa). 
em dois períodos históricos, as Idades Moderna e Contemporânea, em eventos ocorridos a partir da Reforma Protestante e da Contrarreforma Católica até os dias atuais.

Ressalta-se, mais uma vez, que não se pretende analisar toda a história da igreja e da teologia desse período. Tal tarefa seria praticamente impossível. Espera-se que, a partir do objeto de pesquisa, se possa simplesmente perceber como a difusão das Escrituras se deu nesse momento.

\subsection{1}

\section{O lugar das Escrituras Sagradas no período das Confissões de Fé}

Durante o período em que a Reforma protestante emergia por vários lugares da Europa, começaram a surgir, concomitantemente, as Confissões de Fé das igrejas protestantes nacionais que aos poucos estavam sendo estabelecidas. Histórica e teologicamente falando, poderia se dizer que existem pelo menos duas formas de leitura que sobressaem a respeito dessa questão.

A primeira se estabelece sob uma ótica positiva em relação aos documentos confessionais. Simões ${ }^{504}$, nesse sentido, destaca que estes documentos pretendiam, entre outros aspectos, resgatar e resguardar a tradição apostólica revelada nas Escrituras Sagradas. Nesse interím, as Confissões de Fé eram importantes dentro do propósito catequético, litúrgico, político e teológico de cada igreja. Tratava-se, portanto, de um propósito unificador e identidário das recém-criadas igrejas e nações protestantes. Por assim ser, as confissões expressavam o que elas criam sobre os mais diversos temas doutrinários de fé e, por outro lado, procuravam dirimir possíveis controvérsias surgidas frente aos mesmos aspectos. Sob essa ótica, as confissões representavam uma possível unidade na doutrina por meio da fidelidade às Escrituras de cada igreja protestante nacional.

Uma outra leitura, porém, é igualmente possível. E essa se estabelece sob um crivo mais crítico, afinal, o surgimento das mais variadas Confissões de Fé evidenciam o florescimento das divergências estabelecidas entre os próprios protestantes que, como se sabe, ao longo da história se tornaram cada vez mais expressivas. A igreja cristã tinha mantido uma certa unidade até o século XVI. Po-

\footnotetext{
${ }^{504}$ Cf. SIMÕES, Ulisses Horta. Eu creio: no Pai, no Filho e no Espírito Santo. São José dos Campos: Fiel, 2014, pp. 39-86.
} 
rém, no contexto imediato e posterior à Reforma, "o processo foi consumado quando a separação se consolidou e [se estendeu] com a sucessiva e aparentemente irremediável multiplicação das divisões (especialmente do século XVIII)"505. Tais fatos marcam a trajetória protestante desde então.

Por essa razão, mesmo tendo vários pontos de vistas em comum, como, por exemplo, a autoridade final da Bíblia como regra de fé e prática, algumas diferenças se sobressaíram, permitindo com que as diferenças superassem as semelhanças. Como consequência, cada movimento protestante (luterano, reformado, anabatista etc.) se isolou e procurou, a partir de sua livre interpretação da Bíblia, reforçar suas doutrinas, caracterizando, então, o período denominado de "ortodoxia". Como bem destacou Lortz, entre outros, este é um consistente "motivo da constante fragmentação do protestantismo em múltiplos movimentos" ${ }^{\text {"506. }}$.

Cada um criou a sua confissão, baseado num "sistema ortodoxo de doutrina para ser aceito intelectualmente" $" 507$. E assim, quando se findou a Reforma, a Europa estava "transformada numa região da terra profundamente dividida, esfacelada em espaços confessionais" 508 , evidenciando que não havia "uma unanimidade de leitura da Bíblia em todos eles" ${ }^{\text {509 }}$. É interessante notar que, para além das divergências entre as diferentes correntes reformadas, até mesmo dentro dos próprios grupos surgiram controvérsias ${ }^{510}$. Holzem e Kaufmann resumem com propriedade esse período, ao afirmar que

O protestantismo do início da era Moderna formou-se nos sistemas eclesiásticos confessionais, cada um dos quais reivindicando, de modo especial, ser a incorporação da autêntica verdade do cristianismo, tanto na doutrina como no modo de vida.

\footnotetext{
${ }^{505}$ LORTZ, Joseph. Historia de La Iglesia: en la perspectiva de la historia del pensamiento. Antiguedad y edad media. Vol. I, pp. 17-18

${ }^{506}$ Id. Historia de La Iglesia: en la perspectiva de la historia del pensamiento. Edad moderna y contemporanea. Vol. II, p. 156

${ }^{507}$ CAIRNS, Earle Edwin. O cristianismo através dos séculos: uma história da igreja cristã, p. 362.

${ }^{508}$ HOLZEM, Andreas; KAUFMANN, Thomas. "Confessionalização" e "culturas confessionais": o processo de formação das confissões. In: Id. et al (orgs.). História ecumênica da Igreja 2: da alta Idade Média até o início da Idade Moderna., p. 356.

${ }^{509}$ DREHER, Martin Norberto. Bíblia: suas leituras e interpretações na História do Cristianismo, p. 43.

${ }^{510}$ Cf. HÄGGLUND, Bengt. História da teologia, p. 233. Nessa obra, o autor destaca algumas controvérsias entre os luteranos, por exemplo. A Fórmula de Concórdia, mais tarde, ajudou a unilos.
} 
Negava-se às confissões concorrentes sua proximidade da verdade bíblica cristã com a mesma ênfase com que reivindicava essa proximidade para si próprio ${ }^{511}$.

Há de se considerar ainda que, pelo menos em parte deste mesmo período, ocorria, paralelamente ao mundo protestante, a Contrarreforma Católica, que oportunamente, diante da divergência confessional dos protestantes, interpretavaos "como prova evidente de seu caráter herético" 512 . Vale ressaltar que, historicamente, já havia na Igreja Católica uma confissão de fé que remonta ao século IV, isto é, o Credo Niceno-constantinopolitano ${ }^{513}$. Entretanto, como consequência do momento turbulento que a cristandade passava, na ocasião, os católicos formularam "a Confissão de Fé Tridentina, em 1546, a qual deveria ser professada por todo sacerdote católico-romano" ${ }^{\text {514 }}$. Tal Confissão, acrescentada ao Credo Niceno-constantinopolitano, procurou ressaltar as bases doutrinais da Igreja Católica em oposição aos ensinamentos propagados pelo protestantismo.

Se por um lado, o efeito desse processo de confessionalização, que segundo Holzem e Kaufmann ${ }^{515}$ se estendeu de 1555 a 1648, fortaleceu a fé e a identidade de muitas igrejas, por outro, evidenciou uma pluralidade de vida cristã e espiritualidade entre os diversos movimentos que culminou em significativas separações. Assim, "a confissão, a confessio, já não era um momento de comunhão, mas evocava drásticas necessidades de delimitação de culturas religiosas inteiras" ${ }^{\text {516 }}$. Deste modo, "os confessionalismos e as ortodoxias levaram a 30 anos de guerra" Foi um tempo de debates e massacres mútuos que só acabou em 1648.

Considerando que a Bíblia era o fundamento da fé protestante, não restam dúvidas de que ela foi usada para criar, defender e fortalecer as doutrinas confessionais. As Escrituras Sagradas, em vez de serem difundidas para a evangelização, edificação da igreja e comunhão entre os cristãos, passaram a segmentar os diferentes grupos e reforçar os seus respectivos dogmas. A confessionalização não se limitou ao âmbito eclesial; antes, ela avançou por várias áreas da vida e da socie-

${ }^{511}$ HOLZEM, Andreas; KAUFMANN, Thomas. Bases para confessionalização dos territórios alemães. In: KAUFMANN, Thomas et al (orgs.). História ecumênica da Igreja 2: da alta Idade Média até o início da Idade Moderna, pp. 404-405.

${ }^{512}$ Ibid., p. 404.

${ }^{513}$ Posteriormente, as igrejas da Reforma também aderiram ao Credo Niceno-constantinopolitano.

${ }^{514}$ DREHER, Martin Norberto. Bíblia: suas leituras e interpretações na História do Cristianismo, p. 74.

${ }^{515}$ Cf. HOLZEM, Andreas; KAUFMANN, Thomas. "Confessionalização" e "culturas confessionais": o processo de formação das confissões. In: KAUFMANN, Thomas et al (orgs.). História ecumênica da Igreja 2: da alta Idade Média até o início da Idade Moderna, p. 357.

${ }^{516}$ Ibid., p. 356.

${ }^{517}$ DREHER, Martin Norberto. Op. cit., p. 102. 
dade. "O conceito de "cultura confessional" sobressaiu, assim, pelo fato de que controvérsias doutrinais internas e externas, liturgias, confissões de fé e símbolos das confissões se enraizaram profundamente na vida social e política" ${ }^{\natural 18}$. Esse alcance confessional influenciou, posteriormente, até mesmo instituições políticas e sociais, no âmbito do Estado e da sociedade em que essas igrejas estavam inseridas. Deste modo, Estados nacionais constituíram igrejas nacionais e viceversa $^{519}$.

Diversas confissões foram criadas, mas entre elas podem-se destacar: Confissão de Augsburgo (1530), Confissão de Fé Francesa (1559), Confissão de Fé Escocesa (1560), Confissão de Fé Belga (1561), Catecismo de Heidelberg (1563), Segunda Confissão Helvética (1566), Fórmula de Concórdia (1577/1580), Os cânones de Dort (1618), Confissão de Fé Menonita de Dordrecht (1632), Confissão de Fé de Westminster (1646-1649) e a Confissão de Fé Batista (1689). Cada confissão apresentava a sua forma de interpretar a Bíblia, pressupondo ser "o detentor da unidade e da plenitude da verdade cristã, e afirmava que a outra parte perdera. Todo sistema teológico construído visava demonstrar o erro do outro"520.

Uma ressalva, entretanto, se faz necessária. Reafirmando o conceito nascido na Reforma, todas essas confissões apresentam, normalmente no início, uma clara afirmação da suficiência das Escrituras. Dessa forma, "as confissões Reformadas estão em total concordância quanto ao sola Scriptura ou ao princípio regulador da Escritura" ${ }^{21}$. Por isso, pelo menos sob a perspectiva do lugar das Escrituras na vida da igreja e na constituição do dogma, "essas declarações não se limitam de forma alguma aos anglicanos, presbiterianos ou congregacionais; ao contrário, todos os que fazem parte da corrente principal da tradição reformada teriam afirmado a suficiência das Escrituras"522.

Essa ênfase unânime às Escrituras nos diversos espaços confessionais pode, também, ser reflexo e uma contraposição da decisão católica que no Concílio de

\footnotetext{
${ }^{518}$ HOLZEM, Andreas; KAUFMANN, Thomas. "Confessionalização" e "culturas confessionais": o processo de formação das confissões. In: KAUFMANN, Thomas et al (orgs.). História ecumênica da Igreja 2: da alta Idade Média até o início da Idade Moderna., p. 357.

${ }^{519}$ Cf. DREHER, Martin Norberto. Bíblia: suas leituras e interpretações na História do Cristianismo, pp. 100-101.

${ }^{520}$ Ibid., p. 101.

${ }^{521}$ SCHERTLEY, Brian. Sola Scriptura e o princípio regulador do culto. São Paulo: Os Puritanos, 2001, p. 14.

${ }^{522}$ FLUHRER, Gabriel. Firme fundamento Firme fundamento: a inerrante Palavra de Deus em um mundo errante, p. 35
} 
Trento, em sua própria Confissão de Fé Tridentina, reiterava a importância da relação entre Tradição e Escritura como ambas representantes da revelação divina e em mesmo nível de igualdade.

Por outro lado, a elaboração dessas confissões evidencia que os protestantes também fundamentam sua crença em um certo tipo de tradição, se assim se pode dizer. Por mais que se ressalte a importância da Bíblia como única regra de fé, as confissões se tornaram documentos importantes na identidade das igrejas reformadas. Entretanto, há de se considerar que, ainda assim, a ênfase às Escrituras ficou evidenciada.

Os credos e confissões são perfeitamente coerentes com a crença de que só a Escritura é a nossa única fonte de revelação e autoridade. [...] Os credos e as confissões são, na verdade, necessários para o bem-estar da igreja, e que as igrejas que alegam não tê-los colocam-se em permanente desvantagem quando se trata de conservar o modelo das sãs palavras [...]. A necessidade dos credos [e das] confissões [não é] apenas um imperativo prático para a igreja, mas também um imperativo bíblico ${ }^{523}$.

Barth resume a posição protestante nessa relação entre tradição, dogmas e Escrituras da seguinte forma:

\begin{abstract}
A Sagrada Escritura e as Confissões de fé não estão em um plano idêntico. Reservamos à Bíblia uma estima e um amor que não temos, no mesmo grau, pela tradição, nem mesmo pelos mais valiosos de seus elementos. [...] Mas isso não retira nada do fato de que a Igreja escuta e aprecia o testemunho de seus Pais. [...] Diferentemente das Escrituras, as Confissões não têm autoridade que obrigue, mas devemos, todavia, levá-las seriamente em consideração e lhes atribuir uma autoridade relativa $^{524}$
\end{abstract}

Diante da pluralidade que o mundo evangélico se tornou, se faz necessário que as diferentes igrejas busquem na Bíblia e nessas confissões as bases de sua fé, evitando, assim, as confusões e os desvios teológicos que crescem a cada dia na esfera protestante, principalmente nos mais recentes movimentos denominados de neopentecostais e em algumas igrejas independentes. As Escrituras Sagradas precisam voltar a ter a proeminência nessas igrejas, antes que uma "nova Reforma" se faça necessária, se, de fato, já não se faz.

\footnotetext{
${ }^{523}$ TRUEMAN, Carl. O imperativo confessional. Brasília: Monergismo, 2012, p. 29.

${ }^{524}$ BARTH, Karl. Esboço de uma Dogmática. São Paulo: Fonte Editorial, 2006, p. 13. Cf. também BARTH, Karl. Credo: comentários ao Credo Apostólico: São Paulo: Fonte Editorial, 2010.
} 


\subsection{2 \\ O lugar das Escrituras Sagradas em tempos de Puritanismo, Pietismo lluminismo e Liberalismo teológico}

A Reforma tinha se espalhado, e as confissões prevaleciam em suas diversificadas interpretações. Esse era o panorama protestante entre os séculos XVI e XVIII. As reformas estatais na Suíça, na Alemanha, na Inglaterra e em vários outros países tinham conquistado seus espaços, e as confissões reforçavam ainda mais a fé protestante que se ampliava para várias esferas da sociedade. A ortodoxia das confissões, cada qual fundamentada em sua hermenêutica das Escrituras, se tornava, então, o alicerce da fé protestante.

Entretanto, para alguns, esse não era o melhor dos mundos, visto que, ao contrário do que pretendiam os reformadores, "a ortodoxia tornou-se sempre mais erudita, formalista e árida" ${ }^{925}$. Assim, começaram a surgir grupos que se posicionaram contra a ortodoxia rígida que as confissões tinham instigado. Para eles, a piedade, a devoção e a espiritualidade eram mais importantes que o rigor doutrinário. Era o início, como bem afirma Cairns, de um "reavivamentismo" 526 , que começou a tomar forma como uma reação à ortodoxia confessional. Mesmo que tendo seu começo nesse momento, esse movimento caracterizou toda a fé protestante de inúmeros grupos até os dias atuais.

Já no final do século XVI e início do século XVII, na Inglaterra, palco onde se desenvolveu a Reforma Anglicana, um grupo de inconformados se voltou contra a igreja, pois "julgavam-na uma instituição cuja vida não correspondia à Bíblia"527. Esse grupo ficou conhecido na história como "puritanos". Para eles, a Bíblia deveria constituir a norma exclusiva para vida em todas as áreas possíveis, tais quais família, profissão etc. Especificamente em relação à igreja, eles esperavam uma separação total do Estado e o abandono completo de elementos característicos do catolicismo que ainda estavam presentes no cotidiano da Igreja Anglicana. Nesse ínterim, fundamentados em seus ideiais, eles "queriam purificá-la de acordo com a Bíblia, aceita por eles como regra infalível de fé e prática" ${ }^{\natural 28}$.

\footnotetext{
${ }^{525}$ DREHER, Martin Norberto. Bíblia: suas leituras e interpretações na História do Cristianismo, p. 100.

${ }_{526}$ CAIRNS, Earle Edwin. O cristianismo através dos séculos: uma história da igreja cristã, p. 362.

${ }^{527}$ DREHER, Martin Norberto. Op. cit., p. 115.

${ }^{528}$ CAIRNS, Earle Edwin. Op. cit., p. 303.
} 
Logo, outra ênfase característica do puritanismo foi o despertamento para a leitura diária da Bíblia atrelada a uma vida de oração. Foi bem característico do movimento puritano, por exemplo, o "serviço religioso no lar, durante o qual o pai de família lia, de manhã e de noite, uma parte da Bíblia e a explicava para os membros da família"529. Tais práticas exerceram influência na ética e na moral de seus seguidores e influenciaram boa parte da forma como as igrejas evangélicas passaram a lidar com as Escrituras em todo o mundo, até os dias de hoje. Assim, de forma pragmática, eles tinham uma "aceitação simplória e irrefletida da palavra bíblica e de sua aplicação à vida" ${ }^{330}$. Para eles, as "especulações" teóricas e teológicas das confissões não tinham tanta importância assim. Mesmo sob essa posição desvinculativa da teologia, é interessante notar que será entre os puritanos que a doutrina da predestinação ganhará muita força e sustentação teológica.

Dessa forma, simples e pragmática, o puritanismo exerceu influência na difusão das Escrituras. Sua ética social era uma ética bíblica. As Escrituras os acompanhavam para onde quer que eles fossem, inclusive quando migraram para as colônias inglesas localizadas no novo mundo, na América do Norte, onde construíram suas vidas e edificaram suas famílias em um mundo alicerçado na Bíblia. Aliás, o puritanismo não alcançou todo o êxito que pretendia na igreja inglesa. Por outro lado, solidificou-se significativamente no modo de vida da América protestante. Mesmo fragmentado em vários grupos, "o puritanismo foi sempre origem de reavivamentos" ${ }^{\prime 531}$. Por isso, mesmo presente nas correntes batistas, congregacionais, metodistas e presbiterianas, o puritanismo, por meio da vida piedosa e da oração, exerceu influência também entre os pentecostais.

Enquanto na Inglaterra a ênfase puritana tentava avançar, na Alemanha outro movimento se destacou um pouco mais tarde. Esse movimento foi denominado de pietismo. Dreher resume com propriedade a história e a abrangência pietista quando diz:

Ele [o pietismo] surgiu no século XVII e explodiu no século XIX. Ele acentuou e acelerou a individualização e a interiorização da vida religiosa, desenvolvendo novas formas de piedade pessoal e de vida em sociedade. Além disso, provocou mudanças na Teologia e na Igreja. Não ficou restrito a um país ou a uma denomina-

\footnotetext{
${ }^{529}$ AUGUSTIJN, Cornelis. Os reformadores do século XVI e a Bíblia, p. 74.

${ }^{530}$ DREHER, Martin Norberto. Bíblia: suas leituras e interpretações na História do Cristianismo, p. 116.

${ }_{531}^{\text {Ibid., p. } 117 .}$
} 
ção. Talvez seja ele o primeiro movimento transconfessional, um movimento que perpassa todas as denominações ${ }^{532}$.

Assim como o puritanismo ${ }^{533}$, o pietismo, com maior ênfase, procurou superar a ortodoxia. Para os pietistas, as discussões teológicas ocorridas no processo de confessionalização e de constituição dos credos resultou em uma fé estéril, fria, hierárquica e pouco ética. Dessa forma, o pietismo se dirigiu "contra as formas dogmáticas e institucionais assumidas pelas tradições protestantes" ${ }^{534}$ pósReforma. Para eles, a "experiência religiosa pessoal constitui o ponto central"535 da fé cristã. Assim, a conversão individual de cada cristão é mais importante do que qualquer regra ou costume eclesial. Santificação pessoal, renúncia às "coisas do mundo" e esperança escatológica sobre o retorno de Cristo se tornaram mais importantes que qualquer sistematização teológica. Tratava-se de "uma oposição da vida com a doutrina" ${ }^{\circ 36}$. A base para tais crenças e comportamentos é, como não poderia deixar de ser, fundamentada por meio de uma "concentração sobre a Bíblia (não apenas 'somente a Escritura', mas, 'toda a Escritura')"537.

Em relação às Escrituras, portanto, os pietistas instigaram os cristãos a uma leitura diferente da Bíblia. Longe do predomínio confessional ortodoxo, “os pietistas passaram a ler a Bíblia como uma ata da vida da Igreja Antiga e não mais como um compêndio de doutrina". ${ }^{538}$ Para eles, principalmente a partir da leitura do Novo Testamento, a Bíblia tinha aplicação prática e imediata. Por isso, contra a “teologia 'escolástica' [referindo-se ao confessionalismo protestante], o pietismo tenta opor uma teologia bíblica"539. E foi nessa crítica ao formalismo confessional e contra a hierarquização da igreja, que para os pietistas continuava com resquícios do catolicismo, que o pietismo de certa forma instigou, mesmo que contraditoriamente, o pensamento iluminista.

\footnotetext{
${ }^{532}$ DREHER, Martin Norberto. Bíblia: suas leituras e interpretações na História do Cristianismo, p. 119.

${ }^{533}$ Schneider afirma que o pietismo luterano "remonta à linha de reavivamento do puritanismo inglês". SCHNEIDER, Hans. O pietismo. In: KAUFMANN, Thomas et al (orgs.). História ecumênica da Igreja 2: da alta Idade Média até o início da Idade Moderna., p. 526.

${ }^{534}$ VOUGA, François. Protestantismo e Bíblia. In: LONGTON, Joseph; POSWICK, RéginaldFerdinand [et al.] (orgs.). Dicionário Enciclopédico da Bíblia, p. 1103.

${ }^{535}$ SCHNEIDER, Hans. O pietismo. Op. cit., p. 520.

536 VOUGA, François. Protestantismo e Bíblia. Loc. cit.

${ }^{537}$ SCHNEIDER, Hans. O pietismo. Op. cit., p. 526.

${ }^{538}$ DREHER, Martin Norberto. Op. cit., p. 122.

${ }^{539}$ VOUGA, François. Protestantismo e Bíblia. Loc. cit.
} 
O iluminismo, que "teve seu início na filosofia e alastrou-se por todos os âmbitos da vida" ${ }^{540}$, determinou significativamente os rumos da história da Europa por mais de dois séculos, sob a presunção de uma superioridade fundamentada na razão. Obviamente, a igreja, a teologia e a Bíblia foram questionadas sob a ótica racional. Caracterizado pelas profundas transformações que provocou, o iluminismo "alterou completamente as condições nas quais se desenvolvia a atividade teológica"541. Enquanto, por um lado, os pietistas buscaram uma vida de piedade realizando críticas ao formalismo religioso ortodoxo imbricado por uma leitura bíblica dogmática, os iluministas, ao mesmo tempo, se aproveitaram desses julgamentos para criticar o cristianismo, a igreja e a própria Bíblia.

Sob essa perspectiva, Dreher afirma com propriedade que Pietismo e Iluminismo são irmãos ${ }^{542}$. Ambos tinham uma crítica em comum, isto é, à ortodoxia. A diferença é que um buscava a superioridade da razão e o outro buscava o desenvolvimento da espiritualidade. O mentor e desbravador do pietismo, Philip Jacob Spener (1635-1705), que escreveu a obra Pia desideria, de 1676, por exemplo, teceu várias críticas à igreja. Em sua obra, ele enfatizou a necessidade da "internalização da piedade evangélica, a revitalização da fé pessoal e a dedicação intensiva à Bíblia de crentes sérios por meio de um cristianismo edificante e ativo" ${ }^{\text {"543 }}$. Por outro lado, porém, ele estimulou e abriu as portas para que outros também criticassem a teologia e a igreja ${ }^{544}$. Estas críticas se estenderam tanto a católicos como a protestantes. Estes últimos, no entanto, tiveram mais implicações que os primeiros.

Assim, a individualidade que o pietismo intentou como necessária para uma fé sincera culminou em uma busca desenfreada pela razão humana acima de qualquer instituição, inclusive do próprio Deus. Durante “o Iluminismo acentua-se o impulso racionalista" 545 e, assim, tudo passa a ser analisado sob a ótica da racionalidade humana. Como bem afirma Schneider, trata-se de um tempo onde se procu-

\footnotetext{
${ }^{540}$ SCHNEIDER, Hans. O protestantismo. In: KAUFMANN, Thomas et al (orgs.). Op. cit., p. 550. ${ }^{541}$ HÄGGLUND, Bengt. História da teologia, p. 291

542 Cf. DREHER, Martin Norberto. Bíblia: suas leituras e interpretações na História do Cristianismo, p. 119.

${ }^{543}$ LORTZ, Joseph. Historia de La Iglesia: en la perspectiva de la historia del pensamiento. Edad moderna y contemporanea. Vol. II, vol II, p. 311.

${ }^{544}$ Cf. DREHER, Martin Norberto. Op. cit., p. 125.

${ }^{545}$ MONDIN, Battista. Os grandes teólogos do século vinte, p. 21.
} 
ram as "garantias racionais do cristianismo"546. Os principais filósofos desse período, tais quais Hume, Kant, Rosseau, Locke, Voltaire e Diderot, concluíram que poderiam entender o mundo pela razão, e não por explicações teológicas ou bíblicas. Alguns declaravam que "desde a criação do universo, Deus havia evitado qualquer contato com humanos, e, por isso a revelação, como apresentada na Bíblia, seria uma ficção ${ }^{547 "}$. Naquele contexto, "para muitos pensadores iluministas, a Bíblia passou a ser vista como um livro indigno de confiança, criado pelo clero para manter as mentes cativas" 548 . Por assim ser, "a Bíblia não poderia ser levada a sério como um documento revelado" ${ }^{549}$.

A difusão das Escrituras nesse período, como há de se imaginar, passou pelos momentos mais difíceis até aquele momento. Alguns rejeitaram completamente as Escrituras, outros a leram como um livro de moral e ainda outros começaram a usar a razão para interpretá-la e julgá-la. Samuel Reimarus, em sua obra Fragmentos de Wollfenbüttel, por exemplo, "fez observações críticas a respeito da autoria dos escritos bíblicos, apontando contradições existentes nos evangelhos ${ }^{550 "}$. A Bíblia e as suas histórias, para os iluministas, eram um mito. Assim, várias narrativas das Escrituras que continham milagres foram depreciadas. As profecias, a vida e as palavras de Cristo foram igualmente questionadas. Para alguns, os relatos bíblicos sobre Cristo serviam somente para mostrá-lo como um mestre da moral, e não como o salvador da humanidade. Para eles, Jesus tinha sido um personagem comum na história. Teologicamente, portanto, "recusa-se a Encarnação" e, por sua vez, os "relatos da Ressurreição deviam ser tomados num sentido espiritual"551, e não real.

Procurava-se uma explicação lógica e racional para cada narrativa das Escrituras, subjugando a Bíblia como um livro de literatura qualquer. Assim, enquanto

\footnotetext{
${ }^{546}$ SCHNEIDER, Hans. O protestantismo. In: KAUFMANN, Thomas et al (orgs.). História ecumênica da Igreja 2: da alta Idade Média até o início da Idade Moderna., p. 552.

${ }^{547}$ MILLER, Stephen; HUBER, Robert. A Bíblia e sua história: o surgimento e o impacto da Bíblia, p. 188.

${ }^{548}$ GRUDEM, Wayne; COLLINS, John; SCHREINER, Thomas (orgs.). Origem, confiabilidade e significado da Bíblia, p. 25.

${ }^{549}$ LORTZ, Joseph. Historia de La Iglesia: en la perspectiva de la historia del pensamiento. Edad moderna y contemporanea. Vol. II, p. 327.

${ }^{550}$ DREHER, Martin Norberto. Bíblia: suas leituras e interpretações na História do Cristianismo, p. 130

551 ARMOGATHE, Jean-Robert. Os estudos bíblicos no século XVIII. In: BEUKEN, Win; FREYNE, Sean; WEILER, Anton (orgs.). A Bíblia e seus leitores. Revista Concilium. Petrópolis: Vozes, 1991, p. 86.
} 
se fortalecia uma leitura histórica das Escrituras ${ }^{552}$, "a Bíblia deixava de ser vista como testemunho a respeito da revelação na História"553. Como já tinha acontecido com o pietismo, o racionalismo foi, portanto, o outro lado da moeda da reação à ortodoxia ${ }^{554}$. Posteriormente, essas críticas do período contribuirão para o surgimento do método histórico-crítico de interpretação das Escrituras, que passou a ser usado por muitas igrejas cristãs pelo mundo. De certa forma, foi uma resposta em busca do equilíbrio.

Dentro de um tempo, ainda sob influência desse contexto, emergiram pelo mundo a Revolução Francesa (esta principalmente) e a Revolução Industrial, que “do ponto de vista político e de história das ideias, é simultaneamente a transição para a próxima época" ${ }^{555}$. É a entrada definitiva da história no período da contemporaneidade ${ }^{556}$. Ambas as revoluções causaram rupturas na sociedade, transformando a forma de pensamento e de vida. A religião perdia ainda mais sua importância, abrindo espaço para o secularismo. Obviamente, a igreja, a teologia e, por consequência, a Bíblia também se viram envolvidas nesse contexto. Nesta perspectiva, a Bíblia foi vista como "um relato da evolução subjetiva da religião na consciência humana" ${ }^{\text {557 }}$, e não mais como a Palavra de Deus ao ser humano.

Foram tempos em que a teologia e a religião foram duramente questionadas e desvalorizadas pelos principais pensadores da época, tais quais, Feuerbach, Strauss e Marx. A união entre igreja e Estado foi dissolvida. Todos os valores passaram a ser revistos sob uma ótica que se firmava no desenvolvimento histórico, ou seja, o historicismo. Para eles, a humanidade só podia ser compreendia sob esse viés. Assim,

A nova leitura da História com o advento do historicismo levou a uma cosmovisão que via os fatos a partir de seu desenvolvimento, propiciando o surgimento dos fenômenos modernos do Relativismo e do Niilismo. Se no século XVII se discutia a

\footnotetext{
${ }^{552}$ DREHER, Martin Norberto. Bíblia: suas leituras e interpretações na História do Cristianismo, p. 125. 
relação entre fé e razão, no século XIX passou-se a discutir a relação entre fé e História ${ }^{558}$.

Como consequência de toda essa trama de relações entre os fatos históricos e teológicos que ocorreram, "Friedrich E. D. Schleiermacher, considerado universalmente como o pai do protestantismo liberal" ${ }^{559}$, publicou, já no final do século XVIII, quase entrando no século XIX, a obra que abriria principalmente o mundo protestante para a teologia liberal. Sua obra se intitulou Sobre a Religião: discursos dirigidos a seus cultos depreciadores (publicada em 1799) ${ }^{560}$. A teologia liberal, que, entre outros aspectos, procura reduzir o "cristianismo aos limites da razão"561 e, concomitantemente, afirma que "os dogmas são elementos extrínse$\cos { }^{562}$ no relato das Escrituras, é oriunda de toda essa crise político-socialteológica que permeou aquele tempo - marcado por uma expressiva "ruptura com a Bíblia e com a teologia da Reforma" ${ }^{\circ 63}$.

Como se percebe, o século XIX iniciou-se imerso no liberalismo teológico, que, sob a influência do Iluminismo, da Revolução Francesa, entre outros aspectos, relativizou a autoridade da Bíblia, não a considerando como Palavra de Deus. Schleiermacher, por exemplo, contestou todas as doutrinas bíblicas. Por assim ser, deixando a Bíblia de lado, o liberalismo valorizou a filosofia, a moral religiosa, a sociologia da religião, a fraternidade entre as pessoas e o sentimento humano. O cristianismo era, nesse contexto, somente mais uma religião entre tantas outras. $\mathrm{Na}$ crítica às Escrituras, “declaravam o conteúdo da Bíblia como mito, lenda, estórias etc." ${ }^{564}$ Considerando o reducionismo bíblico que foi impregnado, Cairns refere-se a esse período como um tempo de despedaçamento da teologia reformada. A teologia liberal dominou "as faculdades, seminários e púlpitos nas principais igrejas históricas" 565 . Parecia ser uma "nova fé", distanciada do cristianismo histórico e bíblico.

${ }^{558}$ DREHER, Martin Norberto. Bíblia: suas leituras e interpretações na História do Cristianismo., p. 138.

${ }_{559}$ MONDIN, Battista. Os grandes teólogos do século vinte, p. 24.

${ }^{560}$ Cf. DREHER, Martin Norberto. Op. cit., p. 134.

${ }^{561}$ MONDIN, Battista. Op. cit., p. 24.

${ }^{562}$ AUWERS, Jean Marie. Pensamento contemporâneo e Bíblia. In: LONGTON, Joseph; POSWICK, Réginald-Ferdinand [et al.] (orgs.). Dicionário Enciclopédico da Bíblia, p. 1065.

${ }^{563}$ CAIRNS, Earle Edwin. O cristianismo através dos séculos: uma história da igreja cristã, p. 344.

564 MESTERS, Carlos. Por trás das palavras: um estudo sobre a porta de entrada no mundo da Bíblia, p. 49.

${ }^{565}$ CAIRNS, Earle Edwin. Op. cit., p. 484. 
Ainda que este período esteja marcado pelas questões acima delineadas, fazse necessário, ressaltar que nem tudo estava perdido. Concomitantemente, ocorreram importantes pesquisas no campo bíblico que contribuíram no estudo e no aprofundamento exegético das Escrituras.

Pelo lado católico, a Revolução Francesa tinha acendido uma chama que buscava a independência das igrejas em seus respectivos países. Desse modo, a Igreja Católica precisou lutar contra esse "modernismo", fazendo surgir uma reação denominada de ultramontanismo que, entre outros, procurava fortalecer uma Igreja universal sob a liderança do papa. A tônica do documento Syllabus de Erros, promulgado pelo papa Pio IX, em 1864, como apêndice da encíclica Quanta $\mathrm{Cura}^{566}$, é, por exemplo, uma reação católica em que se apresentou oitenta pontos em que o papa rejeitou a sociedade moderna, valorizando o ultramontanismo e a restauração da fé católica. No documento, o papa condenou

O racionalismo, [o] indiferentismo, $[0]$ socialismo, [o] comunismo, [as] sociedades bíblicas, [a] independência do Estado em questões culturais e educacionais. [...] [Ainda] rejeitou a sociedade moderna, a separação da Igreja e Estado, a liberdade religiosa, a educação pública sem controle eclesial e proclamou a autoridade da hierarquia católica para regulamentar a coisa pública ${ }^{567}$.

Como se percebe, ambas as tradições cristãs se viram sob circunstâncias difíceis. Foi um tempo de amplo questionamento e significativa relativização. Pelo lado protestante, a Bíblia era questionada e, pelo lado católico, a sua difusão não era incentivada devido aos perigos da modernidade e receios de interpretações equivocadas, conforme se pode ler nos documentos papais do período. Foi somente durante e após as duas Guerras Mundiais que respostas mais significativas foram dadas, tanto por protestantes quanto por católicos.

Todo o otimismo fundamentando no ser humano, que tinha sido colocado num pedestal pelos pensamentos humanistas e racionais dos séculos anteriores, desmoronou com a barbárie das duas guerras que ocorreram no início do século $\mathrm{XX}$. A ideia de que era possível conquistar um progresso simplesmente por meio dos esforços humanos ruiu ${ }^{568}$. Assim, o "otimismo antropológico chegava ao fim

\footnotetext{
566 PAPA PIO IX. Carta encíclica Quanta Cura. Sobre os principais erros da época, 1864. Disponível em: https://w2.vatican.va/content/pius-ix/it/documents/encyclica-quanta-cura-8-decembris1864.html. Acesso em 8 jul. 2017.

${ }^{567}$ DREHER, Martin Norberto. Bíblia: suas leituras e interpretações na História do Cristianismo, p. 141.

${ }^{568}$ Cf. CAIRNS, Earle Edwin. O cristianismo através dos séculos: uma história da igreja cristã, p. 487.
} 
e, com ele, todo o otimismo da teologia liberal"569. As Escrituras iniciaram, então, um caminho de retorno, que resgatou o prestígio que lhe tinha sido atribuído pelos Pais da Igreja, pelos reformadores e pelo Concílio de Trento. Como bem lembra Lortz, foi um momento em que se procurou resgatar "no coração da teologia evangélica um desenvolvimento que, sem renunciar à pesquisa histórico-crítica, tentasse redirecionar seu trabalho para a mensagem central da Bíblia e da Reforma"570.

Nessa redescoberta pelas Escrituras, no mundo protestante, poder-se-ia afirmar que Karl Barth (1886-1968) é um teólogo importante para o período. Dele surgiu a teologia dialética ou, como também é chamada, neo-ortodoxia ${ }^{571}$, que, segundo Mondim, constituiu “a primeira reação eficaz contra o liberalismo teológico" ${ }^{272}$. Essa teologia se caracterizou, portanto, por se contrapor à tradição liberal alemã da qual Barth era aluno. De fato, antes dessa reação, Barth era mais um pastor liberal da época, fruto do seu tempo e da sua formação. Contudo, quando teve de pregar em meio ao caos que as guerras tinham proporcionado, percebeu que a Bíblia, sob a interpretação liberal, não tinha sentido; era um vazio. Voltando os olhos "às Escrituras e aos escritos de Calvino" 573 , Barth encontrou respostas e significado. De forma oposta ao que pregava o liberalismo, Barth ressaltou, então, que "a Bíblia oferece a cada homem e a cada era respostas à sua questão do modo como elas merecem" 574 .

Muitas críticas posteriores surgiram em relação a Barth e a sua teologia bíblica $^{575}$. Tais criticas evidenciam uma compreensão limitada sobre o contexto teo-

${ }^{569}$ DREHER, Martin Norberto. Bíblia: suas leituras e interpretações na História do Cristianismo, p. 157.

${ }^{570}$ LORTZ, Joseph. Historia de La Iglesia: en la perspectiva de la historia del pensamiento. Edad moderna y contemporanea. Vol. II, p. 498 (tradução nossa).

${ }^{571}$ Teologia dialética se constitui como o movimento teológico que nasceu no início do século XX em reação ao liberalismo teológico da época. A teologia dialética também é reconhecida por outros termos: "teologia da crise", "teologia da palavra" ou "neo-ortodoxia".

${ }^{572}$ MONDIN, Battista. Os grandes teólogos do século vinte, p. 29.

573 CAIRNS, Earle Edwin. O cristianismo através dos séculos: uma história da igreja cristã, p. 488.

${ }^{574}$ BARTH, Karl. Palavra de Deus e Palavra de Homem. São Paulo: Fonte Editorial, 2011, p. 90.

${ }^{575}$ Alguns acham que Karl Barth era liberal pelo seu conceito de que a Bíblia se torna Palavra de Deus quando encontra sentido na vida humana por meio da revelação de Jesus Cristo e não porque ela é a Palavra de Deus. Nesse sentido, vale a pena compreender que, para Barth, "A Sagrada Escritura é o documento de base que tange ao mais íntimo da vida da Igreja, o documento da Epifania da Palavra de Deus na pessoa de Jesus Cristo. Fora desse documento nós não temos nada e, onde a Igreja está viva, ela deve sempre de novo se deixar julgar a si própria segundo esse critério" (BARTH, Karl. Esboço de uma Dogmática, p. 12). Em síntese, para Barth, existem três formas pelas quais a Palavra de Deus alcança o ser humano: (1) pela palavra revelada (revelação); (2) pela 
lógico que dominava naquele tempo. Pois, de fato, ele "estava buscando um meio termo entre a ortodoxia rígida da ala fundamentalista e o liberalismo morto da época" ${ }^{576}$. Em meio à crise social e ao liberalismo teológico, Barth se levantou e assim se destacou pelo seu retorno às Escrituras, principalmente porque passou a utilizar as Escrituras como uma "pregação da palavra viva"577 de Cristo encontrada nos Evangelhos. Entendendo tal importância, ele chamou a igreja protestante que estava imersa no liberalismo para fazer o mesmo ${ }^{578}$. Até então, essa concepção era impraticável para os teólogos liberais. Seu comentário bíblico da Epístola de Romanos ${ }^{579}$ estabelece o marco desse retorno, pois além de ser um significativo protesto ao liberalismo, é a obra que "impôs ao movimento teológico protestante uma virada decisiva, reconduzindo-o ao pensamento genuíno dos fundadores do protestantismo" 580 . A teologia barthiana prevaleceu até meados de 1950, vindo a decair em seguida devido à influência "mais subjetiva e existencial com os escritos de Tilich e Bultmann"581.

No mesmo período de Barth, outro movimento em torno da Bíblia surgiu e se expandiu até os dias atuais. Da mesma forma que a neo-ortodoxia, esse movimento pretendia dar uma resposta bíblica ao liberalismo. Significativamente influenciados pelos movimentos puritanos e pietistas, os personagens que fizeram parte dessa reação foram denominados por alguns como fundamentalistas ${ }^{582}$. Em sua essência, eles buscam valorizar e resgatar a centralidade das Escrituras nas igrejas oriundas da Reforma e, por isso, se distinguiram por sua radicalidade em relação à Bíblia. Para eles, não existia dúvida alguma que pudesse permear a origem divina da Bíblia; pelo contrário, havia plena "convicção de que a Escritura é, em sua literalidade, a palavra mesma de Deus. Seus autores foram apenas instrumentos fiéis de Deus" $" 583$.

palavra escrita (Bíblia); e (3) pela palavra pregada (pregação). Nessas três formas, Deus é o sujeito permanente da sua palavra.

${ }^{576}$ OSBORNE, Grant R. 3 perguntas cruciais sobre a Bíblia: São Paulo: Vida Nova, 2014, p. 22.

577 VOUGA, François. Protestantismo e Bíblia. In: LONGTON, Joseph; POSWICK, RéginaldFerdinand [et al.] (orgs.). Dicionário Enciclopédico da Bíblia, p. 1107.

${ }^{578}$ GOUVÊA, Ricardo. Introdução ao pensamento e obra de Karl Barth. In: BARTH, Karl. Palavra de Deus e Palavra de Homem, pp. 12-14.

${ }^{579}$ Cf. BARTH, Karl. Carta aos Romanos. São Paulo: Fonte Editorial, 2009.

${ }^{580}$ MONDIN, Battista. Os grandes teólogos do século vinte, p. 30

${ }^{581}$ CAIRNS, Earle Edwin. O cristianismo através dos séculos: uma história da igreja cristã, p. 484.

${ }^{582}$ Cf. DREHER, Martin Norberto. Bíblia: suas leituras e interpretações na História do Cristianismo, p. 154

${ }^{583}$ VOUGA, François. Protestantismo e Bíblia. Op. cit., p. 1104. 
O surgimento do movimento se deu por uma série de publicações de textos, entre 1909 e 1915, chamados de The Fundamentals - a Testimonium to the Truth. Esses escritos ressaltavam a Bíblia como algo de extrema importância para a fé cristã, em contraposição à ciência, ao liberalismo e ao racionalismo que haviam impregnado o protestantismo. Já que "o racionalismo do século XIX era hostil aos milagres e ao sobrenatural" 584 , os fundamentalistas olharam para a Bíblia de forma completamente antagônica aos críticos racionalistas. Muitos dos temas abordados em seus escritos se baseavam numa ampla defesa das Escrituras, estabelecidas sob um arcabouço doutrinário sistematizado de uma "fé bíblica". Entre outras, pode-se destacar a doutrina da inerrância verbal e literal das Escrituras, que foi amplamente defendida por eles ${ }^{585}$. Esses conceitos foram propagados por meio de conferências e seminários bíblicos que aderiram e estimularam as igrejas numa relação diferente com a Bíblia, considerando-a "completamente inspirada e infalível regra de fé e prática" ${ }^{\text {"56 }}$.

Concomitante à tais contextos do mundo protestante, a Igreja Católica, principalmente por meio do papa Pio $\mathrm{X}$, reagiu enfaticamente contra o movimento modernista $^{587}$ que rondava a Igreja na época. Conceitualmente, o modernismo se caracteriza como um "um movimento desencadeado na Igreja Católica na viragem do séc. XIX para o séc. XX com o objetivo de adaptar a doutrina e as estruturas do catolicismo às tendências do pensamento contemporâneo" ${ }^{\text {588 }}$. Segundo Auwers ${ }^{589}$, no aspecto bíblico, os modernistas combatiam a exegese tradicional realizada pela Igreja (que, a partir dela, formulava os dogmas) e reduziam o aspecto da revelação bíblica. Era uma oposição entre história e fé. Por assim ser, o movimento modernista intecionava uma renovação da própria Igreja frente aos desafios que o mundo da época oferecia. Era um movimento de dentro para fora, portanto, ele estava imbricado na própria realidade católica.

\footnotetext{
${ }^{584}$ PETERSON, Eugene [et al.]. Ouvindo a Deus: uma abordagen multidisciplinar da leitura bíblica. São Paulo: Shedd, 2001, p. 103.

${ }^{585}$ Cf. DREHER, Martin Norberto. Bíblia: suas leituras e interpretações na História do Cristianismo, p. 154.

${ }^{586}$ CAIRNS, Earle Edwin. $O$ cristianismo através dos séculos: uma história da igreja cristã, p. 502.

${ }^{587}$ Vale ressaltar que o termo "modernismo" é abordado nesta tese sob o viés teológico.

${ }^{588}$ FELÍ́CIO, Manuel da Rocha. Na viragem do século (XIX-XX): a crise modernista. Máthesis. $\mathrm{N}^{\circ} 11,2002$, p. 373.

${ }^{589}$ AUWERS, Jean Marie. Pensamento contemporâneo e Bíblia. In: LONGTON, Joseph; POSWICK, Réginald-Ferdinand [et al.] (orgs.). Dicionário Enciclopédico da Bíblia, pp. 1065-1066
} 
Os modernistas questionavam muitos dos aspectos místicos e sobrenaturais que, firmados nas Escrituras, constituíam um dogma na vida da Igreja. Muitas das crenças fundamentais da fé católica foram, de certa forma, relativizadas ou, pelo menos, questionadas. Entre esses aspectos estavam, por exemplo, a relação Escritura, Tradição e Igreja. Aliás, “a questão bíblica, podemos considerá-la o grande tema do modernismo" $" 590$. Havia uma tentativa de racionalizar o uso e a leitura das Escrituras como forma de se conviver com os questionamentos que emergiam à época e que colocavm em dúvida a fé e o dogma.

O próprio conteúdo da encíclica Providentissimus Deus ${ }^{591}$, de 1893, que instigava o estudo das Escrituras, foi questionado pelos modernistas. Nessa perspectiva, alguns documentos foram escritos na tentativa de responder e reagir a estas questões, levando, à frente uma significativa reação anti-modernista. $\mathrm{O}$ decreto Lamentabili Sine Exitu e a encíclica Pascendi Dominici Gregis ${ }^{592}$, ambas de 1907, foram escritas pelo papa Pio X para refutar e condenar justamente os ensinos modernistas. Ambas ressaltavam, entre outros assuntos, a importância e a inspiração divina das Escrituras. Naquele contexto a Igreja reafirmou, por exemplo, que os três primeiros capítulos do livro de Gênesis deveriam ser compreendidos como uma verdade histórica-literal. Da mesma forma, afirmou que Moisés era o autor do Pentateuco. Essa posição foi mantida até a primeira década do século XX.

O papa Pio X chegou a promulgar um juramento anti-modernista, que deveria ser proferido por todos os membros do clero, pastores, confessores, pregadores, superiores religiosos e professores em seminários de filosofia e teologia. O documento instigava a todos a reforçar a crença nos dogmas da Igreja firmados de acordo com a Tradição e a Escritura e, por outro lado, rejeitar todo o ensino dos modernistas. Como se constata, a reação anti-modernista, de certa forma, tem algumas características semelhantes ao movimento fundamentalista ocorrido no

\footnotetext{
${ }^{590}$ FELÍCIO, Manuel da Rocha. Na viragem do século (XIX-XX): a crise modernista. Máthesis, p. 381.

${ }^{591}$ PAPA LEÃO XIII. Carta encíclica Providentissimus Deus. Sobre los estudios biblicos, 1893, passim. Disponível em: https://w2.vatican.va/content/leo-xiii/es/encyclicals/documents/hf_lxiii_ enc_18111893_providentissimus-deus.html. Acesso em 5 jun. 2017.

592 PAPA PIO X. Carta encíclica Lamentabili Sine Exitu. Das proposições dos modernistas condenadas pela Igreja. Decreto da Sagrada Inquisição Romana e Universal, 1907, n. 9-19. Disponível em: http://www.montfort.org.br/bra/documentos/decretos/lamentabili/. Acesso em 3 jan. 2018; PAPA PIO X. Carta encíclica Pascendi Dominici Gregis. Sobre as doutrinas modernistas, 1907, passim. Disponível em: https://w2.vatican.va/content/pius-x/pt/encyclicals/ documents/hf_p-x_enc_190709 08_pascendi-dominici-gregis.html. Acesso em 4 set. 2017.
} 
meio protestante. Ambos procuraram defender as Escrituras frente ao liberalismo teológico ou a critica racionalista que questionavam a fé cristã e seus dogmas.

\subsection{3 \\ Uma tentativa de síntese: a difusão das Escrituras Sagradas nessas relações contemporâneas}

A maioria das obras que discorrem sobre História da Teologia ou História da Igreja procuram tratar de todos esses aspectos de forma isolada. Alguns poucos os relacionam, como, por exemplo, o fez Dreher ${ }^{593}$. Considerando o objeto de pesquisa nesse trabalho, optou-se por essa conexão, pois, como é possível perceber, todos esses eventos constituem uma trama de relações e, em certos momentos, se apresentam interdependentes. Um fato, mesmo que isolado, influencia e se amalgama a outro. Assim, puritanismo, pietismo, iluminismo, modernismo e liberalismo constituíram um desafio proeminente para a difusão das Escrituras Sagradas entre os séculos XVII e XX.

Em meio aos encantos do iluminismo e da racionalidade, firmados na teologia liberal, pode-se dizer que os movimentos puritanos e pietistas, cada um em sua especificidade e dentro de suas limitações, vieram a exercer significativa influência no surgimento de vários movimentos independentes no meio protestante em relação às Escrituras. Schneider, referindo-se especificamente ao pietismo, chega a afirmar que "desde a Reforma não há no protestantismo um movimento de igual significado histórico" 594 . De fato, são muitos os impactos causados por todos esses movimentos na história da igreja cristã, principalmente protestante.

Influenciado por essa piedade e afeição pelas Escrituras, John Wesley, por exemplo, instigou um movimento que valorizou a devoção pessoal e o estudo da Bíblia. Desse movimento, surgiu, mais tarde, o metodismo. Da mesma forma, George Whitefield, criador do movimento "Grande Avivamento", Jonathan Edwards, um avivalista, e D. L. Moody, um evangelista, começaram a pregar enfaticamente sobre a Bíblia em suas reuniões que atraiam muitas pessoas. Todos

\footnotetext{
${ }^{593}$ Cf. DREHER, Martin Norberto. Bíblia: suas leituras e interpretações na História do Cristianismo, passim.

${ }^{594}$ SCHNEIDER, Hans. O protestantismo. In: KAUFMANN, Thomas et al, (orgs.). História ecumênica da Igreja 2: da alta Idade Média até o início da Idade Moderna., p. 545.
} 
esses movimentos foram caracterizados pelo evangelicalismo ${ }^{595}$ que influenciou boa parte da fé protestante nas Américas. Entre outras, uma dessas influências se deu na difusão das Escrituras; afinal, esse movimento "têm cooperado na tradução e produção de novas versões da Bíblia que receberam ampla aceitação"596 desde então.

Tanto protestantes históricos como pentecostais, influenciados por esses movimentos, se caracterizaram por uma luta significativa contra a racionalidade da fé imposta pelo Iluminismo, pelo relativismo e pelo liberalismo. Por meio de pregações, textos, envio missionário, entre outros aspectos, esses grupos reagiram, procurando enfatizar a leitura e a difusão das Escrituras como paradigma para a vida em todas as esferas. Dessa forma, “o século XIX caracterizou-se por um renovado interesse pela Bíblia. Antigas traduções foram revisadas, novas traduções foram feitas e outras Bíblias surgiram para atrair a atenção de denominações em particular e do cristão comum" $" 597$.

Entre novas traduções e revisões de traduções antigas para boa parte de línguas faladas pelo mundo, os séculos XIX e XX também ficaram marcados pelo surgimento de Bíblias que tinham por objetivo atender interesses específicos de certos grupos que surgiram no período, como um movimento paralelo ao protestantismo. Como exemplo, foram desenvolvidas Bíblias para os unitaristas ${ }^{598}$, que queriam uma tradução bíblica livre do que eles chamavam de "resquícios da doutrina da Trindade".

Da mesma forma, o movimento das Testemunhas de Jeová também criou a sua tradução da Bíblia, publicada pela primeira vez em 1961. Essa Bíblia é conhecida como a Tradução do Novo Mundo das Escrituras Sagradas, atualmente pro-

\footnotetext{
${ }^{595}$ De acordo com Simões, o termo evangelicalismo "refere-se ao movimento de massas que remonta aos 'Grandes Despertamentos' dos séculos XVIII e XIX" (SIMÕES, Eduardo Vagner Santos. Evangelicalismo latino-americano: uma perspectiva histórica. Anais do Congresso ANPTE$C R E$, p. ST0510). Como um movimento transconfessional, o evangelicalismo "foi marcado pelo compromisso com a Bíblia como Palavra de Deus, a confessionalidade credal, a disciplina pessoal, a piedade, o amor aos necessitados, o zelo evangelístico e a denúncia contra a decadência de costumes" (CAVALCANTI, Robinson. As origens do evangelicalismo. Revista Ultimato. Edição 253, jul/ago. 1998).

${ }^{596}$ CAIRNS, Earle Edwin. O cristianismo através dos séculos: uma história da igreja cristã, p. 511.

${ }^{597}$ MILLER, Stephen; HUBER, Robert. A Bíblia e sua história: o surgimento e o impacto da Bíblia, p. 190.

598 O unitarismo (ou unitarianismo) se caracteriza pela crença teológica que Deus é somente um. Eles afirmam, portanto, a unidade absoluta de Deus em contraposição à doutrina cristã da Trindade, ou seja, que Deus é Pai, Filho e Espírito Santo.
} 
duzida e distribuída pela Sociedade Torre de Vigia de Bíblias e Tratados ${ }^{599}$. Entre outros aspectos, mas também por ter uma tendência à ênfase escatológica, isto é, reforçar a preparação dos seus seguidores para o fim do mundo, essa versão bíblica é utilizada exclusivamente pelas Testemunhas de Jeová ${ }^{600}$. Os mórmons, da Igreja de Jesus Cristo dos Santos dos Últimos Dias, apesar de também usarem a Bíblia Sagrada normalmente lida pelos cristãos, também criaram o seu próprio texto sagrado, sob o nome de Livro de Mórmon ${ }^{601}$, publicado pela primeira vez em 1830. Como bem lembra Lortz, entretanto, “a base de sua fé não é a Bíblia, mas o Livro de Mórmon, a revelação privada do fundador" ${ }^{\prime 62}$.

Como consequência de sua piedade evangelística, cabe destacar que o Pietismo instigou muitos movimentos missionários por todo o mundo. Foi, inclusive, a partir de um dos mais importantes representantes do movimento pietista, Augusto Germano Francke, que surgiu a primeira organização cristã que tinha como missão difundir as Escrituras Sagradas. Trata-se de uma organização que antecede, em alguns anos, a primeira Sociedade Bíblica. Fundada em 1710 por Carl Hildebrand von Canstein, essa sociedade contribuiu para que a Bíblia se tornasse realmente popular naquela época. Por meio do surgimento dessa organização e "reduzindo os custos de impressão, conseguiu-se distribuir mais de dois milhões de Bíblias somente no século XVIII"603.

\subsection{4 Questões contemporâneas sobre a difusão das Escrituras Sagradas nas igrejas cristãs}

A Bíblia Sagrada é o livro por excelência da igreja cristã. Tanto católicos quanto protestantes concordam sobre isso, pois “jamais se viu Igreja, de qualquer fundação propriamente cristã, sem a Bíblia"604. Por assim ser, "a Palavra de Deus

599 Cf. BÍBLIA Sagrada. Português. Tradução do Novo Mundo das Escrituras Sagradas. New York: Watchtower Bible; Tract Society of New York, INC; Cesário Lange: Associação Torre de Vigia de Bíblias e Tratados, 2015.

${ }^{600}$ Lortz destaca que no início, o movimento fundado por Clarles Taze Russel recebeu o nome de “investigadores da Bíblia”. In: LORTZ, Joseph. Historia de La Iglesia: en la perspectiva de la historia del pensamiento. Edad moderna y contemporanea. Vol. II, p. 505 (tradução nossa).

${ }^{601}$ Cf. O Livro de Mórmon: Outro Testamento de Jesus Cristo. Salt Lake City, Utah, EUA: A Igreja de Jesus Cristo dos Santos dos Últimos Dias, 2015.

${ }^{602}$ LORTZ, Joseph. Op. cit., p. 506 (tradução nossa, grifo nosso).

${ }^{603}$ DREHER, Martin Norberto. Bíblia: suas leituras e interpretações na História do Cristianismo, p. 124.

${ }^{604}$ KANNENGIESSER, Charles. A leitura da Bíblia na Igreja Primitiva, p. 45. 
deve ocupar o centro fundamental da vida e da missão da Igreja" ${ }^{605}$. Porém, como já foi possível perceber até aqui, as duas tradições cristãs contempladas nesse estudo se relacionam com as Escrituras de forma diferente. Tal fato, porém, não altera a realidade pela qual ambas as consideram como Palavra de Deus e como necessária para a igreja.

A Reforma foi um marco divisor nessa relação entre as respectivas igrejas e as Escrituras. Ênfases foram acentuadas pelos dois lados e cada uma, em sua forma de ler e interpretar as Escrituras, a difundiu. Dessa forma, vale a pena perceber como essa difusão se deu na história pós-Reforma até os dias atuais. Mais uma vez, é importante estabelecer que não se pretende discorrer sobre tudo o que tem acontecido nessa história. Seria impossível fazê-lo. Pretende-se, portanto, realizar alguns apontamentos mais recentes que estão focalizados no objeto desta pesquisa.

\subsubsection{1 Contemporaneidade católica e as Escrituras Sagradas}

“A Igreja Católica jamais esqueceu que a Escritura é uma das fontes essenciais da fé" ${ }^{606}$. Esse é um pressuposto básico que se deve ressaltar. Mesmo que em certos momentos essa realidade tenha sofrido algum aparente revés, engana-se quem pensa o contrário. É possível constatar, através da história da igreja e da história da teologia, que tanto a igreja medieval como os teólogos medievais sempre manifestaram um alto apreço pelas Escrituras.

Entretanto, a diferença ressaltada ${ }^{607}$, principalmente na Contrarreforma, está no fato de que, para a Igreja Católica, a Tradição e, de certa forma, o magistério estão em igualdade com as Escrituras, pois, na ótica católica, a tradição antecede as Escrituras. Essa posição foi discutida e confirmada no Concílio de Trento, na Contrarreforma Católica. Dessa forma, considerando esta realidade e, por vezes, precisando reafirmar sua doutrina em contraposição aos movimentos reformado-

\footnotetext{
${ }^{605}$ FERNANDES, Leonardo Agostini. A Bíblia e sua mensagem: introdução à leitura e ao estudo da Bíblia, p. 5.

${ }^{606}$ CANNUYER, Christian; POSWICK, Réginald-Ferdinand. Catolicismo e Bíblia. In: LONGTON, Joseph; POSWICK, Réginald-Ferdinand [et al.] (orgs.). Dicionário Enciclopédico da Bíblia, p. 283.

${ }^{607}$ Gabriel Fluhrer diz que os reformadores redescobriram a importância preeminente da Bíblia (FLUHRER, Gabriel. Firme fundamento: a inerrante Palavra de Deus em um mundo errante, p. 71).
} 
res, antes, durante e depois da Reforma propriamente dita, “a Bíblia perdeu progressivamente o lugar de honra que era seu na espiritualidade, na teologia e na liturgia" ${ }^{\circ 08}$.

Em 1564, três décadas depois da Bíblia de Lutero, na bula Dominici gregis, o papa Pio IV limitou a leitura de traduções da Bíblia que não estivessem seguidas de notas explicativas baseadas no ensino da Igreja. No documento, se estabelece também que

Somente o bispo pode permitir, a pessoas doutas e piedosas, a utilização das traduções do Antigo Testamento, e mesmo assim, somente para esclarecer a Vulgata; não se permite a utilização das traduções do Novo Testamento, sob a alegação de que elas trariam confusões e pouca utilidade aos leitores. Só o bispo ou o inquisidor pode permitir, a juízo do pároco, a leitura da Bíblia em língua vernácula ${ }^{609}$.

Zimmer acrescenta, ainda, que

Durante o recesso do Concílio [de Trento] (1552-1562), Pio IV publicou a bula Dominici gregis custodias, que estabelecia as regras para a elaboração do Índice dos Livros Proibidos, incluindo a proscrição da Bíblia em traduções para as línguas vernáculas ${ }^{610}$.

Os papas Pio VII, em 1816, Leão XII, em 1824, Gregório XVI, em 1844, e Pio IX, em 1846, seguirão esta mesma linha de restrição, inclusive se manifestando contrários à propagação das Escrituras realizadas por organizações não católicas, como se constatará no próximo capítulo. Como historicamente se verifica, essas decisões criaram algumas dificuldades no decorrer da história da difusão das Escrituras pela Igreja Católica. Assim, “o catolicismo tradicional foi marcado por um afastamento entre o povo e a Bíblia" ${ }^{\text {611 }}$. Cannuyer, ao comentar o resultado do Concílio, resume-o da seguinte forma:

Todas as medidas foram motivadas pela preocupação de proteger e conservar, mas simplesmente não convidam (antes pelo contrário!) a cultivar qualquer desconfiança em face da leitura do texto sagrado... Infelizmente, as consequências foram as mais radicais do que esperavam os padres conciliares. Pouco a pouco, entre os católicos, instalou-se um desinteresse sempre mais acentuado em relação à própria

${ }^{608}$ CANNUYER, Christian; POSWICK, Réginald-Ferdinand. Catolicismo e Bíblia. In: LONGTON, Joseph; POSWICK, Réginald-Ferdinand [et al.] (orgs.). Dicionário Enciclopédico da Bíblia, p. 283.

${ }^{609}$ LOPES, Geraldo. Dei verbum: texto e comentário, p. 48.

${ }^{610}$ ZIMMER, Rudi. O uso da Bíblia no Ocidente: na evangelização. In: SOCIEDADE BÍBLICA DO BRASIL. Fórum de Ciências Bíblicas: 1600 anos da primeira grande tradução ocidental da Bíblia - Jerônimo e a tradução da Vulgata Latina v.1. Barueri: Sociedade Bíblica do Brasil, 2006, p. 125.

${ }^{611}$ KONINGS, Johan. A Palavra se fez livro, p. 87. 
Bíblia, sobretudo ao AT. Do século XVII ao século XIX perdeu-se o gosto e o hábito de ler a Escrituras ao menos individualmente e fora das celebrações litúrgicas. O livro de cabeceira não era mais a Palavra de Deus ${ }^{612}$.

Tais posicionamentos geraram desgastes por um certo tempo na história e "tiveram como consequência o pouco contato dos católicos com a Bíblia, bem

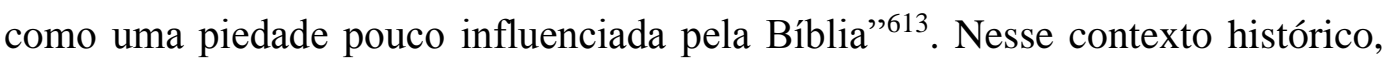
pode-se perceber um diferencial em relação à leitura bíblica entre católicos e protestantes. Ainda que "a interpretação da Bíblia a partir da própria Bíblia não negue o sentido da comunidade de fé" ${ }^{\prime 14}$, a Reforma reforçou a leitura individual pelo cristão. Já a Igreja Católica, com certa ênfase a partir de Trento, reforçou a leitura comunitária das Escrituas, na e pela Igreja.

Em 1713, na bula Unigenitus, que tinha por objetivo refutar o jansenismo ${ }^{615}$, o papa Clemente XI ressaltou que a leitura bíblica era facultativa e não obrigatória aos fiéis. A constituição Auctorem Fidei ${ }^{616}$, de 1794, promulgada pelo papa Pio VI, seguiu o mesmo raciocínio. Como se percebe, as encíclicas não proibiam, mas, por outro lado, ao estabelecer certas restrições, também não estimulavam a leitura das Escrituras pelos católicos. De fato, "no século XIX, o livre exame, o racionalismo moderno e a hipercrítica disso resultantes obrigaram os sumos pontífices a colocar-se sempre mais contra as leituras e os estudos bíblicos independentes do controle da igreja" 617 .

No período do racionalismo, como já visto anteriormente, as críticas externas à Bíblia foram acentuadas. Se, por um lado, a Igreja se preocupou com a leitura bíblica sob a ótica racionalista, por outro, contribuiu significativamente na defesa das Escrituras. A ação católica foi fundamental contra o movimento modernista que, entre outros aspectos, confrontava a Bíblia e a doutrina católica. Em sua

${ }^{612}$ CANNUYER, Christian; POSWICK, Réginald-Ferdinand. Catolicismo e Bíblia. In: LONGTON, Joseph; POSWICK, Réginald-Ferdinand [et al.] (orgs.). Dicionário Enciclopédico da Bíblia, p. 284.

${ }^{613}$ LOPES, Geraldo. Dei verbum: texto e comentário, p. 48.

${ }^{614}$ ROCHA, Alessandro Rodrigues. Entre a solidão, a solitude e a solidariedade. Leituras no contexto brasileiro. In: Proença, Eduardo (org.). Bíblias e outros ensaios. Theologando Revista Teológica, p. 32.

615 Jansenismo é o nome que designa um movimento e um conjunto de princípios criados pelo bispo de Ypres, Cornélio Jansênio (1585-1638) que, entre outros aspectos, defende, com base em Agostinho, a doutrina da predestinação, negando, portanto, o livre-arbítrio. Cf. REINHARDT, Rudolf. A Igreja católica. In: KAUFMANN, Thomas et al (orgs.). História ecumênica da Igreja 2: da alta Idade Média até o início da Idade Moderna, pp. 499-506.

616 PAPA PIO VI. Bolla Auctorem Fidei, 1794, n. 11 (LXVII). Disponível em: https://w2.vatican.va/content/pius-vi/it/documents/bolla-auctorem-fidei-28-agosto-1794.html. Acesso em 19 ago. 2017.

${ }^{617}$ CANNUYER, Christian; POSWICK, Réginald-Ferdinand. Loc. cit. 
reação, a Igreja ressaltou a importância da Palavra de Deus contra toda onda contrária daquele tempo. A encíclica Pascendi Dominici Gregis ${ }^{618}$, de 1907, que contradiz o movimento modernista da época, refutou os historiadores críticos que se achavam superiores por terem "descoberto erros nas Escrituras".

Um pouco antes, na encíclica Providentissimus Deus ${ }^{619}$, de 1893, o papa Leão XIII já tinha abordado a questão da inspiração e do estudo das Escrituras. A encíclica reafirmava Deus como o autor das Escrituras Sagradas, e reiterava que assim elas deveriam ser recebidas e acolhidas. Por outro lado, pedia que se realizassem estudos bíblicos e científicos em torno da Bíblia. Cientistas e fiéis reconheceram o equilíbrio da encíclica, e a Igreja retomou o prestígio em relação às Escrituras diante do conteúdo restritivo dos documentos anteriores.

Como consequência, o teor desta encíclica fez emergir um significativo movimento de toda a Igreja Católica em torno da Bíblia. Este movimento se estendeu por meio de inúmeras contribuições à difusão das Escrituras até à contemporaneidade. Em 1902, por exemplo, o papa Leão XIII criou, por meio da carta apostólica Vigilantiae studiique ${ }^{620}$, a Pontifícia Comissão Bíblica, uma instituição da Santa Sé totalmente voltada para as questões bíblicas da Igreja. Esse órgão tem a finalidade de, por meio de biblistas e especialistas, contribuiur com a correta interpretação das Escrituras e a promoção do estudo das Ciências Bíblicas. Outras iniciativas começaram, igualmente, a se desenvolver entre o final do século XIX e o início do século XX, quando surgiram, por exemplo, vários Centros de Estudos Bíblicos pelo mundo, tais quais:

- École Biblique de Jérusalem (atualmente École biblique et archéologique française de Jérusalem ${ }^{621}$ ): criada em 1890 pelo padre MarieJoseph Lagrange;

- Studium Biblicum Franciscanum: criado em 1901 pelos franciscanos, com avanços históricos no trabalho e na titulação da instituição: em 1924 se ligou à Santa Sé. Em 1960 foi promovido como uma seção bí-

\footnotetext{
${ }^{618}$ PAPA PIO X. Carta encíclica Pascendi Dominici Gregis, 1907, passim.

${ }^{619}$ PAPA LEÃO XIII. Carta encíclica Providentissimus Deus. Sobre los estudios biblicos, 1893, passim.

${ }^{620}$ PAPA LEÃO XIII. Carta apostólica Vigilantiae studiique, 1902, passim. Disponível em: http://w2.vatican.va/content/leo-xiii/la/apost_letters/documents/hf_lxiii_apl_19021030_vigilantiae-studiique.ht ml. Acesso em 15 jun. 2017.

${ }^{621}$ Cf. ÉCOLE BIBLIQUE ET ARCHÉOLOGIQUE FRANÇAISE DE JÉRUSALEM. Desenvolvido pelo Couvent Saint-Étienne, 2018. Homepage institucional. Disponível em: $<$ http://www.ebaf.edu/en/>.
} 
blica da Faculdade de Teologia do Pontifício Antonianum de Roma e, em 2001, tornou-se, oficialmente, Ateneo e Facoltà de Sciencie Bibliche e Archeologiche de Jerusalem ${ }^{622}$;

- Pontificio Istituto Biblico di Roma ${ }^{623}$ : criado pelos jesuítas em 1909 e autorizado pelo Papa Pio X através da Carta Apostólica Vinea Electa do mesmo ano;

- Pontificio Istituto Biblico di Gerusalemme ${ }^{624}$ : criado em 1927 pelos jesuítas, em Jerusalém, como uma extensão do Pontificio Istituto Biblico di Roma;

- Instituto Español Bíblico y Arqueológico de Jerusalén ${ }^{625}$ : criado em 1955 ligado à Universidad Pontificia de Salamanca.

No Brasil, o Centro de Estudos Bíblicos (CEBI) foi fundado em 1979 por Jether e Lucilia Ramalho, Agostinha Vieira de Mello e Carlos Mesters com o propósito de captar e fortalecer uma leitura popular da Bíblia ${ }^{626}$. Atualmente o CEBI está espalhado por vários estados brasileiros contribuindo com o estudo, a leitura e a difusão das Escrituras entre o povo brasileiro. Historicamente, como se percebe, tais ações impactaram significativamente a atuação da Igreja Católica em relação às Escrituras Sagradas e a sua difusão, evidenciado, assim, a importante contribuição da encíclica Providentissimus Deus e dos desdobramentos que dela decorreram.

Já em 1920, na encíclica Spiritus Paraclitus ${ }^{627}$, começa se perceber de forma mais clara um novo paradigma nos documentos oficiais da Igreja sobre as Escrituras Sagradas. Nessa encíclica, o papa Bento XV estimulou a realização de

${ }^{622}$ Cf. ATENEO E FACOLTÀ DE SCIENCIE BIBLICHE E ARCHEOLOGICHE DE JERUSALEM. Desenvolvido por Pontificia Universitá Antonianum, 2012. Homepage institucional. Disponível em: <http://www.antonianum.eu/it/facolta>. Aceso em 27 nov. 2017.

${ }^{623}$ Cf. PONTIFICIO ISTITUTO BIBLICO DI ROMA. Desenvolvido por Pontificio Istituto Biblico di Roma, 2015. Homepage institucional. Disponível em: 〈https://www.biblico.it/〉. Aceso em 27 nov. 2017.

${ }^{624}$ Cf. PONTIFICIO ISTITUTO BIBLICO DI GERUSALEMME. Desenvolvido por Pontificio Istituto Biblico di Roma, 2011. Homepage institucional. Disponível em: <https://www.biblico.it/jerusalem.html >. Aceso em 30 nov. 2017.

${ }^{625}$ Cf. INSTITUTO ESPAÑOL BÍBLICO Y ARQUEOLÓGICO DE JERUSALÉN. Desenvolvido por Universidad Pontificia de Salamanca, 2017. Homepage institucional. Disponível em: <https://www.upsa.es/institutos/detalle-instituto/>. Aceso em 13 dez. 2017.

${ }^{626}$ Cf. MESTERS, Carlos. Balanço de 20 anos: a Bíblia lida pelo povo na atual renovação da Igreja Católica no Brasil 1964-1984. Belo Horizonte: CEBI, 1988, passim.

${ }^{627}$ PAPA BENTO XV. Carta encíclica Spiritus Paraclitus. Sobre la interpretación de la sagrada escritura, 1920, passim. Disponível em: https://w2.vatican.va/content/benedict-xv/es/encyclicals/ documents/hf_ben -xv_enc_15091920_spiritus-paraclitus.html. Acesso em 4 ago. 2017. 
estudos bíblicos e abriu as portas da leitura bíblica por partes dos fiéis. A encíclica tinha por objetivo celebrar o décimo quinto centenário da morte de Jerônimo, o tradutor da Vulgata. E, assim, referindo-se ao desejo de Jerônimo que recomendava a todos a leitura cotidiana das Escrituras, a encíclica, na mesma sintonia, advertiu: "Nunca deixaremos de exortar todos os cristãos fiéis a ler diariamente os Santos Evangelhos de nosso Senhor e os Atos e Epístolas dos Apóstolos, tentando transformá-los em seiva de seu espírito e no sangue de suas veias"628.

O documento, portanto, se caracterizou como um marco divisor na forma que a Igreja Católica passou a incentivar explicitamente a leitura das Escrituras pelos católicos. Em 1943, a encíclica Divino Afflante Spiritu ${ }^{629}$, em comemoração ao $50^{\circ}$ aniversário da encíclica Providentissimus Deus, ampliou ainda mais essa abertura, reforçando o surgimento de movimentos bíblicos entre os leigos católicos. Essa encíclica "foi um documento libertador, responsável por uma notável volta de católicos em todo o mundo à Bíblia, à sua leitura e estudo" ${ }^{630}$. A encíclica tem, inclusive, uma parte em que se instiga a difusão das Escrituras com "certas esperanças de que para o futuro a veneração, uso e ciência das sagradas Escrituras progredirão cada vez mais para o bem das almas" ${ }^{631}$. Como se percebe, a ênfase bíblica se dá pela admiração às Escrituras, pelo seu estudo e, também, pelo incentivo à leitura pelos fiéis católicos.

Obviamente, como em todos os documentos que falam das Escrituras e de sua importância na vida da Igreja, o papa advertiu para que não ocorressem interpretações literais da Bíblia e, por isso, reforçou a importância de se "ler as Escrituras em edições católicas acompanhadas de comentários dos melhores especialis$\operatorname{tas}{ }^{632}$. Essa encíclica constitui, até hoje, um dos principais documentos da Igreja sobre estudos exegéticos no uso das Escrituras. Mesters reforça essa percepção ao lembrar que a encíclica desencadeou "um interesse muito vasto pela Bíblia por parte do povo. O estudo renovado da Bíblia alimentou a teologia, estimulou a re-

\footnotetext{
${ }^{628}$ PAPA BENTO XV. Carta encíclica Spiritus Paraclitus. Sobre la interpretación de la sagrada escritura, 1920, n. 45.

${ }^{629}$ PAPA PIO XII. Carta encíclica Divino Afflante Spiritu. Sobre estudo bíblicos, 1943, n. 9-10, 29-30. Disponível em: http://w2.vatican.va/content/pius-xii/pt/encyclicals/documents/hf_pxii_enc_ 30091943_divino -afflante-spiritu.html. Acesso em 12 set. 2017.

${ }^{630}$ FITZMYER, Joseph. Augustine. A Bíblia na Igreja. São Paulo: Loyola, 1997, p. 16.

${ }^{631}$ PAPA PIO XII. Carta encíclica Divino Afflante Spiritu. Sobre estudos bíblicos, 1943, n. 10.

${ }^{632}$ CANNUYER, Christian; POSWICK, Réginald-Ferdinand. Catolicismo e Bíblia. In: LONGTON, Joseph; POSWICK, Réginald-Ferdinand [et al.] (orgs.). Dicionário Enciclopédico da Bíblia, p. 285.
} 
novação litúrgica e foi o que mais contribuiu para a renovação interna da Igreja"633. Para além do aspecto exegético, esse documento "foi também uma volta à herança original da Igreja que tinha sido negligenciada na Igreja pósTridentina"634.

Como se percebe, a relação da Igreja Católica com as Escrituras é progressiva nos momentos pós-Reforma. Essa relação se dá de acentuada reserva até uma ênfase significativa à leitura, ao estudo e à difusão. Essa perspectiva crescente culminará em um dos Concílios mais marcantes na história da Igreja Católica Apostólica Romana, isto é, o Concílio Vaticano II.

\subsubsection{1 \\ O Concílio Vaticano II, a Dei Verbum e o lugar das Escrituras Sagradas na Igreja Católica}

Entre outros aspectos, a abertura à leitura da Bíblia e a necessidade de tratar questões pertinentes à vida da Igreja na contemporaneidade instigaram a convocação de mais um Concílio da Igreja Católica Apostólica Romana. Foi sob essa perspectiva que o Concílio Vaticano II foi anunciado e convocado pelo papa João XXIII. Como sempre ocorre de forma prévia à reunião do colégio episcopal, criou-se uma comissão que deveria estabelecer os assuntos mais significativos que deveriam ser contemplados durante o Concílio. Após a audição de bispos do mundo inteiro, que apresentaram a realidade e os problemas que as igrejas enfrentavam em seus respectivos países, constatou-se que "os temas ligados à Sagrada Escritura despertaram muito interesse" ${ }^{\$ 35}$. Obviamente, o Concílio não se limitou a esse assunto, mas não há dúvidas de que foi um assunto que instigou uma ação renovada da Igreja pós-Concílio. Nessa perspectiva, pode-se dizer que o Concílio "refez a Igreja Católica em muitos aspectos e, em certa medida, o próprio cristianismo" $" 636$.

Foi um despertar de esperança para a fé católica no mundo todo diante do mundo moderno. Frente à abrangência de assuntos tratados no Concílio, essa análise se limitará aos aspectos relacionados às Escrituras Sagradas, visto ser esse o

\footnotetext{
${ }^{633}$ MESTERS, Carlos. A Bíblia como memória dos pobres. Petrópolis: Vozes, 1987, p. 7.

${ }^{634}$ FITZMYER, Joseph. Augustine. A Bíblia na Igreja, p. 16.

${ }^{635}$ LOPES, Geraldo. Dei verbum: texto e comentário, p. 85.

${ }^{636}$ VASCONCELOS, Pedro Lima. O Vaticano II e a leitura da Bíblia. São Paulo: Paulus, 2015, p. 7.
} 
objeto desta pesquisa ${ }^{637}$. Nessa perspectiva, cabe dizer que "o Concilio destacou, de forma positiva e expressa, o valor e a necessidade da Sagrada Escritura"638 na vida da Igreja Católica.

Como decorrência de tal afirmativa, entre os aspectos mais importantes resultantes do Concílio está a constituição dogmática Dei Verbum $^{639}$, que para Mannucci representa "a consagração oficial da renovação bíblica no campo católico" ${ }^{940}$. De fato, trata-se de uma ênfase significativa da Igreja em sua relação com as Escrituras, visto que "antes do Concílio, com efeito, o interesse pela Bíblia era visto como 'uma forma de protestantização' da Igreja"641. Um exemplo dessa ênfase ressaltada no documento se dá na própria afirmação da "transcendência da Palavra de Deus sobre o Magistério da Igreja" ${ }^{942}$, conforme preconiza a Dei Verbum $^{643}$.

O documento reforçou ainda a importância das traduções da Bíblia (DV 22), a importância do uso das Escrituras na liturgia (DV 21), no estudo exegético e nas ciências bíblicas (DV 23), na pregação (DV 21 e 24), na teologia (DV 24), na leitura pessoal (DV 25) e na oração (DV 25). De fato, são áreas fundamentais para a vida da Igreja. Sob essa abrangência, "a Dei Verbum aponta para o direito dos fiéis ao acesso à Sagrada Escritura" ${ }^{\circ 44}$.

É ressaltada também a importância do trabalho das diversas organizações/sociedades que traduzem e difundem a Bíblia, não se limitando somente às organizações católicas, como anteriormente. Os esforços resultaram numa tentativa de aproximação com os protestantes, na qual se analisou a possibilidade de que se desenvolvesse um trabalho de cooperação nas traduções bíblicas, a saber:

[...] Visto que a palavra de Deus deve estar sempre acessível a todos, a Igreja procura com solicitude maternal que se façam traduções aptas e fiéis nas várias lín-

\footnotetext{
${ }^{637}$ Por exemplo, o documento trata de forma abrangente o aspecto da Tradição colocada ao lado da Sagrada Escritura.

${ }^{638}$ LORTZ, Joseph. Historia de La Iglesia: en la perspectiva de la historia del pensamiento. Edad moderna y contemporanea. Vol. II, p. 207.

${ }^{639}$ Cf. CONCÍLIO VATICANO II. Dei Verbum. Constituição Dogmática sobre a Revelação Divina, passim. Vale ressaltar que o documento, "embora fale muito da Sagrada Escritura, não é um documento sobre a Bíblia e sim sobre a Revelação Divina". Cf. LOPES, Geraldo. Dei verbum: texto e comentário, p. 51.

${ }^{640}$ MANNUCCI, Valério. Bíblia, Palavra de Deus: curso de introdução à Sagrada Escritura, p. 9.

${ }^{641}$ LOPES, Geraldo. Dei verbum: texto e comentário, p. 64.

${ }^{642}$ MANNUCCI, Valério. Op. cit., p. 38.

643 “O Magistério não é superior à Palavra de Deus, mas está a serviço dela”. CONCÍLIO VATICANO II. Dei Verbum. (n. 10).

${ }^{644}$ MALZONI, Cláudio Vianney. As edições da Bíblia no Brasil. São Paulo: Paulinas, 2016, p. 129.
} 
guas, sobretudo a partir dos textos originais dos livros sagrados. Se, porém, segundo a oportunidade e com a aprovação da autoridade da Igreja, essas traduções se fizerem em colaboração com os irmãos separados, poderão ser usadas por todos os cristãos ${ }^{645}$.

São duas aberturas significativas. A primeira é a possibilidade de traduções vernáculas, e a segunda é a possibilidade de cooperação com os protestantes (chamados de irmãos separados) em trabalhos de tradução, onde for possível. Obviamente, essa aproximação, em muitos países, se torna difícil, principalmente por parte de grupos protestantes que rejeitam esse tipo de cooperação no trabalho bíblico. Considerando que a Bíblia não é nem católica, nem evangélica, torna-se intrigante constatar esse tipo de restrição; afinal, a Bíblia é o livro do povo cristão.

Os resultados positivos deste Concílio resultaram, ainda, em um grande movimento em torno da Bíblia por parte da Igreja Católica no século XX e início do século XXI. O surgimento da Federação Bíblica Católica é um exemplo. Por meio dessa organização, a Igreja estimulou que em cada diocese e em cada estrutura fundamental para a vida da Igreja fosse instituída uma pastoral bíblica.

O documento da Pontifícia Comissão Bíblica A Interpretação da Bíblia na Igreja ${ }^{646}$, publicado em 1993, foi um outro marco na difusão das Escrituras no seio católico. Esse documento, "unanimemente saudado por seu equilíbrio e sua abertura, corresponde perfeitamente aos esforços realizados no campo para devolver a Bíblia aos católicos"647. Schwantes, que coordenou a edição da Bibliografia Bíblica Latino-americana, destaca que esse documentou deu força à Bíblia dentro da Igreja, resultando em várias obras produzidas a partir dele ${ }^{648}$.

Todas essas ações, aprofundadas desde o Concilio Vaticano II, fizeram com fiéis, clérigos e teólogos se unissem, fazendo emergir no meio católico um grande movimento bíblico. Entre outros aspectos, muitas Bíblias foram traduzidas e publicadas, obras bíblicas para adultos e crianças foram produzidas, escolas bíblicas foram fundadas, círculos bíblicos foram estimulados, vigílias bíblicas de oração se desenvolveram e, assim, as Escrituras Sagradas passaram a ser significativamente lidas e difundidas entre os católicos. Cairns destaca ainda o surgimento das Co-

\footnotetext{
${ }^{645}$ CONCÍLIO VATICANO II. Dei Verbum, n. 22 (grifo nosso).

${ }^{646}$ Cf. Comissão Pontifícia Bíblica. A interpretação da Bíblia na Igreja. São Paulo: Paulinas, 2010 ${ }^{647}$ CANNUYER, Christian; POSWICK, Réginald-Ferdinand. Catolicismo e Bíblia. In: LONGTON, Joseph; POSWICK, Réginald-Ferdinand [et al.] (orgs.). Dicionário Enciclopédico da Bíblia, p. 286.

${ }^{648}$ SCHWANTES, Milton. Bibliografia bíblica latino-americana. São Bernardo do Campo: Programa Ecumênico de Pós-Graduação em Ciências da religião, 1995, p. 37.
} 
munidades Eclesiais de Base, que são "constituídas de leigos que estudam a Bíblia e a aplicam à sua situação social"649.

Carlos Mesters ressalta, nesse sentido, a importância que a leitura da Bíblia tem na vida das pessoas, em sua maioria pobres, que constituem essas Comunidades Eclesiais de Base. Em sua leitura, ele destaca que a Bíblia tem sido para o povo: o livro da comunidade; o livro da história do passado, mas também do presente; o livro que dá sentido à vida; o livro que leva à oração e ao exercício da fé; o livro que leva a uma prática militante em busca da dignidade; o livro que contribui para a superação das mazelas sociais; o livro que envolve toda a comunidade em sua perspectiva de vida e fé. Como se constata, a Bíblia se constitui, assim, como o livro da vida e da esperança ${ }^{650}$.

Na liturgia, o Concílio Vaticano II realizou uma mudança que urgia, por ser extremamente necessária. A língua utilizada na liturgia era, até então, o latim. Como resultado do Concílio, mesmo não abolindo o latim como língua oficial do Vaticano, se permitiu que que cada Igreja local celebre a missa na língua vernácula onde se encontra. Tal realidade contribuiu para que as Escrituras também passassem a ser lidas na língua do povo, do jeito que eles entendem.

Doravante, os católicos ouvem em sua língua materna três leituras bíblicas nas missas dominicais e festivais, ao passo que a homilia deve partir o mais possível desses textos e analisar seu conteúdo doutrinal e espiritual. [...] Para muitos católicos, a antiga "missa dos catecúmenos", hoje "liturgia da Palavra", reveste-se de uma importância igual à liturgia eucarística. Ela faz surgir a Palavra de Deus no seio da comunidade viva da Igreja e perpetua com eficácia a transmissão da Revelação divina ${ }^{651}$

A vida da Igreja ganhou, portanto, um novo sentido sob a influência da $\mathrm{Pa}$ lavra de Deus. Mesmo não tendo como analisar cada denominação ou cada igreja protestante em particular, é razoável acreditar que os católicos leiam bem mais a Bíblia em sua liturgia quando comparados com muitos cultos de algumas igrejas evangélicas. $\mathrm{O}$ culto neopentecostal e as igrejas emergentes, principalmente, têm se distanciado significativamente da centralidade da Palavra de Deus que os reformadores tanto tinham instigado. $\mathrm{O}$ entretenimento e a lógica de mercado toma-

${ }^{649}$ CAIRNS, Earle Edwin. $O$ cristianismo através dos séculos: uma história da igreja cristã, p. 524.

${ }^{650}$ Cf. MESTERS, Carlos. Flor sem defesa. Uma explicação da Bíblia a partir do povo. Petrópolis: Vozes, 1983, p. 11-29.

${ }^{651}$ CANNUYER, Christian; POSWICK, Réginald-Ferdinand. Catolicismo e Bíblia. In: LONGTON, Joseph; POSWICK, Réginald-Ferdinand [et al.] (orgs.). Dicionário Enciclopédico da Bíblia, p. 288. 
ram o lugar da Palavra. Essa é uma realidade que reflete um distanciamento do movimento evangélico em relação às Escrituras, tanto numa perspectiva histórica quanto bíblica; afinal, "a leitura da Escritura em um cenário litúrgico data da Igreja Primitiva e foi em parte herdada pelos cristãos da prática judaica no serviço da sinagoga" ${ }^{652}$.

Retornando ao aspecto católico, Gudorf reitera que há uma "entusiástica resposta dos leigos à recomendação sobre a leitura da Bíblia" ${ }^{953}$. Mesters ${ }^{654}$, nesse ínterim, destaca certos aspectos que contribuíram para a leitura da Bíblia entre os católicos no Brasil desde o Concílio Vaticano II, tais quais: realização de Semanas Bíblicas, desenvolvimento de traduções da Bíblia em língua vernácula (existem muitas traduções católicas da Bíblia em português, no Brasil, por exemplo), escassez de sacerdotes, o que, como consequência, permitiu uma maior participação de leigos na Celebração da Palavra, e a formação de uma catequese mais bíblica. Dessarte, "antes, a Bíblia era ouvida dentro do contexto sacral da liturgia. Hoje, ela é lida dentro do ambiente familiar da casa, das reuniões populares" ${ }^{255}$. Cavalcanti resume essa caminhada católica em torno da Bíblia da seguinte forma:

\begin{abstract}
A leitura popular da Bíblia se desenvolve mais especialmente a partir dos anos 70, paralelamente ao surgimento das Comunidades Eclesiais de Base. No início, tratava-se simplesmente das leituras de cada domingo na liturgia que substituía a eucaristia, lá onde o padre não podia comparecer. Pouco a pouco as pessoas começaram a se reunir para comentar os textos e ver como eles podiam iluminar a vida cotidiana. Assim nasceram os primeiros círculos bíblicos. Depois eles passaram a se articular nas paróquias e dioceses, independentemente das liturgias dominicais, pelo simples desejo das pessoas de conhecer e entender melhor a Bíblia. Essa iniciativa se espalhou rapidamente nas diversas regiões do Brasil e da América Latina, sempre tentando encontrar as relações entre a vida e a "Palavra de Deus". Surgiu então um interesse crescente pela Bíblia, e muitos textos começaram a ser lidos e comentados pelo povo mais pobre, com a ajuda de agentes de pastoral preparados para isso $^{656}$.
\end{abstract}

Por isso, como bem instiga a Dei Verbum 25, importa que a leitura bíblica, individual, em grupos de estudo ou em família, continue a ser estimulada; afinal, a

\footnotetext{
${ }^{652}$ FITZMYER, Joseph. Augustine. A Bíblia na Igreja, p. 105.

${ }^{653}$ GUDORF, Christine. O Magistério e a Bíblia: a experiência norte-americana. In: BEUKEN, Win; FREYNE, Sean; WEILER, Anton (orgs.). A Bíblia e seus leitores. Revista Concilium. Petrópolis: Vozes, 1991, p. 90.

${ }^{654}$ MESTERS, Carlos. Ouvir o que o Espírito diz às igrejas. BEUKEN, Win; FREYNE, Sean; WEILER, Anton (orgs.). A Bíblia e seus leitores. Revista Concilium. Petrópolis: Vozes, 1991, p. 114; Id. Flor sem defesa, pp. 188-202.

${ }^{655}$ Id. Por trás das palavras: um estudo sobre a porta de entrada no mundo da Bíblia, p. 38.

${ }^{656}$ CAVALCANTI, Tereza Maria Pompéia. A leitura popular da Bíblia e a V Conferência do CELAM. Atualidade Teológica, ano XI, n. 25, jan/abr. 2007, pp. 77-78.
} 
leitura das Escrituras realizada somente na liturgia, mesmo que seja "o lugar privilegiado em que os cristãos entram em contato com a Palavra de Deus" ${ }^{657}$, não é suficiente para que o povo conheça as Escrituras. Tal medida é necessária justamente porque existem certos livros bíblicos que não compõem a leitura litúrgica, seja ela anual ou trienal. A proposta de leitura pelo método da Lectio Divina ${ }^{658}$, que ganhou impulso a partir do Concílio (Dei Verbum 25), é um caminho seguro para tal estímulo; afinal, “a Bíblia é um dos veículos para o povo poder estar em contato permanente com Deus" ${ }^{\prime 659}$. O destaque concedido pela Dei Verbum 25 sobre esses aspectos refletidos acima pode ser percebido em seu próprio texto, conforme segue:

É necessário, por isso, que todos os clérigos e sobretudo os sacerdotes de Cristo e outros que, como os diáconos e os catequistas, se consagram legitimamente ao ministério da palavra, mantenham um contato íntimo com as Escrituras, mediante a leitura assídua e o estudo aturado, a fim de que nenhum deles se torne "pregador vão e superficial da palavra de Deus por não a ouvir de dentro", tendo, como têm, a obrigação de comunicar aos fiéis que lhes estão confiados as grandíssimas riquezas da palavra divina, sobretudo na sagrada Liturgia. Do mesmo modo, o sagrado Concílio exorta com ardor e insistência todos os fiéis, mormente os religiosos, a que aprendam "a sublime ciência de Jesus Cristo" (Fil. 3,8) com a leitura frequente das divinas Escrituras, porque "a ignorância das Escrituras é ignorância de Cristo". Debrucem-se, pois, gostosamente sobre o texto sagrado, quer através da sagrada Liturgia, rica de palavras divinas, quer pela leitura espiritual, quer por outros meios que se vão espalhando tão louvavelmente por toda a parte, com a aprovação e estímulo dos pastores da Igreja. Lembrem-se, porém, que a leitura da Sagrada Escritura deve ser acompanhada de oração para que seja possível o diálogo entre Deus e o homem; porque "a Ele falamos, quando rezamos, a Ele ouvimos, quando lemos os divinos oráculos" 660 .

Trata-se de um incentivo claro para que todos os católicos, leigos e sacerdotes, valorizem, leiam, divulguem e vivam as Escrituras de forma significativa e contínua no cotidiano. Outra área da Igreja Católica que ganhou significativa importância nas últimas décadas é a evangelização. Na verdade, no atual contexto católico, o termo mais apropriado seria 'Nova Evangelização'. Esse conceito está no centro das preocupações pastorais da Igreja desde o Documento de Medellín,

\footnotetext{
${ }^{657}$ MANNUCCI, Valério. Bíblia, Palavra de Deus: curso de introdução à Sagrada Escritura, p. 405.

${ }^{658}$ A temática sobre o método Lectio Divina será melhor abordada no quarto capítulo.

${ }^{659}$ MESTERS, Carlos. Flor sem defesa, p. 182.

${ }^{660}$ CONCÍlIO VATICANO II. Dei Verbum, n. 25.
} 
pelo menos. Mas a maior ênfase foi dada, de fato, na Assembleia do Episcopado Latino-Americano em Santo Domingo, em $1992^{661}$.

Dentro da Igreja, percebeu-se que o conceito de "cristandade" em que as pessoas são católicas por simplesmente nascerem em uma família ou em um país cristão - e depois passam por certos ritos (batismo, casamento etc.) — não é suficiente para o bom desenvolvimento da fé. Sendo assim, esse tipo de fiel precisa passar por uma Nova Evangelização que, entre outros aspectos, resgata a importância da Bíblia nesse desafio missionário contemporâneo.

Mesters, ao descrever esse desafio sob a ótica da relação entre eclesialidade e missão, pressupõe que as experiências bíblicas do povo de Deus na história constituem um paradigma que precisa ser visitado pela Igreja de hoje. Em outras palavras, a Igreja precisa olhar para a Bíblia, aprender com ela para, a partir dela, contextualizando corretamente, conseguir realizar de forma relevante e bíblica sua tarefa de evangelização e missão. Para ele, é preciso "acender a lâmpada da Escritura para que a Palavra de Deus possa iluminar o caminho"662. Nessa perspectiva, a "Sagrada Escritura é a grande fonte de alimentação e dinamização da espiritualidade da Nova Evangelização" ${ }^{663}$. A Bíblia se estabelece, portanto, como um paradigma de evangelização e missão na vida da Igreja.

Cabe ressaltar, ainda, alguns aspectos importantes sobre o ensinamento da Igreja Católica a respeito da leitura da Bíblia no contexto atual. Em primeiro lugar ficou evidente a forte união que deve haver entre a Sagrada Escritura, a Tradição e o magistério da Igreja (DV 10). Este é um principio salutar para a Igreja Católica em toda a sua história. Nesse sentido,

A tradição não é uma fonte de fé independente da escritura. A tradição na Igreja é a "transmissão total e viva da verdade na Igreja hierárquica, cujo órgão central é a escritura inspirada". A escritura precisa ser explicada. Ela só mantém o seu significado completo e autêntico quando permanece "imerso nesta tradição viva da igreja"664

${ }^{661}$ Cf. CONFERÊNCIA GERAL DO EPISCOPADO LATINO-AMERICANO IV. Nova evangelização, promoção humana, cultura cristã: Jesus Cristo ontem, hoje e sempre. Conclusões de Santo Domingo. São Paulo: Loyola, 1992.

${ }^{662}$ MESTERS, Carlos. Eclesialidade e missão: reflexões a partir da Bíblia. Rio de Janeiro: Conferência dos Religiosos do Brasil, 1992, p. 29.

${ }^{663}$ Id. A Bíblia na nova evangelização. Belo Horizonte: [s.n], 1991, p. 6.

${ }^{664}$ LORTZ, Joseph. Historia de La Iglesia: en la perspectiva de la historia del pensamiento. Edad moderna y contemporanea. Vol. II, pp. 154-155 (tradução nossa, grifo nosso). 
Por outro lado, a igreja também busca instigar uma leitura das Escrituras baseada no reconhecimento dos gêneros literários específicos (históricos, proféticos, poéticos ou outros), através dos quais os autores sagrados se expressaram. Nesse sentido, importa que o intérprete contemporâneo busque o sentido que estes autores bíblicos em determinadas circunstâncias, segundo as condições do seu tempo e da sua cultura, pretenderam exprimir servindo-se dos gêneros literários então utilizados. Para se entender corretamente o que os autores sagrados quiseram afirmar, devem-se levar em conta os modos próprios de sentir, dizer ou narrar em uso no tempo deles, como também os modos que então se empregavam frequentemente nas relações entre os seres humanos (DV 12). Em outras palavras, são endossadas as ciências auxiliares e o método histórico-crítico, isto é, o método oficial para a interpretação da Bíblia na Igreja Católica.

Atrelada a essa questão se evidencia a necessidade da realização de um diálogo das Escrituras com a contemporaneidade, incluindo os diversos saberes legítimos por meio de uma correta leitura da realidade. Segundo o Concílio, a lei de toda a evangelização é pregar a Palavra de Deus de maneira adaptada à realidade dos povos. Deve haver, portanto, um intercâmbio permanente entre a Igreja e as diversas culturas. Para isso, a Igreja Católica expressa a necessidade da ajuda dos que conhecem bem as várias instituições e disciplinas, sejam eles crentes ou não. A Igreja reforça, nesse sentido, o dever de todo o Povo de Deus e sobretudo dos pastores e teólogos, com a ajuda do Espírito Santo, saber ouvir e interpretar as várias linguagens ou sinais do tempo hodierno, para avaliá-los adequadamente à luz da Palavra de Deus, de modo que a verdade revelada seja melhor percebida, compreendida e apresentada de modo conveniente ${ }^{665}$.

Para além destes aspectos, a Igreja Católica também reitera um alerta contra o extremismo do fundamentalismo bíblico. O documento $A$ interpretação da Bíblia na Igreja ${ }^{666}$ traz a seguinte conclusão sobre este assunto:

A abordagem fundamentalista é perigosa, pois ela é atraente para as pessoas que procuram respostas bíblicas para seus problemas da vida. Ela pode enganá-las oferecendo-lhes interpretações piedosas, mas ilusórias, ao invés de lhes dizer que a Bíblia não contém necessariamente uma resposta imediata a cada um desses problemas. O fundamentalismo convida, sem dizê-lo, a uma forma de suicídio do pensamento. Ele coloca na vida uma falsa certeza, pois ele confunde inconscientemen-

${ }^{665}$ CONSTITUIÇÃO PASTORAL Gaudium et spes. Documentos do. Concílio Ecumênico Vaticano II. São Paulo: Paulus, 1997, GS 44.

${ }^{666} \mathrm{Cf}$. Comissão Pontifícia Bíblica. A interpretação da Bíblia na Igreja, capítulo F. 
te as limitações humanas da mensagem bíblica com a substancia divina dessa mensagem.

Como se percebe, muito foi e tem sido realizado, e isso é relevante no trabalho de difusão das Escrituras. Por outro lado, a luta continua e há muito que fazer; afinal, a difusão das Escrituras sempre acompanhará a história da Igreja. O Concílio Vaticano II abriu a porta da Bíblia; cabe à Igreja Católica manter essa porta aberta. Nesse sentido, Vasconcelos, ao dissertar sobre a importância da Bíblia na Igreja a partir do Concílio, serve de conclusão a esta seção, ao destacar que "os padres conciliares não temem reconhecer, mesmo implicitamente, que muito está para ser feito, e em boa parte porque os séculos anteriores priorizaram a restrição ao acesso à Bíblia"667.

\subsubsection{2}

\section{O Sínodo dos bispos: continuidade e avanços sobre a importância da Palavra de Deus na vida da Igreja Católica}

A ênfase nas Escrituras provocada pela Dei Verbum e levada adiante pelos mais diferentes movimentos católicos culminou em encontros significativos na história da Igreja Católica. No Brasil, entre outros, ressaltam-se, por exemplo, a $48^{\text {a }}$ Assembleia Geral dos Bispos do Brasil, realizado em Brasília (DF), no ano de 2010, que teve como tema "Discípulos e servidores da Palavra de Deus e a missão da Igreja no mundo" e o $1^{\circ}$ Congresso Brasileiro de Animação Bíblica de Pastoral, realizado em Gôiania (GO), no ano de 2011.

Contudo, de forma especial, um encontro marcante quando pensado sob a ótica da Palavra de Deus na vida da Igreja Católica presente em todo o mundo, foi, sem dúvida, o Sínodo dos bispos Católicos, realizado no Vaticano entre os dias 5 e 26 de outubro de 2008, e cuja temática foi "Palavra de Deus na vida e na missão da Igreja". Semelhante ao que ocorre na preparação de um Concílio, há também um documento prévio de preparação ao Sínodo, em que se apresentam reflexões e sugestões dos bispos do mundo inteiro que poderão ser discutidas na assembleia. Como resposta a esse levantamento, o Sínodo estabeleceu sua temática sob a pretensão de "estender e revigorar a prática do encontro com a Palavra

\footnotetext{
${ }^{667}$ VASCONCELOS, Pedro Lima. O Vaticano II e a leitura da Bíblia, p. 45.
} 
como fonte de vida" ${ }^{\prime 668}$. Mais uma vez, portanto, se percebeu o desejo dos bispos de todo o mundo em torno do assunto.

Um sínodo de bispos, que como uma instituição regular da Igreja é fruto do Concílio Vaticano II, tem por objetivo contribuir com o governo pastoral da Igreja em todo o mundo, mesmo que, como tal, se caracterize por um caráter consultivo. Nesse sentido, os bispos reunidos, inclusive de igrejas orientais, podem "aconselhar o papa sobre assuntos gerais da Igreja"669, e o papa, por sua vez, se entender por bem, pode publicar um documento que servirá de orientação para a Igreja. Foi nessa perspectiva que, dois anos após a realização do Sínodo sobre a Palavra de Deus, o papa Bento XVI apresentou a Exortação Apostólica Pós-Sinodal denominada de Verbum Domini ${ }^{670}$

O documento foi formulado em três partes, além da introdução e conclusão. A primeira parte do documento recebeu o título de Verbum Dei e ali se ressaltou a iniciativa de Deus ao falar com o ser humano; a segunda, denominada de Verbum in Ecclesia, destacou a importância da Palavra de Deus na vida da Igreja e, a última parte, Verbum in mundo, discorreu sobre a Palavra de Deus no mundo. Por todo o documento se evidenciou a importância da Palavra de Deus em todos os níveis da vida, da família, da Igreja, da teologia, da hermenêutica, da homilia, da catequese, da missão, da liturgia, da oração, da evangelização, do estudo acadêmico, da cultura, da sociedade, do diálogo e do mundo em que se busca a justiça e a paz $^{671}$. O papa concluiu o documento conclamando que se ame a Palavra de Deus (VD 121) a ponto de ela ser anunciada, acolhida, celebrada e meditada na Igreja.

Como se percebe, há, de fato, por parte da Igreja Católica, um despertar em torno da Bíblia que vem crescendo desde aproximadamente um século. Percebe-se um claro incentivo para que os cristãos católicos leiam, conheçam, estudem e vivam as Escrituras. Tal realidade é positiva para a Igreja, para a sociedade e para a fé cristã.

\footnotetext{
${ }^{668}$ LOPES, Geraldo. Dei verbum, p. 71.

${ }^{669}$ Ibid., p. 69.

${ }^{670}$ PAPA BENTO XVI. Exortação Apostólica Verbum Domini. São Paulo: Paulinas, 2011.

${ }^{671}$ Ibid, pp. 15-212.
} 


\subsubsection{2}

\section{Contemporaneidade protestante e as Escrituras Sagradas}

“As Igrejas da Reforma do século XVI nasceram, involuntariamente, da leitura das Escrituras" ${ }^{672}$. Esse é um pressuposto básico que se deve ressaltar, visto que, histórica e popularmente, os protestantes sempre foram reconhecidos pelo seu apego à Bíblia. Vale ressaltar que, às vezes, esse apego leva à um biblicismo cego, sem sentido e extremamente prejudicial para a igreja. Nessa pesquisa, muito já foi apresentado sobre como os protestantes se relacionaram com as Escrituras no momento pós-reforma. As eras do confessionalismo, do puritanismo, do pietismo, do liberalismo e da neo-ortodoxia foram momentos importantes nessa relação. Como consequência desses tempos passados, cabe aqui apresentar somente uma síntese de todos esses aspectos na atual igreja protestante, principalmente no Brasil dos últimos anos.

Antes, é preciso esclarecer que não há como falar de uma igreja protestante específica e exclusiva. Como consequência de todo o aspecto histórico já delineado, os protestantes se caracterizaram pela diversidade de igrejas e doutrinas. Essa diversificação se dá tanto no aspecto denominacional (muitas e variadas igrejas) quanto no aspecto teológico-doutrinário (igrejas históricas, igrejas pentecostais, igrejas neopentecostais, igrejas independentes, comunidades etc.). Como se constata, essa realidade parece não se alterar, afinal, a cada dia surgem mais e mais igrejas $^{673}$, demonstrando ser esse um caminho que, em tese, não tem mais retorno, nem solução. Aliás, a influência do atual pós-modernismo na vida religiosa contemporânea só vem reforçar e ampliar tal realidade ${ }^{674}$.

Contudo, resulta que, mesmo sob percalços e dificuldades, divisões e rupturas, as igrejas protestantes, também chamadas atualmente de igrejas evangélicas, continuam a ser reconhecidas por sua dedicação às Escrituras ${ }^{675}$. Nessa perspectiva, a Bíblia ainda constitui o vínculo basilar entre as mais diferentes igrejas; afinal, como herança da Reforma, a maioria ainda tem a Bíblia como autoridade final

\footnotetext{
672 VOUGA, François. Protestantismo e Bíblia. In: LONGTON, Joseph; POSWICK, RéginaldFerdinand [et al.] (orgs.). Dicionário Enciclopédico da Bíblia, p. 1102.

${ }^{673}$ Cf. GRILO, Marcelo. O Globo. Desde 2010, uma nova organização religiosa surge por hora.

${ }^{674}$ Cf. AZEVEDO, Marcos. Modernidade e pós-modernidade: desafios à vida e à fé cristã. São Paulo: Fonte Editorial, 2015, p. 100.

${ }^{675}$ Vale lembrar que cada denominação protestante também possui Catecismos, Confissões de Fé, Manual de Doutrina etc. que constituem os princípios doutrinários que as regem. Ainda que estes referenciais doutrinários sejam importantes em cada respectiva deominação, todos eles estão submetidos às Escrituras em sua ordem de importância.
} 
e como regra de fé e prática. Mesmo que as doutrinas particulares possam separálos, a Bíblia os unirá. De fato, independentemente da denominação, na fé evangélica, ler, estudar e propagar a Bíblia dão significado à sua existência e constituem parte fundamental de sua missão no mundo. "Daí a legitimidade das sociedades bíblicas que se consagram na tradução e na edição da Bíblia numa perspectiva missionária, mas também de movimentos significativamente vivos que alimentam o protestantismo com uma disciplina de leitura da Bíblia"

Para além disso, Cairns destaca que mais recentemente, "tem se dado mais atenção ao estudo da Bíblia em seminários, universidades e pequenos grupos"677. Ler, pregar, ensinar e difundir a Bíblia é algo inerente a quase todo cristão evangélico, visto que, pelo menos em tese, a ética protestante é firmada e reafirmada continuamente sobre as Escrituras. A vida, portanto, é marcada e influenciada por essa realidade.

Pode-se dizer que esse ainda é um diferencial para maioria dos evangélicos e de suas respectivas igrejas, pois "as diferentes famílias protestantes guardam de suas origens o caráter de religião da Bíblia que faz sua particularidade na diversidade de cristianismos" ${ }^{\text {"678 }}$. A casa da família protestante, nesse sentido, é o ambiente singular e apropriado para a leitura bíblica. Se lê a Bíblia em casa; se lê para estudá-la; se lê para realizar a devoção; se lê para encontrar as respostas mais urgentes e sê lê para entender qual é a vontade de Deus para a vida ${ }^{679}$. Obviamente, a lista não para por aí. No protestantismo, sem desconsiderar a leitura comunitária, litúrgica ou familiar, a leitura bíblica ela ganha significado também quando lida na individualidade. Para o protestante, a "vida espiritual" só tem vigor se diariamente ele orar e ler a Bíblia.

Na medida em que a dedicação do crente no catolicismo se expressa em sua participação na missa e nos sacramentos, no protestantismo ela se manifesta na leitura regular da Bíblia. [...] Essa prática, muito divulgada, deu origem a uma abundante literatura de guias bíblicos e de planos de leitura para cada dia ${ }^{680}$.

\footnotetext{
676 VOUGA, François. Protestantismo e Bíblia. In: LONGTON, Joseph; POSWICK, RéginaldFerdinand [et al.] (orgs.). Dicionário Enciclopédico da Bíblia, p. 1104.

677 CAIRNS, Earle Edwin. O cristianismo através dos séculos: uma história da igreja cristã, p. 579.

${ }^{678}$ VOUGA, François. Protestantismo e Bíblia. Op. cit., p. 1102.

${ }^{679}$ Cf. PETERSON, Eugene [et al.]. Ouvindo a Deus: uma abordagen multidisciplinar da leitura bíblica, pp. 94-107.

${ }^{680}$ VOUGA, François. Protestantismo e Bíblia. Op. cit., p. 1108.
} 
A Bíblia é, portanto, o livro de cabeceira e o livro de todas as horas. Da parte dos ministros estabelecidos nas igrejas, cabe o estímulo para que os fiéis leiam as Escrituras com assiduidade e seriedade; afinal, pelo menos em tese, para o crente protestante, "a leitura da Bíblia não é uma obrigação, mas um imenso privilégio" $" 681$.

A consequência dessa valorização das Escrituras nas igrejas protestantes tem direta relação com o conceito de igreja que lhes é comum. Esse conceito, inclusive, se reflete na forma como os protestantes vivem sua fé. Em outras palavras, a autoridade normativa que a Escritura tem em suas vidas, vinculada à liberdade de leitura bíblica individual de cada fiel, resultam no princípio do sacerdócio universal dos crentes. Nessa perspectiva, leigos e ministros estão em pé de igualdade, porque estão sujeitos pelo mesmo critério de valor, isto é, as Escrituras Sagradas. Leigos e ministros, portanto, leem a Bíblia da mesma forma, pois eles são iguais perante Deus e perante as Escrituras. Obviamente, tal postura pode apresentar consequências positivas ou negativas, se assim se pode falar, pois esse tipo de leitura "permite compreender a tendência ao individualismo que caracteriza por vezes o protestantismo. No entanto, ela faz ao mesmo tempo do paroquiano um parceiro exigente da pesquisa teológica e, sobretudo, constitui uma das grandes forças espirituais das Igrejas da Reforma" ${ }^{682}$.

A leitura individual ou em família, obviamente, não exclui o uso das Escrituras na igreja, na leitura pública, na pregação e no estudo bíblico. Além do culto, é muito comum que ocorram encontros para ler e estudar a Bíblia de forma coletiva. Esses encontros podem ser reuniões temáticas, onde o foco é o "estudo bíblico", ou na tradicional "Escola Bíblica Dominical”. O estudo bíblico serve para edificação - pessoal e coletiva —, evangelização, doutrinação e reflexão sobre temas que relacionam as Escrituras e a fé cristã com o cotidiano. A partir desses encontros, muitos leigos despertam para o serviço cristão e aprofundam seu conhecimento da Palavra de Deus. A intenção primordial desses estudos é sempre de aproximar o fiel às Escrituras, visto que, como característica específica da teologia

\footnotetext{
${ }^{681}$ MACINTOSH, Mike. Apaixone-se pela Bíblia. Curitiba: AD Santos, 2007., p. 41.

${ }^{682}$ VOUGA, François. Protestantismo e Bíblia. In: LONGTON, Joseph; POSWICK, RéginaldFerdinand [et al.] (orgs.). Dicionário Enciclopédico da Bíblia, p. 1108.
} 
bíblica protestante, "cada pessoa entra em contato com Deus pela Bíblia, sem a intervenção de homens" 683 .

Nas últimas décadas, uma nova estratégia de estudo bíblico tem sido amplamente utilizada pelas mais diversas igrejas evangélicas. Trata-se da realização de encontros semanais em torno da Bíblia (ou de temas bíblicos), realizados por grupos pequenos que se encontram nas casas de algum anfitrião voluntário. Geralmente, essa estratégia tem por objetivo a comunhão, a evangelização e o crescimento espiritual. Assim, além do engajamento da própria irmandade, procura-se também convidar amigos e vizinhos para participar. Dessa forma, enquanto se estuda a Bíblia, aproveita-se também para evangelizar por meio dela. Tudo ocorre normalmente sob a ênfase do estudo da Palavra de Deus de forma um pouco menos formal quando comparado ao estudo bíblico realizado nos templos. Muitas vezes, inclusive, se aproveita para comentar e aplicar a mensagem pregada no último sermão pastoral. Os nomes dados a essa estratégia por cada denominação podem variar, a saber: células, pequenos grupos, grupos caseiros, PGs etc. ${ }^{684}$

Já no aspecto litúrgico, como herança dos reformadores, "a leitura da Bíblia e a pregação constituem o centro do culto protestante" ${ }^{685}$. Histórica e tradicionalmente, a maioria das igrejas evangélicas inicia a sua liturgia com a leitura da $\mathrm{Pa}-$ lavra. Em alguns casos, leituras bíblicas também podem ocorrer de forma intercalada entre as músicas ou, da mesma forma, por pessoas que em algum momento venham a participar do ato litúrgico, dando uma saudação, contando um testemunho etc. O clímax, porém, de qualquer culto protestante está na proclamação das Escrituras Sagradas, isto é, na pregação da Palavra de Deus. Essa valorização da pregação no culto protestante, como se constatou, tem sua origem nos primórdios da Reforma, pois, para Lutero, "quando a Palavra é dita, eis a Igreja. Ela não cria a Palavra, ela é criada pela Palavra" ${ }^{\text {686. }}$.

Há de se constatar, no entanto, que muitas igrejas na atualidade, optando por reuniões "mais atrativas", têm abandonado o tempo de pregação, de estudo e de leitura da Bíblia em seus encontros, substituindo-o por eventos ou elementos de

\footnotetext{
${ }^{683}$ AUGUSTIJN, Cornelis. Os reformadores do século XVI e a Bíblia, p. 74.

${ }^{684}$ Cf. BEZERRA, Cícero. Os 10 Mandamentos do líder de grupos caseiros. Belo Horizonte: Gráfica Betânia, 2009, pp. 11-14.

${ }^{685}$ VOUGA, François. Protestantismo e Bíblia. In: LONGTON, Joseph; POSWICK, RéginaldFerdinand [et al.] (orgs.). Dicionário Enciclopédico da Bíblia, p. 1108.

${ }^{686}$ LUTERO apud VOUGA, François. Protestantismo e Bíblia. In: LONGTON, Joseph; POSWICK, Réginald-Ferdinand [et al.] (orgs.). Dicionário Enciclopédico da Bíblia, p. 1109.
} 
entretenimento gospel que atraiam mais pessoas. Em muitos cultos, o que se percebe é que a quantidade de músicas cantadas ou de palestras motivacionais realizadas tiraram a centralidade outrora concedida pelos protestantes à Palavra de Deus. Como consequência, em muitas igrejas, "a exposição bíblica semanal não é feita pela maioria dos pastores" ${ }^{687}$. O que era uma marca protestante está se tornando uma vaga lembrança histórica, devido ao espírito pragmático que tem dominado a agenda de muitas igrejas. A decorrência deste tipo de escolha que abandona a Palavra de Deus ou a mistura com elementos alheios à fé cristã é "um ato de culto que se torna crescentemente antropocêntrico e pagão"688.

Nesse sentido, Seibert, ao dissertar sobre a função da Bíblia na igreja local, em contraposição ao "fenômeno da diminuição do conhecimento bíblico que se pode verificar" ${ }^{\prime 69}$, ressalta a importância da ênfase que deve ser dada no uso das Escrituras em todas as atividades da Igreja. Em harmonia com a teologia reformada, o autor ressalta que a Palavra de Deus cria e fortalece a igreja. Sob essa ótica, portanto, Seibert destaca cinco expressões bíblicas que caracterizaram a igreja primitiva do Novo Testamento e que, por consequência, devem servir de paradigma à igreja atual em sua relação com a Palavra de Deus enquanto realiza a sua missão. São elas: adoração, ensino, testemunho, comunhão e serviço ${ }^{690}$.

Concomitantemente, se faz necessário apreender como se dá a relação entre teologia e Escrituras. Nessa perspectiva, a teologia protestante é, pelo menos em tese, uma teologia julgada e, ao mesmo tempo, firmada nas Escrituras. Vale ressaltar, porém, que a pluralidade denominacional entre os protestantes se reflete, também, na pluralidade teológica. $\mathrm{Na}$ teologia protestante encontramos vários tipos de abordagem, que vão desde os grupos mais liberais até os mais fundamentalistas; desde críticos à Bíblia até literalistas em sua leitura e interpretação. Por isso, mesmo sendo difícil defini-los, vale a pena observar alguns aspectos gerais entre os protestantes históricos, pentecostais e neopentecostais.

Nas igrejas protestantes históricas, a teologia sempre teve seu lugar de primazia. A maioria dos cursos realizados pelos seminários confessionais dessas igrejas dão significativa ênfase ao estudo da teologia bíblica em seus currículos.

\footnotetext{
${ }^{687}$ LACHLER, Karl. Prega a Palavra. São Paulo: Vida Nova, 1990, p. 9.

${ }^{688}$ Cf. SCHERTLEY, Brian. Sola Scriptura e o princípio regulador do culto, p. 59.

${ }^{689}$ SEIBERT, Erni Walter. A função da Bíblia na Igreja local. In: ZIMMER, Rudi. Manual do Seminário de Ciências Bíblicas, p. 99.

${ }^{690}$ Cf. Ibid., pp. 102-112.
} 
Geralmente, há pouca filosofia e muito estudo voltado para a teologia bíblica e sistemática. Mesmo que essa seja a realidade mais ampla, não se nega o fato de que o liberalismo teológico também influenciou certas instituições (e até mesmo certas igrejas) em décadas passadas ${ }^{691}$. Atualmente, entretanto, tanto as igrejas como os seminários teológicos confessionais ligados ao protestantismo histórico, em sua maioria, resgataram e firmaram seu estudo teológico como o lugar onde se aprende a Palavra de Deus ${ }^{692}$.

No passado, as igrejas pentecostais surgiram com um certo discurso de aversão à educação teológica formal. Pelo rápido crescimento e abrangência, as Assembleias de Deus no Brasil, por muito tempo, preferiram formar seus ministros nas Escolas Bíblicas de Obreiros, uma espécie de treinamento intensivo e informal, intercalado por grandes encontros que reuniam todos os obreiros da denominação em um certo lugar. Essa prática nasceu e foi influenciada diretamente pelos fundadores suecos das Assembleias de Deus, pois "na Suécia, só havia, na época, as escolas bíblicas de três meses; uma espécie de curso intensivo para formar pregadores pentecostais" ${ }^{\prime 693}$. De forma generalizada, os obreiros eram ensinados que o melhor "seminário é nos pés do Senhor" e que "São Pedro não foi formado em nenhum seminário" ${ }^{\circ 94}$. Historicamente se percebe que a formação teológica e bíblica era muito rasa no contexto assembleiano. Isso não significa, obviamente, que não havia um interesse pelo estudo da Bíblia. Dentro das devidas limitações, desde o início, sempre houve interesse pelo estudo bíblico no meio pentecostal, que por sua vez proporcionou uniformidade doutrinária aos seus respectivos grupos durante um bom tempo.

Mais recentemente, algumas igrejas pentecostais chegaram a criar cursos teológicos mais práticos e mais curtos, como ocorreu, por exemplo, na formação teológica dos ministros da Igreja do Evangelho Quadrangular, cujo período de

${ }^{691}$ Cf. COSTANZA, José Roberto da Silva. As raízes históricas do liberalismo teológico. Fides Reformata X, n. 1, 2005, pp. 79-99.

${ }^{692}$ Um exemplo dessa ênfase bibliocêntrica é a apresentação institucional do Seminário Teológico Presbiteriano Reverendo Ashbel Green Simonton (da Igreja Presbiteriana do Brasil) que afirma ser um seminário teológico com o objetivo de "oferecer sólido conhecimento bíblico-teológico". Cf. SEMINÁRIO TEOLÓGICO PRESBITERIANO REVERENDO ASHBEL GREEN SIMONTON. Desenvolvido pela Igreja Presbiteriana do Brasil, 2017. Apresenta os aspectos institucionais e doutrinários da instituição. Disponível: <http://www.seminariosimonton.com.br/oseminario/quem-somos>. Aceso em 17 out. 2017.

${ }^{693}$ ARAUJO, Isael. Dicionário do movimento pentecostal. Rio de Janeiro: CPAD, 2007, p. 560.

${ }^{694}$ ALENCAR, Gedeon. Assembleias brasileiras de Deus: Teorização, história e tipologia. Tese (Doutorado em Teologia). São Paulo: Pontifícia Universidade Católica de São Paulo, 2012, p. 89. 
formação em sua instituição de ensino, o Instituto Teológico Quadrangular, era, até pouco tempo, de um a três anos ${ }^{695}$. Ainda que com um período de formação relativamente curto, a teologia bíblica, contextualizada obviamente sob o enfoque da teologia pentecostal e confessional, constituía parte fundamental na formação teológica desses ministros.

Esse distanciamento pentecostal que caracterizou o surgimento do movimento vem se alterando já há algum tempo. Constata-se uma busca crescente e contínua por formação teológica e bíblica, de qualidade, entre os pentecostais históricos ${ }^{696}$. A própria Igreja Evangélica Assembleia de Deus, por meio de sua convenção geral (CGADB) e suas respectivas convenções regionais, criou várias faculdades de teologia. Nessa mesma perspectiva, a CPAD (Casa Publicadora das Assembleias de Deus no Brasil) se tornou uma das maiores editoras cristãs do Brasil, com muitos títulos teológicos publicados, com um catálogo composto de obras das mais diferentes correntes existentes na teologia cristã.

Nas igrejas neopentecostais, sob um aspecto mais amplo, pouco se fala de teologia e, quando se fala, é normalmente para criticá-la. Muitas igrejas são, inclusive, contra que seus membros participem de qualquer formação teológica formal. Tal fato evidencia o tipo e a qualidade de formação que os ministros dessas igrejas recebem. Para alguns deles, a teologia é fria e pode até afastar o ser humano de Deus. Importa, pelo contrário, uma formação mais pragmática, em que se busca fazer o que dá certo para atrair mais pessoas às igrejas. As Escrituras recebem, nessa perspectiva, uma interpretação tendenciosa ou relativista. Na maioria das vezes, se busca no texto o que se quer dizer, e não o que o próprio texto realmente diz. E, assim, uma teologia antibíblica, como, por exemplo, a Teologia da Prosperidade - se realmente podemos designá-la como teologia — se constitui o centro da pregação, sob a alegação de que tudo que é falado está nas "Escritu-

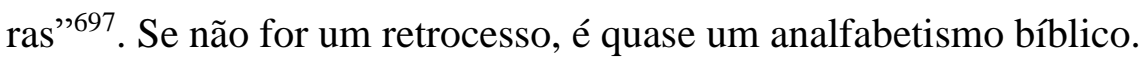

\footnotetext{
${ }^{695}$ Cf. ITQ - Instituto Teológico Quadrangular. Desenvolvido por Igreja do Evangelho Quadrangular, Minas Gerais, 2014. Apresenta a história, os métodos e a grade curricular do curso de teologia oferecido pela instituição. Disponível em: < http://www.quadrangular.org/ieq1regiao/institutoteologico-quadrangular-2/>.

${ }^{696}$ Cf. ALENCAR, Gedeon. Assembleias brasileiras de Deus: Teorização, história e tipologia, pp. 188-189.

${ }^{697}$ Cf. MARIANO, Ricardo. Expansão pentecostal no Brasil: o caso da Igreja Universal. Estud. av. São Paulo, v. 18, n. 52, pp. 124, 130 e 133. Considerando que a Igreja Universal do Reino de Deus não se enquadra no perfil de uma igreja pentecostal, o título mais adequado para o artigo de Mariano seria "Expansão neopentecostal no Brasil...".
} 
Como ressaltado anteriormente, é difícil conceituar, com exatidão, como está a difusão das Escrituras em cada denominação evangélica. Por sua pluralidade e fragmentação, não há análise que alcance sua extensão. Entretanto, diante do cenário religioso atual, intrínseco ao mundo protestante, constata-se a necessidade de os movimentos mais recentes, surgidos por meio das igrejas independentes e neopentecostais, se voltarem mais intensamente para as Escrituras e, assim, as igrejas oriundas da Reforma manterem seu apego e seu legado historicamente firmados na Bíblia Sagrada.

Sob uma perspectiva mais ampla, que alcança tanto católicos quanto protestantes, vale a pena trazer à tona uma advertência preocupante de Mesters em relação a esse tempo atual. Não há como negar que, diante das opções pós-modernas que enfatizam o relativismo, o pluralismo, o pragmatismo, o humanismo etc., temse percebido o crescimento de várias barreiras, as quais se erguem contra a difusão das Escrituras Sagradas na atualidade. Sem dúvida, o mundo hodierno tem se constituído sob a crítica e sob a oposição à Bíblia.

Entretanto, essa forma de lidar com as Escrituras não se limita à sociedade. É possível constatar que, "a Bíblia parece estar perdendo terreno até nas igrejas, cujas preocupações básicas hoje se dirigem mais para o campo social e para os problemas humanos" ${ }^{698}$. Quando se faz tal afirmação, não está se excluindo a importância que deve ser dada aos problemas humanos e sociais. Eles têm a sua importância e o seu lugar na vida, até mesmo na missão da igreja. A questão que preocupa é que, sob o discurso de que a igreja tem que se tornar "aceitável", "adaptável" e "relevante" ao mundo contemporâneo, as Escrituras estão sendo abandonadas em detrimento do que se prega como politicamente correto a se fazer.

\section{4 \\ A difusão das Escrituras Sagradas no Brasil Colônia e início do Império}

Enquanto a Europa do século XVI era estremecida pela Reforma, do outro lado do mundo, uma nova realidade começava a surgir. Um "Novo Mundo" tinha

\footnotetext{
${ }^{698}$ MESTERS, Carlos. Por trás das palavras: um estudo sobre a porta de entrada no mundo da Bíblia, p. 53.
} 
sido descoberto. Desde o início, a colonização das Américas por nações europeias foi realizada sob a presença imediata de missionários cristãos.

$\mathrm{Na}$ América do Norte, missionários ingleses ajudaram a construir uma sociedade pautada nos valores e na ética protestante. Quando eles chegaram, trouxeram também suas Bíblias. Para os grupos indígenas que lá viviam, traduções da Bíblia chegaram a ser produzidas, como foi o caso da Bíblia na língua dos algonquinos, localizados na Baía de Massachussetts. John Eliot, missionário inglês, "traduziu a Bíblia inteira em 1658"699 para esse idioma. Essa foi a primeira Bíblia traduzida na América.

Na América Latina, missionários portugueses e espanhóis ajudaram a construir uma sociedade pautada nos valores e na ética católica. No caso da descoberta do Brasil, mais especificamente, o que se sabe é que, "como acontecia em todas as viagens portuguesas, havia capelães a bordo. No caso de Cabral em sua descoberta do Brasil vieram oito franciscanos junto com o frei Dom Henrique Soares de Coimbra"700, que celebrou a primeira missa no país. A colonização estava atrelada, portanto, à propagação da fé, algo fundamental para o português daquela épo$\mathrm{ca}^{701}$.

Como reação à Reforma ocorrida na Europa, como já visto, a Contrarreforma estabeleceu algumas estratégias, entre as quais a recém-criada Companhia de Jesus, que exerceu significativa participação no desejo católico de resgate e propagação da fé ao mundo. E assim, os jesuítas chegaram ao Brasil alguns anos depois de seu descobrimento, com a desafiadora missão de cristianizar os povos que viviam nas terras "tupiniquins".

Pouco se sabe a respeito das Bíblias que vieram em suas bagagens. Apesar disso, os missionários jesuítas, que chegaram ao Brasil em 1549, "passavam adiante o material bíblico oralmente, como nos primeiros tempos"702. Assim foi o início da difusão das Escrituras no Brasil, isto é, era uma distribuição voltada para a oralidade do conteúdo bíblico, e não pelo exemplar da Escritura em si. Sob esse viés, nesta seção será analisado como se deu esse trabalho inicial, principalmente

\footnotetext{
${ }^{699}$ MILLER, Stephen; HUBER, Robert. A Bíblia e sua história: o surgimento e o impacto da Bíblia, p. 185.

${ }^{700}$ CÉSAR, Elben Magalhães Lenz. História da evangelização do Brasil: dos jesuítas aos neopentecostais. Viçosa: Ultimato, 2000, p. 20.

${ }^{701}$ Cf. VAINFAS, Ronaldo. Trópico dos pecados: moral, sexualidade e inquisição no Brasil. Rio de Janeiro: Nova Fronteira, 1997, p. 15.

${ }^{702}$ MILLER, Stephen; HUBER, Robert. Op. cit., p. 184.
} 
no tempo de permanência dos jesuítas no Brasil. Essa realidade será alterada mais de duzentos anos depois, com a expulsão dos jesuítas do país e, posteriormente, com a chegada do rei de Portugal, D. João VI, em 1808 ao Brasil. Para analisar estes fatos específicos, porém, uma nova análise será realizada no próximo capítulo, visto que coincidirá com o trabalho das Sociedades Bíblicas no país.

Há pouca obra produzida em língua portuguesa que descreva como foi esse processo de difusão das Escrituras no Brasil durante o período do Brasil Colônia e início de Império. Entre possíveis outros, nessa pesquisa serão destacados três autores que trabalharam um pouco mais com essa questão. O primeiro é João Evangelista Martins Terra, que escreveu a obra A Bíblia e a Evangelização do Brasil $^{703}$. Sua análise remonta os primeiros passos da evangelização logo após a descoberta do Brasil pelos portugueses. O segundo é Luiz Antonio Giraldi, que escreveu a obra A Bíblia no Brasil Império: como um livro proibido durante o Brasil colônia tornou-se umas das obras mais lidas nos tempos do Império $^{704}$. Apesar de apresentar alguns traços que remontam o período colonial, Giraldi se concentra mais no período do Brasil Império, com a chegada de D. João VI ao Brasil. O último é Elben M. Lenz César, que na obra História da Evangelização no Brasil apresenta como se deu o processo de evangelização do tempo dos jesuítas aos neopentecostais.

Inicialmente, vale ressaltar a advertência crítica de Terra sobre a difusão das Escrituras no Brasil entre os séculos XVI e XVIII. Para ele, "há uma tendência hoje em se fazer uma autocrítica negativa e arrasadora de nossa primeira catequese e evangelização. Nossos primeiros missionários não teriam valorizado a Sagrada Escritura! A Revelação Bíblica seria a grande ausente na formação cristã do Brasil"705. De fato, é uma questão a ser mais bem compreendida. Historicamente, percebe-se que, se por um lado, "religiosidade é o que não faltava aos portugueses na época da descoberta do Brasil" $" 706$, por outro, o desconhecimento do uso das Escrituras no início da colonização e da consequente evangelização realizada no Brasil é uma realidade histórica. Como já dito anteriormente, poucas obras falam do assunto.

\footnotetext{
${ }^{703}$ Cf. TERRA, João Evangelista Martins. A Bíblia na evangelização do Brasil. São Paulo: Loyola, 1988.

${ }^{704}$ Cf. GIRALDI, Luiz Antonio. A Bíblia no Brasil Império: Como um livro proibido durante o Brasil colônia tornou-se umas das obras mais lidas nos tempos do Império.

${ }^{705}$ TERRA, João Evangelista Martins. Op. cit., p. 4.

${ }^{706}$ CÉSAR, Elben Magalhães Lenz. História da evangelização do Brasil, p. 19.
} 
Terra, em contraposição a essa percepção, procura destacar que o país colonizador, isto é, Portugal, era, na época, um país de referência na produção da exegese bíblica no mundo. Seu primeiro critério de análise é a produção exegética. Por influência de uma colônia judaica existente em Portugal, a exegese portuguesa se desenvolveu fortemente entre os séculos XVI e XVIII. Considerando que o Brasil era a principal Colônia portuguesa, certamente desfrutou desse conhecimento bíblico. Sabe-se, por exemplo, que os missionários Antonio Vieira e José de Anchieta, junto a outros pregadores e missionários jesuítas, tinham notório conhecimento bíblico e das línguas originais ${ }^{707}$.

Constata-se nos anais da história que os "sermões de Vieira são todos elaborados à base de textos bíblicos"708. Terra destaca que nos volumes que compunham os sermões de Vieira, por exemplo, 526 páginas eram compostas de mais de 11.000 citações bíblicas $^{709}$. Todavia, uma ressalva se faz necessária. Toda essa produção exegética refletida em algumas publicações bíblicas, apesar de abundante, se limitava normalmente aos clérigos e aos estudantes de teologia. $\mathrm{O}$ povo não tinha tanto contato com as Escrituras, com o livro sagrado. Trata-se, portanto, de acesso para um público específico dentro da Igreja. Talvez, na tentativa de suprir essa lacuna, "era com a Bíblia na mão que Anchieta cada dia evangelizava os índios. Nas suas excursões levava consigo um exemplar ilustrado da Bíblia e, através das imagens desenhadas, ia revelando aos índios os mistérios da Revelação cristã"710.

Existem relatos em cartas escritas por Anchieta que contam sobre a curiosidade e a atenção dispensada pelos indígenas nessas histórias. Além de ver as imagens, eles também cantavam algumas canções compostas com base nos Salmos, tanto em português quanto em tupi. ${ }^{711}$. Além disso, o teatro religioso também serviu como uma ferramenta importante na catequese bíblica. Inclusive, esse tipo de

\footnotetext{
${ }^{707}$ Anchieta (1534-1597) e Vieira (1608-1697) são as grandes referências sobre o trabalho de evangelização da Igreja Católica nos tempos coloniais. Além disso, eles fundaram escolas, hospitais e cidades, inclusive capitais brasileiras. Anchieta foi canonizado pelo Papa Francisco em 2014 e recebeu o título de "Apóstolo do Brasil". Foi ele que também criou o primeiro dicionário ilustrado da língua tupi no Brasil, em 1595. O tupi era nessa época a língua mais falada na costa do Brasil. Cf. NUNES, J. H. Dicionários no Brasil: análise e história. Campinas: Pontes Editores; São Paulo: FAPESP, 2006, p. 51. Atualmente, essa obra está no acervo digital da Biblioteca Nacional do Rio de Janeiro e pode ser acessada pelo link: <http://objdigital.bn.br/acervo_digital/div_ obrasraras/or812098/or812098.html .

${ }^{708}$ TERRA, João Evangelista Martins. A Bíblia na evangelização do Brasil, p. 6.

${ }^{709}$ Ibid.

${ }^{710}$ Ibid., p. 48.

${ }^{711}$ Ibid.
} 
estratégia chegou a sofrer certa restrição por algumas pessoas de Roma "que não compreendiam o grande valor evangelizador das representações dramáticas de cenas bíblicas" ${ }^{\prime 712}$.

A arte também foi um meio de evangelização com a Bíblia no Brasil. Em muitas cidades do Norte e do Nordeste, há significativo registro "das cenas bíblicas pintadas em painéis, azulejos ou afrescos de nossas igrejas e catedrais do período colonial"713. Considerando a importância dessas obras para a difusão das Escrituras, Terra denomina esse trabalho de "Bíblias de cerâmica" ou "Bíblias dos pobres". A cidade de Congonhas, no estado de Minas Gerais, por exemplo, apresenta uma das mais importantes obras de arte relacionadas à Bíblia do século XVIII. Ali, a Bíblia foi talhada em cedro e esculpida em pedra-sabão ${ }^{714}$ em várias estátuas que representam cenas (passos da Paixão de Cristo) e personagens bíblicos (profetas do Antigo Testamento). Deve-se lembrar que muitos desses mesmos recursos foram utilizados em muitos lugares da Europa, como já visto anteriormente.

Como se constata, a colonização ibérica formou um substrato religioso cristão na população, chamado pelos cientistas da religião de matriz religiosa brasileira. Foi esta realidade que tornou possível, tempos depois, o grande interesse por conhecer a Bíblia, que beneficiou as Sociedades Bíblicas no seu trabalho de difusão. Se a colonização do Brasil tivesse sido feita, por exemplo, pelo Império Otomano ou pelo Império Chinês, a realidade seria completamente diferente.

Foi dessa forma, portanto, que o conteúdo das Escrituras Sagradas marcou "as raízes históricas do nosso cristianismo. [...] Desde o primeiro catecismo composto no Brasil já havia essa integração"715. Deve-se ressaltar que, inclusive, este catecismo foi composto em tupi, a língua indígena. $\mathrm{Na}$ experiência protestante holandesa consta, também, o registro de que "o pastor holandês David à Doreslaer escreveu um catecismo trilíngue para os indígenas (tupi, português e holandês)",716.

Nesse ínterim, mesmo que de forma abreviada, se faz necessário lembrar de duas iniciativas protestantes em terras brasileiras durante esse mesmo período de

\footnotetext{
712 TERRA, João Evangelista Martins. A Bíblia na evangelização do Brasil, p. 53.

713 Ibid., p. 63.

${ }^{714}$ DREHER, Martin Norberto. Bíblia: suas leituras e interpretações na História do Cristianismo, p. 106.

${ }^{715}$ TERRA, João Evangelista Martins. Op. cit., pp. 50-51.

${ }^{716}$ CÉSAR, Elben Magalhães Lenz. História da evangelização do Brasil, p. 54.
} 
colonização. No Rio de Janeiro, pouco tempo depois da chegada dos jesuítas, aportou uma embarcação francesa composta de católicos e protestantes. Tratavase de uma iniciativa francesa, com fins econômicos, políticos e também religiosos, de estabelecer a França Antártica no Brasil. Por iniciativa dos protestantes franceses, conhecidos como huguenotes, por pouco tempo foi "organizada a primeira igreja evangélica do Brasil e da América do Sul"717. Pouco tempo depois, esse grupo foi dissipado; alguns foram expulsos e outros foram mortos, deixando como legado a Confissão Fluminense, que se caracteriza como a primeira confissão de fé elaborada por protestantes no Brasil.

Já no século XVII, 130 anos depois da descoberta, no Nordeste brasileiro, protestantes holandeses chegaram a ser firmar por um bom tempo no Brasil devido à ocupação holandesa ocorrida em 1630. Até 1654, quando foram expulsos, os holandeses construíram casas e igrejas, ordenaram pastores e diáconos, batizaram indígenas e organizaram presbitérios administrativos.

No Brasil holandês, dava-se muita importância à fé e à conduta dos fiéis. Era o reflexo da Reforma Protestante de 100 anos atrás e de um movimento mais recente conhecido como puritanismo holandês. A Bíblia era a norma credenti et agendi, isto é, norma de fé e comportamento. ${ }^{718}$

De fato, devido à centralidade das Escrituras na fé protestante, a Bíblia deve ter estado presente no Brasil durante essas duas experiências mencionadas acima. De qualquer forma, com as expulsões de ambos os grupos, pouco sobrou da influência e dos costumes trazidos por esses protestantes ${ }^{719}$.

Diante destes relatos e retomando o período católico de missão, pelo menos duas constatações podem ser realizadas. A primeira é que o conteúdo bíblico foi, de fato, difundido no Brasil Colônia, de várias formas e por meio de muitas estra-

\footnotetext{
${ }^{717}$ CÉSAR, Elben Magalhães Lenz. História da evangelização do Brasil, p. 38.

718 Ibid., p. 52.

${ }^{719}$ Além dos aspectos político e militar, esse período da dominação holandesa ficou marcado pelo conflito também nas questões religiosas entre católicos e protestantes. Na narrativa católica se tem o fato de que no dia 17 de julho de 1645, em Cunhaú (atual Canguaretama, Rio Grande do Norte) setenta fieís católicos foram assassinados enquanto celebravam a missa. Três meses depois, no dia 3 de outubro de 1645, em Uruaçu (atual São Gonçalo do Amarante, Rio Grande do Norte), mais 70 fiéis católicos foram igualmente assassinados. Todas estas ações eram fruto da retaliação para com aqueles que não recusaram o catolicismo em detrimento da fé protestante dos invasores holandeses. Cf. CAMPOS, Jose Freitas. O sangue dos mártires - A história dos primeiros mártires do Brasil. São Paulo: Loyola, 2017. Por outro lado, na narrativa protestante, se tem o fato de que após a expulsão dos holandeses, igrejas protestantes foram queimadas e parte dos índios que haviam se convertido ao protestantismo foram torturados ou mortos, caso não negassem a fé protestante. Alguns poucos que não foram recatolizados, conseguiram fugir. Cf. SOUZA, Jaquelini de. A Primeira Igreja Protestante do Brasil: Igreja Reformada Potiguara [1625-1692]. São Paulo: Mackenzie, 2013.
} 
tégias, como já visto. Nesse sentido, pode-se dizer que os "jesuítas tiveram algum êxito em seu trabalho com os índios. Porém seus esforços foram seriamente prejudicados pelos seculares que os seguiram"720.

A segunda constatação é a de que a Bíblia em si não foi difundida entre o povo de forma geral. Por mais que o conteúdo bíblico por meio das imagens, músicas, teatro etc. tenham sido importantes na difusão da mensagem Bíblica, elas não excluíram a importância de o povo ter acesso às Escrituras por si só. Essa realidade decorre do fato de que, naquele contexto, "a Bíblia era propriedade dos padres e de mais alguns poucos privilegiados. A censura proibia a posse e a circulação de livros religiosos sem a aprovação da autoridade eclesiástica"721.

Tal ausência de livros, incitados pela proibição da realização de impressão na colônia e pelo controle exercido pela metrópole portuguesa, chega a suscitar certas críticas, até mesmo entre historiadores católicos ${ }^{722}$. Eles criticam o sistema do padroado régio e a conivência com a escravidão. Porém, acrescenta-se também à esta crítica o fato de que a ausência de livros instigou a consequente ausência da Bíblia na evangelização. Hoornaert, nesse sentido, lembra que "um cristianismo sem livros se torna em pouco tempo uma religião sem fundamentação bíblica, divorciada da teologia, uma prática de devoções e cerimônias sem ligações com a vida" ${ }^{, 723}$.

Com o passar do tempo, com a repressão destinada às ordens religiosas no século XVIII, inclusive com a expulsão dos jesuítas do Brasil em 1759, os estudos exegéticos desenvolvidos no âmbito da Companhia de Jesus sofreram uma queda significativa, que, para Terra, "até hoje não logrou ser superada"724. Há de se lembrar ainda que, como já delineado, neste mesmo período, o Iluminismo, com seus desdobramentos, causou significativo desgaste à difusão bíblica ${ }^{725}$. Em consequência, como já visto, o século XIX fica marcado pela "decadência da Igreja na Europa. Na teologia, o caos é total. Os excessos da crítica e do historicismo do

\footnotetext{
${ }^{720}$ HALLOCK, Edgar; SWELLENGREBEL, Jan Lodewijk. A maior dádiva e o mais precioso tesouro: a biografia de João Ferreira de Almeida e a história da primeira Bíblia em português. Rio de Janeiro: JUERP, 2000, p. 153.

${ }^{721}$ CÉSAR, Elben Magalhães Lenz. História da evangelização do Brasil, p. 58.

${ }^{722}$ Cf. HOORNAERT, Eduardo; AZZI, Riolando [et al.] História da Igreja no Brasil. Petrópolis: Vozes, 1992; HOORNAERT, Eduardo. Formação do catolicismo brasileiro. Petrópolis: Vozes, 1991.

${ }^{723}$ HOORNAERT, Eduardo. Formação do catolicismo brasileiro, p. 20.

${ }^{724}$ TERRA, João Evangelista Martins. A Bíblia na evangelização do Brasil, p. 13.

${ }^{725}$ Cf. DREHER, Martin Norberto. Bíblia: suas leituras e interpretações na História do Cristianismo, pp. 125-156.
} 
liberalismo protestante levaram os católicos a se refugiar numa estagnação conservadora" 726 .

Essa realidade, de certa forma, interferiu no trabalho da Igreja Católica no Brasil. Conforme afirma Terra, com exceção dos jesuítas, durante certo tempo, por exemplo, "os sacerdotes tinham uma formação teológica muito precária"727. Além de Terra, Azzi e Matos ${ }^{728}$, o primeiro um sacerdote salesiano e o segundo, membro da Congregação dos Irmãos (Fráteres) de Nossa Senhora Mãe da Misericórdia, ambos pesquisadores da História da Igreja, confirmam tal realidade. Mesmo com o incentivo do Concílio de Trento a respeito do estudo teológico, o primeiro seminário no Brasil levou mais de 250 anos para surgir, e os primeiros seminários que surgiram pouco contribuíram com a evangelização e a difusão das Escrituras $^{729}$. Foi um período de declínio em todo o mundo, o que também se refletiu no Brasil.

Giraldi e Terra ${ }^{730}$ também destacam um lado positivo. É justamente nesse período que duas importantes traduções da Bíblia foram desenvolvidas. A tradução completa da Bíblia de João Ferreira de Almeida foi publicada em 1753 (dois volumes) e a tradução completa da Bíblia de Antonio Pereira de Figueiredo foi concluída em 1790 (vinte e três volumes). Ambas as traduções foram publicadas em volume único em 1819 (Almeida) e 1821 (Figueiredo). Obviamente, porções e revisões destes textos foram publicados muito tempo antes. Porém, vale ressaltar que a tradução da Bíblia de Almeida foi realizada na Batávia, e a tradução da Bíblia de Figueiredo foi realizada em Portugal. O Brasil só recebeu essas Bíblias um pouco mais tarde, dificultando a difusão das Escrituras no Brasil em sua formação como nação. Paralelas a essas traduções, “dessa mesma época, são diversas as traduções parciais, sobretudo de Salmos ou de capítulos de outros livros da Bíblia" ${ }^{\text {731 }}$. A maioria, mais uma vez, ficou restrita à Europa portuguesa.

\footnotetext{
726 TERRA, João Evangelista Martins. A Bíblia na evangelização do Brasil, p. 15.

${ }^{727}$ Ibid., p. 40.

${ }^{728}$ Cf. AZZI, Riolando. A Instituição eclesiástica durante a primeira época colonial. In: HOORNAERT, Eduardo (org.) História da Igreja no Brasil. Ensaio de interpretação a partir do povo. Petrópolis: Vozes, 1983, p. 200; MATOS, Henrique Cristiano José. Nossa história: 500 anos de presença da Igreja Católica no Brasil. $3^{\mathrm{a}}$ ed. Tomo 1. São Paulo: Paulinas, 2011

${ }^{729}$ Cf. TERRA, João Evangelista Martins. Op. cit., pp. 40-42.

${ }^{730}$ Cf. GIRALDI, Luiz Antonio. A Bíblia no Brasil Império, pp. 22-31; TERRA, João Evangelista Martins. A Bíblia na evangelização do Brasil, pp. 20-21.

731 TERRA, João Evangelista Martins. Op. cit., p. 20.
} 
Nesse sentido, Malzoni ${ }^{732}$ faz uma síntese do desenvolvimento e da difusão das Escrituras em língua portuguesa entre os séculos XIV e XVIII, ao destacar que em Portugal surgiram cerca de uma dezena de traduções de partes da Bíblia (Evangelhos, Atos, Epístolas ou alguns livros específicos do AT) ou de histórias bíblicas que eram, mormente, solicitadas por reis ou personalidades de destaque da nação portuguesa. Pouco se sabe quanto à chegada dessas Escrituras no Brasil. Uma exceção é apresentada por Giraldi, ao descrever a história de um navio que, a caminho de Tranquebar (Sul da Índia), passou pelo Brasil e, mesmo após sua chegada ao destino,

Descobriu-se que ele havia deixado [...] uma caixa contendo 150 exemplares do Evangelho de Mateus, na tradução de João Ferreira de Almeida, publicados em Amsterdã, na Holanda, pela Sociedade Promotora da Religião Cristã. Esses evangelhos se destinavam às igrejas protestantes das Índias Orientais. Mas, não se sabe como, acabaram ficando no Brasil. E eles se tornaram os primeiros exemplares das Escrituras Sagradas em português a serem distribuídos no Brasil ${ }^{733}$.

Considerando que as traduções citadas por Malzoni foram desenvolvidas em Portugal e, com a exceção do relato de Giraldi, quase nada chegou ao Brasil, o impacto no país é praticamente imperceptível do ponto de vista histórico da difusão bíblica. Konings, ao comentar sobre o panorama das traduções da Bíblia no Brasil, segue este mesmo raciocínio. Para ele,

\begin{abstract}
A Igreja Católica, até inícios do séc. XX, fomentava desconfiança em relação às traduções vernaculares, sendo a Vulgata considerada a tradução oficial para uso teológico e litúrgico. Assim, não se criou em português uma tradução católica padrão (como tampouco na maioria das outras regiões católicas). Nas regiões protestantes, ao contrário, as grandes traduções bíblicas se impuseram desde o início, acompanharam inclusive a constituição das Igrejas e até contribuíram decisivamente para a unificação do idioma ${ }^{734}$.
\end{abstract}

Uma ressalva se constata pelo fato de Terra relatar ter encontrado edições da Bíblia de Figueiredo nos colégios jesuítas do Brasil ${ }^{735}$. Como e quando chegaram, não foi possível delimitar. De certa forma, "lia-se a Bíblia, ainda que pouco, nos séculos após a descoberta" ${ }^{, 736}$. Essa percepção é compartilhada por pesquisadores católicos e protestantes. Cavalcanti, por exemplo, reforça que "nos quinhentos

\footnotetext{
${ }^{732}$ MALZONI, Cláudio Vianney. As edições da Bíblia no Brasil, pp. 15-20.

${ }^{733}$ GIRALDI, Luiz Antonio. A Bíblia no Brasil Império, p. 59.

${ }^{734}$ KONINGS, Johan. Tradução e traduções da Bíblia no Brasil. Persp. Teol. n. 35, 2003, p. 217.

${ }^{735}$ Vale ressaltar que os jesuítas foram expulsos do Brasil em 1759, e a Bíblia do Figueiredo é de 1790. O que poderia haver eram traduções parciais e incompletas da Bíblia em português, que já existiam desde a Idade Média.

${ }^{736}$ SHEDD, Russel Philip. A Bíblia e os livros, p. 54.
} 
anos de história da Igreja em nosso Continente, o contato mais direto dos leigos católicos com a Sagrada Escritura começa a partir da década de 1960, sob o impulso do Concílio Vaticano II"737.

Giraldi, nessa mesma perspectiva, mas já considerando a divulgação da Bíblia pelos protestantes a partir do Império, lembra que "o desinteresse da Igreja Católica em divulgar a Bíblia e o altíssimo índice de analfabetismo tornaram a Bíblia um livro desconhecido no Brasil desde a sua descoberta, no final do século XVI, até 1808, no início do Brasil Império"738.

Conforme se constata, portanto, durante o Brasil Colônia, havia uma difusão indireta das Escrituras, por meio da arte, da música, da catequese, da pregação etc. Era uma difusão de conteúdo e não do livro em si. No relato de Terra, por vezes, transparece a ideia de que o acesso à Bíblia era mais restrito ao clero e a alguns poucos estudantes do que ao povo propriamente dito ${ }^{739}$. Essa, entre outras, é uma significativa razão pela qual a distribuição de Bíblias iniciada pelos protestantes logo no início do Brasil Império logrou êxito. Durante cerca de 300 anos, a população do Brasil tinha conhecido as Escrituras por ouvir ou ver os relatos bíblicos. A partir da chegada de D. João VI no Brasil, com a abertura dos portos às nações amigas, o povo teve mais oportunidades de ter uma Bíblia em suas mãos.

${ }^{737}$ CAVAlCANTI, Tereza Maria Pompéia. A leitura popular da Bíblia e a V Conferência do CELAM, p. 77.

${ }^{738}$ GIRALDI, Luiz Antonio. A Bíblia no Brasil Império, p. 51.

${ }^{739}$ Cf. TERRA, João Evangelista Martins. A Bíblia na evangelização do Brasil, pp.45-50. 


\section{A história e a atuação das Sociedades Bíblicas na difusão das Escrituras Sagradas}

A Bíblia, Palavra de Deus na história da humanidade; esse é um dos pressupostos fundamentais para se compreender este capítulo. Como já visto nos tópicos anteriores, o povo de Deus, em toda a sua história, entendeu que a palavra divina era importante para a sua vida e para a sua fé. Sob esses valores, a Sagrada Escritura, além de fazer parte do cotidiano de cada crente, também acompanhou a igreja em seu desenvolvimento e expansão pelo mundo. Nesse sentido, por sua origem e essência, a igreja cristã sempre foi uma igreja missionária. Essa é uma de suas marcas distintivas tanto no aspecto bíblico como no aspecto histórico. E foi sob essa missão, de propagação da fé cristã, que "a Bíblia deixou de ser um livro da Igreja para tornar-se o livro da humanidade"740.

Como já visto anteriormente, no decorrer da história, católicos e protestantes lidaram de forma diferente com as Escrituras. Entretanto, mesmo sob tais diferenças, algo foi comum para ambos. Em suas respectivas atividades missionárias, os dois segmentos difundiram as Escrituras Sagradas pelo mundo, marcando substancialmente a história dos povos junto aos quais se estabeleceram. Tal realidade se fundamenta no fato de as Escrituras constituírem o fundamento, a base e a mensagem da missão. Nessa perspectiva, "a igreja busca no testemunho bíblico a natureza missionária de Deus, o chamado para a missão, o caráter do mandato divino e a origem da relação entre o Deus da missão e o povo missionário" ${ }^{, 741}$.

Portanto, significativamente firmada nas Escrituras e obediente ao ordenamento de ir ao mundo, a igreja cristã se espalhou para diversos lugares em sua missão. Povos foram evangelizados, igrejas foram estabelecidas e sociedades foram transformadas. Nessa perspectiva, como já dito, o pensamento filosófico ocidental, por exemplo, ficou imbricado por muitas características bíblicas e cristãs.

\footnotetext{
${ }^{740}$ MESTERS, Carlos. Por trás das palavras: um estudo sobre a porta de entrada no mundo da Bíblia, p. 38

741 GONZALEZ, Justo; ORLANDI, Carlos Cardoza. História do movimento missionário. São Paulo: Hagnos, 2008, p. 38.
} 
Tal realidade se constata por meio de designações de muitas localidades (ruas, bairros, cidades, estados) ou de diversificados valores éticos que consolidaram a moral de muitos povos. Não há, portanto, como não perceber que histórias, personagens e valores bíblicos estão bem presentes no cotidiano da humanidade, principalmente do Ocidente. Tudo isso, sem dúvida, é decorrência direta ou indireta do trabalho missionário realizado pelos cristãos.

Um período de destaque das missões católicas se deu entre os séculos XVI a XVIII e, assim, principalmente sob o estímulo da Contrarreforma, muitas ordens religiosas propagaram a fé católica pelo mundo. Por muito tempo, missionários católicos foram enviados para todos os continentes. Nessa mesma perspectiva, muitos povos foram colonizados, principalmente por Portugal e Espanha, sob os valores tradicionais da fé cristã católica. Entre outros, o Brasil é um exemplo significativo da influência missionária que o catolicismo exerceu. Historicamente, o povo brasileiro é um povo essencialmente religioso e cristão, fruto da fé católica que foi estabelecida em sua gênese, especialmente por meio do trabalho dos jesuítas, bem como por outras ordens e congregações religiosas portuguesas. E, como já visto, neste trabalho missionário, o conteúdo bíblico foi difundido por meio da arte, da pregação, da catequese, do ensino etc.

Ainda que algumas ações missionárias tenham se desenvolvido durante o período da Reforma, como a vinda dos huguenotes franceses enviados por Calvino ao Brasil em 1557, por exemplo, a expansão missionária protestante no mundo teve seu auge a partir do século XVII, estendendo-se até aproximadamente o início do século XX. Como decorrência dos vários movimentos que surgiram dentro do protestantismo, principalmente o puritanismo, o pietismo e o avivamentismo, a fé protestante também se espalhou para muitos lugares do mundo. De fato, se pode dizer que "foi por meio desses movimentos que começou a grande expansão missionária protestante" ${ }^{\text {742 }}$. O Brasil foi alvo desse esforço missionário a partir do século XIX.

As diferenças antes evidenciadas no período das confissões perderam sua preeminência frente aos desafios que o campo missionário apresentava, permitindo, assim, que o esforço conjunto desses movimentos contribuísse para que a pregação protestante fosse levada ao mundo de forma mais significativa e abrangen-

\footnotetext{
${ }^{742}$ GONZALEZ, Justo; ORLANDI, Carlos Cardoza. História do movimento missionário, p. 223.
} 
te. Por assim ser, principalmente presbiterianos, congregacionais, metodistas, episcopais e batistas se interessaram por missões, enviando seus missionários às várias regiões do mundo. Ainda que iniciativas particulares constituíssem o motor principal de algumas dessas ações, muitas delas, rompendo e superando as barreiras denominacionais, se uniram, fortalecendo-se mutuamente, sob o mesmo objetivo de pregação da fé protestante.

Uma das formas pelas quais os protestantes enviaram seus missionários se deu por meio de organizações paraeclesiásticas ${ }^{743}$, que tinham por objetivo semear a Palavra de Deus e pregar o evangelho em diferentes lugares do planeta. Algumas dessas organizações nasceram de forma oficial dentro das próprias denominações, mas muitas delas surgiram pela união entre diferentes cristãos protestantes. Algumas eram confessionais, outras representavam simplesmente a união, o esforço e o desejo de cristãos individuais de contribuir com a pregação do evangelho. Foi, por assim dizer, um movimento em que "os evangélicos deram as mãos [...] para estabelecerem uma rede de sociedades voluntárias"744. Reyli, Gonzaléz e Orlandi ${ }^{75}$ citam algumas dessas sociedades missionárias, surgidas a partir do esforço missionário protestante que emergiu no período:

- Society for the Propagation of the Gospel in New England (1649);

- Society for Promoting Christian Knowledge (1698);

- Society for the Propagation of the Gospel in Foreign Parts (1701);

- Society in Scotland for Propagating Christian Knowledge (1709);

- Particular Baptist Society for Propagating the Gospel among the Heaven (1792);

- London Missionary Society (1795);

- Church Missionary Society (1799);

- Sociedade de Tratados Religiosos (1799).

Dessa maneira, com o objetivo de propagar a fé evangélica inicialmente no Novo Mundo e, posteriormente, a todos os povos (como, por exemplo, no Sul do

\footnotetext{
743 Organizações paraeclesiásticas podem ser compreendidas como organizações que atuam de forma paralela às denominações. Algumas podem estar vinculadas à alguma denominação, outras podem ser totalmente independentes. Podem ser organizações de missão, de ação social, de estudo teológico, de incentivo à cultura etc. Elas têm por objetivo o apoio ao trabalho que faz parte da missão cristã, mas que, por vezes, não é realizado pelas igrejas pelos mais variados motivos.

${ }^{744}$ REILY, Duncan. A história documental do protestantismo no Brasil. São Paulo: ASTE, 2003, p. 28.

${ }^{745}$ Cf. REILY, Duncan. Op. cit., passim; GONZALEZ, Justo; ORLANDI, Carlos Cardoza. História do movimento missionário, pp. 214-215, 236.
} 
Pacífico), as missões protestantes, por meio dessas sociedades e, depois, das agências missionárias, conseguiram avançar e estabelecer uma unidade entre os diferentes grupos ou segmentos denominacionais, fundamentados sob uma mesma missão, isto é, levar a Palavra de Deus a todos os povos.

Segundo González e Orlandi ${ }^{746}$, essas missões, de forma geral, tinham como fundamento de sua ação, a pregação do evangelho, o estabelecimento de escolas e igrejas e a tradução da Bíblia para a língua nativa. Como se percebe, a difusão da Escrituras, por meio de uma tradução para a língua vernácula, sempre esteve entre os principais objetivos de qualquer missão protestante. Foi exatamente isso que John Eliot fez em 1646, quando iniciou sua missão entre os moicanos na Nova Inglaterra e, da mesma forma, William Carey ${ }^{747}$, quando, em 1793, foi para a Índia a fim de, conforme seu relato, obedecer ao chamado missionário que tinha recebido. Ambos pregaram, ensinaram e traduziram a Bíblia para os povos que eram alvo de sua missão ${ }^{748}$. Aliás, para Carey, o trabalho de tradução da Bíblia foi a sua prioridade.

Desse modo, a Bíblia, que já era o livro principal da fé protestante, se tornou, igualmente, o livro por proeminência da expansão missionária evangélica. Evidenciando essa realidade, sabe-se, por exemplo, que, até o dia de sua morte, Carey, junto com sua equipe, "havia traduzido a Bíblia, ou porções dela, para pelo menos 35 idiomas e dialetos da Índia"749. Junto a Carey estavam outros missionários e ajudadores. Dois deles eram William Ward, especialista na área de impressão e Joshua Marshman, especialista na área de linguística, que trabalharam com Carey até o final de sua vida. Eles ficaram conhecidos como "O Trio de Serampore".

Foi, portanto, sob essa perspectiva que o despertar missionário, surgido em muitos países cristãos protestantes, contribuiu para que se "organizassem várias sociedades missionárias, assim como outras sociedades para a distribuição de bíblias e literatura cristã ${ }^{\prime 750}$.

\footnotetext{
${ }^{746}$ GONZALEZ, Justo; ORLANDI, Carlos Cardoza. História do movimento missionário, passim. ${ }^{747}$ Sob a ótica do movimento missionário protestante, foi William Carey que, "em fins do século XVIII, deu início à grande era das missões evangélicas entre os pagãos" (LÉONARD, ÉmileGuillaume. O protestantismo brasileiro. São Paulo: ASTE, 2002, p. 92).

${ }^{748}$ Cf. GONZALEZ, Justo; ORLANDI, Carlos Cardoza. Op. cit., pp. 234-243.

${ }^{749}$ Ibid., p. 238. Constam como fruto do trabalho de tradução de Carey e seus missionários apoiadores, pelo menos, seis Bíblias completas e vinte e três Novos Testamentos traduzidos. Para outras línguas, apenas porções bíblicas foram traduzidas por Carey ou por sua equipe.

${ }^{750}$ Ibid., p. 247.
} 
A partir de todo esse movimento, uma das sociedades criadas, com o objetivo de levar a Palavra de Deus a todos, foi a British and Foreign Bible Society (Sociedade Bíblica Britânica e Estrangeira), criada formalmente em 1804 pelo desejo comum de muitos protestantes de uma organização que tivesse como preocupação central a tarefa de difundir (traduzir e distribuir) a Bíblia para todo o mundo ${ }^{751}$. Nessa perspectiva, “as missões protestantes e as Sociedades Bíblicas passaram a atuar em estreita colaboração, dividindo tarefas e operando cada uma em sua área específica de trabalho"752.

Diante de um contexto em que se buscou a união na realização da missão, o surgimento de Sociedades Bíblicas, com uma missão estabelecida em torno da Bíblia, contribuiu para a aproximação e a unidade da missão sob uma base comum, isto é, a Sagrada Escritura. É justamente sobre essa organização, também percebida como um movimento, que este capítulo pretende se debruçar. Importa, de fato, perceber como surgiu e como se desenvolveu o trabalho das Sociedades Bíblicas pelo mundo e, em especial, no Brasil. Entre outros, os principais referenciais teóricos que discorrem sobre essa história e, por conseguinte, serão utilizados neste capítulo, são Steer ${ }^{753}$ e Giraldi ${ }^{754}$.

\section{1}

\section{A história de Mary Jones como relato fundante das Sociedades Bíblicas e a necessidade das Escrituras Sagradas no mundo}

As notícias e as necessidades referentes ao trabalho missionário realizado por Carey na Índia resultaram em uma significativa sensibilidade nas pessoas, nas igrejas, nas sociedades e nos movimentos de propagação da fé cristã de viés protestante. Diante do clamor e do trabalho de Carey, muitos procuraram se mobilizar, com o objetivo de apoiar, desenvolver e ampliar os recursos necessários para a missão. Entre outros aspectos, Carey evidenciou a necessidade de Bíblias e de

\footnotetext{
${ }^{751}$ Cf. STEER, Roger. Good News for the World, 200 years of making the Bible heard. Oxford, UK; Grand Rapids, Michigan: Monarch Books, 2004, pp. 50-68.

752 GIRALDI, Luiz Antonio. A Bíblia no Brasil Império, p. 122.

${ }^{753}$ Cf. STEER, Roger. Good News for the World, 200 years of making the Bible heard.

${ }^{754}$ GIRALDI, Luiz Antonio. Op. cit.; Id. A Bíblia no Brasil República. Como a liberdade religiosa impulsionou a divulgação da Bíblia. Barueri: Sociedade Bíblica do Brasil, 2013; Id. História da Bíblia no Brasil. Barueri: Sociedade Bíblica do Brasil, 2013; Id. Semeadores da Palavra: personagens que tiveram participação decisiva na divulgação da Bíblia no Brasil. Barueri: Sociedade Bíblica do Brasil, 2015.; Id. The American Bible Society in Brazil. New York; Barueri: American Bible Society; Sociedade Bíblica do Brasil, 2009.
} 
traduções bíblicas para os diversos povos e dialetos existentes na Índia. Dessa forma, não há dúvida de que, diante dessa necessidade, ele instigou o trabalho de uma sociedade específica que tivesse como missão principal a causa da Bíblia. É claro que essa necessidade não se limitava à Índia; pelo contrário, a escassez de Bíblias era uma realidade para muitos lugares. $\mathrm{O}$ fato era: o acesso à Bíblia não deveria se limitar para o uso em alguns poucos países ou igrejas; as Escrituras precisavam chegar às pessoas do mundo inteiro, em sua própria língua e sob um custo que a tornasse acessível para todos.

Entretanto, ainda que o mundo todo precisasse das Escrituras, a Inglaterra (país que instigou e foi o centro do movimento missionário protestante por muito tempo) e seus arredores também careciam de Bíblias. E é a partir dessa realidade que outra história, paralela ao movimento missionário que emergia no mundo, constitui, também, a gênese do movimento das Sociedades Bíblicas. Trata-se de uma história que aconteceu há muito tempo: a história de Mary Jones.

A história da busca de Mary Jones por uma Bíblia constitui, por assim dizer, o relato fundante da primeira Sociedade Bíblica. De forma geral, pode-se entender o relato fundante como um elemento que constitui, na filosofia, na história ou na religião, a explicação sobre a origem de um rito, de um movimento, de um grupo, de uma fé, de uma localidade, de um processo social etc. ${ }^{755}$ Trata-se, portanto, de uma narrativa de origem. No caso das Sociedades Bíblicas, a história de Mary Jones é o relato fundante da organização e constitui, como uma narrativa de origem, um vínculo importante e necessário com o passado, mas que, na atualidade, encontra formas atualizadas para se manifestar, sob os mesmos valores e ideais que a conceberam. Portanto, ainda que um ou outro detalhe tenha adquirido um caráter literário ou lendário, essa obra descreve "uma história verdadeira. Aconteceu há mais de 200 anos. Fala sobre Mary Jones, uma menina cujo desejo de ter uma Bíblia inspirou o movimento das Sociedades Bíblicas"756.

A narrativa que se seguirá pelos próximos parágrafos se encontra principalmente em três obras: A Bíblia de Mary Jones: o início do movimento das Socieda-

\footnotetext{
755 Cf. BRILLANTE, Carlo. Myth and history: the historical interpretation of myth. In: EDMUNDS, Lowell. Approaches to Greek Myth. Baltimore, Maryland, USA: Johns Hopkins University Press, 1990, passim.

756 SOCIEDADE BÍBLICA DO BRASIL. A Bíblia de Mary Jones: o início do movimento das Sociedades Bíblicas. Barueri: Sociedade Bíblica do Brasil, 2009, p. 2.
} 
des Bíblicas ${ }^{757}$, publicada pela Sociedade Bíblica do Brasil; Good News for the World, 200 years of making the Bible heard: the story of Bible Society, de Roger Steer, e A Bíblia no Brasil Império: como um livro proibido durante o Brasil colônia tornou-se umas das obras mais lidas nos tempos do Império, de Luiz Antonio Giraldi.

Mary Jones era uma menina que nasceu por volta de 1785 e vivia com os seus pais numa casa simples, no vilarejo de Llanfihangel, no País de Gales. Seu pai, Jacob Jones, era tecelão e sua mãe, a senhora Jones, cuidava das tarefas de casa. Como se percebe, uma rotina comum e de muito trabalho para qualquer família daquela época. Steer lembra, porém, que "a vida se tornou ainda mais difícil para mãe e filha quando, em março de 1789, alguns meses depois de Mary completar quatro anos, Jacob morreu"758. Certamente, esse fato trouxe sérias dificuldades para o sustento da família, que já era pobre.

Como uma típica família cristã, aos domingos, Mary, já com seus cinco ou seis anos, se dirigia à capela do vilarejo. Seguindo a liturgia de um culto protestante, ela cantava os hinos e se alegrava, mas tinha dificuldades para entender as palavras do sermão. Mesmo assim, Mary sentia um carinho especial pelo livro que o pastor carregava: a Bíblia Sagrada. Ela assim o conhecia porque era dessa forma que o pastor designava o livro quando o pegava para ler. Steer se refere a esse homem como um pregador chamado William Hugh, pastor e pregador metodis$\mathrm{ta}^{759}$. Acredita-se que nas suas visitas aos lares, ao orar, ler e pregar sobre a Bíblia, "Mary Jones ouviu e passou a amar as histórias de Jesus" "760.

Também muito comum para aquele período histórico era o fato de que Mary Jones não sabia ler. Entretanto, quando Mary completou dez anos, foi matriculada na escola que chegou ao vilarejo, a poucos quilômetros de sua casa. Como decorrência da integração entre fé e educação, instigada a partir da Reforma Protestante, Steer lembra que, naquele tempo, várias "escolas foram estabelecidas ao Norte do País de Gales"761. Nesse ínterim, a Bíblia era o livro de instrução em muitas escolas localizadas nas regiões influenciadas pelo protestantismo, pois por meio

\footnotetext{
${ }^{757}$ SOCIEDADE BÍBLICA DO BRASIL. A Bíblia de Mary Jones, p. 2.

${ }^{758}$ STEER, Roger. Good News for the World, 200 years of making the Bible heard, p. 40 (tradução nossa).

${ }^{759}$ Steer lembra que um número crescente de pregadores metodistas circulou pelo País de Gales naquele período. Foi, de fato, o período do grande avivamento de John Wesley, em que muitos pregadores metodistas se espalharam pregando a mensagem das Escrituras.

${ }^{760}$ STEER, Roger. Op. cit., p. 42 (tradução nossa).

${ }^{761}$ Ibid., p. 43 (tradução nossa).
} 
da Bíblia, muitos aprendiam a ler. O método de ensino era aplicado a crianças, jovens e adultos que eram ensinados inicialmente nos rudimentos da fé cristã, para depois também aprenderem a escrever. As escolas fundadas nesse período "ajudaram a fazer dos galeses um dos primeiros povos alfabetizados do mundo moderno"762.

A história registra que em pouco tempo Mary tornou-se uma boa aluna e, em certa ocasião, chegou a ser chamada para ler, em voz alta, uma passagem da Bíblia Sagrada para os seus colegas de classe. Aliás, como bem lembra Steer, naquela época, era bem comum crianças aprenderem a recitar trechos de todos os livros da Bíblia. Numa fazenda não muito longe da casa de Mary, a cerca de três quilômetros, vivia a família Evans. Certo dia, a senhora Evans, que sabia do amor de Mary pelo Livro Sagrado, convidou-a para ir à sua casa para conhecer um pouco mais de perto a Bíblia da família, e, assim, treinar a sua leitura bíblica. A história descreve que, com todo cuidado, Mary virava lentamente algumas páginas e logo mergulhava em suas histórias. Essa cena se repetiu por um tempo, até que Mary percebeu como seria bom "se ela tivesse a sua própria Bíblia"763.

Entretanto, como já constatado anteriormente, naquele tempo, era muito difícil conseguir uma Bíblia, pois ela era um livro muito raro de ser encontrado. Tal realidade, porém, não constituiu um impedimento para Mary. Por seu contato e apreço em relação às Escrituras, ela estava decidida: ela queria ter a sua própria Bíblia. Para tanto, Mary começou a trabalhar de forma intensa a fim de guardar cada centavo que ganhava. Sua rotina, a partir de então, era, durante a semana, estudar e trabalhar (na fazenda, com a venda de meias, fazendo tricô, remendando roupas, carregando água do poço até a casa de pessoas que precisavam etc.); aos sábados, ir à casa da senhora Evans para ler a Bíblia, e, aos domingos, participar do culto.

Numa dessas viagens para ler a Bíblia, numa manhã de tempestade, Mary Jones avistou na estrada um homem que vinha em sua direção montado num cavalo. Este homem perguntou para onde Mary estava indo debaixo de tanta chuva e vento. Depois de Mary responder ao cavaleiro o motivo de sua caminhada, ele se apresentou como Thomas Charles, um pastor e distribuidor de Bíblias. Contou

\footnotetext{
${ }^{762}$ STEER, Roger. Good News for the World, 200 years of making the Bible heard, p. 44 (tradução nossa).

${ }^{763}$ Ibid, p. 46 (tradução nossa).
} 
ainda que vivia em Bala, a 42 quilômetros dali, e que aguardava uma encomenda de Bíblias que deveria vir de Londres. Sendo assim, ele poderia ajudá-la a realizar seu desejo brevemente. Steer lembra que a maior dificuldade que Thomas Charles encontrou, sendo um pastor e vendedor de Bíblias, foi justamente a escassez de Bíblias em galês.

Em 1800, entretanto, ajudado por alguns cristãos, ele conseguiu cerca de 700 cópias da Bíblia em galês por intermédio da Society for Promoting Christian Knowledge (SPCK). Steer lembra que Thomas Charles levava a sério sua missão de difundir as Escrituras, mesmo com os enormes perigos e desafios que tal missão apresentava. Numa dessas viagens de distribuição de Bíblias, ele quase perdeu o polegar da mão esquerda, que ficou congelado pelo frio. Mesmo enfrentando uma dor dilacerante por onze meses, Thomas Charles continuou seu trabalho.

Firmada na esperança dada por Thomas Charles, e após ter passado aproximadamente seis anos trabalhando arduamente, Mary conseguiu juntar o suficiente ("17 shillings" "764) para comprar um exemplar do Livro Sagrado. Seu novo desafio, entretanto, era percorrer longos quarenta e dois quilômetros até o único lugar onde era possível comprar Bíblias naquela região do País de Gales, isto é, a cidade de Bala, na casa de Thomas Charles. A cidade, hoje denominada de Bale, se encontra ao Norte do País de Gales.

Em busca de seu sonho, já com quinze ou dezesseis anos, no verão de 1800 , Mary seguiu viagem para adquirir sua Bíblia. A narrativa descreve vários detalhes dessa viagem. Para alguns que até hoje contam essa história, Mary seguiu a pé, descalça, atravessando vales e ribeirões. Obviamente que, pelo cansaço, chegou a duvidar que alcançaria o seu objetivo. Mas, já ao anoitecer, quando enxergou as luzes da cidade de Bala ao longe, seu coração disparou de alegria. Já em Bala, Mary percorreu algumas casas, batendo de porta em porta, à procura do pastor Thomas Charles.

Porém, nesse ponto da história, há uma divergência nos relatos. A obra $A$ Bíblia de Mary Jones: o início do movimento das Sociedades Bíblicas descreve que, na casa do pastor, Mary contou toda a sua história e Thomas ouviu cada palavra, mas, ao final, lamentou ao afirmar que a única Bíblia em galês que possuía já estava reservada para outra pessoa. Segundo a história, neste momento, a espe-

\footnotetext{
${ }^{764}$ STEER, Roger. Good News for the World, 200 years of making the Bible heard, p. 47
} 
rança de Mary deu lugar à decepção. Sensibilizado, porém, com toda a situação de Mary Jones, o pastor lembrou que o outro comprador também falava outros idiomas e decidiu repassar aquela única Bíblia em galês para Mary.

Já Steer conta que, ao chegar em Bala, ela buscou informações sobre como chegar à casa do Sr. Thomas. Ao bater à porta, ela recebeu a notícia de que as Bíblias ainda não haviam chegado. Chorando, Mary disse que não saberia onde poderia se hospedar, sendo, então, imediatamente acolhida pelo pastor, que permitiu que ela ficasse com sua empregada. Dois dias depois, as Bíblias chegaram, e pelo preço de uma, Charles permitiu que Mary levasse três.

Independentemente de tais desarmonias, ambos descrevem que, quando retornou para sua casa, umas das primeiras ações de Mary foi ler a Bíblia, que agora era da sua família e que estava em sua própria língua. Steer ainda acrescenta que das três Bíblias, a de uso pessoal de Mary está exposta, como parte da coleção da Sociedade Bíblica, na Biblioteca da Universidade de Londres, e uma outra está na Biblioteca Nacional do País de Gales, em Aberystwyth. Não se sabe o que aconteceu com a terceira; acredita-se que tenha ficado com seu filho, Ioan, que pode ter levado a Bíblia para a América quando para lá emigrou.

Mary Jones leu toda a Bíblia quatro vezes enquanto viveu. Ela também decorou grandes porções das Escrituras, o que foi de grande utilidade após a perda de sua visão, visto que, no final da vida, já sem enxergar, ela só pôde contar com a ajuda de outras pessoas que liam a Bíblia para ela. Não obstante sua pobreza, Mary Jones trabalhou criando abelhas, o que a ajudava a complementar sua renda, para que assim pudesse se sustentar e também ofertar à sua igreja e à Sociedade Bíblica. Sem dúvida, Mary, por sua história e exemplo, serve de grande inspiração para aqueles que trabalham em prol da causa da Bíblia.

Steer destaca que em 16 de dezembro de 1864, muito fraca, Mary celebrou seu $80^{\circ}$ aniversário. Quinze dias depois, em 29 de dezembro, rodeada por alguns amigos, ela morreu em sua própria cama, na pequena aldeia de Gwyddelfynydd, ao norte de Bryncrug, no País de Gales. A Bíblia recebida de Thomas Charles, que Mary manteve para seu uso pessoal durante toda a vida, estava em sua mesa de cabeceira. Em sua sepultura há uma lápide erguida por aqueles que desejavam preservar sua memória e legado. Mary marcou a história da difusão da Bíblia e, por isso, se tornou uma das mulheres galesas mais conhecidas, tanto no País de Gales como em outros países, quando se discorre sobre a história da Bíblia. 
Em muitas igrejas, a história de Mary Jones é sistematicamente contada como uma inspiração de amor e dedicação à Palavra de Deus. Nesse sentido, Steer destaca que, fora a Bíblia, o livro da história de Mary Jones é uma das obras com maior publicação e sucesso entre todas as obras editadas pelas Sociedades Bíblicas. A história foi publicada pela primeira vez em 1882 e já foi traduzida para mais de 40 idiomas. Além disso, a história foi contada não apenas em livros, mas também em peças, musicais, fitas, gráficos de flanelógrafos, na Internet etc. Como já citado anteriormente, no Brasil, a obra recebeu o título A Bíblia de Mary Jones: o início do movimento das Sociedades Bíblicas ${ }^{765}$ e é publicada pela Sociedade Bíblica do Brasil.

De fato, foi assim que Mary Jones se tornou parte de uma história que dura até os dias de hoje. Foi esse o relato fundante das Sociedades Bíblicas e são estes os mesmos valores que constituem o fundamento da missão das Sociedades Bíblicas, isto é, levar a Bíblia a todos, numa linguagem que possam entender e a um preço que possam pagar.

\section{2 \\ A fundação da primeira Sociedade Bíblica, seus objetivos no trabalho de difusão das Escrituras Sagradas e alguns aspectos importantes de sua história}

Discorrer sobre o trabalho das Sociedades Bíblicas na difusão das Escrituras constitui um significativo desafio. São mais de 200 anos de história em quase todos os países do mundo. Há muita história; há muito detalhe. Estabelecer o recorte, portanto, é algo necessário e desafiador. Ainda assim, nesta seção especificamente, espera-se que seja possível apresentar os principais aspectos que permeiam a temática desse estudo. Para tanto, o trabalho de Roger Steer, Good News for the World, 200 years of making the Bible heard: the story of Bible Society ("Boasnovas para o mundo, 200 anos fazendo a Bíblia ser ouvida: a história da Sociedade Bíblica") e as obras de Giraldi constituirão os referenciais teóricos fundamentais nessa trajetória histórica. Obviamente, entretanto, tal escolha não constitui um limite em relação ao uso de outros referenciais sobre o mesmo fato, como se perceberá nessa caminhada.

\footnotetext{
${ }^{765}$ Cf. SOCIEDADE BÍBLICA DO BRASIL. A Bíblia de Mary Jones: o início do movimento das
} Sociedades Bíblicas. Barueri: Sociedade Bíblica do Brasil, 2009. 
De início, é importante ressaltar que, para descrever a história da primeira Sociedade Bíblica, por meio de seu início na Inglaterra, se faz necessário, ainda que resumidamente, resgatar um pouco da história da Bíblia e a sua difusão no contexto inglês. Como já visto, parte desse resgate se deu no capítulo anterior, quando se constatou que Wycliffe e Tyndale se firmaram como personagens importantes na história da difusão da Bíblia na Inglaterra (e fora dela). Ambos arriscaram a vida defendendo a importância de que o povo inglês tivesse acesso à Bíblia por meio de uma tradução para a sua própria língua. Como se sabe, o desejo deles se cumpriu, mesmo que ambos não tenham visto tais fatos se concretizarem.

Entre outras traduções que surgiram naquele tempo, o grande destaque é a reconhecida versão King James (1611) que, já no final do século XVII, “havia se tornado a Bíblia do povo de fala inglesa"766. De fato, essa versão se popularizou, e até hoje, com as devidas revisões, é utilizada por muitas pessoas e igrejas de fala inglesa. É por isso que, conforme ressaltou Steer, o povo da Grã-Bretanha sempre considerou a Bíblia King James uma herança verdadeiramente impagável. E foi justamente a partir dessa percepção que, no passado, “a Inglaterra se tornou o povo do Livro" "767, ou seja, o povo da Bíblia.

No capítulo anterior, quando se discorreu sobre a Reforma na Inglaterra, uma observação destacava o fato de que, ainda que doutrinariamente a Reforma Inglesa não tenha seguido os mesmos princípios da Reforma de Lutero, Zuínglio e Calvino, ela teria significativa importância na história. Essa importância se estabeleceu justamente a partir de três aspectos principais. O primeiro é o impulso missionário protestante, que, a partir da Inglaterra, alcançou muitas nações. O segundo é o movimento de reavivamento que se originou nas igrejas protestantes da região. E, consequentemente, porque foi também a partir deste movimento que a difusão das Escrituras foi percebida como algo para além da simples distribuição, ela foi apreendida sob a perspectiva de uma missão que a igreja tinha a cumprir no mundo $^{768}$.

Deste modo, os cristãos ingleses entenderam a importância de juntos cuidarem e trabalharem pela causa da Bíblia e pela causa missionária. Este não foi o

\footnotetext{
${ }^{766}$ MILLER, Stephen; HUBER, Robert. A Bíblia e sua história: o surgimento e o impacto da Bíblia, p. 178.

${ }^{767}$ STEER, Roger. Good News for the World, 200 years of making the Bible heard, p. 35 (tradução nossa).

${ }^{768}$ Cf. DREHER, Martin Norberto. Bíblia: suas leituras e interpretações na História do Cristianismo, pp. 146-147.
} 
trabalho isolado de uma ou outra igreja; antes, foi um trabalho estabelecido sob um esforço conjunto, surgido a partir dos diversos movimentos oriundos do protestantismo inglês, tais quais o puritanismo, o avivamentismo, o metodismo, o presbiterianismo, o congregacionalismo, dentre outros. E assim, como já se tem advertido, o movimento das Sociedades Bíblicas surgiu e se espalhou pelo mundo.

Na seção anterior, o relato histórico enfatizou o retorno de Mary para sua casa, com a sua Bíblia, na sua própria língua. Obviamente, a história não terminou ali, como também não se findou com a sua morte. Depois de toda a situação ocorrida com Mary, por algumas vezes em seu escritório, o pastor Thomas Charles se lembrava de como uma menina tão jovem tinha saído tão feliz de sua casa por causa de uma Bíblia. Em sua reflexão, Thomas Charles questionou a si mesmo sobre quantas "Mary Jones" deveriam existir no mundo, as quais, da mesma forma que ela, precisavam ou queriam ter uma Bíblia em sua própria língua, em seu próprio país. Inicialmente, o Reverendo Thomas Charles procurou levantar recursos que pudessem financiar a impressão de uma edição da Bíblia em galês. Aliás, sua preocupação se estendia um pouco mais do que isto: ele esperava conseguir uma produção de baixo custo, com Bíblias baratas, que poderiam ser distribuídas para os galeses pobres.

De acordo com Steer, a SPCK, que tinha sido responsável pela impressão das Bíblias que Thomas Charles comprou e das quais Mary tinha recebido seu tão sonhado exemplar, não recebeu mais pedidos para a produção da Bíblia em galês depois daquelas produzidas em 1799. Ainda que o trabalho de evangelização da SPCK fosse extremamente importante, a causa da Bíblia era apenas um aspecto de seus objetivos. Era necessário, portanto, encontrar uma solução definitiva para a falta de Bíblias naquela região.

Steer ${ }^{769}$ ressalta que, certa manhã, enquanto pensava no País de Gales e nos milhares de pobres que não podiam pagar por uma Bíblia, Thomas Charles teve a seguinte ideia: por que não estabelecer uma Sociedade Bíblica em Londres, da mesma forma como existiam outras organizações/sociedades com ações de evangelização especificas? Motivado por tal ideia, ele fez contato com pessoas de influência na região, entre os quais cristãos, empresários, líderes etc. Pouco tempo depois, o pastor Thomas se reuniu com essas pessoas, das mais diferentes igrejas,

${ }^{769}$ Cf. STEER, Roger. Good News for the World, 200 years of making the Bible heard, p. 35 (tradução nossa). 
para que juntos pudessem discutir dois assuntos: a necessidade de um suprimento regular de Bíblias para o País de Gales e a criação de uma sociedade responsável por essa produção. Nesse ínterim, diante do alvoroço causado pelo discurso de Charles, pôde-se ouvir Joseph Hughes dizer: "Certamente uma Sociedade deve ser formada para tal propósito, e se for pelo País de Gales, por que não também para o Reino [Grã-Bretanha] e para mundo?" 770

Steer comenta que existem dúvidas se a história de Mary Jones foi contada nesse encontro. Segundo relatos históricos, o próprio Thomas Charles disse a Mary e a um professor chamado Lewis Williams que a história da menina serviu muito bem na reunião ocorrida em Londres em 1802. Pelo menos, o que se sabe é que a história de uma menina que queria ter uma Bíblia já era bem conhecida no início da Sociedade Bíblica. Independentemente de a história ter sido contada ou não, importa, de fato, que aqueles que se reuniram com Charles começaram a definir quais seriam as estratégias da organização. Dentre os objetivos preparados por Hughes para o desenvolvimento da nova Sociedade destacaram-se os seguintes $^{771}$ :

- Providenciar um panorama sistemático da necessidade das Escrituras no mundo inteiro;

- Coletar e administrar fundos para a causa da Bíblia com todo o esforço possível;

- Encorajar cristãos de diversas denominações a trabalharem juntos pela mesma causa.

Aliás, Hughes ressaltou que a Sociedade seria um canal para que todos os cristãos, independentemente de suas diferenças denominacionais e teológicas, pudessem, como um só corpo, contribuir pela causa da Bíblia. Algumas reuniões aconteceram entre 1803 e 1804, e Thomas Charles se fez presente em todas elas. Além do nome da fraternidade - definido como The British and Foreign Bible Society - , ficou decidido que se faria uma convocação pública por meio de uma circular intitulada "A importância da distribuição longínqua da Bíblia"772. Nela,

\footnotetext{
770 STEER, Roger. Good News for the World, 200 years of making the Bible heard, p. 54 (tradução nossa), p. 54.

${ }^{771}$ Ibid., p. 57 (tradução nossa).

${ }^{772}$ Ibid., p. 59 (tradução nossa).
} 
além de se apresentar o nome da nova sociedade, alguns objetivos foram definidos. Entre eles, destacam-se ${ }^{773}$ :

- Promover a circulação das Escrituras em algumas das principais línguas vivas;

- Estabelecer uma prioridade na distribuição das Escrituras. Isso se deu da seguinte forma: em primeiro lugar, distribuir no Reino Unido da GrãBretanha e Irlanda e no continente europeu. Depois, em regiões remotas, dependendo das condições financeiras e da urgência que alguns casos particulares poderiam requerer;

- Comprometer todos os envolvidos a unicamente apresentar as Escrituras, o "volume inspirado", para que tão somente se divulgasse a verdade.

Principalmente em relação a esse último ponto, um princípio importante para o trabalho das Sociedades Bíblicas ficou estabelecido já em sua gênese: essa nova organização não deveria entrar em questões doutrinárias controversas das igrejas; antes, deveria ser um veículo para as contribuições de caridade de toda a cristandade. Estabeleceu-se, assim, mais um propósito norteador, por meio do qual os cristãos eram convidados a contribuir para uma causa nobre e que era comum a todos, isto é, a causa da Bíblia.

De acordo com Steer, a reunião para apresentação da nova Sociedade foi realizada no dia 7 de março de 1804, no centro de Londres, na rua Bishopsgate, número 123. Sob a condução de Granville Sharp, alguns membros do comitê discursaram para mais de 300 pessoas, dentre as quais, personagens importantes da Grã-Bretanha, líderes e representantes de várias igrejas cristãs. Após o discurso em que foram relatados os objetivos da organização, as resoluções propostas foram acatadas, e o comitê oficial, formado por membros voluntários de diversas igrejas cristãs, foi eleito. $\mathrm{Na}$ ocasião, a primeira oferta para a causa da Bíblia foi levantada, e a contribuição "dos presentes somou $£ 700$, equivalente a $£ 30.000$ atualmente" $" 774$.

Imediatamente, a Sociedade Bíblica ganhou o apoio da Igreja oficial da Inglaterra e de outras igrejas da região, firmando-se como "a primeira organização inteiramente interdenominacional a ser formada com o objetivo de distribuir a

\footnotetext{
${ }^{773}$ STEER, Roger. Good News for the World, 200 years of making the Bible heard, p. 60 (tradução nossa).

${ }^{774}$ Ibid., p. 66 (tradução nossa).
} 
Bíblia no mundo inteiro, onde quer que a Bíblia fosse solicitada ou dela houvesse necessidade" "775. A unidade de propósito ficou tão evidenciada que "nada além da harmonia máxima foi ouvida"776, conforme destaca Steer, ao lembrar sobre o que se comentava entre os diversos participantes do encontro.

Como já dito anteriormente, a ideia de distribuir as Escrituras não era nova. Esse também tinha sido um dos objetivos da Society for Promoting Christian Knowledge, desde 1698 e da Society for the Propagation of the Gospel in Foreign Parts, desde 1701. Como fruto do movimento pietista, Carl Hildebrand von Canstein também já tinha criado, em 1710, o Cansteinische Bibelantalt (Instituto Bíblico Canstein), com a missão de produzir e distribuir a Bíblia com baixo custo na Alemanha, utilizando, inclusive, a tradução de Lutero ${ }^{777}$. Portanto, como bem lembram Miller e Huber, "organizações anteriores haviam preparado o caminho"778 para as Sociedades Bíblicas. A novidade, entretanto, foi a natureza interdenominacional, o entusiasmo e a mentalidade única de se difundir as Escrituras e alcançar o mundo inteiro, em várias línguas e sem notas ou comentários ${ }^{779}$.

O primeiro parágrafo do estatuto que regulamenta e estabelece o principal objetivo da Sociedade Bíblica afirma, justamente, a necessidade de "encorajar uma circulação mais ampla das Escrituras sem nota ou comentário" ${ }^{\text {780 }}$. Como se percebe, há uma ênfase na afirmação "sem notas e comentários". Essa era, de fato, uma preocupação naquele contexto histórico. As notas e os comentários representavam, direta ou indiretamente, a doutrina ou a interpretação que cada segmento cristão poderia ter a respeito da Bíblia. No passado, a Bíblia King James, de 1611, tinha ganhado credibilidade justamente porque, não tendo notas ou comentários, conseguiu agradar as pessoas que pensavam de forma diferente no contexto diverso que a igreja da Inglaterra no século XVII se encontrava.

Miller e Huber ajudam a entender a situação quando lembram que na época coexistiam principalmente duas Bíblias: a Bíblia dos bispos, que era supostamente

\footnotetext{
${ }^{775}$ HAHN, Carl Joseph. História do culto protestante no Brasil. São Paulo: ASTE, 2011, p. 275.

${ }^{776}$ STEER, Roger. Good News for the World, 200 years of making the Bible heard, p. 54 (tradução nossa), p. 68 (tradução nossa).

${ }^{777}$ Cf. SCHNEIDER, Hans. O pietismo. In: KAUFMANN, Thomas et al (orgs.). História ecumênica da Igreja 2, p. 533.

${ }_{778}$ MILLER, Stephen; HUBER, Robert. A Bíblia e sua história: o surgimento e o impacto da Bíblia, p. 202.

${ }^{779}$ Cf. HOLMGREN. Laton E. Sociedades Bíblicas. Dicionário Enciclopédico da Bíblia, pp. $1270-1272$

${ }^{780}$ STEER, Roger. Op. cit., p. 80 (tradução nossa).
} 
tendenciosa para o lado da igreja oficial da Inglaterra (que, segundo os puritanos, era católica demais), e a Bíblia de Genebra, que, para o rei Tiago ("king James") era supostamente tendenciosa para o lado protestante. Tiago, aliás, não gostava da Bíblia de Genebra justamente porque ela "não demonstrava o suficiente respeito pelos reis" ${ }^{781}$. Portanto, para que a causa da Bíblia avançasse sem controvérsias denominacionais, importava que o conteúdo bíblico se limitasse simplesmente ao texto sagrado.

Nessa perspectiva, todos os presentes na reunião de fundação da British and Foreign Bible Society entenderam que esse objetivo deveria prevalecer; ou seja, a missão de levar a Bíblia a todos estava acima dos dogmas particulares de cada confissão. Pode-se dizer, portanto, que a BFBS surgiu como resultado do esforço conjunto dos cristãos, que, colocando em segundo plano suas diferenças doutrinárias, entenderam que levar a Palavra de Deus ao mundo constituía a missão por excelência.

De acordo com Steer, a isenção e a neutralidade sobre questões teológicas, mesmo com as reconhecidas diferenças entre as denominações de seus participantes, garantiu um bom suporte e um rápido crescimento para as Sociedade Bíblicas. Em 1804, data de fundação, apenas 70 línguas tinham partes da Bíblia traduzidas, sendo a maioria línguas da Europa e do Mediterrâneo, e apenas uma na África e duas do Extremo Oriente. Para esta lista, que cresceu com muita dificuldade desde a Reforma, as Sociedades Bíblicas contribuíram com a tradução das Escrituras para, aproximadamente, 800 novas línguas no curso dos 150 anos subsequentes à sua fundação. Mais precisamente, até o início do século XXI, cerca de 2.300 línguas receberam a tradução de alguma porção das Escrituras por meio do esforço conjunto das diversas Sociedades Bíblicas espalhadas pelo mundo. Os dados mais recentes, referentes ao ano de 2016, indicam que 3.225 línguas do mundo contêm uma tradução das Escrituras, ou, pelo menos, parte dela, como Novo Testamento, porção ou seleção ${ }^{782}$.

Um significativo exemplo dessa contribuição histórica na tradução da Bíblia se evidenciou no apoio que as Sociedades Bíblicas deram ao trabalho missionário

${ }^{781}$ MILLER, Stephen; HUBER, Robert. A Bíblia e sua história: o surgimento e o impacto da Bíblia, p. 178.

${ }^{782}$ Cf. UBS - United Bible Societies. Key facts about the Bible access. Desenvolvido pela UBS, 2018. Apresenta fatos, dados e números de novas traduções da Bíblia nas diversas línguas do mundo e de projetos bíblicos para surdos e deficientes visuais. Disponível em: <https://www. unitedbiblesocieties.org/key-facts-bible-access>. Acesso em 11 out. 2017. 
de William Carey e sua equipe na Índia. Além do suporte financeiro que em alguns momentos a BFBS deu a ele e a seus associados de missão, o grande destaque se deu no apoio concedido ao trabalho de tradução bíblica que eles realizaram para cerca de 35 línguas e dialetos indianos, em quarenta anos dedicados à missão. E mais: eles não se limitaram à Índia. Steer destaca que em 2003 soube-se que "o trabalho bíblico em Bangladesh tem uma rica herança que remonta ao trabalho de Carey"783, pois ele não só foi o responsável pela tradução da Bíblia Bangla, que ainda é usada depois de dois séculos, como também criou o primeiro dicionário Bangla e a sua gramática. A história registra que três dias antes de morrer, já com 73 anos, Carey precisou ser carregado por causa de uma extrema exaustão provocada por sua dedicação à missão. Na ocasião se constatou que "as folhas revisadas do último idioma em que ele havia traduzido as Escrituras estavam [ainda] sobre a sua mesa",784.

Obviamente, logo após a fundação da primeira Sociedade Bíblica, em 1804, muitas outras sociedades congêneres surgiram, inspiradas e influenciadas pelo trabalho da BFBS. Steer lembra que a maioria delas se desenvolveu na Europa e na Ásia, como, por exemplo, a Sociedade Bíblica Finlandesa, criada em 1812, a Sociedade Bíblica Russa, criada em 1813, e a Sociedade Bíblica da Holanda, em 1814. Giraldi acrescenta à lista as Sociedades Bíblicas surgidas na Alemanha, na Suíça, na Suécia e na França ${ }^{785}$. Assim como já tinha ocorrido com a BFBS, algumas dessas novas Sociedades Bíblicas, diante das necessidades do mundo, não limitaram suas ações em seus países, unicamente. Elas difundiram a Bíblia por várias regiões, sob a mesma missão de levar a Bíblia a todos.

Dentre todas as Sociedades Bíblicas que começaram a surgir, uma de relevada importância na história da difusão das Escrituras foi a American Bible Society (ABS). Tal relevância se aplica inclusive ao Brasil, como se perceberá mais adiante. O surgimento da Sociedade Bíblia Americana se deu por meio da fusão de várias outras sociedades auxiliares que coexistiam em diversas regiões dos EUA e já trabalhavam na difusão das Escrituras, sob o modelo e o apoio da BFBS. O ano que marca o início da $A B S$ é $1816^{786}$. Na ocasião, dezesseis delega-

\footnotetext{
${ }^{783}$ STEER, Roger. Good News for the World, 200 years of making the Bible heard, p. 96 (tradução nossa).

${ }^{784}$ Ibid., p. 97 (tradução nossa).

785 Cf. GIRALDI, Luiz Antonio. A Bíblia no Brasil Império, p. 77.

${ }^{786}$ Cf. HOLMGREN. Laton E. Sociedades Bíblicas. Dicionário Enciclopédico da Bíblia, pp. 1271.
} 
dos compareceram à convenção, representando trinta e uma Sociedades Bíblicas auxiliares para que, a partir daquele momento, se unissem na realização do trabalho bíblico na América. Desde sua fundação, a $A B S$ tem uma constituição modelada nos regulamentos e objetivos da BFBS e, por meio dela, muitos países tiveram um impulso na difusão das Escrituras, principalmente na América Latina.

$\mathrm{Na}$ história desses mais de duzentos anos, muitas outras Sociedades Bíblicas surgiram, cresceram e se desenvolveram, imbuídas da mesma missão. Entre todas, porém, as Sociedades Bíblicas Britânica e Estrangeira, Americana e Holandesa foram as que tiveram o maior sentido de missão, ou seja, elas não se limitaram aos seus respectivos países; antes, ajudaram a difundir as Escrituras nos lugares mais remotos do mundo, conforme destacam Dreher e Holmgren ${ }^{787}$. O Brasil, inclusive, foi significativamente contemplado por todas elas, principalmente pela BFBS e pela ABS. Atualmente, no site que reúne a fraternidade mundial das Sociedades Bíblicas, consta a existência de 149 Sociedades Bíblicas, as quais atuam em mais de 200 países, com a missão de levar a Bíblia para todas as pessoas ${ }^{788}$.

É importante ressaltar que esse trabalho só foi possível porque ele sempre ocorreu em parceria com as igrejas. Nesse sentido, a missão das Sociedades Bíblicas é bem clara, ao firmar que a razão pela qual elas existem é "servir as igrejas em todo o mundo compartilhando a Palavra de Deus" ${ }^{\text {"789. }}$. Por assim ser, as Sociedades Bíblicas reconhecem e valorizam "as igrejas como os principais agentes da missão de Deus no mundo"790. Desde sua origem, portanto, a igreja em missão é a razão da existência das Sociedades Bíblicas. Por isso, como ficou bem definido em sua gênese, as Sociedades Bíblicas não discutem doutrinas, dogmas ou teologia com qualquer igreja que seja. Antes, elas procuram servir todas as igrejas cristãs, em sua missão de levar a Palavra de Deus ao mundo.

\footnotetext{
787 Cf. HOLMGREN. Laton E. Sociedades Bíblicas. Dicionário Enciclopédico da Bíblia, pp. 1270-1272; DREHER, Martin Norberto. Bíblia: suas leituras e interpretações na História do Cristianismo, 176-181.

${ }^{788}$ Cf. UBS - United Bible Societies. About us. Desenvolvido pela UBS, 2018. Apresenta a história da organização, sua missão, visão, valores e parceiros e membros quem compõem a fraternidade. Disponível em: https://www.unitedbiblesocieties.org/about-us/ (tradução nossa). Acesso em 11 out. 2017.

${ }^{789}$ Ibid. (tradução nossa).

${ }^{790}$ Ibid. (tradução nossa).
} 


\subsection{1 \\ Desafios e dificuldades no trabalho das Sociedades Bíblicas no relacionamento com a Igreja Católica}

Até aqui foi possível constatar o crescimento significativo e a contribuição relevante das Sociedades Bíblicas na difusão das Escrituras Sagradas pelo mundo, principalmente nos primeiros anos de sua caminhada. Entretanto, é importante lembrar que, em sua trajetória, momentos difíceis e desafiadores também surgiram. Dentre outros, um desafio que emergiu, limitando, de certa forma, que a difusão das Escrituras se ampliasse em um certo período da história, foi a dificuldade surgida no relacionamento entre a Igreja Católica e as Sociedades Bíblicas. Antes de relatar um pouco sobre tais dificuldades, é importante relembrar que o objetivo das Sociedades Bíblicas é servir as igrejas cristãs com as Escrituras, sem entrar em controvérsias doutrinárias. Sendo assim, quer sejam católicas, ortodoxas ou protestantes, a missão das Sociedades Bíblicas será sempre de servir a todas com a Bíblia.

Quando se afirma que essa é a missão que move as Sociedades Bíblicas, necessariamente se percebe que tal missão só se concretizará caso ocorra um bom relacionamento entre as igrejas cristãs e as Sociedades Bíblicas. Para melhor compreender tal realidade, se faz necessário, portanto, descrever alguns pressupostos históricos que estabeleceram uma distinção significativa no relacionamento inicial das Sociedades Bíblicas com as tradições protestante e católica.

Por um lado, é sabido que boa parte dos apoiadores e dos envolvidos no trabalho das Sociedades Bíblicas, historicamente, foram protestantes, e, por isso, elas chegaram a ser reconhecidas como Sociedades Bíblicas protestantes em diversos momentos de sua história ${ }^{791}$. A raiz dessa aproximação pode ser a Reforma; afi-

\footnotetext{
${ }^{791}$ Atualmente, em todas as esferas de ação das Sociedades Bíblicas, em diferentes países e regiões, existem católicos que estão diretamente envolvidos no trabalho bíblico. Entre outros, por exemplo, há católicos na diretoria das Sociedades Bíblicas da Colômbia, dos Estados Unidos, da Tanzânia, do Quênia, da Namíbia e da Republica da Irlanda. Na Bible Society in Netherlands Antilles and Aruba, com sede em Curaçao, toda a equipe de trabalho (diretores e funcionários) é católica. Em certos países, o trabalho realizado pelas Sociedades Bíblicas serve com Escrituras tanto a protestantes quanto católicos de forma equânime, a saber: Colômbia, Estados Unidos, Filipinas, Nigéria, Namíbia, Quênia, África do Sul, Italía, França, República da Irlanda, entre outros. Aliás, a República da Irlanda é totalmente administrada e comprometida com a distribuição da Bíblia entre católicos. Para além disso, essa Sociedade Bíblica (National Bible Society of Ireland), com sede em Dublin, apoia projetos bíblicos (de tradução e difusão) em vários países ao redor do mundo. De forma também proeminente, o diretor de tradução das Sociedades Bíblicas Unidas um trabalho de extrema relevância e significado dentro da organização -, Alexander Schweitzer, é católico. No Brasil, alguns aspectos sobre o trabalho bíblico desenvolvido com católicos poderão
} 
nal, entre outros aspectos, o grande legado oferecido pelos reformadores foi a insistência veemente de que o povo leigo deveria ter acesso às Escrituras por meio de traduções em línguas vernáculas. Da mesma forma, a Bíblia foi o livro que constituiu a base da pregação, da teologia e da expansão da fé protestante. Por outro lado, porém, em defesa de suas doutrinas, teologia e história, a Igreja Católica, principalmente a partir do contexto pós-reforma, reagiu com a falta de estímulo mais incisivo à leitura bíblica por partes dos seus fiéis leigos. As traduções vernáculas foram restringidas, cabendo ao clero, por muitos anos, a leitura e a interpretação das Escrituras.

Como se percebe, devido a estas questões, não há dúvidas de que dificuldades deveriam surgir. E, de fato, elas surgiram. Steer lembra que, em seu início, as Sociedades Bíblicas receberam "palavras duras"792 do papado, proferidas por meio de algumas encíclicas ou recomendações. Ainda que no capítulo anterior alguns aspectos tenham sido apresentados, vale a pena resgatar alguns pontos históricos da questão a partir da temática proposta.

Algumas décadas após a Reforma Protestante e um ano após o término da Contrarreforma Católica, no documento Dominici gregis, de 1564, o papa Pio IV proibiu a leitura de traduções bíblicas que não tivessem acompanhadas de notas sobre o ensino da Igreja. Na ocasião, as traduções em línguas vernáculas também foram coibidas. Hallock e Swellengrebel descrevem um pouco do que dizia a bula:

Como tem mostrado a experiência que, se as versões da Sagrada Bíblia em língua vulgar forem permitidas a cada passo e sem diferença de pessoas, mais é dano do que utilidade: esteja-se nesta parte pelo juízo do bispo ou do inquisidor, a fim de que, com o conselho do pároco ou do confessor, possam conceder licença de ler a Bíblia vertida para a língua, por autores católicos àqueles de quem eles entenderam desta lição podem receber não dano, mas sim aumento de fé e piedade. Essa licença deverá ser por escrito ${ }^{793}$.

Tal decisão fez com que, por aproximadamente um século e meio, a leitura da Bíblia, na prática, ficasse restringida entre os leigos. Durante este período, na

ser melhor apreendidos no próximo capítulo. Por ora, vale destacar que no Conselho Consultivo, um dos órgãos da atual governança da SBB, há representação católica por meio da presença do Sr. Paulo Fernando Carneiro de Andrade, teológo católico e decano do Centro de Teologia e Ciências Humanas (CTCH) da PUC-Rio.

792 STEER, Roger. Good News for the World, 200 years of making the Bible heard, p. 155 (tradução nossa).

${ }^{793}$ HALLOCK, Edgar; SWELLENGREBEL, Jan Lodewijk. A maior dádiva e o mais precioso tesouro, p. 141 
Espanha, por exemplo, “a Inquisição perseguiu os possuidores, impressores ou importadores de Bíblias não aprovadas pela Igreja Católica"794. O frei Herculano Alves acrescenta ainda que quem burlava essa ordem era condenado à morte ou tinha seus bens confiscados ${ }^{795}$. Somente em 1757, em um adendo à bula Domini Gregis, foi suspensa a exigência de uma licença por escrito para a leitura da Bíblia pelos leigos; bastava que a tradução bíblica fosse aprovada pela Sé Apostólica.

Já em 1713, na bula Unigenitus, o papa Clemente XI advertiu que a leitura bíblica não era obrigatória aos fiéis e em 1794, no documento Auctorem Fidei ${ }^{796}$, do papa Pio VI, a mesma recomendação foi confirmada. Até esse momento, portanto, os documentos discorriam de uma forma mais ampla sobre o lugar das Escrituras na vida da Igreja como uma resposta às iniciativas protestantes de recorrência exclusiva às Escrituras, como regra de fé e prática.

Entretanto, doze anos após a criação da primeira Sociedade Bíblica, a BFBS, e três anos após a criação da Sociedade Bíblica Russa, ou seja, mais especificamente em 3 de setembro de 1816, o papa Pio VII enviou uma carta ${ }^{797}$ ao arcebispo D. Stanisław Bohusz Siestrzeńcewicz, da Arquidiocese Metropolitana de Mohilev, na Rússia, com recomendações que eram contrárias ao trabalho realizado pelas Sociedades Bíblicas na região. Tal carta foi motivada pela notícia de que o arcebispo havia inicialmente apoiado e recomendado ao clero local a distribuição de Bíblias da recém-criada Sociedade Bíblica Russa. Como uma resposta a tal atitude, o papa reiterou que "a circulação das Sagradas Escrituras em língua vulgar em todos os lugares, sem discriminação, poderia provocar mais danos do que benefícios"798 à fé católica. Resgatando ainda as decisões do Concílio de Trento, o papa afirmou que a verdade da doutrina cristã não estava apenas nas Escrituras Sagradas, mas também na Tradição. Diante disso, somente a Igreja poderia interpretar e distribuir as Escrituras. Daí para frente, várias outras advertências foram realizadas.

\footnotetext{
${ }^{794}$ GIRALDI, Luiz Antonio. A Bíblia no Brasil Império, p. 45.

${ }^{795}$ Cf. ALVES, Herculano. A Bíblia de João ferreira Annes d'Almeida, p. 238.

796 PAPA PIO VI. Bolla Auctorem Fidei, 1794, n.11

797 PAPA PIO VII. Epistola Magno et Acerbo, 1816, passim. Disponível em: https://w2.vatican. $\mathrm{va} /$ content/pius-vii/it/documents/epistola-magno-et-acerbo-3-septembris-1816.html. Acesso em 8 mai. 2017.

798 STEER, Roger. Good News for the World, 200 years of making the Bible heard, p. 155 (tradução nossa).
} 
Em 1824, o papa Leão XII, na encíclica Ubi primum ${ }^{799}$, nomeou especificamente a Sociedade Bíblica em seu documento. De forma contrária às intenções da organização, ele afirmou que o trabalho ousado, realizado pelas Sociedades Bíblicas por toda a terra, estava contaminando as tradições dos Santos Pais, como também as decisões do Concílio Tridentino. Para o papa, a Sociedade Bíblica estava pervertendo as Escrituras Sagradas com traduções para as línguas vulgares e, por isso, tal atitude deveria ser temida pelos cristãos. Leão XII acreditava que uma perversa interpretação das Escrituras transformaria o evangelho de Cristo em um evangelho humano, ou pior, em um evangelho do diabo. O papa chegou a fazer referência à distribuição gratuita que estava sendo realizada pela Sociedade Bíblica para muitas pessoas. Nesse sentido, a recomendação foi expressa para que o rebanho fosse afastado dessa novidade perversa e desses pastos venenosos.

A encíclica Traditi humilitati, promulgada por Pio VIII em 1829, defendia o catolicismo como a única religião verdadeira e fazia a seguinte advertência contra o trabalho das Sociedades Bíblicas:

Também precisamos estar vigilantes sobre as sociedades daqueles que publicam novas traduções da Bíblia em todas as línguas vernáculas, contra as regras saudáveis da Igreja, de modo que os textos sejam mal interpretados em significados perversos, dependendo do espírito de cada tradutor. Tais versões são distribuídas gratuitamente em todos os lugares, com despesas exorbitantes, e são oferecidas até aos mais ignorantes, e muitas vezes foram escritas de forma pervertida para que os leitores bebam um veneno letal, onde acreditavam encontrar as águas da sabedoria saudável [...]. É seu dever, Veneráveis Irmãos, dirigir os esforços contra as sociedades secretas de homens defeituosos que, inimigos de Deus, estão empenhados em proclamar a ruína da Igreja, minar a Estados, para subverter a ordem universal, e quebrar a fé verdadeira, abrindo caminho a todos os tipos de perversidade. [...] excomungamos as sociedades (qualquer que seja o nome delas) ${ }^{800}$.

\footnotetext{
799 "Voi ben sapete, Venerabili Fratelli, che una società volgarmente chiamata Biblica si estende ora audacemente su tutta la terra, e che, a dispetto delle tradizioni dei Santi Padri e contro il notissimo decreto del Concílio Tridentino [Sess. 4, De edit. et usu sacrorum librorum], s'impegna con tutte le sue forze e con tutti i mezzi di cui può disporre a tradurre, o per meglio dire a corrompere la sacra Bibbia, volgendola nel volgare di tutte le nazioni. Da ciò deriva un fondato motivo di temere che, come in alcune traduzioni già note, così per altre si debba dire, quale conseguenza di un'interpretazione perversa, che invece del Vangelo di Cristo si trovi il vangelo dell'uomo o, peggio ancora, il vangelo del demônio" (PAPA LEÃO XII. Carta encíclica Ubi primum, 1824. Disponível em: https://w2.vatican.va/content/leo-xii/it/documents/enciclicaubi-primum-5-maggio-1824.html. Acesso em 15 jun. 2017, grifos nossos).

800 PAPA PIO VIII. Carta encíclica Traditi humilitati, 1829. Disponível em: https://w2.vatican. va/content/pius-viii/it/documents/enciclica-traditi-humilitati-24-maggio-1829.html. Acesso em 8 mai. 2017.
} 
O papa Gregório XVI, na encíclica Inter Praecipuas, de $1844^{801}$, aumentou ainda mais o tom da crítica. Ele identificou de forma ainda mais incisiva a Sociedade Bíblica localizada na Inglaterra, que estava difundindo amplamente traduções das Escrituras em línguas vernáculas em vários lugares. O papa inclusive expressou sua preocupação pela grande quantidade de Bíblias distribuídas. Para ele, esse trabalho constituía uma das artimanhas mais sutis que os protestantes de diferentes denominações estavam tentando realizar entre os fiéis católicos. O papa também criticou o fato de que a distribuição era realizada sem discernimento, ou seja, para qualquer pessoa (para "a velha tagarela, o velho a delirar, o infiel e todo o sofista prolixo”), que era convidada a ler as Escrituras sem qualquer orientação de um clérigo.

Nesse documento, sem dúvidas o mais crítico e intenso, o papa afirma que seria muito fácil, por ignorância ou fraude, que as traduções das Sociedades Bíblicas tivessem gravíssimos erros. Tal seriedade é acentuada quando o papa afirma que estes erros poderiam passar despercebidos, mantendo-se ocultos à custa de muitas pessoas que não buscam na Tradição e no Magistério a correta interpretação. Nesse sentido, em tom apologético, o papa respondeu às críticas realizadas pelos protestantes, de que a Igreja tinha mantido as Escrituras distantes dos fiéis. Em sua defesa, o papa descreveu várias ações realizadas pela Igreja Católica para que o povo tivesse acesso às Escrituras. Ele reiterou as decisões de Pio VII e de Leão XII em suas críticas e advertências contra as "armadilhas" criadas pelas Sociedades Bíblicas, advertindo sobre o erro que alguns católicos cometiam ao apoiá-las, quando assim o faziam por meio do trabalho dos missionários (ou como ele mesmo emenda, emissários) que distribuíam as Escrituras livremente, em grande quantidade e em muitos lugares.

Já no final, o papa esclareceu que o documento se originou a partir de uma reunião em que alguns cardeais, depois de terem examinado a situação em sua gravidade, aconselharam o papa para que fosse enviada a referida encíclica com a intenção explícita de condenar, com autoridade apostólica, a Sociedade Bíblica. Além disso, o papa reiterou, mais uma vez, tudo o que falaram seus antecessores e condenou, novamente, todos os que apoiavam o trabalho das Sociedades Bíblicas.

\footnotetext{
801 PAPA GREGÓRIO XVI. Carta encíclica Inter Praecipuas, 1844, passim. Disponível em: https://w2.vatican.va/content/gregorius-xvi/it/documents/encyclica-inter-praecipuasmachinationes-8-maii-1844 .html. Acesso em 6 jul. 2017.
} 
Ele manifestou claramente seu desgosto em relação à produção, divulgação, leitura e retenção de livros da Sagrada Escritura que foram traduzidos em linguagem vulgar. Por assim ser, o papa ratificou, mais uma vez, que tais traduções faziam parte do Índice de Livros Proibidos pela Igreja e, portanto, qualquer pessoa que apoiasse o trabalho ou se relacionasse com as Sociedades Bíblicas deveria ser imediatamente excluída. Nesse ínterim, a recomendação expressa aos bispos foi dada no sentido de que as Bíblias em língua vernácula distribuídas pelas Sociedades Bíblicas deveriam ser removidas das mãos dos fiéis.

Diante do tom severo apresentado, torna-se importante que o teor deste documento seja compreendido no horizonte histórico e teológico daquele momento. Nessa perspectiva, o que fica claro na compreensão do papa era que, disseminar indiscriminadamente as Escrituras entre cristãos e infiéis, aliciando todo tipo de pessoas a lê-las sem nenhum guia, é algo que Jerônimo já deplorava, pois tornava comum à velhinha tagarela, ao velho delirante, ao falante sofista e a todos, a arte de compreender, sem mestre, as Escrituras, desde que se saiba ler. Há, inclusive, um pressuposto bíblico que adverte sobre essa questão. O Apóstolo Pedro admoesta que nas cartas de Paulo "[...] há certas coisas difíceis de entender, que os ignorantes e instáveis deturpam, como também deturpam as demais Escrituras, para a própria destruição deles"; e acrescenta: "Vós, pois, amados, prevenidos como estais de antemão, acautelai-vos; não suceda que, arrastados pelo erro desses insubordinados, descaiais da vossa própria firmeza" $(2 \mathrm{Pd} 3,16-17)^{802}$. Portanto, a Igreja Católica ao analisar a difusão das Escrituras pelas Sociedades Bíblicas entendia que alguns malefícios poderiam acontecer, principalmente porque, nesta ótica católica, há interpretações da Bíblia que obviamente não são aceitas e há leitura bíblica que, se equivocada, pode conduzir ao erro ou a condenação.

Na reflexão de Gregório XVI, portanto, pouco importava às Sociedades Bíblicas quais erros poderiam ser assimilados pelos leitores das traduções vernáculas. Tal postura poderia decorrer em um julgamento audaz em relação ao sentido da Escritura, desprezando as tradições divinas custodiadas pela Igreja Católica segundo a doutrina dos Pais, e repudiando o Magistério da mesma Igreja. Nesse sentido, reiterando o Constituição de Pio IV, do século XVI, a leitura da Bíblia em língua vernácula deveria ser permitida somente àqueles que se julga poderem

${ }^{802}$ BÍBLIA Sagrada. Português. Bíblia de Estudo Almeida, 2Pd 3,16-17. 
crescer na fé e na piedade. E aos próprios bispos católicos se faz esta advertência: "não ousem nunca sob qualquer pretexto interpretar e explicar as divinas Escrituras contra a tradição dos padres, ou em sentido diferente do que tem a Igreja Católica".

Naquela época, em que prevalecia a mentalidade confessional, realçando as diferenças em relação a outros grupos cristãos, ensinava-se que fora da Igreja não há salvação. Só em meados do século XX a Igreja Católica vai matizar esta afirmação. Na época do Concílio Vaticano II, o Decreto sobre o Ecumenismo reconhece a manifestação do mistério cristão em outras confissões religiosas, e a ação do Espírito Santo servindo-se também delas para a salvação. Somente neste contexto se poderia ter uma colaboração mútua estreita e fecunda. Mas, como se percebe pela encíclica, isto era impossível no tempo de Gregório XVI.

Pouco tempo depois, em 1846, na encíclica Qui pluribus ${ }^{803}$, o papa Pio IX faz uma advertência sobre os deveres dos sacerdotes na defesa da fé ante um mundo que resistia à doutrina católica. No documento, o papa combateu o liberalismo, o comunismo, o indiferentismo religioso e o racionalismo. Em relação ao trabalho das Sociedades Bíblicas, o papa resgatou o teor do documento de Gregório XVI que desaprovava as Sociedades Bíblicas e afirmou que, do mesmo modo, ele as condenava. O documento acrescentava ainda a seguinte afirmação: "Essas engenhosas sociedades bíblicas, que renovam o dolo antigo dos hereges, não cessam de distribuir suas Bíblias intensamente a todos os homens, mesmo os iletrados; Bíblias que foram traduzidas contra as leis da Igreja, e que frequentemente contêm falsas explicações do texto" ${ }^{" 804}$.

O último documento contrário às Sociedades Bíblicas foi elaborado pelo papa Pio IX que, “entre as condenações do famoso Syllabus ${ }^{805}$ (8 de dezembro de 1864) havia uma para lançar anátema sobre as sociedades bíblicas e seu traba1ho" ${ }^{\text {"86 }}$. Como se percebe, as Sociedades Bíblicas foram sucessivamente reprova-

803 PAPA PIO IX. Carta encíclica Qui Pluribus, 1846, passim. Disponível em: https://w2.vatican.va/content/pius-ix/it/documents/enciclica-qui-pluribus-9-novembre-1846. html. Acesso em 5 nov. 2016.

${ }^{804}$ REILY, Duncan. A história documental do protestantismo no Brasil, p. 83.

${ }^{805}$ O Syllabus Errorum (Ś́labo dos Erros de Nossa Época) apresenta 80 proposições ou opiniões que foram consideradas errôneas pela autoridade máxima da Igreja. O documento foi publicado como apêndice da encíclica Quanta cura. In: PAPA PIO IX. Carta encíclica Quanta Cura. Sobre os principais erros da época, 1864, índice § IV.

${ }^{806}$ CANNUYER, Christian; POSWICK, Réginald-Ferdinand. Catolicismo e Bíblia. In: LONGTON, Joseph; POSWICK, Réginald-Ferdinand [et al.] (orgs.). Dicionário Enciclopédico da Bíblia, p. 284. 
das, proibidas ou condenadas. Em menor ou maior intensidade, havia sempre uma manifestação contrária à propagação das Escrituras realizada por elas ou por seus agentes. A advertência do papa Gregório XVI, na encíclica Inter Praecipuas, de 1844, é a mais contundente, como já constatado. Convém lembrar que é justamente nesse período que as Sociedades Bíblicas (BFBF e ABS) estavam em pleno desenvolvimento da obra bíblica desenvolvida no Brasil.

Com o passar dos anos, a compreensão da Igreja Católica em relação ao uso, à tradução e à propagação das Escrituras foi se flexibilizando, como já foi percebido no capítulo anterior. Conforme adverte Lortz, "infelizmente, a luta contra as sociedades bíblicas protestantes foi além do justo e exerceu uma influência restritiva sobre a leitura da Bíblia pelos católicos" ${ }^{\$ 07}$. Segundo Lortz, tal realidade só foi alterada no séxulo XX. E é justamente a partir desse período que o relacionamento das Sociedades Bíblicas com a Igreja Católica também foi se alterando. Giraldi lembra que

Em 1878 aconteceu um fato novo e surpreendente: foi eleito o papa Leão XIII, que adotou uma atitude completamente oposta à de seus antecessores e deu início a uma nova fase de diálogo e entendimento com todas as denominações e organizações cristãs, inclusive com as Sociedades Bíblicas ${ }^{808}$.

De fato, Leão XIII é o primeiro papa a não tecer mais criticas às Sociedades Bíblicas e é justamente no período de seu pontificado que as Sociedades Bíblicas publicaram várias edições da Bíblia na tradução de Figueiredo que passaram a ser distribuídas principalmente no Brasil ${ }^{809}$. Por sua vez, a Encíclica Providentissimus Deus, publicada no dia 18 de novembro de 1893, realiza uma abertura maior quando comparada às encíclicas anteriores, recomendando mais claramente a tradução da Bíblia diretamente dos idiomas originais e incentivando a sua leitura. Assim, paulatinamente, diálogos foram realizados e aproximações foram estabelecidas desde então. Steer chega a destacar que, atualmente, "as relações entre as Sociedades Bíblicas e a Igreja Católica Romana são bem diferentes" ${ }^{\text {}}{ }^{10}$. Giraldi segue o mesmo raciocínio e lembra que "hoje as relações entre as Sociedades Bí-

\footnotetext{
${ }^{807}$ LORTZ, Joseph. Historia de La Iglesia: en la perspectiva de la historia del pensamiento. Edad moderna y contemporanea. Vol. II, p. 472 (tradução nossa).

${ }^{808}$ GIRALDI, Luiz Antonio. A Bíblia no Brasil Império, p. 132.

${ }^{809}$ Cf. TERRA, João Evangelista Martins. A Bíblia na evangelização do Brasil, p. 23; MALZONI, Cláudio Vianney. As edições da Bíblia no Brasil, pp. 50-51.

810 STEER, Roger. Good News for the World, 200 years of making the Bible heard, p. 156 (tradução nossa).
} 
blicas e a Igreja Católica são as melhores possíveis. Elas trabalham juntas em projetos de tradução, produção e divulgação da Bíblia no mundo"811.

Como confirmação de tal realidade, dois documentos católicos importantes evidenciam esse fato, quando discorrem sobre a importância das traduções bíblicas. O tema que tinha gerado tanta discórdia no passado, atualmente, é entendido como uma atividade importante para a igreja cristã e, portanto, merece ser apreendido com bastante diligência por todos os envolvidos na árdua tarefa da causa da Bíblia. O primeiro deles é a Constituição Dogmática sobre a Revelação Divina, Dei Verbum, fruto do Concílio Vaticano II, que diz:

[...] visto que a palavra de Deus deve estar sempre acessível a todos, a Igreja procura com solicitude maternal que se façam traduções aptas e fiéis nas várias línguas, sobretudo a partir dos textos originais dos livros sagrados. Se, porém, segundo a oportunidade e com a aprovação da autoridade da Igreja, essas traduções se fizerem em colaboração com os irmãos separados, poderão ser usadas por todos os cristãos (Dei Verbum 22) $)^{812}$.

O segundo é a Exortação Apostólica do papa Bento XVI, Verbum Domini, fruto do Sínodo dos Bispos Católicos, realizado no Vaticano entre os dias 5 e 26 de outubro de 2008, cuja temática foi “A Palavra de Deus na vida e na missão da Igreja".

Se a inculturação da Palavra de Deus é parte imprescindível da missão da Igreja no mundo, um momento decisivo deste processo é a difusão da Bíblia por meio do valioso trabalho de tradução nas diversas línguas. [...] [371] Durante os trabalhos sinodais, pôde-se constatar que várias Igrejas locais ainda não dispõem de uma tradução integral da Bíblia nas suas próprias línguas. Atualmente quantos povos têm fome e sede da Palavra de Deus, mas infelizmente não podem ainda ter um «acesso patente à Sagrada Escritura» [372] como desejara o Concilio Vaticano II. Por isso, o Sínodo considera importante, antes de mais nada, a formação de especialistas que se dediquem a traduzir a Bíblia nas diversas línguas. [373] Encorajo a que se invistam recursos neste âmbito. De modo particular, quero recomendar que seja apoiado o empenho da Federação Bíblica Católica para um incremento ainda maior do número das traduções da Sagrada Escritura e da sua minuciosa difusão. [374] Bom será que tal trabalho, pela sua própria natureza, seja feito na medida do possível em colaboração com as diversas Sociedades Bíblicas ${ }^{813}$.

Como se percebe, nos dois documentos há uma recomendação explícita de que o trabalho de tradução das Escrituras seja realizado em colaboração com os irmãos separados (protestantes) e com as Sociedades Bíblicas. Ambos os docu-

\footnotetext{
${ }^{811}$ GIRALDI, Luiz Antonio. A Bíblia no Brasil Império, p. 123.

${ }^{812}$ Cf. CONCÍlIO VATICANO II. Dei Verbum. Constituição Dogmática sobre a Revelação Divina, n. 22.

${ }^{813}$ Cf. PAPA BENTO XVI. Exortação Apostólica Verbum Domini, p. 206
} 
mentos são comedidos; afinal, se reconhece que tanto para o lado católico como para o lado protestante ainda existem resistências a esse tipo de trabalho conjunto. Entretanto, como já se discorreu no capítulo anterior, mas que é importante repetir, a Bíblia é a Palavra de Deus e, como tal, ela não é evangélica nem católica. As discussões sobre o cânon, que aliás são divergentes em relação a várias outras igrejas cristãs (como os ortodoxos, que têm um cânon igualmente diferente), não deveriam impedir que traduções bíblicas fossem realizadas por representantes de ambas as tradições cristãs.

Considerando a informação das Sociedades Bíblicas ${ }^{814}$, que indica que das 6.880 línguas conhecidas do mundo, ainda existem 3.655 que não tem sequer uma porção das Escrituras traduzidas, seria muito significativo que tal cooperação se desenvolvesse ainda mais, para que, assim, mais pessoas tenham acesso à Palavra de Deus. Nesse sentido, o site da aliança mundial das Sociedades Bíblicas destaca que, entre os seus atuais parceiros na obra bíblica mundial, a Federação Bíblica Católica ${ }^{815}$ é um deles.

\subsection{2 \\ Desafios e dificuldades no trabalho das Sociedades Bíblicas no serviço às igrejas protestantes}

Ainda como consequência dos debates ocorridos durante e depois da Reforma, outro aspecto que constituiu um significativo desafio e provocou intenso debate entre os membros apoiadores e participantes das Sociedades Bíblicas em seu início foi a utilização de Bíblias com (ou sem) os livros deuterocanônicos. Historicamente, ainda que divergências tenham surgido em vários momentos, a igreja cristã usou com certa naturalidade os livros deuterocanônicos. Isso não quer dizer que a questão não era controversa. Por exemplo, o próprio Jerônimo, tradutor da versão latina oficial da Igreja Católica, considerou alguns destes livros apó$\operatorname{crifos}^{816}$. Por outro lado, Lutero, o reformador protestante, ao traduzi-los e inseri-

\footnotetext{
${ }^{814}$ UBS - United Bible Societies. Key facts about the Bible access. Desenvolvido pela UBS, 2018. Apresenta fatos, dados e números de novas traduções da Bíblia nas diversas línguas do mundo e de projetos bíblicos para surdos e deficientes visuais. Disponível em: <https://www.unitedbiblesocie ties.org/key-facts-bible-access>. Acesso em 11 out. 2017.

815 Cf. UBS - United Bible Societies. Partners. Desenvolvido pela UBS, 2018. Apresenta organizações não-governamentais que são parceiras das Sociedades Bíblicas. Disponível em: <https://www.unitedbiblesocieties.org/partners/>. Acesso em 11 out. 2017.

${ }^{816}$ Em seu prefácio ao livro de Samuel e Reis, na tradução Vulgata, Jeronimo declarou: "Hic prolugus Scripturarum quasi galeatum principium omnibus, quos de hebraeo vertimus in latinum,
} 
los em sua tradução da Bíblia para o alemão, considerou-os livros úteis e bons para o conhecimento, ainda que não os considerasse com a mesma inspiração que os demais. A Bíblia de Genebra (publicada na Inglaterra em 1576), uma das preferidas do movimento puritano e reformado, também traduziu os deuterocanônicos, colocando-os em um apêndice.

Publicada pela SPCK em 1799, a Bíblia em galês que Mary Jones recebeu do Reverendo Thomas Charles tinha os livros deuterocanônicos. Steer, inclusive, lembra que justamente no final de um destes livros "Mary Jones escreveu uma nota manuscrita que se tornou famosa na história da Sociedade Bíblica" ${ }^{\$ 17}$. Como se percebe, esses livros foram considerados como canônicos no Concílio de Trento e historicamente úteis pelos reformadores, mas as divergências e os posicionamentos se diversificavam. Como não poderia ser diferente, na história das Sociedades Bíblicas, tais divergências também emergiram e se acirraram.

Steer destaca que entre as igrejas e os membros envolvidos no trabalho das Sociedades Bíblicas, existiam apoiadores e opositores em relação à permanência e à distribuição das Bíblias com os livros deuterocanônicos. Como visto, o desafio estava posto; afinal, a questão para uns era doutrinária e para outros era uma mera formalidade. Como exemplo de tal dificuldade, a igreja da Inglaterra utilizava e recomendava a permanência dos livros nas suas publicações; por outro lado, os reformados calvinistas, ancorados na Confissão de Westminster, consideravam tais livros simples escritos humanos. Portanto, não deveriam fazer parte do cânon sagrado.

Nos debates, constatou-se que as opiniões giravam em torno de três opções, basicamente. Alguns queriam a publicação misturada de ambos os cânones de

convenire potest, ut scire valeamus, quicquid extra hos ext, inter apocrifa seponendum. Igitur Sapientia, quae vulgo Salomonis inscribitur, et Iesu filii Sirach liber et Iudith et Tobias et pastor non sunt in canone. Macchabeorum primum librum hebraicum repperi, secunds graecus est, quod et ex ipsa probari potest”. JERONIMO. Incipit prolugus Sancti Hieronumi In livro regum". In: BÍBLIA Vulgata. Latim. Bíblia Sacra. Stuttgart: Deutsche Bibelgesellschaft, 1969, p. 365. Tradução nossa: "Este prefácio, como se fora o elemento galeato [que precede ou vai à frente] das Escrituras, se pode predicar [ou aplicar] a todos os livros que vertemos do hebraico para o latim, de sorte que deixemos claro que qualquer [que] não se incluir neste rol se deve de classificar entre os apócrifos. Logo, Sabedoria, que vulgarmente se atribui a Salomão, e o livro de Jesus, filho de Siraque, e Judite, e Tobias, e o Pastor, não se incluem no cânon. Dos Macabeus o primeiro livro achei-o em hebraico, o segundo [está] em grego, o que até do próprio estilo se pode comprovar". 817 STEER, Roger. Good News for the World, 200 years of making the Bible heard, p. 158 (tradução nossa). A nota diz o seguinte: "Mary Jones nasceu em 16 de dezembro de 1784. Comprei isso aos meus 16 anos de idade. Eu sou filha de Jacob Jones e Mary Jones, sua esposa. Que o Senhor me conceda graça. Amém. Mary Jones é a verdadeira dona desta Bíblia. Comprada no ano de 1800 aos 16 anos", p. 229 (tradução nossa). 
livros na Bíblia; outros queriam uma publicação com a separação dos deuterocanônicos em um apêndice; e, alguns optavam pela exclusão definitiva dos livros deuterocanônicos. Durante alguns anos (de 1812 a 1826), entre reuniões, encontros e debates contundentes, que chegaram a gerar conflitos entre membros e desligamentos de sociedades auxiliares, um comitê especial foi nomeado para buscar uma resolução definitiva sobre a questão. Steer lembra que a resolução definiu pelo banimento dos livros deuterocanônicos nas Bíblias que viessem a ser publicadas e distribuídas pelas Sociedades Bíblicas. Inicialmente, a resolução foi apoiada pela maioria, sem que ocorressem novos debates. Entretanto, como decorrência de tal resolução, protestos intensos foram paulatinamente realizados.

Além destes aspectos, outra questão conflituosa também desafiou o trabalho de difusão das Escrituras Sagradas pelas Sociedades Bíblicas. Steer lembra que, neste caso, a questão surgiu em torno da participação dos unitários, "aqueles que

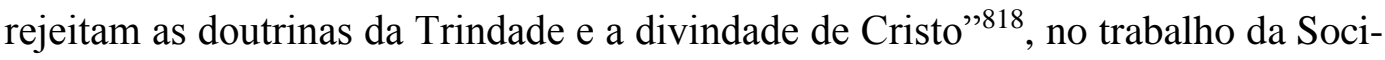
edade Bíblica. Como não existiam barreiras no regulamento que impedissem a participação desse grupo, em 1830, a Sociedade Bíblica Auxiliar de Guernsey enviou uma resolução à BFBS recomendando que todos aqueles que não professassem a Trindade fossem impedidos de ajudar no trabalho da Sociedade Bíblica. Para se descobrir quem professava ou negava tal doutrina, eles sugeriram a criação de algo semelhante a um teste. Imbuídas pela mesma ideia, algumas sociedades enviaram resoluções semelhantes à de Guernsey, enquanto outras preferiram que o trabalho se mantivesse como ora se apresentava, sem impedir ou realizar testes para estes grupos.

Considerando que o objetivo da criação da Sociedade Bíblica era de unir as igrejas em torno da causa da Bíblia sem discutir questões doutrinárias, para, assim, conquistar o maior número possível de apoiadores, o comitê geral se opôs às propostas. Steer destaca que na reunião anual realizada em 4 de maio de 1831, a questão foi abordada, mantendo-se a posição oficial, que reafirmava que o único objetivo da Sociedade Bíblica era promover a circulação de Bíblias, e não assumir um papel de interpretá-la, nem de impor algum teste para admissão de membros.

Dessa forma, em uma nova reunião ocorrida no dia 7 de dezembro de 1831, aqueles que partilhavam a visão de que a Sociedade Bíblica deveria estabe-

818 STEER, Roger. Good News for the World, 200 years of making the Bible heard, p. 166 (tradução nossa). 
lecer testes que poderiam gerar a exclusão dos unitários decidiram abandonar o movimento das Sociedades Bíblicas que teve sua origem em Londres, a fim de formarem uma nova organização, conhecida, a partir de então, como Sociedade Bíblica Trinitariana ${ }^{819}$, organização esta, em atividade até hoje no mundo e no Brasil.

Mesmo sob tais dificuldades ocorridas em sua história, tanto em relação aos católicos como em relação aos movimentos doutrinários divergentes dos protestantes, a BFBS, junto às suas congêneres, continuou a crescer e a cumprir a missão para a qual foi fundada. E, assim, tanto no aspecto histórico como na atualidade,

As Sociedades Bíblicas ganharam renome por investirem em estudo e cuidadosa pesquisa na preparação das Bíblias que distribuem. Com o passar dos anos, elas têm traduzido a Bíblia, na sua íntegra ou apenas em partes dela, em um número expressivo de línguas, em muitos casos levando anos para produzir uma única versão ${ }^{820}$.

Portanto, além da distribuição, que constitui parte importante e significativa do trabalho das Sociedades Bíblicas, um aspecto fundamental é a dedicação diligente ao trabalho de tradução da Bíblia para todas as línguas faladas no mundo. É nesse sentido que Scholz, por exemplo, resume muito bem essa dupla perspectiva da missão. Para ele, as Sociedades Bíblicas são "guardiãs do texto e divulgadoras das Escrituras" ${ }^{\prime 21}$. Como se percebe, portanto, são aspectos fundamentais e indissociáveis, que definem e caracterizam de forma distintiva o trabalho de difusão das Escrituras das Sociedades Bíblicas desde a sua fundação.

Giraldi destaca a proficuidade deste trabalho, ao lembrar que "em 1854, ao completar seus primeiros 50 anos de existência, a Sociedade Bíblica Britânica e Estrangeira anunciou a distribuição em todo o mundo de 28 milhões de Escrituras, em 152 línguas" ${ }^{\prime 22}$. Já em seu centenário, a SBBE comemorou a significativa distribuição de "180 milhões de exemplares das Escrituras" 823 , em mais de 370 línguas. Os dados mais recentes informados pelas Sociedades Bíblicas Unidas, no

\footnotetext{
${ }^{819}$ STEER, Roger. Good News for the World, 200 years of making the Bible heard, p. 170.

${ }^{820}$ MILLER, Stephen; HUBER, Robert. A Bíblia e sua história: o surgimento e o impacto da Bíblia, p. 203.

821 SCHOLZ, Vilson. Sociedades Bíblicas: guardiãs do texto e divulgadoras das Escrituras. In: HEIMANN, Leopoldo (org.). Fórum ULBRA de Teologia. Canoas: ULBRA, 2008, p. 195.

${ }^{822}$ Cf. GIRALDI, Luiz Antonio. A Bíblia no Brasil Império, pp. 131-132.

${ }^{823}$ Ibid., p. 180.
} 
Relatório de Distribuição Mundial de Escrituras de $2016^{824}$, apontam para a distribuição surpreendente de mais de 400 milhões de Escrituras, que variam entre Bíblias completas, Novos Testamentos e porções bíblicas (Evangelhos, Salmos etc.), em 3.225 línguas faladas no mundo ${ }^{825}$. É obvio que tais números apreendem a quantidade de todas as Sociedades Bíblicas que compõem a aliança mundial. Contudo, é bom lembrar que foi a partir da BFBS que todas as outras surgiram e definiram os rumos de seus respectivos trabalhos na causa da Bíblia. Deste modo, constata-se que a semente lançada pela BFBS germinou e deu muitos frutos para a difusão das Escrituras no mundo todo.

É claro que outros aspectos históricos surgiram no decorrer do trabalho das Sociedades Bíblicas, principalmente da BFBS e da ABS. Aliás, muitas Sociedades Bíblicas surgiram e se espalharam pelo mundo - atualmente são 149 Sociedades Bíblicas atuando em mais de 200 países - e, por isso, seria praticamente impossível descrever toda essa história. Considerando, entretanto, o objeto deste estudo, que é a difusão das Escrituras por meio do trabalho das Sociedades Bíblicas no Brasil, os próximos relatos a respeito destas organizações ganharão maior significância diante do trabalho realizado por elas no país, a partir do início do século XIX. Elas serão citadas, portanto, até o final, desde que haja relevância com o trabalho bíblico brasileiro.

\section{3}

\section{A atuação das Sociedades Bíblicas na difusão das Escrituras Sagradas no Brasil}

Desde a sua descoberta, o Brasil, como colônia de Portugal, foi fundamentalmente marcado pela evangelização católica. Aliás, mais do que isso, pelos trezentos primeiros anos da história do Brasil, aproximadamente, houve uma intrínseca relação entre a Igreja e o Estado. A conquista da terra a ser colonizada ocorria sob vários aspectos, entre os quais, a conquista política, social e religiosa, todas acontecendo de forma concomitante. Nesse sentido, histórica e religiosamente falando,

${ }^{824}$ SOCIEDADES BÍBLICAS UNIDAS. Informe de Distribución Mundial de Escrituras 2016. Swindon, England: United Bible Societies, 2016, pp. 1-7.

${ }^{825}$ Porém, segundo o mesmo relatório, em 2016 ainda existiam 3.655 línguas sem nenhuma parte das Escrituras traduzidas. 
No final da Idade Média, a forte integração entre a Igreja e o Estado na Península Ibérica deu origem ao fenômeno conhecido como "padroado" ou "patronato real". Pelo Padroado, a Igreja concedia a um governante civil certo grau de controle sobre uma igreja nacional, em recompensa por seu zelo cristão e como incentivo para futuros benefícios em favor da Igreja. Entre 1455 e 1515, quatro papas concederam direitos de padroado aos reis portugueses $[\ldots]^{826}$.

Sob tais fatos se tem, portanto, uma relação indissociável. A coroa era por natureza católica, e a Igreja Católica era estatal. O vínculo entre Estado e Igreja era comparado à união entre corpo e alma. Nessa perspectiva, a Igreja Católica Apostólica Romana era, portanto, a Igreja oficial do Brasil. Somente seu culto era praticado e apenas seus templos eram construídos. Com exceção de duas "aventuras" protestantes entre 1555 e 1560, com os huguenotes franceses no Rio de Janeiro, e entre 1630 e 1654, com o domínio holandês no Nordeste brasileiro, o protestantismo não encontrou muito espaço em terras "tupiniquins" saltar que essas duas tentativas não aconteceram porque foram intencionadas como uma ação missionária de viés protestante, puramente. Elas surgiram motivadas e atreladas à tentativa também frustrada da França e da Holanda de colonizar essa região. Em ambas as situações, porém, franceses e holandeses foram expulsos. No primeiro caso, alguns protestantes foram banidos ou mortos. No segundo caso, várias igrejas chegaram a ser constituídas, pessoas foram batizadas, índios foram evangelizados, pastores foram ordenados e presbitérios foram constituídos.

Como é comum na forma de culto e missão protestante, Bíblias foram trazidas para o país nessas duas situações. Giraldi, por exemplo, ressalta que "existem fortes indícios de que os calvinistas franceses trouxeram Bíblias para o Brasil, provavelmente na edição francesa de $1478^{\# 828}$. Nesse ínterim, César lembra que nesta mesma ocasião, o primeiro sermão protestante realizado no Brasil teve como base bíblica um Salmo $(\mathrm{S} 127,4)^{829}$. No caso holandês ${ }^{830}$, Mein destaca que em uma reunião ocorrida entre os líderes calvinistas holandeses que estavam em Recife foi aprovada uma resolução em que ficou "decidida a requisição de 20 Bíblias grandes para a introdução da nova tradução e uso de cada um" ${ }^{831}$. Giraldi descre-

\footnotetext{
${ }^{826}$ GIRALDI, Luiz Antonio. A Bíblia no Brasil Império, p. 49.

${ }^{827}$ Cf. HAHN, Carl Joseph. História do culto protestante no Brasil, pp. 63-38.

${ }^{828}$ GIRALDI, Luiz Antonio. Op. cit., p. 53.

${ }^{829}$ Cf. CÉSAR, Elben Magalhães Lenz. História da evangelização do Brasil, p. 38.

${ }^{830}$ César destaca que no Brasil holandês, devido à Reforma ocorrida cem anos antes e ao movimento puritano que já influenciava muitos protestantes, “a Bíblia era a norma credenti et agendi, isto é, a norma de fé e comportamento". In: CÉSAR, Elben Magalhães Lenz. Op. cit., p. 52.

${ }^{831}$ MEIN, John. A Bíblia e como chegou até nós. Rio de Janeiro: JUERP, 1990, p. 90.
} 
ve, ainda, alguns trabalhos bíblicos que foram realizados pelos holandeses no Brasil. Segundo o autor, eles

Também traduziram trechos da Bíblia do holandês para o português e para a língua tupi, para evangelização dos portugueses e dos indígenas [...], os protestantes holandeses não apenas começaram a ler a Bíblia durante o culto, mas passaram a distribuir exemplares dela aos membros de suas igrejas. Como ainda não existia uma tradução da Bíblia para a língua portuguesa, distribuíram a tradução da Bíblia em espanhol, a qual, devido à semelhança com o português, podia ser compreendida por alguns leitores brasileiros. [...] Numa lista de livros enviados no ano de 1624, constam Bíblias e Novos Testamentos em espanhol, os quais foram levados para o Brasil. Em 1636, o pastor Stetten, residente na Ilha de Itamaracá, em Pernambuco, escreveu uma carta à Igreja Reformada Holandesa no Brasil pedindo um exemplar da Bíblia em português, argumentando que as Bíblias em espanhol não eram bem compreendidas no Brasil. E, pouco antes da expulsão dos holandeses do Brasil, ocorrida em 1654, foi encontrado no depósito de livros dos holandeses, em Recife, um estoque de 19 Bíblias e 84 Novos testamentos ${ }^{832}$.

Ainda que a difusão tenha acontecido de forma relevante nesse contexto, como se sabe, tudo se perdeu com a expulsão definitiva dos holandeses do país. O que de fato prevaleceu nestes trezentos primeiros anos foi, portanto, o método de evangelização realizado pela Igreja Católica. Essa evangelização sob o viés da difusão das Escrituras já foi discutida no capítulo anterior. Porém, cabe lembrar que, ainda que os jesuítas tenham evangelizado utilizando algumas formas estratégicas de exposição das Escrituras por meio de pinturas, histórias, músicas, teatro e pregação, na verdade, pouco se sabe sobre a difusão das Escrituras propriamente ditas. Diante disso, a Bíblia, como tal, se tornou um livro praticamente desconhecido no país durante muito tempo. Giraldi acrescenta, ainda, que na época em que a corte real portuguesa chegou ao Brasil, ou seja, cerca de trezentos anos após a descoberta do país, "não existiam gráficas e os livros não podiam ser importados. Não havia liberdade religiosa" ${ }^{\$ 33}$. Como se percebe, esses aspectos favoreciam, ainda mais, a escassez de Bíblias no país.

Como exemplo dessa realidade, Reily apresenta o teor da carta de um missionário metodista chamado Broadbent, que passou pelo Brasil a caminho do Ceilão, em 1816. Nessa carta, Broadbent relata um diálogo ocorrido no Rio de Janeiro com um padre de nacionalidade inglesa. Além de descrever aspectos sociais, políticos, econômicos e religiosos do Brasil, o missionário expressa gratidão a

${ }^{832}$ GIRALDI, Luiz Antonio. A Bíblia no Brasil Império, pp. 55-56. Não foi encontrada a fonte primária que corrobore a afirmação de ter sido encontrado em um depósito na cidade de Recife cerca de 19 Bíblias e 84 Novos Testamentos naquela ocasião, conforme destacou Giraldi acima. ${ }^{833}$ Ibid, pp. 11-12. 
Deus pelo fato de ter nascido em uma terra de liberdade e de Bíblias, e conta, com surpresa, sobre a reação do sacerdote em relação à difusão das Escrituras. Broadbent diz que o padre se referia "às Escrituras como um nariz de cera, dizendo que não deviam ser colocadas nas mãos do vulgo" ${ }^{\text {834 }}$. Por isso, sob raras exceções já apresentadas no capítulo anterior, constata-se que poucas Bíblias (ou partes dela) chegaram às mãos dos brasileiros nos três primeiros séculos desde a descoberta do Brasil.

Essa realidade só se alterou, aos poucos, a partir da chegada de D. João VI ao Brasil, depois de fugir de Napoleão, que ameaçava investir contra Portugal. Aliás, como bem lembra Gomes, entre os 60 mil volumes que compunham os livros da Real Biblioteca, estavam também algumas “antigas cópias manuscritas da Bíblia" ${ }^{\circledR 35}$, ou seja, o próprio Rei se encarregou de trazer as suas Bíblias ao país. Por outro lado, diante dos acordos comerciais firmados principalmente com a Inglaterra $^{836}$ — país este que por meio da marinha inglesa garantiu a segurança da corte portuguesa e dos nobres em sua mudança para o Brasil ${ }^{837}$, Portugal se viu obrigado a flexibilizar sua rigidez religiosa, que era totalmente favorável e exclusiva aos católicos a fim de conceder certa liberdade religiosa a protestantes estrangeiros. Em um dos artigos desse acordo comercial, se "permitia ou tolerava a prática de outros cultos a cidadãos britânicos não católicos romanos dentro de certas limitações e restrições, desde que vivessem no Brasil" ${ }^{\prime 838}$.

Como bem afirma Mendonça ${ }^{839}$, ainda que pouco se saiba sobre a presença de protestantes no país antes da chegada da Família Real, se sabe que, após a sua chegada e com a definitiva abertura dos povos às nações amigas, em 1808, muitos

\footnotetext{
${ }^{834}$ REILY, Duncan. A história documental do protestantismo no Brasil, p. 53.

${ }^{835}$ GOMES, Laurentino. 1808: como uma rainha louca, um príncipe medroso e uma corte corrupta enganaram Napoleão e mudaram a história de Portugal e do Brasil. São Paulo: Planeta do Brasil, 2007, p. 78.

${ }^{836}$ De acordo com Gomes, três acordos foram firmados entre Portugal e Inglaterra, mas o principal deles foi o Tratado de Comércio e Navegação, firmado em 19 de fevereiro de 1810 (cf. GOMES, Laurentino. 1808: como uma rainha louca, um príncipe medroso e uma corte corrupta enganaram Napoleão e mudaram a história de Portugal e do Brasil, pp. 204-212). No artigo XII desse tratado, foi estabelecida a liberdade de culto aos ingleses e uma certa tolerância religiosa a não católicos estrangeiros que residiam no Brasil. A difamação contra o catolicismo e o proselitismo aos brasileiros estavam proibidos (cf. REILY, Duncan. A história documental do protestantismo no Brasil, p. 48).

${ }^{837}$ Cf. GOMES, Laurentino. Op. cit., p. 29

${ }^{838}$ HAHN, Carl Joseph. História do culto protestante no Brasil, p. 22.

${ }^{839}$ Cf. MENDONÇA, Antônio Gouvêa. O celeste porvir: a inserção do protestantismo no Brasil. São Paulo: EDUSP, 2008, pp. 41-42.
} 
protestantes começaram a passar pelos portos brasileiros ${ }^{840}$ e alguns outros se mudaram para o país. O Brasil se abriu para o mundo e, principalmente no aspecto comercial, "os privilégios concedidos à Inglaterra foram superiores até mesmo aos que a metrópole portuguesa teria no Brasil de D. João"841. Foi, portanto, um tempo de preeminência inglesa no Brasil; "o país se encheu de ingleses" ${ }^{842}$. Por conseguinte, foi dessa forma que os primeiros protestantes, com suas Bíblias, chegaram e foram difundido-as no país ${ }^{843}$. Somente um pouco mais tarde ocorreu a autorização do culto anglicano e a consequente abertura de igrejas anglicanas ${ }^{844}$ (sem cruz e sem torre) para atender aos ingleses que residiam no país.

Como se percebe, diante de toda essa perspectiva histórica, é impossível falar da chegada do protestantismo no Brasil sem discorrer sobre o trabalho de difusão das Escrituras Sagradas no país. Essa perspectiva é, por vezes, ignorada nos relatos históricos tradicionais (e exclusivistas) de muitas denominações ${ }^{845}$. Cabe destacar, portanto, que muito antes de qualquer igreja protestante ser estabelecida formal ou informalmente no Brasil, a Bíblia já era disseminada pelos representantes ou apoiadores das Sociedades Bíblicas que viajavam para o Brasil. Alguns só passavam e partiam. Outros chegavam com missões específicas, seja para fixar residência e trabalhar, seja para observar a terra, a fim de que se pudesse, em um futuro breve, estabelecer uma missão/igreja protestante no recém-criado Império do Brasil.

Entretanto, como se constatou, para cada missionário ou protestante que chegava ao Brasil, pelo menos inicialmente, o "propósito central era de levar outros a compartilharem os benefícios da Bíblia [...]"846. A Bíblia foi, portanto, o fundamento de toda e qualquer igreja protestante que chegou ao país. Dessa forma, o grande legado histórico de toda igreja protestante brasileira, em todas as

\footnotetext{
${ }^{840}$ Muitos capelães da marinha britânica começaram a atender os ingleses que passavam pelos portos brasileiros. Era inicialmente uma missão entre marinheiros, mas depois o projeto alcançou também os residentes ingleses. Reily destaca que capelanias foram estabelecidas no país e até mesmo uma organização denominada South American Missionary Society chegou a ser criada para missões no país (cf. REILY, Duncan. A história documental do protestantismo no Brasil, p. 46).

${ }^{841}$ GOMES, Laurentino. 1808, p. 207.

${ }^{842}$ HAHN, Carl Joseph. História do culto protestante no Brasil, p. 22.

${ }^{843} \mathrm{Com}$ a abertura dos portos às nações amigas, não somente Bíblias vieram para o Brasil. Livros e outros produtos que não existiam no país tiveram sua entrada liberada.

${ }^{844}$ A primeira capela protestante construída no Brasil foi fundada em 1822 com o templo da Igreja Anglicana no Rio de Janeiro (inaugurado em 25 de maio do mesmo ano). A construção não tinha aparência exterior de igreja (com torre e cruz); antes, era semelhante a uma residência.

${ }^{845}$ Cf. REILY, Duncan. A história documental do protestantismo no Brasil, p. 15, 39.

${ }^{846}$ Ibid., p. 39.
} 
suas vertentes atuais, se estabelece fundamentalmente nas Escrituras por meio da atuação das Sociedades Bíblicas.

\subsection{1 \\ Os primeiros registros e os primeiros documentos sobre o trabalho das Sociedades Bíblicas no Brasil Império}

De início, nesta seção, cabe uma pergunta intrigante: como uma Sociedade Bíblica, de origem inglesa, criada há pouco tempo, poderia se interessar em distribuir a Bíblia em português? E, ainda, como essas Bíblias poderiam chegar a uma colônia que era, de certa forma, menosprezada e distanciada da Europa? Em primeiro lugar, essa resposta se firma nos propósitos já descritos anteriormente sobre o surgimento e a missão das Sociedades Bíblicas; afinal, o objetivo primordial era o de levar a Bíblia a todos e em todos lugares.

Da mesma forma, outra resposta é dada por Reily, quando afirma que "a primeira edição da Bíblia em português realizada pela BFBS nasceu do desejo da Sociedade de oferecer as Escrituras no vernáculo a refugiados portugueses na Inglaterra, quando Napoleão invadira Portugal" ${ }^{\text {847 }}$. Por tais fatos é possível perceber o quanto a loucura napoleônica em busca de poder instigou significativamente a difusão da Bíblia em Portugal e também no Brasil, visto que as publicações vieram a atender não somente Portugal, mas também suas colônias. No relatório anual de 1809 da BFBS, ou seja, um ano após a instalação do Império Português no Brasil, consta a seguinte descrição sobre tais fatos:

O grande número de imigrantes portugueses em Portsmouth e em outras partes da Inglaterra, e as dificuldades surgidas agora de comunicação de Portugal com suas colônias, nos levaram a tomar a decisão de imprimir uma edição do Novo Testamento para uso das pessoas de língua portuguesa ${ }^{848}$.

Portanto, já cinco anos após a sua fundação, a BFBS estendeu sua ação de difusão das Escrituras para os países de língua portuguesa, produzindo, segundo o mesmo relatório, cerca de 5 mil Novos Testamentos em português. Nos anos subsequentes, os relatórios da BFBS continuaram a apresentar informações sobre a produção e a distribuição das Escrituras na língua portuguesa.

\footnotetext{
${ }^{847}$ REILY, Duncan. A história documental do protestantismo no Brasil, p. 77.

${ }^{848}$ GIRALDI, Luiz Antonio. A Bíblia no Brasil Império, pp. 79-80.
} 
É importante ressaltar que, para realizar tal missão, as versões portuguesas das Bíblias distribuídas pela Sociedade Bíblica foram as mais populares e disponíveis para aquele momento, ou seja, a tradução de Almeida ${ }^{849}$ e a tradução de Figueiredo. Giraldi lembra inclusive que diversas reuniões foram realizadas na BFBS para discutir qual destas duas traduções deveria ser publicada e distribuída em língua portuguesa. As dúvidas que instigaram o tema giravam em torno do público-alvo (católicos ou protestantes) e da linguagem utilizada na tradução (erudita ou popular). Em 1817, a BFBS optou por trabalhar com as duas traduções: Almeida ${ }^{850}$, para atender aos pedidos dos protestantes, e Figueiredo, para alcançar principalmente o público católico.

Sobre esta última, é importante destacar alguns aspectos; afinal, essa foi "a primeira tradução católica de toda a Bíblia para a língua portuguesa, feita pelo

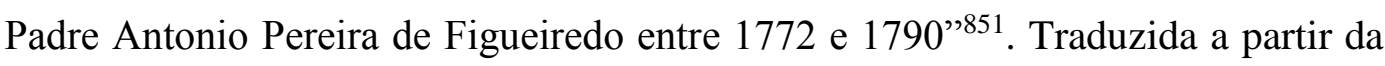
Vulgata, essa tradução foi muito bem-recebida pelos cristãos da época, tanto católicos como protestantes. É importante lembrar que Figueiredo só conseguiu realizar essa tradução graças a um novo direcionamento dado pelo Magistério da Igreja. Malzoni, ao dissertar sobre essa orientação, destaca que se trata de

Uma modificação, introduzida, no espírito do Concílio de Trento, pelo papa Bento XIV, em 1757, na bula de Pio IV, de 1564, permitindo a publicação de traduções da Bíblia em línguas vernáculas, desde que fossem acompanhadas de notas e esclarecimentos tomados dos escritores patrísticos e de reconhecidos teólogos e aprovada pelas autoridades eclesiásticas ${ }^{852}$.

Giraldi e Malzoni lembram, entretanto, que em suas duas primeiras edições a tradução de Figueiredo foi condenada pelas autoridades católicas, visto apresentar em suas notas a defesa do regalismo, isto é, o direito dos reis interferirem em questões religiosas. A tradução, aliás, chegou a ser dedicada a D. João VI. Para além desses aspectos, devido principalmente à fluência e ao estilo linguístico uti-

\footnotetext{
${ }^{849}$ A tradução da Bíblia de João Ferreira de Almeida será melhor compreendida em seu aspecto histórico no próximo capítulo. Aqui, é importante lembrar que as primeiras edições de porções das Escrituras ou Novos Testamentos da Tradução de João Ferreira de Almeida, em português, foram impressas entre o final do século XVII e o início do século XVIII na Holanda, para serem utilizadas nas Índias Orientais, onde Almeida realizou seu trabalho de tradução e era pastor. Giraldi destaca que foram 13 edições durante esse período (cf. GIRALDI, Luiz Antonio. A Bíblia no Brasil Império, pp. 22-28.).

${ }^{850}$ Ainda que a linguagem da tradução de Figueiredo fosse mais atual, com o passar do tempo, houve um preterimento pela tradução de Almeida pelo fato de ela ter sido traduzida diretamente dos originais hebraico, aramaico e grego, e não do latim, como era a versão de Figueiredo.

${ }^{851}$ GIRALDI, Luiz Antonio. Op. cit., p. 29.

${ }^{852}$ MALZONI, Cláudio Vianney. As edições da Bíblia no Brasil, p. 44.
} 
lizado, muitos protestantes preferiram esta tradução em detrimento da tradução de Almeida. Consultada até mesmo como base para a elaboração de um dicionário, ela foi um verdadeiro clássico da língua portuguesa. Figueiredo chegou a destacar em seu prefácio que preferiu não seguir um princípio de tradução que se prendesse rigidamente à estrutura gramatical do texto original; antes, procurou "atender mais ao sentido do que às palavras" ${ }^{\$ 53}$. Portanto, ainda que procurasse seguir o original, ele se preocupou muito mais sobre como as pessoas entenderiam a mensagem.

Diante de tal aceitação, a Sociedade Bíblica Britânica e Estrangeira publicou essa tradução pela primeira vez em $1821^{854}$, com os livros deuterocanônicos. Em 1829, em uma nova publicação, estes livros foram retirados ${ }^{855}$, visto que a publicação com os deuterocanônicos "não agradou os protestantes de língua portuguesa. [Por outro lado] Nos anos seguintes, aumentaram os pedidos dos protestantes

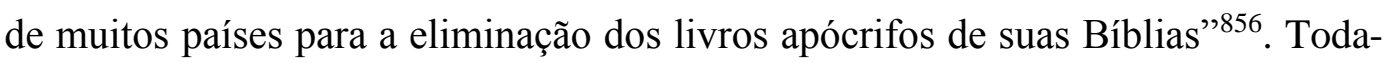
via, mesmo diante de tais percalços, sucessivas edições e publicações da tradução de Figueiredo foram realizadas por ambas as Sociedades Bíblicas, BFBS e ABS, que atuaram no Brasil ${ }^{857}$. Distribuir a tradução católica de Figueiredo constituiu um cuidado importante para evitar problemas e diminuir uma possível resistência dos católicos brasileiros em receber uma Bíblia. Diante disso, muitos clérigos apoiaram o trabalho, e muitas pessoas puderam ler a Bíblia. Nessa perspectiva, Malzoni acrescenta:

Os missionários protestantes no Brasil seguiram três passos em relação à edição da Bíblia a ser apresentada aos brasileiros. O primeiro foi apresentar uma Bíblia sem notas e comentários. O segundo foi adotar a tradução do padre Antonio de Figueiredo. O terceiro foi mostrar que a tradução protestante de João Ferreira de Almeida não divergia substancialmente da tradução de Figueiredo. Havia uma tentativa de demonstrar que "não havia Bíblia falsa" e essa demonstração fazia apelo à razão ${ }^{858}$.

\footnotetext{
${ }^{853}$ MALZONI, Cláudio Vianney. As edições da Bíblia no Brasil, p. 46.

${ }^{854}$ A primeira tradução completa da Bíblia na tradução de Almeida foi publicada em 1819.

${ }^{855}$ Deve-se lembrar que entre 1821 e 1826 as Sociedades Bíblicas debateram sobre a permanência (ou não) dos livros deuterocanônicos em suas publicações. A decisão final foi de que eles deveriam ser excluídos. A resolução, como se percebe, alcançou o Brasil na nova edição de 1829 , já sem os deuterocanônicos (Cf. Seção 4.4.2 desta tese).

${ }^{856}$ GIRALDI, Luiz Antonio. A Bíblia no Brasil Império, p. 85.

${ }^{857}$ Malzoni lembra que até mesmo a Sociedade Bíblica do Brasil chegou a publicar essa tradução em 1955. Até hoje essa tradução é publicada por outras editoras (MALZONI, Cláudio Vianney. Op. cit., pp. 51-52). Giraldi também destaca que foi por meio dessa tradução que foi possível ter "a primeira Bíblia impressa no Brasil", em 1864 pela Editora Garnier no Rio de Janeiro (GIRALDI, Luiz Antonio. Op. cit., p. 31).

${ }^{858}$ MALZONI, Cláudio Vianney. Op. cit., p. 141.
} 
Considerando que essas traduções em português, tanto Almeida quanto Figueiredo, não foram realizadas e nem mesmo publicadas no Brasil, resta óbvio que algumas dessas Bíblias tenham chegado ao país por meio de imigrantes ou viajantes portugueses. Há, por exemplo, um registro de "um correspondente anônimo da BFBS, que distribuía Novos Testamentos em português a bordo de navios que deixavam Lisboa com destino ao Brasil. ${ }^{859 "}$ " A partir deste exemplo, entre outros amplamente relatados por Reily, é possível perceber que "a natureza da disseminação da Bíblia no Brasil na década [de 1820] dependia da boa vontade de capitães de navio, de negociantes, de pessoal diplomático e militar e, naturalmente, dos capelães britânicos radicados nos importantes portos do país"860.

Hahn, nesse mesmo sentido, afirma que as Bíblias enviadas para o Brasil pela Sociedade Bíblica “eram, em geral, remetidas juntamente com a bagagem de homens de negócios que simplesmente deixavam as caixas abertas nas docas à disposição dos interessados" ${ }^{\text {861 }}$. Certamente, alguns eram cristãos e compreendiam a missão; outros, eram simples homens de negócios que, ao serem procurados, traziam as Bíblias e as deixavam em qualquer lugar do desembarque nas docas. É justamente nessa perspectiva que Léonard destaca o fato de muitos desses viajantes terem intencionalmente deixado as caixas de Bíblias "pura e simplesmente abertas nas alfândegas" ${ }^{\$ 62}$. De certa forma, era uma estratégia, pois qualquer pessoa poderia pegar uma Bíblia dessas e ler. Como também lembra Hahn, é claro que muitas dessas Bíblias foram destruídas ${ }^{863}$. Mesmo sob tais desafios, o objetivo da Sociedade Bíblica era de fazer com que essas Bíblias alcançassem as pessoas.

Reily, na obra História documental do protestantismo no Brasil, destaca vários documentos importantes na perspectiva temática desse estudo. Entre outros, o autor insere em sua obra uma carta de um viajante que passava pelo Brasil. Tratase de uma mensagem escrita pelo Reverendo Boys, em 17 de dezembro de 1819, dirigida a um senhor chamado Charles Simeon. Boys era um capelão inglês na ilha britânica de Santa Helena (no Atlântico Sul) que, devido à doença de sua esposa, acometida enquanto estavam em viagem, teve de permanecer no Rio de Janeiro por algum tempo. Nessa carta, Boys descreve sua percepção sobre o Brasil,

\footnotetext{
${ }^{859}$ REILY, Duncan. A história documental do protestantismo no Brasil, p. 77.

${ }^{860}$ Ibid., p. 78.

${ }^{861}$ HAHN, Carl Joseph. História do culto protestante no Brasil, p. 23.

${ }^{862}$ LÉONARD, Émile-Guillaume. O protestantismo brasileiro, p. 48.

${ }^{863}$ Cf. HAHN, Carl Joseph. Op. cit., p. 275.
} 
principalmente nos aspectos sociais e religiosos. Entre outros assuntos abordados, ressaltam-se as seguintes afirmativas históricas:

[...] Não há escolas e nenhuma Bíblia à vista, exceto ocasionalmente, aqui e acolá, nas casas dos negociantes europeus. Certamente, isso é por demais triste - não devia nosso mundo cristão tomar sua atenção para esse lugar (?) [...] A distribuição também das Escrituras em português poderia ser efetuada. Não acho nada improvável que mesmo o rei João e o bispo romano com seu clero pudessem ser persuadidos a sancionar a distribuição $[\ldots]^{864}$.

O que destaca nas notas de Reily é que esta carta faz parte dos arquivos da British and Foreign Bible Society (BFBS) de Londres, criada 15 anos antes com o objetivo de levar a Bíblia para todo o mundo. Tal fato é extremamente relevante, pois "acredita-se que esta carta foi o catalisador da distribuição bem mais intensa e sistemática da Bíblia no Brasil pela BFBS" ${ }^{865}$. O relato de Boys se torna, então, intenso e cheio de significado para a causa da Bíblia no Brasil. Em sua mensagem, ele chega a propor a criação de

Uma sociedade bíblica auxiliar, para facilitar a distribuição da Bíblia em português aos brasileiros. Sua carta, lida no Subcomitê para Impressão e Assuntos Gerais, a 27 de março de 1820, levou a BFBS a buscar contatos com "pessoas de influência nos Brasis" e, por meio delas, distribuiu-se considerável quantidade de Bíblias ${ }^{866}$.

Conforme se constata, portanto, a distribuição de Bíblias no Brasil começou a ocorrer de forma pontual e esporádica, e só a partir da década de 1820 se tornou mais significativa. Difundir a Bíblia no Brasil era, de fato, um enorme desafio. Dá para imaginar a grande dificuldade que Thompson, o primeiro agente oficial da BFBS, enviado para este lado do mundo, teve para distribuir a Bíblia, pois sob sua responsabilidade estava praticamente toda a região da América Latina, do México à Argentina.

Por outro lado, vale ressaltar que a escassez de Bíblias em português no Brasil, percebida exaustivamente por muitos desses viajantes, está também atrelada à ausência de qualquer outro tipo de literatura no país. Gomes, nesse sentido, confirma tal narrativa dos estrangeiros ao descrever que uma "imagem muito frequente nesses relatos dos viajantes é a do analfabetismo, da falta de cultura e ins-

\footnotetext{
${ }^{864}$ REILY, Duncan. A história documental do protestantismo no Brasil, p. 56.

865 Ibid., p. 401.

${ }^{866}$ Ibid., p. 78 (destaque do autor).
} 


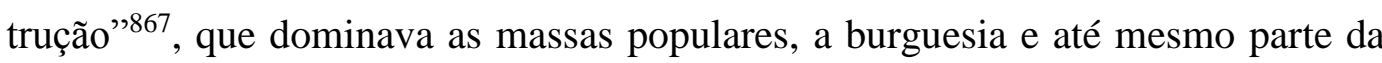
alta nobreza. Contudo,

É bem verdade que os mosteiros e as catedrais eram quase que os únicos asilos das letras, tanto sagradas como profanas; mas sua atuação era modesta e restrita à satisfação de suas necessidades internas; não tinham a consciência de estar cumprindo uma missão social ${ }^{868}$.

Portanto, se constata muita semelhança e certa unanimidade nas descrições históricas, firmadas nos vieses seculares e religiosos, do empobrecido contexto cultural brasileiro $^{869}$, afinal, não havia uma politica de alfabetização universal à época. É por isso que o relato de Boys ressalta igualmente a escassez de escolas e de Bíblias. Para o pensamento protestante, estabelecido sob os pressupostos defendidos na Reforma, essa era uma realidade distante do ideal, afinal a educação e a Bíblia eram importantes e sempre concomitantes na execução de qualquer missão protestante. Mendonça contribui nessa perspectiva quando lembra que

\begin{abstract}
Sendo o protestantismo a "religião do livro", deve ter surgido logo um severo embaraço para os missionários: o analfabetismo do segmento da sociedade que lhes oferecia espaços para a tarefa conversionista, o dos homens livres e pobres da população rural. Os protestantes têm como postulado básico de sua fé que a leitura da Bíblia, por si só, não somente instrui os indivíduos na religião, mas é instrumento de conversão. O próprio culto protestante exige a leitura, pois que seu material litúrgico são a Bíblia e o livro de hinos. Para atender a tal necessidade, os missionários colocaram ao lado de cada comunidade uma escola ${ }^{870}$.
\end{abstract}

Com efeito, o estímulo à leitura da Bíblia realizada pelos protestantes impulsionou a alfabetização no país. Obviamente, quando o autor se refere a protestantes, já fica subentendida uma percepção mais ampla da chegada de imigrantes de outras nações protestantes do mundo ao Brasil. De fato, para além da vinda dos ingleses, quer sejam viajantes ou residentes, D. João VI ampliou a possibilidade de outros povos migrarem para o Brasil. Na história, esse foi um tempo político

\footnotetext{
${ }^{867}$ GOMES, Laurentino. 1808, p. 267.

${ }^{868}$ MATTOS, Luiz Alves de. Primórdios da educação no Brasil: o período heróico (1549-1570). Rio de Janeiro: Aurora, 1958, pp. 37-38.

${ }^{869}$ Mesmo sob tal contexto, é importante lembrar que a situação educacional do país não era pior devido ao trabalho realizado pelos jesuítas. Desde a sua chegada no país em 1549, até 1759 quando foram expulsos pelo Marquês de Pombal -, eles estabeleceram colégios em algumas regiões do Brasil colonial. Segundo Shigunov Neto e Maciel, foram criados, de fato, "18 estabelecimentos de ensino secundário, entre colégios e seminários", além de escolas de ler e escrever em alguns povoados. Com a expulsão dos jesuítas, resta óbvio perceber que a educação se tornou cada vez mais precária, visto que, com o estabelecimento do novo governo, escolas foram fechadas sob a pretensão de se realizar uma reforma e centraliazar o poder. Cf. SHIGUNOV NETO, Alexandre; MACIEL, Lizete Shizue Bomura. O ensino jesuítico no período colonial brasileiro: algumas discussões. Educar, Curitiba, n. 31, 2008, p. 186.

${ }^{870}$ MENDONÇA, Antônio Gouvêa. O celeste porvir, pp. 143-144.
} 
em que se procurou povoar o Brasil, com suas dimensões continentais, por meio do trabalho de agricultores europeus ${ }^{871}$. D. Pedro I seguiu à risca essa mesma política de D. João VI. Léonard destaca, nesse sentido, que principalmente dois fatos favoreceram a chegada dos imigrantes protestantes com suas Bíblias, a saber: "a disposição do Imperador e a necessidade que o Brasil tinha de imigrantes" ${ }^{\text {872 }}$. Assim, suíços e alemães, alguns católicos, mas a maioria protestante, também chegaram ao Brasil a partir de 1818. Alguns foram para Nova Friburgo e outros partiram para o Sul.

Dessa forma, "por volta de 1824, a mesma tolerância concedida à Igreja Anglicana Britânica pelo Tratado de Comércio de 1810 era estendida aos luteranos da Alemanha e da Suíça e a outros grupos evangélicos" ${ }^{873}$ através da Constituição do Império, promulgada em $1824^{874}$. Em seu artigo $5^{\circ}$, apesar de manter a Igreja Católica como Igreja oficial do Estado, abriu-se espaço para a prática do culto não católico no país. Já no artigo $179^{\circ}$, inciso IV, destacou-se a liberdade concedida pela Constituição para se expressar e publicar textos. E, em seguida, no inciso $\mathrm{V}$ do mesmo artigo, ficou proibida qualquer perseguição por motivos religiosos no país.

Entretanto, mesmo com essa liberdade de culto, havia um outro impedimento. Muitos desses imigrantes passaram a residir em regiões totalmente rurais, distantes dos grandes centros urbanos onde estavam localizadas as poucas igrejas protestantes que surgiram à época. Por isso, muitos deles "dependiam unicamente da leitura da Bíblia e do culto doméstico para a preservação da fé" ${ }^{875}$. A Bíblia foi, por assim dizer, o livro da esperança, que marcou a identidade e ajudou no desenvolvimento do povo alemão no Brasil.

Assim como Boys, o pastor Karl Leopold Voges, um pregador superintendente das comunidades protestantes alemãs implantadas no Brasil, também escreveu uma carta para a Sociedade Bíblica Britânica e Estrangeira de Londres, em 1827. A carta apresenta significativas informações sobre alguns aspectos sociais, religiosos e bíblicos daquele período:

\footnotetext{
${ }^{871}$ Cf. FIGUEREDO, Luiz Orencio; ZANELATTO, João Henrique. Trajetória de migrações no Brasil. Acta Scientiarum. Humam and Social Sciences. Maringá, v. 39, n. 1, Jan.-Apr. 2017, p. 79 ${ }^{872}$ LÉONARD, Émile-Guillaume. O protestantismo brasileiro, p. 53.

${ }^{873}$ HAHN, Carl Joseph. História do culto protestante no Brasil, p. 22.

${ }^{874}$ Cf. BRASIL. Constituição (1824). Constituição Política do Império do Brasil, elaborada por um Conselho de Estado e outorgada pelo Imperador D. Pedro I, em 25.3.1824.

${ }^{875}$ REILY, Duncan. A história documental do protestantismo no Brasil, p. 58.
} 
Recebi corretamente a sua estimada carta do dia 27 de janeiro de 1826 e a fatura referente a cem Bíblias e 250 Novos Testamentos encadernados, os quais a mui respeitável Sociedade Bíblica Britânica e Estrangeira se tem designado outorgar para o bem da comunidade evangélica alemã de São Leopoldo e que foram enviados via Rio de Janeiro ao sr. M. Kay [sic]. Mas, visto que ainda não recebi esse presente, escrevi ao Sr. M. Kay indagando se essas Bíblias já chegaram ao Rio de Janeiro. Mandarei notícias sobre o recebimento correto [das Bíblias] o mais breve possível. $\mathrm{V}$. Excia., bem como a mui respeitável sociedade tem manifestado o desejo de saber a respeito dos membros da minha comunidade [...] Faltam pregadores [...] V. Excia. e a Sociedade Bíblica Britânica e Estrangeira se dignam a oferecer-me um número maior de Bíblias para as comunidades alemãs no Brasil, em caso de necessidade. Por isso aceito a oferta benévola, pedindo mais oitocentas Bíblias e oitocentos Novos Testamentos de que necessito muito para a divulgação da religião cristã, a fim de poder suprir cada família com uma Bíblia ou com um Novo Testamento. Pois nos corações de todos os alemães, protestantes e católicos, se faz sentir penosamente a falta de diversos livros de edificação espiritual e nas famílias, as quais possuem uma Bíblia, as Sagradas Escrituras estão sendo lidas muito mais, e está lhes sendo atribuído um valor muito maior do que na Alemanha. [...] Sobretudo, peço duzentos Novos Testamentos em língua portuguesa para acender a luz verdadeira da Sagrada Escritura entre os pobres portugueses. [...] Entre os leigos, não se acha nem um Novo Testamento nem uma Bíblia inteira ${ }^{876}$.

A carta apresenta uma realidade desafiadora para os imigrantes alemães. E como já havia acontecido com os ingleses, mais uma vez, a Sociedade Bíblica externou sua preocupação de que Bíblias estivessem à disposição do povo alemão. As dificuldades de transporte são evidentes; as cartas já tinham chegado, mas as Bíblias ainda não. A falta de pregadores e de igrejas também demonstra as dificuldades de se manter o culto que eles estavam acostumados a praticar na Alemanha. Foi a Palavra de Deus que deu esperança, manteve a fé e uniu a família. Tal realidade, aliás, fez com que aquelas pessoas valorizassem ainda mais as Escrituras. Ressalta-se, também, a perspectiva missionária destacada no desejo de se difundir ainda mais a Bíblia. O Pr. Voges percebeu a necessidade do povo brasileiro em relação às Escrituras e por isso solicitou que as Escrituras em língua portuguesa fossem enviadas ao país.

Mais uma vez, evidencia-se que o trabalho da Sociedade Bíblica no Brasil iniciado juntos aos imigrantes não deixou de lado a importância de o povo brasileiro também receber a Bíblia em sua própria língua. Foi, de fato, um trabalho desafiador e, de certa forma, perigoso diante das restrições que eram impostas aos protestantes naquele período. Aliás, essa realidade tênue prevaleceu por todo o período do império. A liberdade religiosa de forma plena só “veio acontecer com a proclamação da República em 15 de novembro de 1889 e com a desoficialização

${ }^{876}$ REILY, Duncan. A história documental do protestantismo no Brasil, pp. 61-62. 
da Igreja, em janeiro de 1890 "877. Ainda assim, não há como não perceber que durante este período, progressivamente, "foi sendo reduzida a hegemonia católica e os protestantes foram conquistando o seu lugar no espaço social brasileiro. Vieram, espalhando suas Bíblias e praticando seu culto dentro das normas legais restritivas" $\$ 878$.

Portanto, por longas décadas, isto é, cerca de 70 anos, a difusão das Escrituras e a pregação da fé protestante se desenvolveram sob muitos momentos tensos, mas também frutíferos para a causa da Bíblia e para a implantação definitiva da fé protestante no Brasil. Nesse sentido, Mendonça acrescenta que

a liberdade para vender e distribuir Bíblias por parte de agentes das sociedades bíblicas estrangeiras, bem antes da chegada e estabelecimento das missões protestantes, constituiu-se num fator ponderável da estratégia protestante de penetração ${ }^{879}$.

Para Léonard, essa estratégia foi estabelecida porque "o Brasil não se encontrava ainda preparado para os métodos habituais de evangelização anglosaxônica" ${ }^{880}$. Por isso, os primeiros missionários e representantes das sociedades bíblicas que chegaram ao país optaram estrategicamente pela difusão das Escrituras antes de qualquer pregação. Aliás, como já dito, essa difusão se deu, em sua maioria, por meio de Bíblias com a tradução católica do padre Figueiredo ${ }^{881}$; poucas dessas Bíblias, portanto, eram com a tradução de Almeida, um pastor reformado. Mais importante do que qualquer discussão sobre o cânon ou sobre a tradução ser católica ou protestante, estava a causa da Bíblia. A distribuição da Bíblia, por si só, deve ter instigado a leitura de muitas pessoas, seja pela curiosidade, seja pelo desejo de aprender um pouco mais sobre aquele livro desconhecido. Portanto, para falar da chegada da fé protestante ao Brasil, é preciso ressaltar que a Bíblia chegou um pouco antes. Por assim ser, pode-se dizer que foi a difusão da Bíblia que impulsionou o surgimento e o desenvolvimento das missões e, posteriormente, das igrejas protestantes no país. De fato,

Entre a chegada dos primeiros exemplares da Bíblia (1814) e a chegada do primeiro missionário protestante, cujo ministério não foi interrompido (1855), há um es-

\footnotetext{
${ }^{877}$ HAHN, Carl Joseph. História do culto protestante no Brasil, p. 23.

${ }^{878}$ MENDONÇA, Antônio Gouvêa. O celeste porvir, p. 42.

${ }^{879}$ Ibid., p. 44.

${ }^{880}$ LÉONARD, Émile-Guillaume. O protestantismo brasileiro, p. 48.

${ }^{881}$ Essa Bíblia tinha a autorização da hierarquia católica e alcançou ampla aceitação entre o povo brasileiro.
} 
paço de 41 anos. Isso significa dizer que as Escrituras Sagradas precederam a implantação das primeiras igrejas evangélicas brasileiras ${ }^{882}$.

Nessa mesma perspectiva, $\operatorname{Hahn}^{883}$ afirma não haver dúvidas de que a grande influência na realização dos primeiros cultos protestantes no Brasil se deu como decorrência da ampla distribuição de Bíblias que já ocorria por todo o país. Léonard segue o mesmo raciocínio, quando afirma que, antes de qualquer tentativa de implantação de igrejas protestantes entre os brasileiros, ocorreu a difusão das Escrituras, por meios das Sociedades Bíblicas inglesa e americana. Só então foi possível estabelecer um bom ponto de partida. Foi uma estratégia que abriu espaço e ganhou terreno ${ }^{884}$ em um país que era oficial e majoritariamente católico.

De fato, não restam dúvidas: antes do estabelecimento de igrejas e da realização de liturgias propriamente ditas, a difusão da Bíblia se desenvolveu por meio da leitura e da realização de estudos bíblicos em muitos vilarejos, sem a presença oficial de qualquer pastor ou missionário. Era um povo com a Bíblia e nada mais. Citando um documento de 1878, do pastor metodista J. J. Ranson, que viajou pelo Brasil a pedido da Igreja Metodista, Hahn descreve a alegria e o espanto do pastor ao perceber o quanto a Bíblia tinha sido espalhada em numerosos exemplares pelo interior do país. E acrescenta ainda que

Este é um importante e revelador documento a respeito da extensão e dos efeitos da distribuição da Bíblia no Brasil. Cerca de 1878, as Bíblias e Novos Testamentos eram vendidos, distribuídos e doados em muitos lugares do Brasil onde os missionários ainda não haviam chegado. Centenas e milhares de pessoas receberam a Bíblia, leram-na e compreenderam o suficiente para desejar um culto tal qual escrito em suas páginas. Formaram-se pequenas congregações leigas para ler e estudar esse livro antes mesmo de que qualquer ministro ordenado chegasse ${ }^{885}$.

Diante de tais fatos, conclui-se alguns aspectos importantes a respeito desse momento histórico, os quais, aos poucos, impulsionaram a difusão das Escrituras, a saber: ainda que com certas restrições, o Brasil se tornava mais tolerante no aspecto religioso; muitos imigrantes protestantes chegavam ao Brasil e, com eles, o apreço pelas Escrituras; os portugueses e os brasileiros, em sua maioria, desconheciam as Escrituras e cada vez mais pedidos surgiam sob a expectativa de se disponibilizar a Bíblia. Deste modo, a difusão das Escrituras no Brasil, realizada pelas Sociedades Bíblicas, foi um marco importante que os primeiros documentos

${ }^{882}$ CÉSAR, Elben Magalhães Lenz. História da evangelização do Brasil, p. 70.

${ }^{883}$ Cf. HAHN, Carl Joseph. História do culto protestante no Brasil, p. 274.

${ }^{884}$ Cf. LÉONARD, Émile-Guillaume. O protestantismo brasileiro, p. 48.

${ }^{885}$ HAHN, Carl Joseph. Op. cit., p. 274. 
registraram sobre a chegada da fé protestante ao país. Pessoas foram alcançadas, famílias foram edificadas, imigrantes se fortaleceram, cultos foram estabelecidos e igrejas foram implantadas porque a Bíblia estabeleceu a base para todas essas ações.

\subsection{2 \\ A atuação das Sociedades Bíblicas na difusão das Escrituras Sagradas durante o Brasil Império}

Seria muito difícil descrever a totalidade do trabalho de difusão das Escrituras realizado pelas Sociedades Bíblicas durante o Brasil Império. Ainda assim, espera-se, nesta seção, destacar os fatos mais significativos dentro da temática proposta nesse estudo, os quais estão em direta relação com os fatos ocorridos dentro deste período político cheio de conflitos pelo qual o Brasil passou a partir do início do século XIX.

Como se sabe, com a chegada de D. João VI ao Brasil, o país deixou de ser uma simples colônia para se tornar a sede do Império Português. Já em 1815, o Brasil foi elevado de Estado para a designação de Reino Unido de Portugal, Brasil e Algarves. Esse período se estendeu até 1822, quando foi declarada a independência do país em relação a Portugal, tornando-o Império do Brasil. O primeiro período de governo no Brasil Imperial se estendeu até 1831, com D. Pedro I. Com a abdicação deste último, o Brasil ficou sob a égide do período regencial até 1840, quando foi proclamada a maioridade de D. Pedro II, tornando-o, então, suficiente para assumir o trono definitivamente. De 1840 a 1889, D. Pedro II exerceu o governo, até a proclamação da República, em 1889. Foi exatamente por todo este período histórico que o trabalho das Sociedades Bíblicas iniciou, cresceu e se fortaleceu no Brasil.

Como destacado anteriormente, com a chegada da corte real portuguesa, em 1808, e com a consequente abertura dos portos, muitas Bíblias foram enviadas ao Brasil. Essas remessas eram pontuais e dependiam de esforços conjuntos de voluntários. Portanto, tornava-se cada vez mais necessário um trabalho mais efetivo em torno da causa da Bíblia no Brasil; afinal, os pedidos aumentavam, as demandas surgiam e a carência das Escrituras urgia pelos cantos do Brasil.

Em 1818, a primeira agência da BFBS foi inaugurada na Argentina, com a missão de atender toda a América Latina. A partir dessa instalação, a BFBS, por 
meio de sua agência, enviou muitas Bíblias ao Brasil, sem deixar de "atender a pedidos de Escrituras diretamente de Londres" ${ }^{\text {886 }}$. A partir de 1821, os relatórios que apresentam o envio de Bíblias, seja de Londres ou de Buenos Aires, são constantes e sempre destacam quantidades crescentes de Escrituras enviadas ao Brasil, visto que havia significativo interesse dos brasileiros, certa liberdade do governo e pouca resistência do clero católico em relação à distribuição de Bíblias no país ${ }^{887}$.

É importante ressaltar que, paralelamente a esse período, encíclicas papais estavam sendo promulgadas contra o trabalho das Sociedades Bíblicas. Porém, o Brasil foi pouco ou quase nada afetado nesse sentido. Pelo contrário, destacam-se nos relatos históricos a tolerância religiosa por parte dos governos estabelecidos. Como já se constatou, a Constituição de 1824 se configurou como um avanço que abriu as portas da Bíblia no Brasil e, de certa forma, legalizou a distribuição das Escrituras por meio dos colportores, como se constatará mais adiante. Esses aspectos legais resultaram em uma forma de apoio direto e indireto ao trabalho das Sociedades Bíblicas. Nesse sentido, D. Pedro I, por exemplo, não colocou obstáculos à distribuição de Bíblias no país, e seu filho, D. Pedro II, além de não coibir, foi um grande apoiador dessa missão. Tal apoio, tanto às ordens religiosas católicas como ao trabalho realizado pelos protestantes, decorria, entre outras hipóteses, da intenção política do Imperador em manter um bom relacionamento para com todos.

Como já se percebeu desde a seção anterior, a forma que a BFBS escolheu para realizar seu trabalho no Brasil se consolidou por meio de representantes não oficiais. Assim, entre 1821 e 1843, a maioria das Bíblias enviadas ao Brasil pela BFBS chegavam por meio de voluntários — pessoas da área diplomática, militares, capelães, comerciantes etc. - que possuem seus nomes registrados nos relatórios da BFBS. Reily e Giraldi, respectivamente, destacam esse fato quando afirmam que

As atas e correspondências da BFBS em Londres são ricas em nomes de leigos cuja cooperação gratuita e, às vezes, entusiasta, tornou possível a larga distribuição das

\footnotetext{
${ }^{886}$ GIRALDI, Luiz Antonio. A Bíblia no Brasil Império, pp. 86-87.

${ }^{887}$ A pouca resistência do clero, bem como a relativa liberdade governamental, não representaram facilidades. Pelo contrário, por diversos momentos, situações de perseguição, prisão, denúncia, entre outros aspectos, constituíram um grande desafio para o trabalho bíblico realizado pela Sociedades Bíblicas e pelos missionários protestantes no Brasil. Tais fatos serão melhor compreendidos no decorrer do texto.
} 
Escrituras no Brasil [...]. [Foi um] importante serviço que muitos leigos prestaram à causa bíblica ${ }^{888}$.

Esses representantes não oficiais recebiam as Escrituras em consignação, e as vendiam ou doavam em suas cidades ou províncias, prestando contas periodicamente à SBBE. Os representantes que realizavam um bom trabalho e prestavam contas pontualmente se credenciavam a novos pedidos de Escrituras ${ }^{889}$.

Obviamente, tal trabalho foi importante e significativo, pois se trata do início da distribuição bíblica no Brasil. Destaca-se, inclusive, o fato de que a causa da difusão das Escrituras no trabalho se iniciou e se desenvolveu majoritariamente por meio da dedicação de voluntários e leigos. Por outro lado, é justamente devido à ausência de um representante oficial, de uma agência nacional e de um trabalho mais sistematizado que "o contato entre a Sociedade Britânica e o Brasil diminuiu acentuadamente depois de $1843 " 890$.

Ainda que a BFBS contasse com um agente oficial para toda a América Latina, acentuava-se, cada vez mais, a necessidade de um trabalho mais intenso no Brasil. Foi nesse ínterim que outra Sociedade Bíblica iniciou suas atividades com muita proficuidade no país. Trata-se, da American Bible Society (ABS) ou, em português, Sociedade Bíblica Americana (SBA), criada em 1816, em Nova York, nos Estados Unidos. É importante relembrar que a criação da Sociedade Bíblica Americana, bem como de todas as outras Sociedades Bíblicas que surgiram (e surgem até hoje), é fruto do trabalho da BFBS. Foi a BFBS que inspirou e serviu de modelo para o trabalho bíblico realizado pelas Sociedades Bíblicas em todos os tempos. Por isso, desde o início, em sua constituição, a ABS ressaltou que, dentro das possibilidades, seu trabalho com as Escrituras se estenderia "a outros países, tanto cristãos, como maometanos ou pagãos" ${ }^{\text {891 }}$.

Mais especificamente, "a ABS iniciou seu trabalho no Brasil em 1822, apenas seis anos após a sua fundação" ${ }^{" 892}$. Seguindo o exemplo do trabalho da BFBS, a ABS passou a enviar inicialmente as Sagradas Escrituras por meio de navios que vinham para o Brasil. Dessa forma, negociantes, marinheiros e diplomatas americanos também contribuíram com a causa bíblica. Sob tal tática, o trabalho da ABS começou a crescer e se fortalecer rapidamente; isto porque, diferentemente da

\footnotetext{
${ }^{888}$ REILY, Duncan. A história documental do protestantismo no Brasil, p. 83.

${ }^{889}$ GIRALDI, Luiz Antonio. A Bíblia no Brasil Império, p. 88.

${ }^{890}$ REILY, Duncan. Op. cit., p. 78.

${ }^{891}$ Ibid, p. 79.

${ }^{892}$ GIRALDI, Luiz Antonio. The American Bible Society in Brazil, p. 11 (tradução nossa).
} 
BFBS, a ABS optou por uma estratégia diferente e específica na realização do seu trabalho no Brasil. Os seus agentes, enviados ao país, eram missionários das grandes denominações protestantes (ou até mesmo de algumas sociedades paraeclesiásticas ${ }^{893}$ ) dos Estados Unidos e representantes da ABS, concomitantemente. Como se diz no ditado popular, a ABS soube unir o útil ao agradável em seu trabalho bíblico. Por conseguinte, "muitos representantes da American Bible Society dedicaram todas as suas vidas para a tarefa da distribuição da Bíblia no Brasil”894.

Deste modo, inicialmente metodistas, presbiterianos e congregacionais ${ }^{895} \mathrm{e}$, posteriormente, batistas e episcopais, trabalharam de forma bivocacional no país. Eles observavam a oportunidade de implantação de suas respectivas igrejas enquanto distribuíam a Bíblia por todo o território. Os relatórios por eles apresentados normalmente traziam informações positivas do crescimento da obra bíblica. Como exemplo, houve um resumo das atividades realizadas em 1840 enviado para a ABS por meio de um relatório, no qual, conclusivamente, os membros do comitê da ABS afirmavam: "os missionários relatam que o suprimento enviado a eles fora posto em circulação e que a causa [bíblica] florescia no Brasil" ${ }^{1896}$. Essa é uma boa hipótese que configura o sucesso mais significativo dos americanos em seu trabalho bíblico e missionário no Brasil neste início. Havia uma relação intrínseca e necessária entre a difusão da Bíblia e o trabalho missionário protestante das respectivas denominações que aportavam no país. Nessa perspectiva, Reily lembra que

A Sociedade Bíblica Americana começou suas atividades no Brasil mais ou menos simultaneamente à vinda dos missionários metodistas Justin Spaulding e Daniel P. Kidder. [...] $\mathrm{Na}$ verdade, desde a vinda dos missionários, houve estreito relacionamento entre a obra denominacional e a bíblica, pois o conhecimento da Bíblia era universalmente tido como base indispensável para o trabalho evangélico ${ }^{897}$.

\footnotetext{
${ }^{893}$ Reily cita, por exemplo, sociedades que tinham por objetivo realizar a capelania entre os marinheiros. A Sociedade Americana de Amigos dos Marinheiros (1828) é um destes exemplos. James Fletcher, missionário metodista que foi um grande distribuidor de Bíblias no Brasil, era um capelão dessa sociedade e representante de outra, denominada União Cristã Americana e Estrangeira. Cf. REILY, Duncan. A história documental do protestantismo no Brasil, p. 92. ${ }^{894}$ GIRALDI, Luiz Antonio. The American Bible Society in Brazil, p. 12 (tradução nossa). ${ }^{895}$ Deve-se lembrar que o missionário Dr. Robert Reid Kalley, que inaugurou o congregacionalismo no Brasil, era presbiteriano de origem. Quando aqui chegou, ele ainda era um presbiteriano. Foi Kalley quem organizou a primeira igreja protestante no Brasil, em 11 de julho de 1858 . Cf. HAHN, Carl Joseph. História do culto protestante no Brasil, p. 149-151.

${ }^{896}$ REILY, Duncan. Op. cit., p. 78.

${ }^{897}$ Ibid., p. 78.
} 
Spaulding, que chegou ao país em 1836, foi, por exemplo, o primeiro missionário metodista no Brasil. Em boa parte de seu trabalho bíblico-missionário, Spaulding foi acompanhado pelo Reverendo Daniel Parish Kidder. Na obra Reminiscências de Viagens e Permanência no Brasil (1845), que se tornou muito famosa nos Estados Unidos por descrever detalhes gerais sobre o Brasil daquela época, Kidder, o autor, destaca exatamente esse início de trabalho em que se atrelavam a obra missionária e a difusão da Bíblia, percebido em seus escritos como um livro amplamente desconhecido no Brasil. Discorrendo sobre as atividades bivocacionais de Spaulding, Kidder lembra que ele

\begin{abstract}
Não só pregava aos domingos como também fazia profusa distribuição de folhetos e publicações religiosas [...]. A circulação das Sagradas Escrituras em português - que é a língua do país - constituía a nossa missão precípua. Até então jamais se haviam feito esforços sistemáticos para uma larga divulgação da Bíblia nesse vasto e interessante país. Em épocas anteriores, diversas centenas de exemplares da Bíblia e do Novo Testamento, impressos pelas sociedades bíblicas inglesa e norte-americana, haviam sido introduzidos no Brasil por intermédio de viajantes comerciais, e, em alguns casos, grande foi o interesse manifestado pela sua divulgação, conquanto, num sentido geral, pouco esforço se tenha despendido nesse sentido. Apesar de tudo, pode-se com segurança concluir que o número de exemplares do Livro Sagrado posto nas mãos do povo foi maior então do que em qualquer outra ocasião ${ }^{898}$.
\end{abstract}

A descrição de Kidder não é exclusiva. Pelo contrário, entre alguns outros relatos, é possível constatar que os missionários trabalhavam por suas respectivas denominações, ao mesmo tempo em que dedicavam parte de sua vida à difusão das Escrituras no Brasil. Mesmo que houvesse algumas diferenças doutrinárias, o que era comum para todos eles, era o zelo pela Palavra de Deus que os unia. Esse certo desinteresse por questões denominacionais ou doutrinárias evidencia que havia uma motivação mais importante ancourada na difusão das Escrituras em detrimento das questões eclesiásticas particulares. A Bíblia constituiu, portanto, o fundamento primordial para se desenvolver qualquer atividade missionária e evangelística de viés protestante no Brasil. Trata-se de um legado da Reforma; afinal, a prática teológica e missional de qualquer igreja protestante, em sua gênese, está estabelecida sobre a Palavra. Pode-se afirmar, nesse ínterim, que as Sociedades Bíblicas, desde o surgimento, se firmaram como verdadeiras agências de evangelização, servindo e andando sempre ao lado da igreja em sua missão.

\footnotetext{
${ }^{898}$ KIDDER, Daniel Parish. Reminiscências de viagens e permanências no Brasil. Rio de Janeiro e Província de São Paulo. Brasília: Senado Federal, Conselho Editorial, 2001, pp. 121-122 (grifo nosso).
} 
Steer, analisando especificamente o trabalho das Sociedades Bíblicas na Coreia, destaca esse aspecto quanto ao trabalho bíblico no mundo, afirmando que, por meio de suas atividades, "as Sociedades Bíblicas têm sido uma grande agência na evangelização" ${ }^{\prime 899}$. Nessa mesma perspectiva, Giraldi ressalta a existência histórica de uma estreita e harmoniosa colaboração entre as missões/igrejas protestantes e as Sociedades Bíblicas. Para ele, foi por esse motivo que "a distribuição da Bíblia e o número de protestantes registraram, no mundo todo, um crescimento extraordinário durante as primeiras décadas do século XIX"900.

\subsubsection{1 \\ A atuação dos primeiros representantes da Sociedade Bíblica Americana no Brasil e a instalação de sua primeira agência}

Mesmo que Spaulding ${ }^{901}$ não tenha chegado a ser um representante oficial da ABS no país, foi ele quem abriu o caminho para que um pouco mais tarde, isto é, em 1837, Kidder fosse "nomeado para ser o primeiro representante no Brasil da American Bible Society" "902. Para exercer essa tarefa de forma profícua, Kidder viajou pelo Brasil pregando o evangelho e distribuindo Bíblias. Na obra Reminiscências de Viagens e Permanência no Brasil (publicada em 1845, nos EUA), Kidder descreveu situações inusitadas a respeito da causa da Bíblia e de suas percepções sobre o povo e o país.

Em certos momentos de sua narrativa, Kidder ressaltou a mesma impressão que outros viajantes já tinham destacado em suas passagens pelo Brasil, isto é, de que a Bíblia era um livro escasso e desconhecido pelo povo; contudo, com a tolerância religiosa que emergia, ela estava se tornando um livro procurado. Em suas palavras, Kidder diz que,

A tolerância e a liberdade religiosa foram aos poucos se infiltrando no povo, daí estarem muito preparados para receber com simpatia qualquer movimento que lhes

\footnotetext{
899 STEER, Roger. Good News for the World, 200 years of making the Bible heard, p. 241 (tradução e adaptação nossa).

900 GIRALDI, Luiz Antonio. A Bíblia no Brasil Império, p. 122.

${ }^{901}$ Giraldi resgata a interessante história de Spaulding, que pela primeira vez colocou anúncios em jornais do Rio de Janeiro para oferecer Bíblias ao custo de um mil réis. Além de destacar a importância para a fé e para a vida espiritual, Spaulding argumenta que a Bíblia é a base da instrução em países protestantes prósperos e adiantados. Tal argumento se justifica pelo público-alvo escolhido por ele em seu anúncio, que era principalmente formado por professores e diretores de colégios. In: GIRALDI, Luiz Antonio. Op. cit., p. 118.

902 Id. The American Bible Society in Brazil, p. 31 (tradução nossa).
} 
desse aquilo de que até então haviam sido sistematicamente privados: as Sagradas Escrituras $^{903}$.

Por isso, durante as suas viagens pelo Brasil, bem como durante todo o período curto de sua permanência no país"904, "seu objetivo era distribuir a Bíblia a todos os interessados, vendendo a quem pudesse pagar ou doando às pessoas mais pobres"905. Diante de tal êxito,

Não se fez esperar muito a reação que esse interesse popular pelas Sagradas Escrituras haveria certamente de provocar. Apareceu contra nós - em certo jornal cujo estilo correspondia perfeitamente ao espírito e ao caráter de seus redatores — uma série de ataques grosseiros e vis. De fato, imediatamente depois desse movimento de interesse popular, surgiu um periódico intitulado $O$ Católico, com a finalidade manifesta de combater a nós e à nossa obra missionária. [...] Essa forma de oposição teve, quase sempre, o efeito de despertar maior interesse pelo Livro Sagrado e muitos foram os que, ao procurar pela Bíblia, nos disseram ter tido sua atenção inicialmente atraída para o assunto pela tentativa descabida e fanática de impedir sua divulgação ${ }^{906}$.

Kidder reitera que, normalmente, as reações contrárias não decorriam do povo; antes, eram reações isoladas de alguns poucos sacerdotes católicos que procuravam impedir a difusão das Escrituras pelo interior do Brasil. Em certos momentos, por exemplo. Kidder chegou a afirmar que desconhecia a existência de outro país católico que apresentasse tamanha liberdade religiosa e que, até mesmo alguns "sacerdotes católicos fizeram amizade com ele e o ajudaram na distribuição das Escrituras"

Entre outros, alunos e professores das escolas constituíam um de seus alvos principais na distribuição das Escrituras. Nesse sentido, Giraldi ${ }^{908}$ descreve uma história em que Kidder se esforçou sobremaneira para colocar Bíblias nas escolas da cidade de São Paulo. Sua ideia era doar Novos Testamentos com a tradução de Figueiredo, evitando, assim, possíveis resistências. Mesmo sob muitas tentativas e tratativas, políticas e religiosas, Kidder não alcançou o êxito pretendido nesta ocasião; aliás, ele nunca recebeu uma resposta oficial ao pedido que havia encaminhado à Assembleia Provincial de São Paulo, em que solicitou a permissão da doação das Bíblias. Ainda que por pouco tempo, Kidder deixou um significativo

\footnotetext{
${ }^{903}$ KIDDER, Daniel Parish. Reminiscências de viagens e permanências no Brasil, pp. 122-123.

${ }^{904}$ Kidder ficou somente três anos no país. Ele retornou para o EUA depois que sua esposa morreu repentinamente.

905 GIRALDI, Luiz Antonio. A Bíblia no Brasil Império, p. 133.

906 KIDDER, Daniel Parish. Reminiscências de viagens e permanências no Brasil, p. 124.

${ }^{907}$ GIRALDI, Luiz Antonio. The American Bible Society in Brazil, p. 32 (tradução nossa).

908 Cf. Id. Semeadores da Palavra, pp. 28-30.
} 
legado para a difusão das Escrituras no Brasil, influenciando significativamente seu sucessor nesta causa. Com a morte de sua esposa, ele voltou para os EUA, depois de realizar a distribuição "de Bíblias em quase todas as províncias do Brasil"909.

Ainda que a maioria dos representantes da ABS que trabalharam no Brasil fossem missionários enviados pelas igrejas para a implantação do protestantismo denominacional no país, o Reverendo James Cooley Fletcher constitui uma exceção. Fletcher, que veio ao Brasil por influência de Kidder, além de pastor e missionário metodista no Brasil, foi também diplomata, agente de algumas organizações paraeclesiásticas, capelão da marinha americana, membro da alta sociedade do país à época, escritor e outros. Entretanto, sob a ótica da difusão das Escrituras, a partir de 1854, quando aceitou o convite da ABS para ser seu representante, Fletcher foi "uma das figuras mais importantes no processo de introdução da Bíblia em nosso país"910, visto que ele, "durante três anos, de 1854 a 1856, viajou por todo o país, percorrendo cerca de cinco mil quilômetros, promovendo a distribuição das Escrituras Sagradas"911. De Norte a Sul, visitando todas as províncias do Brasil, Fletcher semeou a Palavra de Deus na vida do povo brasileiro.

Um dos destaques do trabalho bíblico de Fletcher se deu pela aproximação conquistada junto a D. Pedro II, então imperador do Brasil. Os relatos indicam que, entre outros assuntos, Fletcher "conversava com ele sobre a Bíblia e os esforços das Sociedades Bíblicas para divulgá-la em todo o mundo" ${ }^{912}$. Para além do fato de o Imperador ser um apreciador e leitor assíduo ${ }^{913}$ das Escrituras, acreditase, que esta amizade tenha sido uma boa razão pela qual D. Pedro II deu certa liberdade e apoio ao trabalho das Sociedades Bíblicas e, igualmente, ampliou e permitiu a implantação legal da primeira igreja protestante no Brasil, isto é, a Igreja Evangélica Fluminense. Em um relato encontrado numa importante obra conjunta de Kidder e Fletcher, em que ambos discorrem sobre a realidade social, econômica, comercial, industrial, educacional, política e religiosa do Brasil, se tem a seguinte informação:

${ }^{909}$ CÉSAR, Elben Magalhães Lenz. História da evangelização do Brasil, p. 91.

${ }^{910}$ GIRALDI, Luiz Antonio. A Bíblia no Brasil Império, p. 149.

911 Id. Semeadores da Palavra, p. 47.

${ }_{912}$ Id. A Bíblia no Brasil Império, p. 157.

${ }^{913}$ Segundo Turner, D. Pedro expressou seu apreço à leitura da Bíblia quando pediram sua opinião sobre ela afirmando: "Eu amo a Bíblia. Eu a leio todos os dias, e quanto mais a leio, mais a amo" (In: TURNER, Charles Willian. La Biblia construye en America Latina. Buenos Aires: Editorial La Aurora, 1954, p. 16). 
Sua Majestade conversou comigo sobre minhas atividades no Brasil e exprimiu sua gratidão pelas lembranças que havia recebido dos cidadãos dos Estados Unidos. Afirmei-lhe que desejava visitar nos próximos meses as diversas províncias do Brasil, a serviço da divulgação da Bíblia e, depois, voltaria para a minha terra natal. Ele, então, me apresentou seus habituais votos de boa viagem ${ }^{914}$.

Como se percebe, Fletcher exerceu significativo impacto no trabalho bíblico e missionário desenvolvido no Brasil. Suas contribuições, porém, foram além disso. Entre outros aspectos, à época, ele chegou a escrever artigos em jornais do Rio de Janeiro combatendo a escravidão e procurou facilitar uma maior integração entre os EUA e o Brasil em diversas áreas. Como fruto de seus relacionamentos, Fletcher ainda influenciou e instigou o missionário Robert Reid Kalley a vir para o Brasil.

Kalley, nesse sentido, se destaca com certa preeminência entre os missionários que chegaram ao Brasil para pregar sobre a fé protestante e difundir a causa da Bíblia. Como médico e missionário, antes de chegar ao Brasil, Kalley passou por momentos difíceis nos trabalhos missionários desenvolvidos por ele na Ilha da Madeira. De lá, ele foi expulso por motivos religiosos e, depois de passar um tempo nos EUA, conhecedor da língua portuguesa, foi influenciado por Fletcher a migrar para o Brasil no ano de $1855^{915}$. Como Fletcher, Kalley também se tornou amigo de D. Pedro II, facilitando, assim, sua missão entre os brasileiros. Foi dessa forma, portanto, que

Durante seu longo ministério no Brasil, Kalley manteve intensa colaboração com as Sociedades Bíblicas e promoveu com entusiasmo a divulgação das Escrituras. Ele descobriu desde o início do seu trabalho que a distribuição da Bíblia de casa em casa era essencial para o desenvolvimento da obra missionária ${ }^{916}$.

Dessa forma, Kalley espalhou colportores pelo Brasil, convicto de que tal trabalho redundaria em êxito para a causa da Bíblia. E, de fato, isso aconteceu. Entre os membros de sua igreja, muitos, inclusive brasileiros, foram colportores, que viajaram pelo Brasil distribuindo a Bíblia. Por outro lado, foi por meio da reação de Kalley à perseguição religiosa ${ }^{917}$ exercida contra os protestantes que a liberdade religiosa deu um grande salto no Brasil. Como resultado de tal luta, a

\footnotetext{
${ }^{914}$ KIDDER, Daniel Parish; FLETCHER, James C. O Brasil e os brasileiros. São Paulo: Companhia Editora Nacional, 1941, p. 287.

${ }^{915}$ Cf. MATOS, Alderi de Souza. Robert Reid Kalley: pioneiro do protestantismo missionário na Europa e nas Américas. Fides Reformata VIII, n. 1, 2003, p. 17.

${ }^{916}$ GIRALDI, Luiz Antonio. A Bíblia no Brasil Império, p. 175

${ }^{917}$ Em 1856, Kalley foi acusado de fazer "propaganda protestante e distribuir Bíblias falsas" (GIRALDI, Luiz Antonio. Op. cit., p. 174).
} 
Kalley é atribuída a implantação da primeira igreja evangélica no país ${ }^{918}$, devidamente registrada como entidade jurídica e reconhecida pelo governo imperial antes mesmo da plena liberdade religiosa que se instaurou no Brasil com a Proclamação da República. Em seu trabalho, Kalley cooperou simultaneamente com o trabalho da BFBS e da ABS, sempre buscando o melhor para a difusão das Escrituras no Brasil.

Considerando o tamanho continental do Brasil, os primeiros representantes da ABS sentiram a necessidade de ampliar o trabalho, enviando um representante específico para a região amazônica. Além disso, é importante lembrar que principalmente na segunda metade do século XIX a região amazônica viveu um período de grande prosperidade econômica — por causa do ciclo da borracha —, e, por conseguinte, significativa relevância política e cultural.

Assim como já ocorrera em outras regiões do Brasil, o êxito na propagação das Escrituras foi imediato naquele período, próximo ao ano de 1857. Motivado por tal realidade, "Nesbitt decidiu fazer uma longa viagem missionária pelo rio Amazonas, desde o oceano Atlântico até onde ele nasce, no Peru"919. Em função disso, através de um navio carregado com exemplares das Escrituras, Nesbitt viajou por vários meses e alcançou inúmeras regiões pouco conhecidas na época. Nesta viagem, ele pregava o Evangelho e distribuía as Escrituras ao povo amazônico, principalmente aos ribeirinhos. Porém, “durante a última etapa desta longa viagem missionária, aconteceu o inesperado. Nesbitt foi acometido de febre amarela e, sem recursos para enfrentar a enfermidade, faleceu no barco, pouco antes de terminar a viagem" 920 .

Para substituir Nesbitt, a ABS enviou para a região amazônica o missionário episcopal Reverendo Richard Holden. Instalando-se em Belém, Holden “divulgou a Bíblia na imprensa e promoveu a sua distribuição através de contatos pessoais na capital e no interior da província, navegando pelos rios da Amazônia"921. Seu trabalho foi tão intenso que chegou a provocar uma discussão longa e polêmica

\footnotetext{
918 Os anglicanos e luteranos que iniciaram suas atividades anteriormente se limitavam aos imigrantes ingleses e alemães, respectivamente. Com Kalley, houve a abertura para que os brasileiros também pudessem frequentar igrejas protestantes. Apesar de a igreja ter sido organizada em 1858, somente "no dia 22 de novembro de 1880, o imperador D. Pedro II assinou o decreto n. 7.907, tornando a Igreja Evangélica Fluminense a primeira igreja evangélica nacional oficialmente registrada no país" (GIRALDI, Luiz Antonio. Op. cit., p. 209).

${ }^{919}$ GIRALDI, Luiz Antonio. The American Bible Society in Brazil, p. 37 (tradução nossa).

${ }^{920}$ Id. Semeadores da Palavra, p. 74.

${ }^{921}$ Id. A Bíblia no Brasil Império, p. 195.
} 
com o bispo católico, D. Antonio de Macedo Costa, na qual Holden defendeu entusiasticamente o direito de se divulgar as Escrituras na região. Depois da saída de Holden, outros representantes chegaram a ser enviados para a região Amazônica, tanto a Belém quanto a Manaus.

Giraldi também ressalta a contribuição de Ashbel Green Simonton no trabalho bíblico e missionário que caracterizou aquele momento histórico. Além de Simonton ter sido o missionário fundador do presbiterianismo no Brasil — chegando no país em 1859 - , foi um dos mais importantes representantes da ABS no início do trabalho bíblico no Brasil. Foi ele quem, "como representante da SBA, começou a promover a distribuição das Sagradas Escrituras no Brasil através de colportores" $" 922$. No exercício deste trabalho, Simonton e seus colportores e apoiadores, em suas viagens por várias cidades do interior do país, realizavam o trabalho sob um duplo aspecto, isto é, distribuíam a Bíblia e organizavam igrejas presbiterianas de forma concomitante.

Simonton foi inovador ${ }^{923}$ em seu trabalho de difusão das Escrituras. Em muitas das cidades visitadas, ele e seus companheiros de trabalho estabeleceram depósitos de Bíblias em casas comerciais e "em 1864 ele começou uma nova maneira de distribuir as Escrituras com a inauguração da primeira livraria protestante na cidade do Rio" ${ }^{924}$. Simonton também visitou sacerdotes católicos em busca de cooperação para a propagação da Bíblia e, como a demanda era crescente, recebeu a ajuda de seu cunhado, Reverendo Alexander Latimer Blackford, que, além de apoiá-lo na causa da Bíblia, também foi o responsável por fundar a Igreja Presbiteriana em São Paulo.

Obviamente, o desenvolvimento do trabalho de difusão das Escrituras não se limita a esses nomes. Pelo contrário, muitos outros personagens contribuíram significativamente com a causa da Bíblia no Brasil durante o século XIX. Esses nomes foram apresentados pelo fato de que, a partir deles e de suas respectivas influências na formação de missionários, pastores e colportores nacionais, a difusão das Escrituras e o crescimento das igrejas protestantes foi, ao longo do tempo,

\footnotetext{
${ }^{922}$ GIRALDI, Luiz Antonio. A Bíblia no Brasil Império, p. 142.

${ }^{923}$ Além de potencializar o trabalho por meio de colportores e abrir a primeira livraria evangélica no Brasil, Simonton criou o primeiro jornal evangélico brasileiro, a Imprensa Evangélica, criou o primeiro presbitério (agrupamento organizacional de igrejas presbiterianas) e em 1867 criou o primeiro seminário teológico protestante no Brasil (que formou os quatro primeiros pastores nacionais).

${ }^{924}$ GIRALDI, Luiz Antonio. The American Bible Society in Brazil, p. 39 (tradução nossa).
} 
alcançando sempre maiores proporções. Eles deram o primeiro passo, e até hoje muitos seguem imbuídos da mesma missão.

Entretanto, diante de todas as dificuldades que surgiam no trabalho de propagação das Escrituras pela ABS, “a distribuição somente viria a crescer de maneira expressiva a partir da inauguração de sua agência bíblica no Rio de Janeiro, em 1876" "925. A pessoa responsável por tal tarefa foi o Reverendo Blackford, que já tinha assumido o cargo de representante da ABS no Rio de Janeiro após a morte de seu cunhado, o Reverendo Simonton. Todavia, com a instalação da agência, Blackford deixou suas funções pastorais para se dedicar integralmente à causa da Bíblia como agente da ABS no Brasil. Sua dedicação foi tanta que os registros de seu trabalho descrevem que ele percorreu mais de cinco mil quilômetros, a maior parte a cavalo, passando de cidade em cidade para semear a Palavra de Deus.

Diante da crescente busca da população pela leitura, Blackford também foi o responsável por promover "uma revisão do Novo Testamento na tradução de João Ferreira de Almeida, com o objetivo de adaptá-la ao português usado na época no Brasil"926. Essa foi a primeira revisão da tradução de Almeida ocorrida no país. Já quase no final do período imperial, Blackford foi substituído pelo Rev. William Campbell Brown, que durante sete anos promoveu a propagação das Escrituras por várias regiões, algumas até então pouca atendidas, como foi o caso de várias cidades da Província do Paraná.

E, finalmente, o último agente da ABS a realizar um relevante trabalho em prol da causa da Bíblia no Brasil imperial foi o Reverendo Hugh Clarence Tucker, nomeado em 1887 para a função. Entretanto, como o trabalho de Tucker se estendeu por muitos anos, ele será melhor compreendido na seção que tratará do trabalho bíblico no Brasil República. Por ora, vale ressaltar somente dois aspectos de sua contribuição para a causa bíblica ainda no Brasil Império. A primeira delas foi sua ação inovadora em produzir "a primeira publicação das Escrituras em braile" no Brasil, em parceria com o Instituto Benjamin Constant ${ }^{927}$, do Rio de Janeiro.

\footnotetext{
925 GIRALDI, Luiz Antonio. A Bíblia no Brasil Império, p. 145.

926 Ibid., p. 204.

927 O Instituto Benjamin Constant (IBC), fundando em 1854 por D. Pedro II, é uma tradicional instituição de ensino para pessoas cegas. Na atualidade, o IBC ampliou seu trabalho, tornando-se um centro de referência nacional para questões relativas à deficiência visual. Deste modo, além da escola, o IBC também realiza capacitação profissional na área da deficiência visual, assessoramento de escolas e instituições em geral. A instituição oferece ainda reabilitação física para seus associados (cf. IBC - Instituto Benjamin Constant. Desenvolvido pelo Ministério da Educação - Go-
} 
Na ocasião, foram produzidos 500 exemplares do Evangelho de João em braile para se distribuir às pessoas cegas. Além de gratuita, a distribuição foi anunciada em um jornal para que alcançasse o maior número de pessoas. Se atualmente esse trabalho é desafiador, é possível imaginar como foi à época.

Outra ação relevante de Tucker foi a sua percepção em relação às necessidades de Escrituras por parte dos mais de um milhão de imigrantes italianos que chegaram ao Brasil no final do século XIX. Para realizar tal trabalho pela causa da Bíblia, "ele importou grandes quantidades de Bíblias, Novos Testamentos e Evangelhos em italiano e em português, e contratou colportores para visitar os imigrantes" 928 . Ressalta-se ainda o fato de que a escolha por esses colportores se deu a partir de um critério específico: eles precisavam falar italiano. Certamente, com tal habilidade, os colportores teriam maior relevância na entrega das Escrituras para aquele povo.

\subsubsection{2 \\ A atuação dos primeiros representantes da Sociedade Bíblica Britânica e Estrangeira no Brasil e a instalação de sua primeira agência}

Como informado anteriormente, o trabalho da BFBS entre 1820 e 1840 aconteceu sob muitas dificuldades, com a ajuda e o apoio de voluntários e representantes não oficiais que viajavam para o Brasil. Já a partir da década de 1840, a relação entre o Brasil e a BFBS reduziu um pouco mais. O trabalho bíblico, obviamente, não foi essencialmente prejudicado por dois motivos principais: primeiro, o afastamento não representou abandono; Bíblias foram enviadas e pessoas continuavam trabalhando na mesma missão. Por outro lado, o trabalho de difusão bíblica da ABS cresceu e se fortaleceu rapidamente no Brasil, como já se destacou acima.

A questão do distanciamento da BFBS só foi resolvida com a vinda definitiva do primeiro agente oficial da BFBS para o Brasil, Richard Corfield, e com o estabelecimento do primeiro depósito de Bíblias no país, em 1856. Vale ressaltar, inclusive, que Fletcher contribuiu significativamente para tal fato, quando, em um comentário, afirmou que "o campo no Brasil é imenso e não está sendo devida- 
mente atendido pelas duas Sociedades Bíblicas"929. Foi justamente depois do Secretário-geral da BFBS, na Inglaterra, ler o relato de Fletcher que a BFBS decidiu, naquele mesmo ano, enviar um agente e abrir a sua agência no país. Giraldi destaca essa decisão ao citar algumas informações contidas no relatório anual da BFBS:

Em 1856, a SBBE decidiu enviar um agente para o Brasil e passou a selecionar um candidato para o cargo. A pessoa escolhida foi Richard Corfield, da cidade de Liverpool, no Reino Unido, fortemente recomendado como um cristão íntegro, honrado, responsável e com experiência na área administrativa. Embora ocupasse um alto cargo na empresa onde trabalhava, ele aceitou imediatamente o convite recebido, partiu para o Brasil e assumiu, no final do ano, o cargo de agente da SBBE no Rio de Janeiro. Como Corfield já morou alguns anos na América do Sul, sua familiaridade com a cultura do povo da região deverá ajuda-lo na distribuição das Escrituras $^{930}$.

Desde sua chegada, Corfield visitou várias regiões do país para distribuir a Bíblia. Porém, em 1859, a BFBS decidiu transferi-lo para Buenos Aires, para que ele assumisse o trabalho em toda a América Latina. Com sua saída, o número de exemplares distribuídos voltou a cair. Para suprir este novo distanciamento, somente em 1864 a BFBS contratou uma pessoa para representá-la no Brasil. A pessoa escolhida foi o pastor episcopal, Reverendo Richard Holden, que já tinha trabalhado com a ABS na Amazônia e agora tinha como missão cuidar, a partir de Salvador, na Bahia, de todo o trabalho bíblico realizado pela BFBS no Brasil.

Em 1867, Holden foi convidado por Kalley a se mudar para o Rio de Janeiro, oportunidade esta que permitiu a Holden, de 1867 a 1872, acumular "as funções de agente da SBBE e pastor auxiliar na Igreja Evangélica Fluminense, ambas com sede no Rio de Janeiro"931. Mais uma vez se atrelavam o trabalho missionário e a causa da Bíblia e, assim como outros, Holden impulsionou a difusão das Escrituras através de colportores.

Depois de seu retorno para a Europa, a função de Holden foi assumida pelo português José de Carvalho, que, durante sua liderança frente à agencia da BFBS no Brasil, "conseguiu aumentar a circulação de Escrituras contratando novos colportores" 932 . Um pouco mais adiante, quase no final do período imperial, o primeiro brasileiro assumiu a agência da BFBS no Brasil. Trata-se do Reverendo

\footnotetext{
929 GIRALDI, Luiz Antonio. A Bíblia no Brasil Império, p. 157.

${ }^{930}$ Ibid., p. 182. (grifo nosso)

931 Ibid., p. 186.

932 Ibid., p. 188.
} 
João Manoel Gonçalves do Santos. Em sua trajetória, Gonçalves foi o segundo membro da Igreja Evangélica Fluminense, portanto, um dos primeiros brasileiros convertidos à fé protestante no Brasil. Depois de estudar teologia em um seminário da Inglaterra, Gonçalves foi ordenado e escolhido como copastor da mesma igreja em que se converteu. Concomitantemente, durante cerca de nove anos, Gonçalves exerceu a função de pastor numa igreja local e de agente da BFBS no Brasil. Em 1887, Gonçalves deixou o pastorado para dedicar-se exclusivamente à causa da Bíblia como agente da Sociedade Bíblica Britânica e Estrangeira. Seu trabalho de difusão das Escrituras alcançou patamares inovadores para a época, visto que ele

Fez o possível para atrair pessoas à livraria da SBBE no Rio de Janeiro, exibindo cartazes com versículos bíblicos e expondo diferentes tipos de Escrituras. Ele enviou também exemplares de Porções Bíblicas como amostra a diversas congregações evangélicas que já tinham sido abertas ${ }^{933}$.

Com tais estratégias, com o apoio da Sociedade Bíblica da Escócia - que no mesmo período ajudou o trabalho bíblico no Brasil - , e com o aumento do número de colportores, a administração de Gonçalves ficou reconhecida pelo crescimento de Escrituras distribuídas no país. Giraldi ${ }^{934}$ destaca que em 1881, por exemplo, tal crescimento foi $48 \%$ superior ao ano anterior e em 1883 já existiam cerca de 21 depósitos de Bíblias espalhados pelo país. Outra ideia estratégica de Gonçalves ocorreu devido ao seu planejamento e à sua capacidade de organização em relação ao trabalho dos colportores. Para evitar que o trabalho deles se sobrepusesse um ao outro, Gonçalves dividiu as Províncias existentes na época em algumas áreas, colocando colportores específicos para regiões específicas. Tal trabalho resultou em benefício para o trabalho bíblico; afinal, houve uma melhor capilaridade, como também se conferiu maior tranquilidade aos colportores e seus familiares, já que o tempo das viagens foi reduzido.

Assim como outros, Gonçalves se aproximou de D. Pedro II, chegando inclusive a entregar-lhe "um exemplar da Bíblia em nome da Sociedade Bíblica Britânica e Estrangeira" ${ }^{935}$. Gonçalves se aposentou em 1901 depois de investir 23 anos de sua vida na difusão das Escrituras no Brasil.

\footnotetext{
${ }_{933}$ GIRALDI, Luiz Antonio. A Bíblia no Brasil Império, p. 211.

934 Ibid.

935 Ibid., p. 213.
} 
Enfim, diante de tantos desafios, a causa da Bíblia foi realizada com diligência por várias pessoas e igrejas durante o período imperial. Em pouco mais de 70 anos, a propagação da Bíblia passou de algo quase inexistente para números antes inimagináveis. Giraldi ressalta tal fato ao lembrar que "durante todo o século XIX, as duas Sociedades Bíblicas que atuaram no Brasil [...] distribuíram, juntas, cerca de um milhão de Escrituras"936. Esse número é significativo quando se constata que o Brasil tinha uma população estimada em pouco mais de 10 milhões de habitantes nas últimas três décadas do século XIX $^{937}$. Tal distribuição só foi possível porque muitas igrejas, missionários, colportores e cristãos de forma geral se uniram sob a mesma missão, isto é, difundir as Escrituras Sagradas. Foi assim que a Bíblia chegou às mãos do povo brasileiro, português, alemão, inglês etc., os quais residiam no Brasil daquela época.

\subsection{3 \\ A atuação das Sociedades Bíblicas na difusão das Escrituras Sagradas durante o Brasil República}

Depois de um início promissor, alicerçado em um momento de transição política e religiosa do período imperial, a difusão das Escrituras cresceu e se fortaleceu no país. De praticamente inexistente nos tempos em que o Brasil era Colônia de Portugal, a divulgação da Palavra de Deus, por meio de Bíblias impressas, se tornou fértil no Brasil durante aquele período. Deste modo, passados cerca de 80 anos desde a chegada da família real - que abriu as portas do Brasil para a Bíblia —, iniciou-se um novo período da história que foi relevante para a causa da Bíblia no Brasil. Esse período adveio com a definitiva Proclamação da República no país.

Tal relevância se explica principalmente porque, com a chegada deste novo momento político, a liberdade religiosa se instaurou de forma legal e, assim, o trabalho bíblico pôde ser desenvolvido de uma maneira mais segura, sem infringir as leis do país. Como se perceberá, isso não quer dizer que tudo se tornou mais fácil; pelo contrário, a liberdade religiosa, consolidada com o estabelecimento da República e com a consequente destituição do catolicismo como religião oficial

\footnotetext{
936 GIRALDI, Luiz Antonio. A Bíblia no Brasil Império, p. 128.

${ }^{937}$ BOTELHO, Tarcísio Rodrigues. População e espaço nacional no Brasil do século XIX. Cadernos de História, Belo Horizonte, v. 7, n. 8, 2ºm. 2005, p. 79.
} 
do Estado, não enfraqueceu a Igreja Católica no país; pelo contrário, tornou-a mais forte em seu trabalho religioso; afinal, ela também se "desprendeu" das interferências do Estado que eram legitimadas pelo sistema de padroado ao qual a Igreja Católica no Brasil estava submetida ${ }^{938}$. Como decorrência, a perseguição àqueles que difundiam a Bíblia, em vez de se tornar amena, ficou mais acirrada por parte de algumas pessoas em determinadas regiões.

De qualquer forma, o trabalho de ambas as Sociedades Bíblicas, imbuídas de sua missão de difundir as Escrituras, continuou crescendo e se fortalecendo. Nesse sentido, Giraldi, em uma síntese introdutória, destaca:

As primeiras décadas do Brasil República foram decisivas para a divulgação da Bíblia no país. Após a proclamação da República, em 1889, foram introduzidas no país a democracia e a liberdade religiosa, e, com isso, muitas portas se abriram para a divulgação da Palavra de Deus no país. As Sociedades Bíblicas aproveitaram a oportunidade, multiplicaram seus esforços e os resultados logo apareceram: a distribuição das Escrituras no Brasil, que havia sido de um milhão de exemplares durante todo o Império, saltou para um milhão por ano na década de $1940^{939}$.

De fato, foi um período singular para a difusão das Escrituras e, sem dúvida, os alicerces lançados naquele período contribuíram significativamente para que o Brasil se tornasse um dos países com maior relevância no trabalho bíblico no mundo, como poderá se constatar no decorrer desta pesquisa. Por ora, cabe entender quais foram os principais aspectos que permearam esse trabalho desde a Proclamação da República até o ano de 1948, quando foi fundada a Sociedade Bíblica do Brasil, objeto fundamental deste estudo que será melhor compreendido no próximo capítulo.

\subsubsection{1 \\ Desafios na difusão das Escrituras Sagradas: as primeiras décadas da causa da Bíblia no Brasil República}

A história secular registra a transição entre Império e República, destacando alguns desafios que caracterizaram aquele período. Várias questões estavam em pauta, tais quais: a escravidão, a liberdade religiosa, o estilo de governo a ser

\footnotetext{
${ }^{938}$ Cf. DREHER, Martin Norberto. Protestantes na América Meridional. In: SIEPIERSKI, Paulo Donizéti; GIL, Benedito (orgs). Religião no Brasil: enfoques, dinâmicas e abordagens. São Paulo: Paulinas, 2003, pp. 39-65.

${ }^{939}$ GIRALDI, Luiz Antonio. A Bíblia no Brasil República, p. 17.
} 
implantado etc. ${ }^{940}$ Entre tantas outras, a questão que emergiu intrincada à difusão das Escrituras foi o tema da liberdade religiosa. Para que tal liberdade fosse alcançada, depois de mais de três séculos de predomínio exclusivamente católico, alguns personagens contribuíram significativamente nesse sentido. Entre eles, destaca-se, "Rui Barbosa, intelectual que inspirou, liderou e norteou as grandes mudanças políticas e sociais que aconteceram naquele período importante da história do Brasil" $" 941$.

Rui Barbosa foi um grande defensor da liberdade e, para ele, "sobre todas as liberdades está para nós a liberdade religiosa" ${ }^{942}$. Foi baseado em tal concepção que Rui Barbosa se tornou, por muitos anos, um apoiador do trabalho das Sociedades Bíblicas e um incentivador do desenvolvimento de igrejas protestantes no Brasil. Turner vai além, ao afirmar que "a grande contribuição dada por Rui Barbosa ao país, graças à sua retidão de caráter e à sua personalidade admirável, foi fruto de seu estudo e meditação da Bíblia"943.

Além de defender a causa da liberdade religiosa, Rui Barbosa participou ativamente na difusão das Escrituras no Brasil. Seu apoio foi além do discurso e se evidenciou, por exemplo, "quando aceitou o convite das Sociedades Bíblicas para participar, como consultor de linguagem, da Tradução Brasileira da Bíblia"944, a primeira Bíblia traduzida para o português corrente no Brasil, entre 1903 e 1914, para atender a alguns pedidos surgidos em um movimento nacional de evangélicos. Por tais motivos, entre outros, Rui Barbosa se tornou um crítico contundente da Igreja Católica e do papa. No prefácio da obra O papa e o Concílio: a questão religiosa" ${ }^{\text {945 }}$, Rui Barbosa enfatizou seu ponto de vista crítico em relação a vários assuntos religiosos da Igreja, alguns brevemente delineados acima. Vale ressaltar, inclusive, que o livro, originalmente escrito por Dollinger, foi proibido no Brasil justamente pelo nível de crítica que exerceu à Igreja.

\footnotetext{
${ }^{940}$ Cf. GOMES, Laurentino. 1889: como um imperador cansado, um marechal vaidoso e um professor injustiçado contribuíram para o fím da monarquia e a proclamação da República no Brasil. São Paulo: Globo, 2013, pp. 38-249.

${ }^{941}$ GIRALDI, Luiz Antonio. A Bíblia no Brasil República, p. 19.

942 DOLLINGER, Johann Joseph Ignaz Von; BARBOSA, Rui. O papa e o Concílio: a questão religiosa. Rio de Janeiro: Brown \& Evaristo, 1877, p. 239.

943 TURNER, Charles Willian. La Biblia construye en America Latina, p. 34.

${ }^{944}$ GIRALDI, Luiz Antonio. Op. cit., p. 20.

${ }^{945}$ Cf. DOLLINGER, Johann Joseph Ignaz Von; BARBOSA, Rui. O papa e o Concílio: a questão religiosa, pp. 20-303.
} 
Para aqueles que trabalhavam nas Sociedades Bíblicas, com a missão de difundir as Escrituras no país, o novo momento histórico foi importante. O Reverendo Gonçalves, que era o agente da BFBS no Brasil durante aquele período, manifestou sua percepção a respeito deste novo cenário ao relatar, em 1890, o seguinte:

Agora, a Igreja Católica não é mais a religião oficial do Estado e nós temos completa liberdade religiosa no Brasil. O governo passou a ter apenas uma relação formal com a Igreja e todas as religiões têm os mesmos direitos perante a lei. Todas são iguais e têm liberdade de culto [...] e o Brasil agora respira um clima de plena liberdade política e religiosa. Todas essas mudanças foram feitas sem tumulto popular, o país está calmo e a Igreja Católica também ${ }^{946}$.

Portanto, ainda que um ou outro aspecto contrário surgisse como reação ao novo momento político-religioso de liberdade, o que prevaleceu foi o bom senso no início da República. Na verdade, ambas as correntes cristãs se fortaleceram. A Igreja Católica deixou de lado os conflitos que surgiram anteriormente devido ao fato de estar submetida ao Estado, fazendo com que suas doutrinas e valores, advindos das recomendações da Igreja de Roma, pudessem ser aplicados livremente em seu governo. Ela não estava mais submetida ao Estado brasileiro; antes, resgatava sua submissão completa e total aos direcionamentos administrativos e doutrinários da Santa Sé. E as igrejas protestantes, deixando de lado os perigos de uma propagação da fé que desafiava o Estado oficialmente católico, passaram a pregar e a crescer. Nessa perspectiva, muitas igrejas foram implantadas; muitas escolas confessionais foram abertas; e a causa da Bíblia se ampliou no país. Nessa perspectiva, o momento foi marcado pela

[...] predisposição para adquirir a Bíblia. Muitos católicos que antes tinham medo de ter em casa a Bíblia ou o Novo Testamento, considerados livros proibidos, mudaram de ideia e se sentiram livres para comprá-los. Por outro lado, o trabalho dos colportores foi facilitado. Embora continuassem a ser perseguidos em muitas regiões do país, em outras passaram a ser recebidos com mais respeito e consideração ${ }^{947}$.

A perseguição ocorrida em alguns lugares, conforme o relato de Giraldi, é confirmada por meio de um segundo relatório de 1890, enviado mais tarde por Gonçalves à BFBS, em que afirma que "a liberdade religiosa não avançou muito

\footnotetext{
${ }^{946}$ GIRALDI, Luiz Antonio. A Bíblia no Brasil República, p. 46.

${ }^{947}$ Ibid., p. 61.
} 
na prática" ${ }^{948}$. Um pouco mais tarde, em 1892, num relatório enviado por Tucker à $\mathrm{ABS}$, tal fato se confirma. Segundo ele, diante do novo momento, "os padres se tornaram os mais fortes oponentes à circulação das Escrituras em todo o país" Tal fato pode decorrer com base no conteúdo da encíclica Inter Praecipuas, promulgada em 1844 pelo papa Gregório XVI, que tecia críticas contundentes em relação à distribuição de Bíblias realizada pelas Sociedades Bíblicas. Constata-se, assim, que a liberdade religiosa, que poderia ter proporcionado mais facilidade, de forma contraditória, instigou parte dos sacerdotes católicos a reagirem contrários à distribuição da Bíblia. Vale a pena reiterar que, historicamente, não foram todos os sacerdotes; pelo contrário, alguns, inclusive, apoiaram o trabalho.

Concomitante a este contexto, a propagação ainda crescia a ponto de ter sido necessário realizar a distribuição por meio de subdepósitos regionais, localizados não mais em lojas comerciais, mas nas maiores igrejas evangélicas do país à época. E assim, entre o final do século XIX e o início do século XX,

[...] as duas Sociedades Bíblicas que atuavam no Brasil, a Britânica e a Americana, passaram a chamar esses depósitos regionais de correspondentes. Correspondentes era uma igreja local que comprava regularmente das Sociedades Bíblicas e mantinha um estoque permanente de Escrituras no templo, para venda aos seus membros e também para a distribuição evangelística a pessoas que não possuíam uma Bíblia $^{950}$.

Esta era, sem dúvida, uma estratégia eficiente, que envolvia capilaridade, ou seja, mais lugares poderiam ter acesso a muito mais Escrituras de forma bem mais facilitada. E, por outro lado, resultava em crescimento do número de evangélicos. Aliás, desde essa época e por muito tempo, esses dados foram indissociáveis. Quanto mais crescia a distribuição de Bíblias, mais crescia o número de protestantes e vice-versa, estabelecendo-se, assim, uma espécie de relação causa e efeito. Por isso, "o desenvolvimento desta interação entre a circulação da Bíblia e a expansão missionária foi um elemento na aceitação do protestantismo e também na determinação do caráter bíblico do protestantismo brasileiro" 951 .

Considerando que a causa da Bíblia avançava no Brasil e que, como já se constatou anteriormente, vários documentos papais já tinham concedido certa li-

\footnotetext{
948 GIRALDI, Luiz Antonio. A Bíblia no Brasil República, p. 69.

949 Ibid., p. 63.

${ }^{950}$ Ibid., pp. 76-77 (grifo do autor).

${ }^{951}$ Cf. CAIRNS, Earle Edwin. O cristianismo através dos séculos: uma história da igreja cristã, p. 412.
} 
berdade de acesso às Escrituras por parte dos leigos, a Igreja Católica no Brasil, ainda que com certo atraso em relação ao estímulo que os papas já estavam dando, começou a realizar uma mudança lenta, mas gradual, no sentido de fazer parte integrante deste trabalho bíblico. Nessa perspectiva, o papa "parou de dirigir críticas às Sociedades Bíblicas" 952 , passando a ter com elas e com os protestantes um diálogo significativo, que se iniciou com o papa Leão XIII. Foi por meio dele, inclusive, que foi aprovada a criação da "Escola Bíblica de Jerusalém", que tanto bem fez ao movimento bíblico entre os católicos.

Foi nesse espírito que em 1903 publicou-se no Brasil, por exemplo, uma "Concordância dos Santos Evangelhos”, feita a partir da tradução da Vulgata Latina $^{953}$. É obvio que, ainda que em menor quantidade em comparação ao que faziam os protestantes, outras traduções bíblicas feitas por católicos surgiram, antes, durante e depois dessa especificamente. A escolha por esta publicação se dá pela aproximação da temática de estudo dentro de um contexto histórico específico. Afinal, o prefácio desta obra, escrito pelo Monsenhor Manoel Vicente da Silva, evidencia bem o clima que estava estabelecido naquele momento:

Certamente, não existe nenhuma leitura mais útil para as almas piedosas do que os Evangelhos. Essa leitura alimenta a mente e o coração. Aprovados pela Igreja, os Evangelhos são os livros mais precisos que existem. Eles contêm a Palavra de Deus, palavra que é luz e verdade, que dirige os passos daqueles que amam a virtude, que civiliza as nações e traz bênçãos e a vida eterna. [...] O momento é oportuno. Os emissários das Sociedades Bíblicas estão se multiplicando entre nós, distribuindo as Escrituras na linguagem falada no país, com evidentes alterações ${ }^{954}$.

Como é possível perceber, há, de certa forma, um estímulo para a leitura, sob a convicção de que ela poderia alimentar a alma. É difícil captar ou analisar a intenção do prefacista. Pode ser fruto do estímulo dos documentos papais, que convidavam os leigos a uma leitura em traduções bíblicas aprovadas pela Igreja, ou pode ser também, como aparentemente se evidencia, uma resposta ao trabalho desenvolvido pelas Sociedades Bíblicas, que distribuíam as Escrituras em português em vários lugares do país. Mais à frente, em outra edição católica do Novo Testamento, publicada em português em 1910, uma advertência semelhante se repetirá. É bem certo que tanto por um lado como por outro, os ânimos se torna-

${ }^{952}$ GIRALDI, Luiz Antonio. A Bíblia no Brasil República, p. 81.

${ }^{953}$ Cf. MALZONI, Cláudio Vianney. As edições da Bíblia no Brasil, p. 63.

954 Cf. SILVA, Duarte Leopoldo E. Concordancia dos Sanctos Evangelhos. São Paulo: Escola Tipográfica Salesiana, 1903, não paginado (grifo nosso). 
ram cada vez mais acirrados neste início de República. Pelo viés do trabalho bíblico desenvolvido pelas Sociedades Bíblicas, tal fato se evidenciará ainda mais na seção em que se discorrerá sobre o trabalho dos colportores; afinal, eram eles que mormente se defrontavam com tais situações.

Como já foi possível perceber, o movimento era tenso e tênue. Ora se manifestava com perseguição, ora com apoio. De fato, diante da grandiosidade da Igreja Católica desde aquela época, é certo que haviam setores favoráveis e outros contrários ao trabalho de difusão bíblica realizado pelas Sociedades Bíblicas. Giraldi, por exemplo, destaca que naquele período, nem tudo foi realizado sob crítica ou perseguição por parte da Igreja. Manifestações positivas também foram realizadas por líderes católicos, como foi o caso, por exemplo, do arcebispo do Rio de Janeiro, D. Joaquim Arcoverde, que em 1908 afirmou que cada família deveria ter em seu lar uma Bíblia, para que ela pudesse ser lida e meditada. Imbuído pelo estímulo de Leão XIII, que incentivou a leitura da Bíblia, Arcoverde chamou os protestantes de "irmãos separados". Trata-se de uma manifestação respeitosa, ainda que discordasse da posição protestante de, segundo ele, "substituir a Igreja pelos Evangelhos"955.

Em 1920, a encíclica Spiritus Paraclitus ${ }^{956}$ evidenciou um avanço significativo para os católicos do mundo inteiro, e obviamente alcançou também os brasileiros. O papa Bento XV, além de incitar o surgimento de estudos bíblicos e estimular a leitura da Bíblia pelo povo, teceu elogios àqueles que lutavam para difundir as Escrituras nas diversas regiões. Ainda que não fique claro que se tratava de um elogio explícito ao trabalho que as Sociedades Bíblicas vinham fazendo, a mensagem do papa, de forma implícita, reconheceu a relevância da missão que era realizada majoritariamente pelas Sociedades Bíblicas naquela época. Concomitantemente, o papa convidou os católicos a se envolverem nessa mesma tarefa.

Por coincidência ou não, "a tradução da Bíblia do padre Matos Soares, feita da Vulgata latina, foi publicada pela primeira vez em 1932"957. Historicamente, trata-se de uma das mais importantes, populares e utilizadas traduções católicas da Bíblia que já existiram em língua portuguesa. Diante de tal relevância, assim

\footnotetext{
955 GIRALDI, Luiz Antonio. A Bíblia no Brasil República, p. 86. Vale lembrar que esta mesma designação, isto é, “irmãos separados”, foi utilizada no Concílio Vaticano II.

956 PAPA BENTO XV. Carta encíclica Spiritus Paraclitus. Sobre la interpretación de la sagrada escritura, 1920, n. 47.

${ }^{957}$ MALZONI, Cláudio Vianney. As edições da Bíblia no Brasil, p. 61.
} 
como já tinha ocorrido com a tradução de Figueiredo, a Bíblia na tradução do padre Matos Soares também "passou a ser oferecida pelos colportores às pessoas que não aceitavam a Bíblia protestante"958. E assim, a difusão das Escrituras se desenvolvia de forma crescente. Bíblias passaram a ser distribuídas, não somente nas casas e nas igrejas, mas também nos ônibus, nos bondes e nos trens que circulavam por algumas cidades brasileiras. A Bíblia foi se tornando, pouco a pouco, o livro do povo brasileiro.

\subsubsection{2 \\ Meio século de história no trabalho de difusão das Escrituras Sagradas realizado pelo Reverendo Tucker}

Muitas pessoas contribuíram com a difusão das Escrituras no Brasil desde o início. Algumas delas já foram apresentadas anteriormente. Entre elas, o Reverendo Hugh Clarence Tucker, pastor e missionário metodista. Essa figura se constitui um dos importantes pioneiros da difusão bíblica, devido ao fato de que, para realizar sua missão, Tucker investiu quase meio século (de 1886 a 1934) de sua existência na causa da Bíblia. Como resultado de seu trabalho, Tucker chegou a escrever um relato com algumas das experiências vivenciadas por ele no Brasil. Trata-se da obra The Bible in Brazil ${ }^{959}$, publicada em 1916 em Nova York pela American Bible Society.

Como descrito anteriormente, Tucker iniciou sua contribuição como agente da ABS no Brasil ainda nos tempos do Império. A falta de recursos à época deve ter sido um enorme desafio. Ainda assim, Tucker conseguiu implementar métodos diferenciados em seu trabalho de difusão das Escrituras. Ele, por exemplo, instigou a primeira publicação bíblica em braile e atentou para a necessidade de Bíblias para os milhares de italianos que migraram para trabalhar no Brasil. Como se percebe, sua cosmovisão se estendia para além da distribuição da Bíblia nas igrejas. Considerando que Tucker iniciou sua missão com a Bíblia “em um momento de mudanças drásticas na vida política e social do Brasil ${ }^{960}$, seu interesse, por quase toda a sua vida, se voltou para aqueles que, excluídos da sociedade, precisavam de esperança e transformação. Para Tucker, a Bíblia tinha de alcançá-los e,

\footnotetext{
958 GIRALDI, Luiz Antonio. A Bíblia no Brasil República, p. 91.

${ }^{959}$ Cf. TUCKER, Hugh Clarence. The Bible in Brazil. New York: American Bible Society, 1916.

${ }^{960}$ GIRALDI, Luiz Antonio. The American Bible Society in Brazil, p. 64.
} 
por isso, "dedicou-se com todas as suas forças à realização de importantes projetos sociais nas áreas da educação e da saúde"961.

Apesar de se estabelecer no Rio de Janeiro, Tucker decidiu "viajar por todo o país porque descobriu que as necessidades espirituais do povo brasileiro eram maiores no interior do que nas grandes cidades"962. Com um mapa nas mãos, ele chegou a "passar 238 dias viajando e distribuindo a Bíblia através do país em trens, barcos a vapor, canoas, carros de boi, a cavalo e a pé"963. Algumas outras viagens aconteceram com a mesma dedicação, e em determinadas regiões, ele constatou que "alguns volumes sagrados, colocados em circulação a partir do Rio de Janeiro, tinham chegado antes" $" 964$ dele.

Em muitos lugares, “Tucker e os colportores realizaram o trabalho com o risco da própria vida" ${ }^{\text {"965 }}$. O próprio Tucker descreve uma dessas situações de perigo ocorridas quando chegaram para distribuir as Escrituras na cidade de São João Batista, em Minas Gerais. Segundo Tucker, na ocasião, “apareceu um padre e leu em voz alta uma carta do bispo de Diamantina, dizendo que nossas Bíblias eram falsas e incitou o povo a nos expulsar dali. Isso agitou ainda mais o ambiente. Muitos deles portavam armas e um deles nos apontou uma arma de fogo" Depois de conseguirem acalmar a população e se livrarem da situação, Tucker e seus colportores partiram para um riacho próximo, a fim de dar água aos animais. Contudo,

De repente apareceram 30 ou 40 homens armados com paus, pedras e armas. Quando um deles apontou uma arma para o meu peito, eu levantei a mão e pedi para falar antes de morrer. Tirei um Novo Testamento católico do bolso e li o versículo 16 do capítulo 3 do Evangelho de João [...] e comecei a explicar a passagem lida. Todos me ouviram, silenciosamente, falar do amor de Deus durante meia hora. Enquanto eu falava, alguns guardaram suas armas e outros ficaram com lágrimas nos olhos. Quando terminei, muitos compraram Bíblias $[\ldots]^{967}$.

Não só por tais relatos, mas também pelo trabalho que realizou, Tucker pode ser considerado um herói na difusão da Bíblia pelo Brasil. Destaca-se, ainda, o fato de que a causa da Bíblia não era sua única motivação. Em suas viagens, ele

\footnotetext{
961 GIRALDI, Luiz Antonio. A Bíblia no Brasil República, p. 97.

962 Ibid., pp. 246-247.

963 Ibid., p. 96.

964 TUCKER, Hugh Clarence. The Bible in Brazil, p. 5.

965 GIRALDI, Luiz Antonio. Semeadores da Palavra, p. 134.

966 TUCKER, Hugh Clarence. Reminiscências - 50 anos no Brasil. Rio de Janeiro: Colégio Bennet, 1933. Livro não publicado, p. 54.

${ }^{967}$ Ibid., p. 54.
} 
percebeu a realidade social em que o Brasil se encontrava. E muito daquilo que ele viu, o incomodou significativamente:

A atenção nos foi chamada devido às lamentáveis condições sociais, o analfabetismo do povo, o fanatismo a ser encontrado, a escassez de dinheiro em muitos lugares, a falta de instalações de transporte, ocasionando viagens longas, difíceis e dispendiosas, as más condições higiênicas e de saúde em um país tropical vasto e subdesenvolvido e a falta de uma versão adequada das Escrituras na língua portugue$\mathrm{sa}^{968}$.

Nesse sentido, Tucker não se limitou à simples constatação crítica; pelo contrário, ele agiu. Giraldi ${ }^{969}$ destaca que Tucker, concomitante à difusão das Escrituras, trabalhou nas seguintes áreas sociais do país:

- Organizou a primeira Associação Cristã de Moços (ACM) no Brasil;

- Fundou, em 1906, o Instituto Central do Povo (ICP), centro social voltado para assistência médica e dentária aos moradores do Morro da Providência (primeira favela do Brasil, surgida em 1897), no Rio de Janeiro. Reily ainda destaca que, com o passar do tempo o ICP ofereceu aos mesmos moradores jardim de infância, parque infantil, escola primária, aulas de enfermagem, culinária, costura, datilografia, educação física e ensino religioso ${ }^{970}$;

- Cooperou, entre 1903 e 1907, com o governo brasileiro na erradicação da febre amarela no Brasil, intermediando o contato do Dr. Oswaldo Cruz e o médico norte-americano Dr. Walter Reed (que tinha erradicado a febre amarela em Cuba) ${ }^{971}$;

- Mobilizou pessoas e trabalhou intensamente na construção do primeiro playground (parque aberto para a recreação infantil) no Bra$\mathrm{sil}^{972}$, em 1911, depois de presenciar a morte de uma criança que foi atropelada enquanto brincava na rua;

- Mobilizou a classe política, econômica, diplomática, religiosa e o próprio povo numa campanha de combate à tuberculose em 1912 .

\footnotetext{
968 GIRALDI, Luiz Antonio. The Bible in Brazil, p. 11.

${ }^{969}$ Id. Semeadores da Palavra, pp. 129-154.

970 Cf. REILY, Duncan. A história documental do protestantismo no Brasil.

971 Cf. LÖWY, Ilana. Vírus, mosquitos e modernidade: a febre amarela no Brasil entre ciência e política. Rio de Janeiro: Editora Fiocruz, 2006, pp. 49-122

972 Cf. DYRESON, Mark; MANGAN, James Anthony.; PARK, Roberta (ed). Sport in the global society - Historical Perspectives: mapping an Empire of American Sport - Expansion, Assimilation, Adaptation and Resistance. Oxford; New York: Routledge, 2013, p. 194.
} 
Como é possível perceber, foi um trabalho que não somente lutava pelo acesso e conhecimento das Escrituras, mas, também, lutava pelos direitos sociais e pela dignidade humana entre o carente povo brasileiro. Para ter maior alcance em suas ações, Tucker manteve um bom relacionamento com a imprensa. Aliás, a imprensa exerceu um papel fundamental na propagação de suas campanhas de combate à tuberculose e na mobilização para se instalar um parque infantil no país. Tucker também fez com que a imprensa, antes retraída e, por vezes, contrária, se voltasse para a causa da Bíblia no Brasil. Em suas próprias palavras, ele ressalta: "o diário principal do Rio de Janeiro publicou três longos artigos que eu preparei sobre os seguintes tópicos: 'A Bíblia e a Educação Pública‘, 'A Bíblia e a Literatura', e "A Bíblia e Ideais Nacionais",973.

É obvio que tais relatos representam apenas parte de tudo o que Tucker fez. Entretanto, o que se ressalta é o fato de que Tucker mergulhou fundo em sua dedicação à difusão das Escrituras no Brasil. Nessa perspectiva, já no final de sua obra, ele conclui com certo entusiasmo que

Todo o movimento religioso no Brasil está sendo focado cada vez mais na Palavra escrita. As Sociedades Bíblicas estão fazendo uma obra de bem incalculável nesta linha. Elas estão preparando o caminho para um grande avivamento religioso e de despertamento através das linhas da doutrina bíblica e da verdade. De fato, como indicado acima, o despertar já está em processo de desenvolvimento ${ }^{974}$.

Sem dúvida, Tucker deixou um grande legado para as próximas gerações. O trabalho da Sociedade Bíblica do Brasil, criada anos depois de sua aposentadoria, é realizado na atualidade de forma semelhante ao trabalho que Tucker realizou ${ }^{975}$, principalmente pelo fato de ser uma missão holística diante das necessidades do povo brasileiro. Tucker, todavia, não olhava só para a realidade social. Para ele, todos deveriam receber uma Escritura. Desse modo, mesmo tendo o povo mais pobre como alvo principal de sua missão, Tucker deu uma Bíblia ao primeiro presidente eleito no Brasil, Prudente de Moraes, em 1894, e ao presidente americano Herbert Clark, quando, após sua eleição, em 1928, visitou o Brasil.

Tucker se aposentou em 1933, e no início da década de 1940, retornou ao seu país de origem, não sem antes ter recebido do governo brasileiro a Ordem Nacional do Cruzeiro do Sul, em "reconhecimento aos relevantes serviços

\footnotetext{
973 TUCKER, Hugh Clarence. The Bible in Brazil, p. 15.

${ }^{974}$ Ibid., pp. 24-25.

${ }^{975}$ No próximo capítulo esse assunto será apresentado.
} 
prestados ao país na área social”976. Em 1949, já com mais de 90 anos, Tucker voltou ao Brasil para ser homenageado pelo Instituto Central do Povo, pelo Colégio Bennet e pela recém-criada Sociedade Bíblica do Brasil, recebendo desta última o título de secretário emérito da organização devido à sua dedicação e ao seu pioneirismo na causa da Bíblia no Brasil.

\subsubsection{3 \\ Entre crises e conquistas: a atuação conjunta das Sociedades Bíblicas na difusão das Escrituras Sagradas no Brasil no início do século $X X$}

Como já percebido no decorrer desse estudo, o trabalho bíblico no Brasil foi desenvolvido pela dedicação de duas Sociedades Bíblicas: a Britânica e Estrangeira (SBBE, ou BFBS) e a Americana (SBA ou ABS). Na história, ainda que cada organização tivesse sua independência em relação à outra, o trabalho bíblico foi sempre de cooperação. Por alguns momentos, chegaram a ocorrer discussões sobre uma possível divisão do território brasileiro entre ambas. Mesmo que inicialmente tal possibilidade não tenha se concretizado, em todos os momentos o trabalho, ainda que separado em termos administrativos e operacionais, foi de apoio mútuo; afinal, ambas tinham a mesma missão, isto é, difundir as Escrituras Sagradas no Brasil.

Obviamente, quando ocorresse, a divisão territorial teria muito a contribuir com a causa da Bíblia. Os esforços não seriam duplicados em muitos lugares; a ausência não seria tão sentida em outros; o tempo de viagens e os gastos de deslocamentos seriam reduzidos. Todavia, "sempre foi muito difícil estabelecer essa divisão territorial, porque os Estados brasileiros eram muito diferentes em extensão, número de habitantes e poder aquisitivo" $" 977$.

Depois de décadas mantendo tal desejo, no início do século XX, os representantes da BFBS e da ABS, respectivamente, Franklin Uttley e Hugh C. Tucker, conseguiram estabelecer um plano aceitável para ambas as organizações e, assim, “o plano de divisão territorial passou a vigorar no mês de julho de 1903. As trans-

\footnotetext{
976 GIRALDI, Luiz Antonio. Semeadores da Palavra, p. 152.

${ }^{977}$ Id. A Bíblia no Brasil República, p. 177.
} 
ferências de colportores e de estoques de livros necessários para a efetivação do acordo foram feitas sem maiores dificuldades até o final daquele ano"978.

O passo seguinte, procurando a mesma eficiência integrada na difusão das Escrituras, foi a unificação das duas lojas das Sociedades Bíblicas em um só local. Para facilitar, cada Sociedade Bíblica também instalou seus respectivos escritórios e depósitos de Bíblias no mesmo local. Tal unidade "teve uma repercussão favorável junto à população evangélica" ${ }^{979}$. Além disso, os resultados financeiros e econômicos contribuíram de forma eficaz para o contínuo crescimento da causa da Bíblia no país. Esses aspectos constituíram, na verdade, os primeiros passos em direção a uma unidade ainda maior, que, aos poucos, começou a se consolidar.

Nesse trajeto, outro passo importante foi a aquisição de um imóvel específico para a causa bíblica; afinal, ter uma sede própria já tinha sido o desejo antigo de muitos dos agentes das Sociedades Bíblicas. Como a demanda de Escrituras e a intensidade do trabalho se ampliavam cada vez mais, ter um espaço próprio era um objetivo importante para que a causa da Bíblia tivesse uma continuidade segura e sustentável no Brasil. Tucker, nesse sentido, chegou a afirmar que por muito tempo "havia sonhado com um Edifício da Bíblia no Rio de Janeiro, [...] grande o suficiente para abrigar as duas Sociedades Bíblicas" ${ }^{980}$.

Em seus relatórios anuais à $\mathrm{ABS}$, Tucker insistia na ideia de que era necessário construir um Edifício da Bíblia, que pudesse dar maior suporte ao trabalho bíblico no Brasil. As respostas, no entanto, eram sempre negativas, frente à escassez de recursos. Sem desistir, Tucker buscou doações e conseguiu a quantia necessária para iniciar o projeto. Depois de muito trabalho, "o edifício foi construído com recursos provenientes de ofertas levantadas no país e nos EUA, e as obras duraram cerca de dois anos. No dia 16 de fevereiro de 1932, o primeiro Edifício da Bíblia no Brasil foi inaugurado festivamente" 981.

Tais conquistas não poderiam ter surgido em um momento tão oportuno como aquele. A igreja evangélica crescia paulatinamente no Brasil e, por conseguinte, a distribuição de Bíblias também aumentava. Entretanto, a integração do trabalho das duas Sociedades Bíblicas, iniciada em 1903 e ampliada aos poucos no decorrer dos anos, também foi estratégica devido aos momentos difíceis pelos

\footnotetext{
978 GIRALDI, Luiz Antonio. A Bíblia no Brasil República, p. 177.

979 Ibid., p. 178.

${ }^{980}$ Id. Semeadores da Palavra, pp. 149-150.

${ }^{981}$ Id. A Bíblia no Brasil República, p. 236.
} 
quais o Brasil e o mundo passaram por cerca de cinco décadas no início do século XX. O primeiro deles foi a Primeira Guerra Mundial, ocorrida entre 1914 e 1918, que trouxe sérias complicações para todo o mundo. Ainda que a causa da Bíblia tenha sido afetada, a guerra não limitou os esforços na difusão das Escrituras; pelo contrário, foi um momento de grande oportunidade. Steer, nesse sentido, enfatiza que a Sociedade Bíblica "trabalhou arduamente para transformar uma enorme emergência em uma grande oportunidade de se difundir a Boa-Nova de Deus" ${ }^{\text {"982. }}$.

Steer ainda acrescenta que se descobriu na época que os combatentes da Primeira Guerra falavam em torno de 50 línguas que, coincidentemente, já tinham as Escrituras (ou parte delas) publicadas. E assim, entre os dois blocos inimigos, as Sociedades Bíblicas nacionais (que estavam situadas tanto de um lado como do outro em relação aos grupos opostos que guerreavam) difundiram as Escrituras entre soldados e prisioneiros de guerra, ou feridos em batalha, sob a missão de levar a eles uma palavra de esperança em meio ao conflito. Steer lembra que a ação bíblica foi realizada com frentes de trabalho nos lugares mais remotos da Europa, com o apoio da Cruz Vermelha e da Associação Cristã de Moços. E assim, mesmo sob dificuldades e desafios, por meio do esforço conjunto de católicos e protestantes, colportores e cristãos voluntários, mais de 5 milhões de exemplares das Escrituras foram distribuídos em aproximadamente 50 línguas diferentes durante a Primeira Guerra.

Ainda que a participação bélica brasileira tenha sido acanhada, Giraldi lembra que "antes de partirem para a guerra, os marinheiros brasileiros receberam das mãos do secretário da Sociedade Bíblica Americana um exemplar do Novo Testamento"983. Por outro lado, é importante lembrar que a causa da Bíblia no Brasil dependia do apoio de duas Sociedades Bíblicas cujos países se envolveram de forma significativa na guerra. Naquela época, os apoios financeiros, bem como as próprias Bíblias, eram enviados diretamente dos EUA e da Inglaterra para o Brasil. Como não poderia deixar de ser, a difusão das Escrituras foi prejudicada entre 1914 e 1918 no Brasil, tornando-se muito dificil enviar recursos — que se tornaram escassos - e remessas de Bíblias de qualquer país para o Brasil. Como consequência, o trabalho bíblico mundial foi reduzido, fazendo com que a distribui-

\footnotetext{
982 STEER, Roger. Good News for the World, 200 years of making the Bible heard, p. 316

${ }^{983}$ GIRALDI, Luiz Antonio. A Bíblia no Brasil República, p. 189.
} 
ção caísse a cerca de um terço das quantidades registradas no período anterior à guerra $^{984}$.

Como se percebe, o momento era cada vez mais complicado. Para que a causa da Bíblia continuasse a existir no Brasil se fazia necessário que decisões administrativas e operacionais fossem pensadas e praticadas de forma estratégica. Deste modo, o secretário da BFBS no Brasil entre 1917 e 1936, o Reverendo Alexander Telford, continuou ampliando e promovendo "vários projetos de cooperação com a agência da Sociedade Bíblica Americana, entre os quais a publicação conjunta de Escrituras, que reduziu o custo dos livros para as duas sociedades"985.

Tal iniciativa integrou ainda mais o trabalho de ambas as Sociedades e foi uma forma adequada de enfrentar a crise econômica que assolou os EUA e o mundo inteiro (o Brasil também) entre as décadas de 1920 e 1930. Deste modo, além da redução de custos, não houve mais duplicidade na produção e na publicação de Bíblias em língua portuguesa. Progressivamente, portanto, as Sociedades passaram a trabalhar cada vez mais juntas. Especificamente deste ponto em diante, além de toda a integração já descrita anteriormente, elas passaram a trabalhar com uma única edição/impressão da Bíblia nas traduções disponíveis daquele momento: Figueiredo, Almeida e a Tradução Brasileira.

Tais decisões foram estratégicas para a continuidade da causa da Bíblia no Brasil nos anos seguintes. Afinal, como bem lembra Giraldi, no contexto mundial, "a década de 1930 começou com a Grande Depressão Econômica e terminou com a Segunda Guerra Mundial"986. Concomitantemente, no Brasil, o período foi marcado por inconstância, violência e muitas incertezas políticas, sociais e econômicas frente à Revolução de 1930 liderada por Getúlio Vargas.

Historicamente, inclusive, esse momento se caracterizou como o período da Segunda República no Brasil ${ }^{987}$. Nessa perspectiva, é importante lembrar que as primeiras décadas pós-República foram marcadas pela exaltação à nação republicana. Já na década de 1930, o nacionalismo de Getúlio Vargas aguçou ainda mais os sentimentos patrióticos. Tais perspectivas históricas vieram a instigar e a contribuir com o processo de nacionalização das igrejas protestantes históricas no

\footnotetext{
${ }^{984}$ GIRALDI, Luiz Antonio. A Bíblia no Brasil República, p. 189.

985 Ibid., p. 216.

986 Ibid., p. 253.

987 Cf. BONAVIDES, Paulo; AMARAL, Roberto. Textos políticos da História do Brasil. Vol. 5. Brasília: Senado Federal, 2002, p. 19.
} 
país. Nesse sentido, Léonard, ao descrever este momento histórico do protestantismo brasileiro, lembra que "num Brasil autônomo mesmo em relação às lembranças que o ligavam à mãe-pátria portuguesa, também o protestantismo quisesse libertar-se das igrejas-mães" ${ }^{988}$, todas elas situadas nos EUA, Inglaterra e Alemanha.

Concomitantemente, esse período também ficou marcado pelo fortalecimento do movimento pentecostal no Brasil que havia surgido entre a primeira e a segunda década do século XX, com a implantação da Congregação Cristã no Brasil (1910) e da Igreja Evangélica Assembleia de Deus (1911) no país. Como se percebe, se por um lado o contexto era conflituoso nos aspectos sociais, econômicos, políticos e religiosos; por outro, o movimento pentecostal mudaria a história e o futuro da difusão das Escrituras no Brasil. O crescimento proporcionado por estas igrejas, que rapidamente se espalharam pelo Brasil nas primeiras três ou quatro décadas do século XX, evidenciavam que a difusão da Bíblia se fortaleceria e se propagaria ainda com mais força, levada à frente pelos cristãos pentecostais brasileiros.

É lógico que tais desafios e tais oportunidades no campo eclesilógico não superaram a grande crise que surgiu no mundo naquele período. Já no final da década de 1930, mais precisamente entre 1939 e 1945, teve início a Segunda Guerra Mundial, fenômeno este que trouxe sérias complicações para a humanidade e que mudou o mundo para sempre. Como se sabe, a participação brasileira foi relativamente pequena nos combates. Entretanto, o efeito para a causa da Bíblia no mundo e no Brasil, mais uma vez, foi enorme e desafiador.

Giraldi e Steer ${ }^{989}$, em uma síntese histórica, destacam que desde o início da guerra, as Sociedades Bíblicas se mobilizaram para atuar na distribuição de Escrituras entre os diversos envolvidos na batalha. Ainda em 1939, mais de um milhão de Novos Testamentos foram produzidos pela BFBS, com o apoio financeiro do Arcebispo de Cantuária, líder espiritual da Igreja Anglicana, que também criou um fundo específico em busca de recursos para este fim. O rei da Inglaterra, George VI, também expressou seu apoio ao enviar uma mensagem impressa no iní-

\footnotetext{
${ }^{988}$ LÉONARD, Émile-Guillaume. O protestantismo brasileiro, p. 146.

989 Cf. GIRALDI, Luiz Antonio. A Bíblia no Brasil República, pp. 187-198; 269-285.; STEER, Roger. Good News for the World, 200 years of making the Bible heard, pp. 316-321; 354-365.
} 
cio de cada um dos Novos Testamentos, em que convidava a todos que recebessem o NT com apego à fé e com base na Bíblia.

Giraldi ainda lembra que homens da polícia secreta do Estado visitaram o depósito de Bíblias da BFBS na Áustria com a seguinte ordem: "todo o trabalho da Sociedade Bíblica Britânica e Estrangeira está proibido em todo território nazista" ${ }^{990}$. As Bíblias foram confiscadas e destruídas. Depois de um tempo, a única maneira de conseguir difundir a Bíblia durante a guerra nos países nazistas se deu com o apoio e o trabalho de representantes da Sociedade Bíblica da Suíça, país este que não havia tomado partido na guerra, e, mais uma vez, de organizações como a Cruz Vermelha e a Associação Cristã de Moços.

No Brasil, obviamente, as consequências foram sentidas. Giraldi lembra que faltaram papel para a impressão de Bíblias e de materiais para a sua encadernação em toda a Europa. Ainda que algumas fossem produzidas, o custo se tornou elevadíssimo. Tais realidades constituíram um desafio para o trabalho das Sociedades Bíblicas no país.

Porém, o maior problema enfrentado por elas durante a Guerra foi o transporte das Bíblias dos Centros de Produção no Estados Unidos e na Inglaterra para os países onde seriam distribuídas. Muitos navios da Marinha Mercante Brasileira que transportavam Bíblias dos Estados Unidos e da Europa para o Brasil foram bombaredeados e afundados durante a $2^{\mathrm{a}}$ Guerra Mundial. Esses sérios obstáculos enfrentados pela SBA e pela SBBE tornaram impossível o suprimento regular de Bíblias no Brasil durante a Guerra ${ }^{991}$.

O lado positivo nesse contexto, se assim se pode definir, foi a mobilização nacional que instigou muitas igrejas no Brasil em busca de uma solução. Foi nessa época, por exemplo, que surgiu a Imprensa Bíblica Brasileira, uma organização batista criada em 1940 para produzir Bíblias no país. Como bem lembra Malzoni ${ }^{992}$, no lado católico, iniciativas também surgiram a partir de encíclicas papais favoráveis à leitura bíblica pelos fiéis. Como exemplo, em 1947, aconteceu a primeira Semana Bíblica Nacional, com a presença de vários biblistas católicos. Tal encontro resultou em decisões que valorizavam a difusão da Bíblia entre os católicos brasileiros, por meio do incentivo à leitura, do incentivo às traduções vernáculas e do incentivo à realização de comemorações em torno das Escrituras. No

\footnotetext{
${ }^{990}$ GIRALDI, Luiz Antonio. A Bíblia no Brasil República, p. 273.

${ }^{991}$ Id. História da Bíblia no Brasil. Barueri: Sociedade Bíblica do Brasil, 2013, p. 94.

${ }^{992}$ Cf. MALZONI, Cláudio Vianney. As edições da Bíblia no Brasil, pp. 126-128.
} 
mesmo encontro foi criada a Liga de Estudos Bíblicos, que, entre outros, tinha por objetivo promover o conhecimento popular da Bíblia entre os católicos brasileiros.

Para complementar tal período de dificuldades, ainda no contexto da guerra, vale ressaltar que muitas Sociedades Bíblicas foram destruídas durante os conflitos; assim, em vez de se investir no Brasil, entre outros países que também dependiam do apoio estrangeiro, as Sociedades Bíblicas optaram por investir seus recursos na reconstrução de suas próprias sedes, localizadas nas diversas cidades da Europa que foram atingidas e destruídas durante o conflito.

A saída encontrada para tentar resolver a situação foi idealizada pelo agente da ABS no Brasil, Reverendo Charles William Turner, que, em 1943, quase no final da guerra, solicitou "as placas tipográficas do Novo Testamento com Salmos,

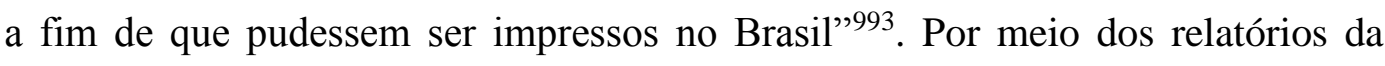
ABS, soube-se que 25 mil Novos Testamentos foram impressos. Para além da necessidade das Escrituras em português, foi publicada uma edição especial das Escrituras para ser entregue aos soldados americanos, os quais, em trânsito, passavam pelos portos do Brasil no Norte, no Nordeste e no Rio de Janeiro.

Como foi possível perceber, todos estes pressupostos históricos foram, progressivamente, culminando em alguns aspectos significativos: havia uma procura cada vez maior por Bíblias no Brasil; as igrejas evangélicas cresciam pouco a pouco a cada ano, principalmente pelo surgimento e crescimento de movimentos pentecostais que tinham chegado ao país entre 1909 e 1910; as dificuldades de importação, diante dos conflitos internos e externos ao Brasil, eram cada vez maiores; as crises econômica e política do período redundaram em sérias dificuldades, tanto para o trabalho das Sociedades Bíblicas no mundo quanto no Brasil. Dessa forma, considerando que o trabalho de ambas as Sociedades Bíblicas já estavam bem interligadas, “em janeiro de 1942, as agências da SBBE e da SBA decidiram se unir no Brasil para formar as Sociedades Bíblicas Unidas"994. Em uma celebração histórica, realizada no templo da Primeira Igreja Batista do Rio de Janeiro, a unificação foi anunciada aos brasileiros.

O fato que se destaca nessa integração é que ela não foi importante somente para o trabalho bíblico no Brasil. Desde 1932 constatava-se que em alguns países, como Chile, Uruguai, China, Japão, entre outros, a administração e o trabalho de

\footnotetext{
${ }_{993}$ GIRALDI, Luiz Antonio. A Bíblia no Brasil República, p. 275.

${ }^{994}$ Ibid., p. 276.
} 
ambas as Sociedades Bíblicas também tinham se unificado. Nesse sentido, o Brasil fazia parte de um movimento que estava acontecendo também em outras partes do mundo. E a experiência positiva dessa integração, principalmente como a ocorrida no Brasil, resultou em uma conferência histórica realizada em Elfinsward, na Inglaterra, no ano de 1946, portanto quatro anos após a fusão no Brasil, onde foi definitivamente criada a aliança mundial das Sociedades Bíblicas Unidas ${ }^{995}$. Diante de um marco histórico significativo em relação ao futuro do trabalho das Sociedades Bíblicas pelo mundo, o secretário-geral das BFBS naquela conferência proferiu as seguintes palavras:

Um dos principais objetivos desta conferência é nos conhecermos melhor, para podermos enfrentar o futuro juntos, como amigos. O Livro que é a nossa ligação e que é o nosso privilégio distribuir é o Livro de Deus. É o bem inestimável dos filhos de Deus, em todos os lugares. Embora as igrejas possuam diferentes hinários e livros de oração, teologias e liturgias diferentes, graças a Deus nós temos apenas um Livro: a Bíblia, que é o elo que nos une ${ }^{996}$.

Como se percebe, esse encontro foi especial porque aconteceu justamente no período posterior à guerra. Foi um momento de renovação de amizade e de fortalecimento mútuo para que a causa da Bíblia continuasse a avançar no mundo. No Brasil, as Sociedades Bíblicas Unidas continuaram a atuar de forma unificada de 1942 até 1948.

Considerando que o primeiro edifício da Bíblia construído no Rio de Janeiro era, naquele tempo, um pouco maior do que se precisava, a SBA decidiu vende-lo "para construir dois menores, um no Rio de Janeiro e outro em Buenos Aires, na Argentina" $" 997$. Essa foi uma decisão importante que fortaleceu a causa da Bíblia em ambos os países. A construção do Edifício da Bíblia no Rio de Janeiro foi coordenada pelo Rev. Charles Willian Turner, que era o secretário executivo da SBA no Brasil naquele período. Até hoje esse prédio é utilizado como um Centro Cultural da Bíblia. Com o passar do tempo, especificamente em 1948, se constatou que era a hora de passar o trabalho de difusão das Escrituras no Brasil aos brasileiros, surgindo, então, a Sociedade Bíblica do Brasil, que servirá de análise desse estudo no próximo capítulo.

${ }^{995}$ Cf. HOLMGREN. Laton E. Sociedades Bíblicas. Dicionário Enciclopédico da Bíblia, pp. 1271-1272; STEER, Roger. Good News for the World, 200 years of making the Bible heard: the story of Bible Society, p. 368.

${ }^{996}$ GIRALDI, Luiz Antonio. A Bíblia no Brasil República, pp. 321-322.

${ }^{997}$ Id. História da Bíblia no Brasil, p. 96. 


\section{4 \\ A atuação dos colportores das Sociedades Bíblicas na difusão das Escrituras Sagradas no Brasil}

$\mathrm{Na}$ caminhada histórica realizada até aqui, ficou evidente que a Bíblia chegou ao Brasil bem antes da vinda de qualquer missionário protestante enviado para implantar igrejas no país. Como já dito, este é um fato importante, que não deve ser ignorado na história do protestantismo no Brasil. Inicialmente, portanto, as Escrituras Sagradas foram enviadas pelas Sociedades Bíblicas para atender aos imigrantes ingleses e alemães que chegaram ao Brasil. Em um segundo momento, a Bíblia chegou por intermédio de voluntários que, majoritariamente cristãos protestantes, passavam pelos portos do Brasil e aproveitam para distribuir Bíblias ao povo. Pouco tempo depois, o trabalho de difusão das Escrituras se ampliou e começou a ser realizado de forma mais sistemática com a chegada dos primeiros representantes das Sociedades Bíblicas ao país. A maioria deles era de missionários enviados por suas denominações — metodistas e presbiterianos ${ }^{998}$ inicialmente —mas, mesmo assim, ainda antes da implantação de suas igrejas, eles trabalharam arduamente na difusão das Escrituras.

Seria praticamente impossível que a difusão das Escrituras fosse realizada de forma tão eficaz, como ocorreu no Brasil, somente pelo trabalho de um ou outro missionário, agente ou voluntário. É justamente nessa perspectiva que a história aponta para a participação dos colportores na causa da Bíblia no Brasil, instigados e enviados, obviamente, pelas Sociedades Bíblicas. Aliás, como bem lembra Steer, "as histórias de suas façanhas em todo o mundo trazem um toque de heroísmo e aventura para a história da Sociedade Bíblica"999.

Segundo o mesmo autor, o primeiro registro de um colportor na história das Sociedades Bíblicas ocorreu na França, em 1830, quando algumas pessoas foram enviadas para vender Bíblias de casa em casa, sendo, justamente a partir deste aspecto histórico que a palavra foi concebida no movimento das Sociedades Bíblicas. Para melhor entender o sentido etimológico de "colportor", vale apreender o que diz Erní W. Seibert, no prefácio de uma obra de Giraldi. Segundo Seibert, "a

\footnotetext{
998 Ainda que Kalley tenha fundando o congregacionalismo no Brasil, em sua chegada ao país, ele ainda era de linha presbiteriana. Por outro lado, ainda que os metodistas tenham enviado missionários antes de qualquer outra denominação, uma Igreja Metodista foi oficialmente estabelecida após os congregacionais e os presbiterianos.

999 STEER, Roger. Good News for the World, 200 years of making the Bible heard, p. 307 (tradução nossa).
} 
palavra colportor por muitos anos não estava dicionarizada no Brasil e era usada ligada à obra bíblica. Esta palavra de origem francesa faz referência à bolsa de livros que o distribuidor ambulante de Bíblias levava pendurada no pescoço"1000. O colportor era, portanto, aquele que distribuía Bíblias, de casa em casa, de mãos em mãos, de forma semelhante ao que fazia um vendedor ambulante com qualquer outro produto. E é por isso que

O sistema de colportagem mostrou-se tão eficaz que a Sociedade [BFBS] e suas auxiliares no exterior o adaptaram rapidamente, primeiro às necessidades de todos os países da Europa e, posteriormente, a quase todos os países do mundo. No final do século XIX, a Sociedade em Londres empregava diretamente mais de 900 colportores e mais algumas centenas trabalhavam para igrejas locais e agências missionárias em todo o mundo ${ }^{1001}$.

Seguindo o modelo do que ocorria no mundo, no Brasil, desde o século XIX, os colportores exerceram um trabalho que marcou e mudou a história da Bíblia (e do protestantismo) no país. Eles foram pioneiros e desbravadores, e entraram pelo interior do país ou pelos centros urbanos enfrentando toda sorte de perigo e desafios possíveis. Muitas vezes sem transporte, comunicação, recursos e condições adequadas, viajando no lombo de mulas, em carroças ou canoas, às vezes sozinhos e bem distantes de seus familiares, eles dedicaram parte significativa de sua vida "tanto por amar o Livro quanto por desejar que outras pessoas [...] o amassem também"1002.

Em muitos casos, as Bíblias eram vendidas; porém, quando não se tinha dinheiro, eles trocavam Bíblias por outros bens, principalmente alimentos, que eram consumidos em suas longas viagens. Caso a compra ou a troca não fosse possível, na maioria das vezes, eles doavam as Escrituras. A missão de difundir as Escrituras era a essência que os movia ao trabalho, afinal, "eles não saíam em busca de lucro; queriam somente cumprir a missão" ${ }^{1003}$.

Por assim ser, eles foram verdadeiros evangelistas, designação esta comprovada pelos vários relatos históricos de que quando os missionários chegaram a certos lugares do interior do Brasil para plantar igrejas, ali já havia uma comunidade reunida em torno das Escrituras, sem pastor, sem missionário; só um povo

\footnotetext{
${ }^{1000}$ GIRALDI, Luiz Antonio. Semeadores da Palavra, p. 9.

1001 STEER, Roger. Good News for the World, 200 years of making the Bible heard, p. 307 (tradução nossa). ${ }^{1002}$ Ibid.

${ }^{1003}$ MILLER, Stephen; HUBER, Robert. A Bíblia e sua história: o surgimento e o impacto da Bíblia, p. 202.
} 
com a Bíblia ${ }^{1004}$. De fato, “os colportores, em comboio de mulas, levavam centenas de Bíblias a comunidades onde nenhum pastor ordenado ou missionário havia chegado, fazendo com que surgissem comunidades de leitores da Bíblia onde jamais se ouvira falar em igrejas"1005. Eles foram verdadeiros heróis anônimos; a maioria, inclusive, sem preparo acadêmico ou qualquer status social relevante, e "se hoje o Brasil é uma das nações que mais distribuem as Escrituras no mundo, é a eles que devemos"1006 tal feito.

Diferentemente dos missionários, que eram estrangeiros, "os colportores eram quase sempre nacionais nos países em que trabalhavam"1007. A remuneração pelo trabalho, aliás, era pequena; e dava para, sob muito esforço, somente alimentar a família. Considerando o tamanho continental do Brasil, a maioria dos colportores trabalhava em suas próprias regiões. É claro que esse não era um fato limitador; pelo contrário, os relatos evidenciam que sozinhos, em companhia de outros colportores ou acompanhados pelos missionários, eles viajavam por meses a fio — em alguns relatos, até mais de um ano - , pelo país inteiro propagando as Escrituras. Matos, nesse sentido, acrescenta que os colportores "foram companheiros e, com frequência, precursores dos missionários e dos pastores nacionais" ${ }^{1008}$.

Aliás, os primeiros pastores congregacionais e presbiterianos no Brasil foram colportores; e a maioria dos primeiros membros convertidos nestas igrejas também pode ser incluída nesta categoria. Era, portanto, um trabalho de colaboração, que resultou em muitos frutos na difusão das Escrituras e na implantação de diversas igrejas pelo país. Entre os missionários que vieram ao Brasil para fundar suas respectivas denominações, e que, concomitantemente, se destacaram no trabalho da difusão bíblica realizado pelas Sociedades Bíblicas através da colportagem, estão o Reverendo Simonton (presbiteriano) e o Reverendo Kalley (congregacional). Em sua síntese, Boanerges Ribeiro historiou algumas das dificuldades mais comuns enfrentadas pelos colportores, ainda no período imperial:

Em 1864 o delegado expulsava um colportor de Santo Amaro, Bahia, depois de apreender seus livros. Em 1867 um delegado negava licença para vender Bíblias

\footnotetext{
${ }^{1004}$ Cf. HAHN, Carl Joseph. História do culto protestante no Brasil, p. 292.

1005 Ibid., p. 24.

1006 GIRALDI, Luiz Antonio. Semeadores da Palavra, p. 11.

1007 STEER, Roger. Good News for the World, 200 years of making the Bible heard, p. 309 (tradução nossa).

1008 MATOS, Alderi de Souza. Colportores: heróis esquecidos da obra missionária no Brasil. Servos Ordenados, out.-dez. 2005, p. 29.
} 
em Sergipe. Em 1869, em Santos, um delegado expulsava o colportor da cidade, obstando a que retirasse um caixote de Bíblias da alfândega. Em 1871, em Olinda, o Vigário Capitular apreendia as Bíblias de um colportor previamente detido pelo delegado de polícia. Em 1873 em Guaratinguetá um colportor era ameaçado de espancamento, após violento sermão do padre contra suas Bíblias - e tinha de retirar-se [...]. Colportores sempre foram parte valiosíssima do staff missionário, nesses anos iniciais. Precediam os pregadores; sofriam os primeiros embates da oposição, e os enfrentavam. Abriam novas frentes evangelísticas. Homens rústicos, primários na instrução, dedicados e decididos, [...] abriram caminho, espalharam Bíblias, e deixaram atrás de si famílias prontas para aderir ao protestantismo ${ }^{1009}$.

Como se percebe, foram muitas situações desafiadoras, tanto no aspecto legal quanto no aspecto religioso. E havia pouca exceção, pois, em muitas regiões, os colportores sofreram algum tipo de perseguição, de proibição de realizar seu trabalho ou de denúncia, sob a acusação de vender Bíblias falsas. Em 1886, no Ceará, por exemplo, "impôs-se uma multa a quem vendesse Bíblias"1010. Em certas ocasiões, eles não tinham o que comer ou onde dormir. Alguns morreram enquanto exerciam seu trabalho, seja pela fadiga provocada pelos desgastes ou pela falta de recursos nas viagens. Em muitos casos, sofreram pela agressão física ou por assaltos ${ }^{1011}$.

Léonard lembra um caso específico em torno do frei Celestino de Padovali que, por volta de 1879 , se tornou célebre pela criação da "Liga contra os protestantes e suas fogueiras de "Bíblias falsas"”1012. Aliás, durante muito tempo, muitas Bíblias, consideradas falsas ou falsificadas, foram publicamente queimadas. A caracterização das Bíblias como falsas pareceu ser uma estratégia para enfraquecer o próprio trabalho de difusão da Bíblia, bem como impedir o avanço do protestantismo. Tal tese é confirmada pelo historiador Alisson Pereira Silva, entre outros autores, quando discorre sobre algumas notícias publicadas pela imprensa secular de Pernambuco em relação aos protestantes e suas Bíblias no final do século XIX ${ }^{1013}$.

\footnotetext{
1009 RIBEIRO, Boanerges. Protestantismo e cultura brasileira: aspectos culturais da implantação do protestantismo no Brasil. São Paulo: Casa Editora Presbiteriana, 1981, pp. 151-153.

1010 DREHER, Martin Norberto. Protestantes na América Meridional. In: SIEPIERSKI, Paulo Donizéti; GIL, Benedito (orgs). Religião no Brasil, p. 56.

${ }^{1011}$ Cf. HAHN, Carl Joseph. História do culto protestante no Brasil, p. 283.

${ }^{1012}$ LÉONARD, Émile-Guillaume. O protestantismo brasileiro, p. 125.

${ }^{1013}$ Cf. SILVA, Alisson Pereira. Nas tessituras do Império do Brasil: o protestantismo sob o olhar da imprensa periódica secular (1860-1870). 2015. Dissertação (Mestrado em História). Universidade Federal de Campina Grande, Campina Grande, 2015, pp. 48-85.
} 
Como bem lembram Mendonça ${ }^{1014}$ e Giraldi, em alguns lugares, ao contrário de oposição e perseguição, quer seja do clero, quer seja da população ou de alguma autoridade, os colportores foram bem-recebidos, principalmente por aqueles que ansiavam por conhecer as Escrituras ou até mesmo por aqueles que não sabiam sobre a sua existência, tornando a Bíblia, assim, uma novidade que "despertou a curiosidade e o interesse do povo"1015. Mas não só o povo; Kidder também relatou alguns casos em que teve o apoio e o incentivo por parte dos sacerdotes católicos ${ }^{1016}$ em sua missão com a Bíblia pelo Brasil.

Para aqueles colportores que não tiveram tal apoio ou facilidade em seus respectivos trabalhos, algo bem comum era a prisão. A maioria das vezes, é claro sob o pretexto de acusações infundadas, conforme relatam alguns historiadores que discorrem sobre essa época ${ }^{1017}$. Porém, ainda que ficassem presos ou sofressem retaliações, na maioria dos casos, os colportores foram liberados. Um exemplo significativo nesse sentido é o que ocorreu com o colportor Torquato Martins Cardoso, que, em 1868, após ter sido preso em Sergipe por estar vendendo livros protestantes e Bíblias falsificadas ${ }^{1018}$, em uma decisão histórica, teve a sua liberdade autorizada por D. Pedro II. E, além de soltá-lo, o imperador o autorizou a continuar seu trabalho. Segundo Giraldi, “essa resolução do Imperador resultou na legalização da profissão de colportor no país e acabou impulsionando a distribuição da Bíblia no Brasil Império"1019.

Ainda que D. Pedro II tenha legalizado a profissão e que, com o fim do Império e a consequente Proclamação da República, a liberdade religiosa tenha concedido direitos iguais para todas as pessoas em relação às suas crenças e expressões de fé, os colportores entraram no período republicano sob as mesmas condições, conforme consta em um relatório enviado pelo Reverendo Gonçalves à BFBS, em 1897:

\footnotetext{
${ }^{1014}$ Cf. MENDONÇA, Antônio Gouvêa. O celeste porvir, pp. 43-44.

${ }^{1015}$ GIRALDI, Luiz Antonio. A Bíblia no Brasil Império, p. 127.

${ }^{1016}$ Cf. KIDDER, Daniel Parish. Reminiscências de viagens e permanências no Brasil, pp. 262263.

${ }^{1017}$ Cf. HAHN, Carl Joseph. História do culto protestante no Brasil, passim; LÉONARD, ÉmileGuillaume. O protestantismo brasileiro, passim; VIEIRA, David Gueiros. O protestantismo, a maçonaria e a questão religiosa no Brasil: Brasília: Universidade de Brasília, 1980, passim.

${ }^{1018}$ Cf. VIEIRA, David Gueiros. O protestantismo, a maçonaria e a questão religiosa no Brasil, p. 223.

${ }^{1019}$ Cf. GIRALDI, Luiz Antonio. Op. cit., p. 186.
} 
Nossos colportores continuam a ser perseguidos no Brasil. [...] As autoridades do interior nada fazem para defender nossos colportores. Nessas regiões elas são submissas às autoridades católicas. Nós temos agora boas leis no Brasil, que garantem a liberdade religiosa e proíbem perseguições aos colportores, mas a lei é letra morta em muitos lugares ${ }^{1020}$.

Ainda assim, o trabalho dos colportores continuou a ser realizado por diversas pessoas que, abrindo mão de sua vida, se entregaram ao trabalho de difusão das Escrituras, deixando, assim, um grande legado na história da Igreja e da Bíblia no Brasil. Para concluir essa seção, vale a pena descrever o relato do colportor João da Cruz, que, em 1927, registrou as principais experiências vivenciadas enquanto distribuía as Escrituras pelo Rio de Janeiro:

[...] Até 5 de julho, visitei sete vilas e povoados. Viajei 1.470 quilômetros, 66 a pé e 1.404 quilômetros de trem e a cavalo. Visitei 841 casas, falei com 8.535 pessoas e vendi 51 Bíblias, 149 Novos Testamentos e 1.456 evangelhos. Doei 148 Evangelhos a presos e pessoas pobres, distribuindo ao todo 1.784 Escrituras nos últimos 31 dias. Por tudo isso, agradeço a Deus, através do Nosso Senhor Jesus Cristo ${ }^{1021}$.

Esta é apenas uma das histórias possíveis aqui relatadas; existem várias outras nas obras de Kidder, Giraldi, Léonard, Hahn e Vieira. Sem dúvidas, portanto, os colportores constituíram parte fundamental da difusão das Escrituras no Brasil. Eles lançaram a semente e, atualmente, a causa da Bíblia no Brasil, colhe seus relevantes frutos. É obvio que não seria possível, nesse estudo, descrever todas as experiências que os mais diferentes colportores tiveram em seu trabalho bíblico no Brasil. Eles foram muitos, trabalhando em muitos lugares e por muitos anos ${ }^{1022}$. Nesse estudo, só foi possível discorrer sobre alguns poucos relatos, devido ao fato de eles estarem relacionados com a temática proposta.

Vale lembrar que os colportores nunca pararam de realizar sua missão. Desde o século XIX, até os dias de hoje, o trabalho de colportagem, ainda que sob uma nova configuração, é realizado por inúmeros voluntários e apoiadores da causa da Bíblia no Brasil por meio do Programa Semeador, da Sociedade Bíblica no Brasil. Esse trabalho será melhor compreendido no próximo capítulo, que tratará especificiamente sobre a atuação da Sociedade Bíblica do Brasil.

\footnotetext{
${ }^{1020}$ GIRALDI, Luiz Antonio. A Bíblia no Brasil República, p. 83.

1021 Ibid., p. 92.

1022 Para melhor aprofundamento sobre como os colportores atuaram na história, recomenda-se a obra Semeadores da Palavra: personagens que tiveram participação decisiva na divulgação da Bíblia no Brasil, de Luiz Antonio Giraldi (Cf. Referências Bíbliográficas na seção 7 desta tese). $\mathrm{Na}$ referida obra existem muitos relatos e experiências sobre o fato.
} 


\section{5 \\ A história e a atuação da Sociedade Bíblica do Brasil na difusão das Escrituras Sagradas}

A Bíblia, Palavra de Deus na história do Brasil; esse é um dos pressupostos basilares para a compreensão deste capítulo. Entre outras, tal afirmativa se fundamenta na mais recente pesquisa do Ibope encomendada pelo Instituto Pró-Livro, publicada em 2016, que procurou analisar os hábitos de leitura da população brasileira. De acordo com a quarta edição da pesquisa, intitulada Retratos da Leitura no Brasil"1023, a Bíblia está em primeiro lugar na lista dos "livros mais marcantes" e dos "últimos livros mais lidos" pelos brasileiros. De fato, $42 \%$ da população brasileira respondeu que a Bíblia Sagrada é o livro de preferência em suas leituras.

Há quem pense que a pesquisa, pelo fato de ter evidenciado a Bíblia como o livro preferido do brasileiro, pode caracterizar um tipo de leitor totalmente religioso. Ledo engano! Entre os mais de cinco mil participantes da pesquisa, das mais variadas idades, abarcando homens, mulheres e crianças, localizados em todas as regiões do país, com escolaridade entre "não alfabetizado" até aqueles com "ensino superior", constatou-se que o motivo religioso estava apenas na quinta posição entre os principais fatores que motivam os brasileiros a ler um livro (apenas $11 \%$ dos entrevistados). As duas principais razões que determinam a razão da busca por um livro, respondidas pelos participantes, foram, simplesmente, o gosto pela leitura (25\% dos entrevistados) atrelado à busca pelo conhecimento ou pela atualização cultural (19\% dos entrevistados) ${ }^{1024}$.

Confirmando tais fatos, a reportagem intitulada "Sagrada e popular", publicada pela repórter Raquel Carneiro, na Revista Veja, destaca que somente no ano de 2016 pelo menos 9 milhões de novas Bíblias circularam no país ${ }^{1025}$. Há ainda o destaque: entre as 9 milhões de Bíblias no Brasil, cerca de 6,7 milhões foram distribuídas pela Sociedade Bíblica do Brasil. Tais números reiteram, portanto, a

\footnotetext{
${ }^{1023}$ FAILLA, Zoara (Org.). Retratos da leitura no Brasil 4. Rio de Janeiro: Sextante, 2016, pp. 31 $32 ; 134-135$.

${ }^{1024}$ Ibid, p. 32

${ }^{1025}$ CARNEIRO, Raquel. Sagrada e popular. Revista Veja. Edição 2538, ano 50, n. 28, 12 de julho de 2017, pp. 86-93.
} 
relevância do trabalho bíblico realizado pela SBB no país. Já na reportagem "O livro dos livros", de autoria do reconhecido filósofo ateu Leandro Karnal, no jornal $O$ Estado de São Paulo, ressaltou-se que a Bíblia

[...] é, de longe, o texto mais influente da história ocidental. A importância não depende de fé. As ideias, enredos, sistemas de pensamento e personagens do Antigo e do Novo Testamentos constituem embasamento amplo para quase tudo que emergiu nessa parte do globo nos últimos séculos [...]. O texto desta crônica estará superado em alguns dias e terá desaparecido em alguns anos. A Bíblia, com 25 séculos de debates, continua presente na mídia, na literatura, nos grupos de WhatsApp. É uma senhora ativa e forte, capaz de despertar paixões contraditórias. Não é possível entender o mundo sem ter lido a Bíblia"1026.

De fato, a Bíblia é o Livro dos livros. É por isso que, há aproximadamente cinquentas anos, ela alcançou o primeiro lugar no ranking dos livros mais traduzidos, mais lidos e mais distribuídos de todos os tempos, no mundo inteiro ${ }^{1027}$. Diante de tais fatos, reiterada a importância da Bíblia na história do Brasil, o objetivo deste capítulo é descrever, ainda que com as devidas limitações, como as Escrituras Sagradas foram difundidas no país a partir da criação da Sociedade Bíblica do Brasil (SBB), umas das organizações que realiza o trabalho de difusão das Escrituras no país.

A metodologia utilizada nos capítulos anteriores se deu por meio de uma narrativa histórica dos fatos. Nessa caminhada, constatou-se como as Escrituras foram difundidas, desde os primórdios da oralidade até os recentes trabalhos realizados pelas Sociedades Bíblicas (SBBE e SBA) no país até, aproximadamente, a década de 1940. O corte temporal foi necessário porque foi justamente no final desta década, depois de mais de aproximadamente 140 anos de atuação no Brasil, que ambas as Sociedades Bíblicas repassaram o trabalho bíblico aos brasileiros, surgindo, então, a Sociedade Bíblica do Brasil.

Há de se reiterar que este é o objeto principal desta pesquisa, isto é, importa saber como as Escrituras Sagradas foram difundidas na história do país, com ênfase especial no trabalho realizado pelas Sociedades Bíblicas no Brasil. Neste capítulo, porém, atrelado à descrição histórica dos fatos, faz-se necessário agregar um elemento metodológico diferenciado. Tal exceção metodológica fortalecerá a percepção dos fatos com melhor acuidade. Isto posto, especificamente a partir da

${ }^{1026}$ KARNAL, Leandro. O livro dos livros. O Estado de S. Paulo. São Paulo, 13 set. 2017, caderno 2, p. C8.

${ }^{1027}$ Cf. SCHOLZ, Vilson. A Bíblia: sua natureza, funções e finalidade. In: ZIMMER, Rudi (org.). Manual de Ciências Bíblicas, p. 8. 
segunda seção deste capítulo (5.2), as informações obtidas a partir da descrição histórico-teológica serão apreendidas de forma concomitante às categorias de análise ${ }^{1028}$ estabelecidas a partir do Ciclo de vida da Bíblia.

\section{1}

\section{A história de fundação da Sociedade Bíblica do Brasil}

Após a abertura dos portos às nações amigas, com a chegada da coroa real portuguesa ao Brasil, em 1808, e por aproximadamente 140 anos, o trabalho bíblico no Brasil foi desenvolvido por iniciativa e apoio da Sociedade Bíblica Americana (SBA) e da Sociedade Bíblica Britânica e Estrangeira (SBBE), ambas pertencentes ao movimento das Sociedades Bíblicas Unidas (SBU). No entanto, conforme já se destacou, já quase no final da primeira metade do século $\mathrm{XX}$, as necessidades de Bíblias no contexto brasileiro eram cada vez mais crescentes. Pelo que se constou, as Sociedades Bíblicas não estavam conseguindo atender tal demanda, nem no Brasil, nem fora dele.

No mesmo período, no Brasil, as igrejas estavam cada vez mais fortalecidas. As igrejas históricas estavam, em sua maioria, nacionalizadas e as igrejas pentecostais experimentavam um período de crescimento incipiente. Tais fatos evidenciavam que as igrejas brasileiras estavam aptas a cooperar, manter e, talvez, coordenar o trabalho de difusão das Escrituras no país. Vale ressaltar que essa não era uma iniciativa isolada no contexto brasileiro. As Sociedades Bíblicas Unidas já vinham discutindo há algum tempo sobre a importância de envolver as igrejas no trabalho bíblico realizado em suas respectivas regiões. Chegava, portanto, o momento de "promover a organização de Sociedades Bíblicas nacionais nos países onde o ambiente fosse favorável"1029. Por consequência,

O término da $2^{\text {a }}$ Guerra Mundial, o fim do Estado Novo, a retomada das liberdades democráticas e as esperanças de melhores dias criaram um ambiente propício para a propagação do Evangelho. A decisão das Sociedades Bíblicas de promover a organização de novas Sociedades Bíblicas, a organização das Sociedades Bíblicas Unidas e o clima propício no Brasil para a propagação do evangelho criaram, em 1948, condições favoráveis para a fundação da Sociedade Bíblica do Brasil ${ }^{1030}$.

${ }^{1028}$ CF. JANIS, Irving Lester. O problema da validação da análise de conteúdo. In: LASSWELL, Harold; KAPLAN, Abraham. A linguagem da política, p. 53.

${ }^{1029}$ GIRALDI, Luiz Antonio. História da Bíblia no Brasil, p. 99.

${ }^{1030}$ Ibid., pp. 99-100. 
De fato, é nesse momento histórico peculiar que, com o apoio da SBA e da SBBE, foi fundada em 1948 a Sociedade Bíblica do Brasil (SBB). Esse momento de fundação é marcado pela participação da maioria das igrejas cristãs da época, que se conscientizaram da importância de assumir o trabalho bíblico em seu próprio país. A eleição da diretoria voluntária da instituição, formada por membros das igrejas Metodista, Presbiteriana, Batista, Congregacional, Presbiteriana Independente, Episcopal e Igreja Evangélica do Brasil evidencia o caráter e o intuito interconfessional da instituição. A SBB, desde a sua fundação e por toda a sua história, se caracterizou pelo trabalho bíblico conjunto e cooperativo com todas as igrejas possíveis. Boa parte desse trabalho é realizado até os dias de hoje por meio de voluntários das mais variadas igrejas.

De acordo com Giraldi ${ }^{1031}$, a cerimônia de fundação, que contou com a participação de mais de três mil pessoas, foi realizada no templo da $1^{a}$ Igreja Batista do Rio de Janeiro e foi transmitida para todo o território nacional, até onde foi possível chegar as ondas da Rádio Clube do Brasil. Além dos líderes eclesiásticos das principais igrejas existentes no país à época, entre os participantes da cerimônia, estavam também os representantes das Sociedades Bíblicas de alguns países, inclusive do Reino Unido (SBBE) e dos Estados Unidos (SBA).

No evento, os oradores que discursaram representaram as igrejas supracitadas (acrescidas do Exército da Salvação e da Igreja Evangélica Assembleia de Deus), as Sociedades Bíblicas Unidas e as Sociedades Bíblicas Americana e Britânica. O discurso de todos girou em torno do resgate histórico da difusão bíblica realizada pelas Sociedades Bíblicas no Brasil, evidenciando a importância de tal trabalho para o país. Era notório entre eles a percepção de que este trabalho não serviu de inspiração exclusiva às igrejas protestantes da época. A leitura conjectural daquelas pessoas era de que a igreja cristã, formada tanto por católicos como por protestantes, bem como outros setores da sociedade brasileira, foram influenciados e instigados para o trabalho na causa da Bíblia. A realidade constatada era de que a propagação das Escrituras no país tinha tomado uma proporção não imaginada e que, portanto, tais frutos redundariam no florescimento do evangelho e no fortalecimento ainda maior da igreja cristã brasileira.

${ }^{1031}$ GIRALDI, Luiz Antonio. História da Bíblia no Brasil, p. 102. 
A fundação da SBB constituía, nesse sentido, um importante fato da história da igreja cristã no país - um marco. Daquele momento em diante, a obra bíblica, levada sob muitas dificuldades por muitos anos pelas Sociedades Bíblicas, era, agora, confiada aos brasileiros. As igrejas e os cristãos do Brasil recebiam, naquele momento, uma auspiciosa missão. Desde a fundação, a percepção de todos era de que tal trabalho não se limitaria aos arraiais eclesiais. Pelo contrário, era uma missão para o Brasil e para o mundo. Já na parte final da cerimônia, o termo de inauguração foi lido pelo pastor batista João Filson Soren, em que se destacou:

Sob a invocação da bênção tríplice da Santíssima Trindade para quantos se associam aos esforços de divulgar a Palavra de Deus e de tornar a Bíblia o "Livro do Brasil", proclamamos formalmente inaugurada nesta data, na capital da República, a Sociedade Bíblica do Brasil ${ }^{1032}$.

Como já se constatou, o sonho intencionado na inauguração, de tornar a Bíblia o "Livro do Brasil", se tornou uma realidade. Não só pela SBB, mas também por meio do trabalho por ela realizado, o Brasil é atualmente um país de significativa relevância no cenário do trabalho bíblico mundial, principalmente entre as Sociedades Bíblicas. Nessa perspectiva, a SBB tem servido de inspiração e exemplo para muitas Sociedades Bíblicas e para outras organizações parceiras que tem a mesma missão, seja dentro ou fora do país.

Scholz ${ }^{1033}$ ressalta que, em termos de valores fundamentais para sua missão, a SBB entende a importância do cumprimento da Grande Comissão de Jesus descrita nos Evangelhos. Considerando, portanto, que "a Palavra de Deus deve ocupar o centro fundamental da vida e da missão da Igreja" ${ }^{1034}$, a SBB, desde a sua fundação e em conformidade com as diretrizes das SBU, procura servir às igrejas como agente primário "da missão de Deus no mundo" 1035 , cooperando, assim, na missão de Deus - Pai, Filho e Espírito Santo - segundo as Escrituras Sagradas: "Mas estes foram escritos para que vocês creiam que Jesus é o Messias, o Filho de Deus. E para que, crendo, tenham vida por meio dele" (Jo 20,31, grifos nossos).

\footnotetext{
${ }^{1032}$ GIRALDI, Luiz Antonio. História da Bíblia no Brasil, p. 110.

${ }^{1033}$ SCHOLZ, Vilson. Sociedades Bíblicas: guardiãs do texto e divulgadoras das Escrituras. In: HEIMANN, Leopoldo (org.). Fórum ULBRA de Teologia, p. 195-196.

${ }^{1034}$ FERNANDES, Leonardo Agostini. A Bíblia e sua mensagem: introdução à leitura e ao estudo da Bíblia, p. 5.

${ }^{1035}$ SOCIEDADE BÍBLICA DO BRASIL. Estatuto 2015. Barueri: Sociedade Bíblica do Brasil, 2015 , p. 1.
} 
Fundada e criada, portanto, pelas igrejas para servir as igrejas, a SBB procura atuar como tradutora, publicadora e distribuidora das Escrituras Sagradas no Brasil. Em seu trabalho de difusão das Escrituras, ela procura realizar a missão de levar a Palavra de Deus a todas as pessoas:

- Nas línguas e meios de comunicação que atendam às necessidades de todas as pessoas;

- Em traduções que sejam fiéis aos textos das Escrituras nas línguas originais e que comuniquem a mensagem bíblica;

- A preços que as pessoas possam pagar;

- Ajudando as pessoas a interagirem com a Palavra de Deus.

Esses aspectos norteiam o trabalho de difusão da Bíblia. É a partir deles que todas as ações são desenvolvidas, como se perceberá mais à frente.

\subsection{1}

\section{Constituição, finalidade e missão da SBB}

Desde a sua fundação, a Sociedade Bíblica do Brasil se caracteriza como uma organização com fins não lucrativos, atuante em nível nacional na área da Assistência Social e da distribuição da Bíblia Sagrada ${ }^{1036}$. Segundo seu estatuto,

A Sociedade Bíblica do Brasil, também designada pela sigla SBB, fundada em 10 de junho de 1948, é uma pessoa jurídica de direito privado, associação civil sem fins lucrativos, entidade beneficente de assistência social, de finalidade filantrópica, educativa, cultural e de saúde ${ }^{1037}$.

A SBB se caracteriza, portanto, por uma perspectiva ampla. Ela é uma entidade sem fins lucrativos, filantrópica, assistencial, educativa e cultural. Tudo isso corrobora a sua finalidade de traduzir, produzir e distribuir a Bíblia, um bem de valor inestimável, que deve ser disponibilizado para todas as pessoas. Sua constituição evidencia que o trabalho de difusão das Escrituras vai além de uma simples distribuição, por venda ou doação.

Para a SBB, a Bíblia é um instrumento de transformação espiritual e social e fonte de conhecimento e educação. Isso porque, como base social e cultural do pensamento filosófico da civilização ocidental, as Escrituras contêm valores éticos

1036 SOCIEDADE BÍBLICA DO BRASIL. Relatório Nacional de Trabalho 2016. Barueri: Sociedade Bíblica do Brasil, 2016, p. 7.

${ }^{1037}$ Id. Estatuto 2015, p. 1. 
capazes de auxiliar na construção de uma sociedade justa e pacífica ${ }^{1038}$. Portanto, firmado em tais pressupostos, o trabalho de difusão bíblica, por meio de cada atividade realizada pela SBB, é desenvolvido a partir do lema da organização, que é "semear a Palavra que transforma vidas"1039. É justamente sob essa perspectiva que a missão da organização se fundamenta em "promover a difusão da Bíblia e sua mensagem como instrumento de transformação e desenvolvimento integral do ser humano" $" 1040$.

\section{2}

\section{A atuação da SBB na difusão das Escrituras Sagradas}

Para cumprir sua missão de forma eficaz, a SBB, em sintonia com as atividades bíblicas realizadas pelas Sociedades Bíblicas Unidas no mundo, estabeleceu seu trabalho a partir do ciclo de vida da Bíblia. No Brasil, é por meio dele que a SBB comunica e realiza seu trabalho de difusão das Escrituras. De forma simples, o ciclo se estabelece por meio de três aspectos principais, que se desdobram em outros dois aspectos secundários. Nessa perspectiva,

Para o cumprimento de sua missão, a SBB tem como base o ciclo de vida da Bíblia. Fundamentado no tripé Disponibilidade, Acessibilidade e Relevância, o ciclo de vida da Bíblia somente termina quando uma vida é transformada. A cada Bíblia produzida, o ciclo deve ser cumprido ${ }^{1041}$.

Para que seja possível apreender um pouco melhor como se desenvolve tal trabalho, segue, abaixo, o ciclo de vida da Bíblia:

${ }^{1038}$ Cf. GIRALDI, Luiz Antonio. História da Bíblia no Brasil, p. 281.

${ }^{1039}$ SOCIEDADE BÍBLICA DO BRASIL. Relatório Nacional de Trabalho 2016, p. 5.

${ }^{1040}$ Id. Estatuto 2015, p. 1.

${ }^{1041}$ Id. Plano Nacional de Trabalho 2017. Barueri: Sociedade Bíblica do Brasil, 2017, p. 5. 


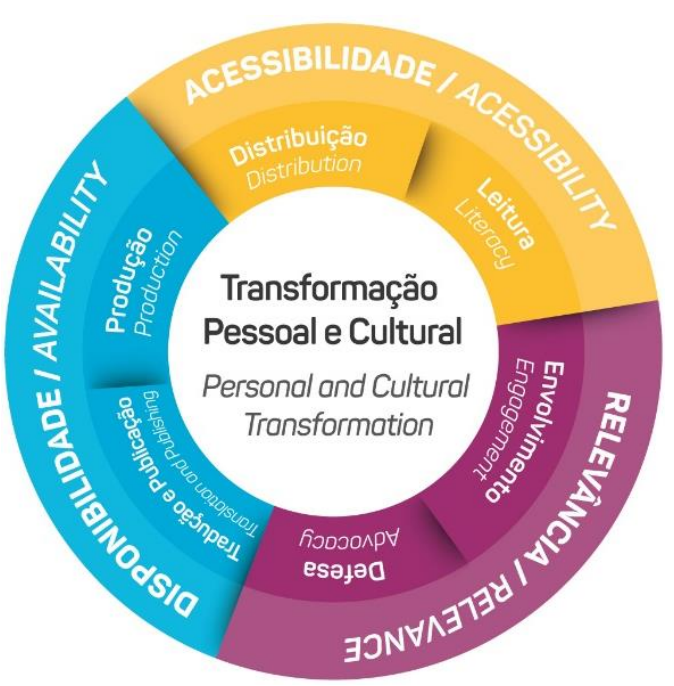

Figura 1 - Ciclo de vida da Bíblia

Fonte: Relatório Nacional de Trabalho $2016^{1042}$

O primeiro aspecto do trabalho de difusão das Escrituras é a Disponibilidade - o desdobramento desse aspecto se dá por meio da tradução, da publicação e da produção das Escrituras. O segundo aspecto é a Acessibilidade - a distribuição e o incentivo à leitura das Escrituras constituem os desdobramentos desse momento do trabalho bíblico. A Relevância é o terceiro aspecto principal no trabalho de difusão das Escrituras, por meio da qual se espera que a difusão da Bíblia promova envolvimento e defesa das Escrituras por partes de todos que participam desse ciclo.

Essa forma de fundamentar o trabalho bíblico, além de firmar suas bases por meio de um direcionamento específico, evita um uma percepção equivocada que poderia se atribuir ao trabalho bíblico ou à própria SBB. Para além da simples venda de Bíblias (enfoque comercial), a SBB consolida seu trabalho sob uma ótica de missão. Não basta produzir e distribuir a Bíblia. Não se trata de uma simples relação de negócio. Pelo contrário, todo o processo está entrelaçado a um aspecto fundamental: espera-se que cada pessoa que tenha acesso à Bíblia tenha, igualmente, sua vida transformada.

Como se perceberá mais adiante, também não se trata de um aspecto limitado ou exclusivo à fé. Ainda que a fé seja um pressuposto importante para o leitor das Escrituras, a SBB entende que, por meio de seu trabalho, a Bíblia pode contribuir para além de qualquer leitura dogmática. A mensagem da Bíblia pode transformar a pessoa, a família, a cultura, a sociedade, a política, a igreja etc.

${ }^{1042}$ SOCIEDADE BÍBLICA DO BRASIL. Relatório Nacional de Trabalho 2016, p. 8. 
Já ficou bem claro que a Bíblia Sagrada tem sido amplamente propagada no Brasil. Isso não é novidade. Muitas organizações, católicas e protestantes, editoras e associações, igrejas e cristãos individuais, estão imbuídos da missão de distribuir a Bíblia. A questão que emerge é se tal distribuição tem gerado o efeito que se espera numa nação que é reconhecidamente uma das que possui a maior distribuição das Escrituras Sagradas na história e na atualidade. É nessa perspectiva que a intenção do trabalho da SBB vai além da simples distribuição da Bíblia. E é por isso que o ciclo de vida da Bíblia amplia a concepção do que é, de fato, relevante no trabalho bíblico.

Nesse sentido, o Plano Nacional de Trabalho da Sociedade Bíblica do Brasil para o ano de 2017 estabelece alguns desafios para a difusão das Escrituras. Erní Seibert, secretário de Comunicação, Ação Social e Arrecadação da SBB, na introdução do plano, reitera que "não basta apenas produzir e distribuir a Bíblia Sagrada em abundância. É preciso promover o envolvimento das pessoas com a mensagem ali contida" ${ }^{" 1043}$. Tal afirmação pressupõe a importância de se estabelecer programas, projetos e ações que estejam em sintonia com a necessidade das pessoas, das igrejas e da sociedade brasileira. Dessa forma, tudo o que for realizado será concebido a partir da relevância que as Escrituras podem ter. Essa percepção contempla, sem dúvida, cada etapa do trabalho bíblico: da tradução à leitura por parte daquele que recebe a Bíblia. Sobre essa realidade, importa perceber como isso se concretiza no trabalho de difusão das Escrituras realizado pela Sociedade Bíblica do Brasil, tanto numa perspectiva histórica como atual.

\subsection{1 \\ 0 aspecto da disponibilidade no trabalho bíblico: tradução, publicação e produção das Escrituras Sagradas no Brasil}

Não há como falar em difusão das Escrituras sem se referir ao trabalho de tradução, publicação e produção da Bíblia. Esses três aspectos constituem uma parte importante para a causa da Bíblia. De certa forma, eles estão interligados e, por assim ser, firmam-se como o primeiro aspecto do ciclo de vida da Bíblia.

${ }^{1043}$ SOCIEDADE BÍBLICA DO BRASIL. Plano Nacional de Trabalho 2017, p. 3. 


\subsubsection{1 Disponibilidade por meio de traduções da Bíblia}

Como já se constatou nos capítulos anteriores, desde a época de Esdras e Neemias, pelo menos, a tradução da Bíblia se faz necessária. Desde então, traduções da Bíblia sempre acompanharam o povo de Deus em sua missão pelo mundo ${ }^{1044}$. Aliás, a tradução das Escrituras sempre contribuiu com a expansão missionária e com a ação evangelizadora da igreja cristã, onde quer que ela tenha chegado. Traduzir a Bíblia, portanto, é uma forma de torná-la disponível a todas as pessoas, em todo o mundo. A SBB, em seu estatuto, deixa bem clara a importância da tradução bíblica, afirmando que, entre as suas diversas atividades, inclui-se proeminentemente o trabalho de "realizar e apoiar a tradução da Bíblia"1045.

Para além disso, a SBB estabelece que um de seus princípios, entendidos sob a ótica de uma convicção fundamental para a realização de seu trabalho, é o de que "a Bíblia é para todas as pessoas, em todas as línguas vivas" - e, portanto, a SBB "vê a tradução da Bíblia como uma de suas atividades-chave"1046. Tais afirmações, inclusive, estão em consonância com o lema que move o trabalho de difusão bíblica realizado pelas Sociedades Bíblicas em todo mundo. Constitui um princípio fundamental da SBU dar a Bíblia a todos, numa linguagem que possam entender e a um preço que possam pagar. Para que isso ocorra, as traduções bíblicas precisam estar no cerne da missão e do trabalho.

No Brasil, como se sabe, a maioria da população fala a língua portuguesa. Por assim ser, equivocadamente se poderia pensar que a questão da tradução bíblica está resolvida, afinal, existem inúmeras traduções da Bíblia em língua portuguesa que atualmente são utilizadas no Brasil, conforme destaca Barnwell ${ }^{1047}$. Malzoni chega a questionar se inclusive "não se chegou a um número excessivo"1048 de traduções. A questão não é tão simples assim; e os motivos são varia-

1044 Cf. GONZALEZ, Justo; ORLANDI, Carlos Cardoza. História do movimento missionário, p. 38.

1045 SOCIEDADE BÍBLICA DO BRASIL. Estatuto 2015, p. 1.

${ }^{1046}$ Ibid., p. 2.

1047 Cf. BARNWELL, Katharine. Tradução Bíblica: um curso introdutório aos princípios básicos de tradução. Barueri; Anápolis: Sociedade Bíblica do Brasil; Associação Internacional de Linguística, 2011, pp. 19-22.

1048 MALZONI, Cláudio Vianney. As edições da Bíblia no Brasil, p. 149. O autor questiona, com razão, o aspecto mercadológico que vem caracterizando a propagação da Bíblia no Brasil. Cabe uma reflexão séria nesse sentido. Por outro lado, na conclusão da obra, o autor parece confundir publicação com tradução. Dessa forma, como se constatará no texto, ainda que se tenha muitas publicações, há, ainda, a falta de mais traduções da Bíblia. As necessidades de tradução para as 
dos. Inicialmente, vale lembrar que as traduções são necessárias porque a língua é viva e dinâmica; portanto, sempre haverá a necessidade de se revisar traduções antigas ou de se preparar traduções novas que possam atender à realidade linguística e social das pessoas.

Por outro lado, as necessidades das igrejas cristãs servem como um indicador sobre o tipo de tradução que se faz necessário para o bom desenvolvimento do trabalho delas. De fato, as traduções podem ter estilos diferentes ${ }^{1049}$; elas podem ser litúrgicas, evangelísticas, eruditas, parafrásticas, segmentadas (crianças, jovens etc.) e assim por diante. Por isso, o trabalho de tradução da SBB para a língua portuguesa constitui, ainda, uma parte fundamental de sua tarefa de difusão das Escrituras.

Uma característica singular deste trabalho de tradução realizado pela SBB (e pelas Sociedades Bíblicas de uma forma geral) é a sua percepção de ser uma agência que está à serviço da igreja. Em todos os relatos históricos é possível perceber que as traduções ou as revisões foram solicitadas pelas igrejas e pelos cristãos. A decisão por uma tradução, portanto, nunca se deu de forma isolada ou unilateral. As igrejas solicitam a tradução (ou a revisão) e a Sociedade Bíblica, em cooperação e com o apoio das igrejas, realiza o trabalho. Em todo o processo, inclusive, a igreja é convidada a se manifestar.

Sem desconsiderar os princípios de tradução e firmadas sob o texto nas línguas originais, opiniões são aceitas e textos são atualizados, para que assim a tradução possa ter uma excelente qualidade linguística e uma necessária neutralidade teológica. A SBB procura não publicar uma tradução que tenha tendência doutrinária ou teológica. Como Palavra de Deus, a Bíblia não pode pertencer a um grupo, seja ele quem for. É por isso que as traduções da SBB são respeitadas e utilizadas pela maioria das igrejas cristãs no Brasil. Para tanto, vale pormenorizar um pouco desse trabalho, tanto no aspecto histórico como atual, sobre as traduções que contemporaneamente são publicadas pela Sociedade Bíblica do Brasil.

línguas indígenas e para as línguas minoritárias faladas no Brasil constituem um desafio para o trabalho bíblico atual no país.

${ }^{1049}$ Cf. KONINGS, Johan. Tradução e traduções da Bíblia no Brasil. Persp. Teol., pp. 21-38. 


\subsubsection{1}

\section{A clássica tradução de Almeida}

É impossível dissertar sobre tradução da Bíblia para a língua portuguesa sem, necessariamente, perpassar pela tradução realizada por Almeida. De fato, esta foi a primeira tradução completa da Bíblia em português. Porém, tal tradução não foi realizada nem em Portugal nem no Brasil. Nessa perspectiva, antes de falar sobre Almeida e sua tradução, é importante lembrar que entre os séculos XVI e XVII a língua portuguesa se expandiu para o Oriente. De acordo com Lopes ${ }^{1050}$, o português foi mormente utilizado pelos negociantes portugueses que residiam e trabalhavam no sul da Índia e em algumas ilhas localizadas no Oceano Índico. Esse foi um período caracterizado pelo avanço comercial e colonial de Portugal naquela região. Pouco tempo depois, superando Espanha e Portugal, a Holanda também se tornou uma grande potência comercial e marítima. Era comum que holandeses partissem para o Oriente em busca das ricas especiarias que lá existi$\mathrm{am}^{1051}$.

Foi nesse contexto que surgiu a Companhia das Índias Orientais, organização responsável pelo comércio na região. Entretanto, para além do aspecto comercial, essa organização acumulava também a função de apoio ao Estado holandês em todas as áreas possíveis. Por meio desta companhia, assuntos de política, religião, comércio etc. eram tratados ${ }^{1052}$. Uma das estratégias do Estado holandês, por meio da Companhia, foi enviar missionários holandeses para a região. Em pouco tempo, esses missionários estabeleceram igrejas em Málaca (Malásia), Batávia (Ilha de Java) e Ceilão (Sri Lanka) ${ }^{1053}$.

1050 Cf. LOPES, David. A expansão da Língua Portuguesa no Oriente durante os séculos XVI, XVII e XVIII. Portucalense Editora: Porto, Portugal, 1969, p. 265.

1051 Cf. BEAUD, Michel. História do Capitalismo: de 1500 anos aos nossos dias. São Paulo: Editora Brasiliense, 1987, pp. 34-37.

${ }^{1052}$ Cf. GELDERBLOM, Oscar. A idade do ouro da República Holandesa. In: BAUMOL, William J. [et. al.]. A origem das corporações: uma visão histórica do emprendendorimo da Mesopotâmia aos dias atuais. Rio de Janeiro: Elsevier, 2010, pp. 179-200.

1053 Cf. GONZALEZ, Justo; ORLANDI, Carlos Cardoza. História do movimento missionário, p. 210. 


\subsection{1 João Ferreira Annes d'Almeida, o tradutor}

Diante dos aspectos acima descritos, muitas pessoas da região (Málaca, Batávia e Ceilão) também passaram a falar o português nas mais diversas atividades. Nas igrejas, por exemplo, a língua portuguesa foi amplamente utilizada. Entre os muitos missionários enviados pela Igreja Reformada Holandesa para a região estava um jovem chamado João Ferreira Annes d'Almeida. O Frei Herculano Alves, em sua tese de doutorado, fez um significativo levantamento histórico e biográfico sobre Almeida e sua tradução ${ }^{1054}$. Para aqueles que querem conhecer um pouco mais desses fatos, vale a pena a leitura. Por ora, vale ressaltar os principais aspectos que marcaram a vida de Almeida e que, por assim ser, culminaram em sua tradução da Bíblia. Todas as informações abaixo descritas constituem uma breve síntese do que pode ser encontrado nas obras de Alves, Fernandes, Giraldi, Hallock e Swellengrebel e Malzoni ${ }^{1055}$.

Almeida nasceu em 1628 (ou 1629), em Torres de Tavares, Portugal. Depois de perder seus pais quando ainda era uma criança, Almeida foi morar com seu tio, que era possivelmente um monge ou padre. A educação recebida o fez notável no conhecimento de outras línguas. Com 14 anos mudou para a Holanda, abandonando o catolicismo para se tornar protestante. Em sua biografia consta que, após sua conversão ao protestantismo, Almeida sentiu o chamado de Deus para o ministério pastoral e, assim, decidiu mudar para Málaca, onde poderia contribuir com a missão da Igreja Reformada Holandesa.

No período em que ficou na região, Almeida mudou de cidades algumas vezes, passando, em determinadas épocas de sua vida, por Málaca, Batávia e Ceilão. Foi na Batávia que ele casou e teve filhos. Lá, em 1657, com 29 anos de idade, foi ordenado pastor e lá morreu em 1691. Além da tradução da Bíblia, “Almeida tam-

\footnotetext{
${ }^{1054}$ Cf. ALVES, Herculano. A Bíblia de João ferreira Annes d'Almeida, pp. 75-168; 257-448.

1055 Cf. ALVES, Herculano. Op. cit.; FERNANDES, Luiz Henrique Menezes. A literatura religiosa polemista nas Índias Orientais seiscentistas e a elaboração da primeira tradução regular da Bíblia em língua portuguesa (1642-1694). Revista de História Regional 18 (2), 2013, pp. 462-479; GIRALDI, Luiz Antonio. A Bíblia no Brasil Império, pp. 22-28; Id. História da Bíblia no Brasil, pp. 33-35; HALLOCK, Edgar; SWELLENGREBEL, Jan Lodewijk. A maior dádiva e o mais precioso tesouro, pp. 35-118; MALZONI, Cláudio Vianney. As edições da Bíblia no Brasil, pp. 21-42.
} 
bém produziu, ao longo de sua vida, várias outras obras, a maioria delas de caráter polemista anticatólico"1056.

Contudo, a grande obra de sua vida foi a tradução da Bíblia para a língua portuguesa. De acordo com Fernandes, Almeida iniciou sua tradução “em 1642, ano de sua conversão ao cristianismo reformado, contando com apenas quatorze anos de idade" ${ }^{1057}$. Hallock e Swellengrebel ${ }^{1058}$, por outro lado, discordam dessa idade. Os autores afirmam que Almeida iniciou sua tradução, de fato, aos 16 anos, portanto dois anos após a sua conversão ao protestantismo. Independentemente de tais discordâncias, importa o fato de que, seja com 14 ou 16 anos, Almeida ainda era muito novo quando começou a traduzir a Bíblia.

A razão que o levou a começar tão cedo esse trabalho, talvez, esteja baseada na indignação de Almeida ao constatar que, entre as grandes nações europeias, somente Portugal ainda não tinha uma Bíblia traduzida para a sua própria língua. Quando terminou a tradução do NT, e antes de iniciar a tradução do AT, Almeida expressou:

Se o Senhor quiser me dar vida, tempo e saúde, então espero, com todas as minhas forças, apesar de serem bem poucas, também traduzir, dentro de poucos anos, o Velho Testamento, e assim poderei vos honrar com a Bíblia toda em vossa língua materna, que será "a maior dádiva e o mais precioso tesouro" que alguém jamais terá vos dado ${ }^{1059}$.

Como se percebe, a tradução da Bíblia para a língua portuguesa era o seu desejo, o projeto de sua vida. Seus primeiros rascunhos surgiram da tradução de algumas Epístolas e de alguns Evangelhos que estavam em espanhol (castelhano). Ainda no início, outros textos foram utilizados como base, tais quais o texto em latim de Teodoro de Beza e as traduções francesas, italianas e holandesas da Bíblia (ainda que nessa última encontrasse mais dificuldades). Obviamente, Almeida também utilizou os textos grego, hebraico e aramaico em seu trabalho. Aliás, o texto grego utilizado como base para a sua tradução foi a $2^{\mathrm{a}}$ edição do Textus Receptus de Erasmo de Roterdã (de 1633).

\footnotetext{
1056 FERNANDES, Luiz Henrique Menezes. A literatura religiosa polemista nas Índias Orientais seiscentistas e a elaboração da primeira tradução regular da Bíblia em língua portuguesa (1642-1694), p. 462.

${ }^{1057}$ FERNANDES, Luiz Henrique Menezes. Op. cit., p. 469.

1058 Cf. HALLOCK, Edgar; SWELLENGREBEL, Jan Lodewijk. A maior dádiva e o mais precioso tesouro, p. 35

1059 Ibid., p. 97. A citação foi transcrita como encontrada na fonte secundária. O grifo, possivelmente, é da fonte secundária, e não do texto original.
} 
Hallock e Swellengrebel relatam inúmeras dificuldades que foram enfrentadas por Almeida em todo o período em que trabalhava em sua tradução, a saber:

- Teve que enfrentar a perseguição da Igreja Católica;

- Teve que enfrentar o menosprezo do Concílio da igreja local, que não dava a devida atenção ao seu projeto de tradução;

- Teve que dividir seu tempo de tradutor com o trabalho de pastor e missionário em Málaca, Batávia e Ceilão;

- Teve que enfrentar sérias dificuldades na comunicação com as autoridades civis que representavam o governo holandês por meio da Companhia das Índias Orientais;

- Teve que administrar a rejeição dos revisores que, inúmeras vezes, procrastinaram a análise de sua tradução;

- Teve que "ajustar" a sua tradução inicial ao texto da tradução oficial holandesa;

- Teve que encontrar meios para publicar seu trabalho sob muitos desafios e dificuldades, tanto na região que estava como na Holanda;

- Teve que consertar os erros de gramática e de impressão que foram identificados na primeira publicação do NT;

- Teve que lidar com a sua própria impaciência, que, por vezes, o levou a se expressar e agir de forma inadequada;

- Teve que enfrentar a realidade e o preconceito de ser um português "dominado" pelos holandeses.

Como se percebe, foram inúmeras as dificuldades. Talvez esteja aí a razão pela qual o projeto levou um longo tempo para ser totalmente concluído. Pelo que parece, os primeiros esboços de seu trabalho só foram autorizados pelo Governo Geral da Holanda devido às intensas solicitações do povo, que estava bem impaciente. Ainda assim, antes mesmo de qualquer autorização, "conta-se que ele próprio [Almeida] fazia cópias de suas traduções para distribuí-las pelas comunidades de Málaca" ${ }^{1060 .}$

A tradução do NT foi iniciada em 1644 e só foi impressa em 1681 pela Companhia das Índias Orientais, mesmo tendo sido concluída em 1676. Devido a

${ }^{1060}$ MALZONI, Cláudio Vianney. As edições da Bíblia no Brasil, p. 22. 
alguns erros ${ }^{1061}$ de impressão e de gramática, muitos desses NTs foram destruídos. Devido aos problemas de impressão, Almeida optou por revisar a tradução. Ele queria ter certeza de que o texto traduzido seria totalmente fiel aos originais. E assim ele o fez. A tradução do AT só se desenvolveu de forma mais significativa a partir de sua aposentadoria, em 1689. Porém, Almeida estava cansado e envelhecido por demais (ainda que fosse relativamente novo, com cerca de 60 anos de idade).

Para piorar, o trabalho dos revisores cada vez mais se alongava. Quando faleceu, em 6 de setembro de 1691, Almeida estava traduzindo Ezequiel, capítulo 48 , versículo 21. A conclusão da tradução foi realizada por um de seus revisores e sucessor no ministério pastoral, o Rev. Jacobus Op den Akker, que terminou a tradução do AT em 1694.

A impressão da $2^{a}$ edição do NT, que havia sido totalmente revista, ocorreu em 1693, dois anos após a morte de Almeida. Já a impressão completa da Bíblia, em dois volumes, só veio a acontecer em 1751, depois de uma longa jornada de revisão e com o apoio da Society for Promotion Christian Knowledge (SPCK), a mesma organização que produziu a Bíblia que o Rev. Thomas Charles, em 1800, deu a Mary Jones.

A história do trabalho de Almeida, como se pode perceber, ficou marcada por dificuldades, dedicação e persistência. Afinal, foram cerca de 108 anos de espera, desde o desejo de Almeida de traduzir a Bíblia até a sua definitiva e completa publicação. A Bíblia completa, impressa em um só volume, só veio a ser publicada pela SBBE em 1819.

A tradução de Almeida marcou a história e por isso é reconhecida como um verdadeiro clássico, que contribuiu com a fé cristã para o povo lusófono, como também com a própria língua portuguesa. Desde o início ela foi utilizada na própria região em que Almeida estava. Mas, para além disso, ela também foi utilizada por missionários que estavam em Tranquebar (na atual Índia) ${ }^{1062}$ e pelos próprios brasileiros. Nesse sentido, Hallock e Swellengrebel acrescentam que os brasileiros foram um dos primeiros povos a se beneficiarem da tradução de Almeida ${ }^{1063}$.

\footnotetext{
${ }^{1061}$ Cerca de mais de mil erros, numa lista elaborada pelo próprio Almeida. 1062 Cf. MALZONI, Cláudio Vianney. As edições da Bíblia no Brasil, pp. 26, 28.

${ }^{1063}$ Cf. HALLOCK, Edgar; SWELLENGREBEL, Jan Lodewijk. A maior dádiva e o mais precioso tesouro, p. 122.
} 
Parte do sucesso alcançado por essa tradução deve ser dada às Sociedades Bíblicas. Foi a tradução de Almeida que as Sociedades Bíblicas Britânica e Estrangeira e, mais tarde, a Americana utilizaram em seu trabalho bíblico nos países de língua portuguesa, com maior proeminência, é claro, no Brasil. Em seu estudo, o frei Herculano Alves ${ }^{1064}$ questiona se ainda é válida a publicação do texto de um Almeida, de certa forma, descaracterizado por suas inúmeras revisões nestes mais de trezentos anos deste os primeiros textos publicados.

Nesse sentido, importa lembrar que o texto de Almeida, como qualquer tradução antiga da Bíblia, precisa passar pela adaptação lexical adequada a cada tempo. Todas as revisões realizadas foram feitas para atender a realidade da adequação do texto ao leitor de cada contexto. Por outro lado, o texto de Almeida estabeleceu um paradigma nas traduções bíblicas em língua portuguesa, principalmente no meio protestante. Almeida é uma referência de comparação em cada nova tradução que surge no Brasil, afinal, seu valor histórico e exegético na história do protestantismo brasileiro é inegável. Almeida estabeleceu termos e conceitos teológicos que são amplamente utilizados nas igrejas por causa de sua tradução.

A tradução de Almeida é ainda hoje publicada pelas Sociedades Bíblicas justamente porque as igrejas que utilizam essa tradução reiteram a importância de sua publicação de forma indireta, através do uso nas igrejas em meio à tantas outras opções, ou de forma direta quando afirmam a importância do texto nos encontros realizados pela SBB junto às igrejas. É por isso que, até hoje, a tradução de Almeida, obviamente com correções e revisões, continua sendo a tradução bíblica mais distribuída pela Sociedade Bíblica do Brasil. Trata-se da tradução bíblica mais utilizada pelas igrejas protestantes/evangélicas do país. Para maior exatidão, porém, vale ressaltar que a tradução está atualmente contemplada em três publicações distintas, todas, entretanto, mantendo o estilo clássico e exegético de Almeida.

${ }^{1064}$ Cf. ALVES, Herculano. A Bíblia de João ferreira Annes d'Almeida, pp. 532-533 


\subsection{2 \\ Almeida Revista e Corrigida (ARC)}

O texto de Almeida passou por diversas revisões ${ }^{1065}$. As próprias Sociedades Bíblicas revisaram o texto por algumas vezes. A maioria, principalmente durante o século XIX, foram de natureza ortográfica ${ }^{1066}$. No Brasil, porém, a necessidade de uma tradução mais adequada ao contexto do país se fazia necessária. De fato,

No final do século XIX, já estava difícil harmonizar a língua portuguesa falada no Brasil com a usada em Portugal. Por essa razão, em 1894, os missionários e líderes evangélicos brasileiros se reuniram no Rio de Janeiro para solicitarem às Sociedades Bíblicas uma revisão da tradução portuguesa de João Ferreira de Almeida para o português usado no Brasil ${ }^{1067}$.

Diante de tal pedido, ambas as Sociedades Bíblicas promoveram, entre 1894 a 1898, uma revisão da tradução de Almeida. E assim surgiu a primeira versão da Revista e Corrigida, publicada em 1898. Nas publicações subsequentes, foram acrescentadas ajudas ao leitor, tais quais: títulos nos parágrafos, datas, referências, mapas etc. Posteriormente, a tradução Almeida Revista e Corrigida passou por novas revisões: em 1969 houve uma pequena revisão da edição de 1898 e, em 1995, uma $2^{\text {a }}$ edição com revisão linguística. Já em 2009 houve uma nova edição devido à necessidade de adaptação às novas regras ortográficas da língua portuguesa. Como se percebe, desde 1898, poucas alterações foram realizadas, visto que essas revisões serviram somente para adequar palavras e regras ortográficas que, com o passar do tempo, surgiram na língua portuguesa falada no Brasil.

Desde sua publicação, em 1898, essa tradução passou a ser a versão preferida de muitas igrejas. As igrejas pentecostais, como por exemplo a Igreja Evangélica Assembleia de Deus, utilizam esse texto como referência litúrgica e acadêmica. O texto é utilizado na maioria das publicações da editora que pertence à igreja, a Casa Publicadora das Assembleias de Deus (CPAD). Outras igrejas pentecos-

\footnotetext{
${ }^{1065}$ Em 1819 a SBBE publicou pela primeira vez a Bíblia em português, na tradução de Almeida. Em 1840, a SBA publicou a Versão Revista e Emendada (parte dessa edição foi enviada para o Brasil). Em 1847, uma nova edição da Versão Revista e Emendada foi publicada para atender aos marinheiros portugueses. Em 1857, a SBA publicou uma edição bilíngue (português-inglês). Em 1864, a SBBE publicou uma revisão ortográfica. Em 1875, a SBBE publicou a Versão Revista e Correcta. Em 1869, a Sociedade Bíblica Trinitariana publicou a Versão Revista e Reformada. No período de 1876 a 1879, a SBA publicou a Primeira Edição Brasileira (adaptada ao português utilizado no Brasil). Em 1894, a SBBE realizou mais uma revisão ortográfica (versão de João Nunes Chagas). Cf. GIRALDI, Luiz Antonio. A Bíblia no Brasil Império, pp. 305-310.

${ }^{1066}$ GIRALDI, Luiz Antonio. A Bíblia no Brasil Império, p. 306.

${ }^{1067}$ Ibid., p. 309.
} 
tais, tais quais a Congregação Cristã no Brasil e a Igreja Pentecostal Deus é Amor, preferem, inclusive, o texto de 1969, por entenderem ser este um texto mais clássico e erudito que preserva os aspectos formais da tradução de Almeida.

\subsection{3}

\section{Almeida Revista e Atualizada (ARA)}

Assim como ocorrera em outros momentos, a versão Revista e Atualizada de Almeida surgiu pelo anseio de líderes cristãos, das mais variadas igrejas existentes em meados da primeira metade do século XX no Brasil, de uma nova tradução da Bíblia. A última revisão do texto de Almeida tinha sido realizada em 1898, portanto, cerca de 45 anos haviam se passado. Como já foi advertido, a língua é dinâmica. Chegava, portanto, o momento de a tradução de Almeida ser revisada. Assim,

Em abril de 1943, realizou-se no Rio de Janeiro um encontro de líderes evangélicos com o propósito de estudarem a possibilidade de promover uma revisão da tradução de João Ferreira de Almeida, Versão Revista e Corrigida. Nesse encontro houve consenso de que havia necessidade de uma nova revisão dessa tradução e foi eleita a Junta Consultiva, composta de 21 membros, para promover o projeto e solicitar a ajuda das Sociedades Bíblicas Unidas (SBUs) ${ }^{1068}$.

O objetivo do encontro, promovido pela SBU, era realizar uma consulta nacional com os líderes evangélicos do país, para tratar de assuntos importantes da causa da Bíblia. Como consequência do encontro, a SBU elegeu uma Junta Consultiva, composta por líderes de várias igrejas e de várias regiões do país. A necessidade de uma nova tradução, como se percebe, constituiu parte importante da pauta. Giraldi destaca que tal ênfase se deu porque as SBU haviam recebido um pedido de "várias denominações evangélicas de uma nova tradução ou versão da Bíblia em português para uso no Brasil" ${ }^{1069}$. Mesmo que o texto de Almeida tivesse sido revisado e adaptado anteriormente, ele ainda era, no aspecto linguístico, muito "português" e pouco "brasileiro".

Nesse sentido, a SBU, em cooperação com as igrejas, decidiu que essa tradução seria feita no Brasil, com o apoio e a participação significativa dos brasileiros. Obviamente, estes deveriam ser especialistas na área bíblica ou linguística. $\mathrm{O}$ que se ressalta é que este era um projeto da e para a igreja brasileira, mesmo que

1068 GIRALDI, Luiz Antonio. História da Bíblia no Brasil, p. 133.

${ }^{1069}$ Id. A Bíblia no Brasil República, p. 299. 
estrangeiros tenham feito parte da elaboração da tradução. Os revisores da SBU foram, inclusive, importantes para a condução do projeto. Entre todos os envolvidos, participaram clérigos e leigos, líderes nacionais e missionários estrangeiros.

Nas discussões, cogitou-se três possibilidades: (1) fazer uma nova tradução; (2) revisar a Tradução Brasileira; ou (3) fazer uma revisão do texto de Almeida (Revista e Corrigida, de 1898). Durante as discussões, a opção por uma revisão profunda no texto de Almeida sobressaiu. Esse era o desejo da maioria dos presentes. Foi nesse contexto que "a Junta Consultiva resolveu promover uma nova revisão da Versão Revista e Corrigida, de Almeida e decidiu que essa nova versão da Bíblia seria intitulada Versão de Almeida Revista e Atualizada no Brasil" ${ }^{1070 .}$.

Conforme destaca Malzoni, o "objetivo era atualizar a linguagem, sem deixar desaparecer as características do antigo texto de Almeida"1071. Ficou decidido, também, que mesmo com essa nova tradução, a versão anterior, Revista e Corrigida, continuaria a ser publicada; afinal, ela já era apreciada e utilizada por muitas igrejas e por muitos cristãos. As mudanças, em geral, variaram em cerca de $30 \%$ do texto da Versão Revista e Corrigida para o texto da Versão Revista e Atualizada.

O processo de tradução se desenvolveu por meio da organização de várias comissões (revisora, consultiva e redatora). As comissões eram formadas por especialistas nas línguas hebraica, aramaica, grega e portuguesa. Entre tantos outros, dois nomes se sobressaíram nesse processo, os quais, por conseguinte, marcaram a história dessa tradução: Antonio Campos Gonçalves (pastor metodista) e Paul Schelp (pastor luterano).

Uma característica especial da $A R A$ foi a ênfase na tentativa de eliminar (ou, pelo menos, amenizar) incoerências, ambiguidades, arcaísmos e, principalmente, cacofonias ${ }^{1072}$ que existiam na tradução anterior. Entre outras, havia uma preocupação de que a tradução não deveria se tornar jocosa, principalmente quando lida em voz alta nas igrejas ou transmitida pelos programadores de rádios. Teixeira acrescenta, ainda, que o trabalho de mais de uma década realizado nesta revisão

1070 GIRALDI, Luiz Antonio. A Bíblia no Brasil República, p. 300. (grifos nossos)

1071 MALZONI, Cláudio Vianney. As edições da Bíblia no Brasil, p. 37.

1072 Palavras que soavam de forma desagradável ou também a união desarmônica de sons diversos. Segundo Giraldi, existiam mais de mil cacófatos na tradução Revista e Corrigida (Cf. GIRALDI, Luiz Antonio. História da Bíblia no Brasil, p. 135). É possível perceber, por exemplo, uma cacofonia na expressão "desde então". Ainda que na escrita seja fácil de identificar que são dois termos diferentes, numa leitura em voz alta a palavra poderá soar de forma desagradável, como "dentão". 
procurou atualizar "não apenas a linguagem, mas também a base textual da tradução, levando em conta os últimos avanços da arqueologia e exegese bíblica"1073.

A revisão foi concluída em 21 de setembro de 1956, ocasião em que foi celebrada por meio de um culto de ação de graças realizado na Primeira Igreja Presbiteriana do Brasil, no Rio de Janeiro. Porém, diante das dificuldades de produção que existiam à época, a Bíblia na tradução Revista e Atualizada de Almeida só foi impressa em 1959. Foi um momento histórico importante para a causa da Bíblia e a sua difusão no Brasil. De fato,

A nova Versão de Almeida foi recebida com entusiasmo pela comunidade evangélica no Brasil. Quase todas as denominações evangélicas tradicionais, adventistas, congregacionais, episcopais, luteranas, presbiterianas, presbiterianas independentes e metodistas adotaram a nova versão ${ }^{1074}$.

Historicamente, a única igreja tradicional a não utilizar oficialmente essa versão foi a Batista. Tal fato se deve, principalmente, porque cada igreja Batista é autônoma em sua forma de governo. Ela não está subordinada a uma instância superior. Quem a governa é a própria congregação local e, por isso, não há uma posição que contemple todos os batistas de forma unânime ${ }^{1075}$. Nem mesmo a Convenção Batista Brasileira (CBB), que reúne as igrejas batistas para fins de cooperação e identidade doutrinária, pode definir a questão. Cada igreja, em sua autonomia, decide, entre outros aspectos, a tradução bíblica a ser utilizada.

Por outro lado, deve-se considerar, também, que os próprios batistas, por meio da CBB, criaram a Imprensa Bíblica Brasileira (IBB) em 1940, com o objetivo de realizarem uma produção exclusiva das Escrituras que atenderiam às igrejas interessadas. É importante lembrar que, naquele período de guerra, havia uma carência de Escrituras produzidas no Brasil. Foi diante deste contexto que surgiu a IBB. As Bíblias editadas pela IBB foram, inicialmente, publicadas na tradução Revista e Corrigida. Em 1967, porém, a Imprensa Bíblica Brasileira lançou a Versão Revisada da Tradução de João Ferreira de Almeida de Acordo os Melhores Textos em Hebraico e Grego, que ficou conhecida popularmente como Almeida

1073 TEIXEIRA, Paulo. Traduções da Bíblia: história, princípios e influência. In: ZIMMER, Rudi (Org.). Manual do Seminário de Ciências Bíblicas, p. 55. O texto grego base utilizado na tradução foi o Texto Critico, diferente da versão Revista e Corrigida, que se baseava no Texto Receptus. 1074 GIRALDI, Luiz Antonio. História da Bíblia no Brasil, p. 140.

${ }^{1075}$ Cf. SILVA, Roberto do Amaral. Princípios e doutrinas batistas. Rio de Janeiro: JUERP, 2003, pp. 27-28. 
Revisada, Versão Revisada, ou Almeida segundo Melhores Textos. Muitas igrejas batistas, e até mesmo outras igrejas e líderes não batistas, utilizaram esse texto.

Entre os pentecostais também ocorreram adesões à nova tradução. A Igreja Assembleia de Deus do Norte do país, juntamente com a Igreja Pentecostal O Brasil para Cristo e a Igreja do Evangelho Quadrangular, também oficializaram a tradução Atualizada de Almeida em suas respectivas denominações. Já na segunda metade do século XX, algumas igrejas recém-surgidas, principalmente as oriundas dos movimentos neopentecostais, também passaram a utilizar a tradução atualiza$\mathrm{da}^{1076}$.

Em 1993, “a Revista e Atualizada foi alvo de nova revisão, na qual algumas palavras já em desuso foram substituídas por termos mais contemporâneos"1077. Atualmente, comparada com todas as outras traduções, de todas as organizações que publicam as Escrituras, a tradução Almeida Revista e Atualizada é a mais utilizada nas igrejas evangélicas do país. Em 2016, a distribuição dessa tradução representou cerca de $40 \%$ do total de Bíblias distribuídas pela SBB.

\subsection{4 \\ Nova Almeida Atualizada (NAA)}

Considerando que se passaram cerca de 25 anos desde a última revisão e cerca de 60 anos desde a primeira publicação da ARA, a SBB lançou, recentemente, um novo texto a partir da tradução Almeida Revista e Atualizada ${ }^{1078}$. Trata-se da Nova Almeida Atualizada. Pelo fato de o texto ser ainda muito recente, sabe-se pouco sobre a nova tradução. Em um encarte explicativo publicado pela SBB ${ }^{1079}$ constam informações que, historicamente, se assemelham a todos os outros processos de tradução.

Mais uma vez, a decisão de se publicar um novo texto, com base em Almeida, não foi unilateral. Desde 2003, pelo menos, já se ouvia entre líderes, estudantes de teologia e leigos sobre a necessidade de se atualizar a tradução ARA. O de-

${ }^{1076}$ Cf. GIRALDI, Luiz Antonio. História da Bíblia no Brasil, p. 140.

1077 TEIXEIRA, Paulo. Traduções da Bíblia: história, princípios e influência. In: ZIMMER, Rudi (Org.). Manual do Seminário de Ciências Bíblicas, p. 55.

1078 As SBU recomendam uma revisão das traduções a cada 25 anos.

1079 SOCIEDADE BÍBLICA DO BRASIL. Nova Almeida Atualizada: uma tradução clássica com linguagem atual. Barueri: Sociedade Bíblica do Brasil, 2017, pp. 2-11. 
sejo era de tornar o clássico texto de Almeida (nesse caso, a $A R A$ ) acessível e compreensível para as novas gerações. Assim sendo,

Representantes das igrejas cristãs foram convidados para uma reunião na Sede Nacional da Sociedade Bíblica do Brasil, em outubro de 2012, em Barueri (SP). Esses representantes de diferentes denominações cristãs acolheram a ideia com entusiasmo e ajudaram a formular os parâmetros para a revisão ${ }^{1080}$.

Iniciada oficialmente em 2013, várias etapas foram desenvolvidas no pro$\operatorname{cesso}^{1081}$ :

- Planejamento da revisão:

- Reunião com os líderes das igrejas;

- Apresentação e aprovação do plano de revisão, com os princípios que norteariam o trabalho;

- Definição da Comissão Revisora.

- Trabalho da Comissão Revisora:

- $1^{\mathrm{a}}$ leitura: análise da ARA à luz do texto original, em que seria possível perceber as possibilidades de mudanças;

- $\quad 2^{\mathrm{a}}$ leitura: análise das mudanças sugeridas e, posteriormente, realizadas;

- $\quad 3^{a}$ leitura: análise do novo texto (ortografia, gramática e fluência). Surgiram, nesse ínterim, quase 17 mil anotações realizadas pelos revisores.

- Leitura em conjunto da Comissão Revisora:

- Leitura em voz alta para verificar a fluência e a facilidade de leitura;

- Análise e definição das anotações e dúvidas;

- Discussão de casos especiais com eventual releitura de textos.

- Publicação do texto:

- Agosto de 2016: publicação do Novo Testamento, Salmos e Provérbios com o texto revisado;

- Submissão do texto para análise das igrejas e dos leitores;

- Recebimento e análise de sugestões feitas pelas igrejas, estudantes e leitores;

${ }^{1080}$ SOCIEDADE BÍBLICA DO BRASIL. Nova Almeida Atualizada, p. 4.

${ }^{1081}$ Ibid., p. 5. 
- Encerramento da revisão de todos os livros da Bíblia em julho de 2017.

- Novembro de 2017: publicação, apresentação e lançamento da tradução Nova Almeida Atualizada à igreja brasileira em novembro de 2017.

Como é possível perceber, trata-se de um trabalho conjunto e colaborativo entre igrejas, líderes, estudantes, revisores e tradutores. O trabalho foi coordenado pelo Rev. Dr. Vilson Scholz (doutor em Teologia e consultor de traduções das SBU), pelo Rev. Denis Timm (bacharel em Teologia e em Letras, com especialização em tradução, e gerente editorial da SBB) e por Quéfren de Moura (mestre em Estudos da Tradução e revisora de textos da SBB).

A nova tradução (completa, com NT e AT), foi lançada no dia 8 de novembro de 2017, no templo da Catedral Evangélica de São Paulo, e passou a ser chamada de Nova Almeida Atualizada (NAA). Mesmo revisada, a tradução pretende manter o estilo clássico de Almeida, utilizando-se, entretanto, de uma linguagem mais atual. Para tanto, procurou-se substituir termos que exigem consulta ao dicionário, sem perder, obviamente, o significado. Entre outros, um exemplo de uma palavra que foi modificada é o termo irrisão (que significa "motivo de riso"). Como se percebe, trata-se de um termo pouco utilizado pela maioria da população brasileira. Termos teológicos, amplamente consolidados pela tradução de Almeida, foram mantidos (ex: justificação, regeneração). Na NAA procurou-se também utilizar a ordem natural das palavras, conforme o português do Brasil. Assim, em vez de "Criou Deus, os céus e a terra" (ARA), utilizou-se, "Deus criou os céus e a terra" (NAA). Os pronomes de segunda pessoa ("tu" e "vós") foram alterados para "você" e "vocês". A exceção se dá quando tais pronomes se referem a Deus.

As mesóclises foram todas substituídas; assim, em vez de usar "responderte-ei" (ARC) o texto ficou simplesmente "eu responderei” (NAA). As unidades de peso, medida e capacidade, comuns na literatura e na cultura hebraica e grega, foram substituídas por termos conhecidos e utilizados pelos falantes de hoje no Brasil. Outras alterações foram realizadas e merecerão, sem dúvidas, um estudo mais profundo e específico, diante do fato de que a NAA é ainda muito recente para se ter uma ideia consistente de seus princípios, definições e alcance. O resultado, por enquanto, pode ser percebido pela manutenção do estilo de Almeida, numa linguagem mais acessível. Dessa forma, além de utilizá-la na liturgia, a 
NAA também poderá ser usufruída pelas novas gerações na leitura individual ou familiar.

\subsubsection{2}

\section{A histórica Tradução Brasileira (TB)}

Entre as traduções da SBB, existe uma que ficou marcada na história como a primeira tradução da Bíblia feita por brasileiros em solo nacional. Trata-se da Tradução Brasileira da Bíblia (TB). Até o início do século XX coexistiam apenas duas traduções completas da Bíblia em língua portuguesa: a tradução de Figueiredo e a tradução de Almeida. Ambas as traduções foram desenvolvidas fora do Brasil e, por conseguinte, estavam enraizadas sob o estilo linguístico de Portugal; afinal, Almeida e Figueiredo eram portugueses. Porém, à tradução de Almeida acrescenta-se a influência holandesa e asiática, fruto de suas mudanças por essas duas regiões. Alves ${ }^{1082}$ reforça que, diante do fato de Almeida ter saído de Portugal com apenas 14 anos, é bem certo que ele tinha mais influência da nova região em que passou a viver e se relacionar do que propriamente de Portugal. O contexto social e a forma de se falar no Brasil estavam, portanto, muito distantes de qualquer intenção de ambos os tradutores.

Por outro lado, as duas reconhecidas traduções já passavam de cem anos de existência e, como já visto, mesmo sob as constantes revisões, não se enquadravam nas necessidades contextuais do povo brasileiro. Aspectos linguísticos, culturais e teológicos, principalmente, eram (e são) apreendidos de forma diferente em Portugal e no Brasil. Sendo assim, no início do século XX “os principais líderes evangélicos brasileiros manifestaram às Sociedades Bíblicas atuantes no país o desejo de terem uma tradução da Bíblia genuinamente nacional" ${ }^{1083}$. E assim, ambas as Sociedades Bíblicas (SBBE e SBA) decidiram promover o projeto de tradução da primeira Bíblia totalmente traduzida no Brasil, feita com o jeito brasileiro de se comunicar, dando, então, surgimento à Tradução Brasileira (TB).

Em 1902 foi estabelecida a comissão de tradução, formada por especialistas nas línguas bíblicas e na língua portuguesa. Ainda que a maioria dos membros fosse brasileira, havia, também, a participação de "tradutores nascidos em outros

\footnotetext{
1082 Cf. ALVES, Herculano. A Bíblia de João ferreira Annes d'Almeida, p. 17.
}

1083 GIRALDI, Luiz Antonio. História da Bíblia no Brasil, p. 71. 
países que conheciam bem a língua portuguesa"1084. Entre os diversos participantes, além de líderes das igrejas existentes no país à época, estavam personagens importantes da história do Brasil - entre os quais Rui Barbosa, José Veríssimo, Heráclito Graça e Machado de Assis, que foram convidados a participar da TB como consultores linguísticos ${ }^{1085}$.

Tal participação, àquela época, constituiu um diferencial relevante; afinal, o Brasil há pouco havia conquistado a plena liberdade religiosa. A participação de personagens como aqueles, sem dúvida, contribuiu para fortalecer a difusão das Escrituras no Brasil. A repercussão foi significativa, e a Bíblia despertou ainda mais interesse na sociedade. Como exemplo, Tucker, secretário da SBA no Brasil, destacou que foi "comovente ver homens tão ilustres e ocupados como Rui Barbosa e o escritor Machado de Assis, dedicarem seu precioso tempo para traduzir a Bíblia para o português do Brasil" ${ }^{1086}$. Contudo, diante de tais participações, a TB ficou marcada por um estilo linguístico pouco popular e muito erudito. Até mesmo "os nomes próprios não foram aportuguesados, mas transliterados, o que dificultava consideravelmente a leitura (especialmente a leitura conjunta na igreja) $\$ 1087$.

A tradução do texto original foi feita literalmente, isto é, palavra por palavra, e o nível de linguagem foi o clássico ou erudito. Não havia naquela época a preocupação existente hoje de traduzir a Bíblia em um português simples, acessível à maior parte da população brasileira ${ }^{1088}$.

Além destes aspectos, a tradução apresentou algumas expressões regionais, comuns no diálogo do povo brasileiro naquele período. Por ter caráter bem literal em relação ao texto nas línguas originais e bem aproximado ao estilo erudito da fala portuguesa (principalmente pela participação de nomes da literatura brasileira), a TB "passou a ser chamada popularmente de "Tira-Teimas" e "Tradução Fiel" "1089. Como toda tradução, em sua época a TB recebeu críticas, por um lado, e elogios, por outro. Talvez, também como ocorre hodiernamente nas traduções da $\mathrm{SBB}$, as reações se firmavam exclusivamente na comparação com texto de Al-

\footnotetext{
${ }^{1084}$ GIRALDI, Luiz Antonio. A Bíblia no Brasil República, p. 146.

1085 Id. História da Bíblia no Brasil, pp. 71-73; Id. A Bíblia no Brasil República, pp. 147-149.

${ }^{1086}$ TUCKER, Hugh Clarence. Reminiscências - 50 anos no Brasil, p. 89.

1087 TEIXEIRA, Paulo. Traduções da Bíblia: história, princípios e influência. In: ZIMMER, Rudi (Org.). Manual do Seminário de Ciências Bíblicas, p. 55.

${ }^{1088}$ GIRALDI, Luiz Antonio. A Bíblia no Brasil República, p. 150.

${ }^{1089}$ Id. História da Bíblia no Brasil, p. 73.
} 
meida. Se para alguns as diferenças eram oportunas, para outros, eram algo inaceitável.

A partir de 1904, progressivamente, foram sendo lançadas pequenas partes do texto, tais quais os Evangelhos e depois o Novo Testamento (1908). Assim como ocorrera com outras traduções, sugestões foram enviadas pelas igrejas e foram aos poucos incorporadas no projeto. A TB foi concluída em 1914, mas a Bíblia completa só veio a ser publicada em 1917, devido ao caos provocado pela Primeira Guerra Mundial ocorrida naquele período. Sua publicação se estendeu até a década de 1950, quando deixou de ser impressa pela SBB.

Afinal, como bem lembra Malzoni, "essa tradução nunca chegou a ter a mesma influência que a tradução de Almeida" ${ }^{1090}$. De fato, o texto de Almeida (inclusive a nova tradução ARA surgida na década de 1950) definitivamente tinha conquistado o coração do povo brasileiro. Atualmente, a SBB ainda publica essa tradução (com as devidas revisões ortográficas) em pequenas quantidades, procurando, assim, resgatar e valorizar a história dessa tradução da Bíblia.

\subsubsection{3}

\section{A dinâmica Nova Tradução na Linguagem de Hoje (NTLH)}

Até meados da década de 1960, todas as traduções da Bíblia difundidas pelas Sociedades Bíblicas tinham sido realizadas a partir de um princípio formal de tradução. Nesse sentido, "não havia muito a se discutir em termo de tradução da Bíblia: traduzia-se o texto bíblico da forma mais literal possível e estava concluído o trabalho. As traduções eram todas mais ou menos iguais" ${ }^{1091}$. A Tradução Brasileira, por exemplo, era bem literal. Já as traduções de Almeida (ARA e $\mathrm{ARC}$ ), ainda que fossem um pouco mais compreensíveis para a leitura do povo comum, apresentavam, igualmente, algumas dificuldades de entendimento em certos termos. O vocabulário de ambas estava bem acima daquele falado pelo povo brasileiro.

Em contraponto a esta realidade, faltava entre as traduções bíblicas de língua portuguesa uma tradução mais dinâmica. Faltava uma Bíblia num português mais simples, mais dinâmico. Para que se possa compreender melhor estas ques-

\footnotetext{
1090 MALZONI, Cláudio Vianney. As edições da Bíblia no Brasil, p. 60.

1091 SCHOLZ, Vilson. 40 anos de Bíblia na Linguagem de Hoje: as grandezas de Deus em nossa própria língua. Barueri: Sociedade Bíblica do Brasil, 2013, p. 37.
} 
tões, vale a pena entender, nas palavras de Konings, o que é uma tradução por equivalência formal e o que é uma tradução por equivalência dinâmica.

Uma tradução formal procura manter o mais possível a estrutura do texto original, tanto na construção da frase ou período quanto na tradução das metáforas e imagens e no uso dos vocábulos (traduzindo, se possível, o mesmo termo original sempre pelo mesmo vocábulo na língua final) [...]. Já a tradução por equivalência dinâmica procura suscitar no leitor, mediante um uso linguístico adequado do idioma final, o efeito de significação que o texto teve no leitor inicial, em outro contexto cultural. Nisso, não se trata somente da semântica dos termos e estruturas linguísticas em si (a semântica no sentido estrito), mas também do efeito produzido no leitor originário (a pragmática do texto) ${ }^{1092}$.

Como se constata, enquanto na tradução formal a preocupação principal do tradutor é traduzir o texto de acordo com a estrutura gramatical do texto nas línguas originais para a língua receptora (verbo por verbo, substantivo por substantivo etc.), na tradução por equivalência dinâmica, ainda que se tenha por base e rigorosidade o mesmo texto nas línguas originais, a preocupação principal do tradutor é de expressar de forma acessível o significado da mensagem, independentemente da estrutura gramatical a ser utilizada. Nesse sentido, "uma boa tradução requer dupla fidelidade: ao texto original e à linguagem falada pelo povo de hoje" ${ }^{" 1093}$. De forma geral, pode-se dizer que o foco numa tradução formal é a estrutura; já o foco numa tradução dinâmica é o significado. É lógico que ambas as opções são úteis e importantes para a igreja e para o cristão. A diferença está no público-alvo e na pretensão de uso de cada uma delas.

Ainda que as traduções de Almeida, Figueiredo e a TB fossem importantes (e continuem a ser) em toda a história da difusão das Escrituras no Brasil, emergia a necessidade de uma outra tradução. Assim, historicamente,

O projeto de tradução da Bíblia na Linguagem de Hoje começou em 1966, quando as Sociedades Bíblicas Unidas promoveram no Brasil o Seminário de Tradução da Bíblia em Linguagem Corrente. [...] O Seminário contou com a presença de líderes evangélicos interessados em apoiarem um projeto de tradução da Bíblia em português moderno ${ }^{1094}$.

Essa não era uma tendência exclusiva do Brasil; projetos semelhantes estavam acontecendo em espanhol, inglês, francês e outros idiomas. É claro que o objetivo não era substituir outras traduções. A tradução de Almeida, inclusive na

\footnotetext{
1092 KONINGS, Johan. Tradução e traduções da Bíblia no Brasil. Persp. Teol., p. 232.

1093 SCHOLZ, Vilson. 40 anos de Bíblia na Linguagem de Hoje, p. 50.

${ }^{1094}$ GIRALDI, Luiz Antonio. História da Bíblia no Brasil, p. 177.
} 
recém-lançada Almeida Revista e Atualizada, continuava crescendo e conquistando seu espaço nas igrejas evangélicas do país. Ainda assim, o Dr. Paul Schelp, um dos grandes colaboradores da tradução ARA, já tinha advertido, em uma palestra proferida em 1964, sobre a necessidade de uma Bíblia simplificada, simples e compreensível, para o contexto brasileiro ${ }^{1095}$.

Como se percebe, a intenção era simplesmente publicar "uma nova tradução destinada aos novos leitores brasileiros e ao uso das igrejas no trabalho de evangelização" ${ }^{1096}$. Aliás, o foco de qualquer projeto de tradução deve ser o contexto da missão. Nesse sentido, Scholz lembra que alguns anos antes de se iniciar o projeto, mais precisamente em 1961, missionários que trabalhavam no Norte do país já haviam solicitado uma nova tradução, sinalizando a necessidade de um texto que fosse mais fácil de ser entendido ${ }^{1097}$. Este era um desejo daqueles que estavam no campo missionário.

Teixeira corrobora essa percepção ao lembrar que esta nova tradução seria muito bem utilizada "para a evangelização e educação de crianças e jovens no Evangelho" ${ }^{1098}$. E assim nasceu a Bíblia na Linguagem de Hoje, sendo substituída, mais tarde, pela sua sucessora, a Bíblia na Nova Tradução na Linguagem de Hoje. Tratava-se de um projeto que intencionou uma Bíblia numa linguagem de fácil entendimento para toda a população. Entre outros, os princípios de tradução do projeto, decididos ainda na mesma edição do Seminário de Tradução, consistiam em ${ }^{1099}$ :

- Basear a nova tradução nos textos originais;

- Ter uma linguagem simples e atual, mas não vulgar, nem com gírias ou regionalismos;

- Direcionar a nova tradução principalmente para evangelização e não necessariamente para o uso litúrgico;

- Adotar a linguagem popular, como a falada (não a escrita) no Brasil;

- Utilizar o princípio dinâmico e não o formal na tradução;

${ }^{1095}$ Cf. SCHOLZ, Vilson. 40 anos de Bíblia na Linguagem de Hoje, p. 15.

${ }^{1096}$ GIRALDI, Luiz Antonio. História da Bíblia no Brasil, p. 177.

${ }^{1097}$ Cf. SCHOLZ, Vilson. Op. cit., p. 12.

1098 TEIXEIRA, Paulo. Traduções da Bíblia: história, princípios e influência. In: ZIMMER, Rudi (Org.). Manual do Seminário de Ciências Bíblicas, p. 58.

${ }^{1099}$ Cf. GIRALDI, Luiz Antonio. Op. cit., p. 177; SCHOLZ, Vilson. Op. cit., p. 17. 
- Priorizar o entendimento da mensagem, procurando manter, quando possível, o estilo do texto original;

- Tornar clara, fluente, agradável e inteligível a eterna mensagem da salvação em Cristo;

- Preferir o modo direto e natural de se dizer algo;

- Priorizar frases curtas, evitando frases intercaladas;

- Substituir e explicar no próprio texto os termos teológicos utilizados;

- Evitar a ambiguidade (indecisão, hesitação, imprecisão, incerteza e indeterminação);

- Utilizar "você" e "vocês", em vez de "tu" ou "vós".

Esse tipo de tradução era algo bem diferente do padrão utilizado nas traduções para a época. O princípio de equivalência dinâmica estava sendo recémutilizado nas traduções pelo mundo. Isso não quer dizer, entretanto, que a ideia já não tinha sido pensada. Lutero, em sua tradução, enfatizou que seria importante que crianças, mulheres e adultos pudessem entender a mensagem das Escrituras. Em suas próprias palavras ele afirmava que pretendia fazer Moisés e os profetas falarem alemão. Como se percebe, o princípio de tradução ainda não existia, mas o desejo de tornar a Bíblia compreensível já era buscado há mais de quatrocentos $\operatorname{anos}^{1100}$.

Para iniciar o projeto no Brasil, as SBU convidaram líderes de várias igrejas, tradicionais e pentecostais, e, como sempre ocorria, o trabalho começou com alguns livros do NT. Um diferencial nesse projeto foi a participação e a "colaboração de Consultores de Linguagem em diversos estados do Brasil"1101, afinal, a nova tradução deveria ser facilmente entendida por todas as pessoas, de todos os lugares, nos mais distantes rincões do país. Era necessária uma linguagem que todos pudessem entender, como arrazoava um dos princípios das SBU no trabalho bíblico. Durante o processo, um fato aconteceu:

Em 1974, a Conferência Nacional dos Bispos do Brasil (CNBB) nomeou uma Comissão de especialistas para examinar o Novo Testamento na Linguagem de Hoje $(T L H)$ e dar o seu parecer sobre sua fidelidade aos textos originais. Essa Comissão

${ }^{1100}$ Cf. LUTERO, Martinho. Carta aberta do Dr. M. Lutero a respeito da tradução e da intercessão dos santos (1530). In: FURLAN, Mauri (org.). Clássicos da teoria da tradução - VI: Antologia do Renascimento (séc. XVI) (bilíngue). Florianópolis: UFSC, 2016, pp. 157-158.

${ }^{1101}$ GIRALDI, Luiz Antonio. História da Bíblia no Brasil, p. 181. 
examinou a TLH e deu parecer favorável ao seu uso pelos católicos de língua portuguesa $^{1102}$.

Vale lembrar que essa decisão foi, sem dúvida, influenciada pela abertura da Igreja Católica após o Concílio Vaticano II. No referido Concílio, a Bíblia ganhou destaque na vida da igreja e na vida do fiel católico. Para além disso, desde que aprovadas pelas autoridades da Igreja Católica, afirmou-se que seria possível utilizar traduções bíblicas resultantes do trabalho de colaboração entre católicos e protestantes (Dei Verbum 22) ${ }^{1103}$. Dessa forma, a Bíblia na Linguagem de Hoje, já naquela época, passou a ser uma tradução permitida para a leitura e para o uso dos católicos.

A primeira publicação foi uma porção bíblica baseada em Lucas 15 - "E foi achado” -, a qual, aliás, foi muito bem aceita. Posteriormente foram publicados alguns Evangelhos (Marcos, em 1969, e João, em 1972). O Novo Testamento completo só ficou pronto em 1973, ocasião em que foi lançado e impresso com vários recursos (introdução a cada livro, dicionário, mapas, ilustrações etc.).

Giraldi ${ }^{1104}$ lembra que, ainda que a primeira edição de duzentos mil exemplares tenha se esgotado rapidamente, as reações dos leitores diversificaram entre boa aceitação entre os mais jovens e certa reserva entre os mais antigos. À época, entre as igrejas pentecostais, houve uma maior resistência. Já entre os tradicionais, ocorreram críticas mais severas oriundas da ala mais conservadora, principalmente entre presbiterianos e batistas. A segunda edição do NT, revisada e lançada em 1975, depois de serem incorporadas mais de duas mil sugestões enviadas pelas igrejas, foi bem recebida por boa parte dos cristãos do país ${ }^{1105}$.

Enquanto o NT na Linguagem de Hoje conquistava seu espaço, os tradutores começaram, logo em 1974, a tradução do AT. Depois de alguns anos, sob algumas dificuldades, a Comissão de Tradução, reunida na Faculdade Teológica Batista de São Paulo, anunciou o término dos trabalhos em outubro de 1987. Assim, depois de 22 anos desde que se iniciou o projeto, a Bíblia na Linguagem de Hoje foi completamente publicada no Brasil, em 1988.

\footnotetext{
${ }^{1102}$ GIRALDI, Luiz Antonio. História da Bíblia no Brasil, p. 181.

${ }^{1103}$ Cf. CONCÍLIO VATICANO II. Dei Verbum. Constituição Dogmática sobre a Revelação Divina, DV 22.

${ }^{1104}$ GIRALDI, Luiz Antonio. Op. cit., p. 183.

${ }^{1105}$ Cf. SCHOLZ, Vilson. 40 anos de Bíblia na Linguagem de Hoje, pp. 34-35.
} 
Entre outros, Dr. Robert Bratcher e do Dr. Werner Kaschel, ambos pastores batistas, marcaram a história da Bíblia na Linguagem de Hoje por meio da contribuição que deram ao trabalho desta tradução. Logo após o término, o Dr. Werner Kaschel destacou alguns pontos que basearam e consolidaram o projeto de tradução:

Essa tradução procura ser clara e compreensível para todos. Ela não é uma paráfrase ou explicação, pois transmite o sentido exato do original e nada mais. É uma tradução fiel dos melhores textos do Antigo Testamento, hebraico e aramaico, e do Novo Testamento, em grego comum [...]. Fidelidade ao texto original não significa traduzir palavra por palavra, mas traduzir o sentido da mensagem sem acrescentar nem tirar nada. Uma tradução palavra por palavra, ao pé da letra, não seria compreendida pelas pessoas. Por isso, primeiro os tradutores procuram entender o sentido do texto original e depois se esforçam por colocá-lo em palavras e em formas de expressão atuais, que conservem fielmente aquele sentido ${ }^{1106}$.

Diante de tantos recursos que procuravam facilitar a compreensão da mensagem, após o lançamento, a nova tradução foi lida em diversas partes do Brasil, por pessoas das mais variadas igrejas. A SBB recebeu muitas cartas de pessoas que queriam expressar sua gratidão pelo fato de terem lido a Bíblia e conseguido compreendê-la. A clareza de sentido constituiu, portanto, uma das marcas significativas dessa tradução.

Como ocorrera em outros projetos de tradução realizados pela SBB, "logo após o lançamento da Bíblia na Linguagem de Hoje (BLH), a comissão de Tradução começou a examinar as sugestões recebidas" ${ }^{1107}$. Aliás, para além da percepção do público externo, a própria Comissão chegou à conclusão de que a tradução necessitava de alguns ajustes. A compreensão do princípio de tradução dinâmica, que era bem recente na década de 1960, já estava, no início da década de 1990, mais bem estabelecida. E assim se deu início ao trabalho de revisão de toda a BLH.

As mudanças eram, em geral, constituídas de aspectos linguísticos das línguas bíblicas em sua relação com os aspectos linguísticos da língua portuguesa, que precisavam ser corrigidos. Algumas simplificações para a melhor compreensão do texto também foram ajustadas. Substituiu-se a designação do nome de Deus, que na BLH era "Eterno", por "Senhor Deus", "Deus, o Senhor" ou "Se-

\footnotetext{
${ }^{1106}$ KASCHEL, Werner. In: GIRALDI, Luiz Antonio. História da Bíblia no Brasil, p. 223.
}

${ }^{1107}$ GIRALDI, Luiz Antonio. História da Bíblia no Brasil, p. 264. 
nhor". No estilo, procurou-se manter a forma poética do hebraico no texto dos Salmos.

Já no ano de 2001, a SBB promoveu o lançamento da Nova Tradução na Linguagem de Hoje (NTLH) em várias regiões do Brasil. O resultado final do projeto garantiu à igreja brasileira uma Bíblia com "linguagem acessível aos menos iletrados e aceitável aos mais eruditos"1108. Para tanto, a NTLH passou a utilizar um vocabulário de aproximadamente quatro mil palavras. Procurando dar ciência e explicação de que se tratava essa nova tradução, o Dr. Rudi Zimmer, diretor executivo da organização, que na época do trabalho de revisão fazia parte da Comissão de Tradução, realizou: "18 encontros que reuniram pastores, líderes de igrejas, professores e alunos de instituições teológicas. Nessas cerimônias de lançamento foi apresentada a Conferência 'A Bíblia - o livro mais traduzido, distribuído e lido do mundo""1109.

A ideia que motivou tais encontros era apresentar, discutir e explicar aos participantes como o projeto se desenvolveu e qual era a importância dele para a igreja brasileira. Como foi possível perceber, o caminho foi longo e árduo. De fato, até os dias de hoje, por vezes, a tradução é criticada, polemizada ou rejeitada. “Alguns, é bem verdade, nunca entenderão, porque não querem entender"1110. Ainda assim, considerando a extensão da difusão de Bíblias realizada pela SBB, atualmente, a NTLH é a tradução bíblica que mais cresce em distribuição no Brasil. Em 2016 ela representou cerca de 34\% do total de Bíblias distribuídas pela SBB. A questão que se põe sobre essa tradução é adequadamente percebida e comentada por Malzoni, quando afirma que a NTLH é um "contraponto à tradução de João Ferreira de Almeida, uma vez que essa nova iniciativa buscou suprir o que aparecia como uma lacuna na tradução de Ferreira: a linguagem distante do modo de falar da maioria da população brasileira" ${ }^{1111}$. Por assim ser, muitas igrejas passaram a adotar a NTLH como a tradução oficial na liturgia e no material de estudo bíblico. A Igreja Evangélica Luterana do Brasil (IELB) é um exemplo.

No ano de 2005, a Editora Paulinas, uma editora católica, lançou uma Bíblia com a NTLH. No prefácio, há uma declaração de duas autoridades católicas da

\footnotetext{
1108 TEIXEIRA, Paulo. Traduções da Bíblia: história, princípios e influência. In: ZIMMER, Rudi (Org.). Manual do Seminário de Ciências Bíblicas, p. 59.

${ }^{1109}$ GIRALDI, Luiz Antonio. História da Bíblia no Brasil, p. 267.

1110 SCHOLZ, Vilson. 40 anos de Bíblia na Linguagem de Hoje, p. 7.

${ }^{1111}$ MALZONI, Cláudio Vianney. As edições da Bíblia no Brasil, p. 85.
} 
época: o presidente da CNBB e o presidente da Comissão Episcopal Pastoral para a Animação Bíblico-Catequética. A introdução realizada por ambos procurou incentivar o uso dessa tradução por parte dos católicos. Giraldi e Malzoni destacam que a SBB cedeu os direitos da publicação à Editora Paulinas dos livros canônicos que são normalmente publicados pela organização. Já os textos deuterocanônicos, publicados principalmente em edições católicas da Bíblia, foram cedidos pelas SBU, que em certos países publicam Bíblias com os livros deuterocanônicos ${ }^{1112}$. O imprimatur para o uso dessa tradução pelos católicos brasileiros foi concedido em 29 de setembro de 2005, pelo Dom Eugênio Rixen, então presidente da Comissão Episcopal Pastoral para a Animação Bíblico-Catequética da CNBB e do Cardeal Geraldo Majella Agnello, presidente da CNBB à época ${ }^{1113}$.

\subsubsection{4 O desafio de tradução para as línguas indígenas e minoritárias do Brasil}

Para Scholz, todo projeto de tradução da Bíblia deve "nascer no contexto da missão"1114. De fato, historicamente, todas as vezes que a igreja cristã empreendeu o esforço missionário pelo mundo, emergiu, concomitantemente, a necessidade de se traduzir as Escrituras para o povo-alvo da missão. Como visto, John Eliot, entre os índios da América, e William Carey, entre os povos da Índia, são exemplos dessa realidade. E essa é, aliás, uma diferença do cristianismo, em detrimento de muitas outras religiões. Deus, como reconhecido no cristianismo, fala a linguagem do povo por meio da tradução bíblica. Para a fé cristã, principalmente de viés protestante, não há sentido em um deus que se utiliza de uma linguagem sagrada incompreensível e distante. A encarnação de Cristo é um verdadeiro paradigma sobre a necessidade de se contextualizar a mensagem $($ Jo 1,14$)$.

A questão que se põe é: de que tipo de missão se está falando? Historicamente, "falar de missão era falar de missão transcultural"1115, ou seja, equivocadamente muitos pensam que, para se realizar a missão, se faz necessário se deslo-

1112 Cf. GIRALDI, Luiz Antonio. História da Bíblia no Brasil, p. 306; MALZONI, Cláudio Vianney. As edições da Bíblia no Brasil, pp. 85-86.

${ }^{1113}$ Cf. BÍBLIA Sagrada. Português. Nova Tradução na Linguagem de Hoje. São Paulo: Paulinas Editora, 2005, p. 2. Imprimatur: Carta protocolar CNBB SG - no. 0051/03.

1114 SCHOLZ, Vilson. 40 anos de Bíblia na Linguagem de Hoje, p. 9.

1115 PADILHA, Carlos René. O que é Missão Integral? Viçosa, MG: Editora Ultimato, 2009., p. 19. 
car para outras nações, outro continente, outra cultura etc. Por meio dessa visão reducionista da missão, muitas vezes, se esquece de olhar dentro da própria cultura, do próprio país, onde há a necessidade da mensagem de Cristo ser anunciada e vivida. É justamente nessa perspectiva que pelo menos dois aspectos se sobressaem em termos de tradução e difusão das Escrituras: o trabalho entre os povos indígenas e os grupos linguísticos minoritários que vivem no Brasil. Ambos constituem um significativo desafio.

De acordo com os dados do último Censo Demográfico realizado pelo Instituto Brasileiro de Geografia e Estatística (IBGE), em $2010^{1116}$, a população indígena no Brasil é formada por aproximadamente 900 mil indígenas, contemplados em 305 etnias diferentes, vivendo em todas as regiões do Brasil. Toda essa população, ainda que relativamente pequena se comparada ao todo da população brasileira, fala por volta de 274 línguas diferentes. Ainda que, conforme se constatou no censo, muitos destes indígenas falem o português, cerca de $37 \%$ deles falam apenas a língua indígena. Traduzir as Escrituras Sagradas, sob a ótica de se levar a Bíblia a todos, numa linguagem que possam entender, constitui, portanto, um significativo desafio no trabalho de difusão das Escrituras entre os povos indígenas.

A maioria destas línguas está ligada apenas à oralidade, ou seja, não possui um registro formal escrito ${ }^{1117}$. Tal fato amplia ainda mais a dificuldade, pois, para se traduzir a Bíblia, nestes casos, haverá a necessidade de transformar uma língua ágrafa ${ }^{1118}$ em uma língua gráfica, ou seja, será necessário construir toda uma estrutura gramatical e linguística para que, posteriormente, se possa alfabetizar os indivíduos e traduzir as Escrituras. Esse trabalho pode levar muito tempo, muitas décadas. Pode ser um projeto para uma vida toda; afinal,

Aprender uma língua é algo mais do que uma simples habilidade mecânica de reproduzir sinais acústicos como se fosse para conseguir vender uma mercadoria ou encontrar a via de saída. É um processo pelo qual nós fazemos contatos vitais com uma nova comunidade, uma nova maneira de viver e um novo sistema de pensa-

\footnotetext{
1116 Cf. INSTITUTO BRASILEIRO DE GEOGRAFIA E ESTATÍSTICA. Os indígenas no Censo Demográfico 2010. Rio de Janeiro: IBGE, 2012, p. 12.

1117 Cf. FRANCHETTO, Bruna. A guerra dos alfabetos: os povos indígenas na fronteira entre o oral e o escrito. Mana, Rio de Janeiro, v. 14, n. 1, p. 31-59.

1118 A expressão "língua ágrafa" é utilizada para se referir a uma língua que não tem uma escrita ou um alfabeto. Não há nada escrito nessa língua.
} 
mento. Conseguir isso da melhor maneira é o requisito básico da efetiva tarefa missionária ${ }^{1119}$.

No entanto, para além do aspecto da fé e da missão, tal trabalho constitui, concomitantemente, o resgate e a valorização da cultura e da língua. O registro por escrito da língua falada garantirá a continuidade daquela língua para as próximas gerações. Afinal, como se constatou nos dados do Censo, muitos indígenas já estão abandonando sua língua nativa para falarem o português. Por isso, como bem afirmou Franchetto em sua pesquisa, “onde estiverem presentes os evangélicos, eles a seu modo 'preservam' o uso das línguas indígenas" ${ }^{1120}$. Sendo assim, o trabalho de difusão das Escrituras entre os povos indígenas vai muito além da religião. Trata-se de um trabalho que valoriza e dignifica ao indígena, a sua cultura, a sua história, a sua língua.

Pelo caráter de sua missão e pela compreensão de que a tradução bíblica constitui uma atividade-chave em seu trabalho, a SBB tem se envolvido e contribuído, ainda que de forma bem tímida, com a tradução da Bíblia para os povos indígenas. Diante das dificuldades e limitações pelos fatos descritos acima, o trabalho é realizado em parceria e cooperação com outras instituições que trabalham diretamente com a tradução, tais quais: Associação Linguística Evangélica Missionária (ALEM), Sociedade Internacional de Linguística (SIL), Missão Novas Tribos do Brasil, Jovens com uma missão (JOCUM), Conselho Nacional de Pastores e Líderes Indígenas (CONPLEI), Missão Evangélica da Amazônia (MEVA) e Missão Evangélica aos Índios do Brasil (MEIB) ${ }^{1121}$.

A SBB normalmente participa nas etapas mais avançadas do projeto de tradução. Esse trabalho envolve consultoria, pois normalmente os projetos utilizam as traduções da SBB em português como textos-base, especialmente a NTLH. Depois que a tradução está finalizada, a SBB contribui com a diagramação e a impressão do texto ${ }^{1122}$. Diante da escassez de recursos, situação muito comum à maioria das organizações missionárias, essa etapa é fundamental para que a Bíblia se torne, de fato, disponível e acessível aos povos indígenas.

\footnotetext{
${ }^{1119}$ NIDA, Eugene. Learning a foreign language. Cincinnati: Friendship Press, 1957, p. 8 (tradução de Bruna Franchetto).

${ }^{1120}$ FRANCHETTO, Bruna. A guerra dos alfabetos: os povos indígenas na fronteira entre o oral e o escrito. Mana, p. 36.

1121 TIMM, Denis. Projetos de Tradução em Línguas Indígenas [mensagem pessoal]. Mensagem recebida por<denis@sbb.org.br>em 13 dez. 2017.

1122 Ibid.
} 
Segundo informações publicadas pela SBB em seu site,

Já existem no Brasil, hoje, quatro Bíblias completas em línguas indígenas. A primeira foi a Bíblia em Waiwai (2002), e a mais recente é a Bíblia em Kaingang (2012). Além disso, o Novo Testamento já está traduzido em mais 40 línguas indígenas $^{1123}$.

Atualmente existem projetos de tradução em andamento. A mais recente tradução das Escrituras para uma língua indígena no Brasil ocorreu por meio da publicação do Novo Testamento na língua Jamamadi, que reúne aproximadamente 400 falantes situados na área do Média Purus, próxima à cidade de Labrea, no estado do Amazonas ${ }^{1124}$. Como se constata, independemente da quantidade de pessoas, a ênfase nesse tipo de projeto se dá na disponibilização da Bíblia a todos, onde quer que eles estejam e, obviamente, numa linguagem que possam entender.

Além do português e das línguas indígenas, existem outras línguas que também são faladas no Brasil. Como visto anteriormente, durante o Brasil Império, houve políticas específicas que fortaleceram a migração de vários povos para o Brasil. E assim, os séculos XIX e XX ficaram caracterizados pela chegada de portugueses, italianos, espanhóis, árabes, japoneses, alemães, poloneses, ucranianos etc. no país. Esses povos, junto a outros não relacionados, contribuíram significativamente com a formação do povo brasileiro ${ }^{1125}$. Atualmente, o Brasil é um país misto e plural, justamente porque passou por uma ampla mescla de povos nos últimos duzentos anos de sua história. Tal realidade influenciou de forma direta e indireta nos aspectos sociais, culturais e linguísticos do país.

Ainda que a maioria tenha aprendido a língua portuguesa, é certo que muitos continuaram falando sua língua nativa ou os dialetos das regiões de onde partiram. Segundo Oliveira, existem cerca de trinta línguas de migrantes sendo faladas em várias regiões do Brasil ${ }^{126}$. É nesse ínterim que surge mais um desafio para o

\footnotetext{
${ }^{1123}$ Cf. SBB. Outras línguas brasileiras. Desenvolvido pela Sociedade Bíblica do Brasil, 2013. Apresenta informações sobre línguas de imigração, libras e indígenas faladas no Brasil. Acrescenta ainda informações sobre o processo de tradução da Bíblia para línguas minoritárias e a missão da SBB. Disponível em: <http://www.sbb.org.br/a-biblia-sagrada/outras-linguas-brasileiras/>. Acesso em 27 nov 2017.

${ }^{1124}$ Cf. ABNB. Valorização da língua e da cultura. Revista A Bíblia no Brasil, n. 257, ano 69, dez. 2017-fev.2018, p. 27.

${ }^{1125}$ Cf. RIBEIRO, Darcy. O povo brasileiro: a formação e o sentido do Brasil. São Paulo: companhia das Letras, 1995, pp. 19-21 et seq.

${ }^{1126}$ Cf. OLIVEIRA, Gilvan Müller de. Plurilinguismo no Brasil: repressão e resistência linguística. Synergies Brésil n 7 - 2009, p. 20.
} 
trabalho de difusão das Escrituras. Torna-se necessário disponibilizar a Bíblia também para esses povos.

Ainda que não se tenha dados estatísticos com a precisão que se deveria, entre as várias línguas de imigração faladas no Brasil, uma delas é o alemão, que, em terras brasileiras, passou a ser falado em duas de suas vertentes principais: o hunsrik (ou hunsrückisch) e o pomerano ${ }^{1127}$. Assim como muitas línguas indígenas, esses dois dialetos são ágrafos, isto é, não há registros de escrita. Equivocamente se poderia argumentar que uma Bíblia traduzida para o alemão atenderia a necessidade desse grupo. Porém, não é bem assim. No site da SBB consta a seguinte explicação para tal fato:

Para muitos imigrantes, como os espanhóis e franceses, uma tradução feita em outro lugar ou país pode ser perfeitamente satisfatória. Não é o caso da maioria dos falantes de línguas germânicas no Brasil, particularmente o hunsrik e o pomerano. Estas são línguas do baixo-alemão e os falantes dessas línguas têm dificuldade de entender o alto-alemão ${ }^{1128}$.

Atualmente, há um trabalho de tradução bíblica para essas línguas sendo elaborado pela SBB, em parceria com outras organizações (The Seed Company; $A B S)$ e igrejas luteranas e católicas do Brasil. O projeto teve início com a publicação de histórias bíblicas ilustradas para crianças: Bibliha Aventures ${ }^{1129}$ (Aventuras Bíblicas em Pomerano) e Piiplixe Awentuure ${ }^{1130}$ (Aventuras Bíblicas em Hunsrik). Em ambas as publicações foram colocadas histórias bíblicas de reconhecidos personagens, tais quais Noé, Moisés, Sansão e Davi. No final de cada história, há uma parte com o texto traduzido também em alemão e em português. As traduções foram realizadas uma ao lado da outra, procurando, assim, auxiliar o leitor infantil no processo de alfabetização.

${ }^{1127}$ Cf. SPINASSÉ, Karen Pupp. O hunsrückisch no Brasil: a língua como fator histórico da relação entre Brasil e Alemanha. Espaço Plural, Ano IX, no 19, 20 semestre 2008, p. 117; WILLE, Leopoldo. Pomeranos no Sul do Rio Grande do Sul: trajetória, mitos e cultura. Canoas: Ed. ULBRA, 2011, passim. Segundo a própria SBB, acredita-se que existam cerca de 400 mil falantes de pomerano e cerca de 2 milhões de falantes do hunsrik.

1128 Cf. SBB. Outras línguas brasileiras. Desenvolvido pela Sociedade Bíblica do Brasil, 2013. Apresenta informações sobre línguas de imigração, libras e indígenas faladas no Brasil. Acrescenta ainda informações sobre o processo de tradução da Bíblia para línguas minoritárias e a missão da SBB. Disponível em: <http://www.sbb.org.br/a-biblia-sagrada/outras-linguas-brasileiras/>. Acesso em 27 nov 2017.

${ }^{1129}$ Cf. Bibliha Aventures. Aventuras da Bíblia em Pomerano. Barueri: Sociedade Bíblica do Brasil, 2012.

${ }^{1130}$ Cf. Piiplixe Awentuure. Aventuras da Bíblia em Hunsrik. Barueri: Sociedade Bíblica do Brasil, 2012. 
Assim como ocorre nas línguas indígenas, para além do aspecto da fé, este projeto tem sua relevância pelo fato de contribuir com a preservação da língua (e da cultura) desse povo. Nesse sentido, mesmo tendo como foco o contexto hunsrik, Spinassé contribui também por inferência em relação ao dialeto pomerano, ao ressaltar a importância de projetos que resgatem a história e a cultura destes povos, marcando suas respectivas identidades, principalmente em relação à geração mais nova. Para ela,

A língua materna caracteriza o indivíduo e é estreitamente ligada com a sua identidade e sua família. Os jovens das colônias de língua alemã sabem que sua língua materna está em um patamar emotivo/familiar. Ela os liga com o "lar" (a colônia, os pais) e ainda caracteriza identidade - pessoal, não "nacional"1131.

Para quem fala qualquer uma dessas línguas, indígenas ou de migração, a língua portuguesa nunca será a língua do coração, a língua materna. Tal fato evidencia a importância do trabalho de tradução da Bíblia para estes povos. Em outro exemplo significativo, em 2004, iniciou-se mais um projeto, que contempla o idioma Calon Chibi, falado pelos ciganos no Brasil ${ }^{1132}$. Na ocasião, foi lançada a tradução do livro de Rute em parceria com a Missão Amigos dos Ciganos (MACi), a Sociedade Internacional de Linguística (SIL), a Associação Linguística Evangélica Missionária (ALEM), o Instituto Antropos e o Conselho Nacional de Pastores e Líderes Indígenas (CONPLEI) ${ }^{1133}$.

Portanto, como se pode perceber, "tornar o texto bíblico disponível aos mais diferentes públicos"1134 constitui um grande desafio. E é por isso que ele faz parte do plano de trabalho contínuo da SBB. Existem ainda outros projetos que serão descritos um pouco mais à frente, pelo fato de estarem atrelados a outros tipos de programas desenvolvidos pela organização.

Pela importância dessa atividade, destacada pela própria SBB em sua finalidade estatutária, faz-se necessário que mais projetos nestas duas áreas sejam desenvolvidos (e talvez em outras). A carência de Escrituras para as línguas indígenas e minoritárias é enorme, e a SBB poderia, sem dúvida, se engajar um pouco

\footnotetext{
${ }^{1131}$ SPINASSÉ, Karen Pupp. O hunsrückisch no Brasil: a língua como fator histórico da relação entre Brasil e Alemanha. Espaço Plural, p. 126.

${ }^{1132}$ Cf. MELO, Fábio José Dantas de. Os ciganos de Mambaí: a sobrevivência de sua língua. Brasília: Thesaurus Editora, 2006, passim.

${ }^{1133}$ Cf. ABNB. O livro de Rute para os ciganos. Revista A Bíblia no Brasil, n. 240, ano 65, jul-dez 2013, p. 12.

${ }^{1134}$ SOCIEDADE BÍBLICA DO BRASIL. Plano Nacional de Trabalho 2017, p. 9.
} 
mais intensamente nesta tarefa. Seria um grande ganho para a causa da Bíblia no Brasil.

\subsubsection{2}

\section{Disponibilidade por meio de publicações da Bíblia}

Por ser uma organização reconhecida por suas publicações, resta óbvio que disponibilizar as Escrituras por meio de edições diversificadas do texto bíblico constitui parte importante de seu trabalho. Seu estatuto, nesse sentido, ressalta que, para cumprir sua missão, a SBB deverá:

Traduzir, revisar, publicar, comercializar, difundir a Bíblia e sua mensagem, sem fins lucrativos, bem como outros conteúdos de apoio e incentivo à leitura, pesquisa e compreensão da mensagem bíblica, por meios impressos, audiovisuais, eletrônicos e digitais, incluindo o desenvolvimento e a distribuição de conteúdos multimídia e afins, por si ou em cooperação com pessoas físicas ou jurídicas, respeitada sua linha editorial, definida no Regimento Interno; Desempenhar atividades editoriais e gráficas de impressão e encadernação do Livro Sagrado, a Bíblia, e outros produtos e conteúdos correlatos ${ }^{1135}$.

Os aspectos destacados na citação acima evidenciam a amplitude e a complexidade de tal trabalho de publicação das Escrituras. $\mathrm{O}$ foco em cada edição publicada deverá ser sempre a Bíblia e sua mensagem. O objetivo é fazer com que o leitor se sinta instigado a ler as Escrituras, conhecer e entender o que ela ensina, para que, assim, possa aplicá-la em sua vida. É por isso que o lema da organização se fundamenta em semear a Palavra que transforma vidas.

Um aspecto que também se destaca é que a finalidade principal de suas publicações não é pura e simplesmente o lucro. Não se trata, portanto, de um aspecto mercadológico. É claro que, sem ingenuidades, até mesmo para a manutenção da organização e da própria missão, os aspectos econômicos e financeiros são considerados. Isso ocorre em qualquer organização, principalmente por causa da atual lógica de mercado que está em vigor na sociedade.

A questão é que o aspecto comercial ou mercadológico não pode ditar os rumos do que se deve publicar. Como se perceberá mais à frente, muitas das publicações existentes não têm foco comercial. Elas são realizadas por causa da missão de difundir a Bíblia e sua mensagem. Afinal, ainda que houvesse uma real possibilidade, seria muito difícil um cego pagar por uma Bíblia em braile que cus-

${ }^{1135}$ SOCIEDADE BÍBLICA DO BRASIL. Estatuto 2015, p. 2 (grifos nossos). 
ta, em sua edição popular, aproximadamente $\mathrm{R} \$ 1.400,00$. Seria muito pretensioso achar que uma porção infantil na língua pomerana ou indígena poderia dar lucro. Essas, entre outras publicações, evidenciam que a difusão da Bíblia não focada no lucro direciona a causa da Bíblia levada à frente pela SBB no país. Ademais, a SBB é uma organização sem fins lucrativos. Ainda que se busque o equilíbrio ou o crescimento financeiro, todo o valor proveniente das vendas deverá ser revertido e aplicado na própria missão.

Outro aspecto destacado em seu estatuto é a necessidade de que suas publicações estejam de acordo com a sua linha editorial. Historicamente, já se constatou que o trabalho das Sociedades Bíblicas busca atender todas as igrejas. Em seu trabalho atual fica evidente que a SBB não pertence individualmente a nenhuma denominação; ela pertence a todas. A composição de sua governança evidencia bem essa realidade, visto ser formada por pessoas (líderes e leigos) de várias igrejas e de várias regiões do país ${ }^{1136}$. Ela foi criada por várias igrejas e, em sua gênese, está o princípio de servi-las. Por isso, “a SBB afirma que a interpretação doutrinária das Sagradas Escrituras é da competência das igrejas" ${ }^{1137}$. Seu trabalho é interconfessional e, portanto, suas publicações devem estar em harmonia para atender às necessidades das igrejas cristãs no Brasil. Sem dúvida, esse é um desafio e tanto.

As questões doutrinárias e teológicas que separam as igrejas entre católicas e evangélicas, e as segmentam entre históricas, pentecostais, neopentecostais, independentes etc., evidenciam a grande dificuldade de realizar tal trabalho. Ainda assim, a SBB tem conseguido atender a grande maioria das igrejas, contempladas em todas as categorias delineadas acima. Suas traduções são amplamente utilizadas por quase todas as igrejas no Brasil ${ }^{1138}$. Sua capacidade de se manter neutra

\footnotetext{
${ }^{1136} \mathrm{Na}$ atual Assembleia Administrativa (2015-2018) da organização, representada por membros da Diretoria, do Conselho Consultivo, do Conselho Fiscal, do Conselho da Gráfica e dos Diretórios Estaduais existem mais de 25 denominações representadas, incluive com participação católica. ${ }^{1137}$ SOCIEDADE BÍBLICA DO BRASIL. Estatuto 2015, p. 2.

1138 Cf. CESAR, Marilia de Camargo. Igrejas do Brasil transformam SBB em líder global do mercado. Valor Econômico. São Paulo, 20 jan 2017. A NTLH, por exemplo, é utilizada por igrejas protestantes (históricas, pentecostais e neopentecostais) e, individualmente, por católicos, com o Imprimatur concedido pelas autoridades eclesiásticas da Igreja Católica na Bíblia lançada pela Editora Paulinas. A tradução de Almeida (ARC, ARA ou NAA) são utilizadas tanto por protestantes históricos quanto por evangélicos pentecostais e neopentecostais. Até mesmo algumas religiões ou igrejas consideradas pseudo-cristãs utilizam a tradução de Almeida, como, por exemplo, a Ciência Cristã e os mórmons.
} 
em sua linha editorial tem permitido que a SBB mantenha diálogo com as diferentes denominações e serviço para muitas igrejas de forma eficaz.

É importante lembrar que, desde o início, para evitar justamente as dificuldades doutrinárias, as Sociedades Bíblicas haviam decidido publicar Bíblias sem notas e comentários ${ }^{1139}$. É lógico que, passados mais de duzentos anos, a situação mudou. Giraldi faz uma apropriada síntese histórica destes fatos ao destacar que

\begin{abstract}
Quando as primeiras Sociedades Bíblicas foram organizadas, no início do século XIX, elas decidiram publicar a Bíblia "sem notas e comentários". O objetivo dessa medida foi não interferir na interpretação do texto bíblico. A primeira Bíblia em português na tradução de Almeida publicada pela SBBE em 1819 não incluía nenhuma ajuda aos leitores. O mesmo ocorreu com a Bíblia na tradução de Figueiredo, editada pela SBBE a partir de 1821. Durante todo o século XIX, tanto as Bíblias como os Novos Testamentos da SBBE foram publicados sem nenhum tipo de auxílio para o leitor. [...] A partir de 1880, porém, a SBBE começou a publicar a Bíblia com ajudas ao leitor. [...] E a partir da década de 1980, a SBB passou a publicar Bíblias de Estudo, com diversas ajudas ao leitor ${ }^{1140}$.
\end{abstract}

Atualmente, portanto, a SBB consegue transitar com certa tranquilidade entre as mais diversas igrejas, mantendo em seu catálogo um número significativo de Bíblias que possuem, concomitantemente, traduções bíblicas imparciais (ARC, ARA, NAA ou NTLH) atreladas a notas e comentários que podem ser doutrinariamente neutros, com leve tendência doutrinária ou totalmente doutrinários. Normalmente, as Bíblias com tendências teológicas confessionais são publicadas em coedição com editoras cristãs das mais variadas igrejas e/ou convergências teológicas no Brasil ${ }^{1141}$. A SBB procura dividir da seguinte forma este tipo de publicação:

[Bíblia Temáticas] São Bíblias cuja ênfase não é somente o estudo do texto bíblico, mas também a meditação e a aplicação pessoal. Tem como foco um determinado tema ou público. Seus auxílios são mais indicados para a meditação e a aplicação pessoal. Em geral, seus recursos estão relacionados a um tema ou são voltados a um público específico. [Bíblias de Estudo] São Bíblias que oferecem variados recursos para que o leitor se aprofunde no estudo do texto bíblico e aumente seu conhecimento. Trazem um grande conjunto de recursos e auxílios. As notas de estudo podem ou não ter conotação doutrinária. São indicadas para o estudo aprofundado da Palavra de Deus ${ }^{1142}$.

\footnotetext{
${ }^{1139}$ CF. STEER, Roger. Good News for the World, 200 years of making the Bible heard, p. 80.

${ }^{1140}$ GIRALDI, Luiz Antonio. A Bíblia no Brasil Império, pp. 309-310.

${ }^{1141}$ SOCIEDADE BÍBLICA DO BRASIL. Bíblias de Estudo: diferenças e diferenciais. Barueri: Sociedade Bíblica do Brasil, [201], p. 5-6.

${ }^{1142}$ Ibid., p. 6.
} 
Atualmente, as Bíblias de estudo e as Bíblias temáticas constituem um diferencial quando se analisa as publicações das mais diferentes organizações que trabalham com edições da Bíblia. Pela credibilidade que a SBB tem junto às igrejas cristãs do país, suas Bíblias são reconhecidas e amplamente utilizadas entre os mais diferentes públicos ${ }^{1143}$. Considerando a advertência de Konings sobre o fato de que "precisamos também de boas bíblias de estudo"1144, esse é um trabalho desenvolvido pela SBB que é teológicamente importante.

Paralelamente, um nicho em que a SBB conseguiu realizar um importante trabalho de serviço às igrejas "desde o seu lançamento é o da publicação de Bíblias voltadas às comemorações especiais"1145. Trata-se do projeto Bíblia de Afinidades. Para realizar tal publicação, as igrejas escolhem uma tradução de preferência, seja ela ARA, ARC, NAA ou NTLH. Porém, a publicação ganha um destaque especial ao receber, em um encarte separado do texto bíblico, informações e imagens específicas de cada denominação. Esse projeto tem servido muitas igrejas, as quais encontram neste tipo de publicação uma forma de ressaltar a importância e a centralidade das Escrituras em sua história, sem deixar de comemorar, ao mesmo tempo, um fato histórico importante, como, por exemplo, datas de bodas e jubileus ( 25 anos, 50 anos etc.).

Sob um viés sociológico, o mundo religioso de forma geral é muito plural $^{1146}$. No mundo cristão protestante, em particular, o surgimento de várias igrejas, sob diferentes tipos de teologias e denominações (históricas, tradicionais, pentecostais, neopentecostais etc.) evidenciam uma fragmentação intensa e significativa da fé evangélica. Já se constatou as possíveis causas desses fatos no segundo capítulo desta pesquisa. Nesse sentido, difundir as Escrituras de forma concomitante a todas as igrejas e a todas as pessoas nesse emaranhado contexto religioso constitui um verdadeiro desafio.

Acrescida a esta realidade, principalmente quando se procura analisar aspectos de publicações, se torna praticamente impossível não se referir às questões de mercado e marketing. Ainda que a missão sobreponha o aspecto comercial no trabalho bíblico desenvolvido pela SBB, a lógica de mercado também se faz pre-

${ }^{1143}$ Cf. CAMPOS, Leonildo Silveira. Bíblias no Mercado: o poder dos consumidores e a competição entre os editores - o caso da Sociedade Bíblica do Brasil. Rever, pp. 35-61.

${ }_{1144}$ KONINGS, Johan. Tradução e traduções da Bíblia no Brasil, p. 236.

${ }^{1145}$ CAMPOS, Leonildo Silveira. Op. cit., p. 54.

${ }^{1146}$ Cf. GERONE JUNIOR, Acyr de. Sociologia da religião: introdução, história, perspectivas e desafios contemporâneos. Curitiba: Intersaberes, 2017, pp. 162-166. 
sente $^{1147}$. É nessa perspectiva que o conceito de segmentação passa a ser um critério na forma de se publicar as Escrituras. Aliás, segmentação é um conceito que está em voga na atualidade nos mais diferentes tipos de nichos, incluindo, obviamente, o mercado editorial ${ }^{1148}$.

É justamente nessa perspectiva que, em termos de publicações, uma forma específica de se desenvolver o trabalho bíblico se torna imprescindível. Faz-se necessário segmentar a publicação, o meio e o público-alvo. O estatuto da SBB ressalta tal percepção quando afirma que a organização procura "publicar a Bíblia em idiomas e meios que todas as pessoas possam acessar e entender"1149. De fato, tal forma de se realizar o trabalho de difusão das Escrituras está no cerne das atividades planejadas e realizadas pela SBB.

Como exemplo, no Relatório Nacional de Atividades 2016, destacou-se o fato de que "a SBB lançou, em 2016, perto de 100 títulos"1150. Já no Plano Nacional de Trabalho 2017 consta a informação de que "para tornar o texto bíblico disponível aos mais diferentes públicos, a SBB planejou para 2017 mais de 40 títulos" ${ }^{1151}$. Em ambos os documentos, o público-alvo é formado por crianças, adultos, estudantes, pessoas com deficiência, famílias, jovens, entre outros públicos. Trata-se de uma quantidade significativa de Escrituras para atender um número amplo de pessoas.

A segmentação pode acontecer no design da publicação, por meio de capas com desenhos de surfistas, de skatistas, com cor "rosa-choque", toda florida etc., ou por meio do conteúdo, elaborado "com comentários para ajudar a família, as mulheres, os homens de negócios, crianças e adolescentes”, conforme destaca Cesar em ambos os casos ${ }^{1152}$. O meio, impresso ou digital, também é segmentado de acordo com o uso que se pretende dar à publicação. Um exemplo bem claro,

1147 Cf. CAMPOS, Leonildo Silveira. Bíblias no Mercado: o poder dos consumidores e a competição entre os editores - o caso da Sociedade Bíblica do Brasil. Rever, pp. 36, 45-59; CESAR, Marilia de Camargo. Igrejas do Brasil transformam SBB em líder global do mercado. Valor Econômico. São Paulo, 20 jan 2017.

${ }^{1148} \mathrm{Cf}$. ROSA, José Antonio. Análise do livro como produto e como negócio no contexto brasileiro atual: referências para a estratégia de marketing e comunicação na indústria editorial e para decisões de fomento e difusão do livro, no âmbito governamental e institucional. Tese de Doutorado em Ciências da Comunicação. São Paulo: Universidade de São Paulo, Escola de Comunicações e Artes, 2008, pp. 62-64.

1149 SOCIEDADE BÍBLICA DO BRASIL. Estatuto 2015, p. 1.

${ }^{1150}$ Id. Plano Nacional de Trabalho 2017, p. 11.

${ }^{1151}$ Id. Relatório Nacional de Trabalho 2016, p. 9.

1152 CESAR, Marilia de Camargo. Igrejas do Brasil transformam SBB em líder global do mercado. Valor Econômico. São Paulo, 20 jan 2017. 
que será melhor analisado à frente, é o download das Escrituras por meio de aplicativos.

Portanto, a escolha do que se publicar não é arbitrária. Muito menos se limita ao aspecto mercadológico. A escolha por publicações procura atender às necessidades da igreja e da sociedade. Para se ter ideia, o atual catálogo de produtos da organização, que prioriza quase que totalmente publicações da Bíblia ou de edições que tenham total relação com as Escrituras (Dicionário Bíblico, Atlas Bíblico, Manual Bíblico, Porção Bíblica etc.) apresenta, na edição do segundo semestre de 2017, cerca de 460 itens que são atualmente publicados, subdivido nas seguintes categorias ${ }^{1153}$ : Bíblias, Bíblias de Estudo e Temáticas, Novos Testamentos, Acadêmicos, Infantis, Juvenis, Livretos, Folhetos e Digital.

Nele constam alguns best-sellers, como a Bíblia da Mulher, uma das publicações temáticas/de estudo de maior distribuição pela organização, já há muitos anos. Mas constam também publicações que procuram apoiar o trabalho no contexto missionário, evangelístico e social, nos quais as igrejas estão inseridas. Existem Bíblias a valores subsidiados (a R \$ 3,00), por exemplo. Já outros se limitam a públicos bem específicos, como os materiais acadêmicos. As Sociedades Bíblicas, por meio da Sociedade Bíblia da Alemanha, possuem o direito de publicação dos textos nas línguas originais em hebraico (Biblia Hebraica Stuttgartensia) e grego (The Greek New Testament), ambas utilizadas para o estudo teológico e para a elaboração de traduções em línguas vernáculas. Na edição do catálogo de 2018, consta, por exemplo, a Biblioteca Acadêmica SBB, que contempla quatro obras de relevância teológica, a saber: Biblia Hebraica Stuttgartensia, Septuginta, Biblia Sacra Vulgata e O Novo Testamento Grego ( $5^{\text {a }}$ edição revisada).

Tanto no Relatório Nacional de Atividades 2016 quanto no Plano Nacional de Trabalho 2017 constam uma variedade de publicações que procuram ajudar as pessoas a interagir com as Escrituras a partir da realidade por elas vivenciadas, publicações estas que, concomitantemente, procuram contribuir com a igreja em sua missão. São elas:

- Publicações com enfoque nas questões de dependência química, sexual, emocional, como a Bíblia de Estudo Despertar, Bíblia e Guia Celebrando a Recuperação;

${ }^{1153}$ Cf. SOCIEDADE BÍBLICA DO BRASIL. Catálogo de Produtos SBB. Barueri: Sociedade Bíblica do Brasil, 2017, pp. 9-93. 
- Publicações com enfoque na vida cristã diária e seus desafios, como a Bíblia Bom dia;

- Publicações com enfoque em situações difíceis e desafiadoras que jovens e adolescentes estão enfrentando, como a Bíblia Extreme Teen, o livreto GPS - Encontre sua vocação (dúvidas sobre o futuro), o livreto Não Morda a Isca (sobre pornografia) etc.;

- Publicações com auxílios homiléticos e exegéticos para obreiros, como a Bíblia do Pregador, a Bíblia do Obreiro etc.;

- Publicações de interação e atividades com crianças, como Salmos para colorir, a Bíblia do bebê etc.;

- Publicações temáticas, como a Bíblia de Estudo da Reforma, a Bíblia da Escola Bíblica etc.;

- Publicações missionárias, como a Bíblia Sagrada Mude o Brasil pela Bíblia, que traz um encarte com valores-chave (textos bíblicos) para a transformação da sociedade (educação, respeito, solidariedade, dentre outros), a Bíblia Missionária de Estudos etc.

São muitas as publicações e, por isso, considerando o enfoque estabelecido nesta pesquisa, não haveria como relacioná-las todas. Acima se destacou somente algumas das publicações lançadas em 2016. Historicamente, até a década de 1990, as publicações giravam em torno de poucos modelos de Bíblias. Era um tempo mais de reimpressão daquilo que já existia (sobretudo Bíblias em encadernações simples, normalmente de capa preta, na tradução de Almeida). De lá para cá, muita coisa mudou. $\mathrm{O}$ que de fato se constata atualmente é a perspectiva missionária e teológica que norteia as publicações realizadas pela organização. O trabalho se desenvolve por meio da descoberta de necessidades e oportunidades que podem ser "traduzidas" em publicações e programas que venham a impulsionar a causa da Bíblia. De fato, como é possível perceber, trata-se de uma relevante e significativo trabalho de difusão da Escrituras no Brasil, em apoio e serviço às igrejas e aos cristãos. 


\subsubsection{3 Disponibilidade por meio da produção das Escrituras Sagradas: a Gráfica da Bíblia}

Por mais de cento e trinta anos, as Bíblias distribuídas no Brasil pelas Sociedades Bíblicas (SBBE, SBA e SBB) foram produzidas fora do país. Tal fato decorre da realidade histórica que se vivenciou durante um longo período. Inicialmente (e por muito tempo), o Brasil, numa condição de colônia, não tinha estrutura nem autorização de Portugal para realizar o trabalho gráfico no país. O atraso em relação à Europa e aos Estados Unidos era um problema. Tal realidade mudou com a chegada do governo imperial, em 1808, quando oficialmente foi implantada a primeira tipografia, por intermédio de um decreto régio. As primeiras impressões foram do jornal A Gazeta do Rio de Janeiro. Porém, a primeira impressora offset (necessária para a impressão gráfica) só chegou ao Brasil em $1922^{1154}$.

Giraldi ${ }^{1155}$ destaca que, por vezes, na história do trabalho bíblico realizado no Brasil, ocorreram tentativas de se produzir Bíblias no país. As dificuldades surgidas na Primeira e na Segunda Guerra Mundial tinham evidenciado o quanto era prejudicial para a difusão bíblica brasileira a dependência de produções no contexto estrangeiro. Como exemplo, durante as duas guerras, a propagação das Escrituras foi prejudicada no mundo, e também no Brasil.

Logo após sua fundação, “a SBB imprimiu suas primeiras Bíblias no Brasil, em 1956" "1156. Com o passar dos anos, porém, a indústria gráfica brasileira se deteriorou, e a qualidade das Bíblias produzidas no país, principalmente na década de 1990, era bem inferior quando comparada ao que existia fora do Brasil. Só que este não era o problema principal. A igreja evangélica brasileira cresceu entre as décadas de 1970 e $1990^{1157}$ e, assim, a necessidade de Escrituras também aumentava.

Esse crescimento vertiginoso da distribuição da Bíblia no Brasil começou a ser ameaçado, nos anos seguintes [depois do início dos anos 1970], pela limitada capacidade de impressão e encadernação das gráficas brasileiras. No início da década

\footnotetext{
1154 ABRIGRAF. História. Desenvolvido pela Associação Brasileira da Indústria Gráfica, 201 ? Apresenta a história do setor gráfico no Brasil desde 1808 até 2015. Disponível em: <http://www.abigraf.org.br/historia>. Acesso em 17 nov 2017.

1155 Cf. GIRALDI, Luiz Antonio. História da Bíblia no Brasil, p. 229.

1156 Ibid., p. 229.

1157 CAMPOS, Leonildo Silveira. Os Mapas, Atores e Números da Diversidade Religiosa Cristã Brasileira: Católicos e Evangélicos entre 1940 e 2007. Revista de Estudos da Religião. Dez 2008, pp. 9-47.
} 
de 90, o parque gráfico brasileiro não tinha condições de suprir a demanda de Bíblias no Brasil. E a importação era inviável devido à instabilidade econômica do País ${ }^{1158}$.

Como se percebe, questões de tecnologia, de custo, de importação, de logística e de fabricação constituíam um desafio à continuidade do trabalho bíblico no Brasil. Se o surgimento da imprensa havia impulsionado o acesso e a publicação das Escrituras no tempo da Reforma Protestante, em outro momento, muito tempo depois, no Brasil, o efeito contrário poderia ocorrer. A tendência natural seria de queda na distribuição das Escrituras no país, algo impensado até o momento diante das perspectivas de crescimento que há anos vinham se estabelecendo no cenário brasileiro. O fato é que muitas dificuldades existentes "ocasionavam a falta de Bíblias durante boa parte do ano" ${ }^{1159}$.

Na obra História da Bíblia no Brasil, o historiador Rev. Luiz Antonio Giraldi descreve os pormenores de como o processo se desenvolveu para que pudesse existir, atualmente, uma gráfica exclusiva para a produção de Bíblias no Brasil. No início, pelas próprias condições econômicas do país e pela estrutura da SBB, tal ideia era praticamente impossível, e até mesmo inviável. Entre esboços iniciais, planos e projetos, membros das Sociedades Bíblicas Unidas chegaram a duvidar de que no Brasil fosse possível executar um projeto audacioso como o intencionado pela direção executiva da SBB no início da década de 1990. Segundo Giraldi, o projeto inicial "consistia na construção de uma gráfica capaz de produzir 2 milhões e 500 mil Bíblias por ano, em diversos formatos e diferentes tipos de encadernação, e meio milhão de Novos Testamentos"1160.

Apesar das muitas dificuldades e dos ajustes necessários durante todo o projeto, com o apoio de Sociedades Bíblicas coirmãs, de igrejas e cristãos brasileiros, o que era um desejo distante e quase impossível se tornou realidade. A construção aconteceu entre 1992 e 1995. E assim,

Na tarde do dia 2 de setembro de 1995, a Sociedade Bíblica do Brasil (SBB) viveu um momento especial em sua história. Depois de quatro anos de muita oração, planejamento e trabalho, estava sendo inaugurada a Encadernadora da Bíblia, que, poucos anos depois, seria transformada na Gráfica da Bíblia, o maior empreendimento gráfico destinado à produção da Bíblia na América Latina ${ }^{1161}$.

\footnotetext{
${ }^{1158}$ GIRALDI, Luiz Antonio. História da Bíblia no Brasil, p. 229.

${ }^{1159}$ Ibid., p. 230.

${ }^{1160}$ Ibid.

${ }^{1161}$ Ibid., p. 240.
} 
Nesses mais de vinte anos da Gráfica da Bíblia (GB), pode-se perceber que assim como a imprensa estimulou a difusão das Escrituras desde a sua invenção, hoje ela é uma ferramenta indiscutivelmente necessária para uma profícua difusão das Escrituras no Brasil. As publicações digitais, que há pouco tempo estão emergindo no cenário mundial, não constituem um impedimento para que o trabalho de produção física das Escrituras continue. Pelo contrário, os aspectos descritos anteriormente, ratificados pela quantidade de publicações que ora constam no catálogo da SBB, demonstram o quanto a Gráfica da Bíblia exerceu (e exerce) papel preponderante no trabalho bíblico no Brasil.

Por meio da Gráfica da Bíblia, a SBB busca desenvolver publicações que atendam às necessidades dos leitores, garantindo que a Palavra de Deus esteja disponível com qualidade, custos reduzidos e formatos adequados para diferentes necessida$\operatorname{des}^{1162}$.

De certa forma, os trabalhos de tradução, publicação e produção são indissociáveis. Como resultado do trabalho de produção de Escrituras realizado na Gráfica da Bíblia, “em 1997, a SBB conquistou o primeiro lugar em distribuição de Bíblias entre as 139 Sociedades Bíblicas nacionais ${ }^{1163}$ que operavam em mais de 200 países"1164 à época. Portanto, dois anos após a sua inauguração, a GB já se estabelecia de forma relevante e necessária para a propagação das Escrituras no Brasil.

Entretanto, para além de contribuir com a difusão bíblica no Brasil e impulsioná-la, muitos países do mundo foram igualmente beneficiados pela GB. Numa retrospectiva histórica, Giraldi destaca que a SBB iniciou o seu trabalho de apoio e de exportação das Escrituras para outros países em 1982, ocasião em que a Argentina, por estar envolvida na Guerra das Malvinas, ficou totalmente sem condições de realizar o trabalho bíblico. Na época, a SBB enviou, em forma de doação, cerca de 3 milhões e 500 mil seleções bíblicas em espanhol para o país coirmão. Nos anos que se sucederam, entretanto, devido às dificuldades de demanda de Escrituras no Brasil, somente alguns poucos projetos foram pontualmente realizados, principalmente para servir países da América Latina nas décadas de 1980 e $1990^{1165}$.

\footnotetext{
${ }^{1162}$ SOCIEDADE BÍBLICA DO BRASIL. Relatório Nacional de Trabalho 2016, p. 16.

${ }^{1163}$ Atualmente existem de 149 Sociedades Bíblicas, atuando em mais de 200 países.

${ }^{1164}$ GIRALDI, Luiz Antonio. História da Bíblia no Brasil, p. 268.

${ }^{1165}$ Ibid.
} 
A retomada histórica do serviço bíblico a outros países ocorreu um ano depois da implantação da GB. Bíblias na tradução Reina-Valera, em espanhol, foram produzidas e enviadas para várias nações vizinhas do Brasil. Considerando que nenhuma Sociedade Bíblica, daquelas localizadas em países da América Latina, tinha ${ }^{1166}$ uma gráfica específica onde pudesse produzir suas Bíblias, “com a inauguração da Gráfica da Bíblia, o Brasil se tornou a melhor opção para os países latino-americanos"1167, tanto pelo custo, quando comparado com a Europa, quanto pela proximidade geográfica.

Porém, conforme destaca Giraldi, pelo êxito que a GB conquistou no Brasil e na América Latina, a SBB "recebeu um apelo dos dirigentes das SBU para colaborar no desenvolvimento das Sociedades Bíblicas da África" ${ }^{1168}$. Entre outros, a Nigéria, desde o início, foi um exemplo do quanto a GB contribuiu com a difusão das Escrituras no continente africano. O propósito de Dar a Bíblia à Pátria, que tinha sido o lema de fundação da SBB, ganhou um novo significado. A SBB estava dando a Bíblia ao mundo. Para se ter ideia, durante o ano de 2000, a Sociedade Bíblica da Nigéria (SBN) tinha distribuído cerca de 277 mil Bíblias, principalmente na língua iorubá. Essa era a sua média anual de distribuição. O custo e as condições econômicas impediam um maior crescimento. Por meio da GB, entretanto, a SBN alcançou, em 2006, a quantidade de mais de um milhão de Bíblias distribuídas no país nas línguas hausá, igbô, iorubá e inglês ${ }^{1169}$.

Nos anos subsequentes, muitos outros países receberam o apoio da GB. Com isso, "a SBB passou a ser, a partir de 2001, o maior centro produtor de Escrituras das Sociedades Bíblicas no mundo" ${ }^{1170}$. Os dados mais recentes, de 2017, dão conta de que 107 países, que falam cerca de 30 línguas diferentes, já receberam Bíblias produzidas na Gráfica da Bíblia, da SBB ${ }^{1171}$. Segundo o atual gerente da GB, Luiz Forlim, desde 1995, quase 30 milhões de Bíblias, sem incluir Novos Testamentos ou outras publicações, já foram enviadas do Brasil para o mundo ${ }^{1172}$.

\footnotetext{
1166 Até hoje, somente a Sociedade Bíblica Colombiana possui uma encadernadora da Bíblia. A impressão é externa; já o acabamento e a encadernação ocorrem internamente.

1167 GIRALDI, Luiz Antonio. História da Bíblia no Brasil, p. 273.

1168 Ibid., p. 275.

1169 Ibid.

1170 Ibid., p. 279.

1171 SOUZA, Alessandro. Idiomas e países atendidos na GB [mensagem pessoal]. Mensagem recebida por<alessandro@sbb.org.br> em 11 dez. 2017.

1172 FORLIM, Luiz. Bíblias produzidas na GB [mensagem pessoal]. Mensagem recebida por <forlim@sbb.org.br> em 12 dez. 2017.
} 
Como se constata, quando somadas as quantidades de Escrituras produzidas para o Brasil e para o exterior, se chega a um número que evidencia o relevante trabalho de difusão das Escrituras, conforme destacado pela imprensa, em 2017, ao lembrar que "em janeiro a SBB alcançou a marca de 150 milhões de Bíblias e Novos Testamentos produzidos no acumulado desde 1995" ${ }^{1173}$. Tudo realizado na Gráfica da Bíblia. Além disso, outras organizações que publicam as Escrituras no Brasil, católicas e evangélicas, em diversos momentos utilizaram a GB para imprimir ou encardenar suas publicações ${ }^{1174}$. Entre outros, um exemplo significativo dessa realidade se evidenvia no projeto realizado para atender uma solicitação da American Bible Society e da Libreria Editrice Vaticana. Na ocasião, a Gráfica da Bíblia da SBB imprimiu a Bíblia Polyglotta ${ }^{1175}$, uma edição completa da Bíblia em cinco idiomas (hebraico, grego, latim, inglês e espanhol), que foi utilizada e distribuída para todos os participantes do Sínodo dos Bispos sobre a Palavra de Deus, realizado no Vaticano em 2008.

Portanto, sob a ótica do ciclo de vida da Bíblia, a GB constitui um aspecto de vital importância para que as Escrituras continuem sendo difundidas no Brasil e no mundo.

\subsection{2 \\ 0 aspecto da acessibilidade no trabalho bíblico: distribuição e incentivo à leitura das Escrituras Sagradas no Brasil}

O processo de tradução, publicação e produção das Escrituras alcançará maior relevância se a próxima etapa do ciclo de vida da Bíblia acontecer. Nesse sentido, ao passo em que se tem a Bíblia disponível, faz-se necessário torná-la também acessível. A Palavra de Deus precisa alcançar as pessoas; ela precisa encontrar o ser humano, a família, a igreja, a sociedade. Para tanto, importa, também, que ocorra um trabalho que procure facilitar esse encontro entre as pessoas e as Escrituras. Sob a ótica do ciclo de vida da Bíblia, esse encontro pode ser insti-

${ }^{1173}$ Cf. CESAR, Marilia de Camargo. Igrejas do Brasil transformam SBB em líder global do mercado. Valor Econômico. São Paulo, 20 jan 2017.

${ }^{1174}$ Entre várias outras organizações parceiras, no segmento editorial evangélico se tem, por exemplo, as editoras Vida Nova e CPAD (Casa Publicadora das Assembleias de Deus). Já no segmento católico se tem, por exemplo, as editoras Paulus e Paulinas. Cf. FORLIM, Luiz Antonio. Parceiros [mensagem pessoal]. Mensagem recebida por <forlim@sbb.org.br>em 15 jun. 2018.

${ }^{1175}$ Bíblia Sagrada. Bíblia Polyglotta: Synodi De Verbo Dei ocasione exarata. New York; Città Del Vaticano: American Bible Society; Libreria Editrice Vaticana, 2008 
gado por, pelo menos, duas formas. As Escrituras podem ser distribuídas, mas, mais do que isso, faz-se necessário incentivar a sua leitura. Nessa perspectiva, em seu estatuto, a SBB reforça que

Sua forma de atuação busca alcançar a distribuição mais ampla possível, eficaz e significativa das Sagradas Escrituras, e ajudar as pessoas a interagir com a Palavra de Deus, a fim de promover sua transformação e desenvolvimento, em todo o território nacional ${ }^{1176}$.

Não se trata de uma distribuição aleatória, realizada de qualquer forma. A finalidade não é simplesmente mercadológica. Se assim o fosse, bastava vender, e nada mais. A missão de difundir as Escrituras vai além disso. Ela se encaixa na perspectiva do serviço, da diakonia. Trata-se de colocar a Palavra em ação para que pessoas sejam transformadas pela mensagem das Escrituras. Essa transformação pode ser no aspecto da fé, é claro; mas pode alcançar outras áreas da vida. É por isso que o trabalho é realizado por meio de uma distribuição relevante, eficaz e significativa, porque o ciclo de vida da Bíblia não termina na entrega do texto bíblico. Pelo contrário, ele se amplia quando permite que as pessoas respondam ao que as Escrituras ensinam, gerando, assim, transformação e desenvolvimento, no indivíduo e na sociedade.

\subsubsection{1 \\ Acessibilidade às Escrituras Sagradas por meio da presença}

O Brasil é um país de proporções continentais, e cada região dele possui a sua especificidade. Entre o Norte e o Sul, podem existir muitas diferenças, em muitos aspectos. O clima é diferente, o sotaque é diversificado, a cultura é plural, a economia é desigual, a condição social é excludente, e assim por diante. Tais aspectos, entre muitos outros, sempre constituíram um verdadeiro desafio para o trabalho bíblico no país.

Entre outros, Giraldi, Reily, Hahn, Léonard e Mendonça ${ }^{1177}$ descreveram os desafios que permearam a história da difusão das Escrituras no Brasil. Os primei-

\footnotetext{
1176 SOCIEDADE BÍBLICA DO BRASIL. Estatuto 2015, p. 1. (grifos nossos)

1177 Cf. GIRALDI, Luiz Antonio. A Bíblia no Brasil Império, passim; Id. A Bíblia no Brasil República, pp. 159-169; Id. História da Bíblia no Brasil, pp. 43-69; Id. Semeadores da Palavra, passim; Id. The American Bible Society in Brazil, pp. 13-50; REILY, Duncan. A história documental do Protestantismo no Brasil, pp. 76-87; HAHN, Carl Joseph. História do culto protestante no Brasil, pp. 283-293; LÉONARD, Émile-Guillaume. O protestantismo brasileiro, pp. 53-115; MENDONÇA, Antônio Gouvêa. O celeste porvir, pp. 22-27.
} 
ros missionários, agentes e colportores que desbravaram o país nos grandes centros urbanos da época, mas também nos povoados longínquos do interior do Brasil, enfrentaram muitas dificuldades. As distâncias eram grandes, os meios de transporte não eram adequados, as doenças os acometiam, o tempo distante de casa era um empecilho, os perigos de morte os rondavam etc. Nessa perspectiva, a história da difusão bíblica representa, de fato, uma história de luta e muita perseverança para que a missão fosse cumprida.

Com o passar do tempo, algumas agências bíblicas foram instaladas em regiões de difícil acesso, como, por exemplo, em cidades do Norte do país. Por outro lado, considerando as dificuldades e a própria extensão geográfica que a região amazônica apresenta, tal presença, ainda assim, era (e é) um desafio ${ }^{1178}$. O fato é que, na história da difusão das Escrituras, sempre se procurou (e se encontrou) meios que pudessem garantir o acesso às Escrituras. Por colportagem ou por agências bíblicas, a Bíblia sempre foi difundida. Atualmente, essa realidade não é diferente no trabalho da SBB.

\subsubsection{1 A adaptação histórica da colportagem bíblica para se dar acesso às
Escrituras Sagradas}

Em tempos em que não existiam livrarias ou até mesmo igrejas que pudessem distribuir Bíblias, os colportores difundiram as Escrituras em muitos lugares, de porta em porta, de cidade em cidade. No capítulo anterior, foi possível constatar o legado que aqueles homens deixaram para a causa da Bíblia no Brasil. Historicamente, aqueles primeiros colportores eram assalariados. Eles se dedicavam exclusivamente e integralmente a esta função, e, para tanto, recebiam um salário (ainda que pouco, o básico para sobreviver) depois de realizarem sua missão. Nesse sentido,

À medida que as Sociedades Bíblicas aumentavam o número de colportores, crescia também a quantidade de Bíblias distribuídas. O número de colportores contratados pelas Sociedades Bíblicas chegou ao máximo no final do século XIX. Em 1900 , elas tinham cerca de 2.000 colportores trabalhando em tempo integral em todo o mundo. E, na mesma época, a SBA e a SBBE tinham no Brasil mais de 40 colportores assalariados ${ }^{1179}$.

${ }^{1178}$ Cf. GIRALDI, Luiz Antonio. A Bíblia no Brasil Império, pp. 195-196.

${ }^{1179}$ Id. História da Bíblia no Brasil, p. 121. 
A narrativa de Giraldi está envolvida por uma certa lógica. Quanto mais pessoas trabalhando, mais resultados são obtidos. Na difusão das Escrituras não foi diferente. Entretanto, o século XX começou com muitas dificuldades. As crises econômicas e as duas guerras fizeram com que o trabalho bíblico fosse reduzido em muitos aspectos, entre eles o trabalho de colportagem. Giraldi ${ }^{180}$ ressalta que, já em 1917, somente quinze colportores estavam trabalhando no Brasil e, em 1948, data de fundação da SBB, somente cinco ainda continuavam a realizar a propagação das Escrituras de forma integral. Um deles, o baiano José Araujo, era cego e marcou a história como um dos grandes colportores da Sociedade Bíblica em seus 25 anos de trabalho. Segundo seus registros, José Araujo visitou 141 cidades $^{1181}$. Entretanto, já na década de 1950, nos primeiros anos de vida da SBB, José e todos os outros haviam se aposentado.

Diante de tal realidade, o projeto de colportagem passou por uma reestruturação. Como já na segunda metade do século XX algumas igrejas evangélicas, históricas e pentecostais, haviam se espalhado pelo Brasil, a estratégia se deu com o apoio e a contribuição das próprias igrejas. Muitas campanhas de colportagem (dois ou três dias intensivos de distribuição de Bíblias) foram realizadas em diversas igrejas, em várias regiões do país. Como se percebe, o trabalho bíblico da SBB, em toda a sua história, está atrelado à igreja em sua missão evangelizadora. Assim, ambos se apoiam na missão de difundir as Escrituras.

\begin{abstract}
Surgiram, então, os colportores das igrejas. Eles trabalhavam com tempo parcial, não recebiam salário e eram remunerados com os descontos que recebiam na compra das Escrituras. As Sociedades Bíblicas lhes davam um desconto especial na compra das Escrituras e também um prazo para pagarem. Para darem credencial de colportor, as Sociedades Bíblicas exigiam do candidato uma carta de apresentação da igreja que ele frequentava ${ }^{1182}$.
\end{abstract}

Para fortalecer tal trabalho, as Sociedades Bíblicas criaram um instituto de treinamento para os interessados na colportagem; era o Instituto Francisco Penzotti. O nome do instituto foi uma homenagem a um colportor da SBA que foi pioneiro na distribuição da Bíblia na América Latina. Essa modalidade de trabalho bíblico deu certo. As pessoas se engajavam no trabalho bíblico e, ao mesmo tempo, recebiam uma recompensa financeira pelo trabalho. Historicamente, a maioria

\footnotetext{
${ }^{1180}$ GIRALDI, Luiz Antonio. História da Bíblia no Brasil, p. 121.

${ }^{1181}$ Id. Semeadores da Palavra, pp. 241-243

${ }^{1182}$ Ibid., p. 123.
} 
dos colportores eram aposentados, seminaristas ou pessoas que precisavam complementar sua renda.

Já no final da década de 1950, surgiu outra modalidade de colportagem, denominada colportores voluntários. Giraldi pontua que esses colportores "eram crentes de igrejas evangélicas que distribuíam as Escrituras a pessoas não crentes com propósito unicamente evangelístico" ${ }^{1183}$. Não se tratava, portanto, de uma venda de Escrituras. O propósito era outro, e normalmente se distribuía um Evangelho ou um Novo Testamento. Vale a pena lembrar que mesmo os primeiros colportores, por vezes, também entregavam gratuitamente as Escrituras. Esse é um aspecto que proporciona uma melhor compreensão do porquê, até os dias de hoje, muitos cristãos, principalmente os evangélicos, compram Bíblias ou porções bíblicas para a distribuição gratuita. Trata-se de uma experiência que está na gênese do trabalho bíblico no Brasil. Mais tarde, a partir dos anos 1980, o colportor voluntário passou a ser reconhecido como sócio evangelizador. Porém, este projeto será analisado em outra etapa do ciclo de vida da Bíblia.

O trabalho dos colportores das igrejas se manteve presente por toda a história da SBB. Na atualidade, o Plano Nacional de Trabalho 2017, da SBB, destaca uma readequação do projeto, mudando, inclusive, sua designação. Denominado de Projeto Semeador, a ação se desenvolve a fim de

\begin{abstract}
Possibilitar que os ensinamentos sagrados cheguem a todas as pessoas pelas mãos dos semeadores, revendedores autônomos, que atuarão como braços da SBB na distribuição de literatura bíblica, especialmente em locais de difícil acesso. O projeto também tem cunho social, ao possibilitar uma fonte ou complementação de renda aos semeadores, além de estimular o desenvolvimento de relacionamentos e uma distribuição personalizada ${ }^{1184}$.
\end{abstract}

Pelo que parece, o Projeto Semeador resgata aspectos históricos do trabalho dos colportores, sem, no entanto, deixar de atualizar a forma de se desenvolver o trabalho na atualidade. Uma das novidades pode ser percebida no canal exclusivo criado para o colportor em seu relacionamento com a SBB ${ }^{1185}$. Atualmente, existem cerca de cinco mil pessoas cadastradas na SBB com o intuito de realizarem o

\footnotetext{
${ }^{1183}$ GIRALDI, Luiz Antonio. História da Bíblia no Brasil, p. 124.

${ }^{1184}$ SOCIEDADE BÍBLICA DO BRASIL. Plano Nacional de Trabalho 2017, p. 16.

1185 Cf. SBB. Projeto Semeador. Desenvolvido pela Sociedade Bíblica do Brasil, 2017. Apresenta informações históricas e atuais sobre como uma pessoa pode adeirir ao Projeto Semador, tornadose um revendedor de Bíblias em sua igreja ou comunidade (um colportor, um missionário da Bíblia, um semeador). Para os interessados há, também, a possibilidade de cadastrar-se no próprio site. Disponível em: 〈www.sbb.org.br/semeador〉. Acesso em 29 nov 2017.
} 
trabalho de colportagem. O fato que se destaca é que, até hoje, os colportores são pessoas imprescindíveis para fazer com que as Escrituras estejam acessíveis às pessoas, de casa em casa, em eventos, nas igrejas, no interior, nas vilas, de forma diferenciada e pessoal.

\subsubsection{2 \\ A criação de unidades regionais para se dar acesso às Escrituras Sagradas}

Historicamente, os primeiros missionários enviados para o Brasil para propagar as Escrituras chegaram ao Rio de Janeiro. Assim, obviamente, as primeiras agências das Sociedades Bíblicas também foram implantadas na cidade carioca, sede do Império à época e, depois, capital da República. Como já visto, a primeira agência foi implantada em 1856 pela SBBE. No desenvolvimento do trabalho pelo país, as cidades de Manaus e Belém ficaram marcadas por contarem, em certos momentos entre os séculos XIX e XX, com a presença específica de missionários que propagavam as Escrituras a partir de um escritório local. Agências foram instaladas em ambas as cidades para que de lá se pudesse atender de forma mais ampla a região amazônica, marcada pelas dificuldades de acesso, por causa de seus rios e florestas. Com o tempo, diante da dificuldade do trabalho, se fez necessário fechá-las.

Nessa perspectiva, se evidencia que espalhar unidades que possam ampliar o atendimento sempre marcou a história do trabalho bíblico realizado pelas Sociedades Bíblicas. As próprias Sociedades Bíblicas estrangeiras, SBBE e SBA, perceberam esta necessidade e por isso implantaram suas agências no país. Ambas ampliaram essa visão enviando seus agentes a outras regiões brasileiras. Nesse sentido, capilaridade no atendimento constitui um aspecto histórico importante para o trabalho bíblico no Brasil. Em seu estatuto, a organização deixa claro esse aspecto, ao afirmar que "As atividades da SBB abrangem todo o território nacional e, a fim de cumprir sua finalidade e missão, a entidade poderá organizar-se em tantas unidades e filiais que se fizerem necessárias”1186.

Alguns anos depois da criação da SBB, que no início tinha sua sede na cidade do Rio de Janeiro, entre 1956 e 1960, foram criadas Secretarias Regionais nas

\footnotetext{
${ }^{1186}$ SOCIEDADE BÍBLICA DO BRASIL. Estatuto 2015, p. 3.
} 
cidades de São Paulo, Porto Alegre (em 2005 foi transformada numa Unidade Regional, subordinada a Curitiba), Belém, Belo Horizonte, Recife e Goiânia (transferida para Brasília em 1972). Em 2005 foi aberta a Secretaria Regional de Curitiba e em 2011 a Unidade Regional de Manaus (subordinada a Belém). A sede da organização atualmente está na cidade de Barueri, em São Paulo. Pela capilaridade constatada, as unidades foram distribuídas para conferir melhor qualidade ao serviço bíblico realizado com os parceiros, livreiros, igrejas, semeadores e público em geral.

Giraldi já ressaltou que a presença física amplia a distribuição. Assim foi com os colportores e assim ocorre com as Secretarias e Unidades Regionais da SBB na atualidade. No relatório de atividades da organização, destaca-se a informação de que, entre vendas, doações e downloads digitais, "em 2016, a SBB realizou a distribuição de 6.773.421 Bíblias completas no Brasil"1187. Quando se subtrai a quantidade de Bíblias digitais, distribuídas gratuitamente pelas plataformas digitais da SBB e de parceiros (1.506.406 downloads), a quantidade de Bíblias físicas ainda é significativa. Foram 5.184.123 Bíblias distribuídas e, desse total, mais de $70 \%$ foram distribuídas por meio das unidades regionais.

É obvio que essas nove unidades, apesar da importância que possuem na realização do trabalho bíblico, não conseguem atender toda a demanda. Para tanto, a SBB ampliou sua forma de atendimento por meio do portal SBB PontoCom ${ }^{1188}$. Nesse portal, clientes (livrarias e igrejas) do Brasil inteiro podem se cadastrar para adquirir as Escrituras. São novos tempos, e há novas estratégias para que as pessoas tenham acesso às Escrituras de forma facilitada e eficaz. Assim, a difusão das Escrituras continua a se desenvolver no país.

\subsubsection{3 \\ A acessibilidade das Escrituras Sagradas por meio de programas e projetos especiais de propagação da Bíblia}

Na história do trabalho bíblico desenvolvido pelas Sociedades Bíblicas, é comum encontrar relatos de projetos que foram desenvolvidos a partir de um con-

1187 SOCIEDADE BÍBLICA DO BRASIL. Relatório Nacional de Trabalho 2016, p. 19.

1188 Cf. SBB. SBBPontoCom Atacado. Desenvolvido pela Sociedade Bíblica do Brasil, 2017. Apresenta informações sobre a venda de produtos da SBB para livrarias, distribuidores etc, por meio do atacado. O site apresenta igualmente a missão da organização, central 'fale conosco' e pesquisas de produtos. Numa seção restrita, o cliente pode cadastrar-se e realizar seus pedidos. Disponível em: <https://atacado.sbb.com.br/>. Acesso em 30 nov 2017. 
texto social ou religioso específico. Como visto no capítulo anterior, na chegada dos primeiros migrantes alemães, e depois dos italianos e japoneses, as Sociedades Bíblicas perceberam uma ocasião oportuna para a distribuição da Bíblia. Daniel Kidder, um dos primeiros agentes das SBA no Brasil, tinha uma visão muito estratégica. Em conversas informais, ele era capaz de captar oportunidades que se abriam para a semeadura bíblica, como foi o caso em que tentou colocar Bíblias na tradução de Figueiredo nas escolas de São Paulo (entre 1837 e 1842).

Quase um século depois, o próprio caos provocado pelas duas guerras abriu as portas para que um projeto especial fosse realizado. Na ocasião, uma edição especial das Escrituras, em inglês, foi distribuída aos combatentes americanos que passavam pelo país e outra, uma edição especial do Evangelhos, em língua portuguesa, foi distribuída para os soldados que compunham a Força Expedicionária Brasileira $^{1189}$. Mais recentemente, por meio do Projeto Joga Limpo Brasil, os eventos da Copa do Mundo e das Olimpíadas, realizados no Brasil, respectivamante em 2014 e 2016, ficaram marcados por ações especiais de distribuição de Escrituras, em várias línguas, junto a várias igrejas e parceiros da SBB.

Todos estes aspectos históricos constituem um norte no trabalho de difusão bíblica. Nessa perspectiva, em 2017, pelo menos dois projetos especiais foram desenvolvidos, procurando dar maior acesso às Escrituras por parte da população brasileira. O primeiro deles é realizado por meio do movimento denominado $A$ Bíblia em cada casa. O objetivo central do projeto é envolver igrejas (evangélicas e católicas), organizações missionárias (JOCUM - Jovens com uma missão) e cristãos em geral, numa grande mobilização nacional, para que juntos possam, até 2050, colocar uma Bíblia na casa de cada família brasileira.

Já o projeto Mude o Brasil pela Bíblia foi criado como uma resposta à caótica realidade política e social do Brasil. Afinal, “em todas as épocas da história, sobretudo em época de crise como a nossa, voltamos a alimentar-nos da Bíblia. Pois acreditamos que este livro tem a ver com Deus" ${ }^{1190}$. Nessa perspectiva, a partir das Escrituras, foram selecionados 100 versículos baseados em 15 valoreschave que tratam de valores morais e universais que estão contidos nas Escrituras e que, de acordo com as notícias amplamente divulgadas pela mídia, estão em

${ }^{1189}$ GIRALDI, Luiz Antonio. A Bíblia no Brasil República, p. 278.
${ }^{1190}$ MESTERS, Carlos. Flor sem defesa, p. 12. 
falta no país ${ }^{1191}$. Entre eles, destacam-se a educação, a honestidade, a integridade, a justiça, a paz, a solidariedade, a união e a verdade.

Trata-se, portanto, de um projeto que procura resgatar valores que, diante dos muitos problemas políticos e sociais no Brasil, encontram-se distanciados do cotidiano da sociedade ${ }^{1192}$. Por meio de ambos os projetos, a SBB pretende dar maior acesso às Escrituras e, por conseguinte, com o apoio e o envolvimento dos cristãos e das igrejas, contribuir com a transformação social e espiritual do país.

\subsubsection{2}

\section{A acessibilidade das Escrituras Sagradas por meio dos Programas Bíblicos de Impacto Social}

Como já amplamente descrito nesta pesquisa, um lema que move o trabalho de difusão das Escrituras realizado pelas Sociedades Bíblicas em todo o mundo é dar a Bíblia a todos, numa linguagem que possam entender e a um preço que possam pagar. Entretanto, para além desta convicção, emergem as seguintes questões: será que o ciclo de vida da Bíblia, que caracteriza o método pelo qual a SBB realiza seu trabalho, se limita a distribuir a Bíblia a todos (normalmente os que estão em uma igreja), em boas traduções (normalmente nas traduções já existentes) e com um bom preço (normalmente a um custo baixo como existe no catálogo)? Será que não há algo mais a fazer? As possíveis respostas para essas questões podem ser encontradas em uma das principais áreas de ação da SBB na atualidade: os Programas Bíblicos de Impacto Social. Trata-se de uma atividade que torna a Bíblia e a sua mensagem bem acessível e relevante na vida dos beneficiados.

\subsubsection{1}

\section{Pressuposto histórico no trabalho holístico das Sociedades Bíblicas}

Ainda que no início a intenção primordial do surgimento de uma Sociedade Bíblica tenha sido a de criar uma organização cujo enfoque esteja voltado para a tradução, a publicação e a distribuição das Escrituras, historicamente, esse traba-

\footnotetext{
${ }^{1191}$ Cf. MARTíN, Maria. A tragédia do Rio, do pódio à lama: "Estamos sofrendo, mas continuaremos gritando". El País. Rio de Janeiro, 18 jul 2017; NOBLAT, Ricardo José Delgado. A crise moral e a incredibilidade que atingem o país. Blog do Noblat. Jornal O Globo. Rio de Janeiro, 20 Mai 2017.

1192 Cf. SOCIEDADE BÍBLICA DO BRASIL. Relatório Nacional de Trabalho 2016, p. 35; Id. Plano Nacional de Trabalho 2017, p. 11.
} 
lho bíblico precisou ser ampliado. Nestes mais de duzentos anos de existência, uma boa parte das Sociedades Bíblicas espalhadas pelo mundo constataram que tal trabalho carecia de uma atuação mais ampla, que envolvia vários aspectos. A forma de distribuir a Bíblia precisava ser repensada, pois o indivíduo que a recebia tinha certas carências, e o contexto em que o trabalho acontecia demandava uma resposta mais eficaz.

Desde o início, um aspecto que norteou o trabalho de difusão da Bíblia realizado pelas Sociedades Bíblicas foi o desejo de levar a Bíblia a todas as pessoas, inclusive àquelas que não tem como pagar e que muitas vezes também não estão nas igrejas. O desejo de Thomas Charles, por exemplo, era de que a Bíblia chegasse aos galeses pobres, assim como era a família de Mary Jones, que sonhava ter uma Bíblia ${ }^{1193}$.

Uma preocupação da Sociedade Bíblica, logo após sua fundação, em 1804, era o fato de que já "em 1811, havia na Inglaterra aproximadamente 50.000 prisioneiros estrangeiros de guerra" 1194 , aprisionados nos porões dos navios ao longo das baías de todo o país. Para amenizar tais condições, o governo britânico decidiu construir uma prisão em Dartmoor (Princetown), que ficou pronta em 1806. Antes mesmo de que ela fosse aberta, a Sociedade Bíblica fez a sua primeira doação para os presos, dois dias antes do Natal. Segundo Steer, eles receberam as Bíblias “com gratidão, lágrimas e alegria"1195.

Reily, nessa mesma perspectiva, lembra que "a primeira edição da Bíblia em português realizada pela BFBS nasceu do desejo da Sociedade de oferecer as Escrituras no vernáculo a refugiados portugueses na Inglaterra, quando Napoleão invadira Portugal"1196. Tratava-se de uma ação humanitária para aquelas pessoas.

Giraldi, em suas obras ${ }^{1197}$, destacou o Rev. Hugh Clarence Tucker, um personagem importante na história do trabalho bíblico no Brasil nos tempos do Império e da República. Tal ênfase se deu, principalmente, por sua capacidade de integrar a difusão bíblica com o trabalho holístico. Tucker entendia que a mensagem

\footnotetext{
${ }^{1193}$ Cf. STEER, Roger. Good News for the World, 200 years of making the Bible heard, pp. 35, 54. 1194 Ibid., p. 135 (tradução nossa).

1195 Ibid.

${ }^{1196}$ REILY, Duncan. A história documental do Protestantismo no Brasil, p. 77.

1197 Cf. GIRALDI, Luiz Antonio. A Bíblia no Brasil Império, pp. 243-253; Id. A Bíblia no Brasil República, pp. 93-107; Id. História da Bíblia no Brasil, pp. 83-91; Id. Semeadores da Palavra, pp. 129-153; Id. The American Bible Society in Brazil, pp. 63-70.
} 
da Bíblia, para além de inspirar a busca pela justiça, se concretizava de forma prática por meio das ações.

Em seus quase cinquentas anos de trabalho bíblico no Brasil, Tucker, no fim do período imperial, lutou pela publicação de 500 porções do Evangelho de João em braile. Por meio do êxito conquistado, os cegos tiveram garantido o direito de ler a Bíblia, ainda naquela época. No mesmo período, Tucker percebeu a pobreza e as necessidades dos migrantes italianos que chegaram ao Brasil e, assim, desenvolveu um programa especial de distribuição de Bíblias bilíngue (italiano e português). Para tanto, ele contratou colportores que falavam italiano para que, assim, a missão fosse realizada de forma eficaz. Além de uma mensagem de esperança, contida na Palavra de Deus, Tucker oportunizou o aprendizado da língua portuguesa por meio das Escrituras.

Em 1906, Tucker criou uma instituição social, o Instituto Central do Povo (atualmente, Instituto Metodista de Ação Social - IMAS), que priorizou o atendimento à população que morava no Morro da Providência, a primeira favela do Rio de Janeiro, já naquela época. Por meio desse trabalho, serviços médicos e dentários foram realizados, uma creche popular foi inaugurada e cursos profissionalizantes foram oferecidos. Entre 1903 e 1907, apoiando o Dr. Oswaldo Cruz, contribuiu com a erradicação da febre amarela no país. Em 1911, depois de ter visto uma criança morrer atropelada por brincar na rua, construiu o primeiro parque infantil para atender a população pobre do Rio de Janeiro. Em 1912, publicou folhetos para esclarecer o povo sobre a tuberculose, distribuindo-os em vários lugares da cidade numa campanha intensiva contra a doença ${ }^{198}$. Todas essas ações foram realizadas de forma concomitante ao trabalho de representante e agente da Sociedade Bíblica Americana no Brasil. Para Tucker, diante da necessidade percebida no contexto social brasileiro, tais atividades constituíam aspectos indissociáveis em sua missão ${ }^{1199}$.

Como se percebe, os relatos que atrelam a difusão das Escrituras ao trabalho social, na história das Sociedades Bíblicas, surgem, eventualmente, a partir das

\footnotetext{
${ }^{1198}$ Cf. LÖWY, Ilana. Vírus, mosquitos e modernidade: a febre amarela no Brasil entre ciência e política. Rio de Janeiro: Editora Fiocruz, 2006, pp. 135, 183; DYRESON, Mark; MANGAN, James Anthony; PARK, Roberta (ed). Sport in the global society - Historical Perspectives: mapping an Empire of American Sport - Expansion, Assimilation, Adaptation and Resistance. Oxford; New York: Routledge, 2013, pp. 186-192; WAY, Anita Betts. Instituto Central do Povo: 100 anos em Missão. São Paulo: UMESP, 2006, passim.

${ }^{1199}$ Cf. TUCKER, Hugh Clarence. The Bible in Brazil; Reminiscências - 50 anos no Brasil, p. 11.
} 
necessidades das pessoas. Aqui coube destacar somente alguns deles para evidenciar que o trabalho de difusão das Escrituras em diversos momentos se estaleceu e foi praticado sob um viés holístico. Por assim ser, desde sua gênese, na Inglaterra e posteriormente no Brasil, o trabalho de difusão das Escrituras, realizado pelas Sociedades Bíblicas, sempre procurou alcançar as pessoas mais necessitadas.

O que talvez seja diferente nos dias de hoje, desde três décadas, aproximadamente, é a ênfase que procura se dar neste tipo de trabalho. Não são todas as Sociedades Bíblicas que entendem e, por consequência, praticam um trabalho sob essa perspectiva integral. Porém, muitas delas, inclusive a SBB, entenderam a importância dessa tarefa e passaram a realizar, junto à propagação da Bíblia, uma ação holística em busca de justiça social por meio da mensagem bíblica. E esse tipo de trabalho atualmente constitui um paradigma que é reforçado e instigado a partir do direcionamento das $\mathrm{SBU}^{1200}$ sobre a necessidade de uma forma mais ampla de se difundir as Escrituras idealizado no trabalho holístico.

\subsubsection{2 \\ Pressupostos bíblico, teológico, social e estatutário no trabalho bíblico holístico da SBB}

A fundamentação para que esse tipo de trabalho ocorra encontra base em vários pressupostos. Entre algumas opções, a Bíblia, a teologia, a realidade social e a finalidade estatutária da SBB constituem, por assim dizer, o norte para a realização de tais programas. O primeiro pressuposto é o bíblico-teológico. Como bem afirmou Carriker, "a existência de toda a Bíblia é a primeira evidência de que Deus tem uma missão, um propósito salvífico para este mundo" ${ }^{1201}$. Nessa perspectiva, Bíblia e missão são aspectos indissociáveis.

Todo o cânon das Escrituras é um fenômeno missional, no sentido de que ele testifica o movimento de autodoação de Deus por meio da revelação e da redenção, um movimento em direção à sua criação e a nós, seres humanos feitos à imagem do próprio Deus, mas desobedientes e rebeldes. Os escritos que compõem a nossa Bí-

${ }^{1200}$ SOCIEDADE BÍBLICAS UNIDAS. Renew: UBS \& The impact of globalization. Report. Nanjing, China: May 2011, p. 70.

${ }^{1201}$ CARRIKER, Timóteo. Teologia da Missão. Missionews - Revista de Missiologia. Volume 1, Ano 1, abril de 2009, p. 78. 
blia são, eles próprios, produto e testemunho da missão última de Deus para a redenção da humanidade e da criação ${ }^{1202}$.

A Palavra de Deus ganha sentido e aplicação quando a mensagem nela contida alcança o ser humano e o instiga à transformação. Como visto até aqui, a história das Escrituras Sagradas está bem atrelada à história cotidiana das pessoas; afinal, a Bíblia é o "livro da caminhada do povo" 1203 de Deus. Portanto, a Bíblia tem implicação direta na forma de o povo viver; afinal, "grande parte das coisas que estão na Bíblia nasceu assim da vida do povo simples" ${ }^{1204}$. Como tal, a Escritura Sagrada é relevante para todos os tempos e para todos os povos. Trata-se de um livro que venceu o tempo; sua mensagem é capaz de encontrar uma pessoa ou uma sociedade e transformá-la completamente. Na própria SBB existem relatos e depoimentos, normalmente publicados nas edições da Revista A Bíblia no Brasil, que evidenciam o quanto isso é uma realidade.

A mensagem das Escrituras traz esperança e salvação, mas também reitera a importância da justiça social ${ }^{1205}$, como foi amplamente defendido pelos profetas do Antigo Testamento, sobretudo por Amós. Ela apresenta uma mensagem de equidade, como consta nas leis de convívio social estabelecidas no Pentateuco. Ela apresenta uma mensagem de inclusão e dignidade, como se percebe nos relatos dos Evangelhos, por meio do ministério público de Jesus. Ela apresenta uma mensagem que exige cuidado e compartilhamento, como se contempla nos relatos da igreja primitiva no livro de Atos. Ela apresenta uma mensagem de responsabilidade mútua e de boas obras como um requisito necessário para o povo de Deus, como é destacado em muitas das Cartas Paulinas e Gerais. Ela apresenta uma mensagem de que céus e terra serão transformados e, por isso, o povo de Deus é chamado a fazer a diferença hoje sob essa perspectiva, como é possível ler no livro de Apocalipse.

Se faz necessário, portanto, resgatar uma leitura da Bíblia como um todo, pois nas Escrituras Sagradas existem mais de dois mil versículos que mostram o

1202 BÍBLIA Sagrada. Português. Bíblia missionária de estudo. Barueri: Sociedade Bíblica do Brasil, 2014, p. XIX.

${ }^{1203}$ MESTERS, Carlos. Flor sem defesa: uma explicação da Bíblia a partir do povo, p. 12.

${ }^{1204}$ Id. Palavra de Deus na história dos homens, p. 23.

1205 SHEDD, Russel Philip. A justiça social e a interpretação da Bíblia. São Paulo, SP: Editora Vida Nova, 1993, pp. 1-6. 
que Deus tem a dizer sobre questões de pobreza, exclusão e justiça social ${ }^{1206}$. Como se percebe, a Bíblia nunca abriu mão da integralidade da missão. Para além da teoria e do dogma, a Bíblia "precisa ser compreendida e aplicada com relevância à complexidade das situações do indivíduo e do mundo" ${ }^{1207}$. Estes mais de dois mil versículos indicam uma sistematização da mensagem bíblica. Trata-se, portanto, não simplesmente de um texto isolado, mas de uma forma de perceber que a Palavra de Deus emerge da realidade cotidiana das pessoas. Ela foi pertinente à realidade dos tempos bíblicos e continua sendo no contexto atual.

Nessa mesma perspectiva, Jesus é o paradigma da missão. É o próprio Cristo que demonstra em seu ministério público como deve ser realizada a missão que foi atribuída à igreja. Na grande comissão joanina, ele afirmou: “Assim como o meu Pai me enviou, eu também vos envio" (Jo 20,21). Ele próprio, num contexto de carências e de exclusão, como era Nazaré, enfatizou que foi enviado para evangelizar os pobres e trazer liberdade aos cativos e oprimidos (Lc 4,18-20). Em outro momento, ressaltou que tudo o que se fizer àqueles que têm fome ou sede, que estão doentes ou presos, que são estrangeiros ou estão nus, não apenas se constitui um critério de julgamento, mas, mais do que isso, foram ações, para o bem ou para o mal, realizadas para o próprio mestre (Mt 24,31-40). Portanto, imbuídos na mesma missão de Cristo, em sua encarnação, se faz necessário realizar uma missão junto a essas pessoas sob a ótica de que, com a mensagem bíblica e um trabalho relevante, Deus age no mundo necessitado. "Para o povo de Deus contemporâneo, à luz da plenitude da Revelação trazida por Jesus de Nazaré, reconhecido como Messias e Filho de Deus, a leitura da Bíblia é um forte convite a reconhecer o mesmo Deus em ação no mundo atual" ${ }^{208}$.

É sob estes pressupostos que o trabalho bíblico deve ser apreendido a partir do conceito de um ministério holístico ${ }^{1209}$. Trata-se de uma teologia de missão

\footnotetext{
${ }^{1206}$ Cf. BÍBLIA Sagrada. Português. Bíblia Sagrada Pobreza e Justiça. Barueri: Sociedade Bíblica do Brasil, 2011. Essa edição da Bíblia, na versão NTLH, destaca vários versículos bíblicos que falam sobre justiça social, pobreza, exclusão, opressão, direitos, etc. A edição destaca mais de dois mil versículos, selecionado-os com a cor laranja nas próprias páginas das Escrituras, deste o AT até o NT. Há, também, um encarte de 32 páginas, com mais de 50 tópicos, que discorrem sobre o tema por meio de estudos e sugestões práticas sobre como os cristãos podem enfrentar tais realidades a partir do que as Escrituras ensinam e advertem.

${ }^{1207}$ SHEDD, Russel Philip. A justiça social e a interpretação da Bíblia, p. 2.

${ }^{1208}$ FERNANDES, Leonardo Agostini. A Bíblia e sua mensagem: introdução à leitura e ao estudo da Bíblia, p. 218.

${ }^{1209}$ Sob a ótica da Teologia Bíblica da Missão Integral. Cf. PADILHA, Carlos René. O que é Missão Integral?
} 
integral, para que, sob essa perspectiva bíblico-teológica, o trabalho de difusão das Escrituras não se limite a uma simples entrega da Bíblia para qualquer pessoa que seja. Ainda que entregar uma Bíblia a alguém seja algo importante, se faz necessário ampliar a compreensão. $\mathrm{O}$ trabalho bíblico não pode ser percebido sob uma perspectiva reducionista, como normalmente ocorre entre aqueles que se limitam à proclamação verbal do evangelho em detrimento das necessidades mais urgentes que emergem principalmente no contexto das camadas mais pobres da população.

Este é um princípio atemporal para aqueles que difundem a Bíblia e encarnam a teologia. Tais convicções resultam, portanto, num trabalho em que se procura levar um atendimento integral às pessoas com base na mensagem bíblica, para que, assim, o ser humano possa se desenvolver também de forma integral. Nesse sentido, trata-se de "ler a Bíblia, levando conosco as perguntas que a nossa realidade levanta, motivados pelos problemas e pelas preocupações de hoje" ${ }^{1210}$. E aí, entrelaçado aos aspectos bíblico e teológico, está o pressuposto social.

De forma geral, o contexto brasileiro é caracterizado por uma população que está em situação de risco e vulnerabilidade social, sem saúde, sem educação, sem moradia etc. ${ }^{1211}$ Não há dúvida de que se trata de uma realidade social excludente. Os direitos mínimos para a sobrevivência são desrespeitados. Faz parte do senso comum e da estatística oficial o fato de existir uma pequena parte da população brasileira muito rica e uma grande parte desta mesma população muito pobre ${ }^{1212}$. A injustiça social, a falta de garantia, de dignidade humana e de direitos básicos para a população brasileira constituem, portanto, um desafio para a missão de qualquer igreja ou organização cristã. É óbvio, portanto, que o trabalho bíblico realizado no Brasil deve se atentar a esta realidade.

Contudo, ainda que saúde, educação, entre outros, constituam direitos fundamentais à vida, será que as necessidades do ser humano se limitam a estes as-

\footnotetext{
${ }^{1210}$ MESTERS, Carlos. Palavra de Deus na história dos homens, p. 199.

${ }^{1211}$ Cf. INSTITUTO BRASILEIRO DE GEOGRAFIA E ESTATÍSTICA. Síntese de indicadores sociais: uma análise das condições de vida da população brasileira. Rio de Janeiro: IBGE, 2017, passim.

${ }^{1212}$ Cf. ONUBR. Desenvolvimento sustentável. Desenvolvido pela Trusted Team e administrado pelo UNIC Rio, 2018. Em um artigo, apresenta dados do relatório "Panorama Social da América Latina 2017" divulgado pelo Comissão Econômica para a América Latina e o Caribe (CEPAL). Sob o título, "Entre 22 países, Brasil lidera concentração de riqueza nas mãos do $1 \%$ mais rico", o artigo descreve a desigualdade de renda existente no Brasil, apontando que $1 \%$ da população brasileira detém $27 \%$ da renda nacional. Disponível em: <https://nacoesunidas.org/entre-22-paisesbrasil-lidera-concentracao-de-riqueza-nas-maos-do-1-mais-rico/> Acesso em 13 nov 2017.
} 
pectos? Mais recentemente tais concepções estão sendo ampliadas. Atualmente evidencia-se que saúde integral não se limita a ausência de doença ${ }^{1213}$; e pobreza não se limita a ausência de recursos financeiros ${ }^{1214}$ etc.

Como exemplo, desde o início da década de 1980, a Organização Mundial da Saúde (OMS) começou a discutir tais concepções. A partir de 1998, a OMS passou a entender que um ser humano só pode ser plenamente saudável quando for considerada sua realidade biopsicossocial e espiritual ${ }^{1215}$. Não se trata, portanto, de um ou outro aspecto isolado; ambos, de forma holística, são fundamentais e constituem um equilíbrio para uma necessária qualidade de vida. Pela própria definição da OMS, portanto, a pessoa é constituída de integralidade - e de tal forma deve ser percebida. Não há um aspecto mais importante e outro menos significante. Ambos constituem sua realidade socioexistencial e ambos precisam ser contemplados.

Nessa perspectiva, por exemplo, a ausência de espiritualidade e de equilíbrio emocional reduzem a percepção do que realmente é um ser saudável - e, como tal, constituem uma limitação ao conceito acima descrito. Faz-se necessário, portanto, que ações holísticas procurem contemplar o ser humano em sua totalidade, ou seja, em seus aspectos físico, mental, emocional, social e espiritual. Tais aspectos, de forma integrada, constituem o ser humano e suas necessidades.

Sendo assim, o conceito do que é pobreza também passa a contemplar diferentes e variadas formas, não se restringindo às condições materiais. Portanto, não se limita a ausência da alimentação, habitação, vestuário, educação e saúde. Tudo isso é fundamental, desde que não se esqueça de que o ser humano tem, também, a "carência de direitos, de possibilidades, de esperança"1216. Na mesma lógica, Yasbek, doutora em Serviço Social e professora do programa de Pós-Graduação em Serviço Social da Pontifícia Universidade Católica de São Paulo, destaca que “a pobreza é a expressão direta das relações sociais vigentes na sociedade e cer-

\footnotetext{
1213 Cf. SCLIAR, Moacyr. História do Conceito de Saúde. Physis: Rev. Saúde Coletiva, Rio de Janeiro, 17(1):29-41, 2007, p. 37.

1214 Cf. YASBEK, Maria Carmelita. Classes subalternas e assistência social. São Paulo: Cortez, 2007, p. 63.

1215 Cf. WORLD HEALTH ORGANIZATION. WHOQOL and spirituality, religiousness and personal beliefs (SRPB): report on WHO Consultation. Geneva; 1998, pp. 18-20.

1216 JESUS, Aline de [et al.]. Assistência social: direito ou favor? As percepções dos usuários do Km 7 do município de Presidente Prudente. Monografia (Bacharelado em Serviço Social). Faculdades Integradas “Antônio Eufrásio de Toledo”, Presidente Prudente, 2004, p. 43.
} 
tamente não se reduz às privações materiais. Alcança o plano espiritual, moral e político dos indivíduos submetidos aos problemas da sobrevivência"1217.

Constata-se, portanto, que escassez espiritual, moral e emocional também constituem um tipo de pobreza. Entre outros, na sociedade atual, a ausência destes aspectos em especial tem proporcionado um contexto de ansiedade, questionamentos, infelicidades, incertezas, angústias etc. A vida no contexto da pósmodernidade tem levado muitas pessoas a um colapso sem precedentes em relação ao sentido de sua existência ${ }^{1218}$. Mesmo com o êxito do ser humano em diversas áreas da vida, o avanço da informação e a expansão da ciência, constata-se uma crise de valores, moral e ética.

De forma geral, o ser humano tem procurado valorizar o dinheiro e os bens, o possuir e o poder. Tais valores estão normalmente resultando em angústia, decepção, depressão e ausência de sentido, levando-os a vivenciar uma profunda crise existencial. Pelo que parece, tais realidades existem porque o ser humano tem optado pelo abandono do aspecto holístico de sua existência. Por vezes, ele tem descartado a necessidade da espiritualidade. Entretanto, na perspectiva da integralidade, a espiritualidade é uma característica inerente ao ser humano. Para Boff ${ }^{1219}$, espiritualidade é "aquilo que produz no ser humano uma mudança interior". Sendo assim, a espiritualidade equivale às “motivações maiores e últimas, seu ideal, sua utopia, sua paixão, a mística pela qual vive e luta e com a qual contagia" 1220 .

Sob tais aspectos, não há dúvidas de que a sociedade precisa de esperança; mas não qualquer esperança. Se faz necessário uma esperança firmada em algo que vai além das questões humanas, que não estaria em outro lugar, senão nas Escrituras Sagradas; afinal, "a Bíblia é o livro da vida"1221. "A grande promessa de Deus, por isso mesmo, no último livro da Bíblia, o Apocalipse de João, é: "Eis que faço novas todas as coisas" $(21,5)$. À luz desse último horizonte nós lemos a

\footnotetext{
1217 YASBEK, Maria Carmelita. Classes subalternas e assistência social, p. 63.

1218 Cf. AZEVEDO, Marcos. Modernidade e pós-modernidade: desafios à vida e à fé cristã., passim.

1219 BOFF, Leonardo. Espiritualidade: um caminho de transformação. Rio de Janeiro: Sextante, 2006, p. 43.

${ }^{1220}$ Ibid.

${ }^{1221}$ FERNANDES, Leonardo Agostini. A Bíblia e sua mensagem: introdução à leitura e ao estudo da Bíblia, p. 9.
} 
Bíblia como o livro das promessas de Deus e das esperanças humanas" ${ }^{1222}$. De fato, a Bíblia é o livro da esperança para muitos que vivem uma realidade desafiadora. Nesse sentido, a Bíblia precisa ser

Lida na perspectiva da renovação de nossos primeiros amores, na perseverança da fé que temos em Deus, mas que também temos na humanidade e, sobretudo, como fonte de nossas utopias. Nunca foi tão importante ler a Bíblia com os olhos bem abertos e atentos aos horizontes dos sonhos que virão alimentar nossa sede de justiça e fome de amor ${ }^{1223}$.

A Bíblia, portanto, é fundamental para que a população brasileira obtenha a possibilidade de uma transformação social e espiritual, concomitantemente. Nesse sentido, as pessoas que precisam da Bíblia estão nos mais diversos segmentos sociais. Elas podem ser/estar enfermas, presas, com problemas na vida familiar, em situações de dependência química, com necessidades especiais (cegos, surdos etc.), em situações de vulnerabilidade (extrema pobreza, refugiados, migrantes, analfabetos) etc.

Destarte, para que a Bíblia possa alcançar essas pessoas, a SBB realiza seu trabalho por meio de programas bíblicos de impacto social. Facilitando o acesso às Escrituras a todas as pessoas, a SBB tem como objetivo principal resgatar e fortalecer os valores éticos e espirituais, que são vitais para a construção de uma sociedade mais justa e pacífica. Portanto, a SBB não vê a missão holística como qualquer outra coisa senão como a sua própria missão.

Nessa perspectiva, o estatuto ${ }^{1224}$ da SBB destaca de forma proeminente a ênfase nesse tipo de trabalho. Sua missão consiste essencialmente em "promover a difusão da Bíblia e sua mensagem como instrumento de transformação e desenvolvimento integral do ser humano". Tal ênfase se dá porque "a SBB reconhece que a Bíblia tem relevância direta para enfrentar os problemas do mundo e para atender as necessidades das pessoas por palavras e ações, seguindo os passos de Jesus". Para tanto, procura "trabalhar, inclusive com outros agentes, em programas holísticos para levar a Palavra de vida e esperança às pessoas em necessidade". Todos esses aspectos, definidos estatutariamente, foram estabelecidos para que se possa

\footnotetext{
${ }^{1222}$ MOLTMANN, Jürgen. No fim, o início: No fim, o início. Breve tratado sobre a esperança. São Paulo: Loyola, 2007, p. 10.

${ }^{1223}$ LARA, Valter Luiz. A Bíblia e o desafio da interpretação sociológica: introdução ao primeiro testamento à luz de seus contextos históricos e sociais. São Paulo: Paulus, 2009, p. 18.

${ }^{1224}$ SOCIEDADE BÍBLICA DO BRASIL. Estatuto 2015, pp. 1-2.
} 
Prestar à comunidade serviços de caráter assistencial, espiritual, educacional, social, cultural e de saúde, realizando serviços de convivência e fortalecimento de vínculos familiares e comunitários, incentivando a autonomia, o protagonismo e o desenvolvimento integral da pessoa humana e a melhoria da qualidade de vida ${ }^{1225}$.

É justamente com base em tais pressupostos que, para além de continuar com a provisão do texto bíblico impresso, a SBB desenvolve em todo o território nacional programas e projetos bíblicos de alcance social e espiritual, voltados para as populações em situação de risco e vulnerabilidade social e a pessoas com deficiências $^{1226}$. Tais atividades são desenvolvidas a fim de contribuir relevantemente nesse contexto, visando promover uma melhor qualidade de vida dos brasileiros por meio de ações transformadoras provenientes de suas áreas de trabalho ${ }^{1227}$. É nessa perspectiva que a missão da SBB é sintetizada pelo slogan: "Semeando a Palavra que Transforma Vidas" ${ }^{1228 .}$

\subsubsection{3 História e atualidade dos programas bíblicos de impacto social desenvolvido pela SBB}

Como já se constatou, para cumprir a missão de difundir, de forma relevante, a Bíblia a todas as pessoas, a SBB desenvolve programas bíblicos de impacto social e espiritual em todo o país. Historicamente, a ênfase no trabalho holístico teve seu início entre as atividades desenvolvidas pela SBB quatorze anos após a sua fundação. De fato, tudo começou quando

Em 1962, a SBB recebeu um apelo das igrejas evangélicas de Manaus para melhorar o suprimento de Bíblias na região. Estavam faltando Bíblias não apenas em Manaus, mas também em quase todas as cidades da região. E as poucas Bíblias que lá chegavam estavam sendo vendidas a preços muito altos ${ }^{1229}$.

A primeira necessidade destacada por Giraldi é a escassez das Escrituras na região amazônica. Aliás, essa também tinha sido a preocupação das Sociedades Bíblicas que iniciaram o trabalho bíblico no Brasil. Diante da realidade social e geográfica da Amazônia brasileira, não há dúvidas de que difundir a Bíblia naquela região sempre foi um grande desafio. Como resposta a tal realidade, Giraldi

\footnotetext{
1225 SOCIEDADE BÍBLICA DO BRASIL. Estatuto 2015, p. 2.

1226 Id. Plano Nacional de Trabalho 2017, p. 5.

1227 Ibid.

1228 SOCIEDADE BÍBLICA DO BRASIL. Relatório Nacional de Trabalho 2016, p. 2.

${ }^{1229}$ GIRALDI, Luiz Antonio. História da Bíblia no Brasil, p. 149.
} 
destaca que a SBB, depois de entender tal situação, perguntou aos líderes cristãos da região amazônica, principalmente Manaus e Belém, como poderia contribuir para transformar tal realidade. A ideia inicial era, portanto, simplesmente ampliar a difusão de Bíblias por toda a região. Giraldi lembra que a resposta unânime dos cristãos amazônicos foi: “Aqui não temos estradas. As nossas estradas são os rios. Para alcançarmos as pessoas da região, é preciso ter um barco da Bíblia. A melhor coisa que a Sociedade Bíblica do Brasil pode fazer em favor das igrejas da região é ter aqui um barco da Bíblia"1230.

Diante de tal necessidade, e com o apoio da Sociedade Bíblica da Escócia, a SBB conseguiu adquirir um barco, que passou a realizar um trabalho de colportagem, navegando pelos rios amazônicos, alcançando grandes e pequenas cidades, vilarejos e comunidades ribeirinhas, todas na imensa floresta amazônica. O barco passou a se chamar Luz na Amazônia, designação esta resgatada historicamente através do trabalho realizado pelo antigo agente da SBBE em Manaus, Rev. Charles H. Morris, quando no passado havia realizado algumas viagens de distribuição de Bíblias pela região. Aliás, desde a época do Império, as Sociedades Bíblicas realizaram esse tipo de trabalho na região. Como visto anteriormente, Nesbitt e Holden foram os precursores a entrar pelos rios amazônicos para difundir as Escrituras. Nesbitt, inclusive, faleceu durante a viagem.

Em 1963 ocorreu a primeira viagem, de quase trinta dias de duração, do Barco Luz na Amazônia, sob a coordenação do Rev. João Batista da Silva. Giraldi ressalta que, sob perigos de navegação (com muitos paus nos rios), suntuosas tempestades e muitos mosquitos, o relatório apresentado na ocasião destacou uma distribuição de quase 65 mil exemplares das Escrituras. Nos períodos subsequentes, duas viagens anuais passaram a ser realizadas pela região amazônica, interligadas pelo trecho Belém-Manaus. No roteiro, muitos vilarejos e pequenas cidades receberam as Escrituras Sagradas ${ }^{1231}$.

Como na região sempre houve uma significativa população carente, por vezes, as pessoas não tinham dinheiro para comprar uma Bíblia, apesar de a desejarem muito. A solução encontrada pode ser percebida no relato do Rev. João Batista da Silva, a respeito de uma viagem realizada em 1969:

${ }^{1230}$ GIRALDI, Luiz Antonio. História da Bíblia no Brasil, p. 19.

${ }^{1231}$ Ibid. 
Dado a pobreza da região [rio Xingu], o dinheiro é muito escasso, mesmo porque o povo vive na base da troca, e foi nessa base que conseguimos vender as Escrituras, registrando o seguinte resultado: Bíblias e Novos Testamentos distribuídos $=73$ exemplares que foram trocados por 22 galinhas, 6 patos, 12 frangos, 6 tracajás, 4 $\mathrm{kg}$ de queijo, 1 papagaio, 3 galos, 1 porco e 1 lata de farinha, que deverão ser revendidos pelo preço correspondente ao valor dos 73 exemplares ${ }^{1232}$.

Entre outros aspectos, tal relato evidencia que a região era muito necessitada e que, por outro lado, havia uma carência muito grande das Escrituras. Como é de se esperar, tais necessidades não se limitavam à escassez de recursos financeiros. Nas viagens realizadas, a tripulação começou a perceber que em muitas das regiões visitadas havia inúmeras outras carências. E, assim,

Logo nos primeiros meses de atividade, a tripulação do Barco chegou à conclusão de que seria impossível realizar o trabalho de colportagem sem prestar assistência social aos ribeirinhos. Durantes as viagens, a tripulação do barco encontrou pessoas doentes, famintas e sem roupa para vestirem ${ }^{1233}$.

Foi nesse ambiente que o projeto Luz na Amazônia cresceu e se desenvolveu, proporcionando, por muitos anos, um grande impacto na região amazônica. As primeiras atividades nesse sentido foram organizadas em parceria com igrejas que doaram roupas e alimentos. Já na década de 1980, o projetou se ampliou para atender as demandas mais urgentes da população, principalmente na área da saúde por meio do atendimento de enfermeiros, médicos e dentistas. Novas parcerias foram estabelecidas com universidades, organizações sociais e governamentais. A partir de 1994, além da assistência médica, odontológica, laboratorial, social e espiritual, uma nova metodologia foi adotada, enfocando a prevenção na área de saúde, a promoção social e cultural. Para tanto, passaram a ser desenvolvidas ações e projetos com maior potencial transformador da realidade social das regiões abarcadas ${ }^{1234}$.

O projeto atualmente continua em ação, por meio de dois barcos. Um é o barco-hospital e o outro é um barco-cultural (livraria e museu). É óbvio que algumas coisas mudaram desde o início da atuação do Luz na Amazônia. Diante de muitas mudanças no contexto e depois de intensos anos de trabalho, a SBB começou a trabalhar de forma direta com as comunidades atendidas na busca pela pro-

${ }^{1232}$ Cf. ANDRADE, Marizete Lopes; GERONE JUNIOR, Acyr de. Luz na Amazônia: um projeto de missão holística. In: VIII Fórum de Ciências Bíblicas, 2012, Barueri. Apresentação. Barueri: Sociedade Bíblica do Brasil, 2012

${ }^{1233}$ GIRALDI, Luiz Antonio. História da Bíblia no Brasil, p. 154.

${ }^{1234}$ Cf. SOCIEDADE BÍBLICA DO BRASIL. Luz na Amazônia: 50 anos. Barueri: Sociedade Bíblica do Brasil, 2012, p. 6 
moção da justiça social. O trabalho continua a ser realizado com parceiros, mas envolve também, de forma direta e indispensável, a própria comunidade. Tal trabalho se desenvolve sob uma perspectiva emancipatória, lutando, sobretudo, pela justiça social para assegurar à população a segurança de uma vida familiar e comunitária desenvolvida com autonomia. Por meio dos valores e da mensagem das Escrituras Sagradas, procura-se desenvolver ações que instiguem o fortalecimento dos laços familiares e comunitários, para que, assim, a comunidade ribeirinha se sinta responsável por seus moradores, através do auxílio mútuo ${ }^{1235}$.

É claro que, por vezes, há a necessidade de agir em situação de emergência, seja na área da saúde ou por meio da entrega de alimentos. Mas esse não é mais o foco. Não há interesse em manter essa população dependente; pelo contrário, espera-se que seja possível que ela se emancipe, de modo que possa ser protagonista de sua própria história. Por meio de orientação (palestras, rodas de conversa, estudos etc.), a partir da importância da Bíblia, o trabalho procura ressaltar os direitos da população ribeirinha e como ela pode acessá-los. Para a SBB, isso constitui sua missão. Trata-se de uma missão holística por meio do impacto da mensagem bíblica.

Diante de tal relevância, o projeto Luz na Amazônia passou a inspirar outras iniciativas pelo Brasil. Giraldi lembra que uma área específica foi organizada a partir de 2001 para que, assim, se pudesse ampliar tal tarefa. Como consequência, “foram, então, criados novos programas" ${ }^{1236}$. De acordo com o Plano Nacional de Trabalho $2017^{1237}$, portanto, o mais recente em vigor, os programas bíblicos de impacto social existentes na SBB estão estruturados conforme segue.

A Bíblia para fortalecer a família: por meio de uma grande rede de organizações e voluntários, o programa procura "prestar serviços de convivência e promover ações de fortalecimento de vínculos"1238. Para tanto, são realizados encontros para treinamento e troca de experiências com os parceiros; é distribuída literatura bíblica gratuita para crianças, idosos, adolescentes e famílias; são desenvolvidas mobilizações sociais para atendimento ao público, onde são oferecidos diversos tipos de atendimento socioassistencial e espiritual. O programa está subdivido em assessoramento de parceiros, resgate do vínculo familiar do preso e ação hu-

${ }^{1235}$ Cf. SOCIEDADE BÍBLICA DO BRASIL. Plano Nacional de Trabalho 2017, p. 17.

${ }^{1236}$ GIRALDI, Luiz Antonio. História da Bíblia no Brasil, p. 281.

${ }^{1237}$ SOCIEDADE BÍBLICA DO BRASIL. Op. cit., p. 3.

${ }^{1238}$ Ibid., p. 20. 
manitária por meio da Bíblia em situações de emergência. As capelanias hospitalares também são atendidas por esse programa. Por meio de cooperação e doação de materiais bíblicos, em 2016, a SBB contribuiu com 811 organizações que atuam no país ${ }^{1239}$.

Estudando com a Bíblia: esse programa surgiu em 2001, com o objetivo de "favorecer o resgate de valores éticos e espirituais entre crianças e adolescentes e contribuir para o fortalecimento da família" ${ }^{240}$. Por meio de um material didático específico (do $1^{\circ}$ ao $9^{\circ}$ ano), elaborado por professores através de história e personagens bíblicos que destacam os valores contidos nas Escrituras (amor, perdão, amizade etc.), o programa atendeu, em 2016, 64.645 estudantes, em mais de 254 escolas. Desde o seu início, o programa tem contribuído com a "redução dos índices de violência, prevenção ao uso de drogas, incentivo à leitura, ampliação dos valores bíblicos na vida comunitária"1241. Nesse sentido, as histórias bíblicas, quando ministradas pelo professor em sala de aula, podem estabelecer conexão com a realidade vivenciada pelos alunos.

A Bíblia na Recuperação da Dependência: não há dúvidas de que os problemas decorrentes do uso, do abuso e da dependência de drogas tornaram-se uma preocupação mundial, que perpassa por vários campos da ciência, tais como a medicina, a sociologia, a psicologia/psiquiatria, a religião, dentre outros. Tal realidade potencializou uma reação na sociedade, mobilizando recursos e ações interventivas na atenção aos usuários e dependentes químicos ${ }^{1242}$. É nessa perspectiva que a SBB desenvolve esse programa, caracterizado pela promoção de uma cultura de paz e de ressocialização do indivíduo.

O trabalho é realizado por meio da promoção de Seminários de Prevenção à Dependência Química em várias regiões do Brasil e por meio da COMTER Comunidades Terapêuticas em Rede, criada pela SBB em 2007, que, atualmente, reúne mais de cinquenta organizações que utilizam a Bíblia como instrumento principal na recuperação. Essas organizações também recebem o suporte da SBB no desenvolvimento do trabalho que realizam e, igualmente, recebem a doação de

\footnotetext{
${ }^{1239}$ SOCIEDADE BÍBLICA DO BRASIL. Relatório Nacional de Trabalho 2016, p. 24.

${ }^{1240}$ GIRALDI, Luiz Antonio. História da Bíblia no Brasil, p. 282.

${ }^{1241}$ SOCIEDADE BÍBLICA DO BRASIL. Op. cit., p. 23.

${ }^{1242}$ Cf. KANTORSKI, Luciane Prado; LISBOA, Liliane de Mello; SOUZA, Jacqueline de. Grupo de prevenção de recaídas de álcool e outras drogas. SMAD. Rev. Eletrônica Saúde Mental Álcool Drog. (ed. port.), v.1, n. 1, Ribeirão Preto, fev. 2005, p. 2.
} 
literatura bíblica. Entre estes materiais, está a Bíblia de Estudo Despertar ${ }^{1243}$. Trata-se de uma Bíblia de Estudo diferenciada, pois está focada em estudos bíblicos fundamentados nos 12 passos cristãos para vencer a dependência, bem semelhante aos 12 passos dos Alcoólicos Anônimos. Em 2016, foram realizadas seis edições do Seminário de Prevenção à Dependência Química e 194 comunidades terapêuticas foram beneficiadas com doações de literatura bíblica específica sobre os temas da dependência química ${ }^{1244}$.

Luz no Brasil: o programa Luz no Brasil foi inspirado no Programa Luz na Amazônia. A partir da realidade social que existe nas mais diferentes regiões do país, a SBB percebeu que o programa, atuante desde 1962 na região amazônica, poderia beneficiar também outras regiões carentes do Brasil. Nessa perspectiva, o programa procura atender "famílias em situação de risco e vulnerabilidade social" ${ }^{\prime 245}$. Tais realidades, como se sabe, estão em todas as cidades brasileiras, em maior ou menor proporção.

Dessa forma, em 2008, a SBB implantou o Luz no Sul, que realiza atendimentos em comunidades em situação de vulnerabilidade e risco social da região Sul, especialmente na região do Vale do Ribeira. O trabalho é realizado por meio do ônibus Rodas do Socorro, adaptado com sala de atendimento e um pequeno Museu da Bíblia. Em 2009, a SBB implantou o Luz no Nordeste, que realiza atendimentos em regiões necessitadas dos Estados de Pernambuco, Paraíba e Ceará. O trabalho é realizado por meio de um caminhão, equipado com duas salas de atendimento e um espaço de exposição bíblica, designado "Mundo da Bíblia". Em 2010 a SBB implantou o Luz no Sudeste, que realiza atendimentos nas favelas e nas comunidades de periferia do Rio de Janeiro. O trabalho é realizado por meio de um ônibus, equipado com duas salas de atendimento e um espaço de exposição bíblica. Normalmente, nos atendimentos, utiliza-se também a estrutura de escolas ou igrejas situadas nos locais de atendimento. Em 2016, por meios desses quatro programas, a SBB realizou 128 ações em regiões carentes e 62.413 atendimen$\operatorname{tos}^{1246}$.

\footnotetext{
${ }^{1243}$ Cf. Bíblia Sagrada. Bíblia de Estudo Despertar. Nova Tradução na Linguagem de Hoje. Barueri: Sociedade Bíblica do Brasil, 2012.

${ }^{1244}$ SOCIEDADE BÍBLICA DO BRASIL. Relatório Nacional de Trabalho 2016, p. 24.

${ }^{1245}$ Id. Plano Nacional de Trabalho 2017, p. 17.

${ }^{1246}$ Id. Relatório Nacional de Trabalho 2016, p. 21.
} 
A Bíblia para pessoas com Deficiência: desde 1956 a SBB desenvolve programas para pessoas com deficiência ${ }^{1247}$. As ações têm o mesmo intuito que o projeto de Tucker tinha intencionado ainda no tempo do Brasil imperial, isto é, fazer com que o cego tenha acesso às Escrituras. Nesse sentido, "o programa promove a inclusão social deste público, ao possibilitar que as pessoas tenham acesso à Palavra de Deus em braile e em áudio"1248. Entre as décadas de 1950 e 1990, parte desse público foi atendido, inicialmente com "a Bíblia falada em português, gravada em disco"1249 e, mais recentemente, com a Bíblia em áudio (em CD ou pen drive). A Bíblia, narrada ou dramatizada, foi repassada a muitas pessoas cegas. Entretanto, o sonho de muitos cegos era ter, de fato, a Bíblia em sua própria língua, ou seja, se fazia necessário ter uma Bíblia em braile.

Lovera $^{1250}$ fez um resgate histórico de como a SBB conseguiu avançar e desenvolver esse projeto tão esperado. $\mathrm{O}$ autor reitera que a tecnologia utilizada em impressões em braile sempre foi custosa. Durante muitos anos a SBB encontrou dificuldades para conseguir desenvolver a Escritura em braile. Porém, "em 2001 a SBB inaugurou sua Imprensa Braile. E, em 2002, lançou a Bíblia completa no sistema braile" ${ }^{1251}$.

Essa é uma das atividades com relevância no trabalho bíblico realizado pela SBB. O programa é desenvolvido por meio da doação completa da Bíblia em braile ao cego ${ }^{1252}$, que também pode optar pela Bíblia em áudio e pelo recebimento da Revista A Bíblia no Brasil também em braile. Em 2016, a SBB doou Escrituras em braile para 946 pessoas cadastradas em seu sistema, realizou sete edições do Encontro de Pessoas com Deficiência Visual, com mais de 1.300 participantes, e doou 14 edições da Bíblia em braile a bibliotecas públicas que atendem pessoas com deficiência visual ${ }^{1253}$.

Em 2012, a SBB deu mais um passo no sentido de atender pessoas com deficiência, ao implantar o programa A Bíblia para pessoas com Deficiência Auditiva. O programa, desde sua criação, procura atender pessoas surdas, suas respecti-

\footnotetext{
${ }^{1247}$ Cf. GIRALDI, Luiz Antonio. História da Bíblia no Brasil, p. 177.

1248 SOCIEDADE BÍBLICA DO BRASIL. Plano Nacional de Trabalho 2017, p. 18.

1249 GIRALDI, Luiz Antonio. História da Bíblia no Brasil, p. 117.

1250 Cf. LOVERA, Marcos Adriano. Da escuridão para a luz: origem e extensão da Bíblia em Braile no Brasil. São Paulo: Fonte Editorial, 2017, passim.

1251 GIRALDI, Luiz Antonio. Op. cit., p. 288.

1252 Em 2018, o custo de produção dessa Bíblia varia entre R \$ 1.400,00 (edição popular) e R\$ 2.800,00 (edição capa dura).

${ }^{1253}$ SOCIEDADE BÍBLICA DO BRASIL. Relatório Nacional de Trabalho 2016, p. 22.
} 
vas famílias, além de bibliotecas e instituições que trabalham com esse público. As pessoas e as organizações inscritas no programa recebem literatura bíblica em Libras (Língua Brasileira de Sinais). Tal ação ganha relevância justamente pelo fato destacado por Vergamini ${ }^{1254}$ ao lembrar a grande escassez de projetos e materiais voltados para a cultura surda na sociedade brasileira. Portanto, tal trabalho está para além de uma simples publicação. Trata-se de um programa que procura contribuir com a inclusão social, facilitar o desenvolvimento cultural, promover o amparo espiritual, integrar a pessoa com deficiência auditiva à vida comunitária e auxiliar na alfabetização em libras.

O programa também incentiva a família da pessoa surda a aprender libras, facilitando, assim, o processo de comunicação entre ambos. O primeiro material publicado foi Aventuras Bíblicas em libras, atualmente nos volumes 1, 2 e $3^{1255}$. Estas publicações reúnem um livreto com histórias bíblicas infantis, acompanhado de DVD com as mesmas narrativas interpretadas em Libras. Em 2016, a SBB doou materiais bíblicos em libras para 597 pessoas surdas e realizou dois Encontros de Pessoa com Deficiência Auditiva, os quais contaram com a participação de 1.318 pessoas $^{1256}$.

Como é possível perceber, o trabalho realizado pela SBB por meio dos Programas Bíblicos de Impacto Social constitui um diferencial em suas atividades. É um relevante instrumento que possibilita tornar a Bíblia acessível a todas as pessoas, em diversos lugares, nas mais diferentes condições sociais. Esses trabalhos são reconhecidos por meio de vários títulos de utilidade pública em âmbito municipal, estadual e federal concedidos à entidade. Da mesma forma, são confirmados por meio de inscrições no Conselho Nacional de Assistência Social e em Conselhos Municipais de Assistência Social de diversos municípios do país ${ }^{1257}$.

De acordo com o Relatório Nacional de Trabalho de 2016, a SBB atendeu mais de 800 mil pessoas em todos os seus programas durante o referido ano. É obvio que esse trabalho não é realizado de forma solitária. Como instiga o próprio estatuto da SBB, trata-se de um trabalho de cooperação com inúmeros parceiros e

\footnotetext{
${ }^{1254}$ Cf. VERGAMINI, Sabine Antonialli Arena (Org.). Mãos fazendo história. Petrópolis: Editora Arara Azul, 2003, p. 14.

1255 Cf. Aventuras Bíblicas em libras. Vol. 1. Barueri: Sociedade Bíblica do Brasil, 2012; Aventuras Bíblicas em libras. Vol. 2. Barueri: Sociedade Bíblica do Brasil, 2015; Aventuras Bíblicas em libras. Vol. 3. Barueri: Sociedade Bíblica do Brasil, 2016.

1256 SOCIEDADE BÍBLICA DO BRASIL. Relatório Nacional de Trabalho 2016, p. 22.

${ }^{1257}$ Cf. GIRALDI, Luiz Antonio. História da Bíblia no Brasil, pp. 290-291.
} 
voluntários. Em 2016, mais de 600 organizações, de todo o Brasil, estabeleceram uma parceria formal com a SBB. Algumas das atividades foram realizadas por essas organizações, com a contrapartida de terem recebido o material bíblico como doação; outras foram conduzidas pela própria SBB. Como exemplo desta última, nas mobilizações sociais e nos diversos encontros com os diferentes públicos já delineados, a SBB contou com a participação e o apoio de mais de 1.400 voluntários $^{1258}$.

Numa perspectiva histórica, é possível perceber que os programas realizados pela SBB estão sempre em processo de aprendizado e melhoria. Em todos eles, a Bíblia e sua mensagem constituem sempre o fundamento. É claro que não é possível alcançar todos os lugares e todas as pessoas que precisam de ajuda. Tal realidade só se torna possível por meio das parcerias e do relacionamento com cristãos e igrejas em todo o país.

\subsubsection{3 \\ O incentivo à leitura bíblica nos Programas de Difusão das Escrituras Sagradas}

Pelo fato de ser uma organização voltada para as Escrituras, resta óbvio que um dos objetivos da organização é instigar a leitura da Bíblia. Como visto anteriormente, esse é um dos aspectos do ciclo de vida da Bíblia. De forma geral, é claro que a maioria das atividades até aqui apresentadas (se não todas) tem por objetivo incentivar as pessoas a manterem contato com a Bíblia. Em todas as ações, programas e projetos realizados, espera-se que a pessoa, ao receber uma Bíblia, consiga lê-la na coletividade de sua comunidade de fé, na individualidade para seu desenvolvimento espiritual e na comunhão fraterna da vida familiar. E aí está um grande desafio; afinal,

É comum encontrar pessoas em nossas comunidades que não só possuem a Bíblia, mas querem ler, entender e alcançar sua mensagem. Todavia, um número considerável alega que essa leitura, apesar de ter sido várias vezes iniciada, não prosseguia, porque, dizem: "A Bíblia é um livro difícil de ser lido e entendido"1259.

\footnotetext{
1258 ARAUJO, Emilene. Programas e projetos sociais desenvolvidos pra SBB [mensagem pessoal]. Mensagem recebida por<emilene@ @bb.org.br> em 11 dez. 2017.

${ }^{1259}$ FERNANDES, Leonardo Agostini. A Bíblia e sua mensagem: introdução à leitura e ao estudo da Bíblia, p. 11.
} 
De fato, por mais que a Bíblia seja um livro que está bem presente na vida dos brasileiros - alguns chegam a ter vários exemplares em casa -, se faz necessário conscientizar as pessoas sobre a necessidade e a importância de sua leitura. Nessa perspectiva, não basta simplesmente dar a Bíblia por meio de doações ou programas. Para que o ciclo de vida da Bíblia se concretize, a leitura da Bíblia precisa ser instigada e, para realizar tal trabalho, a SBB desenvolve alguns programas específicos de difusão das Escrituras.

O Plano Anual de Leitura da Bíblia é um deles. De forma simples, a SBB disponibiliza aos cristãos de todo o país planos específicos de leitura da Bíblia em um ano. Esses planos são desenvolvidos para adultos, jovens e crianças. Trata-se, na verdade, de um convite para que as pessoas leiam a Bíblia por meio de um compromisso diário. Assumindo o compromisso, a pessoa recebe um encarte onde os textos bíblicos estão categorizados para que possa ler toda a Bíblia em um ano. Em 2016 "foram entregues mais de 73 mil exemplares da publicação, além de 1.231 certificados de conclusão de leitura, uma ação que visa estimular o contato com as Escrituras Sagradas" 1260 .

Considerando alguns aspectos intrínsecos à realidade brasileira, a SBB também incentiva o acesso às Escrituras e o contato com elas por meio da audição da Bíblia. Entre outros, trata-se de resgatar o aspecto da oralidade que desde o início impulsionou a difusão das Escrituras na história do povo de Deus. Tal projeto procura alcançar principalmente pessoas analfabetas; afinal, o índice de analfabetismo no Brasil ainda é significativo ${ }^{1261}$. Para além disso, existem os analfabetos funcionais, ou seja, aqueles que até conseguem ler certas palavras, mas não conseguem compreender o que estão lendo. Entretanto, é claro que o programa não se limita a esse público; ele pode alcançar a todos que, por um motivo ou outro, prefiram ter acesso às Escrituras por meio da audição.

Uma forma de envolver os cristãos na audição da Bíblia ocorre por meio do projeto A fé vem pelo ouvir, criado com base na epístola de Paulo aos Romanos, capítulo 10, versículo 17, que diz: “E, assim, a fé vem pelo ouvir, e o ouvir, pela palavra de Cristo”. Para tanto, a SBB disponibiliza gravações do Novo Testamento em formato MP3. Para aqueles que residem em locais onde não existe

\footnotetext{
1260 SOCIEDADE BÍBLICA DO BRASIL. Relatório Nacional de Trabalho 2016, p. 26.

${ }^{1261}$ Cf. INSTITUTO BRASILEIRO DE GEOGRAFIA E ESTATÍSTICA. Pesquisa Nacional por Amostra de Domicílios (Pnad): síntese de indicadores. Rio de Janeiro: IBGE, 2016, pp. 42-44.
} 
energia elétrica, outra forma de ter acesso às Escrituras gravadas se dá por meio do aparelho proclaimer. De acordo com o Relatório Nacional de Atividades 2016: "Mais de 280 Proclaimers foram distribuídos em 2016. O Proclaimer é um aparelho digital que tem a capacidade de reproduzir textos bíblicos em áudio sem necessidade de energia elétrica. O projeto é desenvolvido com igrejas e organizações"1262.

O proclaimer foi criado pela organização missionária Hosanna ministries para ser um dispositivo de reprodução para pessoas necessitadas ou analfabetas que não possuem recursos ou condições suficientes para receber a Palavra de Deus em formato impresso. Seu objetivo, portanto, é de proclamar a Palavra de Deus na linguagem do coração de seus ouvintes. As traduções bíblicas utilizadas são aquelas mais fáceis de entender, como a NTLH no Brasil, por exemplo. A leitura e a audição em uma tradução como esta reduz em muito a dificuldade de compreensão do texto bíblico. Normalmente, a SBB distribui os proclaimers em comunidades ribeirinhas, pequenos vilarejos ou aldeias indígenas, todas caracterizadas pela dificuldade de acesso tradicional às Escrituras. Como se percebe, tratase de uma ação que procura promover um encontro entre as pessoas, com o objetivo de escutarem sistematicamente a Bíblia em formato de áudio, não importando onde estejam.

Uma forma de também dar acessibilidade às Escrituras nas mais diferentes regiões e contextos brasileiros ocorre por meio do projeto Pedalando por Bíblias. Historicamente, o projeto surgiu em 1984, na Austrália, quando o ciclista Bob Forrest pedalou cerca de $900 \mathrm{~km}$ na companhia de um filho e de um amigo. Seu objetivo era conseguir recursos, que seriam aplicados em projetos de distribuição de Bíblias ${ }^{1263}$. A iniciativa de Forrest influenciou muitas pessoas; o projeto passou a ser realizado em vários países.

Seguindo o ideal para o qual foi concebido, no Brasil, o projeto Pedalando por Bíblias procura mobilizar grupos de pessoas, adultos, jovens e crianças em um passeio ciclístico que integra a propagação das Escrituras às atividades recreativa e esportiva. Cada participante é convidado a fazer uma inscrição por meio de uma doação de recursos, os quais são totalmente aplicados na obtenção de Escrituras.

${ }^{1262}$ SOCIEDADE BÍBLICA DO BRASIL. Relatório Nacional de Trabalho 2016, p. 25.

${ }^{1263}$ Cf. SCHOKMAN, Suzanne. Bike For Bibles celebrates 30 years on the road. Bible Society News. Sydney, 13 jan 2014. Disponível em: http://www-archive.biblesociety.org.au/news/bikebibles-celebrates-30-years-road. Acesso em 13 dez. 2017. 
Após o evento, as Escrituras Sagradas são distribuídas para a população mais carente da região, em parceria com igrejas ou organizações ${ }^{1264}$.

Como foi possível perceber, facilitar e promover o acesso às Escrituras, através da distribuição e do incentivo à leitura, constituem um trabalho significativo na difusão da Palavra de Deus a partir do contexto brasileiro. Para aqueles que não leem a Bíblia sob o pressuposto da fé, a leitura bíblica pode instigar, pelo menos, o conhecimento da história. Para aqueles que fazem uma leitura a partir da fé que vivenciam, a mensagem contida nas Escrituras pode transformar a vida. Ela muda os valores, o modo de viver, de se relacionar etc.

Como bem lembra Mesters, "a Bíblia apenas descreve fatos, situações, experiências, esforços, ideais, verdades e valores que para alguns foram a porta para um encontro com Deus" ${ }^{1265}$. Nessa perspectiva, proporcionar acessibilidade às Escrituras Sagradas representa, também, aproximar o ser humano de um encontro transformador com o próprio Cristo; afinal, "a Bíblia é a voz de Deus que continua ecoando em nossos ouvidos, graças à sua fixação por escrito" 1266 .

\subsection{3 \\ 0 aspecto da relevância no trabalho bíblico: envolvimento e defesa das Escrituras Sagradas no Brasil}

A terceira e última etapa do ciclo de vida da Bíblia se fundamenta em dois aspectos importantes no trabalho de difusão das Escrituras. Para além da disponibilidade (tradução, publicação e produção) e da acessibilidade (distribuição e incentivo à leitura), ressalta-se a necessidade da relevância (engajamento e defesa) da Bíblia na sociedade hodierna. Pelo que parece, esta etapa é significativamente desafiadora, principalmente pelo contexto contrário à religião que cresce nos círculos sociais, midiáticos e acadêmicos na contemporaneidade.

É claro que tais aspectos não são novidade. Já se constatou anteriormente que, com o advento da modernidade (no viés sociológico), e com o aparecimento

\footnotetext{
${ }^{1264}$ Cf. SBB. Incentivo à leitura. Desenvolvido pela Sociedade Bíblica do Brasil, 2013. Apresenta os vários programas desenvolvidos pela SBB pelos quais os leitores são incentivados a ler a Bíblia. Entre eles, consta a descrição do Projeto Pedalando por Bíblias. Disponível em: <http://www.sbb.org.br/nossos-programas/de-incentivo-a-leitura/pedalando-por-biblias/>. Acesso em 2 dez. 2017.

1265 MESTERS, Carlos. Palavra de Deus na história dos homens, p. 201.

1266 FERNANDES, Leonardo Agostini. A Bíblia e sua mensagem: introdução à leitura e ao estudo da Bíblia, p. 43.
} 
do liberalismo (no viés teológico), a Bíblia foi e continua sendo questionada pelos críticos. Numa perspectiva histórica, mas também atual, as Escrituras foram entendidas como um livro ultrapassado, inconsistente, alienado e falso, a ponto de muitos declararem "o conteúdo da Bíblia como mito, lenda, estória etc."1267

Por outro lado, tais críticas não suplantaram a difusão das Escrituras. Pelo contrário, "a Bíblia foi e ainda é o maior best-seller da história da humanidade, pois é o livro mais vendido, traduzido e difundido em várias línguas e dialetos" ${ }^{268}$. Os fatos históricos descritos nessa pesquisa corroboram a afirmação de Fernandes. E, como se constata, a SBB tem feito parte desta caminhada.

Historicamente, o trabalho bíblico realizado pelas Sociedades Bíblicas (SBBE, SBA e SBB) no país foi pontualmente marcado pelo caráter de relevância e defesa das Escrituras para a sociedade. Foi isso que os primeiros missionários, agentes e colportores das Sociedades Bíblicas fizeram ao viajar pelo interior do país propagando a Bíblia e a importância de sua mensagem entre o povo. Foi isso que também ocorreu quando as Escrituras foram entregues a personagens importantes da história do Brasil, tais como D. Pedro II ou Prudente de Moraes, que foi o primeiro presidente eleito na República.

Nesta perspectiva, portanto, importa perceber como o trabalho de relevância é realizado pela SBB, alicerçado sob o objetivo de "envolver diferentes públicos com a Palavra de Deus e a Causa da Bíblia" ${ }^{1269}$. Acredita-se que o engajamento das pessoas no trabalho bíblico resultará na defesa de sua importância.

\subsubsection{1 \\ O trabalho de difusão das Escrituras Sagradas por meio do envolvimento das pessoas na Causa da Bíblia}

Como já se constatou, o trabalho bíblico no Brasil nunca foi realizado de forma solitária. Pelo contrário, tal trabalho é fruto de uma rede de cristãos, igrejas e organizações espalhadas pelo Brasil. E essa é a maneira pela qual a SBB procura envolver as pessoas no trabalho bíblico. A credibilidade das Escrituras se torna visível e, também, sustentável quando as próprias pessoas estão engajadas no tra-

\footnotetext{
${ }^{1267}$ MESTERS, Carlos. Por trás das palavras: um estudo sobre a porta de entrada no mundo da Bíblia, p. 52.

${ }^{1268}$ FERNANDES, Leonardo Agostini. A Bíblia e sua mensagem: introdução à leitura e ao estudo da Bíblia, p. 16.

${ }^{1269}$ SOCIEDADE BÍBLICA DO BRASIL. Relatório Nacional de Trabalho 2016, p. 27.
} 
balho. Por ser uma organização criada pelas igrejas para servir as igrejas, envolver as pessoas no trabalho bíblico representa dar continuidade ao serviço bíblico por todas as gerações.

Já se destacou que, na década de 1950, uma nova modalidade de colportor surgiu no trabalho bíblico no Brasil. Trata-se dos colportores voluntários, que tinham por único objetivo adquirir as Escrituras para entregar gratuitamente às pessoas como uma forma de evangelização. Por outro lado, entre as décadas de 1960 e 1970, um novo formato de material bíblico passou a ser publicado pela SBB. Trata-se das seleções bíblicas, ou folhetos, os quais caíram rapidamente no gosto do povo brasileiro. Esses folhetos são simples: uma publicação relativamente curta de um texto das Escrituras a partir de um tema específico. Além de terem baixo custo, são fáceis para carregar e distribuir. Muitas igrejas e pessoas passaram a usar os folhetos em seu trabalho de divulgação.

Nesse ínterim, a partir da década de 1980, depois de realizar um projetopiloto em Belém e no Rio de Janeiro, a SBB formalizou seu projeto, denominando-o "Sócio Evangelizador"1270. O programa é formado por pessoas de todas as regiões do país, das mais diferentes igrejas e com as mais diferentes idades. De forma simples e objetiva, o programa é realizado da seguinte maneira:

A pessoa que se escreve como Sócio Evangelizador recebe mensalmente da SBB um pacote com mil Seleções Bíblicas. Ela assume o compromisso de distribuir mensalmente as mil seleções bíblicas recebidas e de dar uma pequena contribuição para ajudar a pagar o seu custo ${ }^{1271}$.

Para se ter uma ideia da credibilidade alcançada pelo programa, o Plano Nacional de Trabalho 2016 destaca que foram distribuídos mais de 268 milhões de folhetos, por mais de 11 mil pessoas inscritas no programa. Para facilitar e apoiar tal trabalho, a SBB também realizou nove encontros denominados Treinamentos para Evangelização com Literatura. Trata-se de um trabalho significativo, que procura envolver as pessoas na manutenção da causa da Bíblia e na propagação da mensagem bíblica por meio dos folhetos.

De forma concomitante ao Programa Sócio Evangelizador, existe o Programa Sócio Intercessor. Em sua gênese, este programa foi criado para “despertar

${ }^{1270}$ Cf. GIRALDI, Luiz Antonio. História da Bíblia no Brasil, pp. 195-196.

${ }^{1271}$ Ibid., p. 195. 
as pessoas a orarem em favor da obra de evangelização no Brasil e no mundo" ${ }^{1272}$. De forma prática, o programa é realizado da seguinte maneira:

O sócio intercessor assume o compromisso de orar todos os dias em favor da obra bíblica, e para isso, recebe anualmente da SBB o livrete Calendário de Oração, com motivos de oração para cada dia do ano. Esse calendário contém informações sobre o trabalho realizado pelas Sociedades Bíblicas em mais de duzentos países e pedidos de oração para cada país. A SBB envia gratuitamente o Calendário de Oração aos sócios intercessores ${ }^{1273}$.

Como se percebe, trata-se de um trabalho voluntário, cujo foco é simplesmente orar pela difusão da Bíblia no Brasil e no mundo diante dos desafios que emergem constantemente. Como consequência desse engajamento, “em 2016, 7.689 sócios seguiram o roteiro de orações da Agenda de Oração"1274, isto é, o Calendário de Oração que reúne relatos de conquistas, desafios e necessidades da obra bíblica.

De forma paralela a esses dois programas de difusão bíblica que envolvem muitas pessoas, a organização também instiga o engajamento dos cristãos por meio de contribuições voluntárias para seus programas e projetos. Para cada programa já descrito nesta pesquisa, existe a possibilidade de apoio e oferta, seja por meio do trabalho voluntário ou por meio da aplicação de recursos. Um programa distinto é o Clube Uma Bíblia por Mês. Por meio deste programa, as pessoas assumem o compromisso de ofertar o valor referente a uma Bíblia para os diversos programas da SBB.

Uma forma de proporcionar amplo engajamento das pessoas com o trabalho de difusão das Escrituras são as celebrações do Dia da Bíblia, comemorado no segundo domingo do mês de dezembro. Historicamente, o dia começou a ser celebrado na Grã-Bretanha, em 1549, quando o Bispo Cranmer selecionou uma data para que o povo intercedesse em favor da leitura das Escrituras. O propósito estabelecido foi incluído no livro de orações do Rei Eduardo VI, do Reino Unido, e a partir desta data começou a ser comemorado em diversos lugares, mormente pelas igrejas protestantes ${ }^{1275}$. No Brasil, a data passou a ser timidamente celebrada com a chegada dos primeiros missionários, os quais, como já visto, eram também

\footnotetext{
${ }^{1272}$ GIRALDI, Luiz Antonio. História da Bíblia no Brasil, p. 173.

${ }^{1273}$ Ibid.

${ }^{1274}$ SOCIEDADE BÍBLICA DO BRASIL. Relatório Nacional de Trabalho 2016, p. 28.

${ }^{1275} \mathrm{Na}$ Igreja Católica, a Bíblia é celebrada durante o mês de setembro desde 1971. O mês de setembro foi escolhido como mês da Bíblia porque o dia 30 de setembro é considerado o dia de São Jerônimo, um dos grandes biblistas da história, que nasceu em 340 e faleceu em 420 d.C.
} 
agentes e colportores das Sociedades Bíblicas. Porém, as celebrações mais significativas passaram a acontecer depois da fundação da SBB ${ }^{1276}$. Desde 2001, a data passou a integrar o calendário oficial do país com base na Lei Federal 10.335.

A primeira manifestação pública aconteceu no Monumento do Ipiranga, em São Paulo. Giraldi acrescenta que "em dezembro de 1951, o Departamento de Correios e telegráficos [...] publicou um selo comemorativo do Dia da Bíblia"1277. A partir deste período, o dia passou a ser celebrado de muitas formas: cultos especiais e temáticos, ajuntamento de diferentes igrejas, carreatas, shows, maratonas de leitura bíblica, exposições bíblicas, construção de monumentos à Bíblia e ampla distribuição de Escrituras. Entre estas formas, Giraldi destaca os monumentos e praças, que a partir da década de 1970 passaram a ser erigidos em homenagem à Bíblia. De acordo com o autor, em 2006 havia cerca de 200 monumentos espalhados pelo Brasil ${ }^{1278}$.

Um desafio contemporâneo significativo para a causa da Bíblia é a necessidade de engajar os jovens na leitura e no trabalho de difusão das Escrituras. Para tanto, a SBB, juntamente com outras organizações cristãs, desenvolve o Projeto Lectionautas. Trata-se de um projeto que teve em sua gênese dupla iniciativa: das Sociedades Bíblias Unidas (SBU) e do CELAM (Conselho Episcopal Latinoamericano), este último formando por bispos católicos. O projeto Lectionautas completou dez anos em 2016. Metodologicamente, o projeto procura ressaltar que "entre as muitas formas de se aproximar da Sagrada Escritura existe uma privilegiada, à qual todos estão convidados: a Lectio Divina, ou exercício orante da Sagrada Escritura"1279. Assim, "Baseado no Método Lectio Divina, leitura orante da Bíblia, o projeto utiliza a Internet como principal meio de comunicação com o jovem, visando incentivar a leitura e a prática dos ensinamentos sagrados"1280.

Como se percebe, trata-se de um resgate de um dos princípios do modo de vida monástica por meio da leitura orante da Bíblia, adaptada à realidade dos jovens na atualidade. No Brasil, o trabalho é coordenado em conjunto pela SBB e pela CNBB. As SBU, inclusive, publicam uma Bíblia especifica para esta ação, a

\footnotetext{
1276 Cf. GIRALDI, Luiz Antonio. História da Bíblia no Brasil, p. 299.

1277 Ibid., p. 114.

1278 Ibid.

1279 LECTIONAUTAS. Manual de Lectio Divina. CELAM e SBU, 2016, p. 7.

${ }^{1280}$ SOCIEDADE BÍBLICA DO BRASIL. Relatório Nacional de Trabalho 2016, p. 30
} 
Bíblia Sagrada com Método Lectio Divina ${ }^{1281}$. No Brasil, essa Bíblia é impressa e distribuída pela SBB. De acordo com o Plano Nacional de Trabalho de 2016, "para multiplicar o programa pelo País, foram realizadas capacitações em Montes Claros e Belo Horizonte (MG), Curitiba e Apucarana (PR), Palmas (TO), Goiânia e Formosa (GO), alcançando 1.550 jovens"1282.

Se, por um lado, tais ações se fundamentem na esperança de que realmente a Palavra de Deus ocupe "o centro fundamental da vida e da missão da Igreja"1283, por outro, elas instigam o engajamento das pessoas no trabalho de difusão das Escrituras. Para além destes aspectos, elas estimulam as pessoas, por meio desse envolvimento, a tornarem público seu apreço e seu trabalho pela causa da Bíblia. Trata-se, portanto, de um trabalho relevante para a missão da igreja e para o resgate de valores na sociedade.

\title{
5.2.3.2 \\ O trabalho de difusão das Escrituras Sagradas por meio da defesa da Bíblia e a sua causa
}

Em sua última categoria, o ciclo de vida da Bíblia apresenta um aspecto fundamental para que a difusão das Escrituras se desenvolva e se fortaleça. Para além de tornar as Escrituras disponíveis e acessíveis, a partir de sua relevância para a vida e para sociedade, urge a necessidade de defendê-la. Tal necessidade é quase um imperativo diante do complexo contexto que a sociedade impõe direta ou indiretamente aos cristãos. De fato,

\begin{abstract}
O advento de uma sociedade pluralista, agitada por aceleradas mudanças socioculturais, constitui um fato inesperado e problemático, ao menos para um cristianismo acostumado ao aconchego da cristandade. Desse modo, a transmissão da fé, tão óbvia em tempos passados nos países marcados pela fé cristã, se tornou um problema sério para a Igreja ${ }^{1284}$.
\end{abstract}

Sem dúvida, a transmissão da fé é um grande desafio na atualidade e, de certa forma, para transmitir a fé nos dias atuais se faz necessário antes defendê-la. Em relação às Escrituras, tal realidade não se altera. Como bem afirmou Mesters,

\footnotetext{
${ }^{1281}$ BÍBLIA Sagrada. Português. Bíblia Sagrada com Método Lectio Divina. [s.l.]. Sociedades Bíblicas Unidas, 2012.

${ }^{1282}$ SOCIEDADE BÍBLICA DO BRASIL. Op. cit., p. 30

${ }^{1283}$ FERNANDES, Leonardo Agostini. A Bíblia e sua mensagem: introdução à leitura e ao estudo da Bíblia, p. 5.

${ }^{1284}$ FRANÇA MIRANDA, Mario de. A Igreja numa sociedade fragmentada. São Paulo: Loyola, 2006, p. 201 (grifo nosso).
} 
"na base duma competição honesta, avaliada pelo serviço que presta e pelo valor que oferece, a Bíblia disputará, junto com as outras filosofias e religiões, um lugar no coração dos homens"1285. Como se percebe, os desafios impostos à difusão das Escrituras são muitos.

Nesse ínterim, se faz necessário defender as Escrituras e a sua relevância para a humanidade por meio de ações que, entre outras, advoguem seu conteúdo e consolidem sua credibilidade. Essas ações podem ser focadas sob a ótica da defesa interna, isto é, se faz necessário defender a relevância das Escrituras na realidade da própria igreja cristã. Por outro lado, se faz também necessário defender a pertinência das Escrituras na realidade da sociedade hodierna. Este último, portanto, se firma sob a ótica da defesa externa. Para realizar ambas as ações em prol da defesa das Escrituras, uma forma possível ocorre através da valorização da história e da cultura bíblica.

De acordo com Giraldi ${ }^{1286}$, a SBB começou a resgatar o aspecto histórico das Escrituras com a criação de um Museu da Bíblia em 1981. Na época, ele estava situado no Rio de Janeiro. Com o passar dos anos, o acervo cresceu e a sede da SBB foi transferida para São Paulo. Por conseguinte, por meio de um convênio com a Prefeitura Municipal de Barueri, foi construído um novo, moderno e informativo Museu da Bíblia (MuBi), inaugurado em 2003. Desde seu início, o MuBi tem por objetivo "promover o conhecimento da Bíblia, enfatizando os aspectos culturais, éticos e religiosos" $" 1287$. Para tanto,

O acervo do Museu foi apresentado de maneira didática e agradável, em uma sequência de dez ambientes, que apresentam a história do Livro Sagrado através dos séculos. A exposição começa com a história da escrita e do livro, passa pela história da tradução da Bíblia, pela história da Bíblia no Brasil e no mundo, pela Bíblia falada, a Bíblia para crianças, novidades sobre a Bíblia e termina com um espaço reservado para exposições rotativas ${ }^{1288}$.

Por meio desses ambientes, as pessoas que visitam o MuBi podem conhecer, por exemplo, uma réplica da prensa de Gutemberg, ou, ainda, analisar edições raras da Bíblia, sejam elas antigas ou estejam elas nas mais de mil línguas disponíveis na exposição. As exposições rotativas são variadas a cada período. De forma geral, elas procuram estabelecer um diálogo que favoreça o conhecimento do

\footnotetext{
${ }^{1285}$ MESTERS, Carlos. Palavra de Deus na história dos homens, p. 200.

${ }^{1286}$ Cf. GIRALDI, Luiz Antonio. História da Bíblia no Brasil, pp. 321-322.

1287 Ibid., p. 323.

1288 Ibid., p. 324.
} 
público visitante diante de temas e assuntos pertinentes e contemporâneos. Como exemplo, já passou pelo MuBi uma exposição voltada para os direitos humanos e sua direta relação com a história bíblica. Em 2016, o MuBi recebeu "perto de 20 mil visitantes, entre membros de igrejas, crianças e acadêmicos, incluindo ainda pessoas de diferentes países" $" 1289$.

De forma anexa ao MuBi, há também a Biblioteca da Bíblia, criada em 2006, com o objetivo de "colocar a Bíblia em todos os idiomas à disposição de brasileiros e oferecer aos tradutores da Bíblia em atividade no Brasil um amplo e confiável centro de consulta e pesquisa para a elaboração de novas traduções" 1290 . De maneira análoga ao que ocorre com a Biblioteca da Universidade de Cambridge, na Inglaterra, a Biblioteca da Bíblia se tornou o acervo oficial das publicações das Sociedades Bíblicas Unidas. Portanto, cada edição das Escrituras, publicada em qualquer idioma no mundo, é enviada por meio de uma cópia para ambas as bibliotecas, para que possam ser registradas e preservadas. A partir de 2007, o SLR - Scriptures Languages Report, passou a ser desenvolvido em parceria por essas duas instituições. O SLR foi criado com o objetivo de registrar o crescimento das traduções bíblicas realizadas no mundo, defindo-as por regiões e por características de cada publicação, isto é, se são porções, seleções, testamentos ou Bíblias completas.

Deste modo, a Biblioteca da Bíblia e a Biblioteca de Cambridge são dois centros de referência mundial para novas traduções bíblicas. De acordo com Daniele Santos ${ }^{1291}$, bibliotecária responsável pela Biblioteca do Museu da Bíblia, atualmente, o acervo brasileiro reúne mais de 18 mil títulos, em mais de 20 mil volumes de Escrituras Sagradas, composto por exemplares da Bíblia em mais de 1000 idiomas, obras raras, obras acadêmicas, literatura bíblica em braile e material em áudio e vídeo. Entre outros, o acervo contém obras de referência como Dicionários, Enciclopédias, Manuais de Tradução voltados para a área bíblica, e obras antigas e raras que documentam a história da tradução da Bíblia. Além disso, por estar localizada no Brasil, a Biblioteca também possui literatura bíblica e registros que documentam a tradução para a língua portuguesa, para as línguas

\footnotetext{
1289 SOCIEDADE BÍBLICA DO BRASIL. Relatório Nacional de Trabalho 2016, p. 27.

1290 GIRALDI, Luiz Antonio. História da Bíblia no Brasil, pp. 329-330.

${ }^{1291}$ SANTOS, Daniele. Biblioteca do Museus da Bíblia [mensagem pessoal]. Mensagem recebida por<daniele.santos@sbb.org.br> em 17 jun. 2018.
} 
indígenas do Brasil e para as línguas das Américas. Como se percebe, trata-se de uma significativa valorização e preservação histórica para a causa da Bíblia.

De forma semelhante ao trabalho realizado pelo MuBi, em São Paulo, a SBB também resgata a importância cultural e histórica das Escrituras por meio do Centro Cultural da Bíblia (CCB), localizado na cidade do Rio de Janeiro. O CCB é constituído de um espaço dedicado a atividades artísticas, culturais e educacionais relacionadas à Palavra de Deus. Durante todo o ano, são realizados encontros cujo enfoque é a Bíblia e sua relevância para os diversos segmentos da sociedade (crianças, jovens, idosos, músicos, líderes, mulheres, entre outros). Em 2016, "mais de 2,2 mil visitantes participaram destes encontros" 1292.

Como se percebe, ambos os espaços, MuBi e CCB, procuram enfatizar a importância do Livro Sagrado na formação da cultura e da civilização ocidental, oferecendo um espaço cultural em torno da Bíblia Sagrada. As programações se voltam para despertar o interesse pela leitura da Bíblia na população brasileira e, por outro lado, fortalecer o trabalho da igreja em sua missão evangelizadora.

Nessa mesma perspectiva, um trabalho realizado pela SBB, que se estabelece sob a ótica da defesa das Escrituras, ocorre por meio do aprofundamento de questões acadêmicas em relação à Bíblia. Trata-se do Seminário de Ciências Bíblicas (SCB), realizado em várias edições e em várias regiões do país, e o Fórum de Ciências Bíblias, realizado uma vez ao ano em São Paulo.

De acordo com Giraldi ${ }^{1293}$, o primeiro SCB aconteceu no ano de 2001, na cidade do Rio de Janeiro. O seminário é realizado por meio de palestras, as quais ocorrem em seis painéis. Os palestrantes são variados; atualmente são 16 pessoas. Alguns pertencem ao corpo funcional da própria SBB e outros são reconhecidos biblistas brasileiros. De forma geral, os temas procuram disseminar mais conhecimento sobre o surgimento da Bíblia, a transmissão do seu texto, a história da sua tradução e as diferentes maneiras de usá-la na missão e na igreja local. De acordo com Camila Vilvock ${ }^{1294}$, já foram realizadas 141 edições do SCB em 69 cidades do Brasil e 11 em outros países. No total, já participaram 34.454 pessoas em todas as edições por meio de 38 temas diferentes.

\footnotetext{
1292 SOCIEDADE BÍBLICA DO BRASIL. Relatório Nacional de Trabalho 2016, p. 29.

${ }^{1293}$ CF. GIRALDI, Luiz Antonio. História da Bíblia no Brasil, p. 294.

1294 VILVOCK, Camila. Seminário de Ciências Bíblicas realizados pela SBB [mensagem pessoal]. Mensagem recebida por<camila@sbb.org.br> em 13 dez. 2017.
} 
Em edição realizada uma vez ao ano, o Fórum de Ciências Bíblicas também constitui uma forma pela qual a SBB procura defender e legitimar as Escrituras Sagradas em sua relação com os aspectos históricos quem envolvem a sua tradução. Portanto, historicamente,

Ao criar um Fórum de Ciências Bíblicas, a Sociedade Bíblica do Brasil tinha alguns objetivos. Primeiro, foi criar um espaço para a pesquisa, o debate, o relatório da frente de tradução bíblica. Em segundo lugar, a intenção era abrir um espaço de diálogo entre a academia e as entidades que se empenham na complexa tarefa de tradução do texto bíblico. Em terceiro lugar, a intenção era socializar um pouco desse conhecimento, tornando-o público ${ }^{1295}$.

A ênfase, como se percebe, é acadêmica e teológica. Considerando que "a teologia, portanto, se remete à Bíblia, e a toda a Bíblia”, é obvio que os temas debatidos se tornam convergentes às questões da história, da arqueologia e, como não poderia ser diferente, da própria teologia. Por isso, o público principal do Fórum é formado por estudantes, pesquisadores, professores, sacerdotes religiosos, teólogos, entre outros. Em 2016, “o $12^{\circ}$ Fórum de Ciências Bíblicas, realizado no Centro de Eventos de Barueri, no Museu da Bíblia (SP), contou com mais de 400 participantes e teve como tema Traduções da Bíblia" ${ }^{1296}$.

Igualmente, vale ressaltar que as novas tecnologias podem contribuir com a difusão, o envolvimento e a defesa das Escrituras. As plataformas e as mídias sociais são, atualmente, conhecidas e utilizadas por boa parte da população. Na verdade, de forma ampla, para o bem ou para o mal, o ambiente virtual tem se caracterizado como um verdadeiro campo de batalha ideológica. Por outro lado, é claro que ele também pode ser utilizado de forma construtiva e transformadora.

É nessa perspectiva que a SBB tem procurado ampliar e fortalecer seu trabalho, por meio da comunicação com seus diferentes públicos. A Revista A Bíblia no Brasil, que desde 1948 se caracteriza como uma publicação voltada unicamente para descrever fatos, notícias e artigos sobre o mundo da Bíblia, é disponibilizada de forma impressa, em braile e digital. Os sites da Internet da SBB também estão voltados para os diferentes públicos. Há uma plataforma específica para livrarias, que adquirem as Bíblias. Há outra para os semeadores, pessoas físicas que realizam o trabalho de colportagem. Para atender clientes de forma geral, há

${ }^{1295}$ SOCIEDADE BÍBLICA DO BRASIL. Fórum de Ciências Bíblicas, p. 5.

${ }^{1296}$ Id. Relatório Nacional de Trabalho 2016, p. 28. 
uma plataforma específica de venda de Bíblias. E há um portal mais amplo, que se caracteriza por apresentar a instituição e todas as suas ações ${ }^{1297}$.

Nas redes sociais, o trabalho também é realizado para "potencializar a divulgação da Palavra de Deus"1298. Os números mais recentes ${ }^{1299}$ apresentam o seguinte resultado: no Facebook, a SBB conta com 1.506.977 seguidores; no Twitter, conta com 32.995 seguidores; no Instagram, há 16.879 seguidores; e no YouTube, 4.961 inscritos e mais de 427.625 visualizações. Em projetos específicos, como o Movimento Jovem Evangelizador, a SBB tem no Facebook 40.667 seguidores, e no Projeto Lectionautas a SBB tem no Facebook 3.425 seguidores.

Uma forma de também defender as Escrituras é torná-la amplamente disponível. Já se descreveram algumas formas pela qual a SBB torna a Bíblia acessível anteriormente. Nesta seção, a ênfase está no tipo de plataforma utilizada. Nesse caso, a SBB torna a Bíblia ainda mais relevante quando a distribui por meio digital e por aplicativos para smartphones e tablets de forma gratuita. Para se ter ideia, em 2016, "o grande destaque foi o aumento da distribuição de Bíblias digitais, com 1.506.406 unidades, um crescimento da ordem de 400\%"1300. Conhecendo e acessando as Escrituras de forma fácil, é bem possível que as pessoas a defendam como algo importante em sua vida.

De fato, é possível perceber que, por meio dessas ações, a SBB procura ressaltar a relevância das Escrituras para a sociedade e para a igreja. Nessa perspectiva, a defesa da Escrituras não é um trabalho isolado da SBB ou de uma ou outra organização que publica a Bíblia. Pelo contrário, trata-se de um trabalho de todos,

${ }^{1297}$ Cf. em ordem de citação: SBB. SBBPontoCom Atacado. Desenvolvido pela Sociedade Bíblica do Brasil, 2017. Apresenta informações sobre a venda de produtos da SBB para livrarias, distribuidores etc, por meio do atacado. $\mathrm{O}$ site apresenta igualmente a missão da organização, central 'fale conosco' e pesquisas de produtos. Numa seção restrita, o cliente pode cadastrar-se e realizar seus pedidos. Disponível em: <https://atacado.sbb.com.br/>. Acesso em 30 nov 2017; SBB. Projeto Semeador. Desenvolvido pela Sociedade Bíblica do Brasil, 2017. Apresenta informações históricas e atuais sobre como uma pessoa pode adeirir ao Projeto Semador, tornado-se um revendedor de Bíblias em sua igreja ou comunidade (um colportor, um missionário da Bíblia, um semeador). Para os interessados há, também, a possibilidade de cadastrar-se no próprio site. Disponível em: <www.sbb.org.br/semeador>; SBB. Loja virtual SBB. Desenvolvido pela Sociedade Bíblica do Brasil, 2017. Como um catálogo digital, apresenta os produtos da SBB e possibilita a compra de clientes previamente cadastrados. Disponível: <http://www.sbb.com.br/. Acesso em 2. dez. 2017; SBB. Portal oficial da Sociedade Bíblica do Brasil. Desenvolvido pela Sociedade Bíblica do Brasil, 2013. Apresenta todo o trabalho realizado pela SBB no Brasil, nos aspectos social, institucional, comunicacional e histórico. Disponível em: 〈http://www.sbb.org.br/>. Acesso em 11 nov. 2017.

${ }^{1298}$ SOCIEDADE BÍBLICA DO BRASIL. Relatório Nacional de Trabalho 2016, p. 33.

${ }^{1299}$ CARNEIRO, Marcia. Plataformas Sociais da SBB [mensagem pessoal]. Mensagem recebida por<marciacarneiro@sbb.org.br> em 11 dez. 2017.

${ }^{1300}$ SOCIEDADE BÍBLICA DO BRASIL. Op. cit., p. 19. 
pois "defendendo a Bíblia defenderão a esperança que ela fez nascer no coração" ${ }^{\prime 301}$. 


\section{6 \\ Conclusão}

A Bíblia, Palavra de Deus na história. Este foi um pressuposto básico pelo qual essa pesquisa transcorreu e se fundamentou em cada capítulo. De fato, a partir desta premissa, constatou ser, praticamente, improvável discorrer sobre a história dos seres humanos, a história da igreja, a história da humanidade e sobre a história do Brasil sem considerar a contribuição e a participação que as Escrituras Sagradas tiveram em cada momento. Seja por considerar a Bíblia um livro sagrado ou simplesmente por contraditá-la como um livro qualquer, a história da difusão das Escrituras Sagradas é intrínseca à história da humanidade. Ela faz parte da história de todos, pois, de fato, a Palavra de Deus se imbricou na história dos seres humanos, na forma de se lidar com o sofrimento, na forma de se estabelecer valores, na forma de se construir a cultura de um povo e na forma de se relacionar com Deus.

Baseado na temática proposta, a difusão das Escrituras esteve sob análise a partir de suas diversificadas relações na história. Essas relações foram, por vezes, intesas e, em outras vezes, tenuês. Nessa perspectiva, vários assuntos foram apresentados sempre sob uma relação de complementariedade e não de exclusão em relação às Escrituras. Como consequência, constata-se que as diferentes formas pela qual as Escrituras foram historicamente difundididas resultaram em uma ampla e significativa história da difusão bíblica que, por sua vez, contribuiu de forma relevante com a caminhada do povo de Deus por meio da igreja de Cristo.

Lá no inicío, se constatou que as palavras foram inicialmente transmitidas de forma oral e, aliás, sempre continuaram a ser transmitidas dessa forma, seja por meio da arte, da homilia, da música, da liturgia, da escuta etc. Mesmo hoje, a Bíblia é mais ouvida do que lida nas igrejas. Porém, para além da oralidade, foi por meio da escrita que as Escrituras Sagradas se firmaram de forma preponderante na história. De fato, os Escritos Sagrados só se difundiram porque a mensagem nela contida foi considerada relevante e significativa. Foi por meio dessa mensagem 
que o povo de Deus se formou, foi por meio dessa mensagem que igreja cresceu e se espalhou pelo mundo e foi por meio dessa mensagem que muitas pessoas, por toda a história, encontraram sentido para viver.

É por isso que, para se difundir e alcançar a humanidade, as Escrituras Sagradas, à serviço do povo de Deus, foram traduzidas. A tradução das Escrituras, ainda no contexto do povo judeu, por meio da Septuaginta, bem como por meio das inúmeras traduções surgidas na história ou existentes na atualidade, deu um grande impulso à difusão da Bíblia. Afinal, Deus falou a língua dos seres humanos. Contudo, além de tornar a mensagem compreensível por meio das traduções, o próprio Deus "se tornou um ser humano e morou entre nós, cheio de amor e de verdade" (Jo 1,14). Deus, por meio de Cristo, irrompeu na história e isso mudou toda a história. A partir d'Ele, as Escrituras ganharam nova interpretação e, por meio d'Ele, novos escritos considerados inspirados foram estabelecidos. Cristo se tornou, portanto, o paradigma na difusão das Escrituras. E foi sob esse fundamento que os apóstolos se firmaram para anunciar e difundir a mensagem, pois, como bem lembra o relato histórico do início da igreja primitiva, "a palavra do Senhor crescia e prevalecia poderosamente" (At 19,20).

No período pós-apostólico, coube aos Pais da Igreja a missão de ler interpretar e difundir os Escritos Sagrados. E isso eles fizeram com excelência e proficuidade nos primeiros seis séculos da história da igreja. O cânon foi estabelecido de forma natural e gradual. Mais traduções foram elaboradas e novos formatos foram criados para que a mensagem contida nos rolos, se tornasse o Livro Sagrado que foi (e continua sendo) amplamente difundido pelos cristãos. Pouco depois, a difusão se ampliou por meio dos monges, que ofereceram às gerações futuras inúmeras cópias dos textos sagrados. Se atualmente há uma abundância de cópias dos manuscritos originais para que se façam traduções e publicações fidedignas das Escrituras, aos copistas da Idade Média se deve dar um lugar de proeminência na história.

Ainda na Idade Média uma nova forma de se ler e difundir as Escrituras Sagradas marcou a história da igreja. A Bíblia foi lida e transmitida a partir de uma teologia mais voltada para o conhecimento e a razão, isto é, a teologia escolástica. Paralelamente, já no final da Idade Média, as Escrituras Sagradas passaram a ser lidas por algumas pessoas que queriam resgatar princípios que consideravam importantes em seus modos de viver e crer. Dessa forma, a mensagem das Escrituras 
se tornou um paradigma na vida de Francisco, de Pedro Valdo, entre outros. E assim, tal leitura começou a instigar em algumas pessoas o desejo de se valorizar e resgatar a Palavra de Deus no centro da igreja e no modo de vida.

Como se constatou, todo o movimento descrito acima, atrelado à outras questões, culminou em um momento crítico da história da igreja. O movimento da Reforma Protestante, recorrendo para a importância da centralidade das Escrituras e a sua livre interpretação e leitura, constituiu um novo momento significativo na história de difusão da Bíblia. Entre os principais aspectos que dividiram católicos e protestantes, estava a forma pelo qual ambos passaram a se relacionar com as Escrituras. Tais fatos geraram discórdias e até mesmo guerras. Foi, de fato, um momento desafiador nessa história.

Do lado católico, por algum tempo, restrições à leitura, tradução e difusão das Escrituras, foram estabelecidas. Tal realidade começou a se alterar no início do século XIX. Atualmente a Igreja Católica incentiva a leitura da Bíblia e o seu uso nas mais diversas ações pastorais que realiza. Pelo lado protestante, a ênfase na livre interpretação (isto é, não mais custodiada pela igreja, como no caso da Igreja Católica), entre outros aspectos, instigou as inúmeras divisões denominacionais e teológicas que marcam os 500 anos de história do protestantismo. E assim, o que se começou na era das confissões se estendeu até os dias atuais. Historicamente, percebe-se que aspectos significativos e outros contraditórios marcaram esse contexto. Contudo, sob o viés da difusão das Escrituras, tal realidade contribuiu com a ampla propagação da Bíblia Sagrada.

No decorrer da pesquisa, evidenciou-se que o pressuposto de uma difusão das Escrituras como se tem atualmente é bem recente. O conceito não era simples, nem óbvio. De fato, a ideia de que cada individuo ou família tenha a sua própria Bíblia é relativamente nova quando se considera os mais de dois mil anos de história da igreja. Desde os primórdios até a Reforma Protestante, pelo menos, a Bíblia estava mais restrita ao uso dos clérigos ou especialistas.

Ficou claro que inúmeros fatores históricos contribuíram para que essa realidade se alterasse. Entre eles, o surgimento da imprensa deu um impulso significativo na propagação da Bíblia. Porém, há, também, a questão histórico-teológica que norteou ambas as igrejas cristãs. No contexto da Reforma Protestante, a ideia do acesso à Bíblia adquiriu rápida aceitação entre as igrejas oriundas da Reforma. No âmbito da Igreja Católica essa realidade começou a se alterar a partir da encí- 
clica Providentissumus Deus, promulgada em 1893 pelo papa Leão XIII, e se estabeleceu de forma consistente a partir do Concílio Vaticano II. Atualmente, ambas as igrejas realizam um trabalho relevante na difusão das Escrituras, permitindo com que a ideia de uma ampla difusão das Escrituras se estabeleça de forma universal nas igrejas cristãs. É nessa perspectiva que as Sociedades Bíblicas têm procurado servir ambas as igrejas no mundo todo.

Como foi possível perceber, entre os séculos XVI e XIX, a história da difusão das Escrituras passou por momentos altos e baixos. A Bíblia e a sua mensagem foram questionadas pelo iluminismo, num aspecto mais sociológico, e pelo liberalismo, num aspecto mais teológico. Concomitantemente, porém, principalmente a partir do século XVIII, alguns movimentos oriundos de igrejas protestantes, reconhecidos historicamente como puritanismo, pietismo e avivamentismo, deram uma nova projeção à difusão das Escrituras. E assim, a Bíblia adquiriu mais significância para vida das pessoas que a passaram a ler não só mais de forma comunitária nas igrejas, mas também de forma devocional, seja por meio de uma leitura individual ou por meio da leitura em família.

Como a importância das Escrituras estava sendo resgatada sob a mesma relevância defendida anteriormente pelos reformadores, entendeu-se que era importante que as Escrituras Sagradas alcançassem não somente algumas poucas igrejas dos grandes centros do mundo da época, principalmente na Europa. Era fundamental que a mensagem cristã e, por conseguinte, as Escrituras fossem difundidas por todo mundo. Iniciava-se, assim, o movimento missionário de igrejas protestantes que, entre outros aspectos, tinha como missão primordial levar a mensagem da Bíblia a todas as pessoas, em todo o mundo.

Foi a partir desse contexto que, entre o fim do século XVIII e o início do século XIX, várias igrejas cristãs de origem protestante, entenderam que era importante criar uma organização que se preocupasse única e exclusivamente em levar a Bíblia a todos, numa linguagem que pudessem entender e a um preço que pudessem pagar. Em sua gênese, o movimento já estabelecia suas bases: traduzir, publicar e difundir as Escrituras seria o paradigma que nortearia o trabalho bíblico. Assim surgiu a primeira Sociedade Bíblica na Inglaterra em 1804 e, a partir dela, muitas outras surgiriam imbuídas da mesma missão. Sob a estratégia de levar as Escrituras Sagradas à todas as pessoas, muitos lugares do mundo receberam agen- 
tes ou colportores das Sociedades Bíblicas que tinham a missão de propagar a Bíblia. Entre eles, o Brasil também foi alvo dessa missão.

É claro que desde o descobrimento havia um trabalho bíblico no Brasil. Os jesuítas já tinham lançado as bases de uma evangelização baseada em histórias da Bíblia. Como se constatou, as estratégias por eles utilizadas contribuíram para que o povo brasileiro tivesse maior familiaridade com as Escrituras por meio de teatros, musicas, pregações e catequese. Porém, também se constatou que a Bíblia, como um livro a ser utilizado de forma individual não fez parte do trabalho bíblico nos primeiros trezentos anos de história do Brasil. A Bíblia, portanto, era um livro desconhecido por muitos no início do século XIX no país.

Nesse interim, a difusão das Escrituras no Brasil, caracterizada por meio da distribuição da Bíblia à população, teve início pouco tempo depois da chegada da coroa portuguesa ao país e a consequente implantação do Império. Inicialmente, por meio do trabalho da Sociedade Bíblica Britânica e Estrangeira, Bíblias foram enviadas por comerciantes ingleses. Algumas foram distribuídas, outras foram deixadas nas docas dos portos sob a esperança de que alguém se interessasse por elas e as pegassem para ler. Depois, a Sociedade Bíblica Americana também começou a realizar o trabalho bíblico entre o povo brasileiro.

Entre outros aspectos, um fato que se destacou nessa pesquisa é que a Bíblia chegou ao Brasil muito antes do que qualquer missionário protestante denominacional. Nesse sentido, a história da difusão das Escrituras no país é uma história que antecede e, depois, se entrelaça à história da evangelização das missões protestantes no Brasil. A ênfase na distribuição da Bíblia e o papel desempenhado pelas Sociedades Bíblicas constituíram um eixo comum entre as diferentes igrejas protestantes que chegavam ao Brasil naquela época. Elas contribuíam entre si, compartilhavam do mesmo desejo e realizavam uma mesma missão, mesmo sob uma forma de governo e, por vezes, um corpo doutrinário diferente entre si. Portanto, a Bíblia e as Sociedades Bíblicas tiveram um papel agregador ao início do protestantismo no Brasil. Até hoje as Sociedades Bíblicas procuram realizar essa missão, mesmo sob algumas dificuldades que marcam a trajetória relacional de muitas igrejas evangélicas no país.

Historicamente, o que se constata é que, entre desafios e oportunidades, por mais de um século, as Sociedades Bíblicas (Britânica e Americana) realizaram um significativo trabalho de difusão das Escrituras no país. Os colportores e os agen- 
tes adentraram pelo interior do Brasil, vendendo as Escrituras àqueles que queriam e podiam comprar e doando àqueles que mesmo querendo não tinham condições de adquiri-las. A difusão das Escrituras realizadas por ambas as Sociedades Bíblicas estavam acima de qualquer diferença doutrinária. Para cumprir tal missão, por exemplo, quando se constatava certa rejeição à tradução de Almeida, as Sociedades Bíblicas distribuíam traduções católicas da Bíblia, dos padres Figueiredo e Matos Soares. Essa realidade perdurou por muitos anos. E foi dessa forma que a Bíblia foi se tornando, pouco a pouco, um livro desejado pelo povo brasileiro, transformando o Brasil em um dos países com maior relevância no trabalho de difusão das Escrituras no mundo todo.

Esse trabalho se ampliou ainda mais quando, em 1948, as Sociedades Bíblicas estrangeiras entregaram a responsabilidade e a missão de difundir as Escrituras no país aos cristãos brasileiros. A criação da Sociedade Bíblica do Brasil constituiu um marco nessa história, afinal, desde o seu surgimento, até os dias atuais, o que se constata é uma história de serviço à igreja brasileira em sua missão, e de transformação social à população brasileira diante de suas necessidades. Nesse sentido, se constatou que o trabalho realizado pela SBB, baseado no método do ciclo de vida da Bíblia, contribuiu historicamente e tem contribuído contemporaneamente, sob diversas formas, com a difusão das Escrituras Sagradas no Brasil.

O primeiro aspecto que se ressaltou foi a importância da disponibilidade das Escrituras. A Bíblia, para além das traduções em língua portuguesa, utilizadas por protestantes e católicos, tem sido também traduzida para línguas indígenas e minoritárias. É claro que há ainda existem muitas necessidades nesta área e, como já se dissertou, a SBB pode ampliar sua ação nesse campo especifico.

Depois de traduzida, a Bíblia tem sido publicada não para simplesmente ser um livro de capa preta nas estantes das famílias. Pelo contrário, ela tem sido publicada de forma estratégica para atender as mais diferentes necessidades e os mais distintos segmentos da população. A Bíblia, nesse sentido, tem alcançado, dentro das possibilidades inerentes ao contexto brasileiro, a igreja e a sociedade; a criança, o jovem e o adulto; o cego e o surdo; o leigo e clérigo; e assim por diante. Para que tudo isso seja possível, ela tem sido impressa na Gráfica da Bíblia por aqueles que se interessam em lê-la no formato mais tradicional, mas também tem sido disponibilizada de forma gratuita nas plataformas digitais. As Escrituras Sa- 
gradas, portanto, estão sendo amplamente disponibilizadas para que possa se difundir ainda mais no Brasil.

O segundo aspecto que se ressaltou foi a importância da acessibilidade às Escrituras. Nesse sentido, o trabalho bíblico da SBB não se limita à tradução, publicação e produção das Escrituras. Depois destas etapas, para que a difusão das Escrituras ocorra de forma eficaz, constatou-se necessário torna-la mais acessível às pessoas. $\mathrm{A} \mathrm{SBB}$, para cumprir tal propósito, continuou, ampliou e adaptou o trabalho histórico de colportagem. Como se percebeu, esse trabalho é significativo porque ele envolve as pessoas na mesma missão. $\mathrm{O}$ trabalho bíblico se torna, nesta perspectiva, um trabalho de todos os cristãos. Porém, para atender a demanda diante da extensão territorial do país, a SBB tem implantado unidades regionais que facilitam o acesso às Escrituras para os seus mais diferentes públicos.

Considerando que tais etapas possibilitam uma integração mais aproximada aos cristãos e às igrejas, a SBB tem procurado, histórica e contemporaneamente, tornar acessível a Bíblia e a sua mensagem por meio de projetos que envolvam a sociedade. Ainda que a fé seja um elemento importante para o leitor das Escrituras, a difusão das Escrituras por meio desses projetos, também tem sido realizada com o objetivo de contribuir com o resgate de valores que possibilitem a transformação social do povo brasileiro. Para além disso, entretanto, um diferencial significativo nesse trabalho tem sido realizado por meio dos Programas Bíblicos de Impacto Social. Por meio deles, a Bíblia tem servido de inspiração contra as injustiças sociais que permeiam o país. E, como tal, tem sido entregue ao povo brasileiro, principalmente o mais carente, sob uma perspectiva de uma mensagem de esperança que possa transformar a realidade social, cultural, familiar, espiritual e pessoal em que vivem. Espera-se que por meio destas atividades realizadas pela $\mathrm{SBB}$, as pessoas sintam-se instigadas a ler a Bíblia e praticar seus ensinamentos. As Escrituras Sagradas, portanto, estão se tornando mais acessíveis para que, assim, se difunda ainda mais pelo imenso Brasil.

O terceiro aspecto que se ressaltou foi a relevância que deve ser dada às Escrituras pela sociedade e pela igreja. Constatou-se que, para realizar tal missão, a SBB tem procurado engajar as pessoas no trabalho bíblico por meio de distintos programas de difusão bíblica. Essas pessoas, na grande maioria, cristãs das mais diferentes igrejas, se envolvem por meio da entrega de porções das Escrituras, por meio da oração pela causa da Bíblia, por meio da celebração conjunta de cristãos 
em torno de um Dia da Bíblia e por meio do incentivo à leitura em programas com jovens e adultos, envolvendo protestantes e católicos.

Além de engajar pessoas, uma parte importante do trabalho destacado pela SBB é a defesa da Bíblia e a sua mensagem. Essa defesa é realizada por meio da valorização da história, no Museu da Bíblia e no Centro Cultural da Bíblia; e, também por meio de encontros sistemáticos realizados com estudantes, pesquisadores e lideres cristãos, com o objetivo de apresentar e debater temáticas no campo das Ciências Bíblicas em suas variadas relações com a arqueologia, história, teologia, ciência etc. As Escrituras Sagradas, portanto, estão sendo defendidas a partir de sua relevância na vida de muitas pessoas, contribuindo para que sua difusão se amplie, mas, também, tenha continuidade no Brasil.

Vale lembrar que nesta caminhada não se intentou discorrer sobre toda a história da difusão das Escrituras, nem no mundo, nem no Brasil. Essa história é muito ampla para que se pudesse apreendê-la de forma plena numa pesquisa delimitada como esta. Da mesma forma, resta óbvio que o trabalho de difusão das Escrituras Sagradas realizado no Brasil não se limitou (nem se limita) ao trabalho realizado pelas Sociedades Bíblicas no Brasil. A ênfase no trabalho de difusão das Escrituras realizado pelas Sociedades Bíblicas, especialmente no trabalho da SBB, objeto principal desta pesquisa, se deu pela relevância e pela amplitude que essa difusão tem apresentado. Esta afirmação encontra base nos relatos históricos apresentados por toda essa pesquisa.

A SBB tem servido a todas as igrejas cristãs indistintamente por meio de suas traduções bíblicas; por meio das publicações que, quando produzidas, servem a igreja em sua missão e servem o estudante em seu labor teológico; por meio dos encontros em que a Bíblia e a sua história são debatidas e apresentadas sob o viés de sua relevância para a vida de todos. A SBB, portanto, tem sido uma organização fundamental de apoio à igreja cristã brasileira e mundial, como já se constatou. Esse trabalho, realizado em parceria com protestantes e católicos, tem sido muito frutífero. Concomitantemente, ela tem servido à população mais necessitada do país. Por meio de parceria com organizações cristãs distintas e por meio da realização de projetos holísticos, a SBB tem distribuído gratuitamente milhares de Escrituras, sob o objetivo de ressaltar a importância da Bíblia como um elemento que instiga a transformação. 
Como se percebe, tem sido um trabalho diferenciado e reconhecidamente necessário. Afinal, a história da difusão das Escrituras é, também, a história de pessoas que tiveram um encontro com a Bíblia e que, por meio desse encontro, tiveram suas vidas transformadas. Elas mudaram também suas realidades em relação à família, ao trabalho, ao estudo, à vida em sociedade etc. Por assim ser, mudaram o seu presente e seu futuro, contribuindo para que o Brasil e o mundo, por meio dos valores contidos das Sagradas Escrituras, possam ser um lugar melhor de se viver tanto por meio da relação estabelecida com Deus, quanto por meio da relação estabelecida com a criação, com os outros seres humanos e consigo mesmo.

Conclusivamente, cabe salientar alguns aspectos importantes. A relevância do trabalho realizado na difusão das Escrituras não deixou (e não deixa) de apresentar, também, certos limites. Como se sabe, no seio cristão, ainda existem demandas e questões que não foram resolvidas. A difusão da Bíblia, nesse sentido, não resolve (e nem pretende resolver) todos os problemas que surgem na caminhada da igreja, seja ela católica ou protestante. Alguns exemplos sobre essa realidade podem ser considerados. A pregação extra-bíblica da "teologia da prosperidade" evidencia, por exemplo, que não basta ter acesso à Bíblia quando o tipo de leitura que se faz dela é equivocado ou mal-intencionado. Da mesma forma, a leitura extremista por meio dos fundamentalismos ou imediatista em busca de soluções pragmáticas também evidenciam que há um longo caminho a percorrer nesse sentido. Além de continuar com o trabalho de difusão das Escrituras, é importante que as igrejas, e até mesmo as Sociedades Bíblicas, possam promover, de forma integradada, ações que instiguem uma leitura e uma difusão significativa e relevante da Bíblia na vida das pessoas, para a edificação do corpo de Cristo, ou seja, a sua igreja.

"A erva seca e as flores caem, mas a palavra do nosso Deus permanece para sempre" (Is 40,8). 


\section{7 \\ Referências bibliográficas}

\section{1}

Bíblia Sagrada

ALAND, Barbara [et al.] (ed.). O Novo Testamento Grego. 5a edição. Deutsche Bibelgesellschaft. Barueri: Sociedade Bíblica do Brasil, 2018

BÍBLIA Hebraica. Stuttgartensia. Editio quinta. Deutsche Bibelgesellschaft. Barueri: Sociedade Bíblica do Brasil, 2009

BÍBLIA Vulgata. Latim. Bíblia Sacra. luxta Vulgatam Versionem. Stuttgart: Deutsche Bibelgesellschaft, 1969.

BÍBLIA Sagrada. Bíblia Polyglotta: Synodi De Verbo Dei ocasione exarata. New York; Città Del Vaticano: American Bible Society; Libreria Editrice Vaticana, 2008

BÍBLIA Sagrada. Português. Bíblia de Estudo Almeida. Trad. de João Ferreira de Almeida, versão Revista e Atualizada. Barueri: Sociedade Bíblica do Brasil, 2006.

BÍBLIA Sagrada. Português. Bíblia de Estudo Despertar. Nova Tradução na Linguagem de Hoje. Barueri: Sociedade Bíblica do Brasil, 2012

BÍBLIA Sagrada. Português. Bíblia de Estudo NTLH. Nova Tradução da Linguagem de Hoje. Barueri: Sociedade Bíblica do Brasil, 2005.

BÍBLIA Sagrada. Português. Bíblia de Jerusalém. São Paulo: Paulus, 2002.

BÍBLIA Sagrada. Português. Bíblia missionária de estudo. Barueri: Sociedade Bíblica do Brasil, 2014.

BÍBLIA Sagrada. Português. Bíblia Sagrada com Método Lectio Divina. [s.I.] Sociedades Bíblicas Unidas, 2012.

BÍBLIA Sagrada. Português. Bíblia Sagrada Pobreza e Justiça. Barueri: Sociedade Bíblica do Brasil, 2011.

BÍBLIA Sagrada. Português. Nova Tradução na Linguagem de Hoje. São Paulo: Paulinas Editora, 2005. 
BÍBLIA Sagrada. Português. Revista e Corrigida. 4ª edição. Barueri: Sociedade Bíblica do Brasil, 2009

BíBLIA Sagrada. Português. Revista e Atualizada. $3^{a}$ ed. Nova Almeida Atualizada. Barueri: Sociedade Bíblica do Brasil, 2017.

BÍBLIA Sagrada. Português. Tradução brasileira. Barueri: Sociedade Bíblica do Brasil, 2010.

BíBLIA Sagrada. Português. Tradução do Novo Mundo das Escrituras Sagradas. New York: Watchtower Bible; Tract Society of New York, INC; Cesário Lange: Associação Torre de Vigia de Bíblias e Tratados, 2015.

BÍBLIA. Septuaginta. Editio Altera. Revised Edition. Stuttgart: Deutsche Bibelgesellschaft. Barueri: Sociedade Bíblica do Brasil, 2011.

NESTLE-ALAND. Novum Testamentum Graece. 28 edição. Deutsche Bibelgesellschaft. Barueri: Sociedade Bíblica do Brasil, 2018

\section{2}

\section{Bibliografia fundamental}

ABNB. Valorização da língua e da cultura. Revista A Bíblia no Brasil, n. 257, ano 69, dez. 2017 - fev. 2018.

ABNB. O livro de Rute para os ciganos. Revista A Bíblia no Brasil, $n$. 240, ano 65, jul-dez 2013.

AGEL, Henri. Cinema e Bíblia. LONGTON, Joseph; POSWICK, RéginaldFerdinand [et al.] (orgs.). Dicionário Enciclopédico da Bíblia. São Paulo: Loyola, Paulinas, Paulus; Santo André: Academia Cristã, 2013, pp. 305308.

ALENCAR, Gedeon. Assembleias Brasileiras de Deus: Teorização, história e tipologia. São Paulo, 2012. Tese (Doutorado em Teologia). Pontifícia Universidade Católica de São Paulo.

ALENCAR, Gedeon. Assembleia de Deus: origem, implantação e militância. São Paulo: Arte Editorial, 2010.

ALEXANDER, David; ALEXANDER, Pat. Manual Bíblico SBB. Barueri: Sociedade Bíblica do Brasil, 2008.

ALVES, Herculano. A Bíblia de João Ferreira Annes d'Almeida. Coimbra; Barueri: Sociedade Bíblica de Portugal; Sociedade Bíblica do Brasil, 2006. 
ANDRADE, Marizete Lopes; GERONE JUNIOR, Acyr de. Luz na Amazônia: um projeto de missão holística. In: VIII Fórum de Ciências Bíblicas. Apresentação. Barueri: Sociedade Bíblica do Brasil, 2012

ARAUJO, Isael. Dicionário do Movimento Pentecostal. Rio de Janeiro: CPAD, 2007.

ARENHOEVEL, Diego. Assim se formou a Bíblia. São Paulo: Paulinas, 1978.

ARMOGATHE, Jean-Robert. Os estudos bíblicos no século XVIII. In: BEUKEN, Win; FREYNE, Sean; WEILER, Anton (orgs.). A Bíblia e seus leitores. Revista Concilium. Petrópolis: Vozes, 1991, pp. 82-29.

ARRUDA, José Jobson de A. História moderna e contemporânea. São Paulo: Ática, 1980.

AUGUSTIJN, Cornelis. Os reformadores do século XVI e a Bíblia. In: BEUKEN, Win; FREYNE, Sean; WEILER, Anton (orgs.). A Bíblia e seus leitores. Revista Concilium. Petrópolis: Vozes, 1991, pp. 71-81.

AUWERS, Jean-Marie. Antiguidade Cristã Latina e Bíblia. In: LONGTON, Joseph; POSWICK, Réginald-Ferdinand [et al.] (orgs.). Dicionário Enciclopédico da Bíblia. São Paulo: Loyola, Paulinas, Paulus; Santo André: Academia Cristã, 2013, pp.104-105.

AUWERS, Jean-Marie. Pensamento contemporâneo e Bíblia. In: LONGTON, Joseph; POSWICK, Réginald-Ferdinand [et al.] (orgs.). Dicionário Enciclopédico da Bíblia. São Paulo: Loyola, Paulinas, Paulus; Santo André: Academia Cristã, 2013, pp.1064-1067.

AZEVEDO, Marcos. Modernidade e pós-modernidade: desafios à vida e à fé cristã. São Paulo: Fonte Editorial, 2015.

AZZI, Riolando. A Instituição eclesiástica durante a primeira época colonial. In: HOORNAERT, Eduardo (org.) História da Igreja no Brasil. Ensaio de interpretação a partir do povo. Primeira Época. $3^{\underline{a}}$ edição, Petrópolis: Vozes, 1983, p. 153-242.

Aventuras Bíblicas em libras. Vol. 1. Barueri: Sociedade Bíblica do Brasil, 2012.

Aventuras Bíblicas em libras. Vol. 2. Barueri: Sociedade Bíblica do Brasil, 2015.

Aventuras Bíblicas em libras. Vol. 3. Barueri: Sociedade Bíblica do Brasil, 2016. 
BARNWELL, Katharine. Tradução Bíblica: um curso introdutório aos princípios básicos de tradução. Barueri; Anápolis: Sociedade Bíblica do Brasil; Associação Internacional de Linguística, 2011.

BARRERA, Julio Trebolle. A Bíblia judaica e a Bíblia cristã. Petrópolis: Vozes, 1995.

BARTH, Karl; CUERVO-ARANGO, Francisco. Introducción al pensamiento de Karl Barth: el destino del reprobado. Barcelona: Editorial Nova Terra, 1970.

BARTH, Karl. A proclamação do evangelho. São Paulo: Fonte Editorial, 2000.

BARTH, Karl. Carta aos Romanos. São Paulo: Fonte Editorial, 2009.

BARTH, Karl. Chamado ao Discipulado. São Paulo: Fonte Editorial, 2006.

BARTH, Karl. Credo: comentários ao Credo Apostólico. São Paulo: Fonte Editorial, 2010.

BARTH, Karl. Esboço de uma Dogmática. São Paulo: Fonte Editorial, 2006b.

BARTH, Karl. Fé em busca de compreensão. São Paulo: Fonte Editorial, 2012.

BARTH, Karl. O Pai Nosso: a oração que Jesus ensinou aos seus discípulos. São Paulo: Fonte Editorial, 2003.

BARTH, Karl. Palavra de Deus e Palavra de Homem. São Paulo: Fonte Editorial, 2011.

BARTH, Karl. Revelação de Deus como sublimação da religião. São Paulo: Fonte Editorial, 2011b.

BARTH, Karl. Introdução à teologia evangélica. São Leopoldo: Sinodal, 1996.

BARTH, Karl. Dádiva e louvor: ensaios teológicos de Karl Barth. São Leopoldo: Sinodal/EST, 2006.

BARTH, Karl. Senhor! Ouve a nossa oração. São Leopoldo: Sinodal, 2013.

BATCHELOR, Mary. A Bíblia em foco: introdução passo a passo aos livros sagrados: ilustrações, mapas, cronologia, fatos históricos, documentos, personagens. São Paulo: Melhoramentos, 1995. 
BATISTA, Marcos da Silva. História de Israel. Vol. 1. Rio de Janeiro: [s.n.], 2015.

BEAUD, Michel. História do Capitalismo: de 1500 aos nossos dias. São Paulo: Editora Brasiliense, 1987.

BEAUMONT, Mike. Enciclopédia bíblica ilustrada. Barueri: Sociedade Bíblica do Brasil, 2013.

BEAUMONT, Mike. Guia prático da Bíblia. Barueri: Sociedade Bíblica do Brasil, 2012.

BETTENCOURT, Dom Estevão. Os estudos bíblicos no Brasil. Rio de Janeiro: Ministério da Cultura, 1950.

BEUKEN, Win; FREYNE, Sean; WEILER, Anton (orgs.). A Bíblia e seus leitores. Revista Concilium. Petrópolis: Vozes, 1991.

BEZERRA, Cícero. Os 10 Mandamentos do líder de grupos caseiros. Belo Horizonte: Gráfica Betânia, 2009.

Bibliha Aventures. Aventuras da Bíblia em Pomerano. Barueri: Sociedade Bíblica do Brasil, 2012.

BIEGEMER, Maria Clara Licchetti. O mistério e o mundo: paixão por Deus em tempos de descrença. Rio de Janeiro: Rocco, 2013.

BLACK, Matthew. The Printed Bible. In. GREENSLADE, S. L. (ed.). The Cambridge History of the Bible: The West from the Reformation to the present day. Cambridge; London; New York; Melbourne: Cambridge University Press, 1963.

BOFF, Leonardo. Espiritualidade: um caminho de transformação. Rio de Janeiro: Sextante, 2006.

BONAVIDES, Paulo; AMARAL, Roberto. Textos políticos da História do Brasil. Vol. 5. Brasília: Senado Federal, 2002

BOSELLI, Goffredo. O sentido espiritual da liturgia. Brasília: CNBB, 2014.

BOTELHO, Tarcísio Rodrigues. População e espaço nacional no Brasil do século XIX. Cadernos de História. Belo Horizonte, v. 7, n. 8, ํㅗ sem. 2005, pp. 67-83.

BRAGA, James. Como preparar mensagens bíblicas. São Paulo: Vida, 2005.

BRIGGS, Asa; BURKE, Peter. Uma história social da mídia: de Gutemberg à Internet. Rio de Janeiro: Jorge Zahar Ed., 2006. 
BRIGHT, John. História de Israel. São Paulo: Paulinas, 1978.

BRILLANTE, Carlo. Myth and history: the historical interpretation of myth. In: EDMUNDS, Lowell. Approaches to Greek Myth. Baltimore, Maryland: Johns Hopkins University Press, 1990, pp. 91-140.

BRUCE, Frederick Fyvie. The New Testament development of some Old Testament themes. The Paternoster Press, 1970.

BRUSTOLIN, Leomar Antônio. Textos Sagrados nas grandes religiões. Revista Renovação da CNBB Sul 3. Porto Alegre, julho/agosto de 2004, n. 357.

BUENO, Eduardo. Brasil, uma história. São Paulo: Texto, 2010.

CAIRNS, Earle Edwin. O cristianismo através dos séculos: uma história da igreja cristã. São Paulo: Vida Nova, 2008.

CAMPOS, Jose Freitas. O sangue dos mártires: A história dos primeiros mártires do Brasil. São Paulo: Loyola, 2017.

CAMPOS, Leonildo Silveira. Bíblias no mercado: o poder dos consumidores e a competição entre os editores - o caso da Sociedade Bíblica do Brasil. Rever, ano 12, n. 2, jul./dez. 2012, pp. 35-61.

CANNUYER, Christian. Artes plásticas e Bíblia. In: LONGTON, Joseph; POSWICK, Réginald-Ferdinand [et al.] (orgs.). Dicionário Enciclopédico da Bíblia. São Paulo: Loyola, Paulinas, Paulus; Santo André: Academia Cristã, 2013, pp. 174-178.

CANNUYER, Christian. Literatura e Bíblia. In: LONGTON, Joseph; POSWICK, Réginald-Ferdinand [et al.] (orgs.). Dicionário Enciclopédico da Bíblia. São Paulo: Loyola, Paulinas, Paulus; Santo André: Academia Cristã, 2013, pp. 810-818.

CANNUYER, Christian; POSWICK, R Réginald-Ferdinand. Catolicismo e Bíblia. In: LONGTON, Joseph; POSWICK, Réginald-Ferdinand [et al.] (orgs.). Dicionário Enciclopédico da Bíblia. São Paulo: Loyola, Paulinas, Paulus; Santo André: Academia Cristã, 2013, pp. 289-283

CARNEIRO, Marcelo (org.). Bíblia e cultura: tradição e exegese - debatendo as diferentes leituras da Bíblia: conferências e ensaios apresentados no VI Congresso Brasileiro de Pesquisa Bíblica. São Paulo: Fonte Editorial, 2014.

CARNEIRO, Raquel. Sagrada e popular. Revista Veja. Edição 2538, ano 50, n. 28, pp. 86-93, 12 de julho de 2017. 
CARRIKER, Timóteo. Teologia da Missão. Missionews - Revista de Missiologia. Volume 1, Ano 1, abril de 2009

CARSON, Donald Arthur. As Escrituras dão testemunho de mim: Jesus e o evangelho no Antigo Testamento. São Paulo: Vida Nova, 2015.

CARSON, Donald Arthur; KELLER, Timothy. O Evangelho no centro: renovando nossa fé e reformando nossa prática. São José dos Campos: Fiel, 2013.

CARVALHO, Maria Cecília Maringoni. Construindo o saber - Metodologia científica: Fundamentos e técnicas. Campinas: Papirus, 1997.

CAVALCANTI, Tereza Maria Pompéia. 0 método de leitura popular da Bíblia na América Latina. A contribuição de Carlos Mesters. Rio de Janeiro, 1991. Tese (Doutorado em Teologia). Faculdade de Teologia da Pontifícia Universidade Católica do Rio de Janeiro.

CAVALCANTI, Tereza Maria Pompéia. Espiritualidade bíblica. A Palavra na Vida n. 97, São Leopoldo, 1996, pp. 2-23.

CAVALCANTI, Tereza Maria Pompéia. A leitura popular da Bíblia e a V Conferência do CELAM. Atualidade Teológica, ano XI, n. 25, jan./abr. 2007, pp. 76-103.

CERFAUX, L. Cristo na teologia de Paulo. São Paulo: Teológica, 2003.

CÉSAR, Elben Magalhães Lenz. História da evangelização do Brasil: dos jesuítas aos neopentecostais. Viçosa: Ultimato, 2000.

CÉSAR, Elben Magalhães Lenz. Conversas com Lutero: história e pensamento. Viçosa: Ultimato, 2006.

CESAREIA, Eusébio de. História Eclesiástica. São Paulo: Novo Século, 2002.

COMBLIN, José. Desafios aos cristãos do Século XXI. São Paulo, SP: Editora Paulinas, 2004

COMFORT, Philip Wesley. Origem e autenticidade da Bíblia. Rio de Janeiro: CPAD, 1998.

CONCÍLIO VATICANO II. Dei Verbum - Constituição Dogmática sobre a Revelação Divina. Tradução portuguesa do Secretariado Nacional do Apostolado da Oração em Portugal. São Paulo: Paulinas, 2005.

CONFERÊNCIA GERAL DO EPISCOPADO LATINO-AMERICANO IV. Nova evangelização, promoção humana, cultura cristã: Jesus Cristo ontem, hoje e sempre. Conclusões de Santo Domingo (10.11.1992). São Paulo: Loyola, 1992. 
COSTANZA, José Roberto da Silva. As raízes históricas do liberalismo teológico. Fides Reformata X, n. 1, 2005, pp. 79-99.

CONSTITUIÇÃO PASTORAL Gaudium et spes. Documentos do. Concílio Ecumênico Vaticano II. São Paulo: Paulus, 1997

CULLMANN, Oscar. A formação do Novo Testamento. São Leopoldo: Sinodal, 2001.

CUNHA, Mauricio José Silva. O Reino entre nós: transformação de comunidades pelo evangelho integral. Viçosa, MG: Editora Ultimato, 2003

CUNNINGHAM, Loren; LOREN, Janice. O livro que transforma nações: o poder da Bíblia para mudar qualquer país. Almirante Tamandaré: Jocum Brasil, 2009.

DANIEL, Silas. A sedução das novas teologias. Rio de Janeiro: CPAD, 2007.

DAVIS, John. Novo Dicionário da Bíblia. São Paulo: Hagnos, 2006.

$\mathrm{DE}$ BONI, Luis Alberto. O reformador Lutero e as causas que levaram à Reforma do século XVI. In: HEIMANN, Leopoldo (org.). Fórum ULBRA de Teologia. Canoas: ULBRA, 2008, pp. 13-28.

DENZIGER, Heinrich; HÜNERMANN, Peter. Compêndio dos símbolos, definições e declarações de fé e moral. São Paulo: Paulinas/Loyola, 2007

DORCY, Jean Marie. St. Dominic's Family. Charlotte, Carolina do Norte: Tan Book and Publishers, 1983.

DORIVAL, Gilles. Antiguidade Cristã Grega e Bíblia. In: LONGTON, Joseph; POSWICK, Réginald-Ferdinand [et al.] (orgs.). Dicionário Enciclopédico da Bíblia. São Paulo: Loyola, Paulinas, Paulus; Santo André: Academia Cristã, 2013, pp. 91-104

DOUGLAS, James Dixon (org.). O Novo Dicionário da Bíblia. São Paulo: Vida Nova, 2006.

DOUGLAS, William; TEIXEIRA, Rubens. As 25 leis bíblicas do sucesso. Rio de Janeiro: Sextante, 2012.

DREHER, Martin Norberto. Bíblia: suas leituras e interpretações na História do Cristianismo. São Leopoldo: CEBI e Sinodal, 2006.

DREHER, Martin Norberto. Protestantes na América Meridional. In: SIEPIERSKI, Paulo Donizéti; GIL, Benedito (orgs.). Religião no Brasil: enfoques, dinâmicas e abordagens. São Paulo: Paulinas, 2003, pp. 39-65. 
DWIGHT, Henry Otis. The Centenary History of the American Bible Society. New York: American Bible Society, 1916.

DYRESON, Mark; MANGAN, James Anthony; PARK, Roberta (ed). Sport in the global society - Historical Perspectives: mapping an Empire of American Sport - Expansion, Assimilation, Adaptation and Resistance. Oxford; New York: Routledge, 2013

EISENSTEIN, Elisabeth L. A revolução da cultura impressa: os primórdios da Europa Moderna. São Paulo: Ática, 1998.

FAILLA, Zoara (Org.). Retratos da leitura no Brasil 4. Rio de Janeiro: Sextante, 2016.

FEBVRE, Lucien. MARTIN, Henri-Jean. 0 aparecimento do livro. Lisboa: Fund. Calouste Gulbenkian, 2000.

FERGUNSON, Sinclair B. Novo Dicionário de Teologia. São Paulo: Hagnos, 2009

FERNANDES, Leonardo Agostini. A Bíblia e sua mensagem: introdução à leitura e ao estudo da Bíblia. Rio de Janeiro: PUC-Rio; São Paulo: Reflexão, 2010.

FERREIRA, Franklin. Karl Barth: uma introdução à sua carreira e aos principais temas de sua teologia. Fides Reformatta, v. 8, n. 1, 2003, pp. 29-62.

FERREIRA, Franklin. Pilares da fé: a atualidade da mensagem da Reforma. São Paulo: Vida Nova, 2017.

FERREIRA, Sueli Mara Soares Pinto; KROEFF, Márcia Silveira. Referências bibliográficas de documentos eletrônicos. v. 1, Ensaios APB, n.35. São Paulo: APB, 1996

FIGUEREDO, Luiz Orencio; ZANELATTO, João Henrique. Trajetória de migrações no Brasil. Acta Scientiarum. Humam and Social Sciences. Maringá, v. 39, n. 1, pp. 77-90, Jan.-Apr. 2017.

FITZMYER, Joseph Augustine. A Bíblia na Igreja. São Paulo: Loyola, 1997.

FLUHRER, Gabriel. Firme fundamento: a inerrante Palavra de Deus em um mundo errante. Rio de Janeiro: Anno Domini, 2013.

FRANÇA MIRANDA, Mario de. A Igreja numa sociedade fragmentada. São Paulo: Loyola, 2006.

GABEL, John; WHEELER, Charles. A Bíblia como literatura. São Paulo: Loyola, 2003. 
GARCÍA-MORENO, Antonio. Recensiones. Scripta Theologica. Vol. 19, $N^{\circ}$. 1-2, 1987, pp. 457-459. Disponível em: https://www.unav.edu/publicaciones/revistas/index.php/scriptatheologica/article/view/19741/15597. Acesso em 3 abr. 2018.

GEISLER, Norman; HOWE, Thomas. Manual popular de dúvidas, enigmas e "contradições" da Bíblia. São Paulo: Mundo Cristão, 1999.

GEISLER, Norman; NIX, William. Introdução bíblica: Como a Bíblia chegou até nós. São Paulo: Vida, 2003.

GELDERBLOM, Oscar. A idade do ouro da República Holandesa. In: BAUMOL, William J. [et. al.]. A origem das corporações: uma visão histórica do emprendendorimo da Mesopotâmia aos dias atuais. Rio de Janeiro: Elsevier, 2010

GEORGE, Timothy. Teologia dos reformadores. São Paulo: Vida Nova, 1993.

GERONE JUNIOR, Acyr. Sociologia da religião: introdução, história, perspectivas e desafios contemporâneos. Curitiba: Intersaberes, 2017

GIRALDI, Luiz Antonio. A Bíblia no Brasil Império: Como um livro proibido durante o Brasil colônia tornou-se umas das obras mais lidas nos tempos do Império. Barueri: Sociedade Bíblica do Brasil, 2012.

GIRALDI, Luiz Antonio. A Bíblia no Brasil República: Como a liberdade religiosa impulsionou a divulgação da Bíblia. Barueri: Sociedade Bíblica do Brasil, 2013.

GIRALDI, Luiz Antonio. História da Bíblia no Brasil. Barueri: Sociedade Bíblica do Brasil, 2013.

GIRALDI, Luiz Antonio. Semeadores da Palavra: personagens que tiveram participação decisiva na divulgação da Bíblia no Brasil. Barueri: Sociedade Bíblica do Brasil, 2015.

GIRALDI, Luiz Antonio. The American Bible Society in Brazil. New York; Barueri: American Bible Society; Sociedade Bíblica do Brasil, 2009.

GLASS, Frederick Charles. Aventuras com a Bíblia no Brasil. Rio de Janeiro: Livraria Evangélica Ltda., 1963.

GOLDBERG, David; RAYNER, John Desmond. Os judeus e o judaísmo. Rio de Janeiro: Xenon, 1989.

GOMES, Laurentino. 1808: como uma rainha louca, um príncipe medroso e uma corte corrupta enganaram Napoleão e mudaram a história de Portugal e do Brasil. São Paulo: Planeta do Brasil, 2007. 
GOMES, Laurentino. 1822: como um homem sábio, uma princesa triste e um escocês louco por dinheiro ajudaram D. Pedro a criar o Brasil - um país que tinha tudo para dar errado. Rio de Janeiro: Fronteira Participações, 2010.

GOMES, Laurentino. 1889: como um imperador cansado, um marechal vaidoso e um professor injustiçado contribuíram para o fim da monarquia e a proclamação da República no Brasil. São Paulo: Globo, 2013.

GONZALEZ, Justo. Uma história ilustrada do cristianismo: A era dos reformadores. Vol. 6. São Paulo: Vida Nova, 1995.

GONZALEZ, Justo; ORLANDI, Carlos Cardoza. História do movimento missionário. São Paulo: Hagnos, 2008.

GRELLERT, Manfred. Os compromissos da missão: a caminhada da igreja no contexto brasileiro. Rio de Janeiro: JUERP, 1987

GRESSLER, Lori Alice. Introdução à pesquisa: projetos e relatórios. São Paulo: Loyola, 2004.

GRUDEM, Wayne; COLLINS, John; SCHREINER, Thomas (orgs.). Origem, confiabilidade e significado da Bíblia. São Paulo: Vida Nova, 2013.

GUDORF, Christine. O magistério e a Bíblia: a experiência norteamericana. In: BEUKEN, Win; FREYNE, Sean; WEILER, Anton (orgs.). A Bíblia e seus leitores. Revista Concilium. Petrópolis: Vozes, 1991, pp. 90-101.

GUIMARÃES, Andréa Bastos da Silva. A companhia das Índias Orientais e a conquista britânica na Índia: terra, tributo, comércio e moeda. Tese de Doutorado - Instituto de Economia. Universidade Federal do Rio de Janeiro: Rio de Janeiro, 2010

GUSSO, Antonio Renato. Como entender a Bíblia: orientações práticas para a interpretação correta das Escrituras Sagradas. Curitiba: AD Santos, 1998.

HÄGGLUND, Bengt. História da teologia. Porto Alegre: Concórdia, 2003.

HALE, Broadus David. Introdução ao Estudo do Novo Testamento. São Paulo: Hagnos, 2001.

HALL, Christopher. Lendo as Escrituras com os pais da Igreja. Viçosa: Ultimato, 2007.

HALLOCK, Edgar; SWELLENGREBEL, Jan Lodewijk. A maior dádiva e o mais precioso tesouro. A biografia de João Ferreira de Almeida e a história da primeira Bíblia em português. Rio de Janeiro: JUERP, 2000. 
HANH, Carl Joseph. História do culto protestante no Brasil. São Paulo: ASTE, 2011.

HARTMANN, Wilfried. A Igreja no período carolíngio. In: KAUFMANN, Thomas et al (orgs.). História ecumênica da Igreja 1: dos primórdios até a Idade Média. São Paulo: Loyola; Paulus; São Leopoldo: Sinodal, 2012, pp. 209-224.

HEIMANN, Leopoldo (org.). Fórum ULBRA de Teologia. Canoas: ULBRA, 2008.

HOFFMANN, Arzemiro. A cidade na missão de Deus: o desafio que a cidade representa para a Bíblia e à missão de Deus. Curitiba: Editora Encontrão, 2007.

HOLMGREN. Laton E. Sociedades Bíblicas. Dicionário Enciclopédico da Bíblia. São Paulo: Loyola, Paulinas, Paulus; Santo André: Academia Cristã, 2013, pp. 1270-1272.

HOLZEM, Andreas. Bases européias para uma confessionalização católica. In: KAUFMANN, Thomas et al (orgs.). História ecumênica da Igreja 2: da alta Idade Média até o início da Idade Moderna. São Paulo: Loyola; Paulus; São Leopoldo: Sinodal, 2012, pp. 375-393.

HOORNAERT, Eduardo; AZZI, Riolando [et al.]. História da Igreja no Brasil. Petrópolis: Vozes, 1992.

HOORNAERT, Eduardo. Formação do catolicismo brasileiro. Petrópolis: Vozes, 1991.

HORSTER, Gerhard. Introdução e síntese do Novo Testamento. Curitiba: Esperança, 1996.

IBGE - Instituto Brasileiro de Geografia e Estatística. Os indígenas no Censo Demográfico 2010. Rio de Janeiro: IBGE, 2012

IBGE - Instituto Brasileiro de Geografia e Estatística. Pesquisa Nacional por Amostra de Domicílios (Pnad): síntese de indicadores. Rio de Janeiro: IBGE, 2016, pp. 42-44.

IBGE - Instituto Brasileiro de Geografia e Estatística. Síntese de indicadores sociais: uma análise das condições de vida da população brasileira. Rio de Janeiro: IBGE, 2017

IGREJA CATÓLICA. Comissão Pontifícia Bíblica. A interpretação da Bíblia na Igreja. São Paulo: Paulinas, 2010. 
JANIS, Irving Lester. O problema da validação da análise de conteúdo. In: LASSWELL, Harold; KAPLAN, Abraham. A linguagem da política. Brasília: Editora da Universidade de Brasília, 1982, pp. 53-76.

JEDIN, Hubert. A History of the Council of Trent. Volume 1. St. Louis: B. Herder book co., 1957

JERONIMO. The letters of St. Jerome. Vol. 1. Tradução de Charles Christopher Mierow. New York: Newman Press, 1936.

JESUS, Aline de [et al.]. Assistência social: direito ou favor? As percepções dos usuários do Km 7 do município de Presidente Prudente. Monografia (Bacharelado em Serviço Social). Faculdades Integradas "Antônio Eufrásio de Toledo", Presidente Prudente, 2004.

KAISER JUNIOR, Walter Christian; SILVA, Moises. Introdução à Hermenêutica Bíblica. São Paulo. Editora Cultura Cristã, 2002

KANNENGIESSER, Charles. A leitura da Bíblia na Igreja Primitiva: exegese patrística e seus pressupostos. In: BEUKEN, Win; FREYNE, Sean; WEILER, Anton (orgs.). A Bíblia e seus leitores. Revista Concilium. Petrópolis: Vozes, 1991, pp. 41-49.

KANTORSKI, Luciane Prado; LISBOA, Liliane de Mello; SOUZA, Jacqueline de. Grupo de prevenção de recaídas de álcool e outras drogas. SMAD. Rev. Eletrônica Saúde Mental Álcool Drog. (ed. port.), v.1, n. 1, Ribeirão Preto, fev. 2005.

KARNAL, Leandro. O livro dos livros. O Estado de S. Paulo. São Paulo, 13 set. 2017, Caderno 2, p. C8.

KASCHEL, Werner; ZIMMER, Rudi. Dicionário da Bíblia de Almeida. Barueri: Sociedade Bíblica do Brasil, 2005.

KAUFMANN, Thomas [et al.] (orgs.). História ecumênica da Igreja 1: dos primórdios até a Idade Média. São Paulo: Loyola; Paulus; São Leopoldo: Sinodal, 2012.

KAUFMANN, Thomas [et al.] (orgs.). História ecumênica da Igreja 2: da alta Idade Média até o início da Idade Moderna. São Paulo: Loyola; Paulus; São Leopoldo: Sinodal, 2014.

KIDDER, Daniel Parish. Reminiscências de viagens e permanências no Brasil: Rio de Janeiro e Província de São Paulo. Brasília: Senado Federal, Conselho Editorial, 2001.

KIDDER, Daniel Parish; FLETCHER, James C. O Brasil e os brasileiros. São Paulo: Companhia Editora Nacional, 1941. 
KLEIN, William; HUBBARD JR, Robert; CRAIG, Blomberg. Introdução à intepretação bíblica: Rio de Janeiro: Thomas Nelson Brasil, 2017

KONINGS, Johan. A Bíblia, sua origem e sua leitura: introdução ao estudo da Bíblia. Petrópolis: Vozes, 2014.

KONINGS, Johan. A Palavra se fez livro. São Paulo: Loyola, 2014.

KONINGS, Johan. Tradução e traduções da Bíblia no Brasil. Persp. Teol. 35, 2003, pp. 215-238.

KORNTGEN, Ludger. A Igreja no século XII: vida religiosa, educação e ciência. In: KAUFMANN, Thomas [et al.] (orgs.). História ecumênica da Igreja 2: da alta Idade Média até o início da Idade Moderna. São Paulo: Loyola; Paulus; São Leopoldo: Sinodal, 2014, pp. 5-52.

KOTJE, Raymund. A Idade Média. In: KAUFMANN, Thomas [et al.] (orgs.). História ecumênica da Igreja 1: dos primórdios até a Idade Média. São Paulo: Loyola; Paulus; São Leopoldo: Sinodal, 2012, pp. 181208.

KOTJE, Raymund. A Igreja ocidental rumo a uma nova unidade exterior e interior. In: KAUFMANN, Thomas [et al.] (orgs.). História ecumênica da Igreja 1: dos primórdios até a Idade Média. São Paulo: Loyola; Paulus; São Leopoldo: Sinodal, 2012, pp. 194-209.

KUMMEL, Werner Georg. Síntese Teológica do NT de acordo com as testemunhas principais: Jesus, Paulo e João. São Paulo: Editora Teológica.

LACHLER, Karl. Prega a Palavra. São Paulo: Vida Nova, 1990.

LAPLANTE, Alcide. Idade Média Ocidental e Bíblia. Dicionário Enciclopédico da Bíblia. São Paulo: Loyola, Paulinas, Paulus; Santo André: Academia Cristã, 2013, p. 656.

LARA, Valter Luiz. A Bíblia e o desafio da interpretação sociológica: introdução ao primeiro testamento à luz de seus contextos históricos e sociais. São Paulo: Paulus, 2009.

LAUSANNE, Série. O Evangelho e a cultura: a contextualização da $\mathrm{Pa}$ lavra de Deus. O Evangelho e o homem secularizado: o desafio do homem e da sociedade moderna. São Paulo, SP: ABU, 2007

LAWRENCE, Paul. Atlas Histórico e Geográfico da Bíblia. Barueri: Sociedade Bíblica do Brasil, 2008.

LAZARE, Lucien. Judaísmo e Bíblia. In: LONGTON, Joseph; POSWICK, Réginald-Ferdinand [et al.] (orgs.). Dicionário Enciclopédico da Bíblia. 
São Paulo: Loyola, Paulinas, Paulus; Santo André: Academia Cristã, 2013, pp. 769-773

LECTIONAUTAS. Manual de Lectio Divina. CELAM e Sociedades Bíblicas Unidas, 2016

LEINHARD, Marc. Martin Lutero: tempo, vida e mensagem. São Leopoldo: Sinodal, 1998.

LÉONARD, Émile-Guillaume. O protestantismo brasileiro. São Paulo: ASTE, 2002.

LEPPIN, Volker. Teologia da Idade Mérdia tardia. In: KAUFMANN, Thomas [et al.] (orgs.). História ecumênica da Igreja 2: da alta Idade Média até o início da Idade Moderna. São Paulo: Loyola; Paulus; São Leopoldo: Sinodal, 2014, pp.180-234.

LIBÂNIO, João Batista. Eu creio, nós cremos: tratado de fé. $2^{\underline{a}}$ ed. São Paulo: Loyola, 2000.

LIMA, Maria de Lourdes Corrêa. História e Teologia. Reflexões na perspectiva da exegese bíblica. Atualidade Teológica. Ano XVII, n. 43, jan.abr. 2013, pp. 101-111.

LIPINSKI, Édouard. Música e Bíblia. In: LONGTON, Joseph; POSWICK, Réginald-Ferdinand [et al.] (orgs.). Dicionário Enciclopédico da Bíblia. São Paulo: Loyola, Paulinas, Paulus; Santo André: Academia Cristã, 2013, pp. 936-939.

LINDBERG, Carter. As reformas na Europa. São Leopoldo: Sinodal, 2001.

LONGTON, Joseph; POSWICK, Réginald-Ferdinand [et al.] (orgs.). Dicionário Enciclopédico da Bíblia. São Paulo: Loyola, Paulinas, Paulus; Santo André: Academia Cristã, 2013.

LOPES, David. A expansão da Língua Portuguesa no Oriente durante os séculos XVI, XVII e XVII. Portucalense Editora: Porto, Portugal, 1969.

LOPES, Geraldo. Dei verbum: texto e comentário. São Paulo: Paulinas, 2012.

LORTZ, Joseph. Historia de La Iglesia: em la perspectiva de la historia del pensamiento. Antiguedad y edad media. Vol. I. Madrid: Ediciones Cristandad, 1965

LORTZ, Joseph. Historia de La Iglesia: em la perspectiva de la historia del pensamiento. Edad moderna y contemporanea. Vol. II. Madrid: Ediciones Cristandad, 1965 
LOVERA, Marcos Adriano. Da escuridão para a luz: origem e extensão da Bíblia em Braile no Brasil. São Paulo: Fonte Editorial, 2017

LÖWY, Ilana. Vírus, mosquitos e modernidade: a febre amarela no Brasil entre ciência e política. Rio de Janeiro: Editora Fiocruz, 2006

LUTERO, Martinho. Martinho Lutero: uma coletânea de escritos. São Paulo: Vida Nova, 2017.

LUTERO, Martinho. Carta aberta do Dr. M. Lutero a respeito da tradução e da intercessão dos santos (1530). In: Martinho Lutero: obras selecionadas. vol. 8. São Leopoldo e Porto Alegre: Sinodal e Concórdia, 2003

LUTERO, Martinho. Carta aberta do Dr. M. Lutero a respeito da tradução e da intercessão dos santos (1530). In: FURLAN, Mauri (org.). Clássicos da teoria da tradução - VI: Antologia do Renascimento (séc. XVI) (bilíngue). Florianópolis: UFSC, 2016, pp. 147-166.

MACDONALD, Lee Martin. A origem da Bíblia: um guia para os perplexos. São Paulo: Paulus, 2013.

MACINTOSH, Mike. Apaixone-se pela Bíblia. Curitiba: AD Santos, 2007.

MALZONI, Cláudio Vianney. As edições da Bíblia no Brasil. São Paulo: Paulinas, 2016.

MANNUCCI, Valério. Bíblia, Palavra de Deus: curso de introdução à Sagrada Escritura. São Paulo: Paulus, 1985.

MATOS, Alderi de Souza. Colportores: heróis esquecidos da obra missionária no Brasil. Servos Ordenados, out.-dez. 2005, pp. 29-31.

MATOS, Henrique Cristiano José. Nossa história: 500 anos de presença da Igreja Católica no Brasil. 3ª̣ ed. Tomo 1. São Paulo: Paulinas, 2011

MATTOS, Luiz Alves de. Primórdios da educação no Brasil: o período heróico (1549-1570). Rio de Janeiro: Aurora, 1958.

MAZZAROLO, Isidoro. A Bíblia em suas mãos: estudo dirigido na metodologia da linha do tempo: é um guia de leitura para agentes, CEBs, círculos bíblicos e outros amigos das escrituras. Rio de Janeiro: Mazzarolo, 2012.

MAZZAROLO, Isidoro. Florilégios da Bíblia. Rio de Janeiro: Mazzarolo, 2009.

MAZZAROLO, Isidoro. Florilégios da Bíblia 2. Rio de Janeiro: Mazzarolo, 2009. 
MCALISTER, Walter. Neopentecostalismo - a história não contada: quem foi Roberto McAlister, conhecido como o pai desse movimento. Rio de Janeiro: Anno Domini, 2012.

MEIN, John. A Bíblia e como chegou até nós. Rio de Janeiro: JUERP, 1990.

MELO, Fábio José Dantas de. Os ciganos de Mabaí: a sobrevivência de sua língua. Brasilia: Thesaurus Editora, 2005.

MENDONÇA, Antônio Gouvêa. O celeste porvir: a inserção do protestantismo no Brasil. São Paulo: EDUSP, 2008.

MENDONZA-ÁLVAREZ, Carlos. O Deus escondido da pósmodernidade: desejo, memória e imaginação escatológica: ensaio de teologia fundamental pós-moderna. São Paulo: Realizações, 2011.

MESTERS, Carlos. Balanço de $\mathbf{2 0}$ anos: a Bíblia lida pelo povo na atual renovação da Igreja Católica no Brasil 1964-1984. Belo Horizonte: 1988. MESTERS, Carlos. A Bíblia como memória dos pobres. Petrópolis: Vozes, 1987.

MESTERS, Carlos. A Bíblia e a defesa dos direitos humanos. Belo Horizonte: [s.n.] [199-].

MESTERS, Carlos. A Bíblia na nova evangelização. Belo Horizonte: [s.n] 1991.

MESTERS, Carlos. Bíblia: livro feito em mutirão. São Paulo: Paulus, 1993.

MESTERS, Carlos. Criança na Bíblia. Petrópolis: Vozes, 1997.

MESTERS, Carlos. Deus, onde estás? Uma introdução prática à Bíblia. Petrópolis: Vozes, 1989.

MESTERS, Carlos. Eclesialidade e missão: reflexões a partir da Bíblia. Rio de Janeiro: Conferência dos Religiosos do Brasil, 1992.

MESTERS, Carlos. Flor sem defesa: uma explicação da Bíblia a partir do povo. Petrópolis: Vozes, 1983.

MESTERS, Carlos. Ouvir o que o Espírito diz às igrejas. A interpretação popular da Bíblia no Brasil. In: BEUKEN, Win; FREYNE, Sean; WEILER, Anton (orgs.). A Bíblia e seus leitores. Revista Concilium. Petrópolis: Vozes, 1991, pp. 112-123.

MESTERS, Carlos. Palavra de Deus na história dos homens. Petrópolis: Vozes, 1970. 
MESTERS, Carlos. Palavra de Deus na história dos homens. $2^{\circ}$ volume. Petrópolis: Vozes, 1971.

MESTERS, Carlos. Por trás das palavras: um estudo sobre a porta de entrada no mundo da Bíblia. Petrópolis: Vozes, 2012.

MIES, Françoise. Bíblia e teologia: a inteligência da fé. São Paulo: Loyola, 2011.

MIES, Françoise. (org.). Bíblia e filosofia: as luzes da razão. São Paulo: Loyola, 2012.

MILLER, John. As origens da Bíblia: repensando a história canônica. São Paulo: Loyola, 2004.

MILLER, Stephen; HUBER, Robert. A Bíblia e sua história: O surgimento e o impacto da Bíblia. Barueri: Sociedade Bíblica do Brasil, 2006.

MINAYO, Maria Cecilia de Souza (org.). Pesquisa social: teoria, método e criatividade. Petrópolis: Vozes, 2007.

MIRANDA, Evaristo Eduardo de. Bíblia: história, curiosidades e contradições. Petrópolis: Vozes, 2015.

MOELLER, Bernd. A era de ampliação e consolidação da Reforma 1525-1555. In: KAUFMANN, Thomas [et al.] (orgs.). História ecumênica da Igreja 2: da alta Idade Média até o início da Idade Moderna. São Paulo: Loyola; Paulus; São Leopoldo: Sinodal, 2014, pp. 302-348.

MOLTMANN, Jürgen. No fim, o início: No fim, o início. Breve tratado sobre a esperança. São Paulo: Loyola, 2007

MONDIN, Battista. Os grandes teólogos do século vinte. São Paulo: Teológica, 2003.

MORAIS, José Elenito Teixeira; FERREIRA, Luiz Carlos; GOMES, Renata Ferreira. Palavra de Deus, na neo-ortodoxia, segundo Karl Barth. Revista de Cultura Teológica v. 18, n. 70, abr./jun. 2010, pp. 69-75.

MORELLO, Rosângela [et al.]. Línguas brasileiras: A diversidade de um campo e pesquisas. Brasília: UNESCO, 1999

NICOLE, Roger. New Testament Use of the Old Testament. In: HENRY, Carl F. H. Revelation and the Biblie: Contemporary Evangelical Trought. Grand Rapids: Backer, 1958; London: The Tindayle Press, 1959.

NIDA, Eugene. Learning a foreign language. Cincinnati: Friendship Press, 1957 
NUNES, José Horta. Dicionários no Brasil: análise e história. Campinas: Pontes Editores; São Paulo: FAPESP, 2006

O LIVRO de Mórmon: Outro Testamento de Jesus Cristo. Salt Lake City, Utah, EUA: A Igreja de Jesus Cristo dos Santos dos Últimos Dias, 2015.

OHST, Martin. A Igreja no Século XIII: as ordens mendicantes. In: KAUFMANN, Thomas et al (orgs.). História ecumênica da Igreja 2: da alta Idade Média até o início da Idade Moderna. São Paulo: Loyola; Paulus; São Leopoldo: Sinodal, 2014, pp. 53-113.

OSBORNE, Grant R. 3 perguntas cruciais sobre a Bíblia: Podemos confiar na Bíblia? Podemos entender a Bíblia? Podemos fazer teologia a partir da Bíblia? São Paulo: Vida Nova, 2014.

PADILHA, Carlos René. O que é Missão Integral? Viçosa, MG: Editora Ultimato, 2009

PADOVESI, Luigi. Introdução à teologia patrística. São Paulo: Loyola, 1999.

PAPA BENTO XVI. Exortação Apostólica Verbum Domini. São Paulo: Paulinas, 2011.

PEREIRA, Nancy Cardoso; MESTERS, Carlos. A leitura popular da Bíblia: à procura da moeda perdida. Belo Horizonte, 1994.

PETERSON, Eugene [et al.]. Ouvindo a Deus: uma abordagem multidisciplinar da leitura bíblica. São Paulo: Shedd, 2001.

Piiplixe Awentuure. Aventuras da Bíblia em Hunsrik. Barueri: Sociedade Bíblica do Brasil, 2012.

PRADO, José Luiz Gonzaga do. A Bíblia e suas contradições: como resolvê-las? São Paulo: Paulus, 2002.

PROENÇA, Eduardo (org.). Bíblias e outros ensaios. Theologando Revista Teológica, ano V, n. 5. São Paulo: Fonte Editorial, 2011.

QUEIROZ, Martha Maria Romeiro de. Do plurilinguismo em Babel ao ecumenismo na tradução bíblica: o caso da versão católica da Bíblia Sagrada - Nova Tradução na Linguagem de Hoje. 2001. Dissertação (Mestrado em Letras) Pontifícia Universidade Católica do Rio de Janeiro, Rio de Janeiro, 2007.

RAMM, Bernard. Revelação especial e a Palavra de Deus. São Paulo: Cristã Novo Século, 2004.

REILY, Duncan. A história documental do protestantismo no Brasil. São Paulo: ASTE, 2003. 
REINHARDT, Rudolf. A Igreja católica. In: História ecumênica da Igreja 2: da alta Idade Média até o início da Idade Moderna. São Paulo: Loyola; Paulus; São Leopoldo: Sinodal, 2014, pp. 479-515.

RIBEIRO, Boanerges. Protestantismo e cultura brasileira: aspectos culturais da implantação do protestantismo no Brasil. São Paulo: Casa Editora Presbiteriana, 1981.

RIBEIRO, Darcy. O povo brasileiro: A formação e o sentido do Brasil. São Paulo: Companhia das Letras, 1995

RICOEUR, Paul. A hermenêutica bíblica. São Paulo: Loyola, 2006.

RICOEUR, Paul. Do texto à acção: ensaios de hermenêutica II. Porto: Res. Ed., 1989.

RICOEUR, Paul. Ensaios sobre a interpretação bíblica. São Paulo: Fonte Editorial, 2004.

RICOEUR, Paul. Sobre a tradução. Belo Horizonte: UFMG, 2012.

ROBERTSON, A.W. El Antiguo Testamento en el Nuevo. Buenos Aires: Nueva Creación, 1996.

ROCHA, Alessandro Rodrigues. Entre a solidão, a solitude e a solidariedade. Leituras no contexto brasileiro. In: PROENÇA, Eduardo (org.). Bíblias e outros ensaios. Theologando Revista Teológica. Ano V, n. 5. São Paulo: Fonte Editorial, 2011.

ROCHA, Alessandro Rodrigues. (org.). Teologia e sociedade: um olhar sobre as relações entre teologia e a realidade social brasileira. São Paulo: Reflexão, 2013.

ROSA, José Antonio. Análise do livro como produto e como negócio no contexto brasileiro atual: referências para a estratégia de marketing e comunicação na indústria editorial e para decisões de fomento e difusão do livro, no âmbito governamental e institucional. Tese de Doutorado em Ciências da Comunicação. São Paulo: Universidade de São Paulo, Escola de Comunicações e Artes, 2008

SCHWERTLEY, Brian. Sola Scriptura e o princípio regulador do culto. São Paulo: Os Puritanos, 2001.

SCHILLEBEECKX, Edward. História humana: revelação de Deus. São Paulo: Paulus, 1994.

SCHINDLER, Alfred. Os primórdios do monasticismo. In: KAUFMANN, Thomas [et al.] (orgs.). História ecumênica da Igreja 1: dos primórdios até a Idade Média. São Paulo: Loyola; Paulus; São Leopoldo: Sinodal, 2012, pp. 154-178. 
SCHNEIDER, Hans. O protestantismo. In: KAUFMANN, Thomas [et al.] (orgs.). História ecumênica da Igreja 2: da alta Idade Média até o início da Idade Moderna. São Paulo: Loyola; Paulus; São Leopoldo: Sinodal, 2012, pp. 517-567.

SCHNEIDER, Hans. O pietismo. In: KAUFMANN, Thomas [et al.] (orgs.). História ecumênica da Igreja 2: da alta Idade Média até o início da Idade Moderna. São Paulo: Loyola; Paulus; São Leopoldo: Sinodal, 2012, pp. 525-544.

SCHÖKEL, L. Alonso. A Bíblia à luz da ciência da linguagem. São Paulo: Loyola, 1992.

SCHOLZ, Vilson. 40 anos de Bíblia na Linguagem de Hoje: As grandezas de Deus em nossa própria língua. Barueri: Sociedade Bíblica do Brasil, 2013.

SCHOLZ, Vilson. A Bíblia: sua natureza, funções e finalidade. In: ZIMMER, Rudi (org.). Manual do Seminário de Ciências Bíblicas. Barueri: Sociedade Bíblica do Brasil, 2008, pp. 7-13.

SCHOLZ, Vilson. A transmissão do texto bíblico. In: ZIMMER, Rudi (org.). Manual do Seminário de Ciências Bíblicas. Barueri: Sociedade Bíblica do Brasil, 2008, pp. 27-39.

SCHOLZ, Vilson. Princípios de interpretação bíblica: introdução à hermenêutica com ênfase em gêneros literários. Canoas: ULBRA, 2006.

SCHOLZ, Vilson. Bíblia de Almeida: sua origem, as revisões e os princípios envolvidos. In: SOCIEDADE BÍBLICA DO BRASIL. Fórum de Ciências Bíblicas: 1600 anos da primeira grande tradução ocidental da Bíblia vol.1. São Paulo: Sociedade Bíblica do Brasil, 2006, pp. 7-36.

SCHOLZ, Vilson. Sociedades Bíblicas: guardiãs do texto e divulgadoras das Escrituras. In: HEIMANN, Leopoldo (org.). Fórum ULBRA de Teologia. Canoas: ULBRA, 2008, pp.195-200.

SCHWANTES, Milton. Bibliografia bíblica latino-americana. São Bernardo do Campo: Programa Ecumênico de Pós-Graduação em Ciências da Religião, 1995.

SCHWANTES, Milton. Novos rumos da teologia bíblica. Petrópolis: Vozes; São Bernardo do Campo: Metodista, 1989.

SCHWANTES, Milton. Caminhos da teologia bíblica. In: Estudos Bíblicos № 24. Petrópolis: Vozes, 1989.

SCLIAR, Moacyr. História do Conceito de Saúde. Physis: Rev. Saúde Coletiva, Rio de Janeiro, 17(1): 29-41, 2007 
SEIBERT, Erní Walter. Historiografia das traduções da Bíblia para o português. In: SOCIEDADE BÍBLICA DO BRASIL. Fórum de Ciências Bíblicas: 1600 anos da primeira grande tradução ocidental da Bíblia. Vol. 1. Barueri: Sociedade Bíblica do Brasil, 2006, pp. 81-101.

SEIBERT, Erní Walter. A função da Bíblia na Igreja local. In: ZIMMER, Rudi. Manual do Seminário de Ciências Bíblicas. Barueri: Sociedade Bíblica do Brasil, 2008, pp. 99-112.

SEMBLANO, Martinho Lutero. Materiais, formatos e instrumentos utilizados no processo de escrituração da Bíblia. Rio de Janeiro: Scriptura, 2013.

SEVERA, Zacarias. Manual de teologia sistemática. Curitiba: AD Santos, 1999.

SHEDD, Russel Philip. A Bíblia e os livros. São Paulo: Shedd Publicações, 2013.

SHEDD, Russel Philip. A justiça social e a interpretação da Bíblia. São Paulo, SP: Editora Vida Nova, 1993.

SHIGUNOV NETO, Alexandre; MACIEL, Lizete Shizue Bomura. O ensino jesuítico no período colonial brasileiro: algumas discussões. Educar, Curitiba, n. 31, p. 169-189, 2008.

SICRE, José Luis. Profetismo em Israel: o profeta, os profetas, a mensagem. Petrópolis: Vozes, 2008.

SIEPIERSKI, Paulo Donizéti; GIL, Benedito (orgs.). Religião no Brasil: enfoques, dinâmicas e abordagens. São Paulo: Paulinas, 2003.

SILVA, Alisson Pereira. Nas tessituras do Império do Brasil: o protestantismo sob o olhar da imprensa periódica secular (1860-1870). 2015. Dissertação (Mestrado em História). Universidade Federal de Campina Grande, Campina Grande, 2015.

SILVA, Duarte Leopoldo e. Concordancia dos Sanctos EvangeIhos. São Paulo: Escola Tipográfica Salesiana, 1903.

SILVA, Roberto do Amaral. Princípios e doutrinas batistas. Rio de Janeiro: JUERP, 2003

SILVA, Wagner Bandeira da. E-BIBLE: características de hipertexto na Bíblia impressa e digital. 2007. Dissertação (Mestrado em Artes e Design). Pontifícia Universidade Católica do Rio de Janeiro, Rio de Janeiro, 2007.

SILVA JUNIOR, Antonio Carlos da Rosa. Deus na prisão: uma análise jurídica, sociológica e teológica da capelania prisional. Rio de Janeiro: Betel, 2015. 
SIMÕES, Eduardo Vagner Santos. Evangelicalismo latino-americano: uma perspectiva Histórica. Anais do Congresso ANPTECRE, v. 5, 2015, p. ST0510.

SIMÕES, Ulisses Horta. Eu creio: no Pai, no Filho e no Espírito Santo. São José dos Campos: Fiel, 2014.

SIMPÓSIO NACIONAL DA ASSOCIAÇÃO BRASILEIRA DE HISTÓRIA DAS RELIGIÕES. Chico Xavier, mística e espiritualidade nas religiões brasileiras. Anais do evento. Juiz de Fora: UFJF, 2015.

SMALLEY, Beryl. The Bible in medieval schools. In: LAMPE, G. W. H. (ed.). The Cambridge history of the Bible: The West from the Fathers to the Reformation. Cambridge: Cambridge University Press, 1969.

SMOLINSKY, Heribert. Os pressupostos da Reforma. In: KAUFMANN, Thomas [et al.] (orgs.). História ecumênica da Igreja 2: da alta Idade Média até o início da Idade Moderna. São Paulo: Loyola; Paulus; São Leopoldo: Sinodal, 2014, pp. 239-285.

SOCIEDADE BÍBLICA COLOMBIANA. Introducción a la Bíblia. Bogotá: Sociedade Bíblica Colombiana, 2010.

SOCIEDADE BÍBLICA DO BRASIL. A Bíblia de Mary Jones: o início do movimento das Sociedades Bíblicas. Barueri: Sociedade Bíblica do Brasil, 2009.

SOCIEDADE BÍBLIA DO BRASIL. Biblias de Estudo: diferenças e diferenciais. Barueri: Sociedade Bíblica do Brasil, [201?]

SOCIEDADE BÍBLIA DO BRASIL. Estatuto 2015. Barueri: Sociedade Bíblica do Brasil, 2015.

SOCIEDADE BÍBLIA DO BRASIL. Luz na Amazônia: 50 anos. Barueri: Sociedade Bíblica do Brasil, 2012

SOCIEDADE BÍBLIA DO BRASIL. Nova Almeida Atualizada: uma tradução clássica com linguagem atual. Barueri: Sociedade Bíblica do Brasil, 2017

SOCIEDADE BÍBLIA DO BRASIL. Relatório Nacional de Trabalho 2016. Barueri: Sociedade Bíblica do Brasil, 2016.

SOCIEDADE BÍBLIA DO BRASIL. Plano Nacional de Trabalho 2017. Barueri: Sociedade Bíblica do Brasil, 2017.

SOCIEDADE BÍBLIA DO BRASIL. Revista "A Bíblia no Brasil". [Edições de 1948-2015]. Barueri: Sociedade Bíblica do Brasil. 
SOCIEDADE BÍBLICAS UNIDAS. Renew: UBS \& The impact of globalization. Report. Nanjing, China: May 2011

SOCIEDADE BÍBLICAS UNIDAS. Informe de Distribución Mundial de Escrituras 2016. Swindon, England: United Bible Societies, 2016

SOCIEDADE DE TEOLOGIA E CIÊNCIAS DA RELIGIÃO. Religião e transformação social no Brasil hoje. São Paulo: Paulinas, 2007.

SOUZA, Jaquelini de. A Primeira Igreja Protestante do Brasil: Igreja Reformada Potiguara [1625-1692]. São Paulo: Mackenzie, 2013.

SPINASSÉ, Karen Pupp. O hunsrückisch no Brasil: a língua como fator histórico da relação entre Brasil e Alemanha. Espaço Plural, Ano IX, № 19, $2^{\circ}$ Semestre 2008, pp. 117-126.

STEER, Roger. The story of Bible Society. Oxford, UK; Grand Rapids, Michigan: Monarch Books, 2004.

STEER, Roger. Good News for the World, 200 years of making the Bible heard: the story of Bible Society. Oxford, UK; Grand Rapids, Michigan: Monarch Books, 2004.

STEUERNAGEL, Valdir Raul [et al.]. Em Cristo proclamando e servindo. Curitiba: BPH, 2013.

TEIXEIRA, Paulo. Traduções da Bíblia: história, princípios e influência. In: ZIMMER, Rudi (org.). Manual do Seminário de Ciências Bíblicas. Barueri: Sociedade Bíblica do Brasil, 2008, pp. 41-70.

TEIXEIRA, Paulo; ZIMMER, Rudi. A formação do cânon. In: ZIMMER, Rudi (org.). Manual do Seminário de Ciências Bíblicas. Barueri: Sociedade Bíblica do Brasil, 2008, pp. 15-26.

TELLES, André. A revolução das mídias sociais. São Paulo: M. Books, 2010

TERRA, João Evangelista Martins. A Bíblia na evangelização do Brasil. São Paulo: Loyola, 1988.

TRUEMAN, Carl. O imperativo confessional. Brasília: Monergismo, 2012.

TUCKER, Hugh Clarence. Reminiscências - $\mathbf{5 0}$ anos no Brasil. Rio de Janeiro: Colégio Bennet, 1933. Livro não publicado.

TURNER, Charles Willian. La Biblia construye en America Latina. Buenos Aires: Editorial La Aurora, 1954. 
VAINFAS, Ronaldo. Trópico dos pecados: moral, sexualidade e inquisição no Brasil. Rio de Janeiro: Nova Fronteira, 1997.

VALENTIM, Carlos Antonio. O Brasil e os brasileiros. Fides Reformata XV, n. 2, 2010, pp. 97-107.

VALKENBERG, Pim. Leitores da Escritura e ouvintes da Palavra na Igreja da Idade Média. In: BEUKEN, Win; FREYNE, Sean; WEILER, Anton (orgs.). A Bíblia e seus leitores. Revista Concilium. Petrópolis: Vozes, 1991, pp. 60-70.

VASCONCELOS, Pedro Lima. O Vaticano II e a leitura da Bíblia. São Paulo: Paulus, 2015.

VERGAMINI, Sabine Antonialli Arena (org.). Mãos fazendo história. Petrópolis: Editora Arara Azul, 2003

VIEIRA, David Gueiros. O protestantismo, a maçonaria e a questão religiosa no Brasil. Brasília: Universidade de Brasília, 1980.

VOUGA, François. Protestantismo e Bíblia. Dicionário Enciclopédico da Bíblia. São Paulo: Loyola, Paulinas, Paulus; Santo André: Academia Cristã, 2013, pp. 1102-1109.

WAY, Anita Betts. Instituto Central do Povo: 100 anos em Missão. São Paulo: UMESP, 2006.

WALKER, Williston. História da Igreja cristã. Rio de Janeiro; São Paulo: JUERP/ASTE, 1981.

WEBER, Max. A "objetividade" do conhecimento nas ciências sociais. São Paulo: Ática, 2006.

WILLE, Leopoldo. Pomeranos no Sul do Rio Grande do Sul: trajetória, mitos, cultura. Ed. ULBRA. Canoas, 2011

WILLIANS, Mary. Memórias Quadrangular (Série) - Harold Willians. São Paulo: Quadrangular, 1997.

WYCLIF'S, John. De veritate Scrae Scripturae. Londres: The Wiclif Society by Trubner \& Co, 1905.

WYCLIF'S, John. Opus Evangelicum. Londres: The Wiclif Society by Trubner \& Co, 1895

WORLD HEALTH ORGANIZATION. WHOQOL and spirituality, religiousness and personal beliefs (SRPB): report on WHO Consultation. Geneva; 1998. (WHO/MSA/MHP/98.2, 2-23) 
YASBEK, Maria Carmelita. Classes subalternas e assistência social. São Paulo: Cortez, 2007.

ZIMMER, Rudi (org.). Manual do Seminário de Ciências Bíblicas. Barueri: Sociedade Bíblica do Brasil, 2008.

ZIMMER, Rudi. O uso da Bíblia no Ocidente: na evangelização. In: SOClEDADE BÍBLICA DO BRASIL. Fórum de Ciências Bíblicas: 1600 anos da primeira grande tradução ocidental da Bíblia - Jerônimo e a tradução da Vulgata Latina v.1. Barueri: Sociedade Bíblica do Brasil, 2006, pp. 117143.

ZUCK, Roy. A interpretação bíblica: meios de descobrir a verdade da Bíblia. São Paulo: Vida Nova, 1994. p. 43

\section{3}

\section{Acesso exclusivo em meio eletrônico}

ABRIGRAF. História. Desenvolvido pela Associação Brasileira da Indústria Gráfica, 201?. Apresenta a história do setor gráfico no Brasil desde 1808 até 2015. Disponível em: <http://www.abigraf.org.br/historia>. Acesso em 17 nov 2017.

ARAUJO, Emilene. Programas e projetos sociais desenvolvidos pela SBB [mensagem pessoal]. Mensagem recebida por <emilene@sbb.org.br> em 11 dez. 2017.

ATENEO E FACOLTÀ DE SCIENCIE BIBLICHE E ARCHEOLOGICHE DE JERUSALEM. Desenvolvido por Pontificia Universitá Antonianum, 2012. Homepage institucional. Disponível em: <http://www.antonianum. eu/it/facolta>. Acesso em: 27 nov. 2017.

BASTOS, Márcio Vinicius. Breve história da Escola de Antioquia e sua influência na hermenêutica da Reforma Protestante. Revista Ensaios Teológicos. Vol. 1, no 01, Jun 2015. Disponível em: http://ead.batistapioneira.edu.br/ojs/index.php/ensaios/article/download/80 /131. Acesso em 5 jan. 2017.

BRASIL. Constituição (1824). Constituição Política do Império do Brasil, elaborada por um Conselho de Estado e outorgada pelo Imperador D. Pedro I, em 25.3.1824. Disponível em: http://www.planalto. gov.br/ccivil_03/constituicao/constituicao24.htm. Acesso em 15 ago. 2017.

CAMPOS, Leonildo Silveira. Os Mapas, Atores e Números da Diversidade Religiosa Cristã Brasileira: Católicos e Evangélicos entre 1940 e 2007. Revista de Estudos da Religião. Dez 2008, pp. 9-47. Disponível em: http://www.pucsp.br/rever/rv4_2008/t_campos.pdf. Acesso em 18 ago. 2017 
CAVALCANTI, Robinson. As origens do evangelicalismo. Revista Ultimato, edição 253, jul./ago. 1998. Disponível em: http://www.ultimato.com.br/ revista/artigos/253/as-origens-do-evangelicalismo. Acesso em 10 set. 2017.

CESAR, Marilia de Camargo. Igrejas do Brasil transformam SBB em líder global do mercado. Valor Econômico. São Paulo, 20 jan 2017. Disponível em: <http://www.valor.com.br/empresas/4842456/igrejas-do-brasiltransfor mam-sbb-em-lider-global-do-mercado>. Acesso em 8 jul. 2017.

DOLLINGER, Johann Joseph Ignaz Von; BARBOSA, Rui. O papa e o Concílio: a questão religiosa. Rio de Janeiro: Brown \& Evaristo, 1877. Disponível em: http://www2.senado.leg.br/bdsf/handle/id/222262. Acesso em 2 jul. 2017.

ÉCOLE BIBLIQUE ET ARCHÉOLOGIQUE FRANÇAISE DE JÉRUSALEM. Desenvolvido pelo Couvent Saint-Étienne, 2018. Homepage institucional. Disponível em: <http://www.ebaf.edu/en/>. Acesso em 27 nov. 2017.

FELÍCIO, Manuel da Rocha. Na viragem do século (XIX-XX): a crise modernista. Máthesis. №. 11, 2002, pp. 373-387. Disponível em: http://www4.crb.ucp.pt/biblioteca/Mathesis/Mathesis11/mathesis11_373.pd f. Acesso em 5 mar. 2017.

FERNANDES, Luiz Henrique Menezes. A literatura religiosa polemista nas Índias Orientais seiscentistas e a elaboração da primeira tradução regular da Bíblia em língua portuguesa (1642-1694). Revista de História Regional 18 (2), 2013, pp. 462-479. Disponível em: http://www.revistas2. uepg.br/index.php/rhr. Acesso em 1 out. 2017.

FORLIM, Luiz. Bíblias produzidas na GB [mensagem pessoal]. Mensagem recebida por <forlim@sbb.org.br> em 12 dez. 2017.

FRANCHETTO, Bruna. A guerra dos alfabetos: os povos indígenas na fronteira entre o oral e o escrito. Mana, Rio de Janeiro, v. 14, n. 1, p. 3159, Apr. 2008. Disponível em: <http://www.scielo.br/scielo.php?script =sci_arttext\&pid=S0104-93132008000100002\&Ing=en\&nrm=iso>. Acesso em 14 dez. 2017.

GRILO, Marcelo. Desde 2010, uma nova organização religiosa surge por hora. O Globo. Disponível em: https://oglobo.globo.com/brasil/desde2010-uma-nova-organizacao-religiosa-surge-por-hora-

21114799\#ixzz4qantrGal. Acesso em 23 ago. 2017.

GUARALDO, Luciano. Tramas bíblicas da Record quebram hegemonia da Globo. Notícias da TV. Publicado em 21 jun. 2017. Disponível em: http://noticiasdatv.uol.com.br/noticia/televisao/tramas-biblicas-da-recordquebram-hegemonia-da-globo-nos-estados-unidos-15586?cpid=txt. Acesso em 21 ago. 2017. 
IBC - Instituto Benjamin Constant. Desenvolvido Ministério da Educação d - Governo Federal do Brasil, 2018. Apresenta a história, o regimento interno e alguns dados estatísticos da organização. Disponível em: <http://www.ibc.gov.br/o-ibc>. Acesso em 10 ago 2017.

INSTITUTO ESPAÑOL BÍBLICO Y ARQUEOLÓGICO DE JERUSALÉN. Desenvolvido por Universidad Pontificia de Salamanca, 2018. Homepage institucional. Disponível em: <https://www.upsa.es/institutos/detalleinstituto/>. Acesso em: 13 dez. 2017.

ITQ - Instituto Teológico Quadrangular. Desenvolvido por Igreja do Evangelho Quadrangular de Minas Gerais, 2014. Apresenta a história, os métodos e a grade curricular do curso de teologia oferecido pela instituição. Disponível em: <http://www.quadrangular.org/ieq1regiao/institutoteologico-quadrangular-2/>. Acesso em 13 jun 2018.

KUNZ, Claiton André. Martinho Lutero: vida, doutrina e contribuições. Revista Via Teológica vol. 17, n. 34, dez. 2016. Faculdades Batista do Paraná. Disponível em: http://fabapar.ddns.net/ppe/index.php/VIATEOLOGI CA/article/view/90/pdf. Acesso em 24 ago. 2017.

MARIANO, Ricardo. Expansão pentecostal no Brasil: o caso da Igreja Universal. Estud. av. São Paulo, v. 18, n. 52, p. 121-138, Dec. 2004. Disponível em: <http://www.scielo.br/scielo.php?script=sci_arttext\&pid $=$ S0103-40142004000300010\&lng $=e n \& n r m=i s o>$. Acesso em: 19 Jun 2018.

MARTín, Maria. A tragédia do Rio, do pódio à lama: "Estamos sofrendo, mas continuaremos gritando". El País. Rio de Janeiro, 18 jul 2017. Disponível em: https://brasil.elpais.com/brasil/2017/07/16/politica/ 1500222336_134535.html. Acesso em 13 ago 2017.

MATOS, Alderi de Souza. Breve história do protestantismo no Brasil. Vox Faifae, Revista de Teologia da Faculdade FAIFA v. 3, n. 1, 2011. Disponível em: http://www.faifa.edu.br/revista/index.php/voxfaifae/article /view/27. Acesso em 15 ago. 2017.

MATOS, Alderi de Souza. Robert Reid Kalley: pioneiro do protestantismo missionário na Europa e nas Américas. Fides reformata VIII, n. 1, 2003, pp. 9-28. Disponível em: http://www.mackenzie.br/fileadmin/Mantenedora /CPAJ/revista/ VOLUME_VIII_2003_1/v8_n1_alderi_matos.pdf. Acesso em 19 set. 2017. Acesso em $\overline{9}$ ago 2017

NOBLAT, Ricardo José Delgado. A crise moral e a incredibilidade que atingem o país. Blog do Noblat. Jornal O Globo. Rio de Janeiro, 20 Mai 2017. Disponível em: http://noblat.oglobo.globo.com/artigos/noticia/2017/ 05/crise-moral-e-incredibilidade-que-atingem-o-pais.html. Acesso em 13 jul 2017 
OLIVEIRA, Gilvan Müller de. Plurilinguismo no Brasil: repressão e resistência linguística. Synergies Brésil $\mathrm{n}^{\circ} 7-2009$. Disponível em: <http://gerflint.fr/Base/Bresil7/bresil7.html> Acesso em 30 jun 2018.

ONUBR. Desenvolvimento sustentável. Desenvolvido pela Trusted Team e administrado pelo UNIC Rio, 2018. Em um artigo, apresenta dados do relatório "Panorama Social da América Latina 2017" divulgado pelo Comissão Econômica para a América Latina e o Caribe (CEPAL). Sob o título, "Entre 22 países, Brasil lidera concentração de riqueza nas mãos do $1 \%$ mais rico", o artigo descreve a desigualdade de renda existente no Brasil, apontando que $1 \%$ da população brasileira detém $27 \%$ da renda nacional. Disponível em: <https://nacoesunidas.org/entre-22-paises-brasillidera-concentracao-de-riqueza-nas-maos-do-1-mais-rico/> Acesso em 13 nov 2017.

PAPA BENTO XV. Carta encíclica Spiritus Paraclitus. Sobre la interpretación de la sagrada escritura, 1920. Disponível em: https://w2.vatican.va/content/benedict-v/es/encyclicals/documents/hf_benxv_enc_15091920_spiritus-paraclitus.html. Acesso em 4 ago. 2017.

PAPA GREGÓRIO XVI. Carta encíclica Inter Praecipuas. Disponível em: https://w2.vatican.va/content/gregorius-xvi/it/documents/encyclicainter-praecipuas-machinationes-8-maii-1844.html. Acesso em 6 jul. 2017.

PAPA JOÃO PAULO II. Liturgiam authenticam. Nova instrução para a reta aplicação da constituição sobre a Sagrada Liturgia do Concílio Vaticano II, 2001. Disponível em: http://www.vatican.va/roman_curia/congrega tions/ccdds/documents/rc_con_ccdds_doc_20010507_comunicatostampa_po.html. Acesso em $1 \overline{3}$ jul. 2017

PAPA LEÃO XII. Carta encíclica Ubi primum. Disponível em: https://w2.vatican.va/content/leo-xii/it/documents/enciclica-ubi-primum-5maggio-1824.html. Acesso em 15 jun. 2017.

PAPA LEÃO XIII. Carta Apostólica Vigilantiae Studiique. Disponível em: http://w2.vatican.va/content/leo-xiii/la/apost_letters/documents/hf_lxiii_apl_19021030_vigilantiae-studiique.html. Acesso em 15 jun. 2017.

PAPA LEÃO XIII. Carta encíclica Providentissimus Deus. Sobre los estudios biblicos, 1893. Disponível em: https://w2.vatican.va/content/leoxiii/es/encyclicals/documents/hf_I-xiii_enc_18111893_providentissimusdeus.html. Acesso em 5 jun. 2017.

PAPA PIO VI. Bolla Auctorem Fidei. Disponível em: https://w2.vatican.va/content/pius-vi/it/documents/bolla-auctorem-fidei-28agosto-1794. html. Acesso em 19 ago. 2017.

PAPA PIO VII. Epistola Magno et Acerbo. Disponível em: https://w2.vatican.va/content/pius-vii/it/documents/epistola-magno-etacerbo-3-septembris-1816.html. Acesso em 8 mai. 2017. 
PAPA PIO VIII. Carta encíclica Traditi humilitati. Disponível em: https://w2.vatican.va/content/pius-viii/it/documents/enciclica-traditihumilitati-24-maggio-1829.html. Acesso em 8 mai. 2017.

PAPA PIO IX. Carta encíclica Quanta Cura. Sobre os principais erros da época, 1864. Disponível em: https://w2.vatican.va/content/piusix/it/documents/encyclica-quanta-cura-8-decembris-1864.html. Acesso em 8 jul. 2017.

PAPA PIO IX. Carta encíclica Qui Pluribus. Disponível em: https://w2.vatican.va/content/pius-ix/it/documents/enciclica-qui-pluribus-9novembre-1846.html. Acesso em 5 nov. 2016.

PAPA PIO X. Carta encíclica Lamentabili Sine Exitu. Das proposições dos modernistas condenadas pela Igreja. Decreto da Sagrada Inquisição Romana e Universal, 1907. Disponível em: http: //www.montfort. org.br/bra/documentos/decretos/lamentabili/. Acesso em 3 jan. 2018.

PAPA PIO X. Carta encíclica Pascendi Dominici Gregis. Sobre as doutrinas modernistas, 1907. Disponível em: https://w2.vatican.va/content/ pius-x/pt/encyclicals/documents/hf_p-x_enc_19070908_pascendi-dominici -gregis.html. Acesso em 4 set. 2017.

PAPA PIO XII. Carta encíclica Divino Afflante Spiritu. Sobre estudo bíblicos, 1943. Disponível em: http://w2.vatican.va/content/piusxii/pt/encyclicals/documents/hf_p-xii_enc_30091943_divino-afflante-spiritu .html. Acesso em 12 set. 2017.

PONTIFICIO ISTITUTO BIBLICO. Desenvolvido por Pontificio Istituto Biblico, 2015. Homepage institucional. Disponível em: <https://www.biblico. it/>. Acesso em: 27 nov. 2017.

PONTIFICIO ISTITUTO BIBLICO DI GERUSALEMME. Desenvolvido por Pontificio Istituto Biblico di Roma, 2011. Homepage institucional. Disponível em: <https://www.biblico.it/jerusalem.html>. Acesso em: 30 nov. 2017.

SANTOS, Daniele. Biblioteca do Museus da Bíblia [mensagem pessoal]. Mensagem recebida por <daniele.santos@sbb.org.br> em 17 jun. 2018.

SEMINÁRIO TEOLÓGICO PRESBITERIANO REVERENDO ASHBEL GREEN SIMONTON. Desenvolvido pela Igreja Presbiteriana do Brasil, 2017. Apresenta os aspectos institucionais e doutrinários da instituição. Disponível: <http://www.seminariosimonton.com.br/o-seminario/quemsomos>. Acesso em: 17 out 2017.

SBB. Incentivo à leitura. Desenvolvido pela Sociedade Bíblica do Brasil, 2013. Apresenta os vários programas desenvolvidos pela SBB pelos quais os leitores são incentivados a ler a Bíblia. Entre eles, consta a descrição do Projeto Pedalando por Bíblias. Disponível em: 
$<$ http://www.sbb.org.br/nossos-programas/de-incentivo-a-leitura/pedalan do-por-biblias/>. Acesso em 2 dez 2017.

SBB. Loja virtual SBB. Desenvolvido pela Sociedade Bíblica do Brasil, 2017. Como um catálogo digital, apresenta os produtos da SBB e possibilita a compra de clientes previamente cadastrados. Disponível: <http://www.sbb.com.br/; http://www.sbb.org.br/>. Acesso em 2 dez. 2017

SBB. Portal oficial da Sociedade Bíblica do Brasil. Desenvolvido pela Sociedade Bíblica do Brasil, 2013. Apresenta todo o trabalho realizado pela SBB no Brasil, nos aspectos social, institucional, comunicacional e histórico. Disponível em: <http://www.sbb.org.br/>. Acesso em 11 nov. 2017.

SBB. Projeto Semeador. Desenvolvido pela Sociedade Bíblica do Brasil, 2017. Apresenta informações históricas e atuais sobre como uma pessoa pode adeirir ao Projeto Semador, tornado-se um revendedor de Bíblias em sua igreja ou comunidade (um colportor, um missionário da Bíblia, um semeador). Para os interessados há, também, a possibilidade de cadastrar-se no próprio site. Disponível em: <www.sbb.org.br/semeador>. Acesso em 29 nov 2017.

SBB. Outras línguas brasileiras. Desenvolvido pela Sociedade Bíblica do Brasil, 2013. Apresenta informações sobre línguas de imigração, libras e indígenas faladas no Brasil. Acrescenta ainda informações sobre o processo de tradução da Bíblia para línguas minoritárias e a missão da SBB. Disponível em: <http://www.sbb.org.br/a-biblia-sagrada/outras-linguasbrasileiras/>. Acesso em 27 nov 2017.

SBB. SBBPontoCom Atacado. Desenvolvido pela Sociedade Bíblica do Brasil, 2017. Apresenta informações sobre a venda de produtos da SBB para livrarias, distribuidores etc, por meio do atacado. O site apresenta igualmente a missão da organização, central 'fale conosco' e pesquisas de produtos. Numa seção restrita, o cliente pode cadastrar-se e realizar seus pedidos. Disponível em: <https://atacado.sbb.com.br/>. Acesso em 30 nov 2017.

SCHOKMAN, Suzanne. Bike For Bibles celebrates 30 years on the road. Bible Society News. Sydney, 13 jan 2014. Disponível em: http://wwwarchive.biblesociety.org.au/news/bike-bibles-celebrates-30-years-road. Acesso em 13 dez. 2017.

SOUZA, Alessandro. Idiomas e países atendidos na GB [mensagem pessoal]. Mensagem recebida por <alessandro@sbb.org.br> em 12 dez. 2017.

SOUZA, José Carlos; SOARES, Adelzira. Espiritualidade e qualidade de vida. Rev. Psiquiatria RS mai./ago. 2005, vol. 27 , n. 2, pp. 218-219. Disponível em http://www.scielo.br/pdf/rprs/v27n2/v27n2a13. Acesso em 24 mai. 2017. 
STADELMANN, Luís. Lutero, tradutor da Bíblia. Persp. Teol., v. 17, n. 41 (1985), pp. 87-100. Disponível em: http://www.faje.edu.br/periodicos/ index.php/perspectiva/article/view/1938/2241. Acesso em 17 fev. 2018.

TIMM, Denis. Projetos de Tradução em Línguas Indígenas [mensagem pessoal]. Mensagem recebida por<denis@sbb.org.br> em 13 dez. 2017.

TUCKER, Hugh Clarence. The Bible in Brazil. New York: American Bible Society, 1916. Disponível em: https://archive.org/stream/bibleinbrazil00 tuck\#page/ n1/mode/2up. Acesso em 4 jul. 2017.

UBS - United Bible Societies. About us. Desenvolvido pela UBS, 2018. Apresenta a história da organização, sua missão, visão, valoress e membros quem compõem a fraternidade. Disponível em: <https://www.united biblesocieties.org/about-us/>. Acesso em: 11 out 2017

UBS - United Bible Societies. Key facts about the Bible access. Desenvolvido pela UBS, 2018. Apresenta fatos, dados e números de novas traduções da Bíblia nas diversas línguas do mundo e de projetos bíblicos para surdos e deficientes visuais. Disponível em: <https://www.unitedbi blesocieties.org/key-facts-bible-access>. Acesso em: 11 out 2017

UBS - United Bible Societies. Partners. Desenvolvido pela UBS, 2018. Apresenta organizações não-governamentais que são parceiras das Sociedades Bíblicas. Disponível em: <https://www.unitedbiblesocieties.org/ partners/>. Acesso em: 11 out 2017.

VILVOCK, Camila. Seminário de Ciências Bíblicas realizados pela SBB [mensagem pessoal]. Mensagem recebida por <camila@sbb.org.br> em 13 dez. 2017. 